Willkommen: Deutsch für alle 



\title{
Willkommen: Deutsch für alle
}

\author{
CLAUDIA KOST AND CRYSTAL \\ SAWATZKY
}




\section{() (1) (2)}

Willkommen: Deutsch für alle by Claudia Kost and Crystal Sawatzky is licensed under a Creative Commons Attribution-NonCommercial-ShareAlike 4.0 International License, except where otherwise noted. 


\section{Contents}

About this book 1

Notes for Instructors 3

Notes for Students ix

Organization of this OER xiii

Useful Expressions for the German Classroom xix

Acknowledgements xxi

Einheit r: Schön, dich kennenzulernen!

1.125

$1.2 \quad 30$

$1.3 \quad 36$

$\begin{array}{ll}1.4 & 40\end{array}$

$1.5 \quad 46$

$1.6-51$

$1.7 \quad 56$

$1.8 \quad 60$

$1.9 \quad 68$

$\begin{array}{ll}1.10 & 72\end{array}$

$\begin{array}{ll}\text { Wortschatz } & 77\end{array}$

$\begin{array}{ll}\text { Zum Spaß! } & 78\end{array}$ 
$\underline{\text { Einheit 2: Universität und Freizeit }}$

$2.1-85$

$\begin{array}{ll}2.2 & 89\end{array}$

$\begin{array}{ll}2.3 & 97\end{array}$

$2.4 \quad 103$

$2.5-110$

$2.6-117$

$\begin{array}{ll}2.7 & 125\end{array}$

$\begin{array}{ll}2.8 & 129\end{array}$

$2.9-136$

$\begin{array}{ll}2.10 & 139\end{array}$

$2.11+143$

$2.12 \quad 145$

$2.13 \quad 149$

$2.14+151$

$2.15-155$

$\begin{array}{ll}\text { Wortschatz } & 159\end{array}$

$\begin{array}{ll}\text { Zum Spaß! } & 160\end{array}$

Einheit 3: Familie und Freunde

$3.1-165$

$\begin{array}{ll}3.2 & 169\end{array}$

$3.3 \quad 175$

$3.4-178$

$3.5-181$

$\begin{array}{ll}3.6 & 189\end{array}$

$\begin{array}{ll}3.7 & 195\end{array}$

$\begin{array}{ll}3.8 & 198\end{array}$ 
$3.10 \quad 205$

$3.11-209$

$3.12-210$

3.13

$3.14-215$

$3.15-219$

$3.16-225$

$3.17-233$

Wortschatz 236

Zum Spaß! 237

Einheit 4: Pläne und Termine machen

4.1

$4.6-267$

$4.7-275$

$4.8-282$

$4.9-289$

$4.10-295$

Wortschatz 298

Zum Spaß! 299

Einheit 5: Herzlichen Glückwunsch zum Geburtstag!

5.1 


\section{Einheit 6: Auf einer Reise}

6.1

6.2

6.3

6.4

6.5

6.6

374

6.7

378

6.8

381

6.9

384

6.10

386

6.11

393

6.12

396

6.13

400

6.14

405

Wortschatz

408

Zum Spaß!

409 
$\underline{\text { Einheit 7: Eine Stadt kennenlernen }}$

7.1

415

7.2

417

7.3

421

7.4

426

7.5

434

7.6

437

7.7

440

7.8

442

7.9

448

7.10

455

Wortschatz

457

Zum Spaß!

458

Einheit 8: Mein Zuhause

8.1

463

8.2

467

8.3

472

8.4

475

8.5

478

8.6

481

8.7

486

8.8

489

8.9

494

8.10

497

8.11

501

8.12

504

8.13

507 
8.14

509

Wortschatz

512

Zum Spaß!

513

Einheit 9: Guten Appetit!

9.1

519

9.2

522

9.3

530

9.4

533

9.5

540

9.6

543

9.7

552

9.8

554

9.9

562

9.10

564

9.11

567

9.12

569

9.13

573

9.14

575

Wortschatz

578

Zum Spaß!

579

Einheit ro: Nachbar Nr. 5

10.1

585

10.2

589

10.3

595

10.4

597

10.5

601 
10.6

603

10.7

609

10.8

611

10.9

616

10.10

618

10.11

621

10.12

623

10.13

628

10.14

630

Wortschatz

633

Zum Spaß!

634

Grammatik 639

Vergessen Sie nicht! 643

*ACHTUNG* 644

Wortschatz Präsentationen 648

Kultur 650

Redemittel 652

Hörtexte 653

Helpful Resources 654 



\section{About this book}

\section{Willkommen: Deutsch für alle}

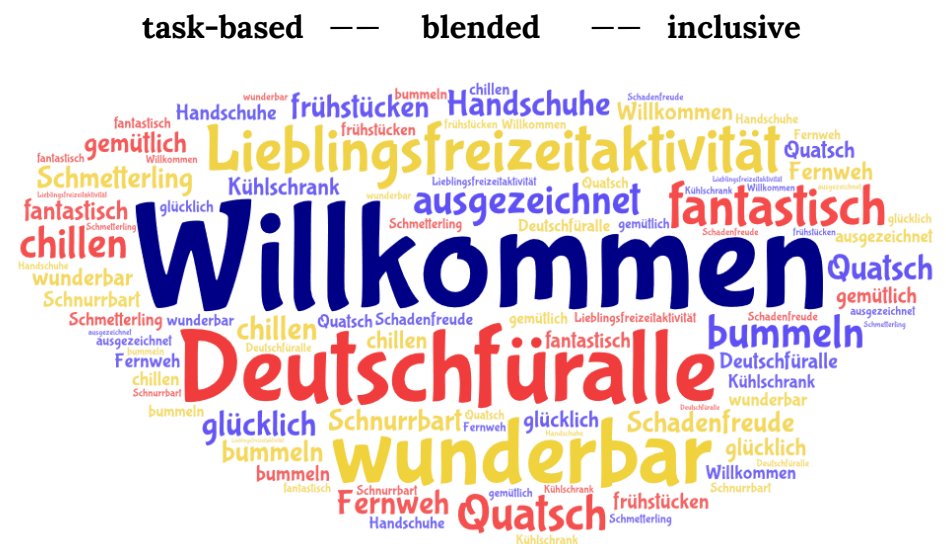

Willkommen: Deutsch für alle has been recognized with the 2021 "Access to Language Education Award" for offering exceptional language learning resources (presented by CALICO, lernu.net, and the Esperantic Studies Foundation).

Willkommen: Deutsch für alle is an innovative first-year German language e-textbook, designed as Open Educational Resource (OER), for learning German at the college/university level. It features a task-based, communicative approach which provides 
students with opportunities to communicate in German in a variety of contexts and situations. Through a wide range of activities, students develop and practice their language skills which they showcase at the end of each chapter by accomplishing a specific task.

Willkommen: Deutsch für alle follows a blended-learning model, a combination of alternating in-class (face-to-face) instruction and interaction, and online (self-paced) individual learning. Both in-class and online activities encourage students to practice the three communicative modes (interpersonal, interpretive, and presentational) and thus the four language skills in an integrated manner. In-class activities provide opportunities for students to use their interactive language skills in a collaborative environment. Online activities aim to review materials from the previous lesson as well as allow students to engage with new information at their own pace.

Willkommen: Deutsch für alle takes an inclusive approach to the depiction of people, contexts, and concepts. It views language learners, instructors and a wide range of individuals interacting in German as belonging to a large German-speaking community. Pedagogical as well as authentic cultural materials emphasize the diversity of speakers of German and are purposely inclusive of sexual orientation, race, and ethnicity.

For more information, please contact:

Dr. Claudia Kost

University of Alberta

ckost@ualberta.ca 


\section{Notes for Instructors}

\section{Dear instructor:}

Welcome to our e-textbook Willkommen: Deutsch für alle. We have collected some information here that you might find useful to understanding the approach we took with our e-textbook. If you have any questions, please don't hesitate to contact us.

\section{Lesson Structure}

Willkommen: Deutsch für alle is an innovative beginning German language e-textbook which follows a blended-learning model. It is designed for two semesters of course work at the college/ university level with three 50-minute classes per week, and students completing online lessons at their own pace between the in-class lessons.

A typical week could look like this:

\begin{tabular}{|l|l|l|l|l|l|}
\hline Monday & Tuesday & Wednesday & Thursday & Friday & Weekend \\
\hline $\begin{array}{l}\text { Unit } 1.1 \\
\text { in-class }\end{array}$ & & $\begin{array}{l}\text { Unit 1.3 } \\
\text { in-class }\end{array}$ & & $\begin{array}{l}\text { Unit 1.5 } \\
\text { in-class }\end{array}$ & \\
\hline & $\begin{array}{l}\text { Unit } 1.2 \\
\text { online }\end{array}$ & & $\begin{array}{l}\text { Unit 1.4 } \\
\text { online }\end{array}$ & & $\begin{array}{l}\text { Unit 1.6 } \\
\text { online }\end{array}$ \\
\hline
\end{tabular}

It features a total of 12 units which range from 8-16 lessons (inclass and online). Units 1-5 should be covered in the first semester and are an equivalent to the A1 level of the Common European Framework of References. Units 6-10 should be covered in the second semester and are an equivalent to the A2 level of the CEFR.

Each lesson is clearly laid out in a vertical manner, you scroll from the top of the page to the bottom. In-class lessons start out with a warm-up activity, intended to review materials from the previous lesson (and the online lesson that students completed at home) and to get students back into "German mode". The warm-up activities are often done with the entire class where students are supposed to 
quickly and spontaneously respond in order to get as many students as possible involved.

Following the warm-up activity, each in-class lesson features a variety of activities practicing listening, speaking, or reading skills. Grammatical structures are introduced implicitly in an oral or written contexts. Students will use the new grammatical structures in a guided activity first before they are asked to hypothesize about any potential rules for the new structure.

Online lessons are to be completed by the students at their own pace at home in between the in-class lessons. They feature listening, viewing, and reading activities as well as easy-tounderstand grammatical explanations and practice exercises. It is important to emphasize to students repeatedly (especially at the beginning of the semester) to complete these online lessons before they come to the next class meeting as they will not only review at home what had been covered in the previous class, but will also learn new materials on their own at home which they need for the next in-class lesson. If they don't complete the online lessons before they come to class, they will not be prepared to participate in the next in-class lesson.

Each online lesson has a link to a quiz to encourage students to work through the materials. These quizzes are housed on a different platform and are only accessible to students at the University of Alberta who are registered in our classes.

\section{Teaching Vocabulary}

At the end of each unit, there is a list of the new vocabulary as a pdf for students to print out if they like. We recommend that students study the new vocabulary after each sub-topic in each unit, using the Quizlet vocabulary stacks that we provide. Students need to sign up for a free Quizlet account to access these stacks. Our username is germanuofa.

Most of the vocabulary teaching takes place in class. We follow the 5-step-technique explained below.

Presenting new vocabulary with the 5-step

Vocabulary at the beginning level is mostly taught in class with 
the presentation of slides with pictures and new words using the 5-step-technique (Tschirner, E., \& Nikolai, B. 2017. Kontakte: A Communicative Approach, 8th ed. New York, NY: McGraw-Hill). Each presentation features the same new vocabulary items on two slides: the first slide with the new words and the second slide with numbers replacing the words. You would continue projecting the e-textbook on the large screen in the classroom and the students would focus on that screen (not on their individual computer screens).

\section{Step 1: Presentation}

In the first step, you present the new words in context. You use very short connected sentences and emphasize each target word in that sentence while pointing to each item on the screen. Use clear pronunciation, pause after each sentence and use lots of repetition. Make sure you present all items. This step is intended to provide comprehensible input to the students.

For example, Unit 2.1 introduces the items in a classroom. For the presentation, you could start by saying something like: "Heute lernen wir die Gegenstände im Seminarraum. Das ist ein Bleistift. Der Bleistift ist gelb. Und das hier ist ein Radiergummi. Der Radiergummi ist rosa..."

To contextualize your sentences more, add things that students know already, such as colours. Students only listen and look at the images, but do not repeat in this step.

\section{Step 2: Receptive Recall}

In the second step, students are only asked to recognize the new vocabulary, but not yet to produce it. Students concentrate on recognizing a new word in the question you ask, using the number of the item to indicate that they know the meaning of the new word. We usually use numbers, but sometimes also names or categories in the question. You could ask either: "Welche Nummer ist der Beistift?" or "Ist der Bleistift Nummer 1 oder Nummer 4?" (giving students a choice) and students would respond with "1". Again, it is important to go through all the items. This step strengthens the binding of the sound of the new word to its meaning. 


\section{Step 3: Choral Repetition}

In the third step, students pronounce the new words for the first time. You point to each item and clearly pronounce the word; all students (as a class) then repeat after you. We model and focus on the correct pronunciation with all students together so that nobody gets singled out. This will prepare them to use the words productively in the next step. You would say: "der Bleistift" and the entire class would repeat: "der Bleistift". Go through all items.

\section{Step 4: Productive Recall}

In the fourth step, you switch to the second slide which only has numbers next to the images, but no words. Now we elicit the new vocabulary and students have to produce them for the first time by saying the word when you point to each image. You would ask: "was ist das?" and students would say: "der Bleistift". Go through all the items on the slide, but change up the order of the items so that students don't memorize the items in order, but rather connect the image with a new word.

\section{Step 5: Personalization}

In the fifth step, we apply the new words to the students' own situation. There are different ways of accomplishing this: list items, write down certain items, or answer questions. In our example from unit 2.1, you could ask: "wer hat einen Bleistift?" and students could respond by just holding up their pencils, thereby showing that they understand the question and know the new word. Or you could ask: "Was ist in diesem Seminarraum? Schreiben Sie alle Gegenstände auf, die Sie sehen." Students would then write a list of all the things in the classroom that they learned new words for. Or you could take a more individualized approach and ask specific students which items they own or have in their backpack.

\section{Tasks}

Willkommen: Deutsch für alle follows a task-based and communicative approach. Each unit features a task (oral or written) which provides students with the opportunity to use the language skills in a meaningful context and show what they have learned in the unit. These tasks are intended to replace more traditional 
assessments like unit exams or midterms and to prepare students for real-life language use so that they can function in a Germanspeaking context.

\section{Assessment}

Assessment takes various forms in a beginning language class taught with this e-textbook. The suggested grade distribution in the first semester language course is as follows:

- Participation

- Quizzes (after each online lesson)

- Tasks

- Oral Assessment

- Written Final Assessment
$10 \%$

$20 \%$

$40 \%$

$10 \%$

$20 \%$

Participation assesses students' preparation for class and active engagement during in-class lessons.

In a blended-learning model, it is paramount that students complete the online lessons on their own, reviewing previously taught materials as well as preparing for the next in-class lesson. By asking them to take a short quiz after each online class (for a total of $20 \%$ of the course grade), we want to encourage and motivate them to work through the online materials on their own so that they are well prepared for the next class.

Following a task-based approach, our assessments are designed to measure how well students perform a task by demonstrating their language skills and knowledge. We moved away from unit exams and midterms, and instead designed more comprehensive tasks in each unit that require students to make use of all the skills and knowledge they acquired to accomplish the task successfully. For each task, we also provide rubrics so that students know exactly what is expected of them and to help instructors to assess their students' performance.

At the end of the term, university regulations require us to do a final assessment. We split it into an oral assessment (assessing speaking, listening, and interactive communicative skills) and a 
written assessment (assessing reading and writing skills) in a more holistic manner.

We hope that you will enjoy your teaching experience with Willkommen: Deutsch für alle!

Please note: Some instructors might teach with this e-textbook via remote delivery due to COVID-19. Therefore, they might change the instructions for activities for the in-class lessons to fit the remote environment. 


\section{Notes for Students}

Dear student:

Welcome to our e-textbook Willkommen: Deutsch für alle. This e-textbook will accompany you through two semesters of learning German. It is designed to be cost-free, user-friendly, and flexible to be used on a variety of digital devices (computer, laptop, tablet, smartphone).

You will learn about the German language and the culture of the German-speaking countries. The topics that we will cover first focus on you personally, then branch out to larger topics (family and friends, leisure time, weather, university studies, making plans, shopping, living arrangements, travelling, food, holidays and celebrations). In second semester, we even read a short novel! Starting with the second semester, each unit also features a UNESCO world heritage site which provides further cultural information on the topic of the unit. These topics will allow you to gain functional proficiency in the German language in case you want to travel there. We use both native speakers and language learners (who at some point started learning German just like yourself).

Here are some important things you need to know:

- Structure:

Willkommen: Deutsch für alle follows a blended-learning format, which is a combination of in-class lessons (face-to-face with your instructor) and online, self-paced individual lessons. The online lessons are more than just homework. It is crucial that you complete the online lessons on your own in between the in-class lessons because they are not only designed to let you practice and review what you have learned in the previous class, but they also help you learn something new that you need to prepare for your next class.

A typical week could look like this: 


\begin{tabular}{|l|l|l|l|}
\hline Monday & Tuesday & Wednesday & Thursday \\
\hline Unit 1.1 in-class & & Unit 1.3 in-class & \\
\hline & Unit 1.2 online & & Unit 1.4 onlin \\
\hline
\end{tabular}

- Student Handouts:

You will practice listening, speaking, reading and writing in a variety of activities in class. Some of these activities require you to take notes or have additional materials which we provide as a PDF. Please print out the Student Handouts (Einheit 1 - 5/ Einheit 6 - 10) before classes start so that you have everything handy for your in-class instruction.

- Online lessons:

Each online lesson is clearly laid out in a vertical manner, you scroll from the top of the page to the bottom. You have to complete these lessons at your own pace at home in between the in-class lessons. The lessons feature listening, viewing, and reading activities as well as easy-to-understand grammatical explanations and practice exercises. You have unlimited attempts to practice with these exercises, just refresh the webpage. If you don't complete the online lessons before you come to class, you will not be prepared to participate in the next in-class lesson.

At the end of most online lessons there is a link to a quiz "Was wissen Sie jetzt?" where you can show what you have learned. These quizzes are housed on a different platform and are only accessible to students at the University of Alberta who are registered in our classes. Some quizzes will also take place in class following the online lesson.

Some online lessons also feature a section called "Extra Practice (optional)". Throughout the semester we will use clips from the 
video series "Nicos Weg" to help you practice what you are learning in this course. Nicos Weg is a video series developed by Deutsche Welle. Feel free to use other parts of the series if you want to practice more. You can watch the videos and also do the accompanying exercises, it's all free and easily accessible. The activities do function a little differently. Please read scroll to the section called Exercises for guidance on how the activities work.

- Vocabulary:

Most of the new vocabulary will be taught in class, but sometimes you will also learn new vocabulary in an online lesson. In order to practice the new vocabulary, we recommend that you study the new vocabulary after each sub-topic in each unit, using the Quizlet vocabulary sets that we provide. You need to sign up for a free Quizlet account to access these sets and all their study options. Our username in Quizlet is germanuofa. There is also a list of the new vocabulary as a PDF at the end of each unit if you like to print it out.

- Tasks:

Each unit features a task (oral or written) which provides you with the opportunity to use your language skills in a meaningful context and show what you have learned in the unit. These tasks are intended to replace more traditional assessments like unit exams or midterms and prepare you for real-life language use so that you can function in a German-speaking context. For each task, we also provide rubrics so that you know exactly what is expected of you and to help you accomplish the task successfully.

- Roll the dice:

We sometimes use an activity that requires you to roll the dice. If you don't have any dice, you can use this website.

- Zum Spaß: 
Each unit ends with a section "Zum Spaß" (for fun) with links to additional activities, German music, and funny videos which will enhance your understanding of German culture.

- Grammatik:

Under "contents" on the left hand side of the book and below all the units, we put a reference section that lists all of the grammar items that you learn here. This is an easy way for you to find a specific grammar item (it is either linked back to the unit where it was covered or is has the PPT linked right there).

We hope you will enjoy learning the German language and about the culture in the German-speaking countries with Willkommen: Deutsch für alle!

Please note: Some instructors might teach with this e-textbook via remote delivery due to COVID-19. Therefore, they might change the instructions for activities for the in-class lessons to fit the remote environment. 


\section{Organization of this OER}

Willkommen: Deutsch für alle is an innovative first-year German language e-textbook, designed as Open Educational Resource (OER), for learning German at the college level. The materials cover approximately two semesters (semester 1: units 1-5; semester 2: units 6-10) and are equivalent to the $\mathrm{A} 1$ level (semester 1) and the A2 level (semester 2) of the CEFR.

Willkommen: Deutsch für alle follows a blended-learning model. In-class sessions taught by an instructor (odd numbered lessons: 1.1, 1.3, etc.) alternate with online sessions (even numbered lessons: 1.2, 1.4 , etc.) which students complete at their own pace at home.

Each unit is prefaced by clear learning outcomes so that students know what they are expected to achieve by the end of the unit in terms of skills and knowledge. At the end of each unit, students demonstrate what they can do by accomplishing a specific task. These tasks resemble real-world tasks, requiring students to combine their accumulated skills and knowledge, in either oral or written form.

Each unit provides ample materials to practice all four language skills (listening, speaking, reading, and writing) with culturally authentic materials. Students practice their interactive language skills in a collaborative environment through a variety of in-class activities (e.g., signature search, info-gap, role plays, interviews). Listening and viewing activities (employing learners of German as well as speakers from German-speaking countries) sharpen students' aural and interpretive skills. Pedagogical and authentic texts enhance students' reading skills and cultural awareness.

New vocabulary is often introduced in class using a specific teaching technique (see Notes for instructors), but also sometimes learned by the students at home. Students are encouraged to practice the new vocabulary via Quizlet. Each unit features a number of Quizlet stacks organized by topic (sign up for free 
account is required for access). Our Quizlet username is germanuofa. All vocabulary of a unit is also compiled in a list at the end of each unit (printable as PDF).

New grammatical structures are introduced implicitly in their authentic context (text or audio), then followed up by a section asking "Was ist neu hier?" which allows students to discover the new forms themselves and to hypothesize how they are being used. Grammatical explanations are part of the online sessions where students can read through the explanations at their own pace and do practice activities. Longer grammatical explanations are provided in a PDF format for those students who would like to print them out. There is also a grammar reference page at the end of the e-textbook which lists and links again to all structures that were covered in the units.

Each unit also features a collection of useful phrases ("Redemittel") for students to use in interactive activities in class as well as for quick reference. Cultural notes (in English) throughout the OER provide students with more insights into the Germanspeaking cultures. At the end of each unit, a section "Zum Spa $\beta$ " offers further practice activities, and links to German music and videos. Starting in the materials for the second semester, each unit features a UNESCO world heritage site which provides further cultural information on the topic of the unit. Specific sections throughout the OER are also highlighted by the use of different coloured boxes:

- green: learning outcomes at the beginning of each unit

- blue: a collection of useful phrases ("Redemittel")

- orange: grammar explanation

- purple: cultural notes

Willkommen: Deutsch für alle employs a scaffolded approach regarding the use of English and German. Instructions for in-class lessons are entirely in German, from the first day on. Instructions for the online sessions start out in English to ensure that students 
working at home don't struggle with understanding what they are supposed to do. As students progress through the units and acquire more German, instructions slowly change from English to German. In the second semester (units 6-10), instructions for the online sessions (including in the h5p activities) are entirely in German.

The following icons are used to indicate different activity types: 


\begin{tabular}{|l|} 
short grammar \\
H5P activities (for \\
explanations in English
\end{tabular}




\begin{tabular}{|l|l|}
\hline $\begin{array}{l}\text { Was ist neu? (allows } \\
\text { students to discover and speculate } \\
\text { about underlying grammatical } \\
\text { patterns after they used the new } \\
\text { forms in context) }\end{array}$ & $\begin{array}{l}\text { Was wissen Sie jetzt? Quiz } \\
\text { (for students enrolled in a German } \\
\text { class at the University of Alberta, } \\
\text { this link connects them to the } \\
\text { quizzes on eClass) }\end{array}$ \\
\hline external link & $\begin{array}{l}\text { vocabulary list at the end } \\
\text { of each unit }\end{array}$ \\
\hline reading strategies & $\begin{array}{l}\text { (highlights previously taught } \\
\text { material as a quick reminder) }\end{array}$ \\
\hline
\end{tabular}

\section{Media Attributions}

- star (C) IO-Images is licensed under a Public Domain license

- headphones (C) IO-Images is licensed under a Public Domain license

- partner (C) IO-Images is licensed under a Public Domain license

- book (C) IO-Images is licensed under a Public Domain license

- group (C) IO-Images is licensed under a Public Domain license

- magnifying-glass (C) IO-Images is licensed under a Public Domain license

- speech bubble (C) IO-Images is licensed under a Public Domain license

- pen (C) IO-Images is licensed under a Public Domain license

- document (C) IO-Images is licensed under a Public Domain license

- keyboard (c) IO-Images is licensed under a Public Domain license 
- presentation icon (C) quinntheislander adapted by Solomon Hajramezan is licensed under a Public Domain license

- person (C) IO-Images is licensed under a Public Domain license

- question-mark (C) IO-Images is licensed under a Public Domain license

- check mark (C) janjf93 adapted by Solomon Hajramezan is licensed under a Public Domain license

- link (C) IO-Images is licensed under a Public Domain license

- pdf (C) IO-Images is licensed under a Public Domain license

- wrench (C) IO-Images is licensed under a Public Domain license

- $\underline{\text { information (C) IO-Images is licensed under a Public Domain }}$ license 


\section{Useful Expressions for the German Classroom}

Useful Expressions for the German Classroom

Here are some useful expressions. Listen to the audio recording while you read along.

One or more interactive elements has been
excluded from this version of the text. You can view them online here:

https://openeducationalberta.ca/willkommendeutsch/?p=4189\#audio-4189-1

- $\quad$ Ich habe eine Frage!

(I have a question!)

- Ich verstehe das nicht!

(I don't understand that!)

- $\quad$ Noch einmal, bitte!

(Once again, please!)

- $\quad$ Entschuldigung, ...

(Excuse me,...)

- Was ist das?

(What is that?)

- Wie sagt man ... auf Deutsch? (How do you say ... in German?)

- Wiederholen Sie, bitte! (Repeat, please!

- Lesen Sie, bitte! (Read, please!) 
- $\quad$ Schreiben Sie, bitte!

- Hören Sie bitte zu!

- Wie schreibt man das? that?)

- $\quad$ Alle zusammen!
(Write, please!)

(Listen, please!)

(How do you spell

(All together!) 


\section{Acknowledgements}

With this e-textbook, we fulfilled a long-time dream of writing our own beginning German language textbook. Inspired by a workshop on Open Educational Resources by the Centre for Teaching and Learning at the University of Alberta, we decided to write our textbook as an OER to provide students interested in learning German with pedagogically-sound, current, and freely accessible educational materials. In addition, we designed this e-textbook in a blended-learning format to address students' scheduling issues and to allow them to take a more self-regulated approach towards their own learning by completing the online lessons at their own pace.

We are grateful for receiving the University of Alberta Open Educational Resources (OER) Grant from CTL and for some financial support from the Provost.

We would also like to thank our wonderful former and current students who inspired us to take on this enormous task. We are especially excited that we were able to feature some of you in our audiovisual materials. You made our e-textbook come alive!

And very special thanks go out to our amazing friends in Germany who are featured in our e-textbook. Thank you for sending us photos, videos, and audio-recordings whenever we sent an email asking for yet another thing!

We hope that students and instructors alike will enjoy learning and teaching German with Willkommen: Deutsch für alle.

The Authors

Claudia Kost and Crystal Sawatzky 
22 | Acknowledgements 


\section{EINHEIT r: SCHÖN, DICH KENNENZULERNEN!}

Learning Outcomes

At the end of Einheit 1, you will be able to...

- $\quad$ introduce yourself and others

- greet and say good-bye

- $\quad$ address people appropriately using Sie, du oder ihr

- $\quad$ spell using the German alphabet

- $\quad$ use numbers from 1-1000

- describe geographical locations

- describe objects using colours

- $\quad$ speak about the weather

- $\quad$ give polite instructions or make requests

- $\quad$ ask for, understand, and express basic information about yourself

You will also have learned about the following structures:

- $\quad$ personal pronouns

- conjugation of verbs in present tense

- $\quad$ questions using was, wie, woher

- "Sie"-imperative

- $\quad$ grammatical gender of nouns and pronouns (masculine, feminine, neuter) 
24 | Einheit 1: Schön, dich kennenzulernen! 


\section{Einheit 1.1}

Willkommen bei Deutsch 111!
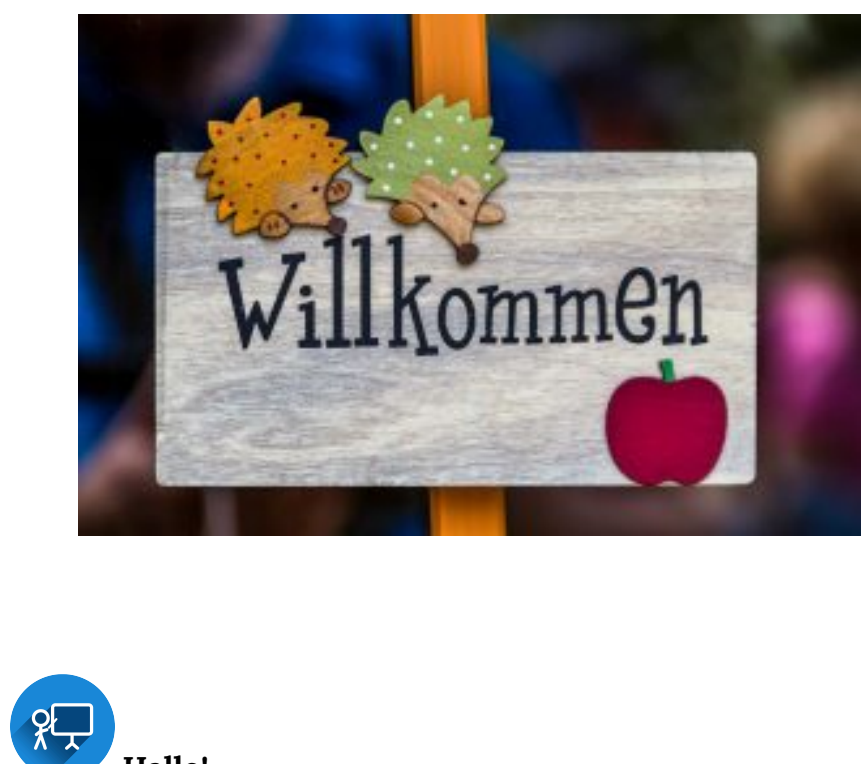

Hallo!

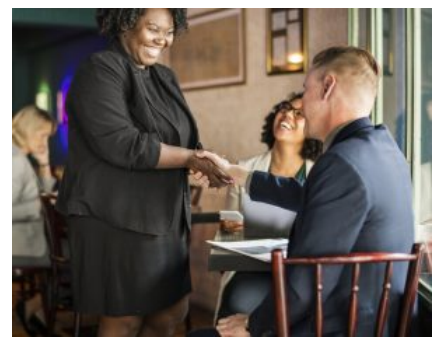

Hallo! Ich heiße Monique Laval. Wie heißen Sie?

Guten Tag Frau
Laval!
Mein Name ist Stefan
Berg.
Woher kommen Sie, Herr Berg?
Ich komme aus
Frankfurt. Und Sie?
Ich komme aus Montreal.

Das ist ... 


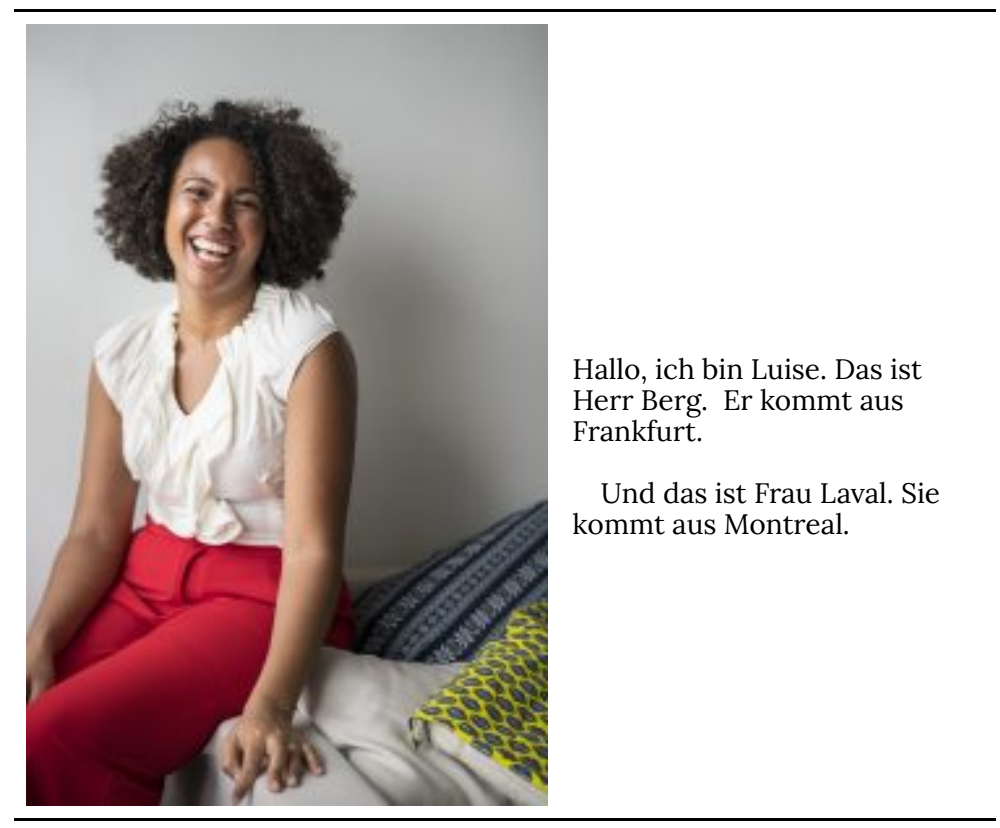

Wie geht es Ihnen? 

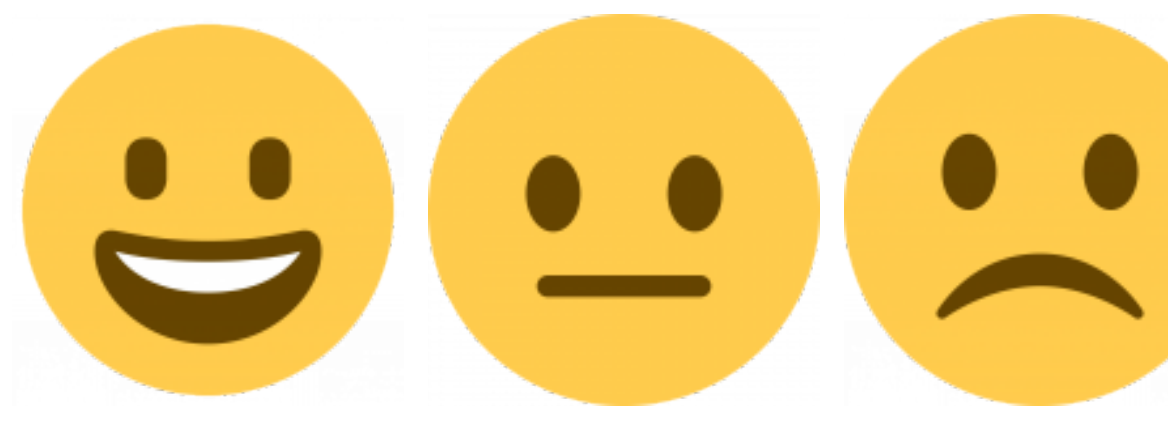

Sehr gut!

Es geht!

Schlecht!

Kennenlernen. Lernen Sie jetzt 5 neue Studentinnen oder Studenten kennen. Benutzen Sie die Redemittel aus der Box und machen Sie Notizen. 


\begin{tabular}{|l|l|l|l|}
\hline & Name & Stadt & Wie geht es Ihnen? \\
\hline 1. & & & \\
\hline 2. & & & \\
\hline 3. & & & \\
\hline 4. & & & \\
\hline 5. & & & \\
\hline
\end{tabular}

Redemittel

\section{Sich vorstellen}

\begin{tabular}{|c|c|c|}
\hline $\begin{array}{c}\text { Wie heißen } \\
\text { Sie? }\end{array}$ & $\begin{array}{c}\text { Ich heiße ... / Ich bin } \\
\text { Mein Name ist ... }\end{array}$ & $\begin{array}{c}\text { Freut mich! } \\
\text { Schön, Sie } \\
\text { kennenzulernen! }\end{array}$ \\
\hline $\begin{array}{c}\text { Woher } \\
\text { kommen Sie? }\end{array}$ & Ich komme aus ... & \\
\hline $\begin{array}{c}\text { Wie geht es } \\
\text { Ihnen? }\end{array}$ & $\begin{array}{l}\text { Mir geht es sehr gut. } \\
\text { Es geht. } \\
\text { Mir geht es schlecht. }\end{array}$ & \\
\hline
\end{tabular}

*ACHTUNG* Dark blue bolded words are clickable and glossed in English for you. Other vocabulary can be found in the "Wortschatz" section at the end of the unit. Bright 
blue non-bolded words throughout the units are also clickable, however they are links to external websites or downloadable PDFs.

\section{Media Attributions}

- presentation icon (C) quinntheislander adapted by Solomon Hajramezan is licensed under a Public Domain license

- speech bubble (C) IO-Images is licensed under a Public Domain license

- document (C) IO-Images is licensed under a Public Domain license 


\section{Einheit 1.2 (online)}

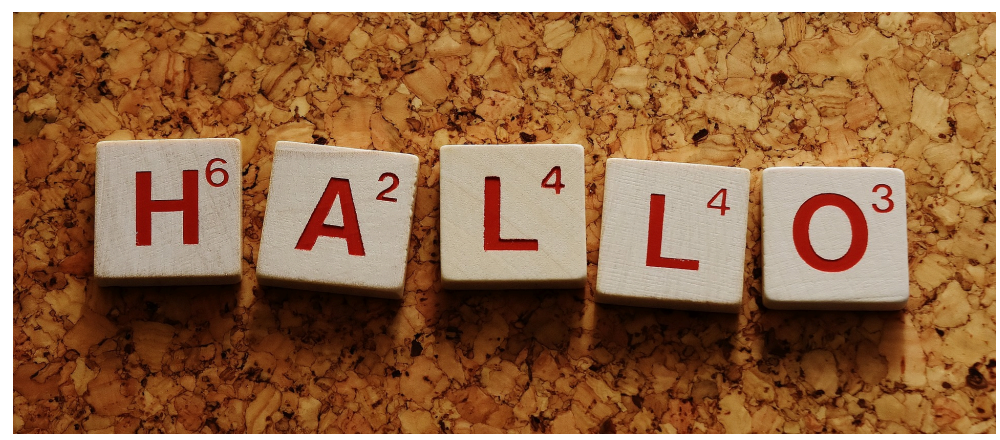

Übung 1a. Listen to the dialogue and click on the correct answer based on what you hear.

\footnotetext{
国

An interactive H5P element has been excluded from this version of the text. You can view it online here:
}

https://openeducationalberta.ca/willkommendeutsch/?p=51\#h5p-76

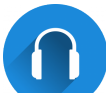

Übung $\mathbf{1 b}$. Listen to the dialogue and click on the correct answer based on what you hear $($ True $=$ Richtig and False $=$ Falsch).
므
An interactive $\mathrm{H} 5 \mathrm{P}$ element has been excluded from this 
$\Delta$ version of the text. You can view it online here:

https://openeducationalberta.ca/willkommen-

deutsch/?p=51\#h5p-74

Übung 1c. Listen to the dialogue.

An interactive H5P element has been excluded from this version of the text. You can view it online here:

https://openeducationalberta.ca/willkommen-

deutsch/?p=51\#h5p-77

Sie, du oder ihr?

The German language has three different words for "you".

Sie (formal singular and plural) - commonly used among adults, with someone you don't know, or who functions in a professional role (e.g., boss, doctor, flight attendant)

Wie heißen Sie? / Woher kommen Sie? 
du (informal singular) - used with friends, family, children, pets, fellow students, longtime coworkers

Wie heißt du? / Woher kommst du?

ihr (informal plural) - this the plural form of "du" - used for example with multiple friends or children

Wie heißt ihr? / Woher kommt ihr?

In general, German speakers use much more formal language when addressing each other than English speakers, especially among older people. It is quite common for many people who have been neighbours for years or coworkers in the same office to still address each other with "Frau Meier" or "Herr Berg" and use the "SieForm".

If you are ever unsure whether to use the "du-Form" or the "Sie-Form" (especially in a professional context or when the other person is older or in a higher position of power), it is always safest to use "Sie" until the person to whom you are talking suggests that you use "du".

Übung 2. Match each picture with its corresponding pronoun.

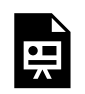

An interactive H5P element has been excluded from this version of the text. You can view it online here:

https://openeducationalberta.ca/willkommendeutsch/?p=51\#h5p-3 


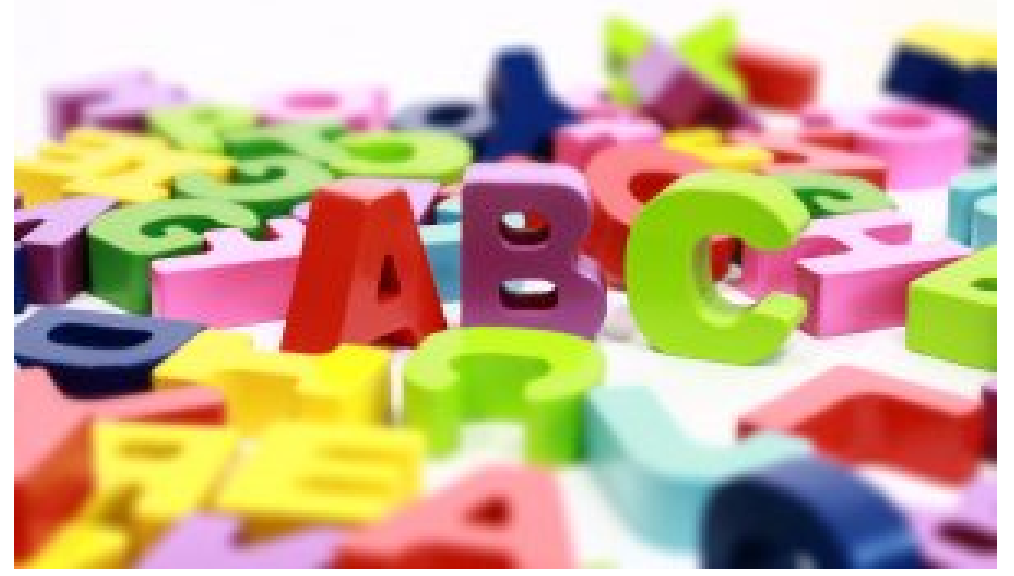

Das Alphabet. Watch this video and practice as she teaches you the alphabet.

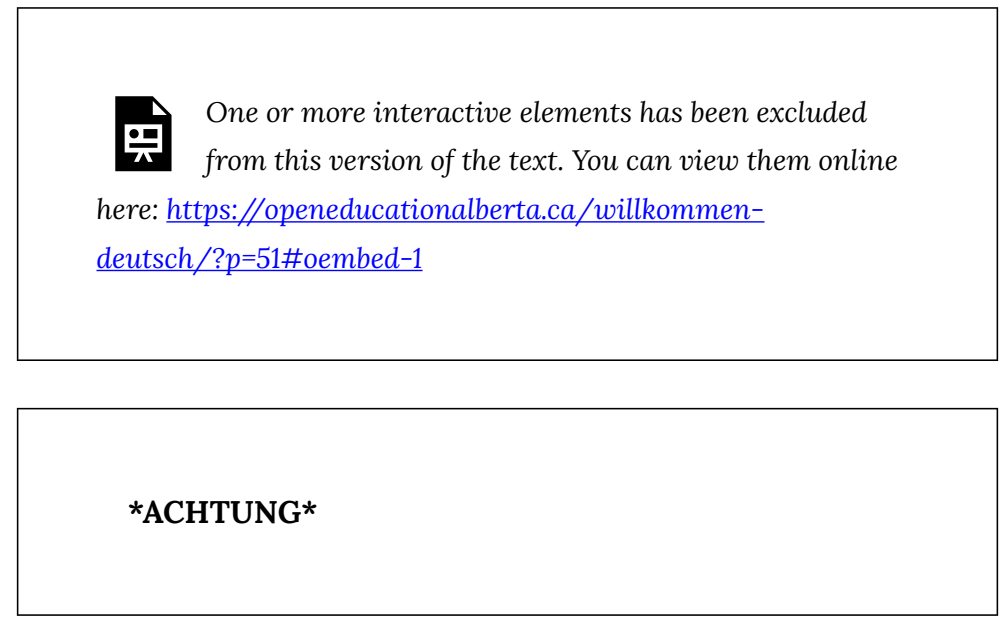


All activities in this e-textbook require ä, ö, ü, and $§$ where necessary and you should learn how to spell words the way we present them. You also need to use ä, $\ddot{o}, \ddot{u}$, and $§$ when you write tasks and quizzes. If you do not know how to make an umlaut or Eszett (§), please refer to this short article. Also please note that we try to always provide the special characters for you so that you can copy and paste them from the instructions. In the German-speaking countries, people usually only use the ae, oe, ue as mentioned in the video when they do a crossword puzzle. Otherwise, they use the umlaut.

Was wissen Sie jetzt? Klicken Sie hier für Quiz 1.2.

\section{Extra Practice (optional):}

\section{Video Serie - Nicos Weg}

Throughout the semester we will use clips from "Nicos Weg" to help practice what we are learning in this course. Nicos Weg is a video series developed by Deutsche Welle. Feel free to use other parts of the series if you want to practice more. If you have trouble figuring out how to complete the exercises, please go to this link and scroll to "exercises" and read about how the activities are to be completed.

Watch the video here. Then click on "start" under the video and do the exercises. 


\section{Media Attributions}

- hello (C) Alexas_Fotos is licensed under a Public Domain license

- star (C) IO-Images is licensed under a Public Domain license

- alphabet (C) Gerd Altmann is licensed under a Public Domain license

- play (C) IO-Images is licensed under a Public Domain license

- check mark (c) janjf93 adapted by Solomon Hajramezan is licensed under a Public Domain license 


\section{Einheit 1.3}
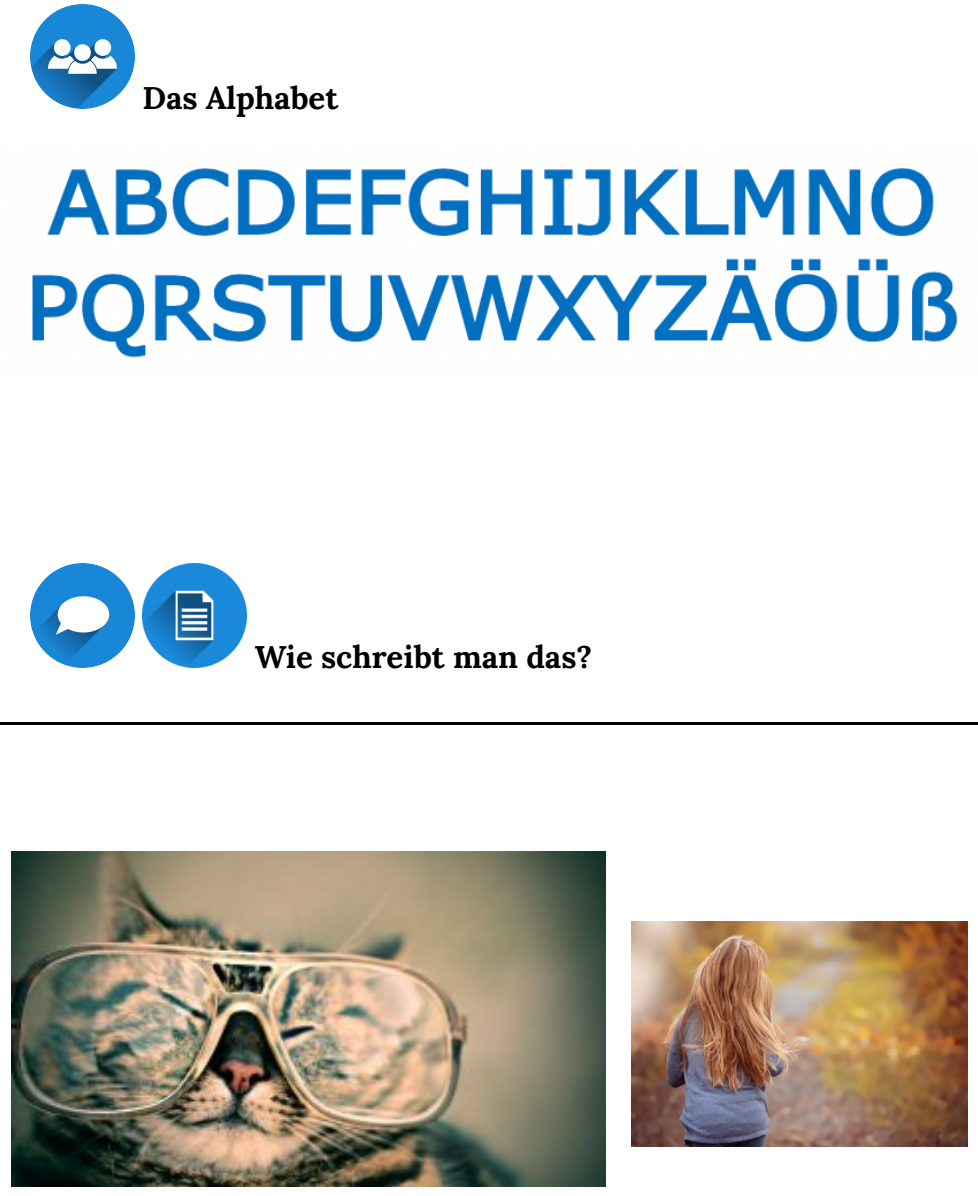

die Brille

lange

Haare

Beispiel: eine Studentin/ ein Student mit einer Brille

S1: Wie heißt du?

S2: Ich heiße Stefanie. 
S1: Wie schreibt man das?

S2: S-t-e-f-a-n-i-e

Name

1. eine Studentin/ein Student mit einer Brille

2. eine Studentin/ein Student in einem T-Shirt

3. eine Studentin/ein Student mit langen Haaren

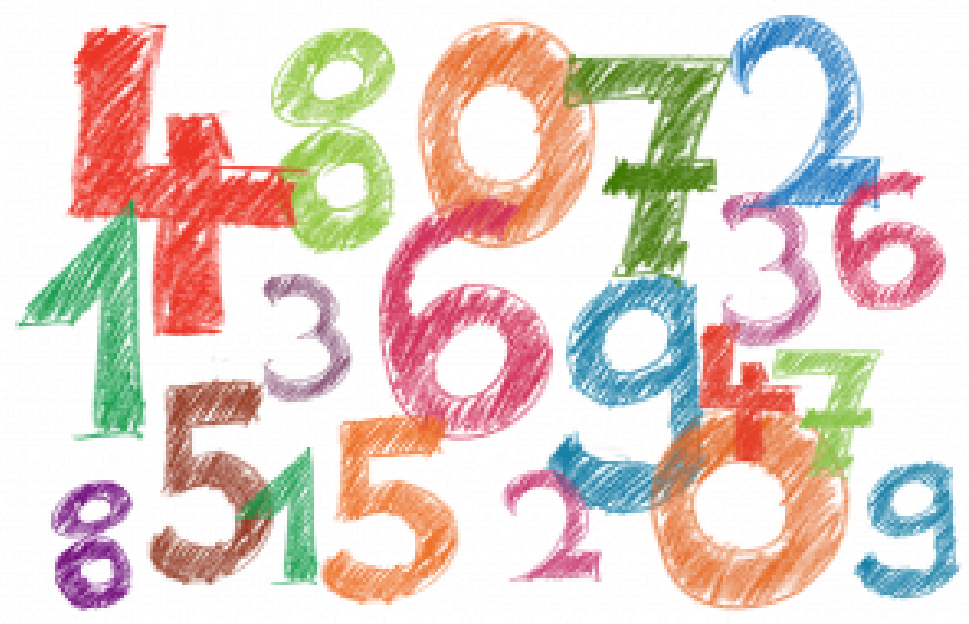

Zahlen 0 - 12 


$$
\begin{array}{cc} 
& 7- \\
0-\text { null } & \text { sieben } \\
1-\text { eins } & 8- \\
2-\text { zwei } & \text { acht } \\
3 \text { - drei } & 9- \\
4-\text { vier } & \text { neun } \\
5-\text { fünf } & 10- \\
6-\text { sechs } & \text { zehn } \\
& 11-\text { elf } \\
& 12- \\
& \text { zwölf }
\end{array}
$$

\section{$\varepsilon$}

Zahlen 1-12. Üben Sie die Zahlen 1 bis 12. Würfeln Sie und addieren Sie die Zahlen. Wenn Sie keine Würfel haben, können Sie hier klicken.

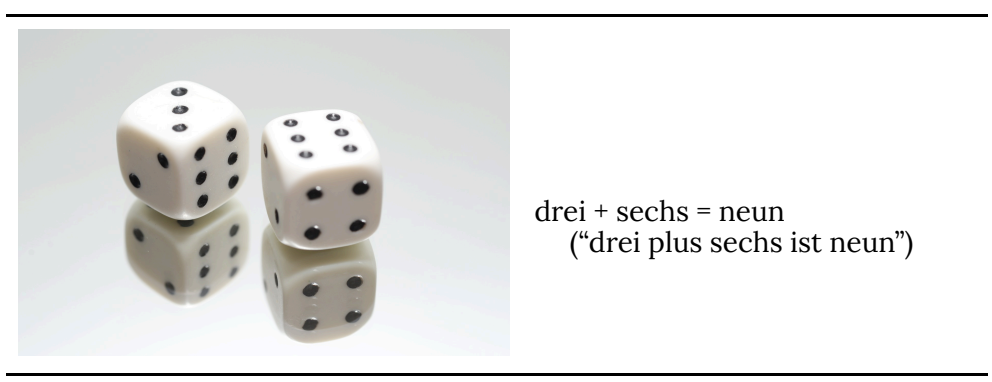

Was ist deine Telefonnummer? Fragen Sie 3 andere Studentinnen oder Studenten im Klassenzimmer.

Beispiel:

Thomas: Hallo Susanne! Was ist deine Telefonnummer? 
Susanne: Hallo Thomas! Ich habe ein Handy. Meine Nummer ist 0173-6734078. Und deine?

Thomas: Meine Handynummer ist 0179-3546183.

\section{Media Attributions}

- group (C) IO-Images is licensed under a Public Domain license

- Alphabet (C) csawatzky is licensed under a CC BY-NC-SA (Attribution NonCommercial ShareAlike) license

- speech bubble (C) IO-Images is licensed under a Public Domain license

- document (C) IO-Images is licensed under a Public Domain license

- Zahlen2 (C) Gerd Altmann is licensed under a Public Domain license

- presentation icon (C) quinntheislander adapted by Solomon Hajramezan is licensed under a Public Domain license

- partner (C) IO-Images is licensed under a Public Domain license

- dice (C) Rudy and Peter Skitterians is licensed under a Public Domain license 


\section{Einheit 1.4 (online)}

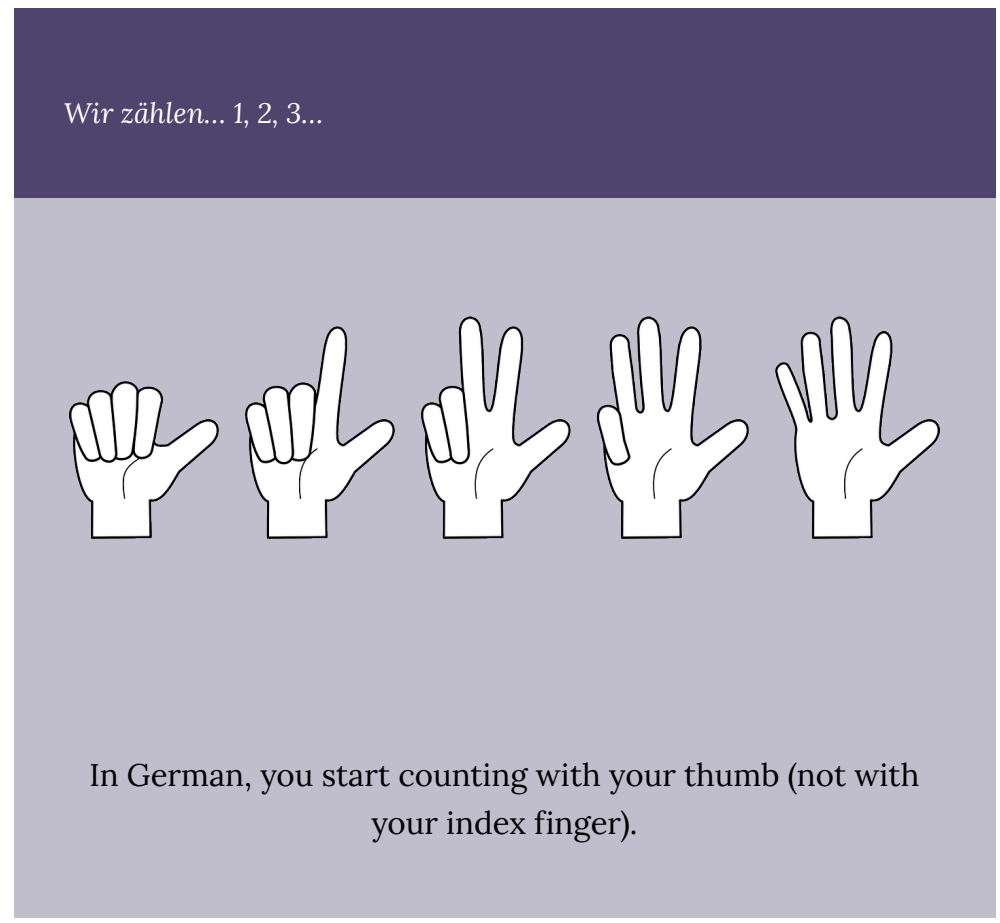

ก

Zahlen. Review 0 - 12 and learn them all the way to $200+$. Listen once and read along and then listen again and say it along with the recording.

One or more interactive elements has been excluded $\sqrt{ }$ from this version of the text. You can view them online here: https://openeducationalberta.ca/willkommendeutsch/?p=55\#audio-55-1 


$\begin{array}{llll} & & 20 \text { zwanzig } & \\ 0 \text { null } & 10 \text { zehn } & 21 \text { einundzwanzig } & 30 \text { dreißig } \\ 1 \text { eins } & 11 \text { elf } & 22 \text { zweiundzwanzig } & 40 \text { vierzig } \\ 2 \text { zwei } & 12 \text { zwölf } & 23 \text { dreiundzwanzig } & 50 \text { fünfzig } \\ 3 \text { drei } & 13 \text { dreizehn } & 24 \text { vierundzwanzig } & 60 \text { sechzig } \\ 4 \text { vier } & 14 \text { vierzehn } & 25 \text { fünfundzwanzig } & 70 \text { siebzig } \\ 5 \text { fünf } & 15 \text { fünfzehn } & 26 & 80 \text { achtzig } \\ 6 \text { sechs } & 16 \text { sechzehn } & \text { sechsundzwanzig } & 90 \text { neunzig } \\ 7 \text { sieben } & 17 \text { siebzehn } & 27 & 100 \text { hundert } \\ 8 \text { acht } & 18 \text { achtzehn } & \text { siebenundzwanzig } & 200 \\ 9 \text { neun } & 19 \text { neunzehn } & 28 \text { achtundzwanzig } & \text { zweihundert } \\ & & \text { neunundzwanzig } & \ldots . .\end{array}$

*ACHTUNG* For fill in the blank activities that correct automatically in this e-textbook, you can correct an incorrect answer right away by continuing to type in the "red" box.

\section{Übung 1}

An interactive H5P element has been excluded from this version of the text. You can view it online here:

https://openeducationalberta.ca/willkommendeutsch/?p=55\#h5p-80

\section{Übung 2}




\section{西}

One or more interactive elements has been excluded

from this version of the text. You can view them online

here: https://openeducationalberta.ca/willkommen-

deutsch/?p=55\#audio-55-2

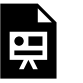

An interactive H5P element has been excluded from this version of the text. You can view it online here:

https://openeducationalberta.ca/willkommen-

deutsch/?p=55\#h5p-79
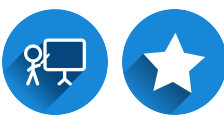

Begrüßen und Verabschieden. Read through the presentation below and complete the activities at the end of the presentation.

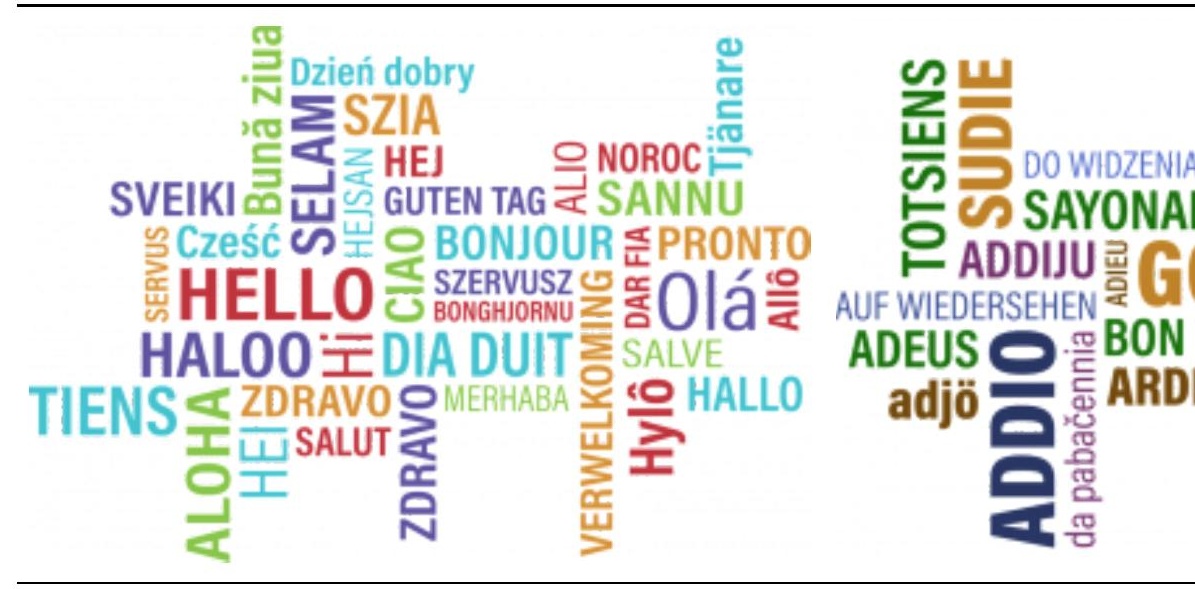


An interactive H5P element has been excluded from this version of the text. You can view it online here:

https://openeducationalberta.ca/willkommen-

deutsch/?p=55\#h5p-14

Aufforderungen. Watch the following video. During Part B of the video please click on the command that you hear.

固

An interactive H5P element has been excluded from this version of the text. You can view it online here:

https://openeducationalberta.ca/willkommen-

deutsch/?p=55\#h5p-75

Übung 3. Drag the commands to the correct picture.

An interactive H5P element has been excluded from this version of the text. You can view it online here:

https://openeducationalberta.ca/willkommendeutsch $/ ? p=55 \# h 5 p-18$ 


\section{Grammatik}

"Sie"-Imperative

In German, we use the "imperative" to give instructions, directions, or commands, and to make requests. There are different forms of the imperative. For now, we are just focusing on the "Sie"-imperative, the polite form used when addressing someone in a formal manner or when addressing a group of people, such as when an instructor is addressing a class of students.

You can add "bitte" to make your command or request more polite.

The "Sie"-imperative is formed with a verb ending in -en, followed by the pronoun "Sie", for example:
Lesen Sie (bitte)!
Please read!

Stehen Sie (bitte) auf! Stand up, please! Please stand up!

\section{Wortschatz in Quizlet:}

$\underline{\text { Kennenlernen }}$

Zahlen

Aufforderungen

Begrüßen und Verabschieden 
Was wissen Sie jetzt? Klicken Sie hier für Quiz 1.4.

Extra Practice (optional):

\section{Video Serie - Nicos Weg}

Click on the link and watch the video. Then click on "start" under the video and do the exercises.

\section{Media Attributions}

- hand (C) OpenClipart-Vectors is licensed under a Public Domain license

- headphones $(\mathbb{C}$ IO-Images is licensed under a Public Domain license

- star (C) IO-Images is licensed under a Public Domain license

- presentation icon (C) quinntheislander adapted by Solomon Hajramezan is licensed under a Public Domain license

- goodbye (C) Mary Pahlke is licensed under a Public Domain license

- link (C) IO-Images is licensed under a Public Domain license

- check mark (C) janjf93 adapted by Solomon Hajramezan is licensed under a Public Domain license 


\section{Einheit 1.5}

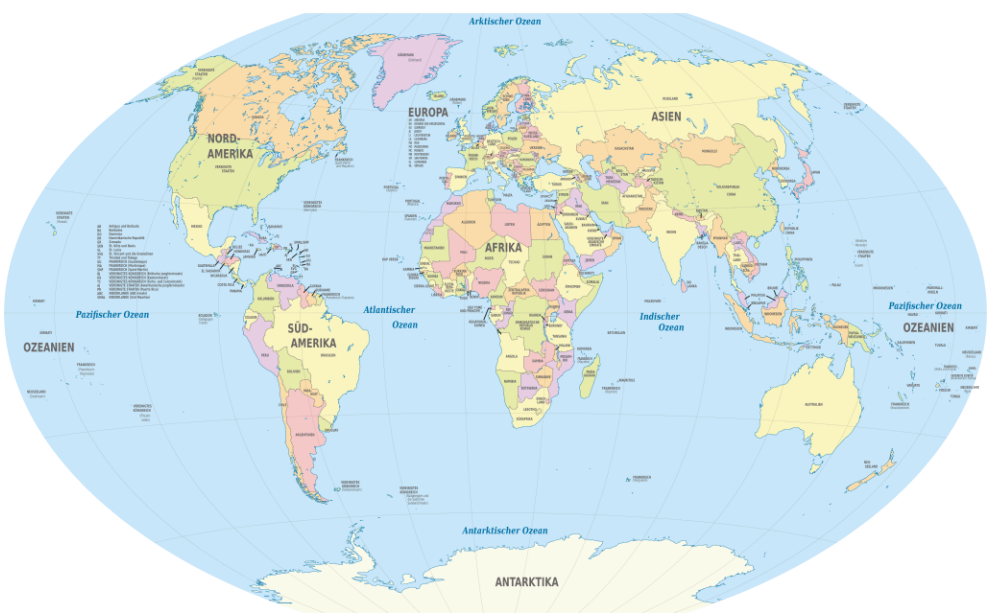

Herkunft und Länder: Woher kommen diese Menschen?

Lesen Sie die Texte. (Please note: the texts refer to the year 2020) 


\begin{tabular}{|c|c|c|}
\hline & $\begin{array}{l}\text { Bonjour! Mein } \\
\text { Name ist } \\
\text { Emmanuel } \\
\text { Macron. Ich } \\
\text { komme aus } \\
\text { Frankreich. Ich } \\
\text { bin Präsident } \\
\text { von Frankreich. } \\
\text { Ich bin } 42 \text { Jahre } \\
\text { alt. Ich bin } \\
\text { Franzose. } \\
\text { Meine } \\
\text { Muttersprache } \\
\text { ist Französisch. } \\
\text { Ich spreche } \\
\text { auch Englisch } \\
\text { und Deutsch. }\end{array}$ & $\begin{array}{l}\text { Guten Tag! Ich } \\
\text { heiße Angela } \\
\text { Merkel und ich } \\
\text { komme aus } \\
\text { Deutschland. } \\
\text { Ich bin } 66 \text { Jahre } \\
\text { alt. Ich bin } \\
\text { Politikerin von } \\
\text { Beruf; ich bin } \\
\text { die } \\
\text { Bundeskanzlerin } \\
\text { von } \\
\text { Deutschland. } \\
\text { Ich bin } \\
\text { Deutsche und } \\
\text { ich spreche } \\
\text { Deutsch, } \\
\text { Russisch und } \\
\text { Englisch. }\end{array}$ \\
\hline & $\begin{array}{l}\text { Hello! Ich heiße } \\
\text { Mila Kunis und } \\
\text { ich bin } \\
\text { Schauspielerin. } \\
\text { Ich bin } 37 \text { Jahre } \\
\text { alt. Ich komme } \\
\text { aus der } \\
\text { Ukraine, aber } \\
\text { ich wohne in } \\
\text { den USA. Ich } \\
\text { bin } \\
\text { Amerikanerin } \\
\text { und ich } \\
\text { spreche } \\
\text { Englisch und } \\
\text { Russisch. }\end{array}$ & $\begin{array}{l}\text { Hi, ich heiße } \\
\text { Connor } \\
\text { McDavid. Ich } \\
\text { komme aus } \\
\text { Kanada; ich bin } \\
\text { Kanadier. Ich } \\
\text { bin } 23 \text { Jahre alt } \\
\text { und ein sehr } \\
\text { guter } \\
\text { Hockeyspieler. } \\
\text { Ich spreche nur } \\
\text { eine Sprache: } \\
\text { Englisch. }\end{array}$ \\
\hline हैenz & $\begin{array}{l}\text { Grüezi! Mein } \\
\text { Name ist Roger } \\
\text { Federer und ich } \\
\text { bin 39 Jahre alt. } \\
\text { Ich spiele sehr } \\
\text { gut Tennis. Ich } \\
\text { komme aus der } \\
\text { Schweiz, ich } \\
\text { bin also } \\
\text { Schweizer. } \\
\text { Aber ich habe } \\
\text { auch einen } \\
\text { Pass aus } \\
\text { Südafrika. Ich } \\
\text { spreche } \\
\text { Deutsch, } \\
\text { Englisch und } \\
\text { Französisch. }\end{array}$ & $\begin{array}{l}\text { Hallo, ich bin } \\
\text { Fatih Akin. Ich } \\
\text { bin } 47 \text { Jahre alt } \\
\text { und mein Beruf } \\
\text { ist } \\
\text { Filmregisseur. } \\
\text { Ich komme aus } \\
\text { Hamburg } \\
\text { (Deutschland), } \\
\text { aber meine } \\
\text { Eltern kommen } \\
\text { aus der Türkei. } \\
\text { Ich bin } \\
\text { Deutscher und } \\
\text { ich spreche } \\
\text { Deutsch und } \\
\text { Türkisch. }\end{array}$ \\
\hline
\end{tabular}


Hören Sie die Texte.

One or more interactive elements has been excluded from this version of the text. You can view them online here: https://openeducationalberta.ca/willkommendeutsch/?p=57\#audio-57-1

Füllen Sie die Tabelle aus.

\begin{tabular}{|c|l|l|l|l|l|}
\hline Name & $\begin{array}{c}\text { Herkunft } \\
\text { (Land) }\end{array}$ & Nationalität & Sprache(n) & Alter & Beruf \\
\hline $\begin{array}{l}\text { Emmanuel } \\
\text { Macron }\end{array}$ & $\ldots$ & & & & \\
\hline
\end{tabular}

Sich vorstellen. Machen Sie Interviews mit 3 Studentinnen oder Studenten und stellen Sie sich vor. Benutzen Sie die Redemittel.

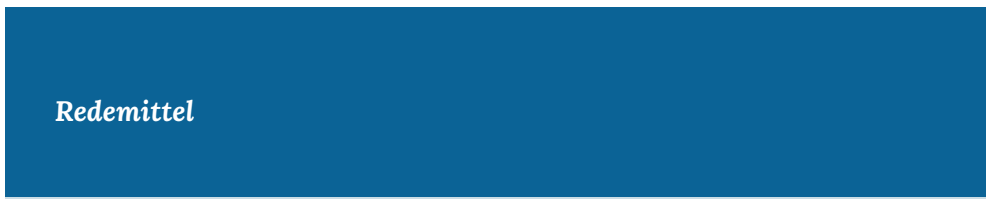

begrüßen: Hallo! / Guten Morgen! / Guten Tag! / Grüß dich! 


\begin{tabular}{|c|l|}
\hline fragen & antworten \\
\hline $\begin{array}{c}\text { Wie geht es Ihnen? / Wie } \\
\text { geht es dir? / Wie geht's? }\end{array}$ & $\begin{array}{l}\text { Mir geht es sehr gut. } \\
\text { Es geht. } \\
\text { Mir geht es schlecht. }\end{array}$ \\
\hline $\begin{array}{c}\text { Wie heißen Sie? / Wie heißt } \\
\text { du? }\end{array}$ & $\begin{array}{l}\text { Mein heiße ... / Ich bin ... / / } \\
\rightarrow \text { Freut mich! .. } \\
\text { Schön, Sie kennenzulernen! } \\
\text { (formal) } \\
\rightarrow \text { Schön, dich } \\
\text { kennenzulernen! (informal) }\end{array}$ \\
\hline $\begin{array}{l}\text { Woher kommen Sie?/ } \\
\text { Woher kommst du? }\end{array}$ & Ich komme aus ... \\
\hline $\begin{array}{c}\text { Wo wohnen Sie (jetzt)?/ Wo } \\
\text { wohnst du (jetzt)? }\end{array}$ & Ich wohne in ... \\
\hline $\begin{array}{l}\text { Wie alt sind Sie?/ Wie alt } \\
\text { bist du? }\end{array}$ & Ich bin ... Jahre alt. \\
\hline $\begin{array}{c}\text { Welche Sprachen sprechen } \\
\text { Sie? / Welche Sprachen } \\
\text { sprichst du? }\end{array}$ & Ich spreche ... \\
\hline $\begin{array}{c}\text { Was ist Ihre } \\
\text { Telefonnummer? / Was ist } \\
\text { deine Telefonnummer? }\end{array}$ & Meine Telefonnummer ist ... \\
\hline
\end{tabular}

verabschieden: Tschüs! / Auf Wiedersehen! / Bis bald! / Bis später!

*ACHTUNG* All German nouns are capitalized, whether they are common nouns (objects, concepts: "die Sprache", "der Kanadier", "das Jahr") or proper nouns (names of people, countries, etc.: "Angela", "Deutschland"). 


\section{Media Attributions}

- World (C) TUBS is licensed under a CC BY-SA (Attribution ShareAlike) license

- book (C) IO-Images is licensed under a Public Domain license

- Emmanuel Macron is licensed under a CC BY (Attribution) license

- Angela_Merkel C Müller / MSC is licensed under a CC BY (Attribution) license

- Mila_Kunis_ (C) Gage Skidmore is licensed under a CC BY-SA (Attribution ShareAlike) license

- $\underline{\text { Connor_McDavid (C) Connor Mah is licensed under a CC BY-SA }}$ (Attribution ShareAlike) license

- $\underline{\text { Roger_Federer (C) Tatiana is licensed under a CC BY-SA }}$ (Attribution ShareAlike) license

- Fatih Akin (C) nicolas genin is licensed under a CC BY-SA (Attribution ShareAlike) license

- headphones (C) IO-Images is licensed under a Public Domain license

- document (C) IO-Images is licensed under a Public Domain license

- speech bubble (C) IO-Images is licensed under a Public Domain license 


\section{Einheit 1.6 (online)}

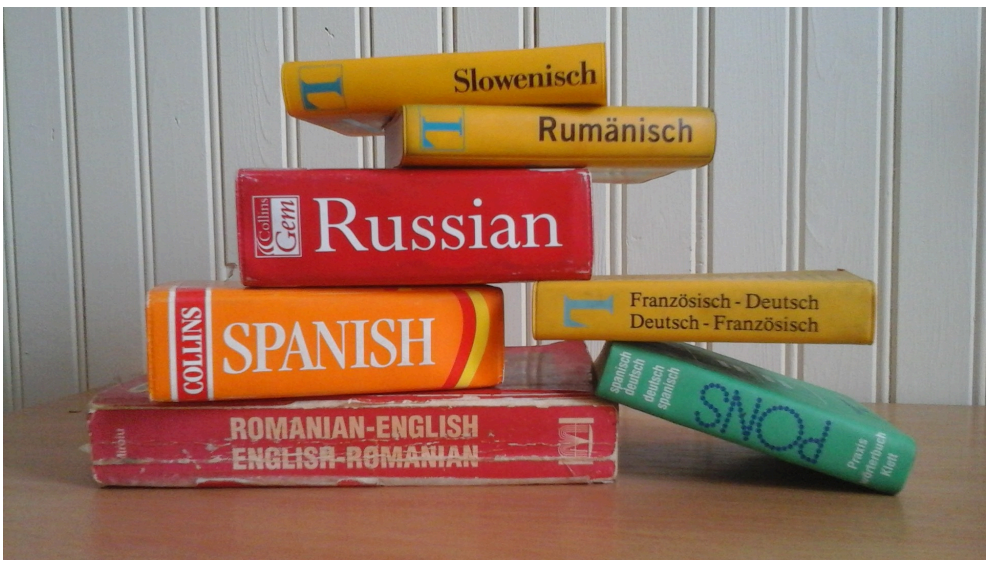

\section{Übung 1: Wer ist Christoph Waltz?}

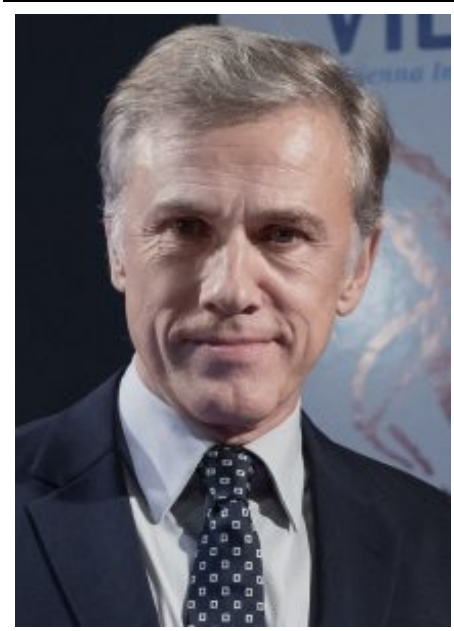

An interactive H5P element has been excluded from this version of the text. You can view it online here:

\section{https://openeducationalberta.ca/} willkommen-deutsch/?p=59\#h5p-1s

Die Weltkarte. Hören Sie: woher kommen diese Menschen? 
Machen Sie Notizen über Herkunft, Nationalität, Sprachen, Alter und Beruf.
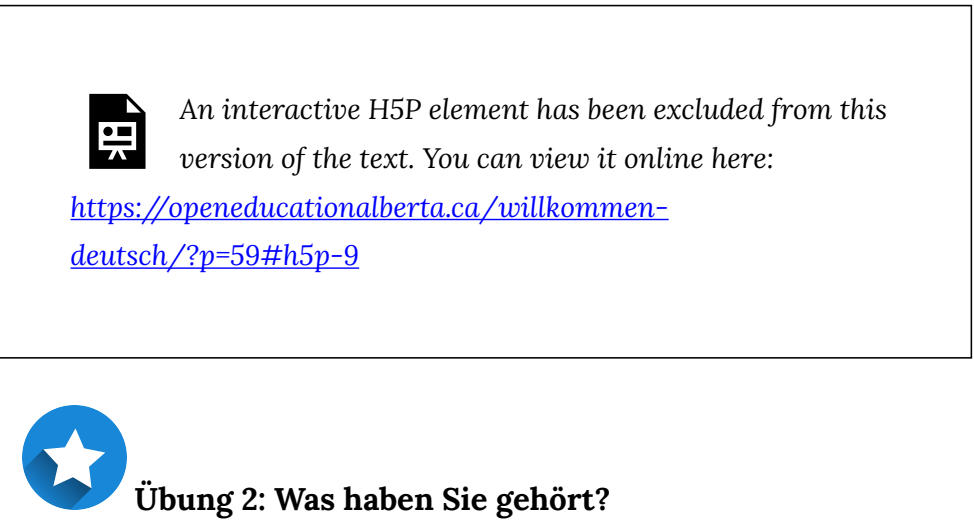

An interactive H5P element has been excluded from this
version of the text. You can view it online here:
https://openeducationalberta.ca/willkommen-
$\underline{\text { deutsch/? } p=59 \# h 5 p-199}$

Übung 3: Welche Sprache passt? Drag the correct language to the correct flag.

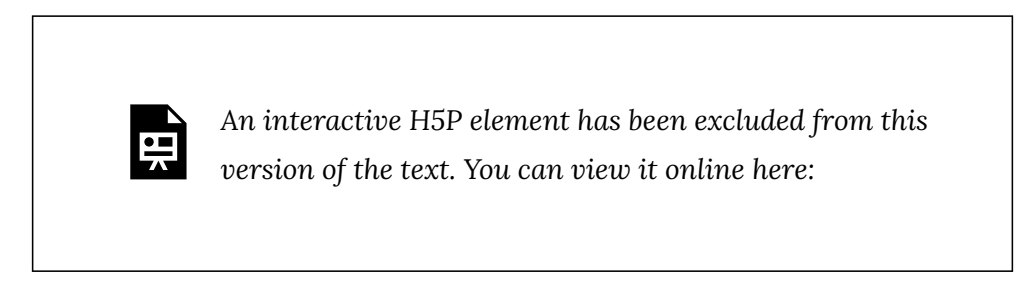


https://openeducationalberta.ca/willkommen-

deutsch/?p=59\#h5p-25

Länder und Sprachen. Click here to find more countries and languages in German. It is important to learn the ones that are applicable to you and your family. Write them into your notes for future use.

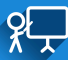

\section{Farben}

An interactive H5P element has been excluded from this version of the text. You can view it online here:

https://openeducationalberta.ca/willkommen-

deutsch/?p=59\#h5p-8

Übung 4. Drag the colour to the correct paint brush. 
https://openeducationalberta.ca/willkommen-

deutsch/?p=59\#h5p-10

\section{Übung 5}

An interactive H5P element has been excluded from this version of the text. You can view it online here:

https://openeducationalberta.ca/willkommendeutsch/?p=59\#h5p-7

\section{*ACHTUNG*}

You will often use colours as adjectives to describe things:

Der Frosch ist grün.

Der Apfel ist rot.

However, there may be times when you use a colour as a noun. Remember all nouns are always capitalized.

Was ist deine Lieblingsfarbe? Meine Lieblingsfarbe ist Blau. 


\section{Wortschatz in Quizlet:}

Länder

Sprachen

Farben

Was wissen Sie jetzt? Klicken Sie hier für Quiz 1.6.

\section{Media Attributions}

- dictionary-2317654_1920 @ Tessa Kavanagh is licensed under a Public Domain license

- star (C) IO-Images is licensed under a Public Domain license

- Waltz (C) Manfred Werner (Tsui) is licensed under a CC BY-SA (Attribution ShareAlike) license

- headphones (C) IO-Images is licensed under a Public Domain license

- link (C) IO-Images is licensed under a Public Domain license

- presentation icon (C) quinntheislander adapted by Solomon Hajramezan is licensed under a Public Domain license

- check mark (C) janjf93 adapted by Solomon Hajramezan is licensed under a Public Domain license 


\section{Einheit 1.7}
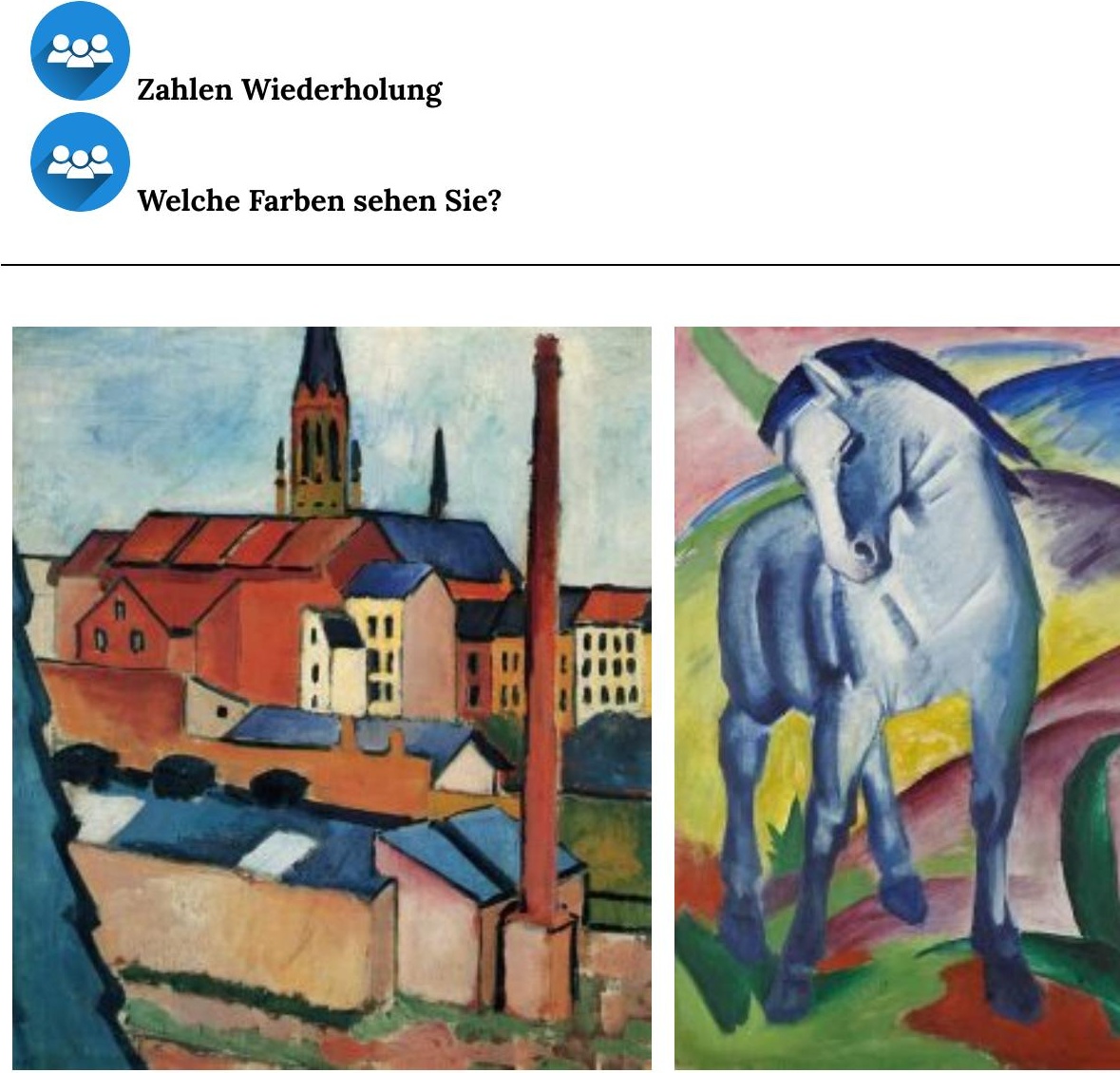

August Macke (1887-1914): Marienkirche mit Häusern und Schornstein

Franz Marc (1880-1916): Blaues P

Wetter und Jahreszeiten 
An interactive H5P element has been excluded from this version of the text. You can view it online here:

https://openeducationalberta.ca/willkommendeutsch/?p=61\#h5p-2

Wie ist das Wetter heute in ...?

Gehen Sie zu wetter.de und sehen Sie die Wetterkarte von Deutschland an. Beschreiben Sie das Wetter in ein paar Städten wie im Beispiel.

Beispiel:

Heute ist es warm in Frankfurt. Die Sonne scheint. Es ist plus 15 Grad.

암ำ

Deutschlandkarte 


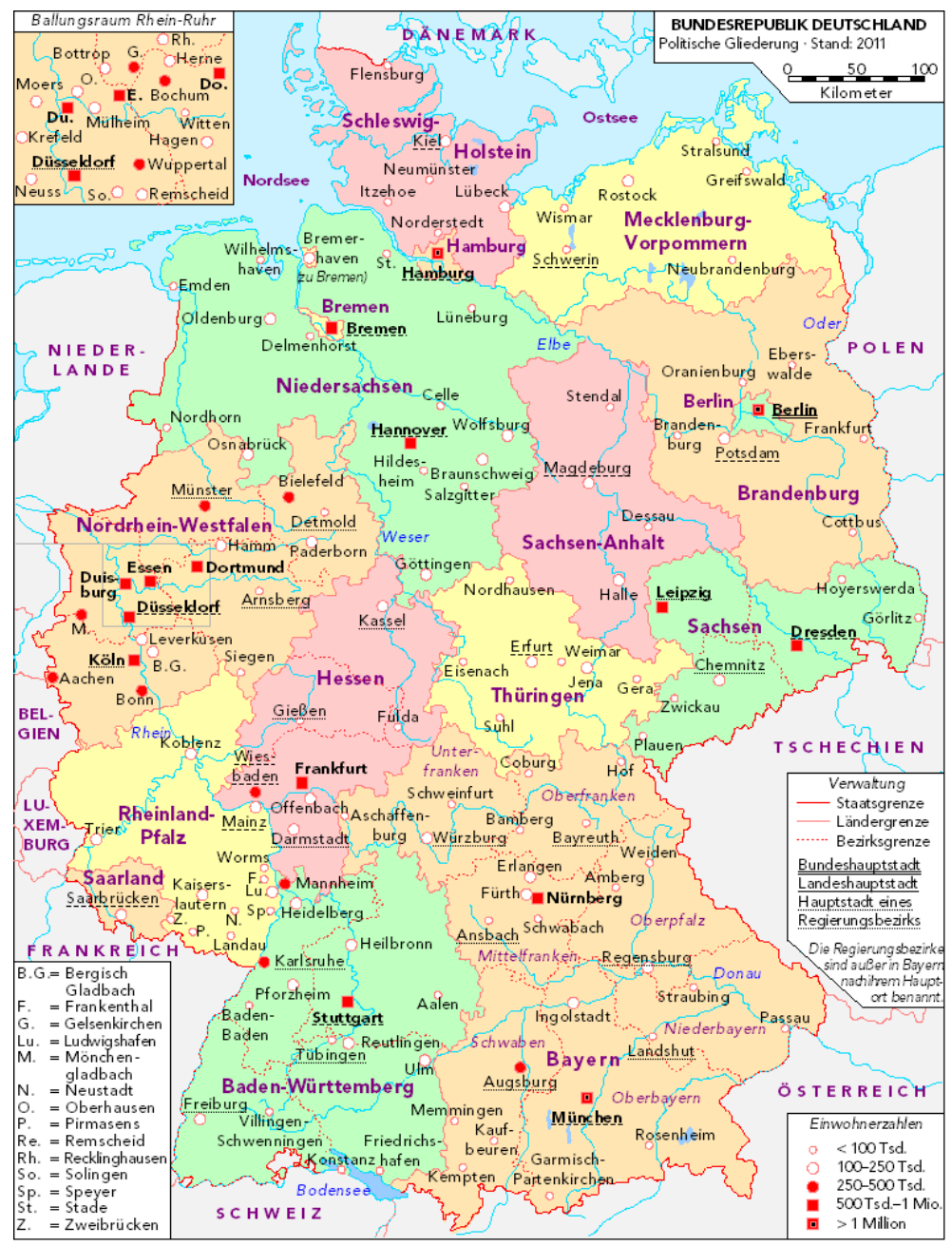


An interactive H5P element has been excluded from this version of the text. You can view it online here:

https://openeducationalberta.ca/willkommen-

deutsch/?p=61\#h5p-11

\section{Media Attributions}

- group (C) IO-Images is licensed under a Public Domain license

- presentation icon (C) quinntheislander adapted by Solomon Hajramezan is licensed under a Public Domain license

- magnifying-glass (C IO-Images is licensed under a Public Domain license

- Deutschland_politisch_bunt (C) Korny78 is licensed under a CC BY-SA (Attribution ShareAlike) license 


\section{Einheit 1.8 (online)}
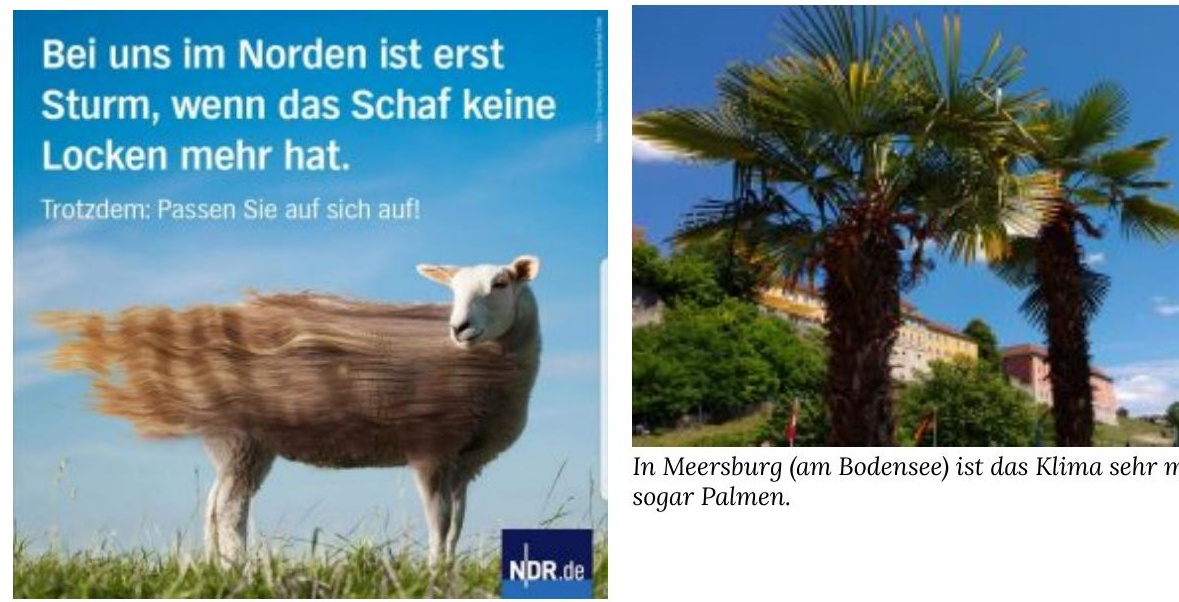

In Meersburg (am Bodensee) ist das Klima sehr $n$ sogar Palmen.

\section{Übung 1}

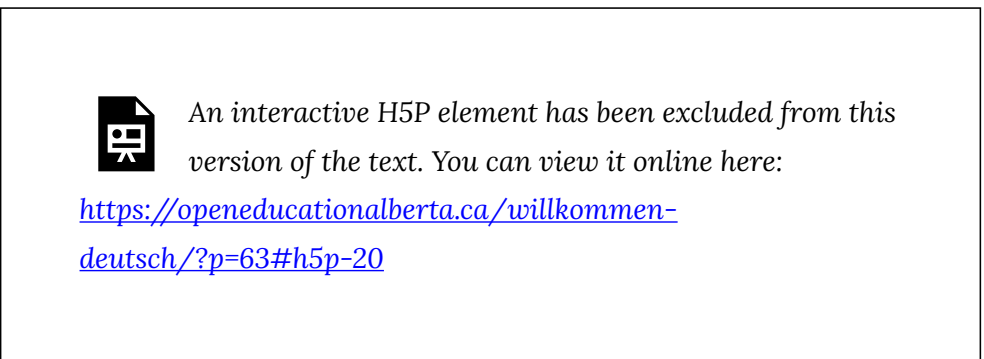

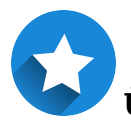

Übung 2. Read through the presentation and then answer the questions at the end of it. 
An interactive H5P element has been excluded from this version of the text. You can view it online here:

https://openeducationalberta.ca/willkommen-

deutsch/?p=63\#h5p-13

\section{Grammatik}

Conjugation of "sein" and "haben"

These two verbs are used frequently and are irregular verbs. They must be memorized!

\begin{tabular}{|c|c|c|c|}
\hline "sein" & & "haben" & \\
\hline ich bin & I am & ich habe & I have \\
\hline du bist & you are & du hast & you have \\
\hline $\begin{array}{c}\text { er/sie/es } \\
\text { ist }\end{array}$ & he/she/it & $\begin{array}{c}\text { er/sie/es } \\
\text { is }\end{array}$ & $\begin{array}{c}\text { he/she/it } \\
\text { has }\end{array}$ \\
\hline wir sind & we are & wir haben & we have \\
\hline ihr seid & you (pl.) are & ihr habt & $\begin{array}{c}\text { you (pl.) } \\
\text { have }\end{array}$ \\
\hline sie/Sie sind & $\begin{array}{c}\text { they/you } \\
\text { (formal) are }\end{array}$ & $\begin{array}{c}\text { sie/Sie } \\
\text { haben }\end{array}$ & $\begin{array}{c}\text { they/you } \\
\text { (formal) have }\end{array}$ \\
\hline
\end{tabular}

*ACHTUNG* Just because we now know "I am ..." or "I have ..." doesn't mean we can just translate from English 
into German. One of the biggest mistakes that language learners make is to think you can just translate from one language into the other.

For example: How are you? I am good.

You may want to say:

Wie bist du? Ich bin gut.

This does NOT work in German. Remember what we learned in 1.1 and 1.5:

Wie geht es dir? Mir geht es gut.

You will learn other expressions like this through out the book.

sie es wir ihr sie ich du er sie es wir duer sie es wir inr sie ich du er sie ichduer sie es, inr sie ich.uer wir ihr sie ich du er sie es wir inr er sie es wir ihr sie ich du er sie es inr sie ichduer sie es wir ihr sie i es wir ihr sie ich du er sie és wir sie ich du er sie es wir inr sie ich

\section{Grammatik}


Personal Pronouns refer to the person or thing which performs the action expressed by the verb. Pronouns stand in for nouns when it is clear who is being talked about. For example, when you want to talk about a person without repeating their name, you use a personal pronoun. You have already seen all these pronouns used in sentences.

\begin{tabular}{|r|l|}
\hline ich & I \\
\hline$d u$ & you (informal singular) \\
\hline $\begin{array}{c}e r / \\
\text { sie/es }\end{array}$ & he/she/it \\
\hline wir & we \\
\hline$i h r$ & you (informal plural) \\
\hline sie & they \\
\hline Sie & $\begin{array}{c}\text { you (formal singular \& } \\
\text { plural) }\end{array}$ \\
\hline
\end{tabular}

Beispiele:

Was sprichst du? Ich spreche Englisch und Deutsch.

Joaquin kommt aus Peru. $=\mathbf{E r}$ kommt aus Peru.

Olena ist Ukrainerin und Kanadierin. $=$ Sie ist Ukrainerin und Kanadierin.

\section{Übung 3}


An interactive $\mathrm{H} 5 \mathrm{P}$ element has been excluded from this version of the text. You can view it online here:

https://openeducationalberta.ca/willkommen-

deutsch/?p=63\#h5p-21

\section{Übung 4}

An interactive H5P element has been excluded from this

圈 version of the text. You can view it online here:

https://openeducationalberta.ca/willkommen-

deutsch/?p=63\#h5p-22

\section{Grammatik}

Conjugation of Verbs (1)

Here is a list of some of the verbs we have used so far in Einheit 1. Please begin to practice and memorize these verbs. Notice anything similar about the endings of the verb stem? You can click on the infinitive forms of the verbs to see what their English translation would be. 


\begin{tabular}{|c|c|c|c|c|c|}
\hline $\begin{array}{l}\text { Pronom } \\
\text { en }\end{array}$ & $\mathrm{en}^{\text {komm }}$ & en & leben & $e^{\underline{\text { heiß }}}$ & en $^{\text {sprech }}$ \\
\hline ich & $\mathrm{e}^{\mathrm{komm}}$ & $e^{\text {wohn }}$ & lebe & heiße & $\mathrm{e}^{\text {sprech }}$ \\
\hline $\mathrm{du}$ & st ${ }^{k o m m}$ & st ${ }^{\text {wohn }}$ & lebst & heißt & st ${ }_{\text {sprich }}$ \\
\hline es $\mathrm{er} / \mathrm{sie} /$ & $\mathrm{t}^{\mathrm{komm}}$ & $t^{\text {wohn }}$ & lebt & heißt & $t^{\text {sprich }}$ \\
\hline wir & 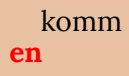 & $\begin{array}{l}\text { wohn } \\
\text { en }\end{array}$ & leben & n heiße & en $\begin{array}{l}\text { sprech } \\
\text { en }\end{array}$ \\
\hline ihr & $\mathrm{t}^{\mathrm{komm}}$ & t wohn & lebt & heißt & t ${ }^{\text {sprech }}$ \\
\hline $\mathrm{sie} / \mathrm{Sie}$ & en ${ }^{k o m m}$ & $e^{\text {wohn }}$ & leben & n heiße & en $\begin{array}{l}\text { sprech } \\
\text { en }\end{array}$ \\
\hline
\end{tabular}

*ACHTUNG*

The underlined portion of the infinitive is the "verb stem". The process of making sure that the verb and pronoun correspond is called conjugation.

Übung 5. Click on the correctly conjugated verb.

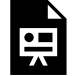

An interactive H5P element has been excluded from this version of the text. You can view it online here:

https://openeducationalberta.ca/willkommen-

deutsch/?p=63\#h5p-23 


\section{Übung 6}

An interactive H5P element has been excluded from this version of the text. You can view it online here:

https://openeducationalberta.ca/willkommen-

deutsch/?p=63\#h5p-24

Wortschatz in Quizlet:

Wetter

Monate und Jahreszeiten

Himmelsrichtungen

Was wissen Sie jetzt? Klicken Sie hier für Quiz 1.8.

Extra Practice (optional):

\section{Video Serie - Nicos Weg}

Click on the link and watch the video. Then click on "start" under the video and do the exercises.

\section{Media Attributions}

- Schaf ohne Locken (C) NDR.de is licensed under a CC BY-NC-SA (Attribution NonCommercial ShareAlike) license 
- star (C) IO-Images is licensed under a Public Domain license

- board-1527805_1920 C Gerd Altmann is licensed under a Public Domain license

- link (C) IO-Images is licensed under a Public Domain license

- check mark (C) janjf93 adapted by Solomon Hajramezan is licensed under a Public Domain license 


\section{Einheit 1.9}

-

Was haben Sie schon gelernt?
An interactive H5P element has been excluded from this version of the text. You can view it online here:
https://openeducationalberta.ca/willkommen- deutsch/?p=65\#h5p-301

8

Verbkonjugation mit Würfeln. Ein Würfel zeigt das Pronomen, ein Würfel zeigt das Verb. Wenn Sie keine Würfel haben, können Sie hier klicken.

Würfeln Sie und konjugieren Sie: 


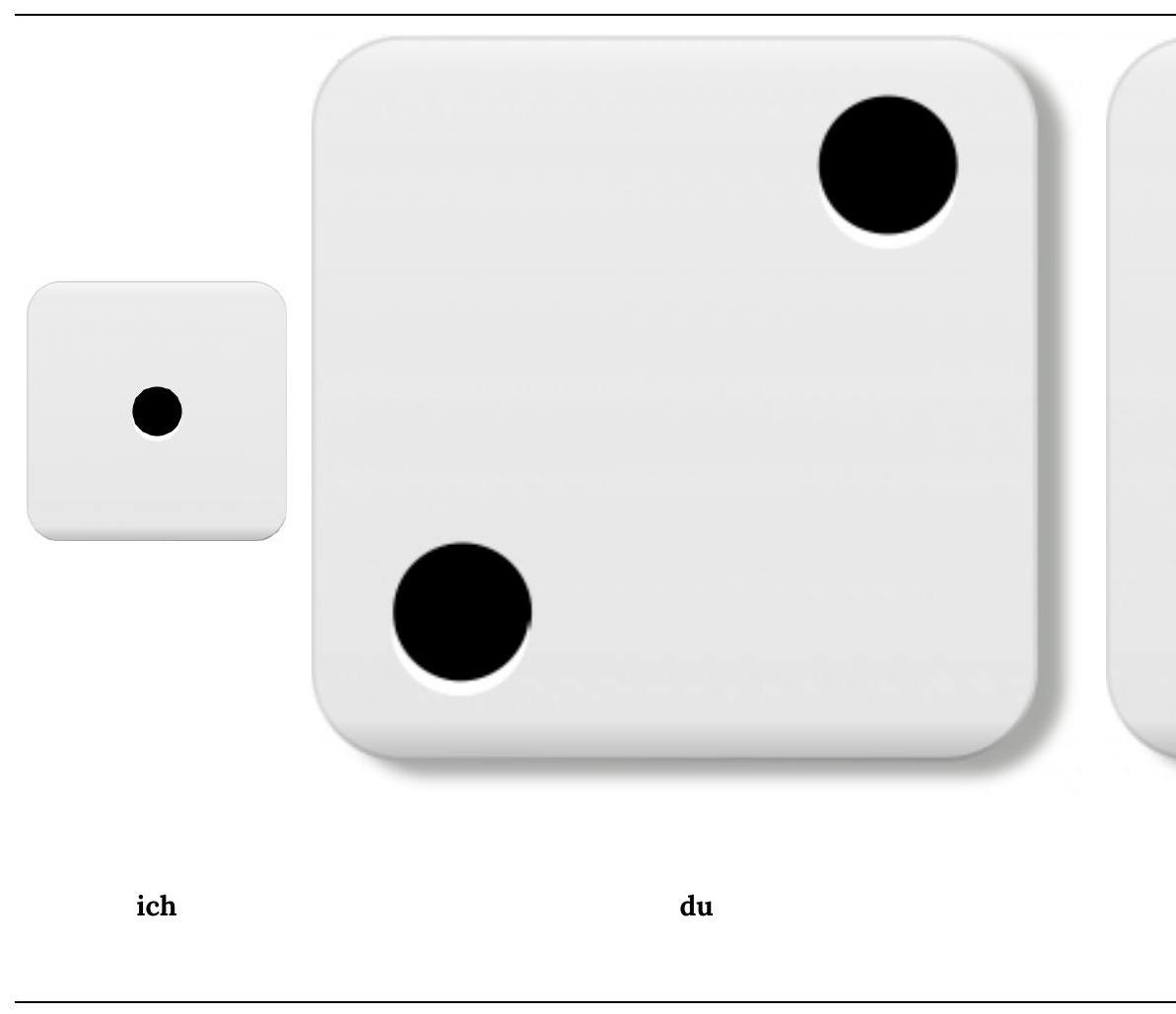




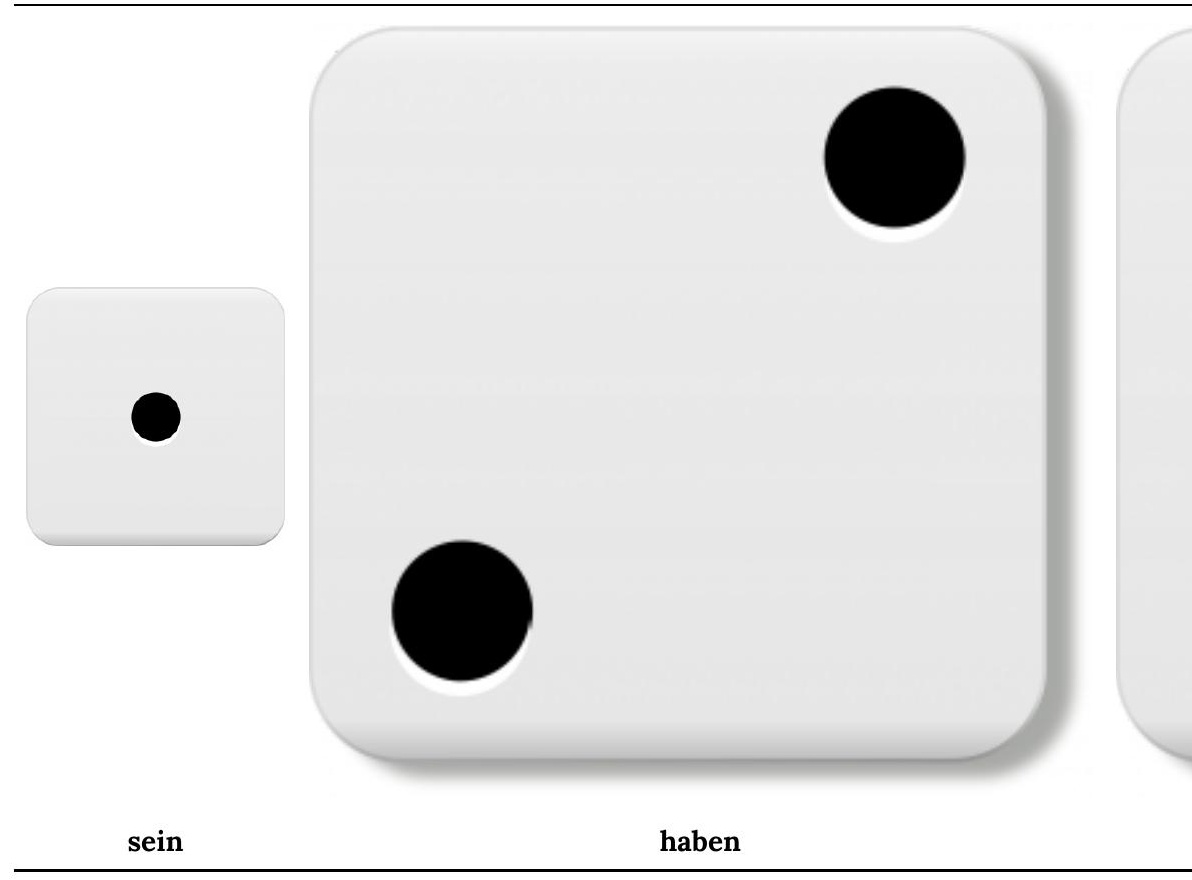

Beispiel:

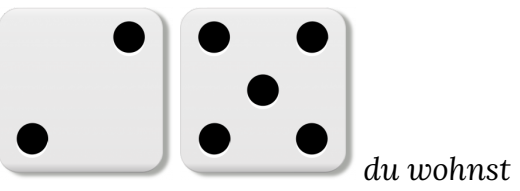

$\varepsilon$

\section{Rollenspiel: Kennenlernen}

Machen Sie ein Rollenspiel mit einer Partnerin oder mit einem Partner. Fragen Sie nach diesen Informationen: Name, Land, Wohnort, Alter, Telefonnummer, Lieblingsfarbe.

- Wie fragt man nach diesen Informationen? Machen Sie Fragen.

- Person A, Person B (Wählen Sie eine Rollenspielkarte aus).

- Machen Sie jetzt ein Interview (Rollenspiel) mit Ihren Fragen und lernen Sie die andere Person kennen. 


\section{Media Attributions}

- group (C) IO-Images is licensed under a Public Domain license

- partner (C) IO-Images is licensed under a Public Domain license

- one (c) Clker-Free-Vector-Images is licensed under a Public Domain license

- two (C) Clker-Free-Vector-Images is licensed under a Public Domain license

- three (C) Clker-Free-Vector-Images is licensed under a Public Domain license

- four (C) Clker-Free-Vector-Images is licensed under a Public Domain license

- five (C) Clker-Free-Vector-Images is licensed under a Public Domain license

- $\underline{\text { six }}$ (C) Clker-Free-Vector-Images is licensed under a Public Domain license 


\section{Einheit 1.10 (online)}

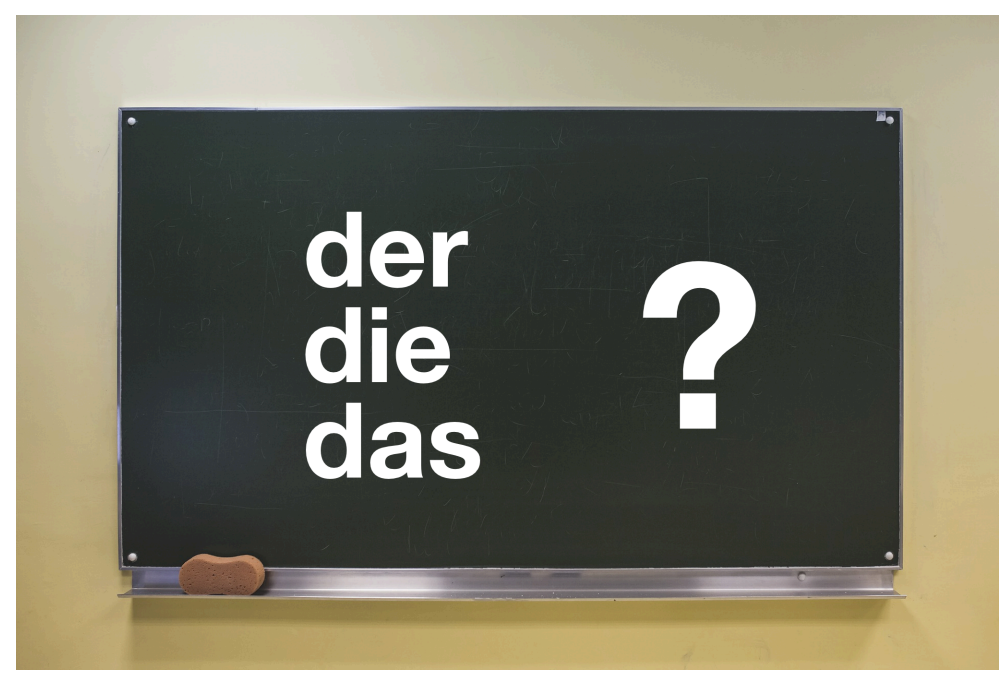

\section{Grammatik}

Grammatical Gender: Nouns and Pronouns

Please work through the following presentation to learn about grammatical gender.

Grammatical Gender: Nouns and Pronouns

\section{Übung 1}


An interactive H5P element has been excluded from this version of the text. You can view it online here:

https://openeducationalberta.ca/willkommen-

deutsch/?p=67\#h5p-26

\section{Q}

Online Dictionary. Use dict.cc and look up the gender of the following German words. Be sure to write down the genders as you will need them in the next activity.

Beispiel: die Frage - there are two places to find the gender. Both places are highlighted on this screenshot.

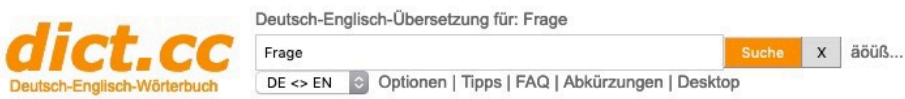

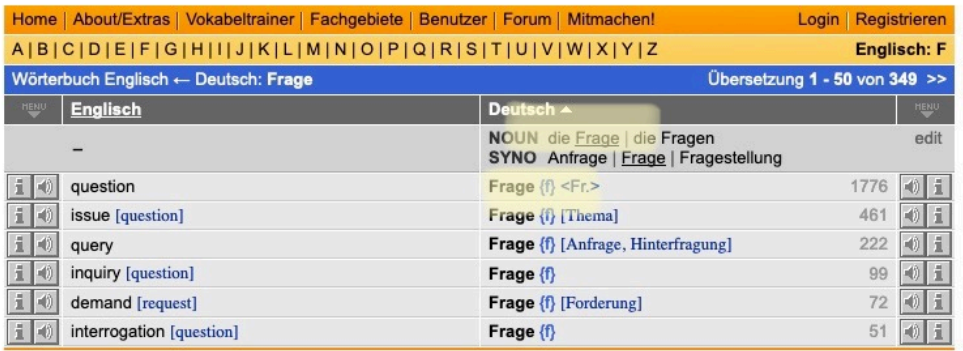

\begin{tabular}{lllll}
\hline Pizza & Natur & Konzert & Supermarkt & Musik \\
Buch & Pilot & Restaurant & Touristin & Haus \\
\hline
\end{tabular}

Übung 2. Drag the noun to the correct article. 
An interactive H5P element has been excluded from this version of the text. You can view it online here:

https://openeducationalberta.ca/willkommen-

deutsch/?p=67\#h5p-27

Wortschatz in Quizlet:

Sonstige Wörter und Ausdrücke

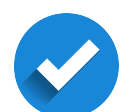

Was wissen Sie jetzt? Klicken Sie hier für Quiz 1.10.

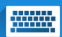

Task 1: Mein Selfie Video

Watch the following examples of Task 1 :

One or more interactive elements has been excluded

므스 from this version of the text. You can view them online here: https://openeducationalberta.ca/willkommendeutsch/?p=67\#oembed-1

One or more interactive elements has been excluded 
$\Delta$ from this version of the text. You can view them online here: $\underline{\text { https://openeducationalberta.ca/willkommen- }}$ deutsch/?p=67\#oembed -2

Make a selfie video introducing yourself and providing basic information about yourself. Use the materials you have learned in this unit. Please do it in one take and do not "edit" your video. Do not read off a script. You can record it yourself or have a friend record it for you. It should be at least 20 seconds long.

This task will be assessed according to the Rubric for Task 1.

*ACHTUNG* In this unit we learned about our "Lieblingsfarbe" and we can even talk about our "Lieblingszahl"; however this doesn't work with "Wetter". We cannot say: Lieblingswetter. Talking about your favourite weather is a little more complicated. If you want to include weather in your selfie video, please focus on the weather in your current city rather than your favourite weather.

\section{Media Attributions}

- design (C) csawatzky is licensed under a CC BY-NC-SA (Attribution NonCommercial ShareAlike) license 
- star (C) IO-Images is licensed under a Public Domain license

- magnifying-glass (C) IO-Images is licensed under a Public Domain license

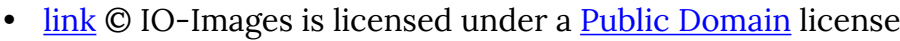

- check mark (C) janjf93 adapted by Solomon Hajramezan is licensed under a Public Domain license

- keyboard (C) IO-Images is licensed under a Public Domain license 


\title{
Wortschatz
}

\author{
Quizlet:
}

Wortschatz Einheit 1 (alle Kategorien)

Kennenlernen

Zahlen

Begrüßen und Verabschieden

Aufforderungen

Länder

Sprachen

Farben

Wetter

Monate und Jahreszeiten

Himmelsrichtungen

Sonstige Wörter und Ausdrücke

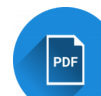

Wortschatz 1

Media Attributions

- $\underline{\text { link }}$ (C) IO-Images is licensed under a Public Domain license

- pdf (C IO-Images is licensed under a Public Domain license 


\section{Zum Spaß!}

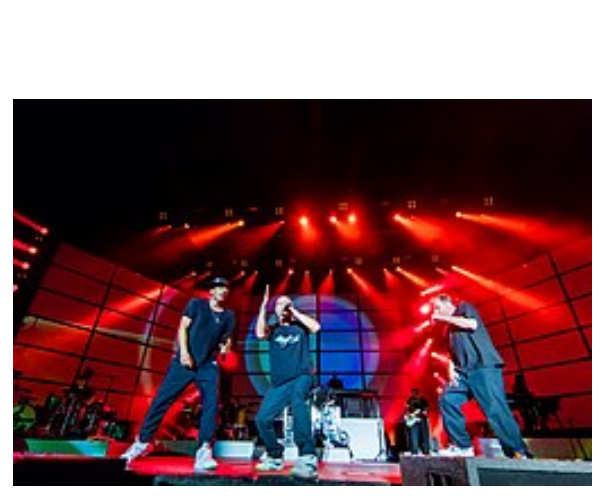

Check out the song "MfG-

Mit freundlichen

Grüßen" byDie

Fantastischen Vier, a

German hip-hop band that

was among the first rap/

hip-hop bands in Germany

actually singing in

German! The song "MfG"

(released in 1999) almost

entirely consists of

abbreviations.

Watch the video here.

How many abbreviations do you understand?

Here are the lyrics if you

want to check or sing along!

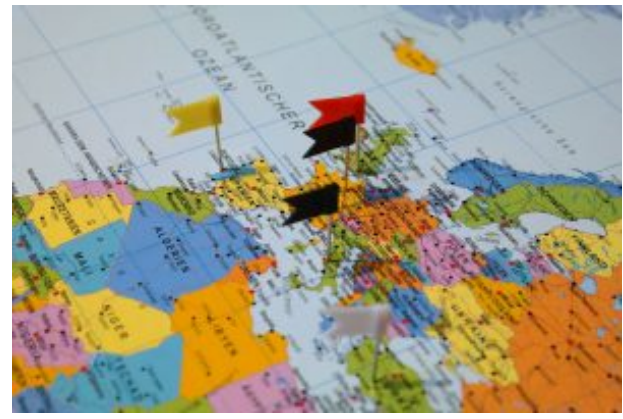

If you'd like to learn the vocabulary for more countries and languages, please check out this link. 

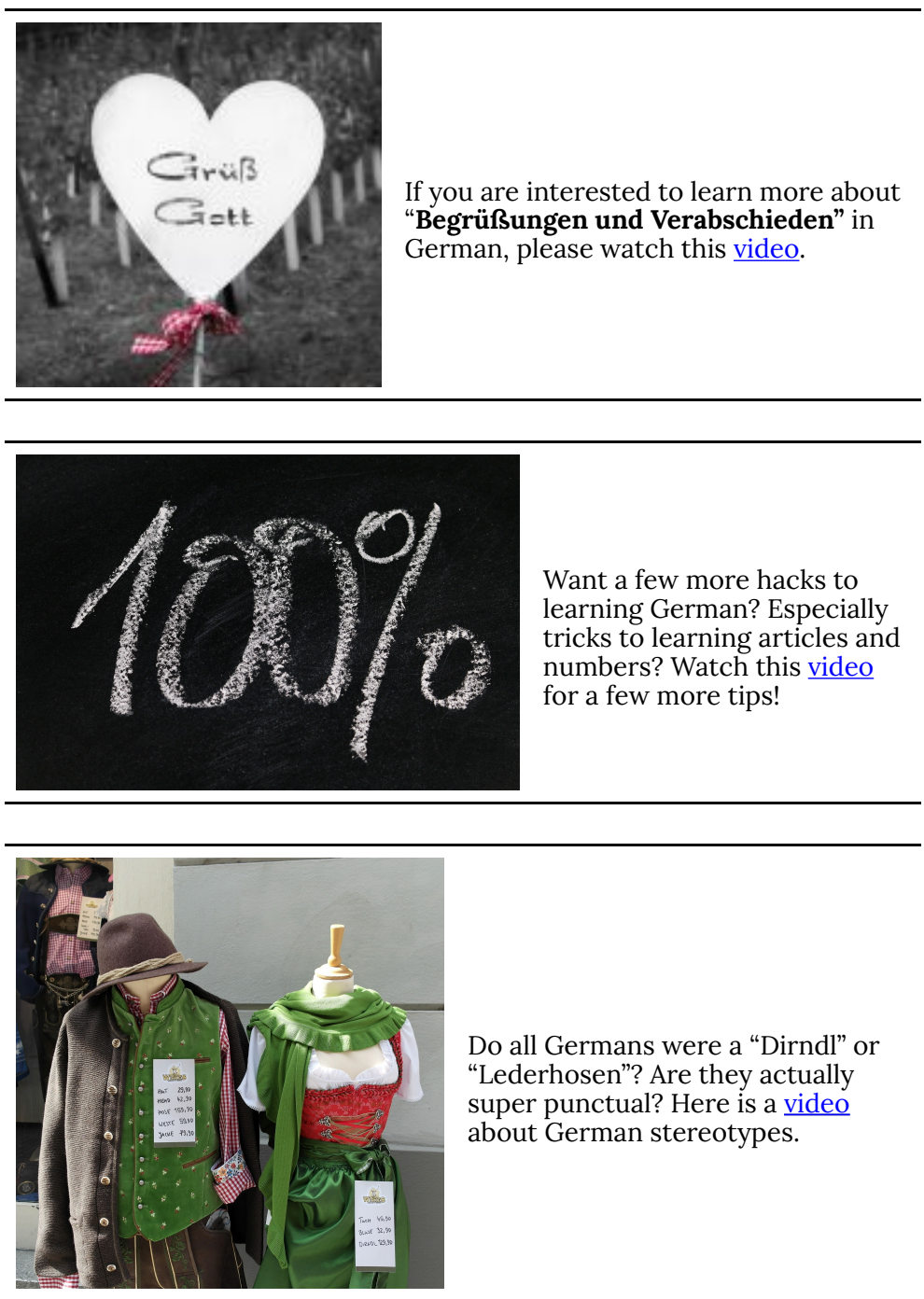

Do all Germans were a "Dirndl" or "Lederhosen"? Are they actually super punctual? Here is a video about German stereotypes. 


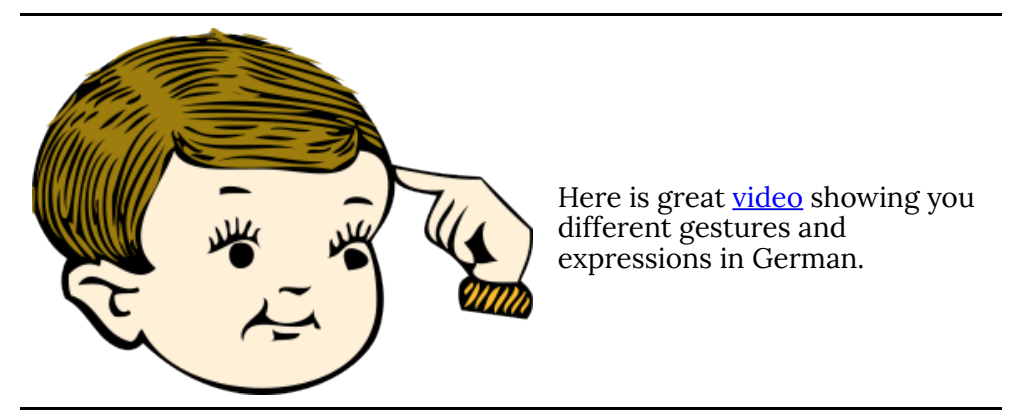

Extra Practice (optional): These activities are from the website Schubert-Verlag.

Zahlen A

Zahlen B

Begrüßen und verabschieden

Sich vorstellen A

Sich vorstellen B

Sich vorstellen $\mathrm{C}$

Sich vorstellen $\mathrm{D}$

Sprachen

Länder und Sprachen

Verben

Wetter und Jahreszeiten

haben

Media Attributions

- 2016225231723 2016-08-12 Rocco del Schlacko - Sven _5DS_R___0236__ 5DSR7614_mod (C) Sven Mandel is licensed under a CC BY-SA (Attribution ShareAlike) license

- destinations (C) Hans Braxmeier is licensed under a Public Domain license

- shield (C) Didgeman is licensed under a Public Domain license 
- one-hundred-1165990_1920 C Gerd Altmann is licensed under a Public Domain license

- clothing (C) RitaE is licensed under a Public Domain license

- alphabet-word-images-g90e6f34ff_1280 (C) OpenClipartVectors is licensed under a Public Domain license 
82 | Zum Spaß! 


\section{EINHEIT 2: UNIVERSITÄT UND FREIZEIT}

\section{Learning Outcomes}

At the end of Einheit 2, you will be able to...

- name and describe items in the classroom

- $\quad$ identify subjects to study at the university

- discuss some of the differences between the German and Canadian school and university systems

- $\quad$ ask what time it is and tell time (both formally and informally)

- negotiate a schedule

- $\quad$ ask and answer questions about a variety of topics

- discuss leisure time activities

- $\quad$ express likes and dislikes

You will also have learned about the following structures:

- the nominative case

- definite and indefinite articles

- negation with "kein"

- $\quad$ plural forms of nouns

- coordinating conjunctions

- $\quad$ word order in statements and questions 
84 | Einheit 2: Universität und Freizeit 


\section{Einheit 2.1}

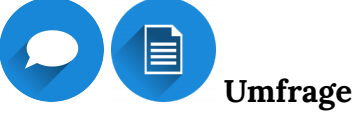

[Ask your fellow classmates these questions. If a student answers with "ja", ask for their name and write it down. If they answer with "nein", ask them a different question. Try to gather as many different names as possible. Always answer in a complete sentence.]

Beispiel:

S1: Bist du 20 Jahre alt? S2: Ja, ich bin 20 Jahre alt./ Nein, ich bin nicht 20 Jahre alt.

1. Bist du 20 Jahre alt?

2. Sprichst du Französisch?

3. Kommst du aus Kanada?

4. Ist deine Lieblingsfarbe Blau?

5. Hast du Freunde in der Schweiz?

6. Sprichst du Spanisch?

7. Ist deine Lieblingsjahreszeit Sommer?

\section{$x$}

\section{Gegenstände im Seminarraum / im Büro}

An interactive H5P element has been excluded from this version of the text. You can view it online here:

https://openeducationalberta.ca/willkommendeutsch/?p=31\#h5p-28 


\section{0}

Beschreibungen von Gegenständen im Seminarraum / im Büro

Was ist ...?

schwarz / weiß / neu / alt / schmutzig / sauber / klein / groß 안

Nomen mit Artikel 
Indefiniter Artikel

Das ist ein Stuhl.

Das ist eine Lampe.

Das ist ein Buch.

Das sind Bücher.

\section{Definiter Artikel}

Der Stuhl ist rot.

Die Lampe ist gelb.

Das Buch ist schwarz.

Die Bücher sind alt.

*Achtung* Das ist/Das sind ("this is/these are") have nothing to do with the article das. 


\section{Im Seminarraum}

An interactive H5P element has been excluded from this version of the text. You can view it online here:

https://openeducationalberta.ca/willkommen-

deutsch/?p=31\#h5p-29

\section{Media Attributions}

- speech bubble (C) IO-Images is licensed under a Public Domain license

- document (C) IO-Images is licensed under a Public Domain license

- presentation icon (C) quinntheislander adapted by Solomon Hajramezan is licensed under a Public Domain license

- group (C IO-Images is licensed under a Public Domain license

- partner (C) IO-Images is licensed under a Public Domain license 
Einheit 2.2 (online)

Grammatik

Cases: The Nominative

You already know that all nouns in German are classified grammatically as masculine, neuter, or feminine, which is indicated by a form of the definite article: "der" (masculine), "die" (feminine), or "das" (neuter), all meaning "the".

When we use a noun or pronoun in a sentence, we also assign specific cases to those nouns and pronouns to signal their function in the sentence. There are four cases in German. Today, we are focusing on the nominative case. Look at the following example sentences:

Die Tafel ist weiß.

Meine Partnerin heißt Karla.

Das ist ein Buch.

Es ist blau.

Monique wohnt in Montreal.

The bolded parts are in the nominative case, because they are the subjects of the sentences.

*ACHTUNG* The subject of a sentence is always in the nominative case.

Übung 1. Drag the noun to the correct article. 
An interactive $\mathrm{H} 5 \mathrm{P}$ element has been excluded from this version of the text. You can view it online here:

https://openeducationalberta.ca/willkommen-

deutsch/?p=84\#h5p-30

\section{Grammatik}

Definite and Indefinite Articles

German uses three definite articles, "der" (masculine), "die" (feminine), or "das" (neuter), all meaning "the", to show the gender of a noun.

There are also indefinite articles in German, meaning "a" or "an" in English, for the three grammatical genders: "ein" (masculine), "eine" (feminine), and "ein" (neuter). Obviously, there is no indefinite article for the plural (just like in English, you couldn't say "a books"). 


\begin{tabular}{|c|l|l|}
\hline masculine & $\begin{array}{l}\text { Singular } \\
\text { der Tisch } \\
\text { ein Tisch }\end{array}$ & $\begin{array}{l}\text { Plural Tische } \\
\text { Tische }\end{array}$ \\
\hline feminine & $\begin{array}{l}\text { die Lampe } \\
\text { eine Lampe }\end{array}$ & $\begin{array}{l}\text { die Lampen } \\
\text { Lampen }\end{array}$ \\
\hline neuter & $\begin{array}{l}\text { das Buch } \\
\text { ein Buch }\end{array}$ & $\begin{array}{l}\text { die Bücher } \\
\text { Bücher }\end{array}$ \\
\hline
\end{tabular}

$\operatorname{der}(\mathrm{m}.) \rightarrow$ ein $\operatorname{die}(\mathbf{f}.) \rightarrow$ eine $\operatorname{das}(n.) \rightarrow$ ein die (pl.) $\rightarrow \varnothing$

*ACHTUNG* In German, when stating someone's nationality, place of residence or occupation no indefinite article is used.

Fatih Akin ist Deutscher. Fatih Akin is a German.

Maren ist Studentin. Maren is a student.

Ich bin Berliner. I am a Berliner.

[Remember when J.F. Kennedy visited Berlin in 1963, he said: "Ich bin ein Berliner." Had he learned German with us, he would have known not to use the indefinite article. Literally, he said "I'm a jelly donut". However, the historical significance of his statement, though not entirely correct, was not lost on the people of Berlin.]

Übung 2 (Reminder: If you get it wrong you can correct it right away. Just continue typing in the "red" box to make your correction.) 
An interactive $\mathrm{H} 5 \mathrm{P}$ element has been excluded from this version of the text. You can view it online here:

https://openeducationalberta.ca/willkommen-

deutsch/?p=84\#h5p-32

\section{Grammatik}

Negation with "kein"

There are several ways to express negation in German. Look at the following three sentences:

Ist das ein Tisch? Nein, das ist kein Tisch.

Ist das eine Lampe? Nein, das ist keine Lampe.

Sind das Amerikaner? Nein, das sind keine Amerikaner, das sind Kanadier.

The negative form of the indefinite article "ein" is "kein" (for masculine and neuter) and the negative form of the indefinite article "eine" is "keine" (for feminine). There is also a plural form "keine". In English, they mean "not a", "not any", "no". 


\begin{tabular}{|l|l|}
\hline masculine & ein $\rightarrow$ kein \\
\hline feminine & $\begin{array}{c}\text { eine }-> \\
\text { keine }\end{array}$ \\
\hline neuter & ein $\rightarrow$ kein \\
\hline plural & $\varnothing->$ keine \\
\hline
\end{tabular}

If you are not negating a noun preceded by an indefinite article ("ein"/"eine") in the sentence, you use "nicht" (not). The "nicht" goes in front of the element you want to negate, for example:

Die Tafel ist nicht weiß.

Monique wohnt nicht in Deutschland.

When you don't want to negate a particular word or expression, you place "nicht" at the end of the sentence.

Heute regnet es nicht.

Stefan kommt auch nicht.

"Nicht" is much more complicated to use than "kein" and you will continue to see examples of where to place it in a sentence in the next few units.

\section{Übung 3}

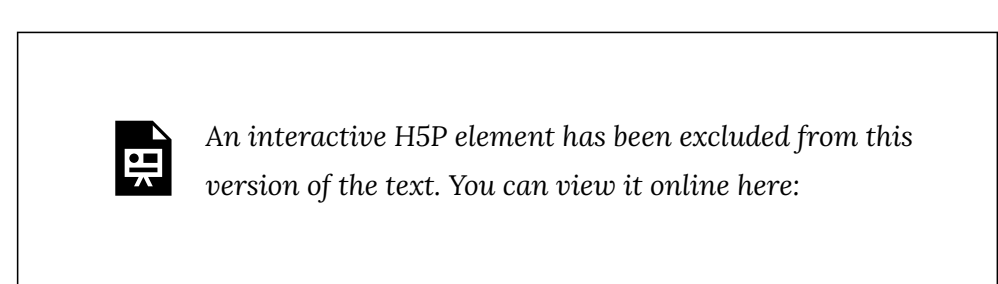


https://openeducationalberta.ca/willkommen-

deutsch/?p=84\#h5p-33

\section{Grammatik}

Plural Forms of Nouns

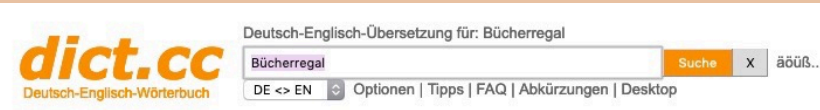

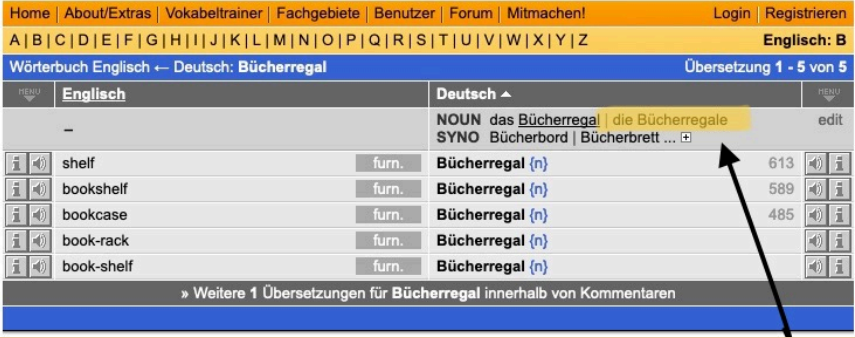

In English, most plurals are formed by adding an "-s" or "es" to the noun (e.g., students, classes, pens), although there are some irregular plural forms in English (e.g., women, children, geese).

Forming the plural of nouns in German is a bit more 
complicated than in English. There are several rules one could memorize, but that wouldn't account for the exceptions. We recommend that you learn the plural form of each noun when you are learning the noun itself: das Bücherregal, die Bücherregale.

Some dictionaries (like dict.cc as shown in the screenshot) write out the plural forms. Other dictionaries only indicate the plural form by abbreviations; you need to understand how to form a plural when you see those abbreviations, for example:

die Lampe, $-n$ (this means: you just add $-n$ to the noun; die Lampen is the plural form)

das Fenster, - (this means: you don't add an ending to the noun; die Fenster is the plural form)

die Mutter, -" (this means: you don't add an ending to the noun, just the Umlaut on the vowel; die Mütter is the plural form)

Online Wörterbuch. Use the online dictionary dict.cc to look up the plural forms of the following nouns. Put in the German word in order to get the plural form indicated as above. Or, if you put in an English word (if you need a translation first), click on the German translation provided and you will get the plural form on a separate page.

Be sure to write down the forms as you will need them in the quiz.

$\begin{array}{lllll}\text { der Computer } & \text { die Wand } & \text { das Tablet } & \text { der Bleistift } & \text { die Uhr } \\ \text { der Stuhl } & \text { das Papier } & \text { die Tafel } & \text { das Auto } & \text { das } \\ & & & \text { Haus }\end{array}$


Wortschatz in Quizlet:

$\underline{\text { Seminarraum }}$

Seminarraum (plurals)

Was wissen Sie jetzt? Klicken Sie hier für Quiz 2.2.

Extra Practice (optional):

\section{Video Serie - Nicos Weg}

Click on the link and watch the video. Then click on "start" under the video and do the exercises.

\section{Extra Hilfe - lingoni GERMAN}

Click on this link if you have any questions or want more examples of "Das ist... / Das sind...".

\section{Media Attributions}

- star (C) IO-Images is licensed under a Public Domain license

- Pluralformen (C) csawatzky is licensed under a CC BY-NC-SA (Attribution NonCommercial ShareAlike) license

- magnifying-glass (C) IO-Images is licensed under a Public Domain license

- $\underline{\text { link }}$ (C) IO-Images is licensed under a Public Domain license

- check mark @ janjf93 adapted by Solomon Hajramezan is licensed under a Public Domain license 


\section{Einheit 2.3}

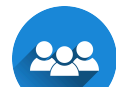

Was ist das?

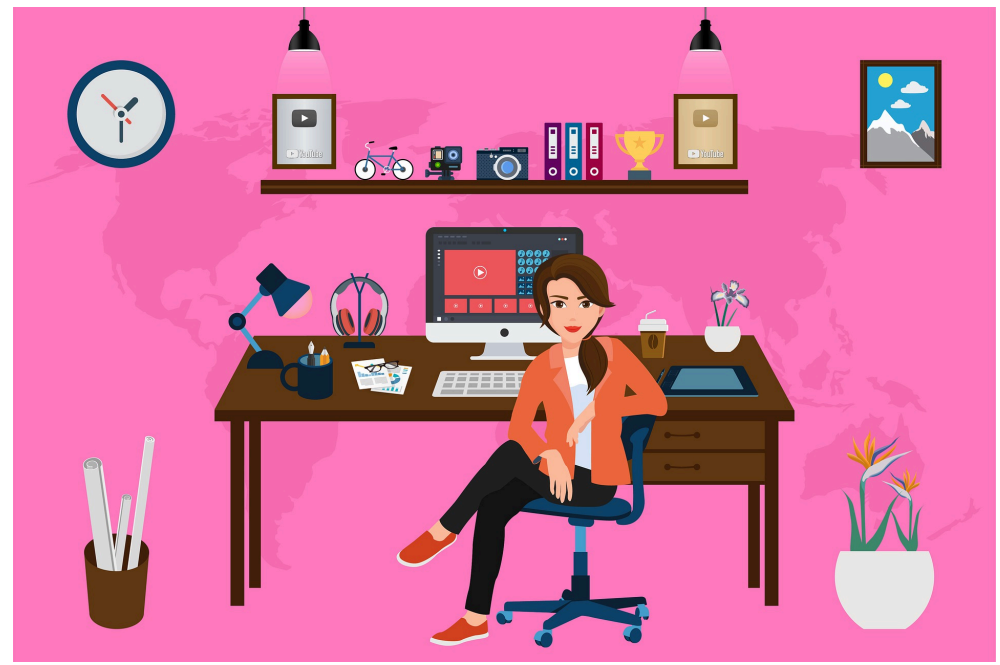

Mein Studium. Lesen Sie die Texte. 


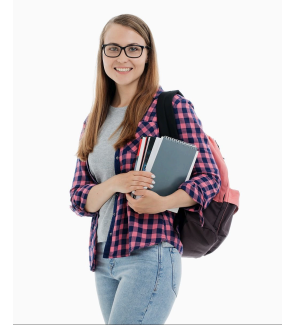

Hallo, ich heiße Paula. Ich bin 21 Jahre alt und komme aus Wiesbaden. Ich studiere an der Johannes Gutenberg-Universität in Mainz. Mein Hauptfach ist Betriebswirtschaftslehre und mein Nebenfach ist Psychologie. Mein Lieblingskurs dieses Semester ist Wirtschaftspsychologie. Ich finde diesen Kurs sehr interessant, aber viele andere Studierende denken, es ist sehr schwierig.

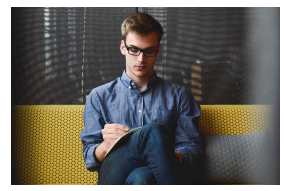

Mein bester Freund heißt Sven und kommt aus Mannheim. Er ist 22 Jahre alt und studiert Politikwissenschaft. Er hat zwei Nebenfächer: Medienwissenschaft und deutsche Literatur, oder Germanistik. Sven liest sehr viele Bücher und schreibt Artikel für die Uni-Zeitung. Wir diskutieren oft über Politik und wir spielen zusammen Tennis.

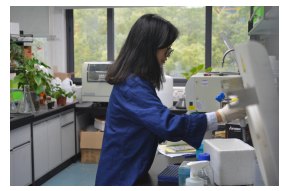

Das ist meine beste Freundin. Sie heißt Lee und ist 21 Jahre alt. Sie ist in Hong Kong geboren, aber sie lebt seit 15 Jahren in Deutschland. Sie studiert auch an der Uni in Mainz. Sie findet Naturwissenschaften sehr interessant. Ihr Hauptfach ist Chemie und ihr Nebenfach ist Physik. Dieses Semester belegt sie einen Kurs in Astronomie und findet ihn super.

Hören Sie die Texte.

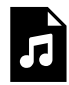

One or more interactive elements has been excluded from this version of the text. You can view them online here: https://openeducationalberta.ca/willkommendeutsch/?p=86\#audio-86-1 
Füllen Sie die Tabelle aus.

\begin{tabular}{|l|l|l|l|l|}
\hline Name & Herkunft & Alter & Studienfach & $\begin{array}{l}\text { andere } \\
\text { Interessen }\end{array}$ \\
\hline Paula & & & & \\
\hline Sven & & & & \\
\hline Lee & & & & \\
\hline
\end{tabular}

Din interactive H5P element has been excluded from this version of the text. You can view it online here:

https://openeducationalberta.ca/willkommendeutsch/?p=86\#h5p-133

Die 10 beliebtesten Studiengänge in ... 
Männer

Frauen

1 Betriebswirtschaftslehre Betriebswirtschaftslehre

2 Maschinenbau Germanistik

\begin{tabular}{lll}
3 & Informatik & Medizin \\
\hline 4 & Elektrotechnik & Rechtswissenschaften
\end{tabular}

5 Rechtswissenschaften Pädagogik

6 Wirtschaftsingenieurwesen Anglistik

7 Wirtschaftswissenschaften Biologie

8 Medizin Wirtschaftswissenschaften

9 Wirtschaftsinformatik Psychologie

1. Humanities

2. Business Administration

3. Nursing

4. Health professions

5. Biology

6. Trades and personal services

7. Psychology

8. Medical Assistant/ Technician

9. Criminal Justice

10. Education

10 Physik

Mathematik

Source: University Magazine

Was studierst du? Hören Sie zu und notieren Sie die Informationen. 


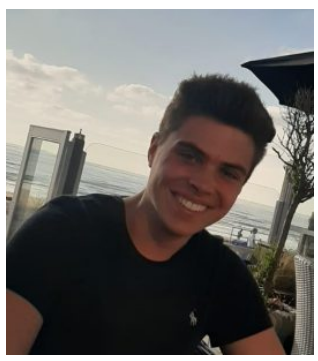

Luca

One or more interactive

dements has been

excluded from this version of the

text. You can view them online here:

https://openeducationalberta.ca/

willkommen-

deutsch/?p=86\#audio-86-2

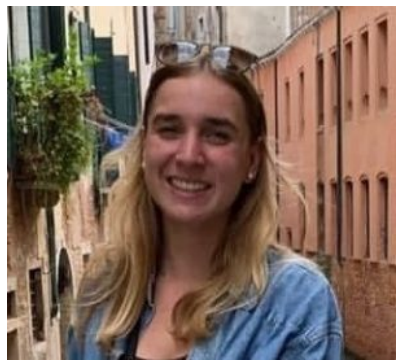

Maren
$\Delta$ One or more interactive elements has been

excluded from this version of the text. You can view them online here:

https://openeducationalberta.ca/ willkommen-

deutsch/?p=86\#audio-86-3

Beantworten Sie die Fragen.

Woher kommt sie/er?

Wie alt ist sie/er?

Was ist ihr/sein Hauptfach?

Was ist ihr/sein Nebenfach? 


\section{Media Attributions}

- group (C IO-Images is licensed under a Public Domain license

- woman-5439837_1920 (c) Mudassar Iqbal is licensed under a Public Domain license

- book (C) IO-Images is licensed under a Public Domain license

- student (c) Анастасия Гепп is licensed under a Public Domain license

- headphones (C) IO-Images is licensed under a Public Domain license

- document (C) IO-Images is licensed under a Public Domain license

- presentation icon (C) quinntheislander adapted by Solomon Hajramezan is licensed under a Public Domain license

- Luca (C) ckost is licensed under a All Rights Reserved license

- Maren (C) ckost is licensed under a All Rights Reserved license

- Sebi C ckost is licensed under a All Rights Reserved license 


\section{Einheit 2.4 (online)}

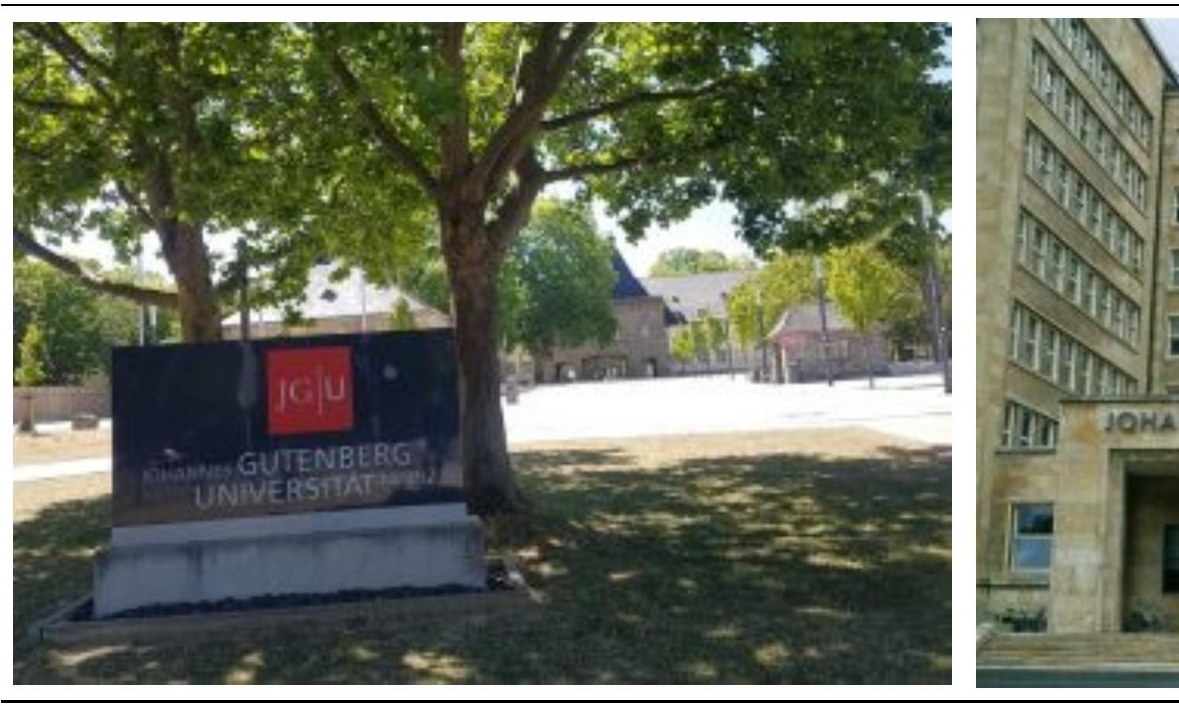

"Wissenschaft"

In the last lesson, the word Wissenschaft appeared several times (Politikwissenschaft, Medienwissenschaft, Naturwissenschaft). In German, Wissenschaft refers to the systematic study of a subject matter. In English, it could be translated as science (as in political science) or studies (as in media studies). Many other subjects that can be studied at the university also have the suffix -wissenschaft, for example Theaterwissenschaft, Sprachwissenschaft, 
Kommunikationswissenschaft, Wirtschaftswissenschaft, or Literaturwissenschaft.

In English, we often tend to think of subjects such as biology, chemistry, or physics when we talk about science. In German, these subjects would be described as natural sciences or Naturwissenschaften.

\section{Übung 1}

An interactive H5P element has been excluded from this

믐 version of the text. You can view it online here:

https://openeducationalberta.ca/willkommen-

deutsch/?p=116\#h5p-35

\section{Studierende in den USA}

Watch the following video from Easy German until 1:23. Then answer the following questions. If you want to learn more about the difference between studying in Germany and the USA please feel free to watch the entire video. 
An interactive $\mathrm{H} 5 \mathrm{P}$ element has been excluded from this version of the text. You can view it online here:

https://openeducationalberta.ca/willkommen-

deutsch/?p=116\#h5p-36

\section{Grammatik}

Since the beginning of this book you have seen examples of possessive determiners.

Mein Name ist ...

Das ist meine beste Freundin und ihr Hauptfach ist Chemie. Ist deine Lieblingsfarbe Blau?

Was ist Ihr Nebenfach?

These little words indicate possession or relationship and precede a noun (e.g., my name, her major, your minor, etc). In the nominative case, masculine and neuter do not have an ending, whereas feminine and plural add an -e. The ending is determined by the gender of the noun that it precedes.

$$
\text { mein/meine - my }
$$

dein/deine - your (informal, singular)

sein/seine - his 
ihr/ihre - her

Ihr/Ihre - your (formal, singular or plural)

We will learn all of the possessive determiners in Einheit 3.2.

\section{Übung 2} An interactive H5P element has been excluded from this
version of the text. You can view it online here:

https://openeducationalberta.ca/willkommendeutsch/?p=116\#h5p-302

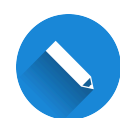

Was studieren Sie? Please answer the following questions in full sentences and bring your answers with you to our next class. You can use dict.cc if you are unsure of the German. If you cannot find a translation for what you study, please pick a subject of study that is close to what you are studying.

1. Was ist Ihr Hauptfach / Ihr Nebenfach? Mein Hauptfach ist ... / Mein Nebenfach ist ...

2. Welche Kurse haben Sie dieses Semester? Dieses Semester habe ich ... 
The school system and the university system in Germany are very different from what you might be familiar with. All children in Germany attend elementary school for 4 years, and then they go to different types of secondary school (completing 9 or 10 grades and then apprentice for a job, or completing 12 or 13 grades to be able to study at the university).

Watch the following video for more info about the German School System.

German also distinguishes between different words used at the school or the university level. Students in school are called Schüler and Schülerinnen, whereas students at the university are referred to as Studenten and Studentinnen. Instructors are also described with different terms: a Lehrer or Lehrerin teaches at a school, whereas a Professor or Professorin teaches at the university. Some subjects of study also have different names, depending on whether you take them in school or at the university. For example, the subject Deutsch in school is called Germanistik at the university, and the subject Englisch in school would be called Anglistik, Amerikanistik, or Kanadistik (depending on the focus of your studies). The English verb to study might also mean different things in German: when someone studies for a test or exam, they would use lernen. When someone talks about the subject that they are studying (for a degree), they would use the verb studieren. For example: Ich lerne für meinen Mathetest. Ich studiere Mathematik. 
Watch the following videos about studying in Germany:

German Higher Education System

German Universities: Studying in Germany

\section{Grammatik}

Please work through the following presentation to learn about coordinating conjunctions.

Coordinating Conjunctions

Q

Wortschatz in Quizlet:

Studienfächer

Schule und Studium

Schule und Studium (plurals)

Was wissen Sie jetzt? Klicken Sie hier für Quiz 2.4. 


\section{Media Attributions}

- Johannes Gutenberg Universität Mainz is licensed under a CC BY-NC-SA (Attribution NonCommercial ShareAlike) license

- Universität-Frankfurt-Bei-Tag (C) ThereWasNoHope is licensed

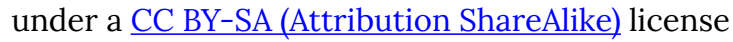

- star (C) IO-Images is licensed under a Public Domain license

- pen (C) IO-Images is licensed under a Public Domain license

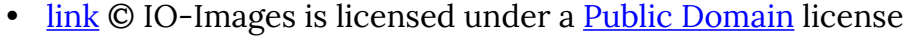

- check mark (C) janjf93 adapted by Solomon Hajramezan is licensed under a Public Domain license 


\section{Einheit 2.5}

\section{0}

\section{Was studieren Sie?}

1. Was ist Ihr Hauptfach / Nebenfach? ist ... / Mein Nebenfach ist ...

2. Welche Kurse haben Sie dieses Semester?

Dieses Semester habe ich ...

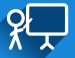

Wochentage

\section{August}

Mo $\mathrm{Di} \mathrm{Mi}$ Do Fr Sa So

$\begin{array}{lllllll}3 & 4 & 5 & 6 & 7 & 8 & 9 \\ 10 & 11 & 12 & 13 & 14 & 15 & 16 \\ 17 & 18 & 19 & 20 & 21 & 22 & 23 \\ 24 & 25 & 26 & 27 & 28 & 29 & 30 \\ 31 & & & & & & \end{array}$

Mo - Montag

Di - Dienstag

Mi - Mittwoch

Do - Donnerstag

Fr - Freitag

Sa - Samstag

So - Sonntag

$x$

Die Uhrzeit

An interactive H5P element has been excluded from this version of the text. You can view it online here: 
https://openeducationalberta.ca/willkommen-

deutsch/?p=112\#h5p-37

Wie spät ist es? Schreiben Sie die Uhrzeiten. 
112 | 2.5 
$114 \mid 2.5$ 
Interview. Machen Sie ein Interview mit einer Partnerin oder mit einem Partner und benutzen Sie die Redemittel aus der Box.

Was studierst du?

Welche Kurse hast du dieses Semester?

Was ist dein Lieblingskurs?

Was hast du am Montag / am Donnerstag?

\section{Redemittel}

\begin{tabular}{|c|c|}
\hline Was studierst du? & Ich studiere ... \\
\hline Welche Kurse hast du? & Dieses Semester habe ich ... \\
\hline Was ist dein Lieblingskurs? & $\begin{array}{c}\text { Mein Lieblingskurs ist ... / ... } \\
\text { ist mein Lieblingskurs. }\end{array}$ \\
\hline $\begin{array}{l}\text { Was hast du am Montag / } \\
\text { am Donnerstag? }\end{array}$ & $\begin{array}{c}\text { Ich habe am Montag ... / Am } \\
\text { Montag habe ich ... }\end{array}$ \\
\hline
\end{tabular}

\section{Media Attributions}

- group (C) IO-Images is licensed under a Public Domain license

- presentation icon (C) quinntheislander adapted by Solomon 
Hajramezan is licensed under a Public Domain license

- kalender (C) Majka57 is licensed under a Public Domain license

- partner (C) IO-Images is licensed under a Public Domain license

- clock-772953_1280 @ Robert Karkowski is licensed under a Public Domain license

- alarm-clock-2115489_1920 (c) Capri23auto is licensed under a Public Domain license

- clock-3744166_640 (C) Squirrel_photos is licensed under a Public Domain license

- speech bubble (C) IO-Images is licensed under a Public Domain license 
Einheit 2.6 (online)

Uhrzeit

In German, there are two ways to ask: What time is it?

Wie spät ist es? or Wie viel Uhr ist es?

Usually, we express time in colloquial terms, just like in English, using a 12-hour clock.

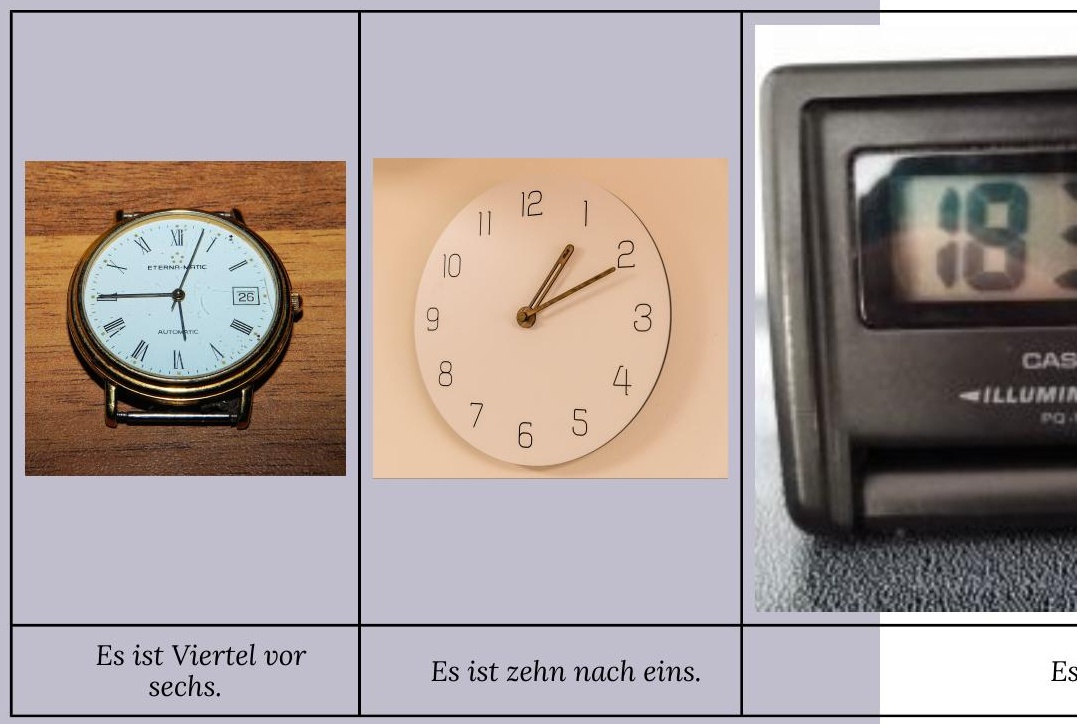

( You cannot use colloquial (inofficial) time with the 24-hour clock)

For some situations (train schedules, time 
announcements, programs, etc.), the 24-hour clock is used for formal (or official) time telling. You also need to include the word Uhr between the hour and the minutes.

\begin{tabular}{|c|l|c|l|r|l|}
\hline 17 & \multicolumn{1}{|c|}{$\begin{array}{c}\text { Es ist } \\
\text { siebzehn Uhr } \\
\text { fünfundvierzig. }\end{array}$} & 13 & $\begin{array}{l}\text { Es ist } \\
\text { dreizehn } \\
\text { Uhr } \\
\text { zehn. }\end{array}$ & $\begin{array}{c}\text { Es ist } \\
\text { 18: }\end{array}$ & $\begin{array}{l}\text { achtzehn } \\
\text { Uhr } \\
\text { dreißig. }\end{array}$ \\
\hline
\end{tabular}

In order to avoid confusion about the time of day, you could add the following adverbs of time which refer to different parts of the day:

morgens: in the morning

nachmittags: in the afternoon

vormittags: in the morning abends: in the evening

mittags: around noon nachts: at night

For example:

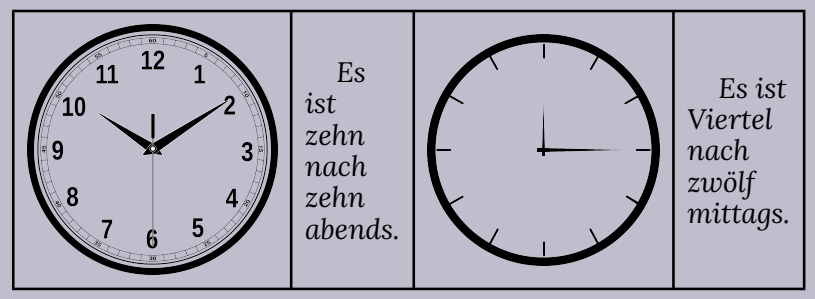


This is particularly handy when you ask when an event is taking place or when you are meeting with someone and you need to be sure of the time, for example:

\begin{tabular}{|c|c|}
\hline $\begin{array}{c}\text { Wann ist der Deutschkurs? - } \\
\text { Um } 9 \text { Uhr morgens. }\end{array}$ & $\begin{array}{c}\text { When is German } \\
\text { class? - At 9am. }\end{array}$ \\
\hline $\begin{array}{c}\text { Wann treffen wir uns? - Um } \\
\text { 4 Uhr nachmittags. }\end{array}$ & $\begin{array}{c}\text { When do we meet? } \\
\text { - At 4pm. }\end{array}$ \\
\hline
\end{tabular}

Notice that you have to include "um" in front of the time in your answer.

Ich habe um 13 Uhr Spanisch.

Similarly, when you indicate a specific day, you have to use "am" in front of the day:

Wann hast du Chemie? - Am Montag.

Was hast du am Dienstagnachmittag? - Am Dienstagnachmittag habe ich Biologie.

If you want to express a duration of time, you need to say: "von ... bis"

Mein Deutschkurs ist von 11 bis 12 Uhr.

Ich habe von Montag bis Freitag Kurse. 
When you talk about months or seasons, you use the word "im":

Wann hast du Geburtstag? - Im April.

Wann ist das Wetter schön? - Im Sommer.

Im Herbst ist es oft windig und im Winter ist es kalt.

Here is a video to help explain everything you have just read about.

Übung 1. Drag the time phrases to the correct time.

An interactive H5P element has been excluded from this
version of the text. You can view it online here:
https://openeducationalberta.ca/willkommen-
deutsch/?p=114\#h5p-38

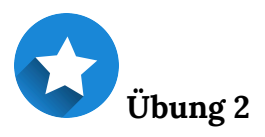


https://openeducationalberta.ca/willkommen-

deutsch/?p=114\#h5p-39 


\section{Grammatik}

Word Order in Statements and Questions

Please work through the following presentation to learn about word order in statements and questions.

Word Order in Statements and Questions

\section{Übung 3}

An interactive H5P element has been excluded from this
version of the text. You can view it online here:
https://openeducationalberta.ca/willkommen-
deutsch/?p=114\#h5p-41

\section{Übung 4}

An interactive H5P element has been excluded from this version of the text. You can view it online here: 
https://openeducationalberta.ca/willkommen-

deutsch/?p=114\#h5p-42

Wortschatz in Quizlet:

Wochentage

Uhrzeit

Fragewörter

Was wissen Sie jetzt? Klicken Sie hier für Quiz 2.6.

Extra Practice (optional):

Video Serie - Nicos Weg

Click on the link and watch the video. Then click on "start" under the video and do the exercises.

Media Attributions

- clock (C) Karsten Paulick is licensed under a Public Domain license

- clock (C) gosari05 is licensed under a Public Domain license

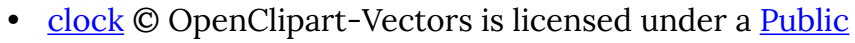
Domain license

- clock (C) KTEditor is licensed under a Public Domain license 
- star (C) IO-Images is licensed under a Public Domain license

- link (C) IO-Images is licensed under a Public Domain license

- check mark (C) janjf93 adapted by Solomon Hajramezan is licensed under a Public Domain license 


\section{Einheit 2.7}

200

Wie viel Uhr ist es? Wie spät ist es?

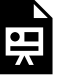

An interactive H5P element has been excluded from this version of the text. You can view it online here:

https://openeducationalberta.ca/willkommendeutsch/?p=94\#h5p-193

\section{8 目}

Wann lernen wir Deutsch?

Mein Stundenplan

\begin{tabular}{|c|c|c|c|c|c|}
\hline & Montag & Dienstag & Mittwoch & Donnerstag & Freitag \\
\hline $\begin{array}{l}9: 00- \\
10: 00\end{array}$ & $\begin{array}{l}\text { 9:00 - } \\
9: 50\end{array}$ & $\begin{array}{l}9: 30- \\
10: 50\end{array}$ & $\begin{array}{l}\text { 9:00 - } \\
\text { 9:50 }\end{array}$ & $9: 30-10: 50$ & $\begin{array}{l}\text { 9:00 - } \\
\text { 9:50 }\end{array}$ \\
\hline $\begin{array}{l}10: 00- \\
11: 00\end{array}$ & $\begin{array}{l}10: 00- \\
10: 50\end{array}$ & & $\begin{array}{l}10: 00- \\
10: 50\end{array}$ & & $\begin{array}{l}10: 00- \\
10: 50\end{array}$ \\
\hline $\begin{array}{l}\text { 11:00 - } \\
12: 00\end{array}$ & $\begin{array}{l}11: 00 \text { - } \\
11: 50\end{array}$ & $\begin{array}{l}11: 00- \\
12: 20\end{array}$ & $\begin{array}{l}11: 00 \text { - } \\
11: 50\end{array}$ & $\begin{array}{l}11: 00- \\
12: 20\end{array}$ & $\begin{array}{l}\text { 11:00 - } \\
11: 50\end{array}$ \\
\hline$\ldots$ & & & & & \\
\hline
\end{tabular}

Füllen Sie Ihren Stundenplan aus. Dann fragen Sie Ihre Partnerin oder Ihren Partner, wann sie/er einen Kurs hat. Versuchen Sie, eine gemeinsame Zeit zum Deutsch lernen zu finden.

Was hast du am Montag um 9 Uhr? ...

Was hast du am Dienstag von 9:30 bis 10:50? ... 


\section{Freizeitaktivitäten}

An interactive H5P element has been excluded from this

믓 version of the text. You can view it online here:

https://openeducationalberta.ca/willkommen-

deutsch/?p=94\#h5p-43

2

Was machen diese Leute in ihrer Freizeit? Machen Sie

Sätze. 

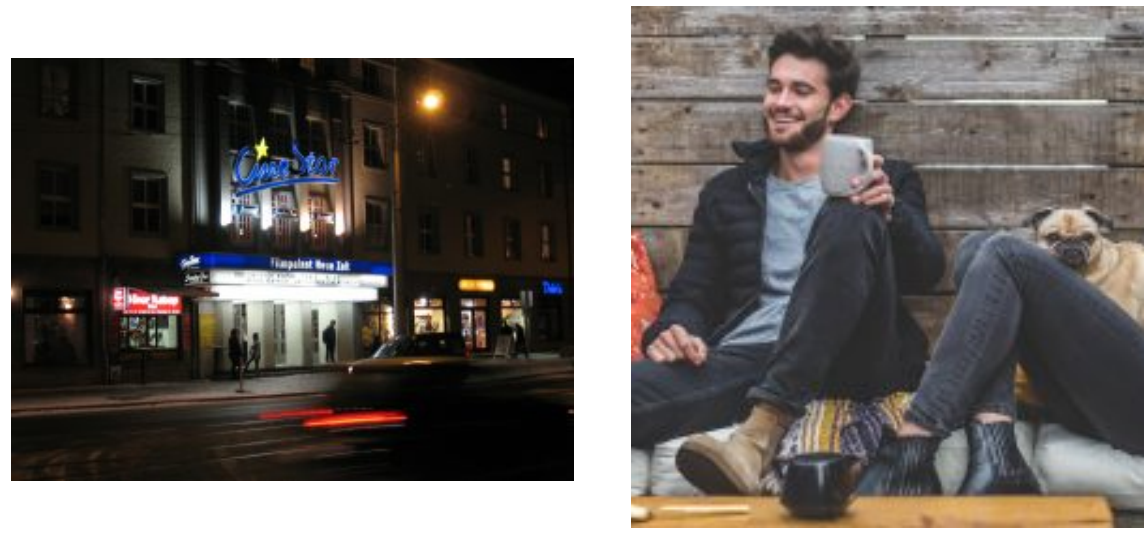

1. am Freitagabend / ich / ins Kino gehen

2. Mario \& Silvia / chillen / am San
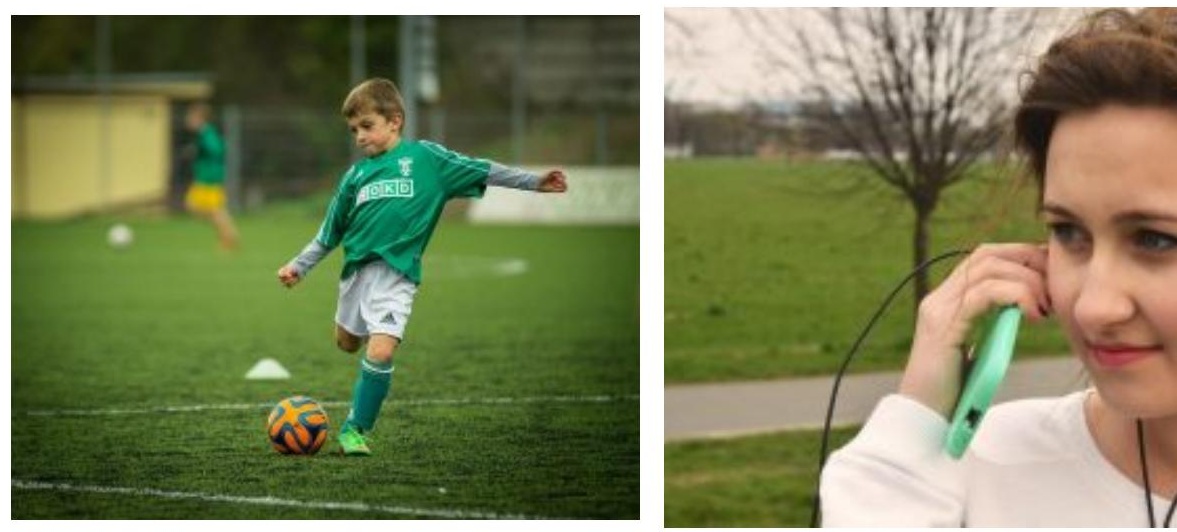

5. Fußball spielen / Noah / am Wochenende

6. Monika / jeden Tag / Mu

Media Attributions

- group (C) IO-Images is licensed under a Public Domain license 
- partner (C) IO-Images is licensed under a Public Domain license

- document (C) IO-Images is licensed under a Public Domain license

- presentation icon (C) quinntheislander adapted by Solomon Hajramezan is licensed under a Public Domain license

- akshar-dave-sNut2MqSmds-unsplash (c) Akshar Dave is licensed under a Public Domain license 


\section{Einheit 2.8 (online)}

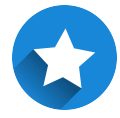

Übung 1. Click the appropriate verb to finish each sentence.

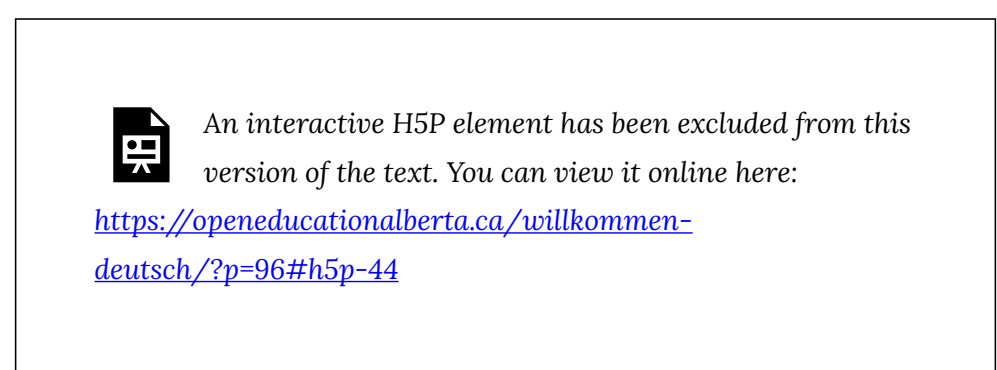

通

In der Freizeit. Lesen Sie die Texte.

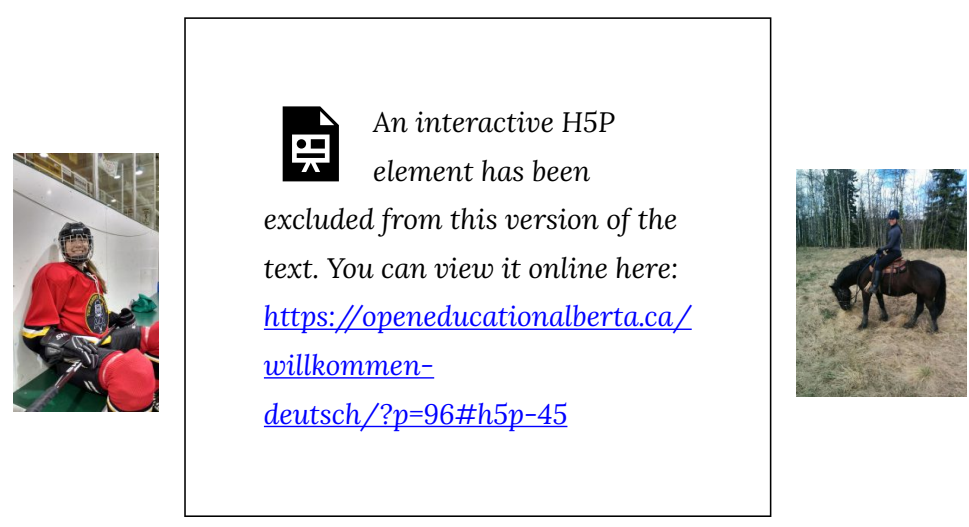



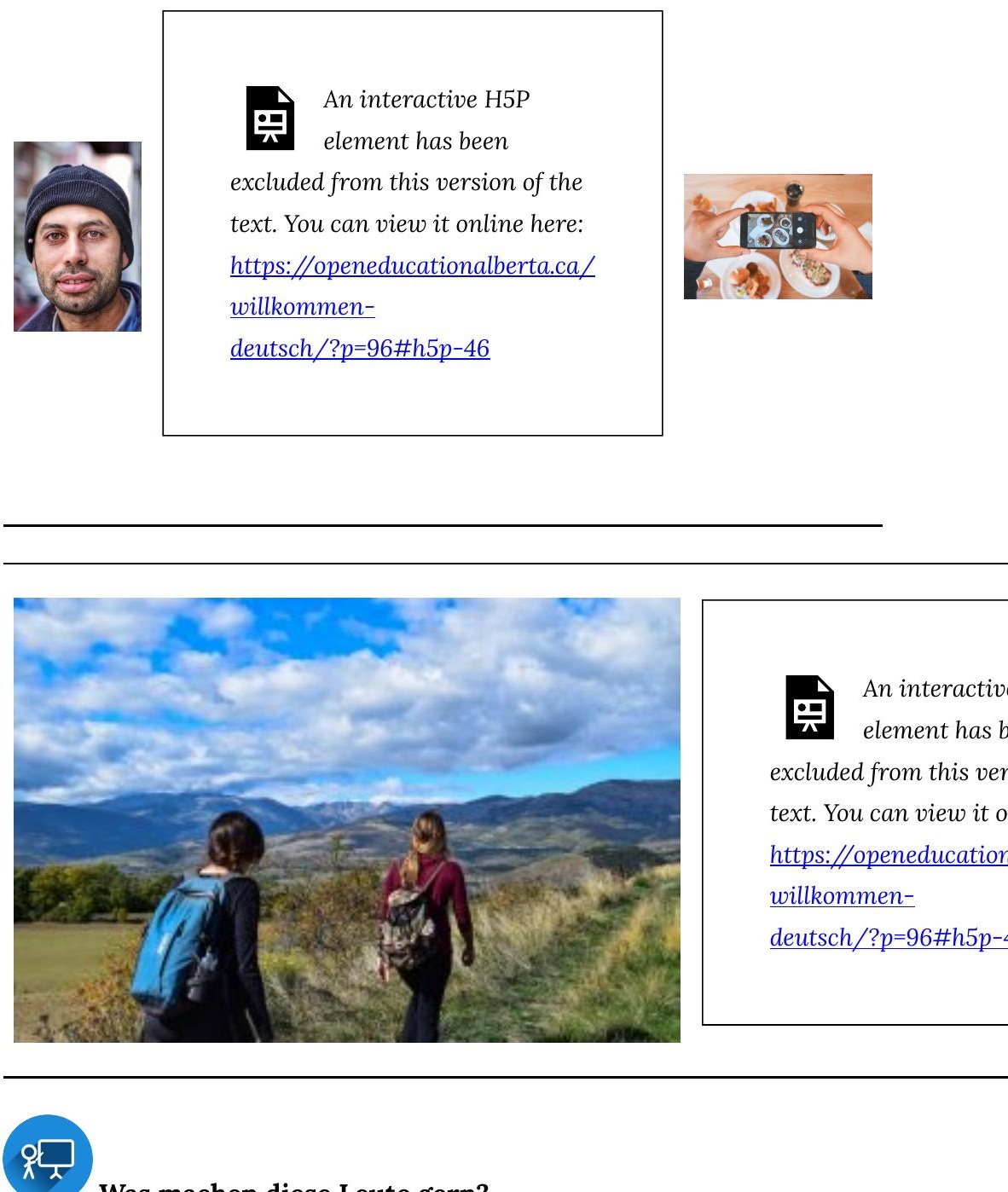

Was machen diese Leute gern? 
An interactive H5P element has been excluded from this version of the text. You can view it online here:

https://openeducationalberta.ca/willkommendeutsch/?p=96\#h5p-48

*ACHTUNG* As you have seen in this presentation as well as earlier in this unit, German verbs are sometimes a combination of a noun + verb or verb + verb:

Fußball spielen - Luca spielt gern Fußball.

Musik hören - Karolina hört gern Musik.

Fotos machen - Houssem macht gern Fotos. ins Konzert gehen - Houssem geht heute Abend ins Konzert.

Sport machen - Sasha macht gern Sport. essen gehen - Houssem geht mit Freunden essen.

Please note that you conjugate the verb in the second position and put the other verb or noun at the end of your sentence. It is the complement that gives you more information about the verb.

\section{Grammatik}


In Einheit 1.8 we first learned about verb conjugation. The verbs we learned in 1.8 had their verb stems plus the ending -en (kommen, wohnen, heißen, etc). In todays lesson you learned a new verb wandern. You will notice that this ends in $-n$ only. Please see the verb conjugation pattern below.

Since 1.8 we have also encountered verbs that don't follow the typical conjugation pattern for various reasons. Here are few of them:

Verbs whose stem ends in an s-sound $(-\mathrm{s},-\mathrm{S},-\mathrm{z},-\mathrm{ss})$ do not add an -s in the du-form:

Wie heißt du? - Ich heiße Isabelle.

Tanzt du heute Abend?

Reist du oft nach Deutschland?

Verbs whose stem ends in - $t$ or $-\mathrm{d}$ add an -e between the stem and the -st ending for the du-form and between the stem and the $-\mathrm{t}$ in the er/sie/es-form and ihr-form:

Du reitest am Donnerstag.

Er arbeitet morgen früh.

Ihr findet den Kurs interessant.

This also applies to some other verbs such as regnen (es regnet) and öffnen (sie öffnet das Buch).

Compare the following conjugations: 


\begin{tabular}{|c|c|c|c|c|c|}
\hline $\begin{array}{l}\text { Pronom } \\
\text { en }\end{array}$ & $\begin{array}{l}\text { spielen } \\
\text { (regular } \\
\text { conjugation) }\end{array}$ & $\underline{\text { rn }}^{\text {wande }}$ & $e^{\underline{\tan z}}$ & $e^{\underline{\text { reis }}}$ & en \\
\hline ich & spiele & re $e^{\text {wande }}$ & $\mathrm{e}^{\tan z}$ & $\mathrm{e}^{\text {reis }}$ & reite \\
\hline $\mathrm{du}$ & spielst & $\begin{array}{l}\text { wande } \\
\text { rst }\end{array}$ & $\mathrm{t}^{\tan z}$ & $\mathrm{t}^{\text {reis }}$ & st ${ }^{\text {reite }}$ \\
\hline es ${ }^{\text {er/sie/ }}$ & spielt & $\mathrm{rt}$ wande & $\mathrm{t}^{\tan \mathrm{z}}$ & $t^{\text {reis }}$ & $t$ reite \\
\hline wir & spielen & $\begin{array}{l}\text { rn wande } \\
\text { rn }\end{array}$ & en $^{\tan z}$ & $e^{\text {en }}{ }^{\text {reis }}$ & $\mathrm{n}^{\text {reite }}$ \\
\hline ihr & spielt & $\mathrm{rt}$ wande & $\mathrm{t}^{\tan \mathrm{z}}$ & $t^{\text {reis }}$ & $\mathrm{t}^{\text {reite }}$ \\
\hline $\mathrm{sie} / \mathrm{Sie}$ & spielen & $\begin{array}{l}\text { rn wande } \\
\text { rn }\end{array}$ & en $^{\tan z}$ & $\begin{array}{l}\text { reis } \\
\text { en }\end{array}$ & $\mathrm{n}^{\text {reite }}$ \\
\hline
\end{tabular}

Please note that the underlined portion of the infinitive is the "verb stem".

\section{Übung 3}

An interactive H5P element has been excluded from this

믓 version of the text. You can view it online here:

https://openeducationalberta.ca/willkommen-

deutsch/?p=96\#h5p-49

\section{Grammatik}


To express that we like doing something, we use a verb + "gern":

Helga spielt gern Fußball. - Helga likes to play soccer.

To express that we do not like doing something, we use a verb + "nicht gern":

Jonas geht nicht gern in die Schule. - Jonas doesn't like to go to school.

To agree with a statement of liking or disliking to do something, we use "auch gern" or "auch nicht gern":

Helga spielt gern Fußball. - Helga likes to play soccer.

Tom spielt auch gern Fußball. - Tom also likes to play soccer.

Jonas geht nicht gern in die Schule. - Jonas doesn't like to go to school.

Max geht auch nicht gern in die Schule. - Max also doesn't like to go to school.

"gern"/"nicht gern"/"auch gern"/"auch nicht gern" are placed after the verb (and before the complement):

Ich esse gern. - I like to eat.

Ich spiele gern Hockey. - I like to play hockey. 
In a sentence with inverted word order, "gern" comes after the subject.

Am Samstag spiele ich gern Fußball.

*ACHTUNG* "gern" is NOT a verb

8

Wortschatz in Quizlet:

Freizeitaktivitäten

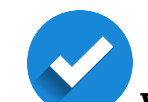

Was wissen Sie jetzt? Klicken Sie hier für Quiz 2.8.

\section{Media Attributions}

- star (C) IO-Images is licensed under a Public Domain license

- book (C) IO-Images is licensed under a Public Domain license

- Sasha (C) ckost is licensed under a All Rights Reserved license

- Sasha reiten (C) ckost is licensed under a All Rights Reserved license

- portrait (C) Mücahit Duman is licensed under a Public Domain license

- delicious (C) Pexels is licensed under a Public Domain license

- presentation icon (C) quinntheislander adapted by Solomon Hajramezan is licensed under a Public Domain license

- link (C) IO-Images is licensed under a Public Domain license

- check mark (C) janjf93 adapted by Solomon Hajramezan is licensed under a Public Domain license 


\section{Einheit 2.9}

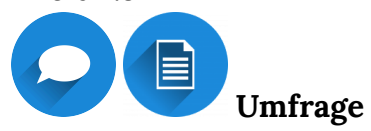

Beispiel:

S1: Hast du am Freitag Psychologie?

S2: Ja, ich habe am

Freitag Psychologie. / Nein, ich

habe am Donnerstag Psychologie.

1. Hast du am Freitag Psychologie?

2. Gehst du oft ins Kino?

3. Schwimmst du gern?

4. Spielst du nicht gern Videospiele?

5. Machst du am Wochenende Sport?

6. Hast du am Dienstag Mathematik?

7. Machst du gern Yoga?

\section{$\varepsilon$}

Was machst du gern?

Beispiel:

S1: Ich spiele gern Fußball. Du auch?

S2: Ja, ich spiele auch gern Fußball. ODER Nein, ich spiele nicht gern Fußball.

1. Ich spiele gern Fußball.

2. Ich wandere gern.

3. Ich reite gern.

4. Ich singe gern.

5. Ich höre gern Musik.

6. Ich mache gern Stand-up-Paddling.

7. Ich spiele gern Gitarre.

8. Ich tanze gern.

9. Ich lerne gern Deutsch.

10. Ich klettere gern.

11. Ich gehe gern ins Kino. 
12. Ich spiele gern Videospiele.

13. Ich koche gern.

14. Ich fotografiere gern.

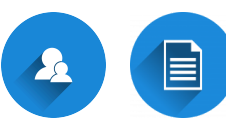

Ein Interview mit Stefanie Meier. Svitlana interviewt Stefanie für die Uni-Zeitung. Arbeiten Sie mit einer Partnerin oder mit einem Partner und stellen Sie die Fragen im Interview.

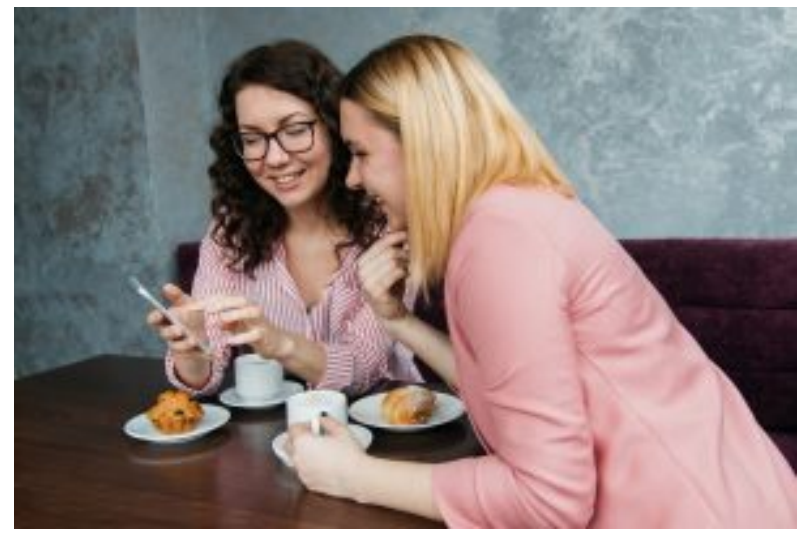

1.

2. aus Frankfurt.

3.

4.

Wirtschaftswissenschaft.

5 . Hannah.

6.

Germanistik.

7.
Ich heiße Stefanie.

Nein, ich komme nicht

Ich komme aus Köln.

Ich studiere

Das ist meine Freundin

Nein, sie studiert

Ja, sie studiert auch in 
Köln.

8. und höre Musik.

9.

Sport: Hockey und Basketball.

10.

zusammen essen und wandern.

Ich spiele gern Gitarre

Hannah macht gern

Wir gehen gern

\section{Media Attributions}

- speech bubble (C) IO-Images is licensed under a Public Domain license

- document (C) IO-Images is licensed under a Public Domain license

- partner (C) IO-Images is licensed under a Public Domain license 


\section{Einheit 2.10 (online)}

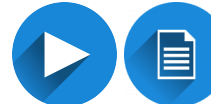

\section{Das bin ich ...}

Watch the following video from Easy German. The first time just listen and read the subtitles when needed. Watch the video again and fill in the chart about 5 of the people we met. You can pause the video while watching to write in the German words. You do not need to write full sentences. You need this information for the activity below.

\begin{tabular}{|l|l|l|l|l|}
\hline $\begin{array}{l}\text { Name } \\
\text { (Wie } \\
\text { heißt } \\
\text { du?) }\end{array}$ & $\begin{array}{l}\text { Herkunft } \\
\text { komer } \\
\text { du? })\end{array}$ & $\begin{array}{l}\text { Wohnort } \\
\text { (Wo } \\
\text { wohnst } \\
\text { du?) }\end{array}$ & $\begin{array}{l}\text { Beruf } \\
\text { (Was ist } \\
\text { dein Beruf?) }\end{array}$ & $\begin{array}{l}\text { Freizeitaktivitäten } \\
\text { Was ist dein } \\
\text { Hobby) }\end{array}$ \\
\hline Rosi & & & Gastronom & \\
\hline Julie & & & & Bier trinken \\
\hline Lui & München & & & \\
\hline $\begin{array}{l}\text { Eckbert } \\
\text { Stein }\end{array}$ & & Berlin & & \\
\hline Pauli & & & Studentin & \\
\hline
\end{tabular}

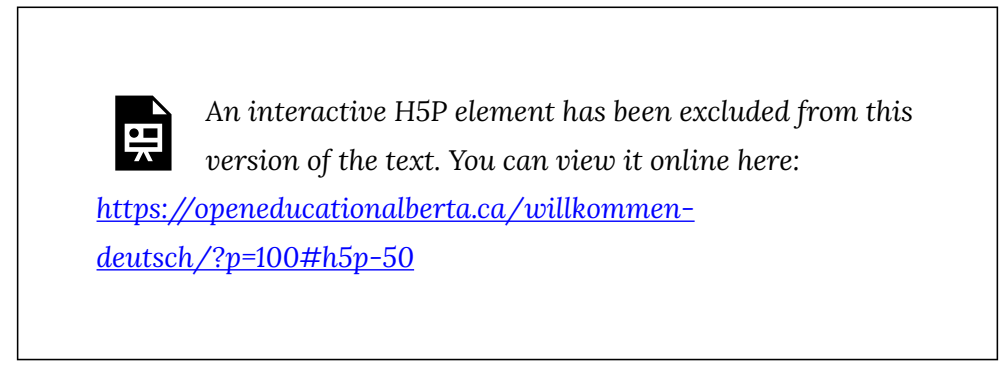

\section{Übung 1}


An interactive H5P element has been excluded from this version of the text. You can view it online here:

https://openeducationalberta.ca/willkommendeutsch/?p=100\#h5p-51

\section{Menschenporträt: Alison and Chris}

Alison and Chris studied at the University of Alberta. Watch the video they made for you and answer the questions.

Achtung: Zahnmedizin = dentistry

One or more interactive elements has been excluded

뭇 from this version of the text. You can view them online here: https://openeducationalberta.ca/willkommendeutsch/?p=100\#oembed-1

呈 An interactive H5P element has been excluded from this version of the text. You can view it online here:

https://openeducationalberta.ca/willkommendeutsch/?p=100\#h5p-93

Wortschatz in Quizlet: 


\section{Freizeitaktivitäten}

Was wissen Sie jetzt? Klicken Sie hier für Quiz 2.10.

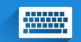

Schreiben Sie Fragen für ein Interview.

Preparation for Task 2: Beschreibung einer Mitstudentin/eines Mitstudenten

For this task, you will describe one of your classmates in writing. This task consists of three parts:

Part 1: First you will prepare a list of questions at home to ask about their personal information (name, age, where they come from and where they live), languages, subject of study, main hobbies, likes and dislikes, etc. Please submit these questions on eClass.

Part 2: Then you will interview a classmate in class (Einheit 2.13) and write down their answers.

Part 3: At home (Einheit 2.14), you will then write a paragraph (120 words minimum) with the information you obtained.

\section{Media Attributions}

- $\underline{\text { document }}$ ( ) IO-Images is licensed under a Public Domain license

- star (C) IO-Images is licensed under a Public Domain license

- link (C) IO-Images is licensed under a Public Domain license

- check mark (C) janjf93 adapted by Solomon Hajramezan is licensed under a Public Domain license 
- pen (C) IO-Images is licensed under a Public Domain license

- keyboard (C) IO-Images is licensed under a Public Domain license 


\section{Einheit 2.11}

200

Welche Freizeitaktivitäten kennen Sie schon?

안단

Mehr Freizeitaktivitäten

An interactive H5P element has been excluded from this version of the text. You can view it online here:

https://openeducationalberta.ca/willkommen-

deutsch/?p=102\#h5p-52

Was ist neu hier? An interactive H5P element has been excluded from this
version of the text. You can view it online here:

https://openeducationalberta.ca/willkommendeutsch/?p=102\#h5p-211

8

Was machst du lieber?

Beispiel:

S1: Liest du lieber Romane oder Comics?

S2: Ich lese lieber Romane. 
1. Spielst du lieber Hockey oder Fußball?

2. Fährst du lieber Ski oder Snowboard?

3. Schreibst du lieber E-Mails oder SMS?

4. Kaufst du lieber online oder im Kaufhaus ein?

5. Siehst du lieber romantische Filme oder Horrorfilme?

6. Triffst du lieber deine Freunde oder deine Familie?

7. Schläfst du lieber im Hotel oder zu Hause?

8. Gehst du lieber am Freitagabend oder am Samstagabend aus?

\section{Media Attributions}

- group (C) IO-Images is licensed under a Public Domain license

- presentation icon (C) quinntheislander adapted by Solomon Hajramezan is licensed under a Public Domain license

- question-mark (C) IO-Images is licensed under a Public Domain license

- partner (C) IO-Images is licensed under a Public Domain license 


\section{Einheit 2.12 (online)}

\section{Grammatik}

Separable-Prefix Verbs

Please work through the following presentation to learn about separable-prefix verbs.

Separable-Prefix Verbs

Übung 1. Match the infinitive to the correct picture.
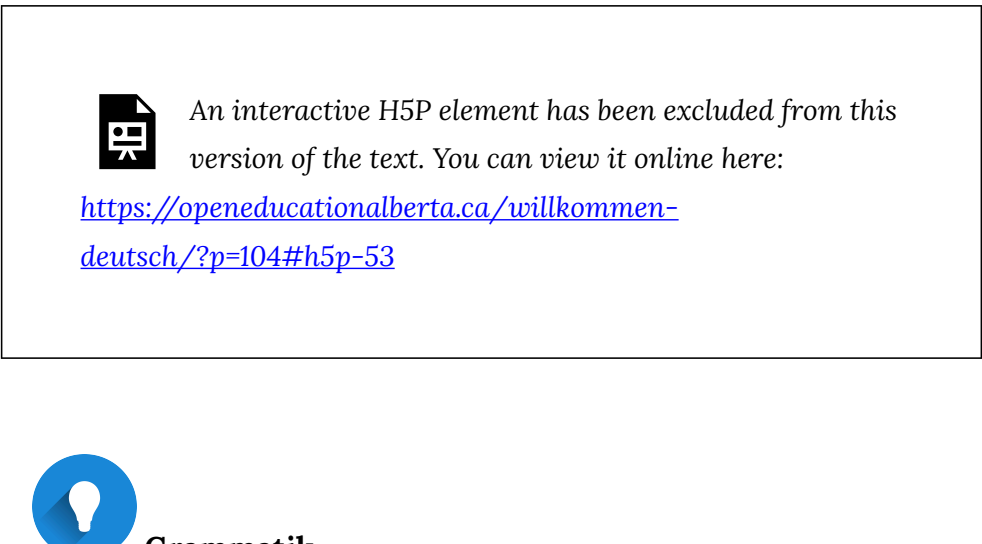

\section{Grammatik}


Please work through the following presentation to learn about stem-vowel changing verbs.

$\underline{\text { Stem-Vowel Changing Verbs }}$

\section{Übung 2}

An interactive H5P element has been excluded from this

国 version of the text. You can view it online here:

https://openeducationalberta.ca/willkommendeutsch/?p=104\#h5p-54

\section{Übung 3}

므 An interactive H5P element has been excluded from this version of the text. You can view it online here:

https://openeducationalberta.ca/willkommendeutsch/?p=104\#h5p-237 
The position of "nicht" in a sentence is complicated in German. When you want to negate a separable-prefix verb, "nicht" is placed right before the prefix (secondto-last element).

Houssem geht heute Abend nicht aus.

Ich lese nicht weiter.

Die Kinder machen die Bücher nicht $z u$.

Hans ruft seinen Freund nicht an.

Remember that "nicht" is always placed in front of "gern" when expressing that you do not enjoy doing something.

Wir spielen nicht gern Golf.

Ich esse nicht gern Pizza.

Anja sieht nicht gern fern.

Andy fährt nicht gern Ski.

Wortschatz in Quizlet:

Freizeitaktivitäten

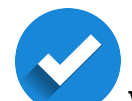

Was wissen Sie jetzt? Klicken Sie hier für Quiz 2.12.

带

Schreiben Sie Fragen für ein Interview.

Preparation for Task 2 Part 1: Beschreibung einer Mitstudentin/ eines Mitstudenten 
Please bring your list of questions to your next lesson and make sure to submit these questions on eClass.

\section{Media Attributions}

- star (C) IO-Images is licensed under a Public Domain license

- information (C) IO-Images is licensed under a Public Domain license

- link (C) IO-Images is licensed under a Public Domain license

- check mark @ janjf93 adapted by Solomon Hajramezan is licensed under a Public Domain license

- pen (C) IO-Images is licensed under a Public Domain license

- keyboard (C) IO-Images is licensed under a Public Domain license 


\section{Einheit 2.13}

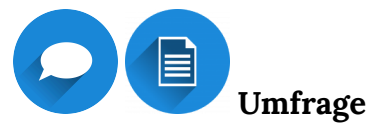

Beispiel:

S1: Siehst du viel fern?

S2: Ja, ich sehe viel fern. / Nein, ich sehe nicht viel fern.

1. Siehst du viel fern?

2. Fährst du im Sommer Kajak?

3. Triffst du oft Freunde?

4. Liest du gern Fantasy?

5. Isst du gern Pizza?

6. Kletterst du?

7. Kaufst du oft online ein?

8. Stehst du gern früh auf?

\section{0}

Welche Fragen haben Sie für das Interview?
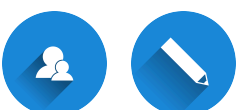

\section{想}

Interview für Task 2 Part 1 \& 2:

Beschreibung einer Mitstudentin/eines Mitstudenten.

Finden Sie eine Studentin oder einen Studenten, die Sie nicht so gut kennen. Stellen Sie die Fragen, die Sie zu Hause aufgeschrieben 
haben und machen Sie Notizen für die Antworten. Sie brauchen die Informationen für Task 2 Part 3.

\section{Media Attributions}

- speech bubble (C) IO-Images is licensed under a Public Domain license

- document (C) IO-Images is licensed under a Public Domain license

- group (C) IO-Images is licensed under a Public Domain license

- partner (C) IO-Images is licensed under a Public Domain license

- pen (C) IO-Images is licensed under a Public Domain license

- keyboard (C) IO-Images is licensed under a Public Domain license 


\section{Einheit 2.14 (online)}

Gender-inclusive and gender-neutral language in German

In the past chapters, you have encountered a number of nouns that showed -in at the end. Many German nouns that refer to professions have a masculine form (referring to male people practicing that profession) and create the feminine form by adding -in (referring to female people practicing that profession). This also works for some nationalities. Here are some examples:

\footnotetext{
der Architekt - die Architektin

der Pilot - die Pilotin

der Arzt - die Ärztin

der Erzieher - die

Erzieherin

der Manager - die

Managerin

der Krankenpfleger - die Krankenpflegerin

der Politiker - die Politikerin

Professorin

der Student - die

Studentin

der Lehrer - die

Lehrerin

der Schüler - die

Schülerin

der Partner - die

Partnerin

der Kanadier - die

Kanadierin

der Italiener - die Italienerin
}

der Professor - die

In the past, the generic masculine form has often 
been used to not only indicate a male person practicing a specific profession but also for situations where the gender of the person was unknown or when talking in the plural about a group of people that also included women.

In order to achieve more gender equality in the language, various alternative forms of spelling were created, such as the internal capitalized $i$ (StudentIn, einE StudentIn) or using both forms (Student und Studentin).

While these forms emphasize both feminine and masculine forms, they leave out diverse and nonbinary gender identities. Just like in the English language, several gender-inclusive forms were created for German, such as the gender-gap (Student_in, ein_e Student_in) or the gender-star (Student*in, ein*e Student*in).

With some words, a gender-neutral form is possible that derives from a verb participle or adjective, or is a synonym or an abstraction, for example: der/die Studierende.

In this beginning German textbook, we have opted to write out both feminine and masculine forms of nouns at first, because they are still the commonly used forms in the German-speaking countries. As we further progress through the book, we will start using gender-neutral forms like "Studierende" whenever possible. 


\section{Wortschatz in Quizlet:}

Sonstige Wörter und Ausdrücke

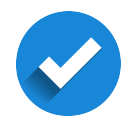

There is no quiz for 2.14

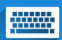

Task 2 Part 3: Beschreibung einer Mitstudentin/ eines Mitstudenten

Write a paragraph (at least 120 words) based on the information you obtained to describe the person you interviewed in the last class.

This task will be assessed according to the Rubric for Task 2 .

*ACHTUNG*: since you will be describing a classmate it might be useful to use "his/her". Just like we have been using "mein(e) / dein(e)" we use "ihr(e)" for her and "sein(e)" for his. You can review this in Einheit 2.4. If you don't want to use these, but want to write about their phone number, major/minor, favourite colour, favourite class, etc., you could also use their name $+\mathrm{s}$ (no apostrophe in German).

- Silvia ist meine Freundin und ihre Telefonnummer ist 0761 494200.

- Mario fotografiert gern. Seine Lieblingsfarbe ist Grün.

- Paulas Lieblingskurs ist Wirtschaftspsychologie.

- Svens Hauptfach ist Politikwissenschaft und sein Nebenfach ist Germanistik. 
Extra Practice (optional):

\section{Video Serie - Nicos Weg}

Click on the link and watch the video. Then click on "start" under the video and do the exercises. There are two good options today:

Video 1

Video 2

\section{Media Attributions}

- link (C) IO-Images is licensed under a Public Domain license

- check mark (C) janjf93 adapted by Solomon Hajramezan is licensed under a Public Domain license

- pen (C) IO-Images is licensed under a Public Domain license

- keyboard (C) IO-Images is licensed under a Public Domain license 


\section{Einheit 2.15}

\section{Q00}

Schlangen und Leitern. Wiederholung der Verbkonjugation.

\section{2 目}

Informationsspiel: Was machen diese Leute

\section{gern?}

Arbeiten Sie mit einer Partnerin oder mit einem Partner. Fragen Sie nach den Informationen, die Ihnen fehlen.

Beispiel:

Person A: Was trägt Thomas gern?

Person B: Er trägt gern T-Shirts. Was tragen Lilly und Frank gern?

Person A: Sie tragen gern Jeans. Was trägst du gern?

Person B: ....

\begin{tabular}{|l|l|l|l|}
\hline & Thomas & $\begin{array}{c}\text { Lilly und } \\
\text { Frank }\end{array}$ & $\begin{array}{c}\text { meine Partnerin/mein } \\
\text { Partner }\end{array}$ \\
\hline tragen & T-Shirts & Jeans & \\
\hline sehen & & & \\
\hline essen & & & \\
\hline sprechen & & & \\
\hline lesen & & & \\
\hline fahren & & & \\
\hline waschen & & & \\
\hline
\end{tabular}

\section{8}

Eine kurze Geschichte. Schreiben Sie eine kurze Geschichte. Was macht Damla heute? Was macht Thomas heute? Sie können entweder über Damla oder über Thomas schreiben. 
Damla

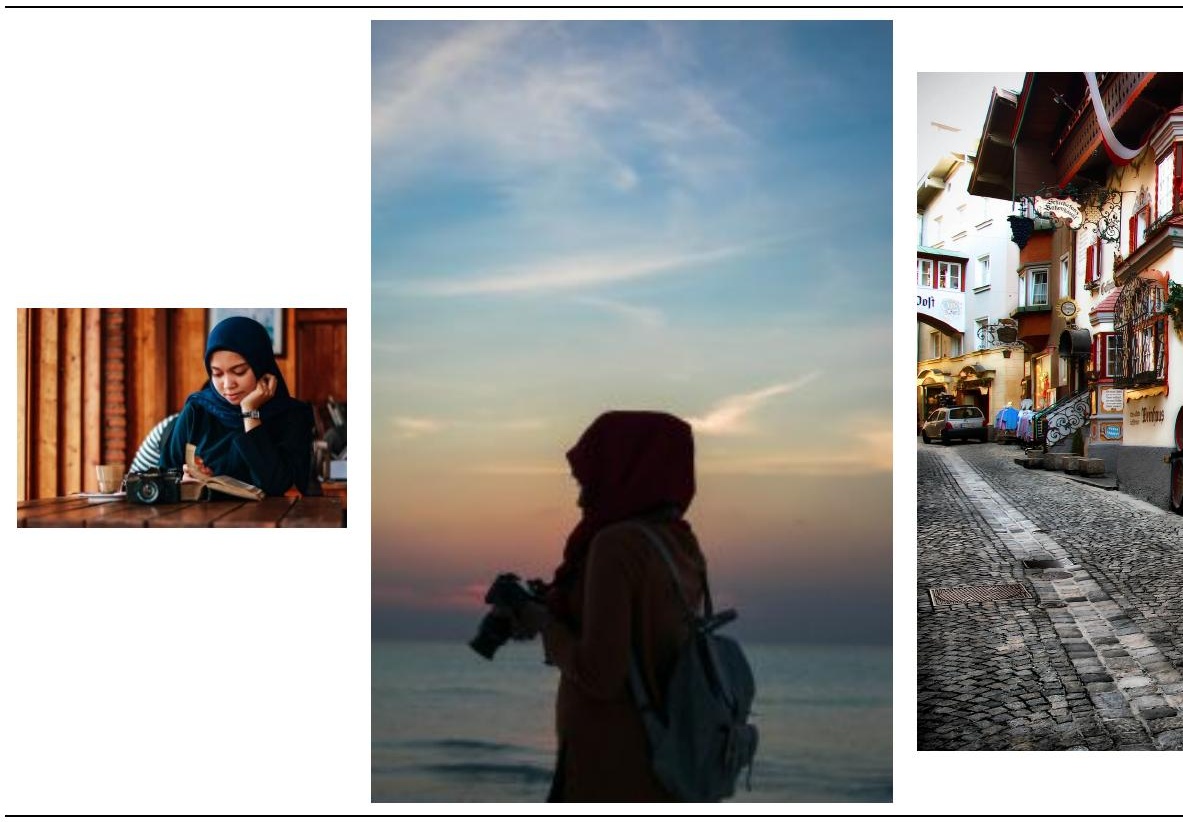

Thomas 


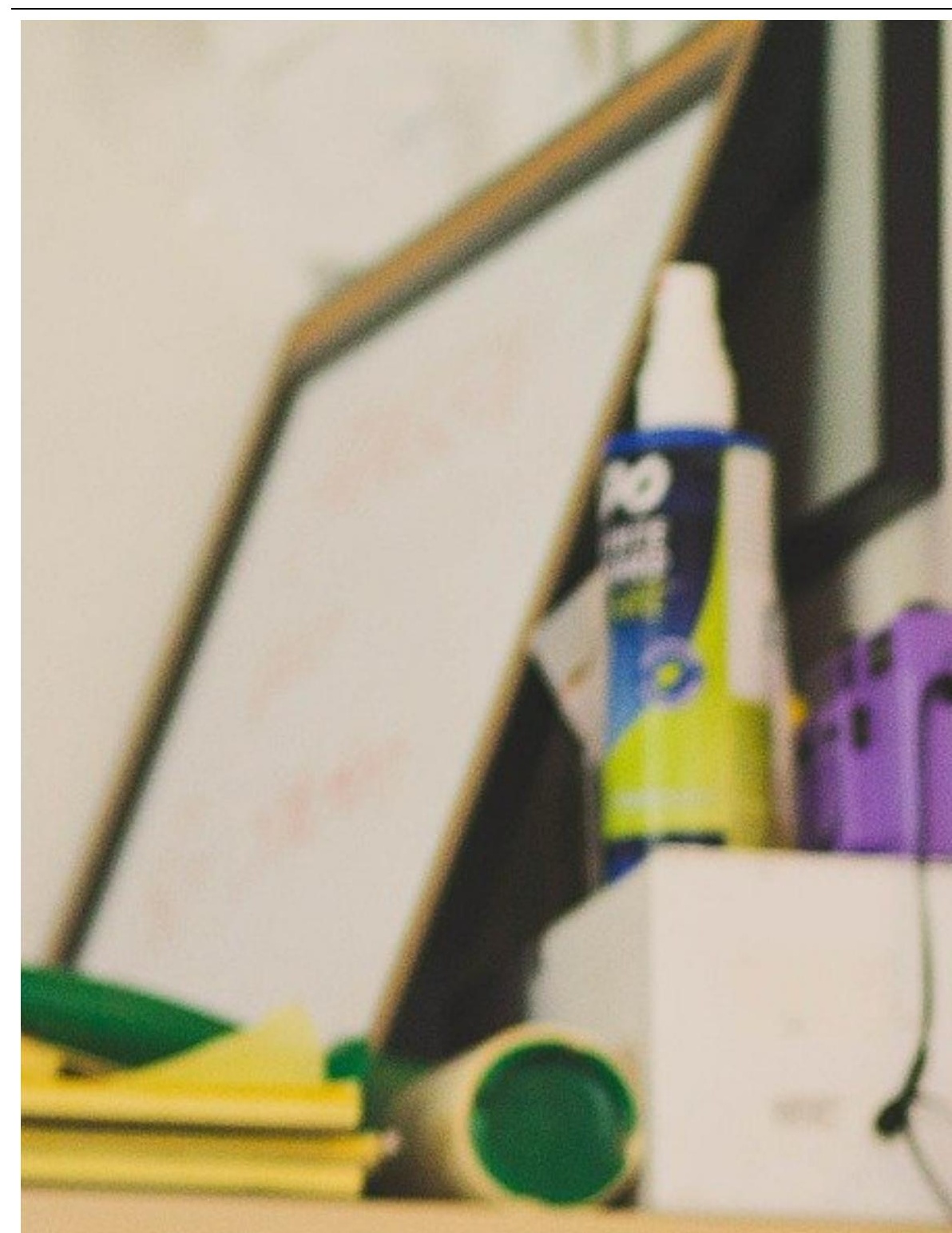




\section{Media Attributions}

- group (C) IO-Images is licensed under a Public Domain license

- partner (C) IO-Images is licensed under a Public Domain license

- document (C) IO-Images is licensed under a Public Domain license

- muhammad-haikal-sjukri-DZOWPLmvK_c-unsplash (C) muhammad-haikal-sjukri is licensed under a Public Domain license

- fotografieren (c) Rax Arn is licensed under a Public Domain license

- kufstein-2059890_1920 C Detlef Ciesla is licensed under a Public Domain license

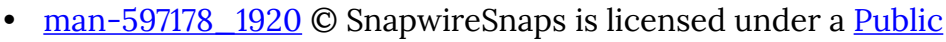
Domain license

- active-1868780 1920 (C) Pexels is licensed under a Public Domain license

- couple-4697055_1920 C Candid_Shots is licensed under a Public Domain license 


\section{Wortschatz}

Quizlet:

Wortschatz Einheit 2 (alle Kategorien)

Seminarraum

Seminarraum (plurals)

Schule und Studium

Schule und Studium (plurals)

Studienfächer

Wochentage

Uhrzeit

Fragewörter

Freizeitaktivitäten

$\underline{\text { Sonstige Wörter und Ausdrücke }}$

Wortschatz 2

Media Attributions

- $\underline{\text { link }}$ (C) IO-Images is licensed under a Public Domain license

- pdf (C IO-Images is licensed under a Public Domain license 


\section{Zum Spaß!}

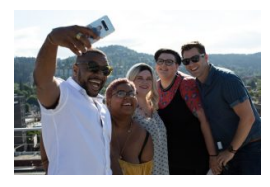

What do younger Germans enjoying doing in their free time? Here is a video to learn more about young Germans and their role models, free time activities and the ages one can smoke, drink, vote, etc.
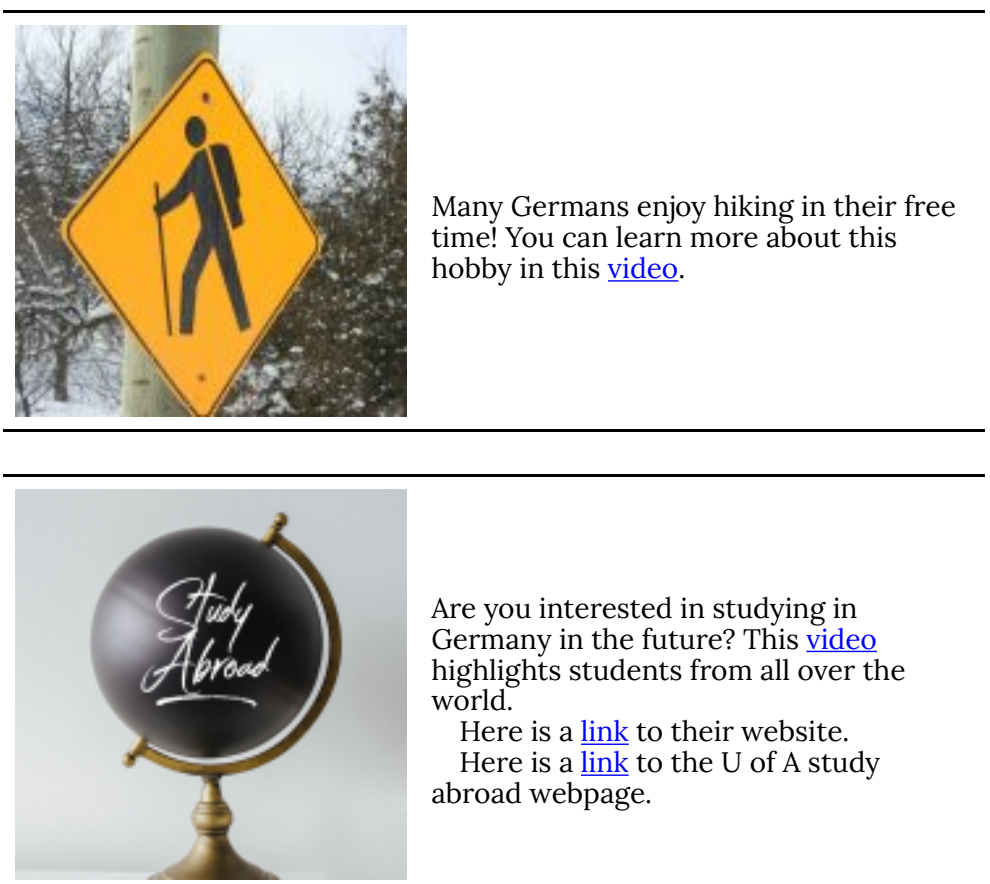

Are you interested in studying in Germany in the future? This video highlights students from all over the world.

Here is a link to their website.

Here is a $\varliminf$ kn to the U of A study abroad webpage. 
Here is a

video to

help

explain

when to

use "nein",

"nicht" and

"kein".

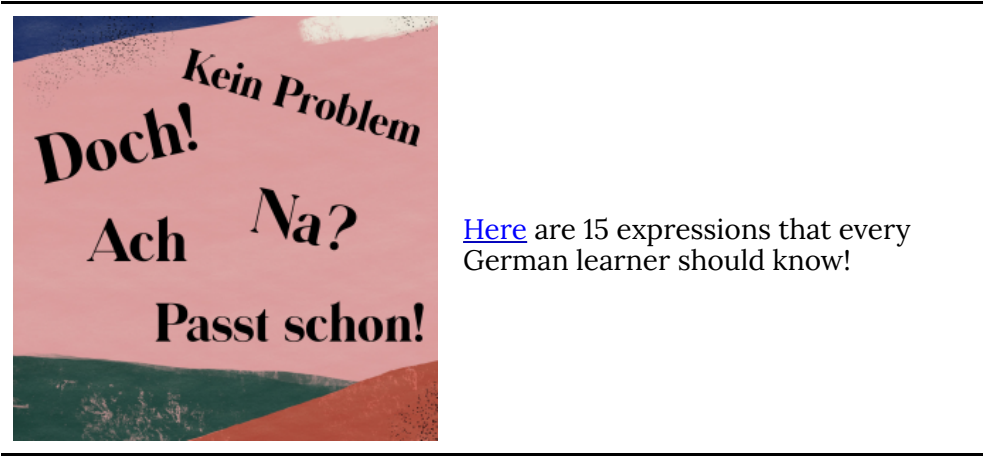

Extra Practice (optional): These activities are from the websites Schubert-Verlag, german.net and SpraKuko.

Freizeitaktivitäten

Uhrzeit

Seminarraum Wortschatz

Verben

Regelmäßige Verben

Unregelmäßige Verben 


\section{Media Attributions}

- allgo-dg06e_wbhUs-unsplash (c) allgo is licensed under a Public Domain license

- road-sign (C) PublicDomainPictures is licensed under a Public Domain license

- Study Abroad (C) charlesdeluvio adapted by csawatzky is licensed under a Public Domain license

- no-1425394_1280 (c) Elisabeth Leunert is licensed under a Public Domain license

- IMG_0324 (C) csawatzky is licensed under a Public Domain license 


\section{EINHEIT 3: FAMILIE UND FREUNDE}

At the end of Einheit 3, you will be able to...

- talk about important people in your life (family and friends) and your relationship to them

- describe what people look like and their characteristics

- $\quad$ name and identify pieces of clothing and other items in a department store

- describe what people wear

- $\quad$ ask about the price of clothing items

- give compliments about clothing items

You will also have learned about the following structures:

- possessive determiners in nominative

- adjective endings in nominative

- the accusative case

- adjective endings in accusative

- "wen"?

- "möchten"

- $\quad$ subordinating conjunction "weil"

- personal pronouns in the accusative case 
164 | Einheit 3: Familie und Freunde 


\section{Einheit 3.1}

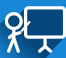

Wichtige Personen in meinem Leben

An interactive H5P element has been excluded from this version of the text. You can view it online here:

https://openeducationalberta.ca/willkommendeutsch/?p=34\#h5p-84

\section{ก}

Was sagt Luca über die wichtigen Personen in seinem Leben? Hören Sie zu, was Luca über die wichtigen Personen in seinem Leben sagt. Machen Sie Notizen!

b.

One or more interactive elements has been excluded from this version of the text. You can view them online here: https://openeducationalberta.ca/willkommendeutsch/?p=34\#audio-34-1

Lexas und Emilias Familienstammbaum 


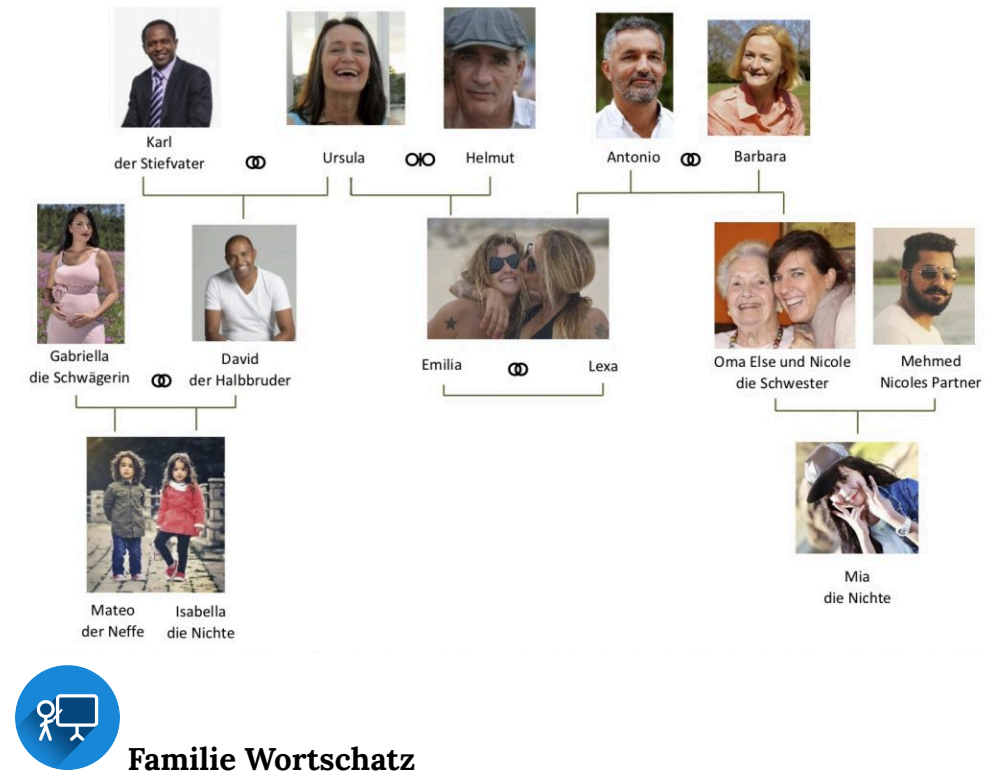

Wortfeld Familie 


\begin{tabular}{|c|c|c|c|c|}
\hline $\begin{array}{c}\text { die } \\
\text { Mutter }\end{array}$ & die Frau & $\begin{array}{l}\text { die } \\
\text { Großmutter }\end{array}$ & die Oma & $\begin{array}{l}\text { ledig/ } \\
\text { single }\end{array}$ \\
\hline der Vater & $\begin{array}{l}\text { der } \\
\text { Mann }\end{array}$ & $\begin{array}{l}\text { der } \\
\text { Großvater }\end{array}$ & der Opa & verlobt \\
\hline die & die & die & die & verheira \\
\hline Tochter & Partnerin & Enkelin & Tante & tet \\
\hline der Sohn & $\begin{array}{c}\text { der } \\
\text { Partner }\end{array}$ & der Enkel & $\begin{array}{r}\text { der } \\
\text { Onkel }\end{array}$ & getrennt \\
\hline die & die & die & die & geschied \\
\hline Schwester & Schwägerin & Cousine & Nichte & en \\
\hline der & der & der & der & verwitw \\
\hline Bruder & Schwager & Cousin & Neffe & et \\
\hline $\begin{array}{c}\text { die } \\
\text { Geschwister }\end{array}$ & das Kind & die Eltern & $\begin{array}{c}\text { die } \\
\text { Großeltern }\end{array}$ & $\mathrm{t}^{\text {adoptier }}$ \\
\hline
\end{tabular}

Stief-: die Stiefmutter, der Stiefvater, ...

Halb-: die Halbschwester, der Halbbruder

Ex-: die Ex-Frau, der Ex-Mann, der Ex-Freund, ...

Schwieger-: die Schwiegermutter, der Schwiegervater, die Schwiegereltern, ...

*ACHTUNG*

"Ich habe zwei Schwestern und einen Bruder."

"Meine Tante hat eine Tochter, aber keinen Sohn."

$\rightarrow$ Masculine nouns in accusative: einen/keinen

\section{8 目}

Wer ist wichtig in Ihrem Leben? Füllen Sie die Tabelle mit Informationen aus. Sprechen Sie dann mit Ihrer 
Partnerin oder mit Ihrem Partner über die wichtigen Personen in Ihrem Leben.

\begin{tabular}{|l|l|l|l|l|}
\hline Name & Beziehung & Alter & Familienstand & Wohnort \\
\hline$\ldots$ & & & & \\
\hline
\end{tabular}

\section{Media Attributions}

- presentation icon (C) quinntheislander adapted by Solomon Hajramezan is licensed under a Public Domain license

- headphones (C) IO-Images is licensed under a Public Domain license

- partner (C) IO-Images is licensed under a Public Domain license

- document (C) IO-Images is licensed under a Public Domain license 


\section{Einheit 3.2 (online)}

\section{Übung 1}

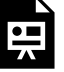

An interactive H5P element has been excluded from this version of the text. You can view it online here:

https://openeducationalberta.ca/willkommen-

deutsch/?p=118\#h5p-56

Beschreibungen Video. Watch the following video to learn how to describe yourself and others. Please take notes as these words will be useful in the following lessons.

One or more interactive elements has been excluded
from this version of the text. You can view them online here: https://openeducationalberta.ca/willkommendeutsch/?p=118\#oembed-1

Übung 2. Drag the descriptions to the correct picture. Not all words will be used.

An interactive H5P element has been excluded from this version of the text. You can view it online here: 
https://openeducationalberta.ca/willkommen-

deutsch/?p=118\#h5p-209

Lexas und Emilias internationale Familien. Read the following texts and answer the questions below.

Antonio ist Lexas Vater. Seine Eltern kommen aus Italien, aber Antonio ist in Deutschland geboren. Er spricht sehr gut Italienisch

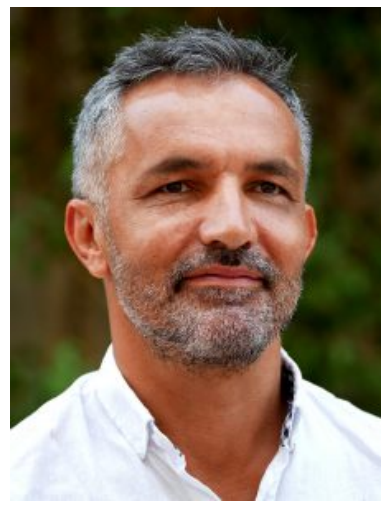
und natürlich Deutsch. Er ist groß und sportlich. Er hat kurze graue Haare und einen grauen Bart. Seine Frau heißt Barbara. Sie ist immer freundlich. Sie wohnen zusammen in Berlin. Antonio arbeitet als Architekt. In seiner Freizeit kocht Antonio gern. Er sagt, das ist entspannend und macht Spaß. In den Ferien fahren Antonio und Barbara oft nach Italien. Manchmal nehmen sie ihre Enkelin Mia mit. Mia fährt gern mit ihren Großeltern in den Urlaub, weil sie dann mit ihrem Opa surfen geht.

An interactive H5P element has been excluded from this version of the text. You can view it online here:

https://openeducationalberta.ca/willkommendeutsch/?p=118\#h5p-86 


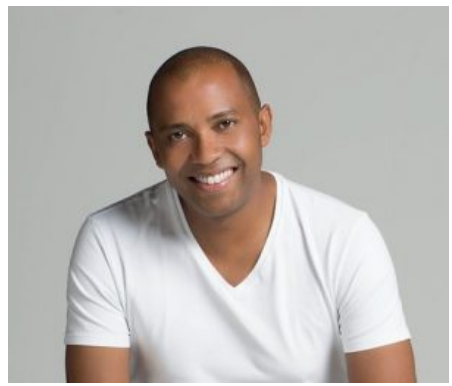

David ist Emilias Halbbruder. Er ist groß und schlank; er ist $1,87 \mathrm{~m}$. David ist auch sehr musikalisch; in seiner Freizeit spielt er Gitarre in einer Band. Seine Mutter Ursula und sein Vater Karl wohnen in Frankfurt. Karl ist Pilot bei Lufthansa und Ursula arbeitet als Erzieherin in einem Kindergarten, weil sie Kinder toll findet. Ursula ist sehr optimistisch und lacht oft. David arbeitet als Krankenpfleger und ist mit Gabriella verheiratet. Gabriella hat lange schwarze Haare und kommt aus Spanien. Gabriella ist Managerin in einer Modefirma, aber zur Zeit arbeitet sie nicht, weil sie schwanger ist. David und Gabriella haben zwei Kinder zusammen: Mateo und Isabella. Sie sind Zwillinge. Sie wohnen alle zusammen in Barcelona.

An interactive H5P element has been excluded from this version of the text. You can view it online here:

https://openeducationalberta.ca/willkommendeutsch/?p=118\#h5p-87 


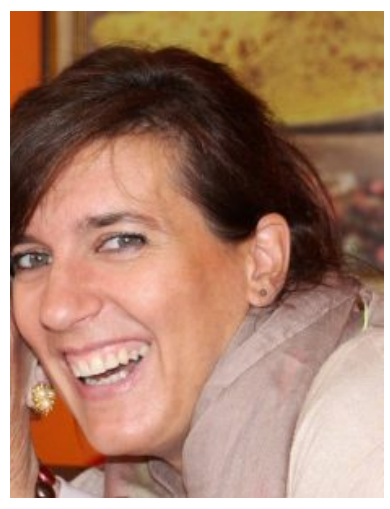

Nicole ist Lexas Schwester. Sie hat lange braune Haare und grüne Augen. Nicole lebt mit Mehmed zusammen; Mehmed ist ihr Partner. Zusammen haben sie eine Tochter; sie heißt Mia und ist 11 Jahre alt. Nicole ist Politikerin für die Partei Bündnis 90/Die Grünen im Stuttgarter Stadtrat. Sie arbeitet an neuen nachhaltigen Konzepten. Ihr Partner Mehmed ist 39 Jahre alt. Er hat kurze schwarze Haare und einen schwarzen Bart. Seine Eltern kommen aus der Türkei, aber sie leben in Köln. Mehmed hat in Deutschland Medizin studiert und arbeitet als Arzt in Stuttgart. Mehmed und Nicole haben sehr stressige Jobs. Aber wenn sie frei haben, fahren sie gern Fahrrad oder gehen im Schwarzwald wandern.

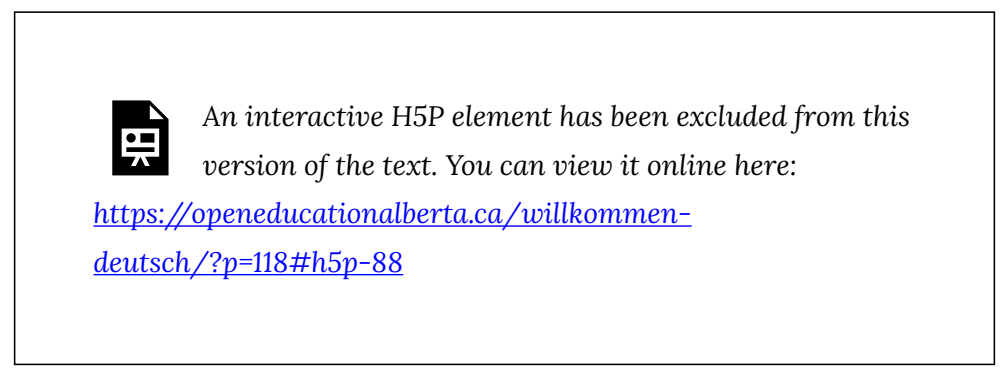

\section{Grammatik}


Please work through the following presentation to learn about possessive determiners.

\section{$\underline{\text { Possessive Determiners }}$}

Foto: Meine wichtigen Personen. Please bring pictures (printed or digital are both okay) of your important family and friends to the next class.

S

Wortschatz in Quizlet:

$\underline{\text { Familie }}$

Familie (plurals)

Beschreibungen

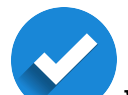

Was wissen Sie jetzt? Klicken Sie hier für Quiz 3.2.

Extra Practice (optional):

\section{Extra Hilfe - lingoni GERMAN}

Click on this link if you have want more examples of Possessive Determiners. 


\section{Media Attributions}

- star (C) IO-Images is licensed under a Public Domain license

- book (C) IO-Images is licensed under a Public Domain license

- man-4623801_1920 C) MarcThele is licensed under a Public Domain license

- David (C) WikimediaImages is licensed under a Public Domain license

- Nicole (C) TaniaVdB is licensed under a Public Domain license

- pen (C) IO-Images is licensed under a Public Domain license

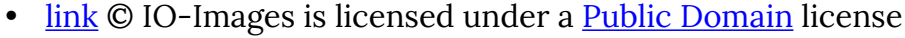

- check mark C janjf93 adapted by Solomon Hajramezan is licensed under a Public Domain license 


\section{Einheit 3.3}

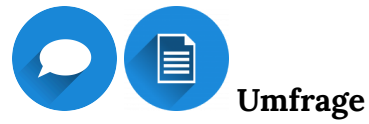

1. Sprichst du Spanisch?

2. Ist dein Vater groß?

3. Hat deine Mutter lange blonde Haare?

4. Ist dein Bruder musikalisch?

5. Ist deine Oma klein?

6. Hat dein Lieblingsonkel einen Schnurrbart?

7. Hat deine Schwester kurze braune Haare?

8. Ist dein Opa mollig?

9. Hat deine Cousine blaue Augen?

10. Ist deine Lieblingstante schlank?

Emilia spricht über Mario und Silvia. Hören Sie zu und machen Sie Notizen. Beschreiben Sie Mario und Silvia: Wie sehen sie aus und welche Eigenschaften haben sie? Welche Berufe haben sie? Was machen sie in ihrer Freizeit?

One or more interactive elements has been excluded 
from this version of the text. You can view them online here: https://openeducationalberta.ca/willkommendeutsch/?p=120\#audio-120-1

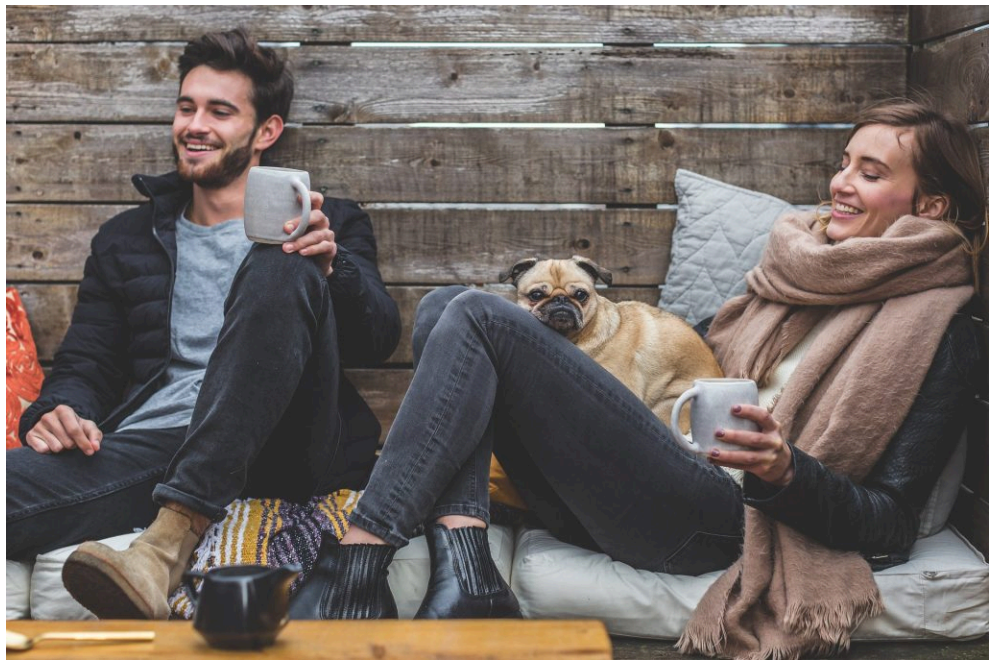

므 An interactive H5P element has been excluded from this version of the text. You can view it online here:

https://openeducationalberta.ca/willkommendeutsch/?p=120\#h5p-200 
Ihre Tabelle von Einheit 3.1 und ergänzen Sie Beschreibungen zu den Personen: Wie sehen die Personen aus? Welche Eigenschaften haben sie?

\begin{tabular}{|l|l|}
\hline Name & Beschreibungen und Eigenschaften \\
\hline$\ldots$ & \\
\hline
\end{tabular}

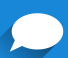

Interview: Wichtige Personen in meinem Leben. Machen Sie ein Interview mit Ihrer Partnerin oder mit Ihrem Partner über die Menschen auf Ihren Fotos.

1. Wer ist das?

2. Wie heißt er/sie?

3. Wie alt ist ...?

4. Wo wohnt ...?

5. Was für Hobbys hat ...?

6. Wie sieht ... aus?

7. Welche Eigenschaften hat ....?

\section{Media Attributions}

- speech bubble (C) IO-Images is licensed under a Public Domain license

- $\underline{\text { document }}$ (C) IO-Images is licensed under a Public Domain license

- headphones (C) IO-Images is licensed under a Public Domain license

- partner (C) IO-Images is licensed under a Public Domain license 
Einheit 3.4 (online)

\section{Übung 1}

An interactive H5P element has been excluded from this

근 version of the text. You can view it online here:

https://openeducationalberta.ca/willkommen-

deutsch/?p=122\#h5p-89

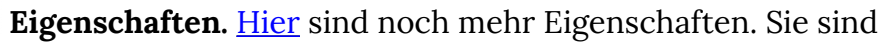
vielleicht hilfreich.

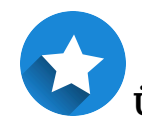

Übung 2 (refresher on Possessive Determiners)

An interactive H5P element has been excluded from this version of the text. You can view it online here:

https://openeducationalberta.ca/willkommendeutsch/?p=122\#h5p-205

Übung 3 
An interactive $\mathrm{H} 5 \mathrm{P}$ element has been excluded from this version of the text. You can view it online here:

https://openeducationalberta.ca/willkommen-

deutsch/?p=122\#h5p-58

\section{Grammatik}

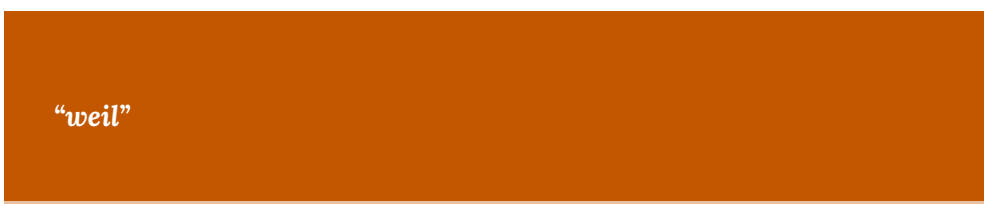

Please work through the following presentation to learn about the subordinating conjunction "weil".

Subordinating Conjunction "weil"

\section{Übung 4}

An interactive H5P element has been excluded from this version of the text. You can view it online here:

https://openeducationalberta.ca/willkommendeutsch/?p=122\#h5p-59 


\section{Wortschatz in Quizlet:}

Berufe

Eigenschaften

Was wissen Sie jetzt? Klicken Sie hier für Quiz 3.4.

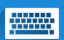

Task 3: Wichtige Personen in meinem Leben

Part 1: In 3.1 and 3.3 you already made a list of the important people in your life and described them. Now pick one of these people and prepare an oral presentation. Please describe the person, your relationship to them, what they look like, their characteristics, etc. In 3.11 or 3.13 you will briefly present "your" person to the class. This presentation should be ca. 2 minutes. Please show a picture of "your" person.

This task will be assessed according to the following Rubric for Task 3 Part 1.

\section{Media Attributions}

- star (C) IO-Images is licensed under a Public Domain license

- link (C) IO-Images is licensed under a Public Domain license

- check mark @ janjf93 adapted by Solomon Hajramezan is licensed under a Public Domain license

- keyboard (C IO-Images is licensed under a Public Domain license 


\section{Einheit 3.5}

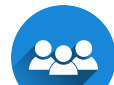

Wer kauft gern ein? Wo kaufen Sie gern ein? Was ist Ihr

\section{Lieblingsgeschäft?}

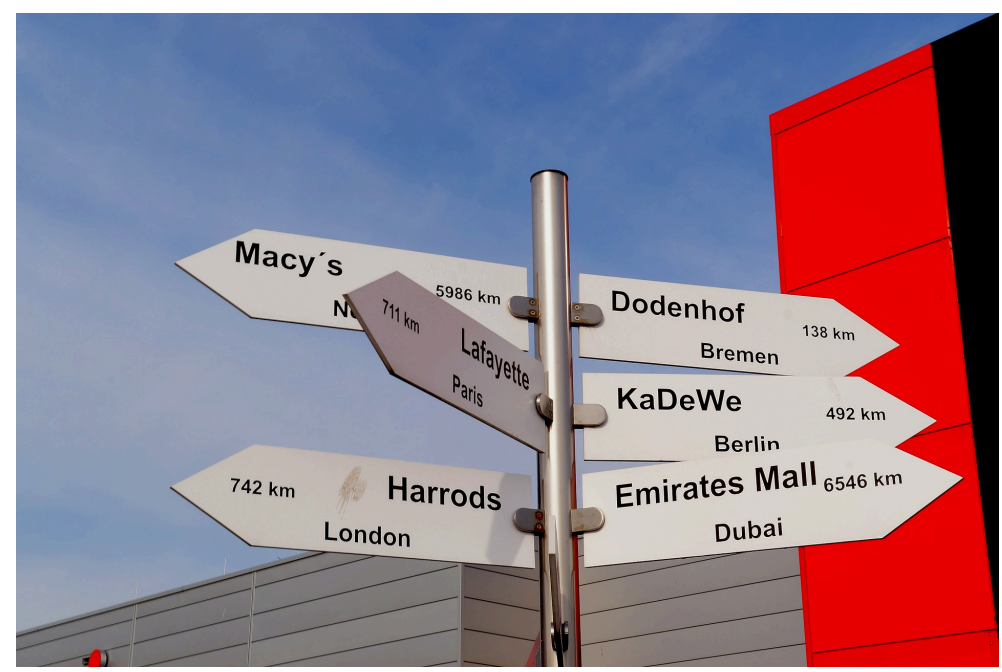

Kleidung
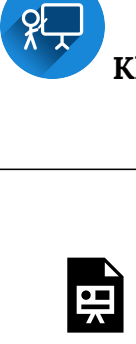

An interactive H5P element has been excluded from this version of the text. You can view it online here:

https://openeducationalberta.ca/willkommendeutsch/?p=124\#h5p-61 
Was kostet der blaue Mantel? Fragen und antworten Sie.

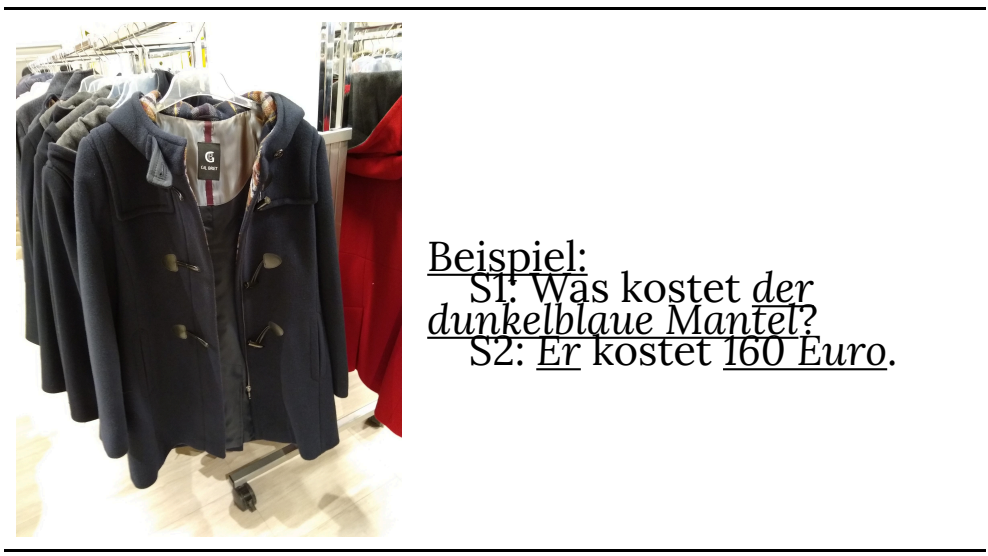




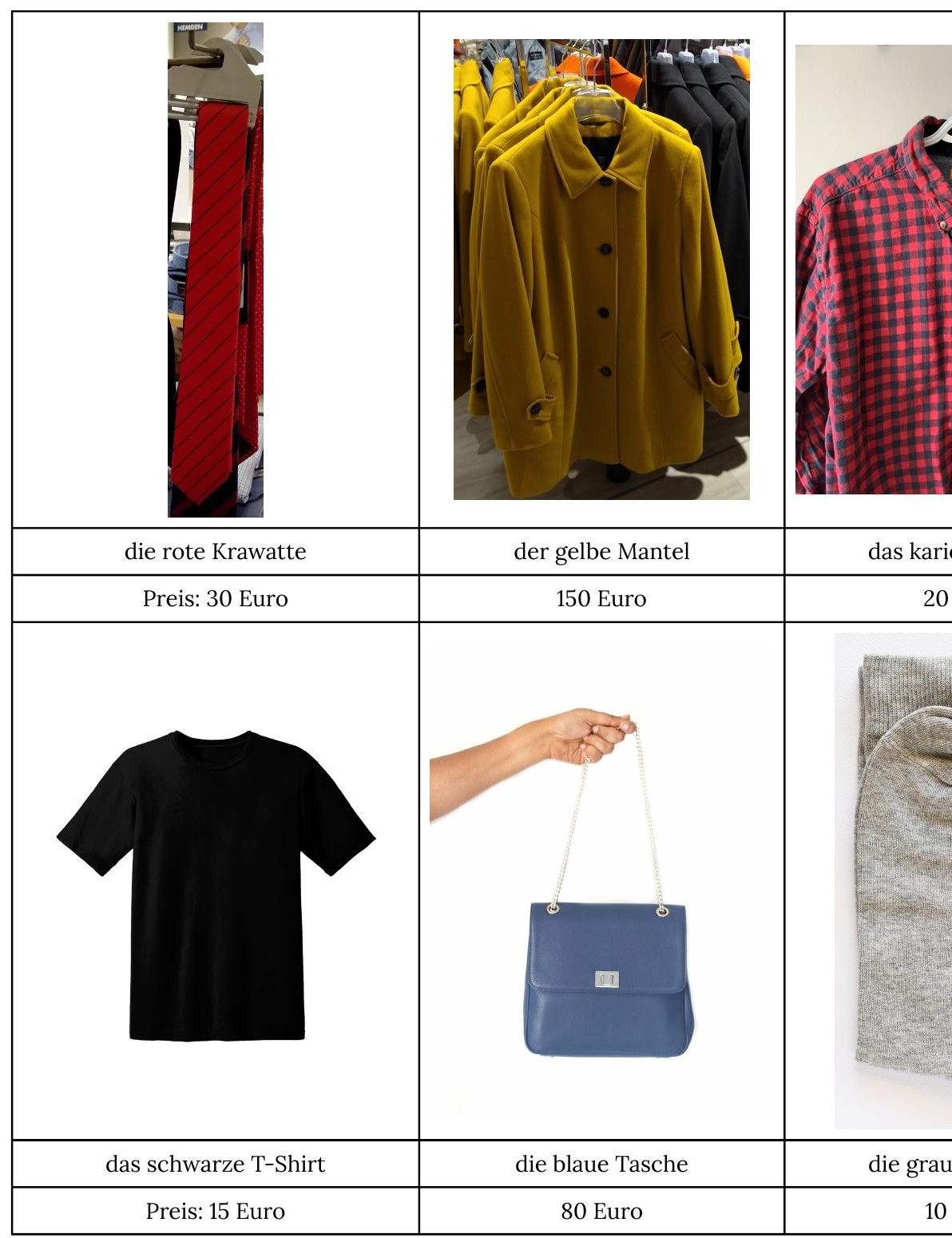




\section{Was ist neu hier?}

圄

An interactive H5P element has been excluded from this version of the text. You can view it online here:

https://openeducationalberta.ca/willkommen-

deutsch/?p=124\#h5p-186

\section{(1)잉}

Einkaufen. Hören Sie die zwei Dialoge. Schreiben Sie die fehlenden Wörter auf.

\section{Dialog A: Im Kaufhaus}

a

One or more interactive elements has been excluded from this version of the text. You can view them online here: https://openeducationalberta.ca/willkommendeutsch/?p=124\#audio-124-1

\section{Dialog B: Im Schuhgeschäft}

田

One or more interactive elements has been excluded from this version of the text. You can view them online here: https://openeducationalberta.ca/willkommendeutsch/?p=124\#audio-124-2 
Was ist das? 


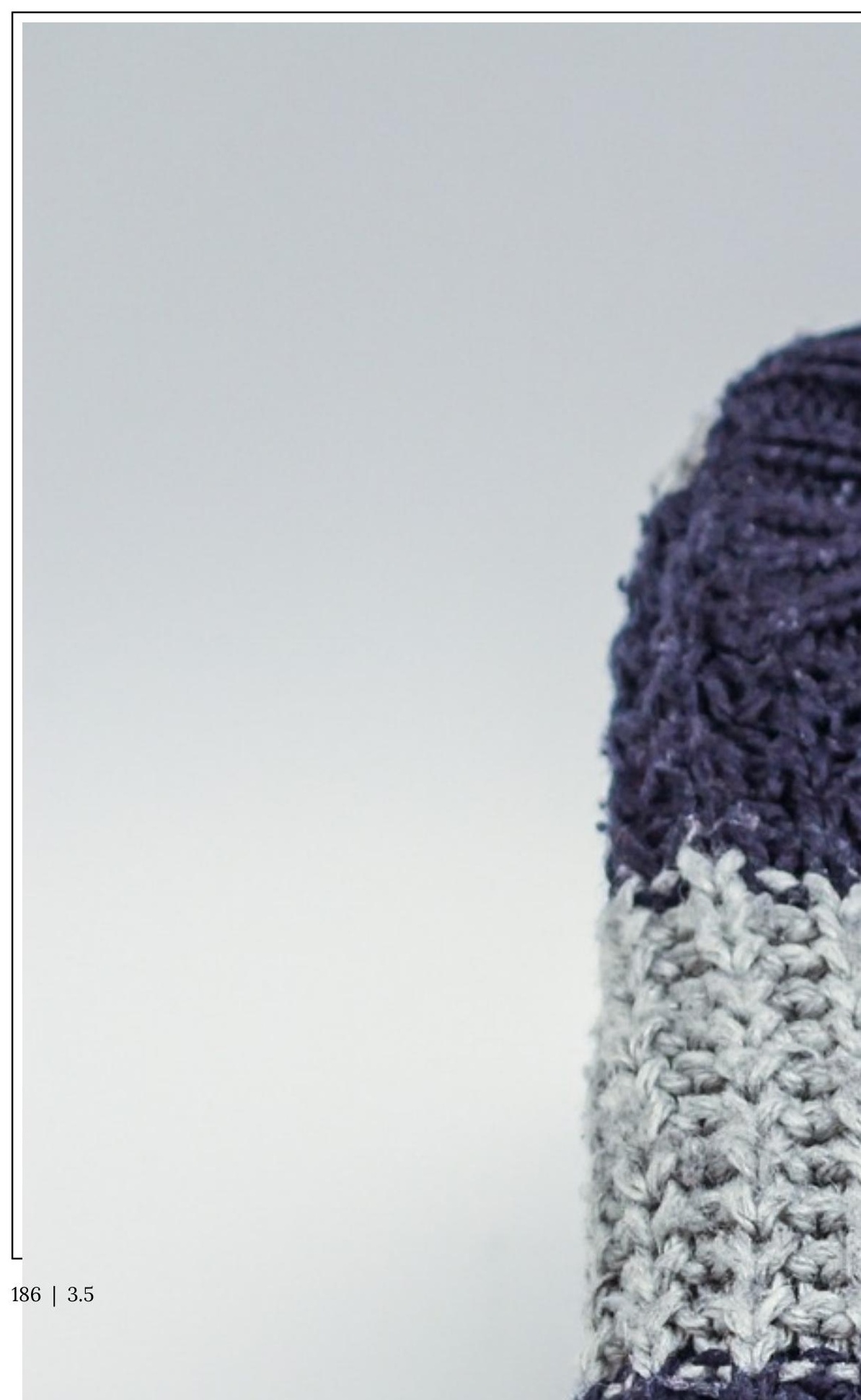




\section{Was ist neu hier?}

An interactive H5P element has been excluded from this version of the text. You can view it online here:

https://openeducationalberta.ca/willkommendeutsch/?p=124\#h5p-187

\section{Media Attributions}

- group (C) IO-Images is licensed under a Public Domain license

- directory (C) Karsten Paulick is licensed under a Public Domain license

- presentation icon (C) quinntheislander adapted by Solomon Hajramezan is licensed under a Public Domain license

- partner (C) IO-Images is licensed under a Public Domain license

- blauer Mantel C ckost is licensed under a CC BY-NC-SA (Attribution NonCommercial ShareAlike) license

- rote Krawatte (C) ckost is licensed under a CC BY-NC-SA (Attribution NonCommercial ShareAlike) license

- gelber Mantel (C) ckost is licensed under a CC BY-NC-SA (Attribution NonCommercial ShareAlike) license

- hemd (C) csawatzky is licensed under a CC BY-NC-SA (Attribution NonCommercial ShareAlike) license 
- shoes-2049298_1920 C Goumbik is licensed under a Public Domain license

- blank-1886001_1920 () jeff burroughs is licensed under a Public Domain license

- blue (C) skivebysonali is licensed under a Public Domain license

- socks-4734095_1920 C Christos Giakkas is licensed under a Public Domain license

- blauer Pullover (C) ckost is licensed under a CC BY-NC-SA (Attribution NonCommercial ShareAlike) license

- question-mark (C) IO-Images is licensed under a Public Domain license

- headphones (C) IO-Images is licensed under a Public Domain license

- document (C) IO-Images is licensed under a Public Domain license

- ties $($ C krawatte_net is licensed under a Public Domain license

- gown (C) Clker-Free-Vector-Images is licensed under a Public Domain license 


\section{Einheit 3.6 (online)}

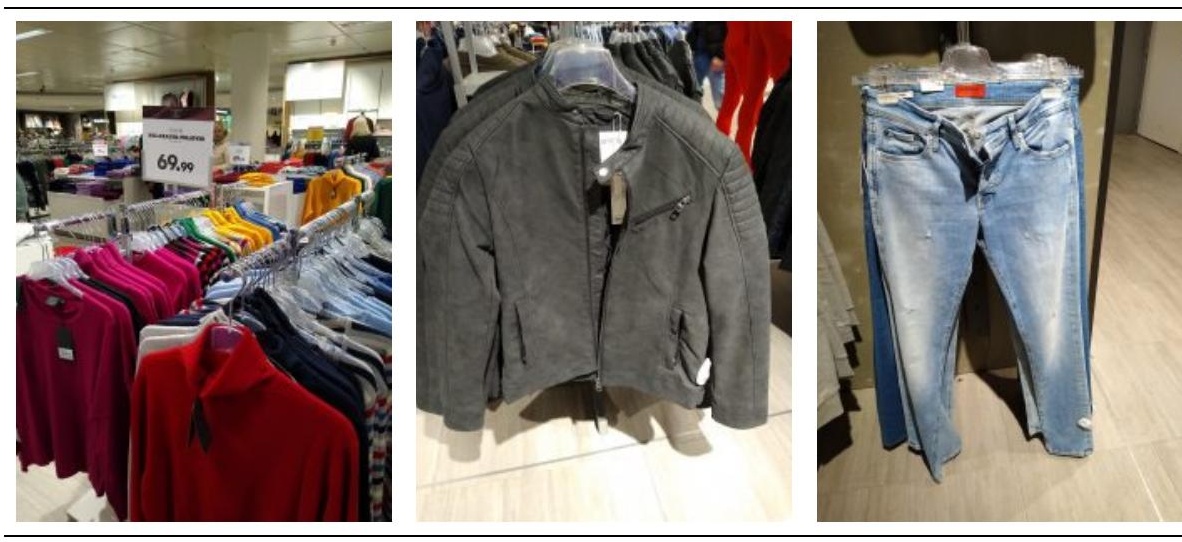

\section{Übung 1}

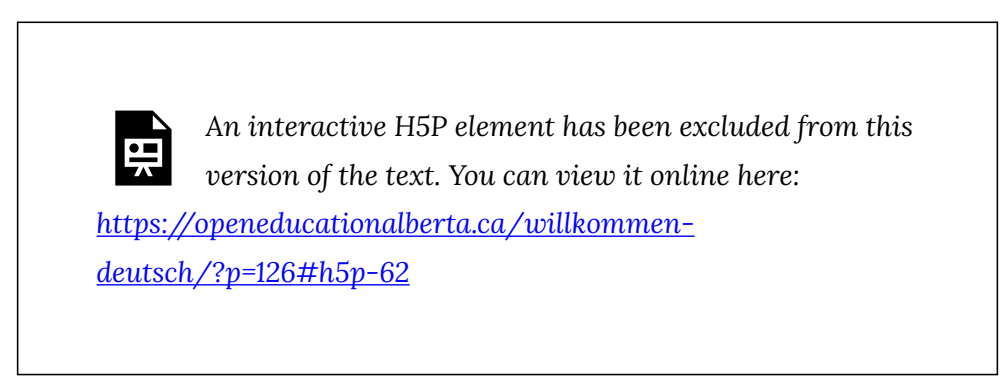

\section{*ACHTUNG*}

In Einheit 3.5 you heard these sentences in the listening:Ja, ich suche eine neue Hose.

Diese Jeans kostet nur 39 Euro. 
Please note that "die Hose", "die Jeans" and "die Brille" are singular. There are plural forms as well.Die Hosen sind teuer.

Die Jeans kosten mehr als die Jogginghosen.

\section{Grammatik}

Adjective Endings in Nominative

Adjectives take an ending when they come directly before the noun they describe. The adjective endings vary depending on the gender, number, and case of the noun which they describe.

In the nominative case, if the adjective is preceded by a der-word (e.g., definite article, "dies-“, "jed-“, "welch-"), the ending for masculine, feminine, and neuter is -e, and the ending for plural is -en.

\begin{tabular}{|c|c|c|l|}
\hline masculine & feminine & neuter & plural \\
\hline $\begin{array}{c}\text { der rote } \\
\text { Rock }\end{array}$ & $\begin{array}{c}\text { die weiße } \\
\text { Bluse }\end{array}$ & $\begin{array}{c}\text { das blaue } \\
\text { Hemd }\end{array}$ & $\begin{array}{l}\text { die } \\
\text { schwarzen } \\
\text { Schuhe }\end{array}$ \\
\hline
\end{tabular}

Der blaue Mantel kostet 80 Euro.

Das gelbe Sakko ist alt. 
Die braunen Stiefel kosten 120 Euro.

However, if the adjective is preceded by an ein-word (e.g., indefinite article, "kein", or any possessive determiner mein, dein, sein/ihr/sein, unser, euer, ihr/Ihr), the adjective endings are different. You will need to learn both charts.

\begin{tabular}{|c|c|c|l|}
\hline masculine & feminine & neuter & plural \\
\hline $\begin{array}{c}\text { ein roter } \\
\text { Rock }\end{array}$ & $\begin{array}{c}\text { eine weiße } \\
\text { Bluse }\end{array}$ & $\begin{array}{c}\text { ein blaues } \\
\text { Hemd }\end{array}$ & $\begin{array}{l}\text { keine } \\
\text { schwarzen } \\
\text { Schuhe }\end{array}$ \\
\hline
\end{tabular}

Das ist ein grauer Hut.

Das sind meine neuen Sandalen.

Please note that the adjective ending will apply to all adjectives preceding the noun. For example:

Der lange rote Rock ist neu.

Das ist ein schönes blaues Kleid.

Meine neuen warmen schwarzen Schuhe sind teuer.

*ACHTUNG* The colours "rosa" and "lila" don't take any adjective endings in the nominative (e.g., der rosa Rock, die lila Bluse, etc.)

\section{Übung 2}

An interactive H5P element has been excluded from this version of the text. You can view it online here: 
https://openeducationalberta.ca/willkommen-

deutsch/?p=126\#h5p-63

\section{Grammatik}

"dieser"/"jeder"/"welcher"

The words "dies-" (this), "jed-" (every, each), and "welch-" (which) take the same endings as the definite articles. Look at the following examples:

Dieser Pullover ist sehr schön.

Diese Bluse ist zu klein.

Dieses Kleid ist hässlich.

Diese Socken sind schmutzig.

Nominative case: 


\begin{tabular}{|c|c|c|c|}
\hline $\begin{array}{l}\text { masculine } \\
\text { (der) }\end{array}$ & $\begin{array}{l}\text { feminine } \\
\text { (die) }\end{array}$ & neuter (das) & plural (die) \\
\hline $\begin{array}{l}\text { dieser } \\
\text { Pullover } \\
\text { jeder } \\
\text { Pullover } \\
\text { welcher } \\
\text { Pullover? }\end{array}$ & $\begin{array}{l}\text { diese Bluse } \\
\text { jede Bluse } \\
\text { welche } \\
\text { Bluse? }\end{array}$ & $\begin{array}{l}\text { dieses Kleid } \\
\text { jedes Kleid } \\
\text { welches } \\
\text { Kleid? }\end{array}$ & $\begin{array}{l}\text { diese } \\
\text { Socken } \\
\text { welche } \\
\text { Socken? }\end{array}$ \\
\hline
\end{tabular}

Accordingly, when you use one of these words together with an adjective, the adjective endings are the same as in the table above when they are used with definite articles.

Dieser schöne blaue Pullover ist neu.

Welche rote Bluse ist teurer?

Jedes karierte Hemd ist altmodisch.

Welche alten Socken haben Löcher?

\section{Übung 3}

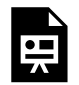

An interactive H5P element has been excluded from this version of the text. You can view it online here:

https://openeducationalberta.ca/willkommen-

deutsch/?p=126\#h5p-60 


\section{Wortschatz in Quizlet:}

Kleidung

Kleidung (plurals)

Was wissen Sie jetzt? Klicken Sie hier für Quiz 3.6.

\section{Media Attributions}

- Rollkragen-Pullover (C) ckost is licensed under a CC BY-NC-SA (Attribution NonCommercial ShareAlike) license

- Lederjacke (C) ckost is licensed under a CC BY-NC-SA (Attribution NonCommercial ShareAlike) license

- Jeans (C) ckost is licensed under a CC BY-NC-SA (Attribution NonCommercial ShareAlike) license

- star (C) IO-Images is licensed under a Public Domain license

- link (C) IO-Images is licensed under a Public Domain license

- check mark (C) janjf93 adapted by Solomon Hajramezan is licensed under a Public Domain license 


\section{Einheit 3.7}

200

\section{Kleidung}

Wer im Deutschkurs trägt ...?

1. eine dunkelblaue Jeans

5. eine teure Sporthose

2. eine alte Jogginghose

6. einen grünen

\section{Kapuzenpullover}

3. einen blauen Pullover

7. ein neues T-Shirt

4. ein langes Kleid

8. keine weißen Socken

\section{2 目}

Informationsspiel: Was tragen diese Leute?

Arbeiten Sie mit einer Partnerin oder mit einem Partner. Finden Sie heraus, welche Kleidung die Personen im Handout tragen.

Beispiel:

Person A: Trägt Charlotte einen Rock?

Person B: Nein. Trägt Alex ein Hemd?

Person A: Ja.

Was ist neu hier?

An interactive H5P element has been excluded from this version of the text. You can view it online here:

https://openeducationalberta.ca/willkommendeutsch/?p=128\#h5p-188 


\section{Im Kaufhaus}

An interactive H5P element has been excluded from this

version of the text. You can view it online here:

https://openeducationalberta.ca/willkommen-

deutsch/?p=128\#h5p-64

8

Im Kaufhaus. Was kaufen diese Leute? Was kaufen Sie? Machen Sie Sätze.

Beispiel: Monika kauft einen Sessel, ein Bett, eine Tasche und Ohrringe. 


\begin{tabular}{|c|c|c|c|c|c|c|}
\hline & Monika & Lara & Walter & $\begin{array}{l}\text { Lilly \& } \\
\text { Frank }\end{array}$ & Thomas & ich \\
\hline der Sessel & $\sqrt{ }$ & & & $\sqrt{ }$ & & \\
\hline das Geschirr & & $\sqrt{ }$ & & & $\sqrt{ }$ & \\
\hline die Halskette & & $\sqrt{ }$ & & & & \\
\hline das Bett & $\sqrt{ }$ & & & $\sqrt{ }$ & & \\
\hline $\begin{array}{l}\text { die Weingläser } \\
\text { (pl.) }\end{array}$ & & & $\sqrt{ }$ & $\sqrt{ }$ & & \\
\hline der Rucksack & & $\sqrt{ }$ & & & $\sqrt{ }$ & \\
\hline die Tasche & $\sqrt{ }$ & & & & $\sqrt{ }$ & \\
\hline der Wecker & & & $\sqrt{ }$ & & & \\
\hline $\begin{array}{l}\text { das } \\
\text { Smartphone }\end{array}$ & & $\sqrt{ }$ & & $\sqrt{ }$ & & \\
\hline der Pullover & & & $\sqrt{ }$ & & $\sqrt{ }$ & \\
\hline $\begin{array}{l}\text { die Ohrringe } \\
\text { (pl.) }\end{array}$ & $\sqrt{ }$ & & $\sqrt{ }$ & & & \\
\hline
\end{tabular}

\section{Media Attributions}

- group (C) IO-Images is licensed under a Public Domain license

- partner (C) IO-Images is licensed under a Public Domain license

- document (C) IO-Images is licensed under a Public Domain license

- question-mark (C) IO-Images is licensed under a Public Domain license

- presentation icon (c) quinntheislander adapted by Solomon Hajramezan is licensed under a Public Domain license 


\section{Einheit 3.8 (online)}

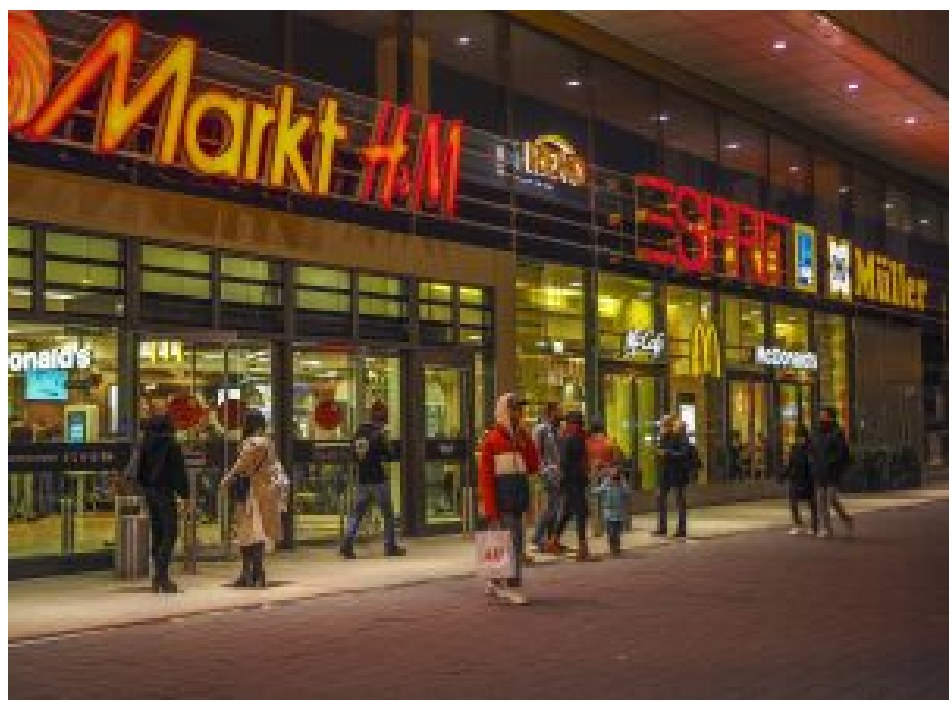

\section{Übung 1}

An interactive H5P element has been excluded from this
version of the text. You can view it online here:
https://openeducationalberta.ca/willkommen-
deutsch/?p=130\#h5p-66

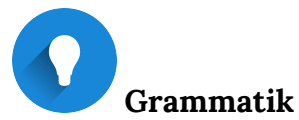


Please work through the following presentation to learn about the accusative case.

Cases: The Accusative

\section{Übung 2}

An interactive H5P element has been excluded from this
version of the text. You can view it online here:
https://openeducationalberta.ca/willkommen-
deutsch/?p=130\#h5p-202

\section{암ำ}

Was kann man im Kaufhaus kaufen?

므 An interactive H5P element has been excluded from this version of the text. You can view it online here:

https://openeducationalberta.ca/willkommendeutsch/?p=130\#h5p-67 
Übung 3. Look at the chart below and then click on to the correct answer in the activity below.

\begin{tabular}{|l|c|c|c|}
\hline & Thomas & Leonie & Lilly \& Frank \\
\hline $\begin{array}{l}\text { der } \\
\text { Hockeyschläger }\end{array}$ & + & + & - \\
\hline das Videospiel & - & - & + \\
\hline die Handschuhe & - & - & + \\
\hline die Sportuhr & + & - & - \\
\hline der Fernseher & - & + & - \\
\hline die Bilder & - & - & + \\
\hline das Armband & - & + & - \\
\hline
\end{tabular}

An interactive H5P element has been excluded from this version of the text. You can view it online here:

https://openeducationalberta.ca/willkommendeutsch/?p=130\#h5p-68

\section{Übung 4}

An interactive H5P element has been excluded from this version of the text. You can view it online here:

https://openeducationalberta.ca/willkommendeutsch/?p=130\#h5p-203 


\section{Übung 5}

An interactive H5P element has been excluded from this version of the text. You can view it online here:

https://openeducationalberta.ca/willkommen-

deutsch/?p=130\#h5p-204

Q

Wortschatz in Quizlet:

Im Kaufhaus

Im Kaufhaus (plurals)

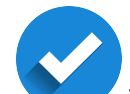

Was wissen Sie jetzt? Klicken Sie hier für Quiz 3.8.

\section{Media Attributions}

- architecture-4748205_1920 (C) MichaelGaida is licensed under a Public Domain license

- star (C) IO-Images is licensed under a Public Domain license

- presentation icon (C) quinntheislander adapted by Solomon Hajramezan is licensed under a Public Domain license

- link (C) IO-Images is licensed under a Public Domain license

- check mark (C) janjf93 adapted by Solomon Hajramezan is licensed under a Public Domain license 


\section{Einheit 3.9}

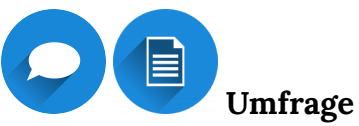

1. Hast du einen schwarzen Anzug?

2. Trägst du heute weiße Socken?

3. Hast du ein schnelles Motorrad?

4. Hast du einen blauen Mantel?

5. Trägst du heute eine neue Hose?

6. Hast du einen großen Fernseher?

7. Hast du eine schöne Sonnenbrille?

8. Hast du ein tolles Parfüm?

9. Trägst du gern teure Ohrringe?

10. Hast du einen lauten Wecker?

Was ist neu hier? 
https://openeducationalberta.ca/willkommen-

deutsch/?p=132\#h5p-190

\section{(2) Bei MediaMarkt}

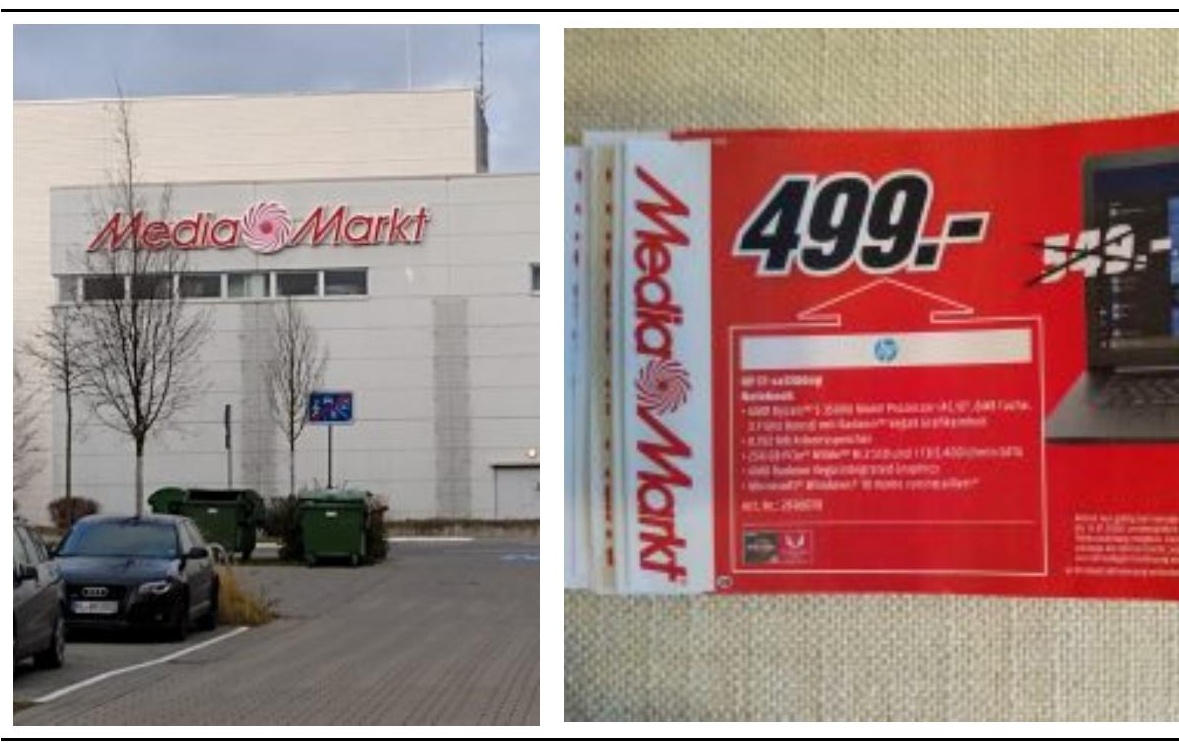

Übung 1: Sie gehen zusammen mit Ihrer Partnerin oder mit Ihrem Partner bei MediaMarkt, einem großen Elektronik-Supermarkt, shoppen. Ergänzen Sie die Dialoge mit den korrekten Adjektivendungen wie im Beispiel.

Beispiel: $\rightarrow$ der Computer / weiß, schwarz

S1: Kaufst du den weißen Computer?

S2: Nein, ich kaufe den schwarzen Computer. 
Übung 2: Jetzt sprechen Sie mit der Verkäuferin oder dem Verkäufer über die Produkte, die Sie kaufen wollen.

Beispiel: $\rightarrow$ der Computer / weiß, schwarz

S1: Möchten Sie einen weißen oder einen schwarzen Computer?

S2: Ich möchte einen schwarzen Computer.

Media Attributions

- speech bubble (C) IO-Images is licensed under a Public Domain license

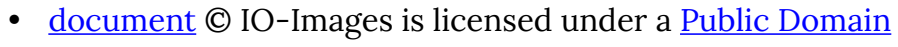
license

- question-mark (C IO-Images is licensed under a Public Domain license

- partner (C) IO-Images is licensed under a Public Domain license

- MediaMarkt (C) ckost is licensed under a CC BY-NC-SA (Attribution NonCommercial ShareAlike) license

- Notebook (C) ckost is licensed under a CC BY-NC-SA (Attribution NonCommercial ShareAlike) license 


\section{Einheit 3.10 (online)}

Übung 1. Drag the item to the correct picture.

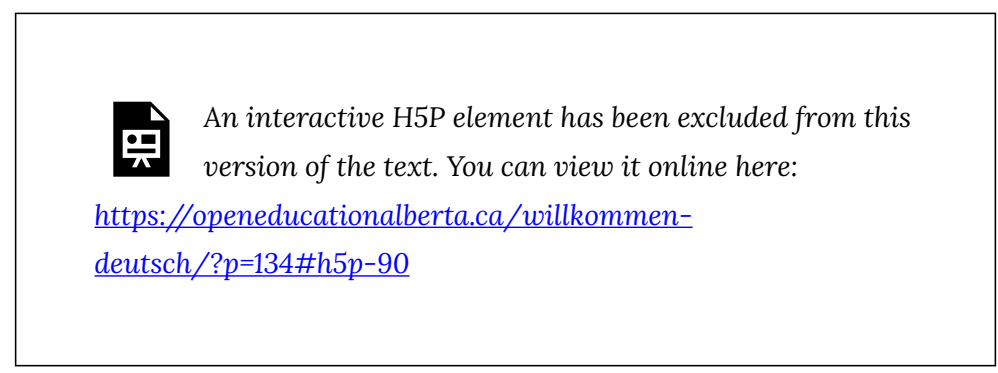

\section{( \\ Grammatik}

Please work through the following presentation to learn about adjective endings in the accusative case.

Adjective Endings in Accusative

Übung 2. Click on the correct adjective and ending. 
https://openeducationalberta.ca/willkommen-

deutsch/?p=134\#h5p-71

\section{Redemittel}

Here are some new verbs used to talk about clothes:

\begin{tabular}{|c|c|c|}
\hline $\begin{array}{c}\text { anprobieren (to } \\
\text { try on) }\end{array}$ & $\begin{array}{c}\text { Was probiert } \\
\text { Lisa an? }\end{array}$ & $\begin{array}{c}\text { Lisa probiert eine } \\
\text { neue Jeans an. }\end{array}$ \\
\hline $\begin{array}{c}\text { anziehen (to put } \\
\text { sth. on) }\end{array}$ & $\begin{array}{c}\text { Was ziehst du } \\
\text { im Winter an? }\end{array}$ & $\begin{array}{c}\text { Im Winter ziehe ich } \\
\text { meinen Wintermantel } \\
\text { an. }\end{array}$ \\
\hline $\begin{array}{c}\text { ausziehen (to } \\
\text { take sth. off) }\end{array}$ & $\begin{array}{c}\text { Was zieht er } \\
\text { aus? }\end{array}$ & $\begin{array}{c}\text { Er zieht seine } \\
\text { Schuhe aus. }\end{array}$ \\
\hline $\begin{array}{c}\text { einpacken (to } \\
\text { pack) }\end{array}$ & $\begin{array}{c}\text { Was packst du } \\
\text { immer ein? }\end{array}$ & $\begin{array}{c}\text { Ich packe immer } \\
\text { meine Jacke ein. }\end{array}$ \\
\hline $\begin{array}{c}\text { gefallen (to } \\
\text { please) }\end{array}$ & $\begin{array}{c}\text { Gefällt dir der } \\
\text { gelbe Rock? }\end{array}$ & $\begin{array}{c}\text { Nein, der gelbe Rock } \\
\text { gefällt mir nicht. }\end{array}$ \\
\hline $\begin{array}{c}\text { passen (to fit) } \\
\text { gut? die Jeans }\end{array}$ & $\begin{array}{c}\text { Ja, die Jeans passt } \\
\text { sehr gut! }\end{array}$ \\
\hline $\begin{array}{c}\text { stehen (to suit } \\
\text { sb./ to look good } \\
\text { on sb.) }\end{array}$ & $\begin{array}{c}\text { Was steht ihm } \\
\text { total gut? }\end{array}$ & $\begin{array}{c}\text { Das Sakko steht ihm } \\
\text { total gut! }\end{array}$ \\
\hline
\end{tabular}

\section{Übung 3}


An interactive H5P element has been excluded from this version of the text. You can view it online here:

https://openeducationalberta.ca/willkommen-

deutsch/?p=134\#h5p-206

i

Vergessen Sie nicht!

Although we have just been focusing on the accusative case, do not forget what we learned earlier in Einheit 2 about the nominative case. It should be noted that the verbs heißen and sein function like an equal sign, meaning that both parts refer to the same person or thing, and are thus in the nominative case.

Mein bester Freund heißt Sebi.

Sebi ist ein guter Skifahrer.

Also do not forget this useful expression:

das ist/das sind ... = "this is" and "these are"

Das ist mein jüngerer Bruder. Das ist meine ältere

Schwester. Das sind meine Eltern.

There is no quiz for 3.10 . 


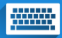

Task 3: Wichtige Personen in meinem Leben

Part 1: In 3.11 or 3.13 you will briefly present "your" person to the class. This presentation should be ca. 2 minutes. Please show a picture of "your" person. Look back at Einheit 3.4 for a full description of Part 1.

This task will be assessed according to the Rubric for Task 3 Part 1 .

Part 2: Now you will make a collage with photos about the important people in your own life (like Luca's collage in 3.1). Write a description about three of these people in your collage. You should write at least 150 words.

This task will be assessed according to the Rubric for Task 3 Part 2 .

\section{Extra Practice (optional):}

\section{Video Serie - Nicos Weg}

Click on the link and watch the video. Then click on "start" under the video and do the exercises.

\section{Media Attributions}

- star (C) IO-Images is licensed under a Public Domain license

- information (C) IO-Images is licensed under a Public Domain license

- check mark (C) janjf93 adapted by Solomon Hajramezan is licensed under a Public Domain license

- keyboard (C) IO-Images is licensed under a Public Domain license 
Einheit 3.11

Oral presentations of Task 3

Media Attributions

- person (C) IO-Images is licensed under a Public Domain license 


\section{Einheit 3.12 (online)}

Übung 1. Take some time to review some of the adjectives that we have learned thus far.

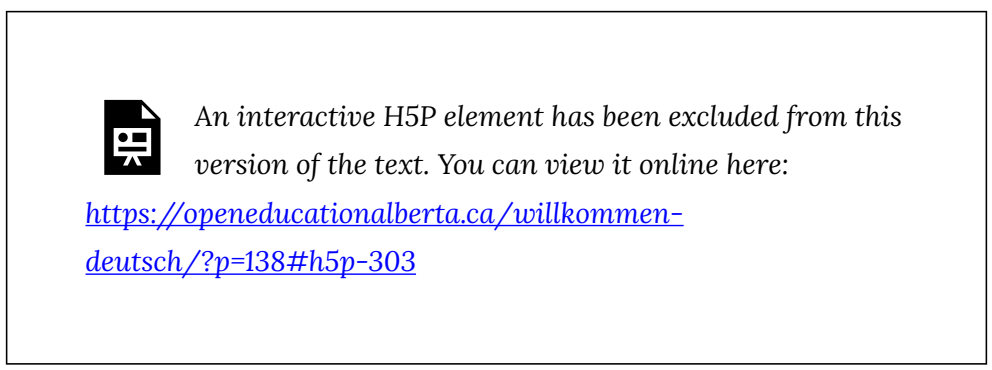

Übung 2. Let the review continue!

$$
\begin{aligned}
& \text { An interactive H5P element has been excluded from this } \\
& \text { version of the text. You can view it online here: }
\end{aligned}
$$

https://openeducationalberta.ca/willkommendeutsch/?p=138\#h5p-201

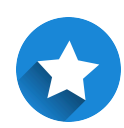

Übung 3. Possessive Determiners can also be in the accusative! Time to practice! 
An interactive H5P element has been excluded from this version of the text. You can view it online here:

https://openeducationalberta.ca/willkommen-

deutsch/?p=138\#h5p-304

Übung 4. Before you try this activity, you can review adjective endings in Einheit 3.10.

An interactive H5P element has been excluded from this

글 version of the text. You can view it online here:

https://openeducationalberta.ca/willkommen-

deutsch/?p=138\#h5p-70

*ACHTUNG* Throughout the e-textbook you will encounter this expression:

es gibt ... = "there is" and "there are"

Bei MediaMarkt gibt es einen sehr billigen Computer. (singular)

Es gibt viele Personen in meiner Familie. (plural) 


\section{Wortschatz in Quizlet:}

Sonstige Wörter und Ausdrücke

Was wissen Sie jetzt? Klicken Sie hier für Quiz 3.12.

\section{邫}

Task 3: Wichtige Personen in meinem Leben.

Part 2: Make a collage with photos about the important people in your own life (like Luca's collage in 3.1). Write a description about three of these people in your collage. You should write at least 150 words. Please submit the collage and the description on eClass.

This task will be assessed according to the Rubric for Task 3 Part $\underline{2}$.

Extra Practice (optional):

\section{Video Serie - Nicos Weg}

Click on a link below, watch the video and then click on "start" under the video and do the exercises.

Video 1 - Adjective Ending (Nominative \& Accusative)

Video 2 - diese- / welch- (Nominative \& Accusative)

Video 3 - Possessive Determiners (Nominative)

Video 4 - Possessive Determiners (Nominative \& Accusative) 


\section{Media Attributions}

- star (C) IO-Images is licensed under a Public Domain license

- link (C) IO-Images is licensed under a Public Domain license

- check mark (C) janjf93 adapted by Solomon Hajramezan is licensed under a Public Domain license

- keyboard (C) IO-Images is licensed under a Public Domain license 


\section{Einheit 3.13}

Oral presentations of Task 3

Media Attributions

- person (C IO-Images is licensed under a Public Domain license 
Einheit 3.14 (online)

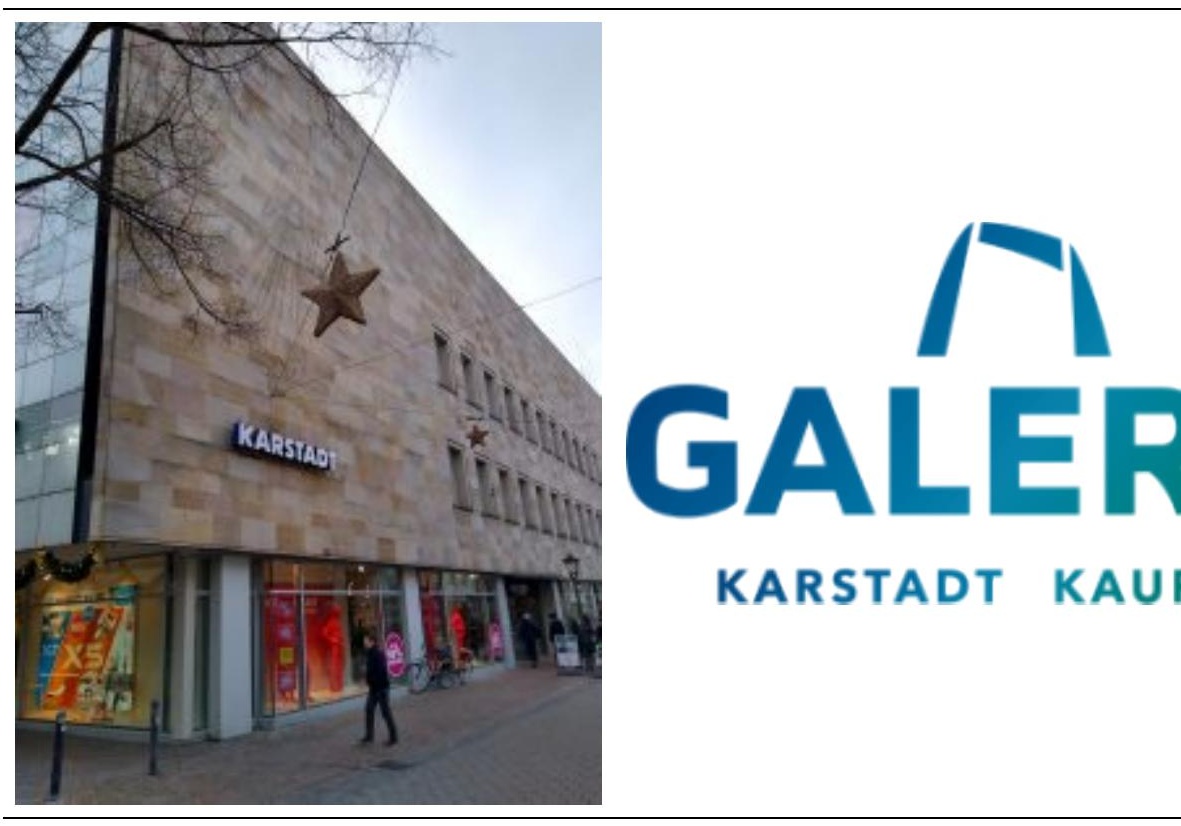

"möchten"

Please work through the following presentation to learn about möchten.

möchten 


\section{Was möchten Sie?}

An interactive H5P element has been excluded from this version of the text. You can view it online here:

https://openeducationalberta.ca/willkommen-

deutsch/?p=1699\#h5p-72

\section{Übung 1}
- An interactive H5P element has been excluded from this version of the text. You can view it online here:

https://openeducationalberta.ca/willkommendeutsch/?p=1699\#h5p-73

Lisa und Max gehen bei Karstadt shoppen. Read the text and answer the questions. Review the Redemittel in Einheit 3.10 before you begin to read. 
Lisa: Hey Max, ich gehe zu Karstadt shoppen.

Max: Super, nimmst du mich mit? Ich habe viel Zeit heute und ich möchte einen neuen Pullover kaufen. Es ist jetzt so kalt draußen. Aber er soll schön sein, nicht so altmodisch!

Lisa: Super Idee! Dann gehen wir am besten in die Herrenabteilung. Welche Farbe möchtest du?

Max: Ich trage am liebsten Blau oder Rot.

Lisa: Wie findest du diesen roten Pullover hier?

Max: Oh nein, dieser Pullover gefällt mir überhaupt nicht. Wie findest du diesen blauen?

Lisa: Ja, ich glaube, diese Farbe steht dir sehr gut. Und der Pulli sieht auch sehr schick und sportlich aus.

Max: Cool! Dann kaufe ich ihn.
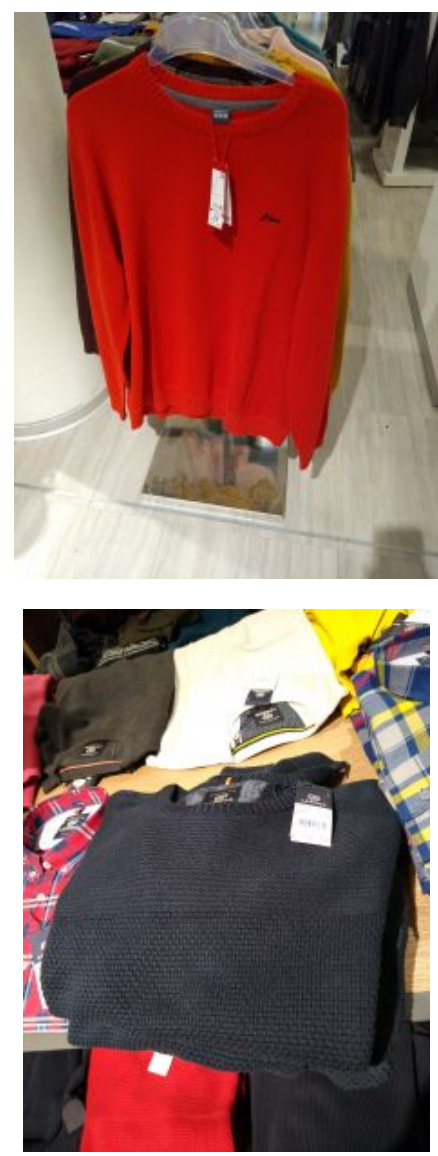

An interactive H5P element has been excluded from this version of the text. You can view it online here:

https://openeducationalberta.ca/willkommendeutsch/?p=1699\#h5p-83 
Was wissen Sie jetzt? Klicken Sie hier für Quiz 3.14.

\section{Media Attributions}

- Galeria Karstadt Kaufhof Logo.svg (C) SIGNA Holding \& Galeria Karstadt Kaufhof S.à r.l. is licensed under a Public Domain license

- presentation icon (C) quinntheislander adapted by Solomon Hajramezan is licensed under a Public Domain license

- star (C) IO-Images is licensed under a Public Domain license

- book (C) IO-Images is licensed under a Public Domain license

- roter Pulli (C) ckost is licensed under a CC BY-NC-SA (Attribution NonCommercial ShareAlike) license

- blauer Pulli (C) ckost is licensed under a CC BY-NC-SA (Attribution NonCommercial ShareAlike) license

- check mark (C) janjf93 adapted by Solomon Hajramezan is licensed under a Public Domain license 


\section{Einheit 3.15}

\section{0}

\section{Was kaufen wir im Kaufhaus?}

$O$

Interview. Machen Sie ein Interview mit einer Partnerin oder mit einem Partner.

1. Was möchtest du im Kaufhaus kaufen?

2. Möchtest du eine neue Sprache lernen?

3. Wohin möchtest du im Sommer reisen?

4. Möchte deine beste Freundin/dein bester Freund ein neues Auto kaufen?

5. Möchtest du eine Katze oder einen Hund haben?

Lisa und Max gehen bei Karstadt shoppen. Lesen Sie die Texte. 


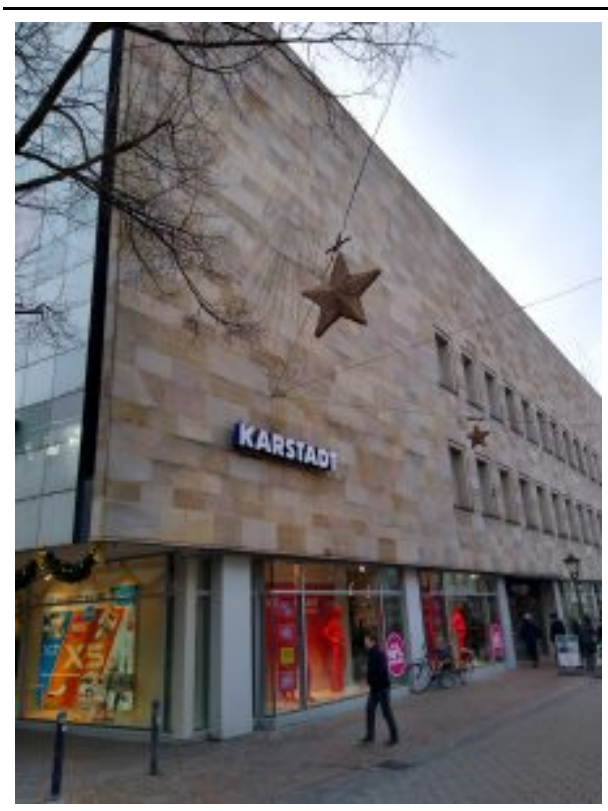

Lisa: Du hast einen

schicken blauen Pullover gekauft. Jetzt brauche ich eine neue Jeans.

Max: Suchst du eine blaue oder eine schwarze Jeans?

Lisa: Eine blaue. Wie findest du diese Jeans?

Max: Diese Jeans gefällt mir nicht. Sie ist zu

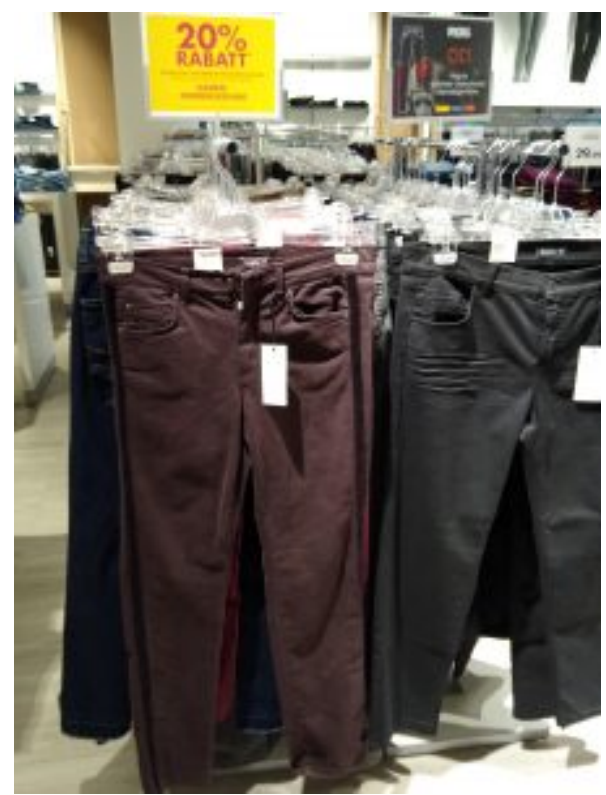
dunkel. Welche Größe hast du?

Lisa: Größe 8. Oh, hier ist eine Jeans im Angebot. Sie kostet nur 29 Euro. Ich probiere sie an.

Max: Diese Jeans sieht echt gut aus! Passt sie auch?

Lisa: Ja, sie passt genau und sie gefällt mir sehr gut. Ich nehme sie.

Beantworten Sie die Fragen. 
1. Wo kaufen sie ein?

2. Was möchte Lisa kaufen?

3. Welche Jeans probiert Lisa an?

4. Wie findet Max diese Jeans?

5. Kauft Lisa diese Jeans?

Das Outfit gefällt mir (nicht). Was tragen diese Leute? Wie finden Sie das? Machen Sie Komplimente oder kritisieren Sie das Outfit. Benutzen Sie die Redemittel aus der Box. 


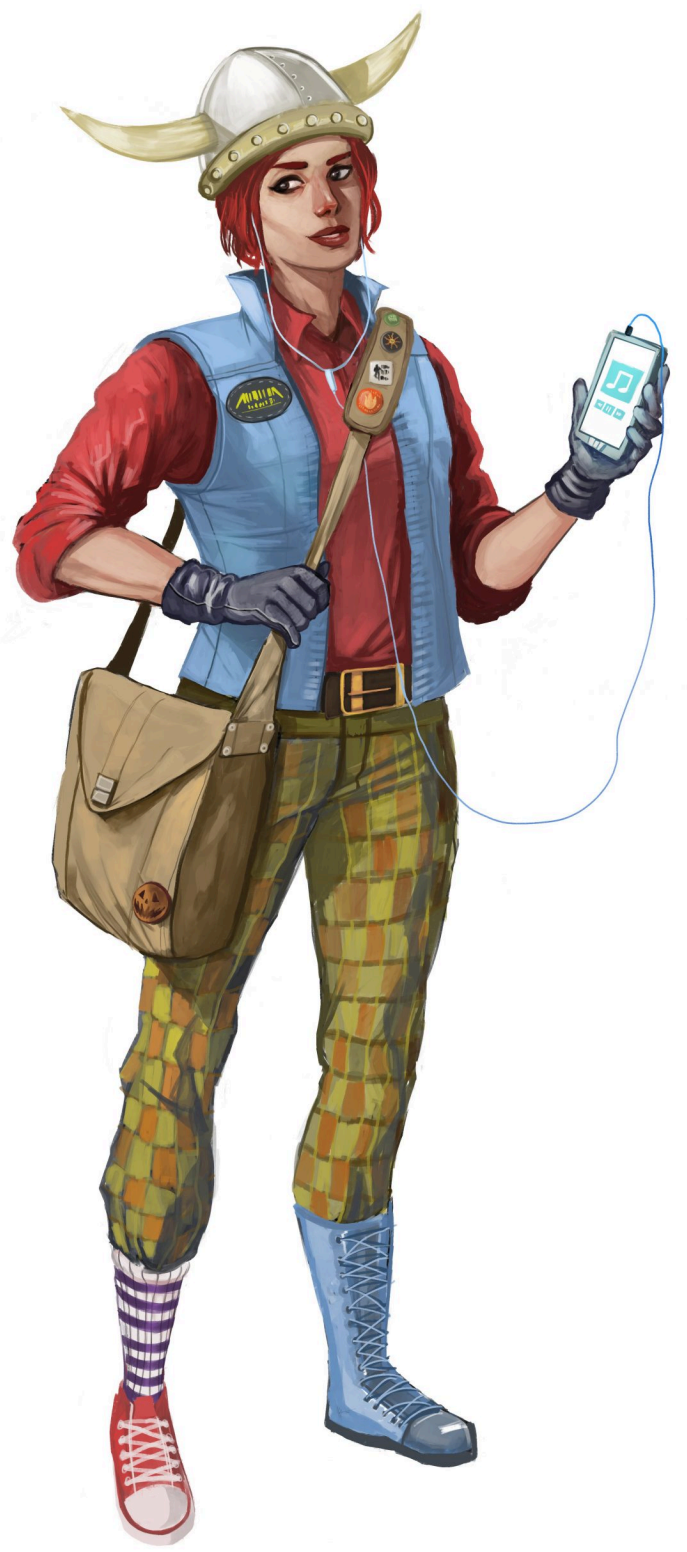


Beispiel:

S1: Wie findest du seinen Hut?

S2: Sein Hut sieht sehr elegant aus!

S1: Wie findest du ihre Tasche?

S2: Ihre Tasche ist total hip.

\section{Redemittel}

Komplimente machen/Kritik üben

\begin{tabular}{|c|c|c|}
\hline positiv & & negativ \\
\hline $\begin{array}{ll}\text { - } & \text { cool } \\
\text { - } & \text { echt spitze } \\
\text { - } & \text { echt gut } \\
\text { - } & \text { echt toll } \\
\text { - } & \text { schön } \\
\text { sehr } \\
\text { - } & \text { elegant } \\
\text { - } & \text { sehr schick } \\
\text { - } & \text { total hip } \\
& \text {... }\end{array}$ & $\begin{array}{l}\text { - } \quad \text { ganz gut } \\
\text { nicht } \\
\text { schlecht } \\
\text {-.. }\end{array}$ & $\begin{array}{ll}\text { - } & \text { altmodisch } \\
\text { - } & \text { hässlich } \\
\text { - } & \text { langweilig } \\
\text { - } & \text { zu groß / } \\
& \text { zu klein / zu } \\
\text { - } & \text { dunkel } \\
\quad . .\end{array}$ \\
\hline
\end{tabular}

Andere Komplimente/Kritik:

$\operatorname{Ihr}(\mathrm{e}) / \operatorname{Sein}(\mathrm{e})$... gefällt mir (nicht)!

$\operatorname{Ihr}(\mathrm{e}) / \operatorname{Sein}(\mathrm{e}) \ldots$ sieht ... aus.

Der/die/das ... steht ihr/ihm total gut / nicht gut! 


\section{Media Attributions}

- group (C) IO-Images is licensed under a Public Domain license

- speech bubble (C) IO-Images is licensed under a Public Domain license

- book (C) IO-Images is licensed under a Public Domain license

- partner (C) IO-Images is licensed under a Public Domain license

- Hilda (C) Solomon Hajramezan is licensed under a All Rights

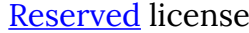

- Cas (C) Solomon Hajramezan is licensed under a All Rights

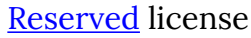


Einheit 3.16 (online)
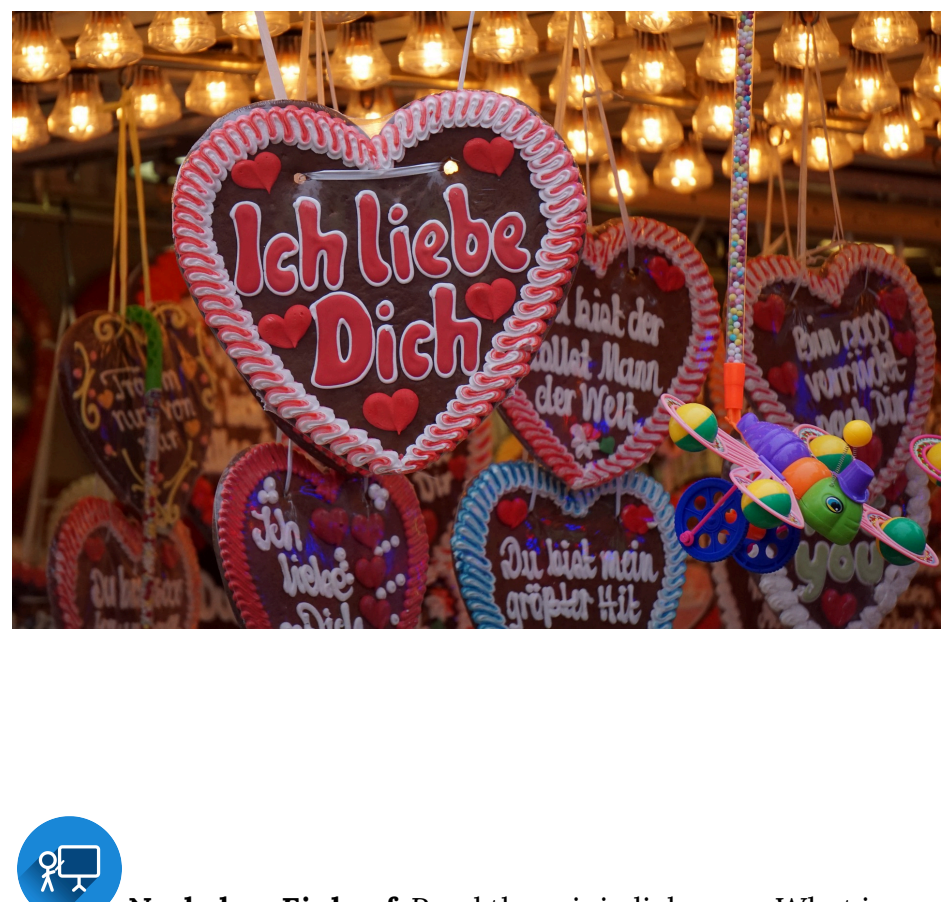

Nach dem Einkauf. Read the mini-dialogues. What is new? 


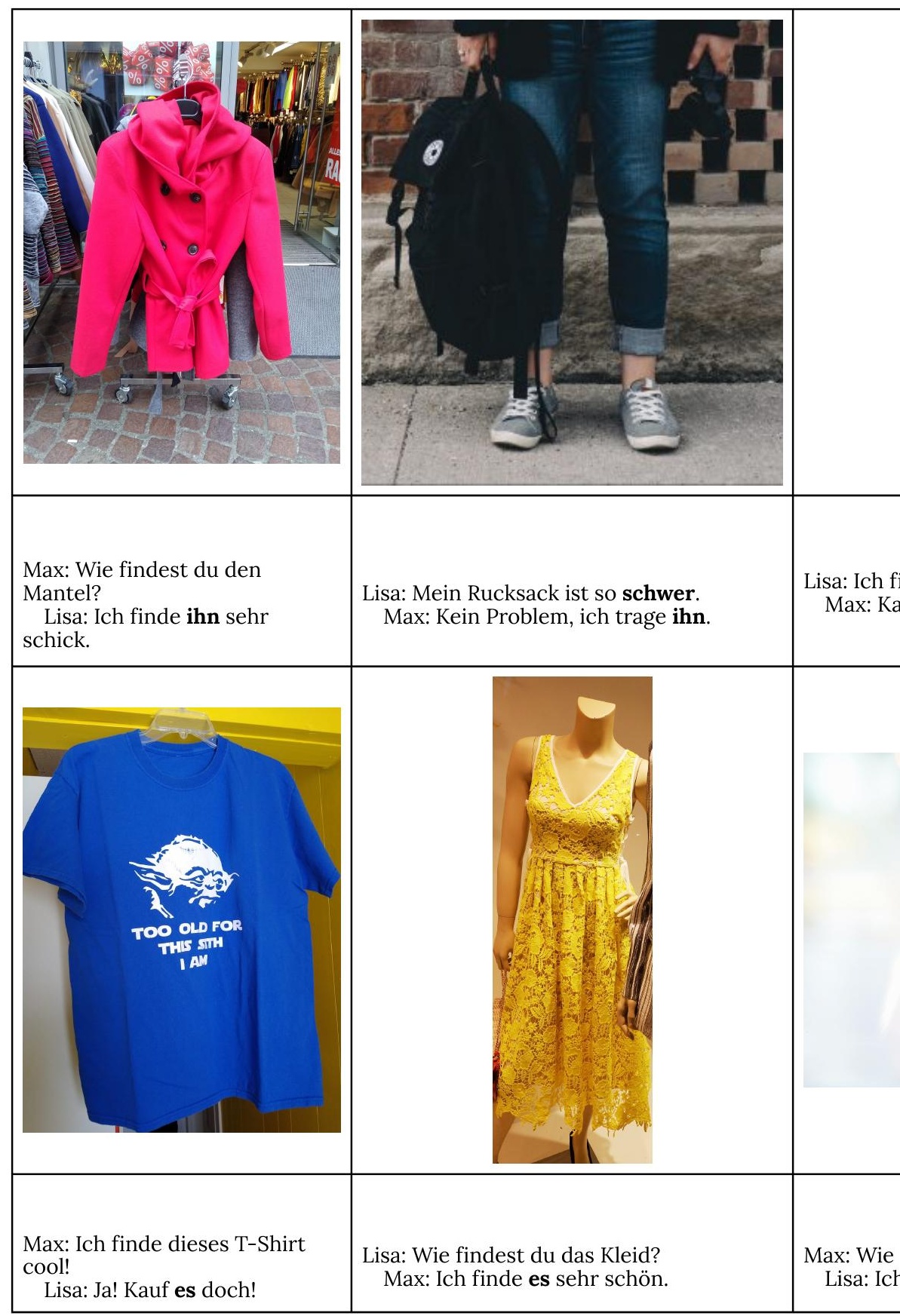




\section{Grammatik}

In Einheit 1, we learned about personal pronouns in the nominative. We also learned in 1.10 about grammatical gender. Remember these basic sentences:

Die Katze ist schwarz und weiß. Sie ist meine neue Katze.

Der Kürbis ist orange. Er ist auch groß.

In these basic sentences, we could have continued to write the proper noun (die Katze, der Kürbis), but why would we when we could also use the pronoun to refer back to the item. Our sentences have gotten much more complicated since Einheit 1, but the concept has not changed. Look back at the previous mini dialogues in Nach dem Einkauf. Why are "sie, es, ihn" bolded? What are they referring back to? Look at this example:

Max:Ich finde dieses T-Shirt cool!

Lisa: Ja! Kauf es doch!

What does the "es" refer to in the statement from Max?

I hope you said: "dieses T-Shirt"!

The only difference between Einheit 1 and now is that when we use a pronoun to replace a noun that is the direct object in a sentence (and therefore in the accusative), the pronoun also has to be in the accusative. 
Here is our chart now with the accusative:

\begin{tabular}{|l|l|}
\hline Nominative & Accusative \\
\hline$i c h(\mathrm{I})$ & mich (me) \\
\hline$d u$ (you - sing. informal) & dich (you - sing. informal) \\
\hline $\boldsymbol{e r} /$ sie/es(he/she/it)* & ihn/sie/es (him/her/it)* \\
\hline $\boldsymbol{w i r}$ (we) & uns (us) \\
\hline $\boldsymbol{i h r}$ (you - pl. informal) & euch (you - pl. informal) \\
\hline sie (they) & sie (them) \\
\hline Sie (you - sing./pl. formal) & Sie (you - sing./pl. formal) \\
\hline
\end{tabular}

* please note: er/ihn, sie, es - can also mean "it" something masculine, feminine or neuter depending on the gender of the noun it is replacing

Beispiele:

Lisa möchte $\mathrm{zu}$ Karstadt shoppen gehen und Max fragt: "Nimmst du mich mit?"

Lisa antwortet: "Ja, ich nehme dich mit!"

Lisa sagt: "Die Jeans gefällt mir sehr gut, ich nehme sie."

Max sagt: "Der Pulli ist sportlich und sehr schick. Ich kaufe ihn."

*ACHTUNG* Here are some separable-prefix verbs that often have an accusative direct object:

abholen (to pick up)

anprobieren (to try on)

anrufen (to call someone on the phone)

einladen (to invite) 
mitbringen (to bring along)

mitnehmen (to take with/along)

Übung 1. Click on the correct accusative personal pronoun.

An interactive H5P element has been excluded from this version of the text. You can view it online here:

https://openeducationalberta.ca/willkommendeutsch/?p=1703\#h5p-82

\section{Übung 2}

An interactive H5P element has been excluded from this

믓 version of the text. You can view it online here:

https://openeducationalberta.ca/willkommen-

deutsch/?p=1703\#h5p-207

Übung 3. This activity will review vocabulary, accusative personal pronouns and possessive determiners. 


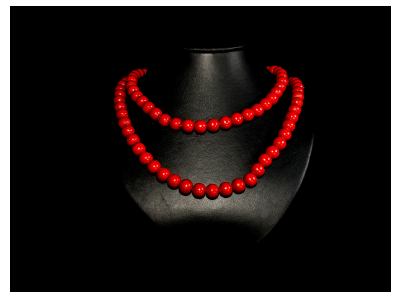

0.

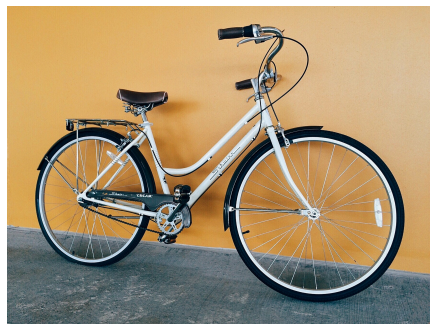

3.

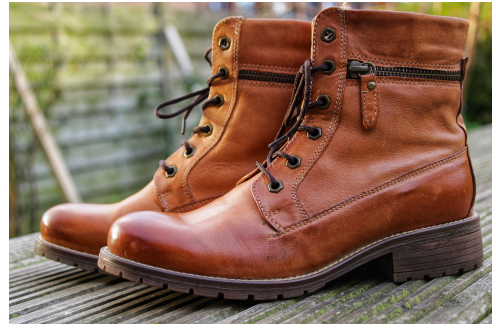

6.

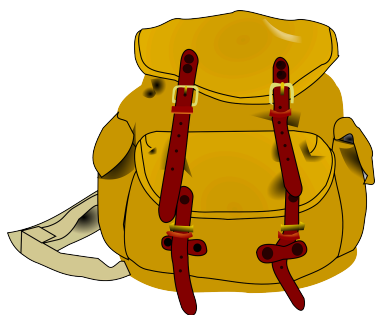

1.

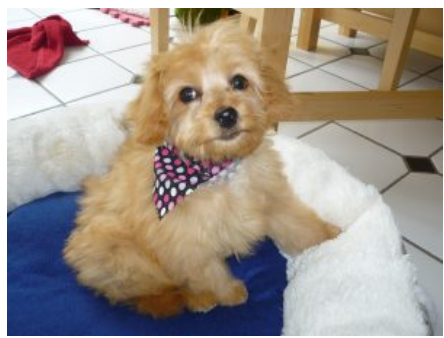

4.

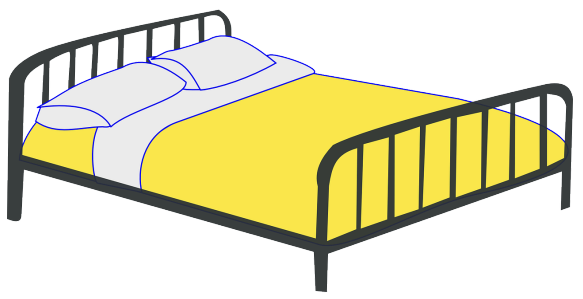

7.

An interactive H5P element has been excluded from this $\frac{0}{1}$ version of the text. You can view it online here:

https://openeducationalberta.ca/willkommendeutsch/?p=1703\#h5p-81 
Was wissen Sie jetzt? Klicken Sie hier für Quiz 3.16.

\section{Media Attributions}

- sommerfest-1442370 1920 (c) Kira Hoffmann is licensed under a Public Domain license

- presentation icon (C) quinntheislander adapted by Solomon Hajramezan is licensed under a Public Domain license

- Mantel (C) ckost is licensed under a CC BY-NC-SA (Attribution NonCommercial ShareAlike) license

- blouse-343352_1920 ( ) motomax is licensed under a Public Domain license

- Krawatten (C) ckost is licensed under a CC BY-NC-SA (Attribution NonCommercial ShareAlike) license

- T-Shirt (C) ckost is licensed under a All Rights Reserved license

- showcase-4465550_1920 (C) engin akyurt is licensed under a Public Domain license

- pink-shoes-2107618 1920 (C) Terri Cnudde is licensed under a Public Domain license

- mens-leather-gloves-1194450_1920 C Domas is licensed under a Public Domain license

- star (C) IO-Images is licensed under a Public Domain license

- pearl-necklace-232335 1920 C Josch13 is licensed under a Public Domain license

- backpack-154121_1280 @ OpenClipart-Vectors is licensed under a Public Domain license

- glasses-4451002_1920 C ANTO ABELLAN is licensed under a Public Domain license

- bike-1627433_1920 (C) Wokandapix is licensed under a Public Domain license

- Lotte (C) ckost is licensed under a All Rights Reserved license 
- Ravi chair 2 (C) ckost is licensed under a All Rights Reserved license

- winter-boots-3867776_1920 C armennano is licensed under a Public Domain license

- bed-35505 1280 (c) Clker-Free-Vector-Images is licensed under a Public Domain license

- football-157930_1280 (1) (C) OpenClipart-Vectors is licensed under a Public Domain license

- check mark (C) janjf93 adapted by Solomon Hajramezan is licensed under a Public Domain license 


\section{Einheit 3.17}

\section{0}

Was ist das? Raten Sie bitte die Antwort.

1. Man trägt es mit einem Sakko.

2. Man trägt sie im Ohr.

3. Man trägt sie im Winter an den Händen.

4. Man trägt ihn auf dem Kopf.

5. Man trägt sie im Sommer an den Füßen.

6. Man trägt sie, wenn man wandert.

7. Man trägt ihn, wenn es schneit.

8. Man trägt sie um den Hals.

\section{$\varepsilon$}

Eine Person beschreiben. Schreiben Sie eine kurze Beschreibung. Sie können entweder Hilda oder Cas beschreiben.

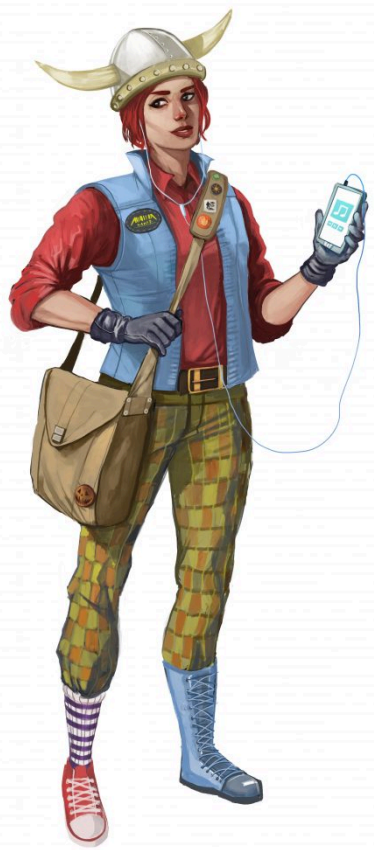




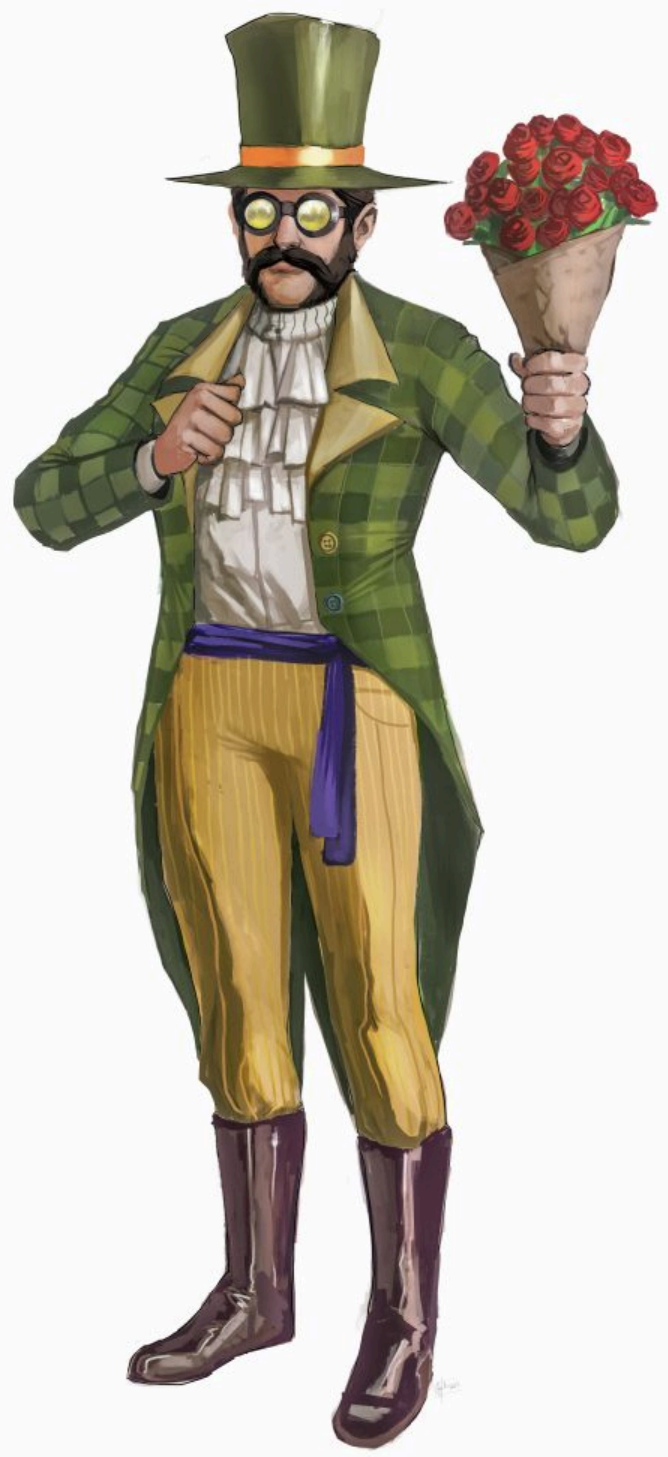

$234 \mid 3.17$ 


\section{Media Attributions}

- group (C) IO-Images is licensed under a Public Domain license

- partner (C) IO-Images is licensed under a Public Domain license

- Hilda (c) Solomon Hajramezan is licensed under a All Rights Reserved license

- Cas (C) Solomon Hajramezan is licensed under a All Rights Reserved license 


\section{Wortschatz}

Quizlet:

Wortschatz Einheit 3 (alle Kategorien)

Familie

Familie (plurals)

Beschreibungen

Berufe

Eigenschaften

Kleidung

Kleidung (plurals)

Im Kaufhaus

Im Kaufhaus (plurals)

$\underline{\text { Sonstige Wörter und Ausdrücke }}$

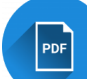

Wortschatz 3

Media Attributions

- $\underline{\text { link }}$ C IO-Images is licensed under a Public Domain license

- pdf (C IO-Images is licensed under a Public Domain license 


\section{Zum Spaß!}
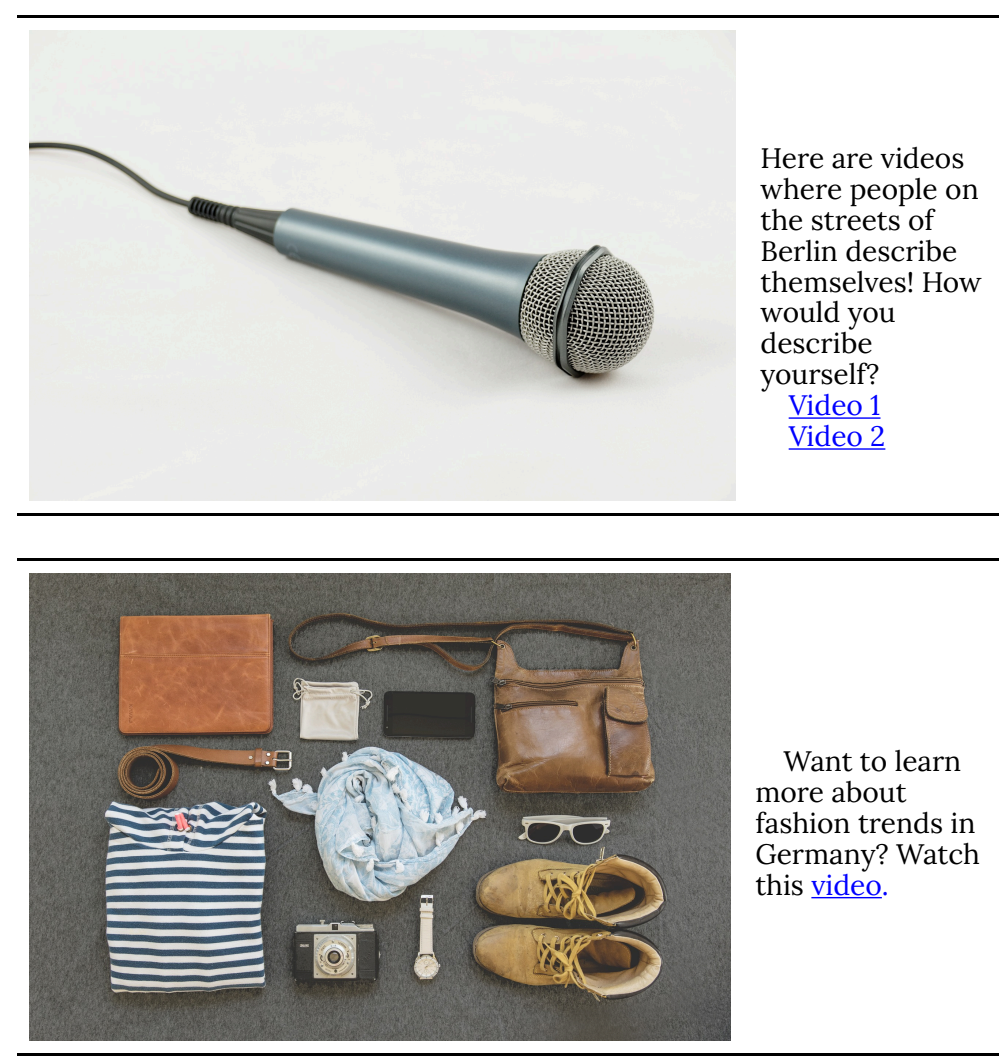


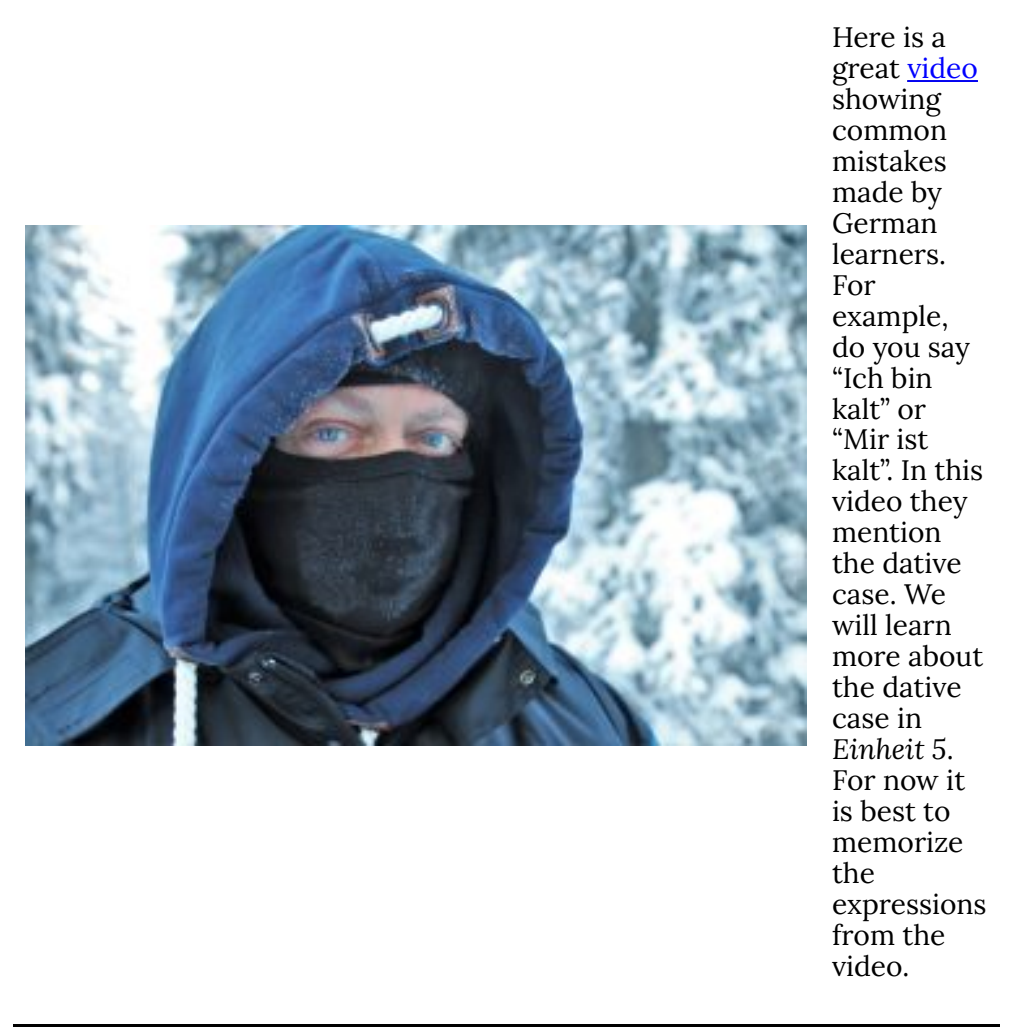

\section{Extra Practice (optional):}

Familie Wortschatz: how fast can you find the 10 missing nouns?

An interactive H5P element has been excluded from this

믓 version of the text. You can view it online here:

https://openeducationalberta.ca/willkommen-

deutsch/?p=2847\#h5p-55 
More extra Practice (optional): These activities are from the website Schubert-Verlag.

$\underline{\text { Familie }}$

Akkusativ

möchten

Adjektivendungen

Media Attributions

- microphone (C) Bruno/Germany is licensed under a Public Domain license

- fashion- (C) LUM3N is licensed under a Public Domain license

- lapland-g5be9aef96_1920 @ pasja1000 is licensed under a Public Domain license 
240 | Zum Spaß! 


\section{EINHEIT 4: PLÄNE UND TERMINE MACHEN}

\section{Learning Outcomes}

At the end of Einheit 4, you will be able to...

- talk about your daily routine

- discuss the cultural importance of breakfast

- make plans for the weekend

- decline an invitation and give a reason

- offer suggestions for a healthier lifestyle

- identify and name parts of the body

- discuss illness and what hurts

- $\quad$ make plans (with friends) and formal appointments (with the doctor's office, bank, professor)

You will also have learned about the following structures:

- reflexive pronouns in the accusative

- modal verbs

- "du"-imperative

- $\quad$ subordinating conjunctions "weil", "wenn", "dass", and "ob" 
242 | Einheit 4: Pläne und Termine machen 


\section{Einheit 4.1}

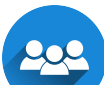

Wochentage und Tageszeiten
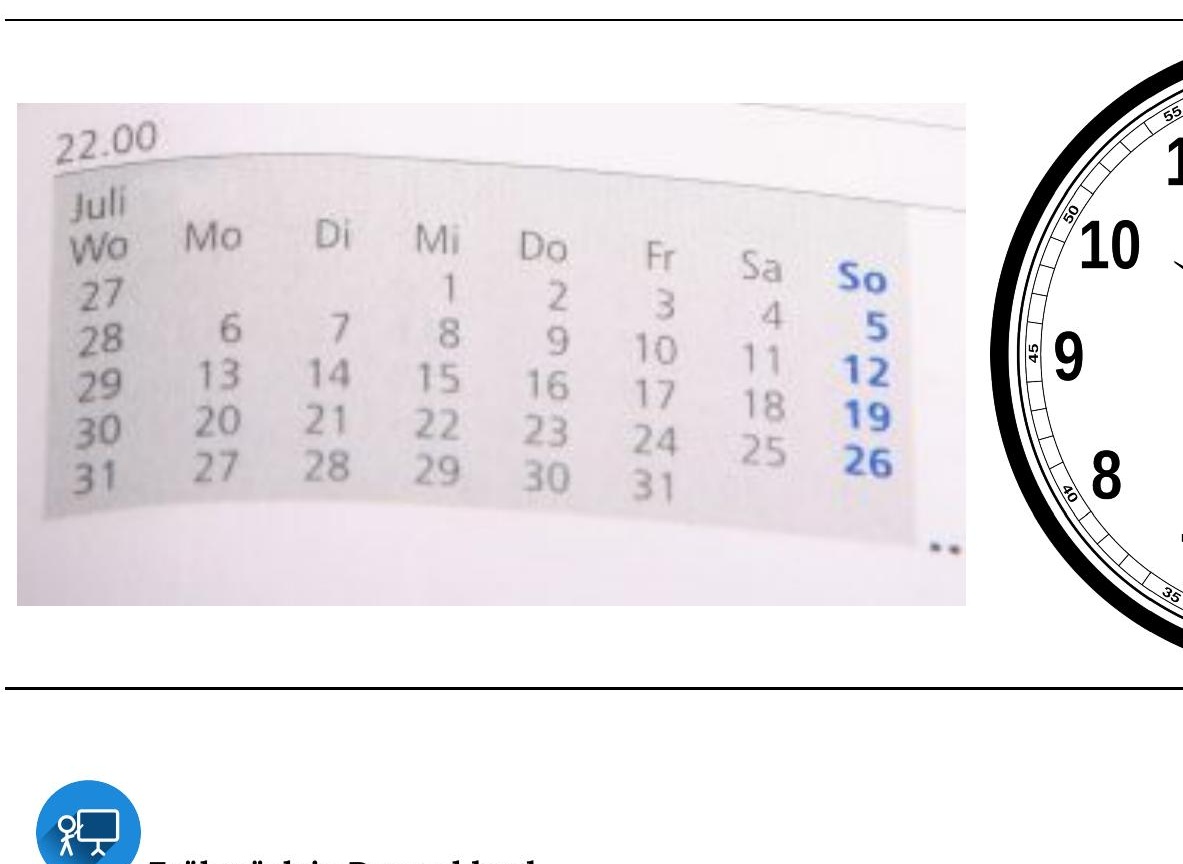

Frühstück in Deutschland

므 An interactive H5P element has been excluded from this version of the text. You can view it online here:

https://openeducationalberta.ca/willkommendeutsch/?p=44\#h5p-111 


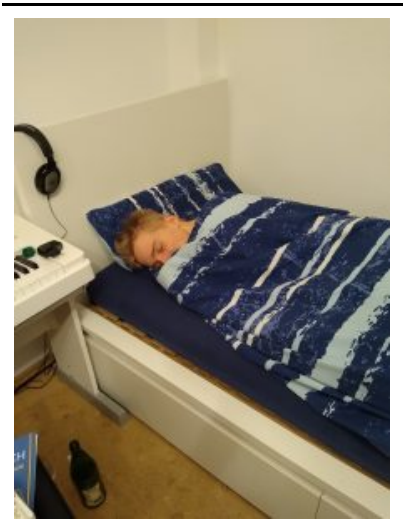

Es ist 6 Uhr morgens. Nico schläft noch.

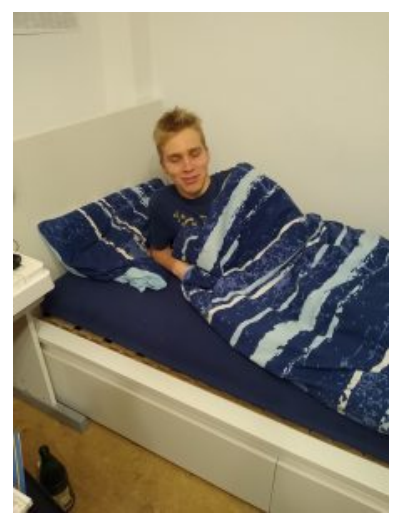

Der Wecker klingelt! Nico wacht auf.

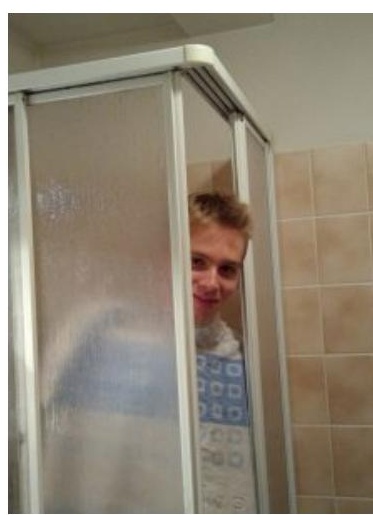

Er geht ins Bad. Er duscht sich.

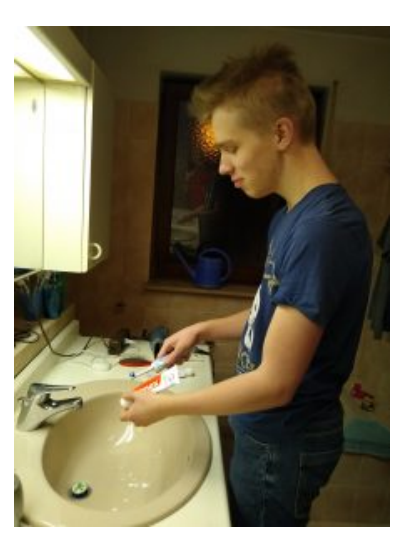

Er putzt seine Zähne.

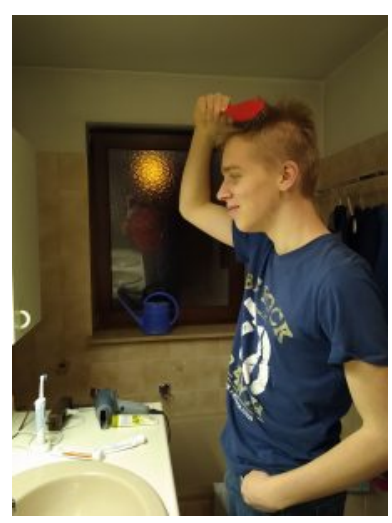

Er kämmt sich.

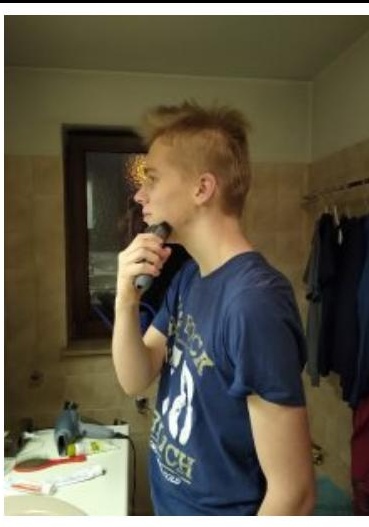

Er rasiert sich. Dann frühstückt er.

\section{$\Omega$}

Interview: Was machst du an einem typischen Tag?

Arbeiten Sie mit einer Partnerin oder mit einem Partner. Fragen und antworten Sie.

1. Wann stehst du an einem Wochentag auf? 
2. Wann stehst du am Wochenende auf?

3. Um wie viel Uhr frühstückst du?

4. Was frühstückst du?

5. Wann gehst du in die Uni?

6. Was machst du am Nachmittag?

7. Gehst du am Freitag- oder Samstagabend aus?

8. Wann machst du Sport?

9. Um wie viel Uhr gehst du ins Bett?

\section{Media Attributions}

- group (C) IO-Images is licensed under a Public Domain license

- clock (C) OpenClipart-Vectors is licensed under a Public Domain license

- presentation icon (C) quinntheislander adapted by Solomon Hajramezan is licensed under a Public Domain license

- schlafen (C) ckost is licensed under a All Rights Reserved license

- aufwachen (C) ckost is licensed under a All Rights Reserved license

- duschen (C) ckost is licensed under a All Rights Reserved license

- sich die Zähne putzen (C) ckost is licensed under a All Rights Reserved license

- sich die Haare kämmen (C) ckost is licensed under a All Rights Reserved license

- sich rasieren (C) ckost is licensed under a All Rights Reserved license

- partner (C) IO-Images is licensed under a Public Domain license 
Einheit 4.2 (online)

Das Frühstück

246 | 4.2 


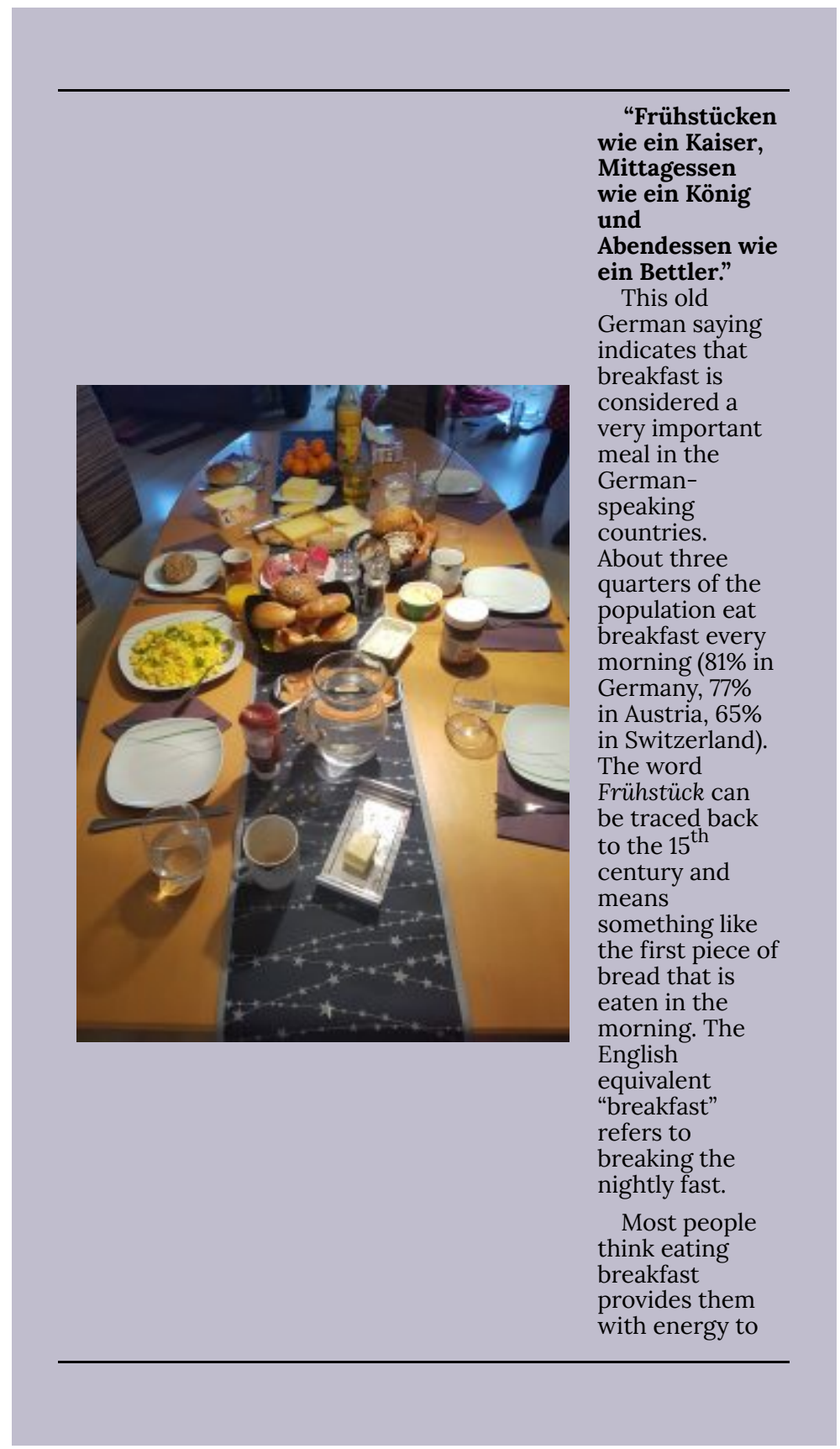




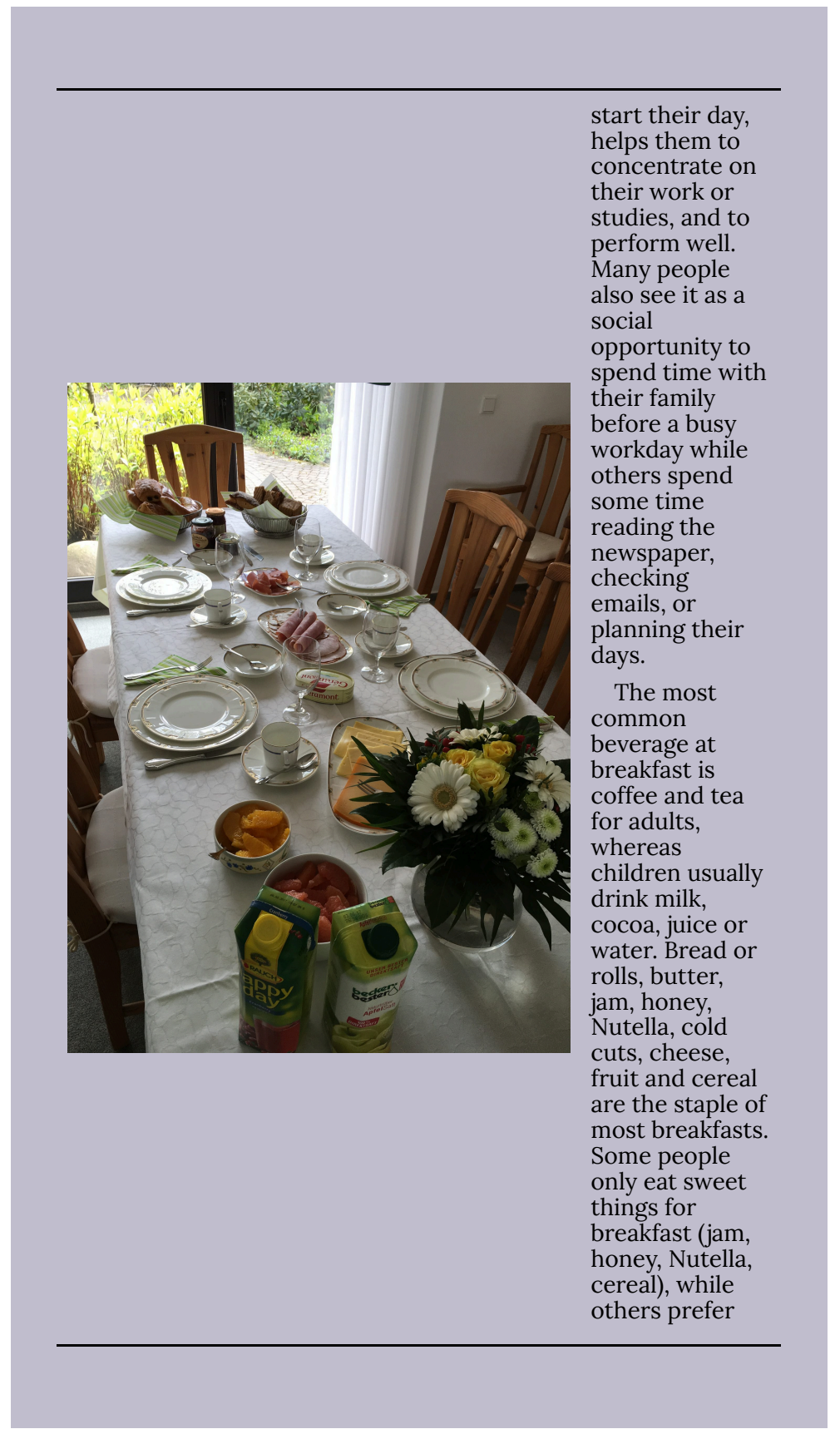


more savoury toppings for their bread. And yet others like to mix. On the weekend, people often take more time for their breakfast or even extend it into a brunch, and add eggs in various forms to their meal.

Übung 1. Drag the nouns to their correct article.

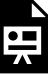

An interactive H5P element has been excluded from this version of the text. You can view it online here:

https://openeducationalberta.ca/willkommen-

deutsch/?p=140\#h5p-113

So frühstückt Deutschland: Die Nutella Frühstücksstudie 2015 zeigt uns, wie Leute in Deutschland ihren Tag beginnen (C) Nutella) 

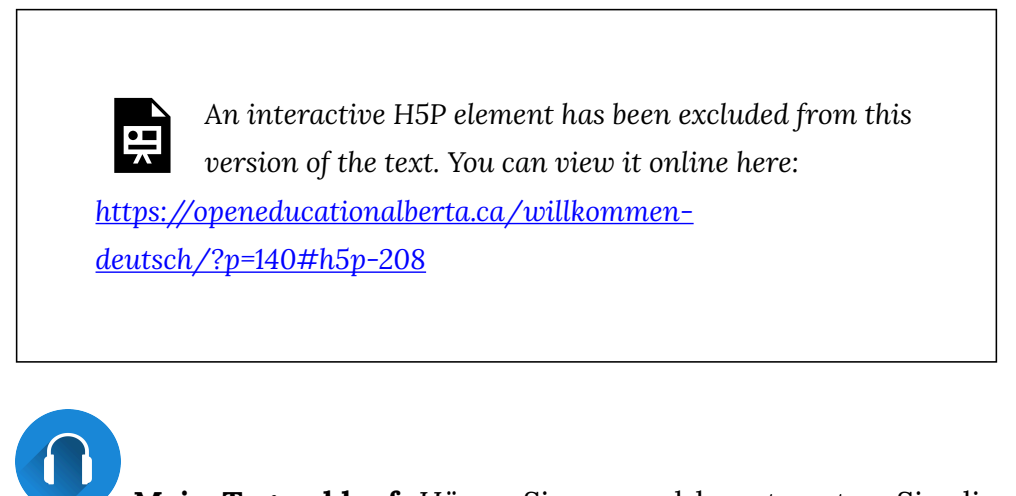

Mein Tagesablauf. Hören Sie zu und beantworten Sie die Fragen. 


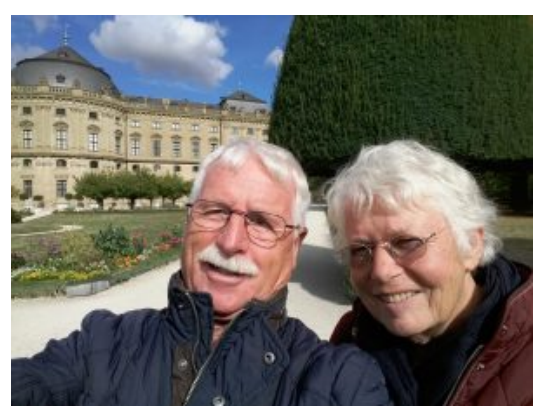

Rolf und Marita

\section{One or more interactive elements has been}

excluded from this version of the text. You can view them online here:

https://openeducationalberta.ca/ willkommen-

deutsch/?p=140\#audio-140-1

\section{An interactive H5P \\ 숫 element has been}

excluded from this version of the text. You can view it online here: https://openeducationalberta.ca/ willkommendeutsch/?p=140\#h5p-115 


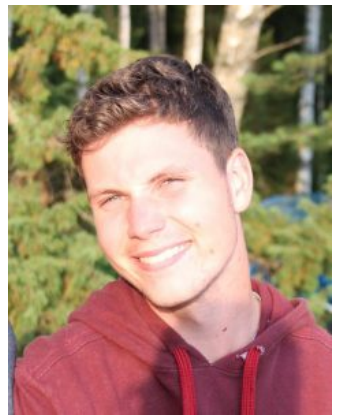

Sebi

\section{One or more interactive elements has been}

excluded from this version of the text. You can view them online here:

https://openeducationalberta.ca/ willkommen-

deutsch/?p=140\#audio-140-2

\section{An interactive H5P \\ 믓 element has been}

excluded from this version of the text. You can view it online here: https://openeducationalberta.ca/ willkommendeutsch/?p=140\#h5p-116

\section{Grammatik}


Please work through the following presentation to learn about reflexive pronouns in the accusative.

Reflexive Pronouns in the Accusative

\section{Übung 2}

An interactive H5P element has been excluded from this version of the text. You can view it online here:

https://openeducationalberta.ca/willkommendeutsch/?p=140\#h5p-232

Was machen Sie an einem typischen Tag? Schreiben Sie 5 Sätze über Ihren Tagesablauf und bringen Sie die Sätze mit in die nächste Deutschstunde.

Q

Wortschatz in Quizlet:

Frühstück

Tagesablauf

Was wissen Sie jetzt? Klicken Sie hier für Quiz 4.2. 


\section{Media Attributions}

- Frühstück (C) csawatzky is licensed under a CC BY-NC-SA (Attribution NonCommercial ShareAlike) license

- star (C) IO-Images is licensed under a Public Domain license

- book (C) IO-Images is licensed under a Public Domain license

- headphones (C) IO-Images is licensed under a Public Domain license

- Rolf und Marita (C) ckost is licensed under a All Rights Reserved license

- Sebi (c) ckost is licensed under a All Rights Reserved license

- pen (C) IO-Images is licensed under a Public Domain license

- link (C) IO-Images is licensed under a Public Domain license

- check mark (C) janjf93 adapted by Solomon Hajramezan is licensed under a Public Domain license 


\section{Einheit 4.3}

200

Was machen Sie an einem typischen Tag?

\section{8 目}

Was machen Sie am Wochenende?

Sagen Sie, ob Sie etwas "ganz bestimmt", "wahrscheinlich", "vielleicht" oder "auf keinen Fall" machen. Vergleichen Sie Ihre Antworten dann mit einer Partnerin oder mit einem Partner.

Beispiel:

S1: Was machst du ganz bestimmt am Wochenende?

S2: Ich schlafe ganz bestimmt aus!

\begin{tabular}{|l|l|l|}
\hline & ich & $\begin{array}{l}\text { meine Partnerin/ } \\
\text { mein Partner }\end{array}$ \\
\hline Ich schlafe aus. & & \\
\hline Ich dusche mich. & & \\
\hline $\begin{array}{l}\text { Ich rufe Freunde oder } \\
\text { meine Familie an. }\end{array}$ & & \\
\hline Ich lerne für eine Prüfung. & & \\
\hline Ich gehe ins Kino. & & \\
\hline Ich ruhe mich aus. & & \\
\hline Ich spiele Brettspiele. & & \\
\hline Ich gehe früh ins Bett. & & \\
\hline Ich chille mit Freunden. & & \\
\hline Ich surfe im Internet. & & \\
\hline
\end{tabular}

\section{E三}

Pläne für das Wochenende. Luca und Sebi sprechen über ihre Pläne für das Wochenende.

Luca: Hey Sebi, was machst du am Wochenende? 
Sebi: Ich will ausschlafen! Ich bin total kaputt, diese Woche war sehr stressig an der Uni.

Luca: Willst du am Samstagabend ins Kino gehen? Der neue Star Wars Film läuft seit einer Woche und ich habe ihn noch nicht gesehen.

Sebi: Oh Mist! Ich kann leider nicht. Ich muss am Samstagabend arbeiten! Kannst du am Freitagabend?

Luca: Nee, da kann ich nicht. Meine Oma hat Geburtstag und wir wollen alle zusammen essen gehen. Und was ist mit Sonntag?

Sebi: Ja, ok, das geht. Ich soll eigentlich für eine Prüfung lernen, aber das kann ich auch am Montagabend machen. Willst du am Sonntagmorgen um $11 \mathrm{zu}$ mir kommen und wir brunchen zusammen? Wir können Rühreier mit Speck kochen, du weißt ja, dass ich gut kochen kann.

Luca: Super Idee! Ich bringe frische Brötchen und Nutella mit. Soll ich auch noch Marmelade mitbringen?

Sebi: Ach nein, ich mag keine Marmelade. Bring lieber noch Wurst und Käse mit.

Luca: Ok, kann ich machen. Jetzt muss ich aber weg, weil meine Psychologievorlesung anfängt.

Beantworten Sie die Fragen:

1. Welchen Film möchte Luca im Kino sehen?

2. Warum kann Sebi am Samstagabend nicht ins Kino gehen?

3. Warum kann Luca am Freitag nicht ins Kino gehen?

4. Was soll Sebi am Sonntag machen?

5. Was wollen Luca und Sebi am Sonntagmorgen zusammen machen?

6. Was bringt Luca mit?

Was ist neu hier? 
An interactive H5P element has been excluded from this version of the text. You can view it online here:

https://openeducationalberta.ca/willkommen-

deutsch/?p=142\#h5p-191

8

Was machst du heute Abend? Laden Sie Ihre Partnerin oder Ihren Partner ein und machen Sie verschiedene Vorschläge. Ihre Partnerin oder Ihr Partner soll die Einladung ablehnen und einen Grund dafür angeben.

Beispiel:

S1: Ich will heute Abend Tennis spielen. Möchtest du mitkommen?

S2: Nein, leider kann ich nicht. Ich muss arbeiten.

\begin{tabular}{|c|c|}
\hline Vorschlag & Grund \\
\hline $\begin{array}{l}\text { - } \quad \text { in einen Club gehen } \\
\text { - } \quad \text { ins Kino gehen } \\
\text { - } \text { Basketball spielen } \\
\text { - } \text { zu einer Party gehen } \\
\text { - } \quad \text { essen gehen } \\
\text { - } \quad \text { in eine Kneipe gehen } \\
\text { - Videospiele spielen }\end{array}$ & $\begin{array}{l}\text { - } \text { meine Eltern besuchen } \\
\text { - } \text { für eine Prüfung lernen } \\
\text { - } \text { meinsaufgaben machen Haare waschen } \\
\text { - } \text { morgen früh aufstehen } \\
\text { - } \text { auf meine kleine Schwester } \\
\text { aufpassen } \\
\text { - mich duschen }\end{array}$ \\
\hline
\end{tabular}

\section{Media Attributions}

- group (C IO-Images is licensed under a Public Domain license

- partner (C) IO-Images is licensed under a Public Domain license 
- document (C) IO-Images is licensed under a Public Domain license

- book (C) IO-Images is licensed under a Public Domain license

- question-mark (C) IO-Images is licensed under a Public Domain license 


\section{Einheit 4.4 (online)}

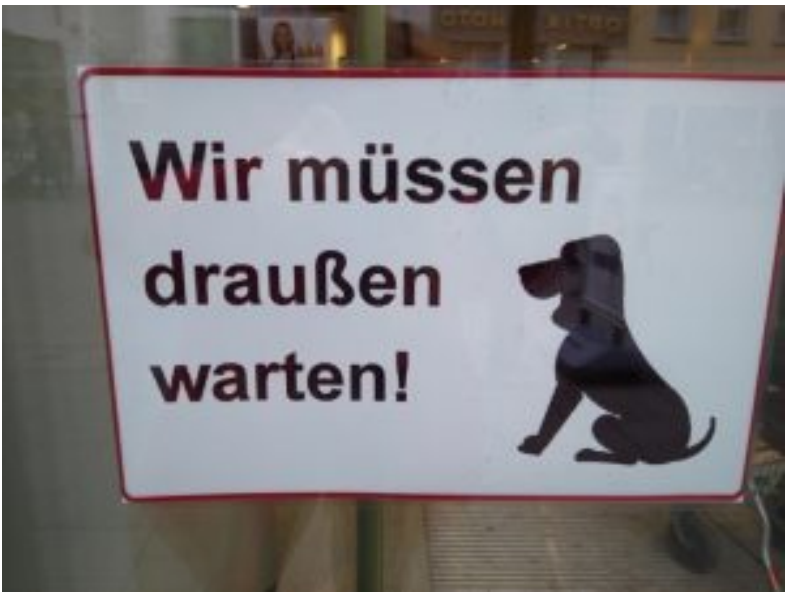

Übung 1. Wiederholen Sie: Reflexive Pronouns in the $\underline{\text { Accusative }}$

므 An interactive H5P element has been excluded from this version of the text. You can view it online here:

https://openeducationalberta.ca/willkommendeutsch/?p=144\#h5p-114

\section{Grammatik}


Modal Verbs: können, wollen, müssen

Please work through the following presentation to learn about the modal verbs können, wollen and müssen.

Modal Verbs: können, wollen, müssen

\section{Übung 2}

An interactive H5P element has been excluded from this
version of the text. You can view it online here:
https://openeducationalberta.ca/willkommen-
deutsch/?p=144\#h5p-118

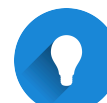

\section{Grammatik}

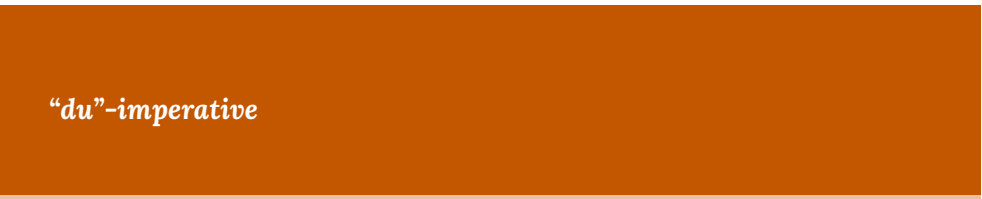

The " $d u$ "-imperative is used for people you normally address with " $d u$ ", like your friends, family, or other 
students. It is formed by dropping the -st ending from the present tense $d u$-form and you don't use the pronoun " $d u$ " in your imperative, for example:

du kommst $\rightarrow$ Komm!

du nimmst $\rightarrow$ Nimm!

du trinkst $\rightarrow$ Trink!

Verbs that have a stem-vowel change from $a \rightarrow$ ä or from $\mathrm{au} \rightarrow$ äu drop the - st and the Umlaut for the imperative form, for example:

$$
\begin{aligned}
& d u \text { fährst } \rightarrow \text { Fahr! } \\
& d u \text { läufst } \rightarrow \text { Lauf! }
\end{aligned}
$$

Verbs whose stem ends in - $d$ or -t add an -e in the " $d u$ "imperative, for example:

$d u$ arbeitest $\rightarrow$ Arbeite!

Verbs whose stem ends in $-s,-\beta$, or $-z$ only drop the $-t$, for example:

$d u$ isst $\rightarrow$ Iss!

$d u$ liest $\rightarrow$ Lies mehr Bücher!

$d u$ tanzt $\rightarrow$ Tanz!

Separable prefix verbs still separate the prefix from the verb stem, for example:

$d u$ siehst fern $\rightarrow$ Sieh nicht so lange fern!

du kaufst zu viel ein $\rightarrow$ Kauf nicht so viel ein!

Reflexive verbs can also be used in the imperative, for example:

du ruhst dich aus $\rightarrow$ Ruh dich aus! 
du ziehst dich warm an $\rightarrow$ Zieh dich warm an!

Der Körper. Sehen Sie sich die Präsentation mit den Skulpturen an. Die Skulpturen sind von dem deutschen Bildhauer und Grafiker Gerhard Marcks (1889-1981), der auch Lehrer am Bauhaus in Weimar war. Seine Arbeit wurde von dem französischen Bildhauer Auguste Rodin inspiriert.

An interactive H5P element has been excluded from this version of the text. You can view it online here:

https://openeducationalberta.ca/willkommendeutsch/?p=144\#h5p-119

Wortschatz in Quizlet:

Körper

Was wissen Sie jetzt? Klicken Sie hier für Quiz 4.4.

Extra Practice (optional): 


\section{Video Serie - Nicos Weg}

Click on the link and watch the video. Then click on "start" under the video and do the exercises.

\section{Media Attributions}

- star (C) IO-Images is licensed under a Public Domain license

- link (C) IO-Images is licensed under a Public Domain license

- check mark (C) janjf93 adapted by Solomon Hajramezan is licensed under a Public Domain license 


\section{Einheit 4.5}

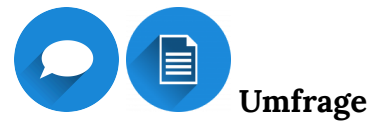

1. Muss dein Bruder/deine Schwester früh aufstehen?

2. Kannst du gut Gitarre spielen?

3. Müssen deine Eltern viel arbeiten?

4. Willst du heute Abend ins Kino gehen?

5. Wollen deine Eltern ein neues Auto kaufen?

6. Können deine Freunde Deutsch sprechen?

\section{2. 目}

Informationsspiel: Kannst du kochen? Arbeiten Sie mit einer Partnerin oder mit einem Partner. Fragen Sie nach den Informationen, die Ihnen fehlen.

- ausgezeichnet, fantastisch, sehr gut $(+)$

- ganz gut (0)

- nicht so gut, nur ein bisschen, gar nicht (-)

Beispiel:

Person A: Kann Veronika kochen?

Person B: Ja, sehr gut.

Person A: Kannst du kochen?

Person B: .... 


\begin{tabular}{|l|l|l|l|}
\hline & Veronika & Max & $\begin{array}{c}\text { meine } \\
\text { Partnerin/mein } \\
\text { Partner }\end{array}$ \\
\hline kochen & sehr gut & & \\
\hline eislaufen & & & \\
\hline ein Auto reparieren & & & \\
\hline Snowboard fahren & & & \\
\hline fotografieren & & & \\
\hline
\end{tabular}

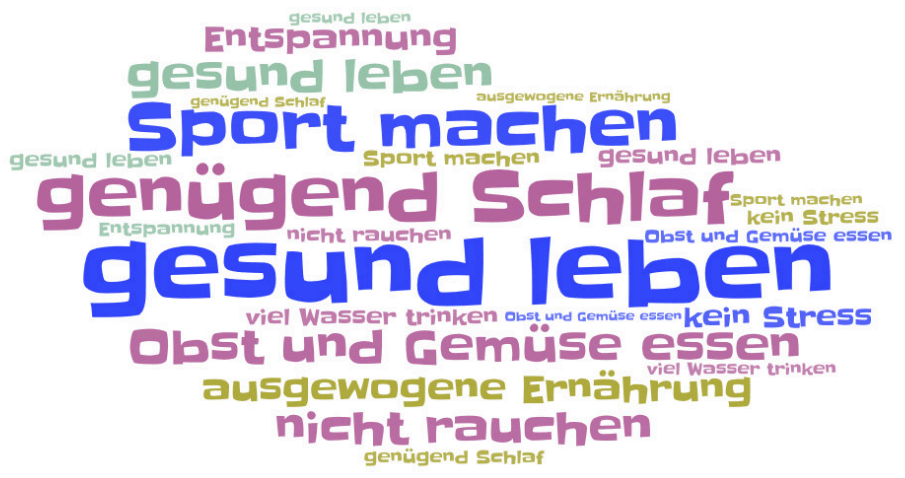

8

Ich will gesünder leben! Sagen Sie drei Dinge, wie Sie gesünder leben wollen. 


\begin{tabular}{|l|l|}
\hline $\begin{array}{l}\text { Ich will nicht mehr so viel/ so oft/ so } \\
\text { lange/ so spät ... }\end{array}$ & Ich will mehr ... \\
\hline & \\
- Bier trinken & \\
- fernsehen & \\
- ins Bett gehen & - Obst und Gemüse essen \\
- Junkfood essen & - Schlafen \\
- in die Kneipe gehen & - Wasser trinken \\
- Zucker essen & - mich entspannen \\
- Kaffee trinken & - mich um mich selbst \\
- rauchen & - kümmern \\
- Schokolade essen & -... \\
\hline
\end{tabular}

2

Tipps: Leb gesund! Sagen Sie Ihrer Partnerin oder Ihrem Partner, wie sie gesünder leben sollen. Benutzen Sie den "duImperativ".

Beispiel:

Trink mehr Wasser! ...

\section{Media Attributions}

- speech bubble (C) IO-Images is licensed under a Public Domain license

- document (C IO-Images is licensed under a Public Domain license

- partner (C) IO-Images is licensed under a Public Domain license 


\section{Einheit 4.6 (online)}

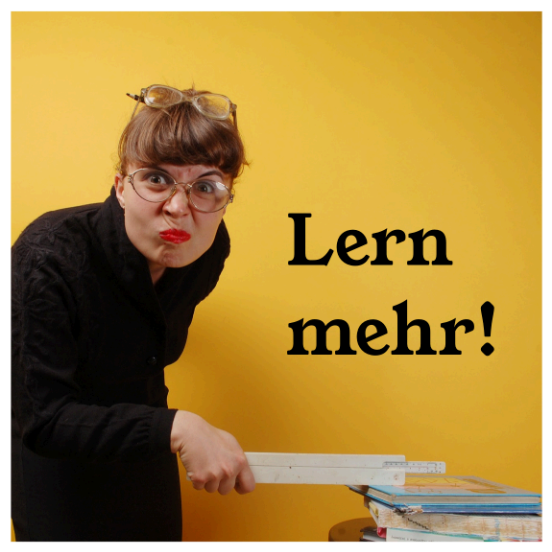

\section{Übung 1}
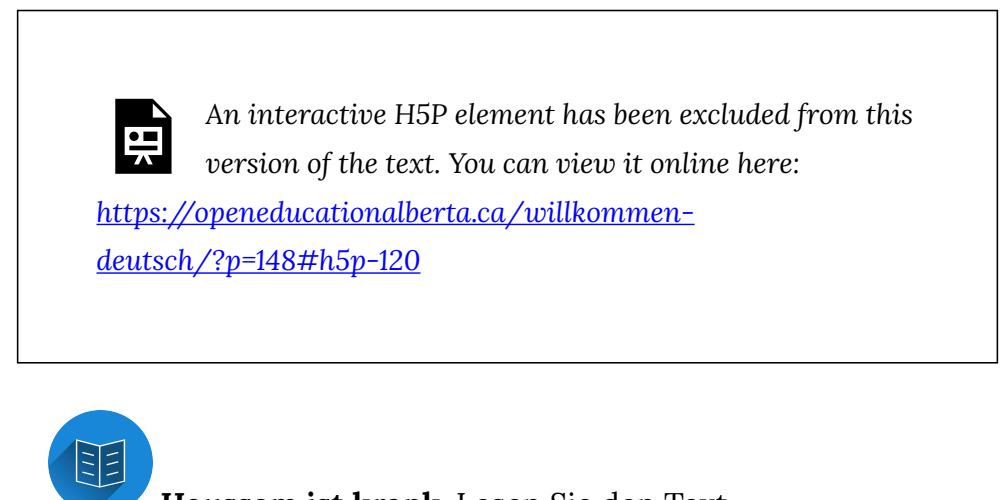

Houssem ist krank. Lesen Sie den Text.

Es ist Donnerstagmorgen. Houssem wacht auf und fühlt sich gar nicht gut. Er hat Halsschmerzen und hustet ein bisschen. Er denkt: "Ich kann nicht arbeiten gehen. Ich fühle mich wirklich schlecht. Ich 
muss zu meiner Ärztin. Hoffentlich kann sie mir helfen." Houssem ruft in der Arztpraxis an, um einen Termin zu bekommen.

Anruf in der Arztpraxis. Hören Sie den Dialog und beantworten Sie die Frage in Übung 2.

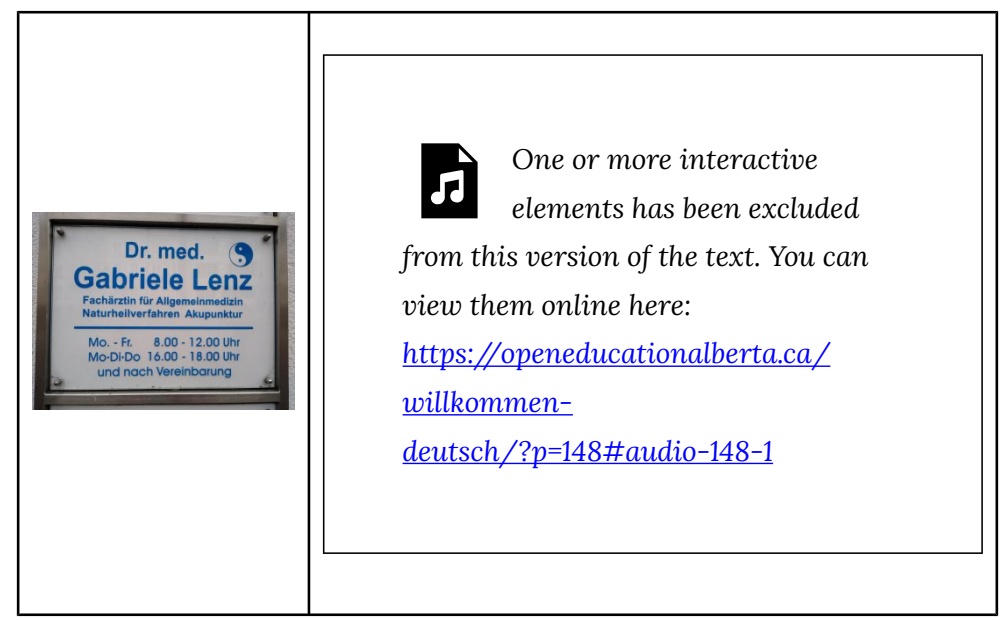

\section{Übung 2: Hörverständnis}

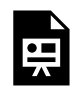

An interactive H5P element has been excluded from this version of the text. You can view it online here:

https://openeducationalberta.ca/willkommendeutsch/?p=148\#h5p-124 
Houssem fährt zur Arztpraxis. Lesen Sie weiter und beantworten Sie die Fragen in Übung 3. 


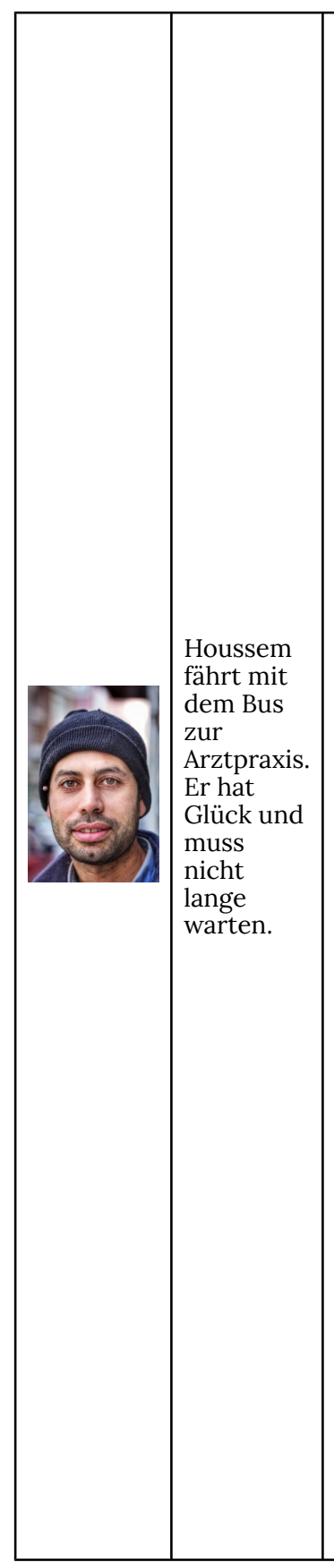

\begin{tabular}{l|l|l}
270 & 4.6
\end{tabular} 
Dr. Lenz: Guten Tag, Herr Bahar. Was kann ich für Sie tun?

Houssem: Guten Tag, Frau Doktor. Mir geht es gar nicht gut. Ich habe Halsschmerzen und Husten und mein Kopf tut weh.

Dr. Lenz: Sagen Sie mal "Aaaaah!" Und husten Sie mal. Oh je, Ihr Hals ist ganz rot. Sie sind erkältet und haben eine starke Halsentzündung.

Houssem: Ja, mein Hals tut sehr weh.

Dr. Lenz: Sie müssen Hustensaft nehmen. Sie müssen auch diese Tabletten nehmen, 2 morgens, 2 mittags und 2 abends. Sie dürfen auch nicht viel telefonieren. Rauchen Sie?

Houssem: Ja, aber nicht so viel. 20 Zigaretten am Tag.

Dr. Lenz: Ich schreibe Sie eine Woche krank. Sie dürfen nicht arbeiten gehen und Sie dürfen natürlich auch nicht rauchen! Sie sollen zu Hause bleiben und viel heißen Tee mit Honig trinken.

Houssem: Oh, ich mag aber keinen heißen Tee.

Dr. Lenz: Das ist kein Problem. Sie können auch heißes Zitronenwasser mit Honig trinken. Da ist auch viel Vitamin C drin, das ist gut gegen eine Erkältung.

Houssem: Oh ja, das mache ich. Das ist eine gute Idee.

Dr. Lenz: Und dann machen Sie bitte einen Termin für nächste Woche. Gute Besserung, Herr Bahar!

Houssem: Vielen Dank, Frau Doktor! Bis nächste Woche!

\section{Übung 3: Leseverständnis}

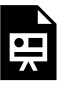

An interactive H5P element has been excluded from this version of the text. You can view it online here:

https://openeducationalberta.ca/willkommendeutsch/?p=148\#h5p-123 


\section{Grammatik}

Modal Verbs: dürfen, sollen, mögen

Please work through the following presentation to learn about the modal verbs dürfen, sollen and mögen.

Modal Verbs: dürfen, sollen, mögen

\section{Übung 4}

An interactive H5P element has been excluded from this
version of the text. You can view it online here:
https://openeducationalberta.ca/willkommen-
deutsch/?p=148\#h5p-125

i

\section{Vergessen Sie nicht!}

There are many idiomatic expressions in German 
which often cause confusion because students want to break them down into their individual parts. We suggest that you always learn them as an expression! Two very common idioms are zu Hause and nach Hause.

$z u$ Hause (at home) - Ich bleibe heute Abend zu Hause. nach Hause (moving in the direction toward home) Ich gehe nach Hause.

Q

Wortschatz in Quizlet:

Gesundheit und Krankheit

Modalverben

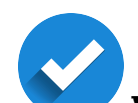

Was wissen Sie jetzt? Klicken Sie hier für Quiz 4.6.

Extra Practice (optional):

Video Serie - Nicos Weg

Click on the link and watch the video. Then click on "start" under the video and do the exercises. 


\section{Media Attributions}

- IMG_2847 (C) Miroslavik adapted by csawatzky is licensed under a Public Domain license

- star (C) IO-Images is licensed under a Public Domain license

- book (C) IO-Images is licensed under a Public Domain license

- headphones (C) IO-Images is licensed under a Public Domain license

- Allgemeinmedizin Ärztin (C) ckost is licensed under a CC BYNC-SA (Attribution NonCommercial ShareAlike) license

- portrait (C) Mücahit Duman is licensed under a Public Domain license

- information (C) IO-Images is licensed under a Public Domain license

- link (C) IO-Images is licensed under a Public Domain license

- check mark (C) janjf93 adapted by Solomon Hajramezan is licensed under a Public Domain license 


\section{Einheit 4.7}

8

Konjugation von Modalverben mit Würfeln. Ein Würfel zeigt das Pronomen, ein Würfel zeigt das Modalverb. Wenn Sie keine Würfel haben, können Sie hier klicken.

Würfeln Sie und konjugieren Sie:

ich du 

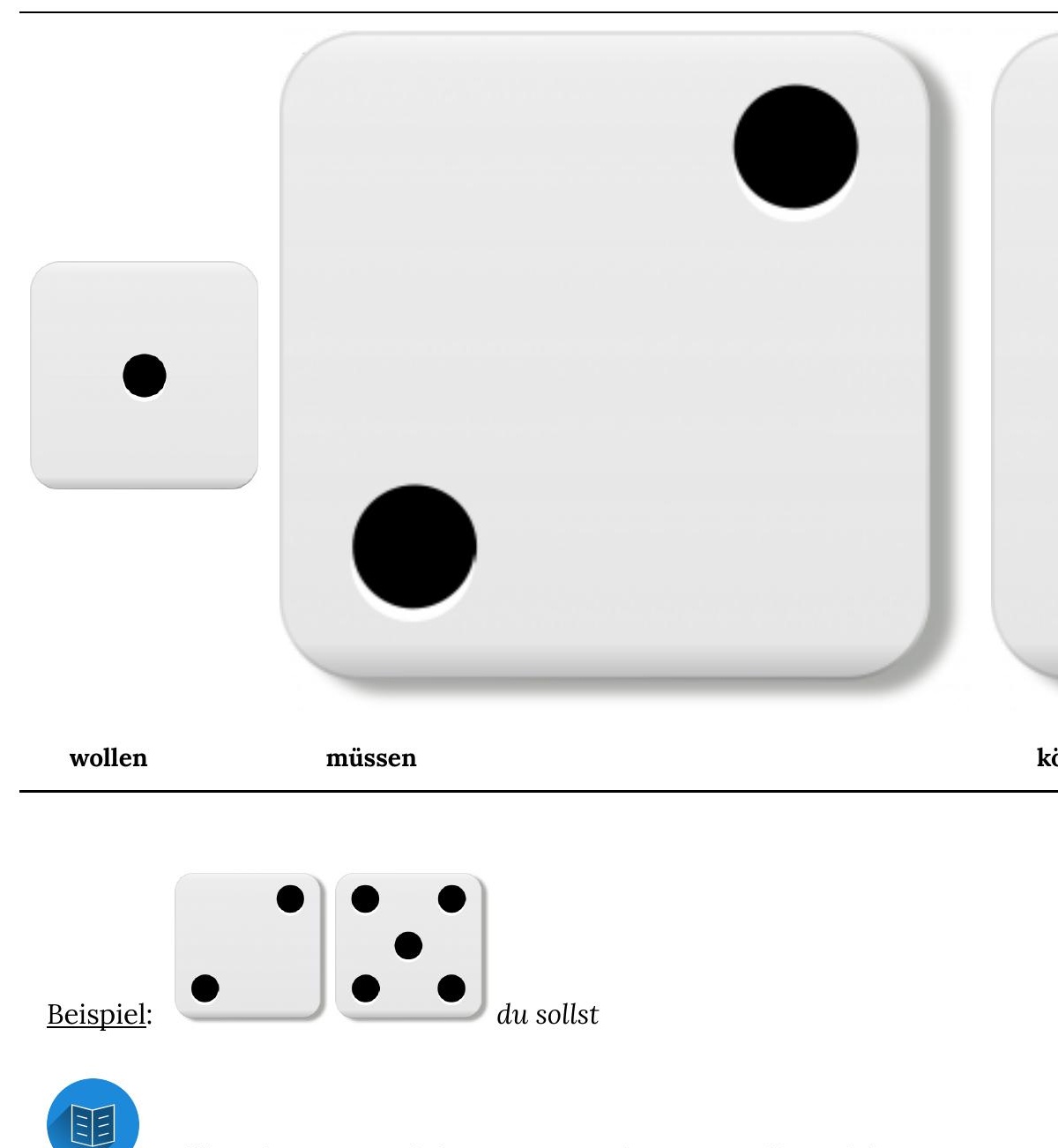

Willst du FIFA spielen? Tim und Anna wollen sich verabreden, um FIFA zu spielen. Tim schreibt Anna eine SMS. Lesen Sie den Text und beantworten Sie die Fragen. 
Anna

Hi Anna, was machst du

gerade?

Ich? Nichts! Mir ist

langweilig! Warum?

Willst du FIFA mit mir

spielen?

$\mathrm{Ne}$, ich muss gleich mit

meiner Mutter einkaufen

gehen. Aber ich kann später

spielen, so um 5 Uhr.

Hm, da kann ich nicht. Ich

soll meinem Vater helfen,

die Garage aufzuräumen.

Was ist mit Samstag? Hast

du da Zeit?

Ja, das ist eine super Idee!

Wann denn?

Ich möchte ausschlafen, die

Schule ist so stressig zur

Zeit. Ist 11 Uhr ok?

Klar, das passt gut! 
Ich muss erst noch meine

Eltern fragen, ob das ok ist.

Ich darf zur Zeit nicht so

oft Videospiele spielen, weil

meine Noten nicht so gut

sind, aber das geht

bestimmt in Ordnung.

Ok, dann bis Samstag!

1. Was möchte Tim spielen?

2. Warum kann Anna in diesem Moment nicht spielen?

3. Was muss Tim später machen?

4. Für welchen Tag verabreden sich Tim und Anna?

5. Warum muss Tim mit seinen Eltern sprechen?

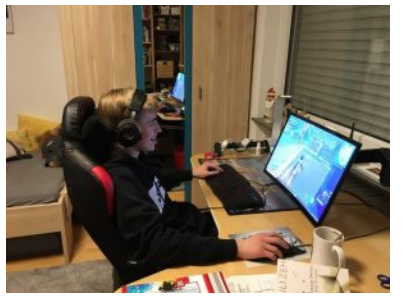

ก

Darf ich mit Anna FIFA spielen? Hören Sie die Dialoge und beantworten Sie die Fragen. 


\section{Dialog 1:}

\begin{tabular}{l}
\hline One or more interactive \\
elements has been \\
excluded from this version of the \\
text. You can view them online \\
here: \\
https://openeducationalberta.ca/ \\
willkommen- \\
deutsch/?p=150\#audio-150-1
\end{tabular}

1. Was sollen Tim und sein Vater heute Nachmittag machen?

2. Warum darf Tim nicht so oft Videospiele spielen?

3. Was muss er machen?

\section{Dialog 2:}

excluded from this version of the
text. You can view them online
here:
https://openeducationalberta.ca/
willkommen-
deutsch/?p=150\#audio-150-2

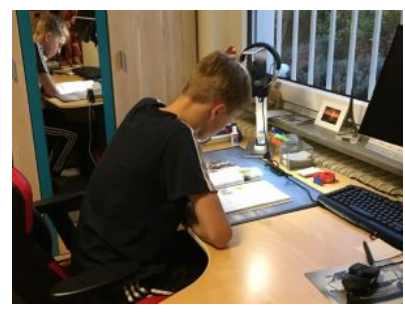

1. Warum will Tim kein englisches Buch lesen?

2. Was muss er auch am Wochenende 
machen?

3. Was darf er machen, wenn er bessere

Noten hat?

\section{8 具}

Tim hat schlechte Noten. Arbeiten Sie mit einer Partnerin oder mit einem Partner. Entscheiden Sie, was Tim machen muss und was er nicht machen darf.

\begin{tabular}{|l|l|l|}
\hline muss & darf nicht & \\
\hline & & Mathe und Englisch lernen \\
\hline & & in einen Club gehen \\
\hline & & das ganze Wochenende Videospiele spielen \\
\hline & & seine Hausaufgaben machen \\
\hline & & mehr für die Schule lernen \\
\hline & & immer nur chillen \\
\hline & & in der Schule besser aufpassen \\
\hline & & $\begin{array}{l}\text { bis nach Mitternacht mit seinen Freunden } \\
\text { SMS schreiben }\end{array}$ \\
\hline
\end{tabular}

Schreiben Sie 3 Sätze, was Tim auch nicht machen $\underline{\text { darf. }}$. Tim darf nicht ...

Und schreiben Sie 3 Sätze, was Tim machen muss.

Tim muss ...

Kein FIFA am Samstag! Tim muss Anna absagen; er darf am Samstag keine Videospiele spielen. Schreiben Sie (als Tim) eine SMS an Anna und verabreden Sie sich wieder zum Videospiele spielen. 


\section{Media Attributions}

- partner (C) IO-Images is licensed under a Public Domain license

- one (c) Clker-Free-Vector-Images is licensed under a Public Domain license

- two (C) Clker-Free-Vector-Images is licensed under a Public Domain license

- three (C) Clker-Free-Vector-Images is licensed under a Public Domain license

- four (C) Clker-Free-Vector-Images is licensed under a Public Domain license

- $\underline{\text { five (C) Clker-Free-Vector-Images is licensed under a Public }}$ Domain license

- $\underline{\text { six }}$ (C) Clker-Free-Vector-Images is licensed under a Public Domain license

- book (C) IO-Images is licensed under a Public Domain license

- headphones (C) IO-Images is licensed under a Public Domain license

- document (C) IO-Images is licensed under a Public Domain license

- pen (C) IO-Images is licensed under a Public Domain license 


\section{Einheit 4.8 (online)}

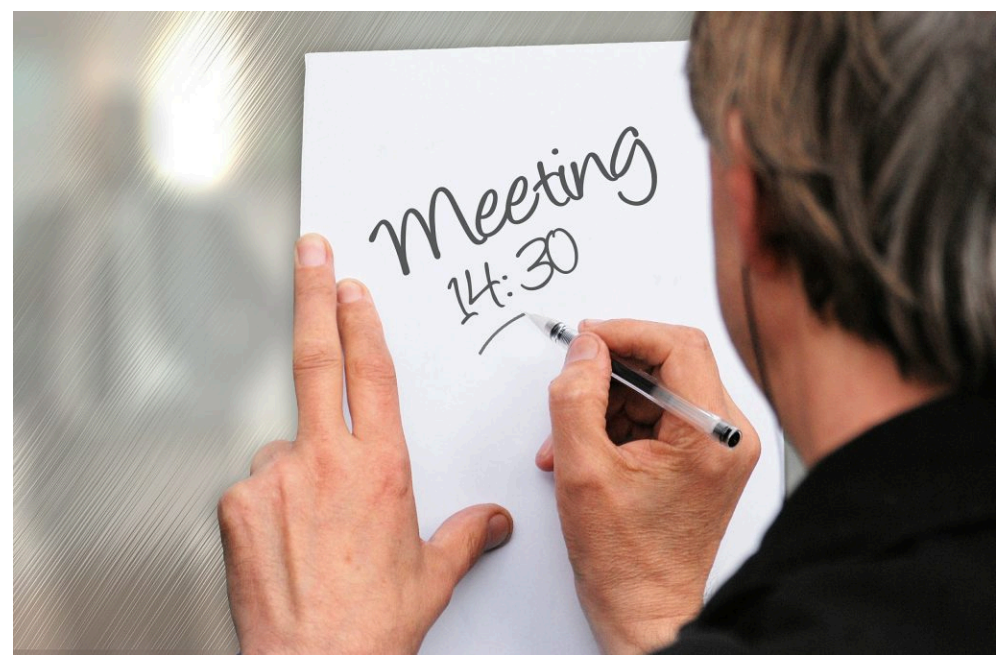

\section{Übung 1}
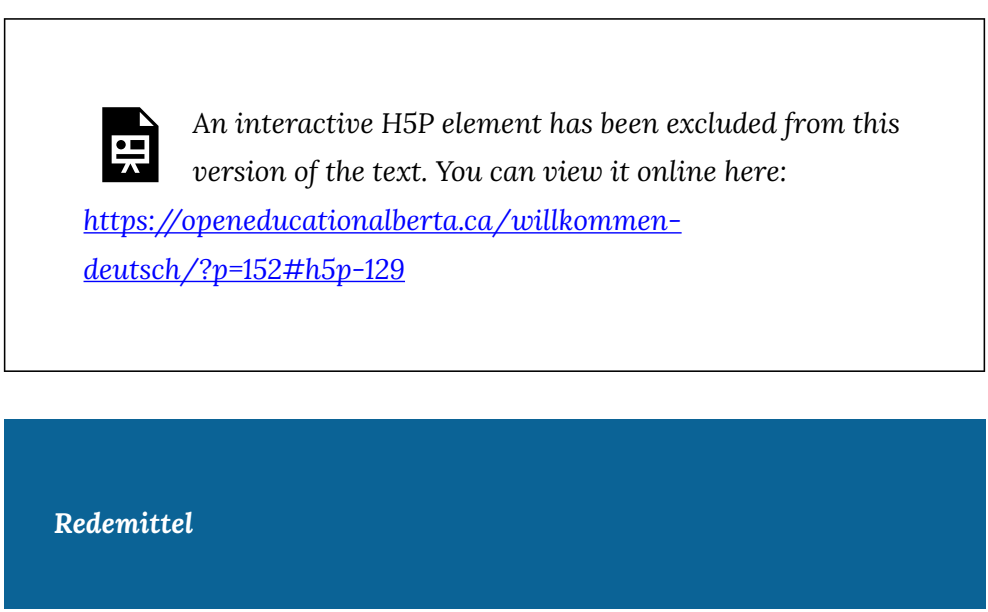


\section{sich verabreden (mit Freunden)}

die Einladung: Wollen wir zusammen ins Kino gehen? / Willst du am Samstag Eis essen gehen? / Gehen wir morgen schwimmen?

nach der Zeit fragen: Um wie viel Uhr treffen wir uns? / Hast du am Sonntag Zeit?

ablehnen: Am Sonntag kann ich leider nicht. / Am Samstag? Nein, das geht nicht. / Nein, da kann ich nicht.

zustimmen: Ja, das passt gut. / Ja, das geht. / Ja, das ist eine super Idee! / Super, ich freue mich schon.

\section{einen Termin machen (offiziell)}

um einen Termin bitten: Haben Sie nächste Woche einen Termin frei? / Kann ich bitte einen Termin bekommen? / Ich möchte gern einen Termin.

einen Termin vorschlagen: Haben Sie am Montag um 8:30 Uhr Zeit? / Geht es am Mittwoch um 10:30Uhr?

ablehnen: Um 10:30 Uhr geht es leider nicht. / Um 8:30 Uhr kann ich nicht. / Tut mir leid, aber am Mittwoch habe ich keine Zeit.

zustimmen: Ja, das passt gut. Vielen Dank! / Ja, das geht. andere Aussagen: Was kann ich für Sie tun? / Leider haben wir geschlossen. / Danke und auf Wiederhören! (am Telefon) 
Termine machen. Hören Sie die Dialoge und beantworten Sie die Fragen. 

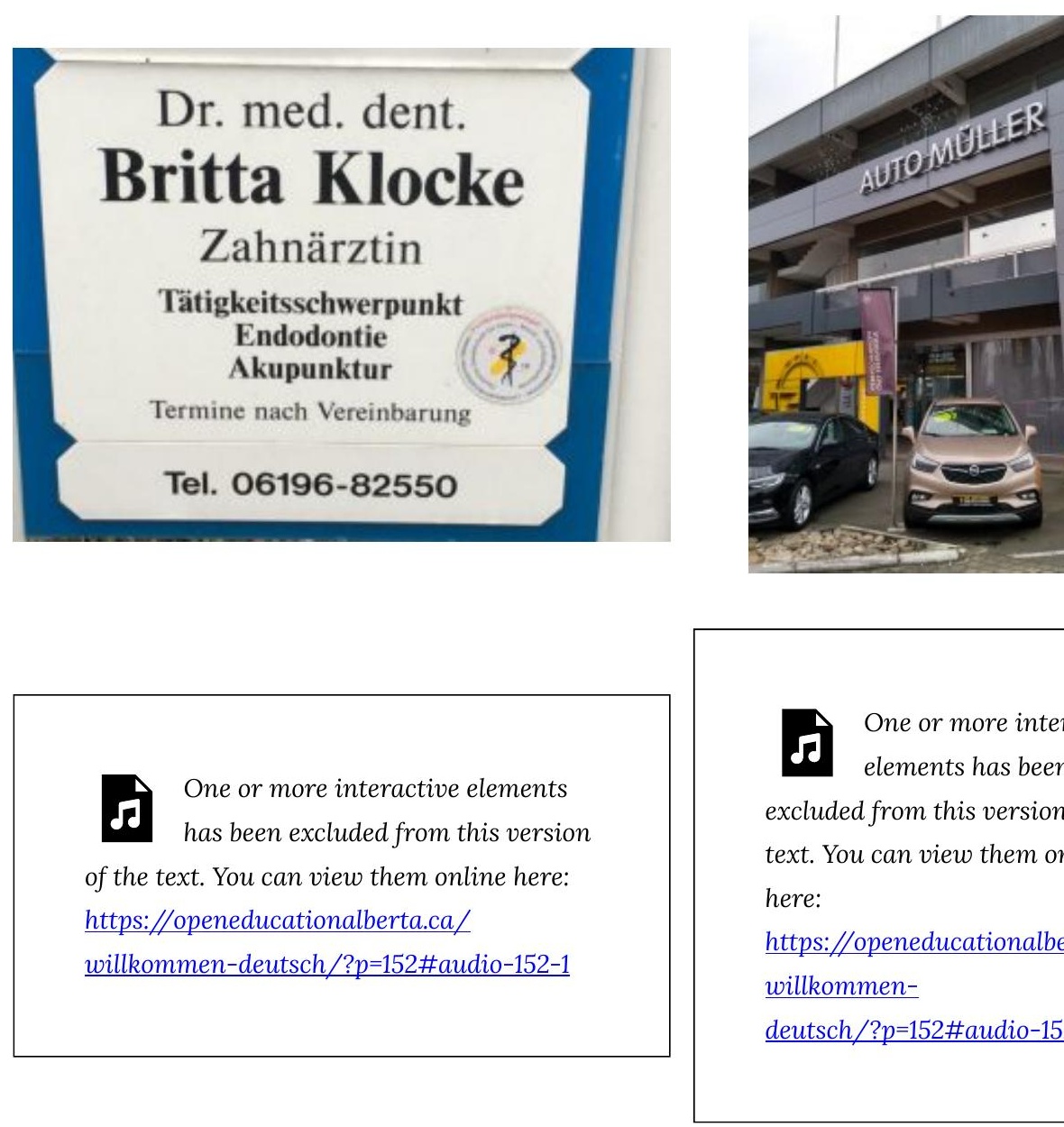


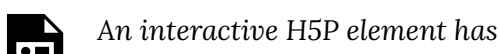

been excluded from this version of

the text. You can view it online here:

https://openeducationalberta.ca/

willkommen-deutsch/?p=152\#h5p-126
Minteratin 因 element has been excluded from this version text. You can view it onlin https://openeducationalbe willkommendeutsch/?p=152\#h5p-127

\section{Grammatik}

Subordinating conjunctions "weil", "wenn", "dass", and "ob"

In Einheit 3.4 you learned about the subordinating conjunction "weil". It is used to give a reason and to connect a dependent clause to a main clause. Remember: the subordinating conjunction kicks the verb to the end of the dependent clause. Here are some more subordinating conjunctions, for example "wenn" (=when, if), "dass" (=that), and "ob" (whether, if).

1. Tim muss viel lernen, weil er schlechte Noten hat.

2. Er darf wieder Videospiele spielen, wenn er bessere Noten hat. 
3. Wenn Tobias sein Zimmer aufräumt, darf er am Sonntag mit Tim Skateboard fahren.

4. Tim denkt, dass er zu viel lernen muss.

5. Er fragt seinen Vater, ob er am Samstag mit Anna Videospiele spielen darf.

If there is a modal verb and a regular verb in the dependent clause, the regular verb stays in the infinitive, and the modal verb is conjugated and placed at the very end of the sentence (examples 4 and 5).

*ACHTUNG* Students sometimes get "wenn" and "ob" confused. Here is a further explanation when to use which one:

$\mathbf{o b}$ - expresses doubt, wondering or when you have two options (Ich weiß nicht, ob Tobias zu Hause ist.)

wenn - expresses condition (Wenn du in Kanada bist, musst du mich besuchen.)

Here is a great video that helps to explain this further and has lots of further examples.

\section{Übung 2}

An interactive H5P element has been excluded from this version of the text. You can view it online here:

https://openeducationalberta.ca/willkommendeutsch/?p=152\#h5p-130 
Wortschatz in Quizlet:

Pläne und Termine machen

Redemittel: sich verabreden

Redemittel: um einen Termin bitten

Was wissen Sie jetzt? Klicken Sie hier für Quiz 4.8.

\section{Media Attributions}

- meeting-552410_1920 (C) Gerd Altmann is licensed under a Public Domain license

- star (C) IO-Images is licensed under a Public Domain license

- headphones (C) IO-Images is licensed under a Public Domain license

- Zahnärztin (C) ckost is licensed under a CC BY-NC-SA (Attribution NonCommercial ShareAlike) license

- Auto Müller (C) ckost is licensed under a CC BY-NC-SA (Attribution NonCommercial ShareAlike) license

- beauty-salon-3277314_1920 C Michelle Maria is licensed under a Public Domain license

- $\underline{\text { link }}$ (C) IO-Images is licensed under a Public Domain license

- check mark (C) janjf93 adapted by Solomon Hajramezan is licensed under a Public Domain license 


\section{Einheit 4.9}

200

sich verabreden/einen Termin machen

$\varepsilon$

Rollenspiel: Einen Termin machen. Arbeiten Sie mit einer Partnerin oder mit einem Partner. Wählen Sie ein Szenario aus.

Redemittel (aus Einheit 4.8)

\section{einen Termin machen (offiziell)}

um einen Termin bitten: Haben Sie nächste Woche einen Termin frei? / Kann ich bitte einen Termin bekommen? / Ich möchte gern einen Termin.

einen Termin vorschlagen: Haben Sie am Montag um 8:30 Uhr Zeit? / Geht es am Mittwoch um 10:30Uhr?

ablehnen: Um 10:30 Uhr geht es leider nicht. / Um 8:30 Uhr kann ich nicht. / Tut mir leid, aber am Mittwoch habe ich keine Zeit.

zustimmen: Ja, das passt gut. Vielen Dank! / Ja, das geht. andere Aussagen: Was kann ich für Sie tun? / Leider haben wir geschlossen. / Danke und auf Wiederhören! (am Telefon) 


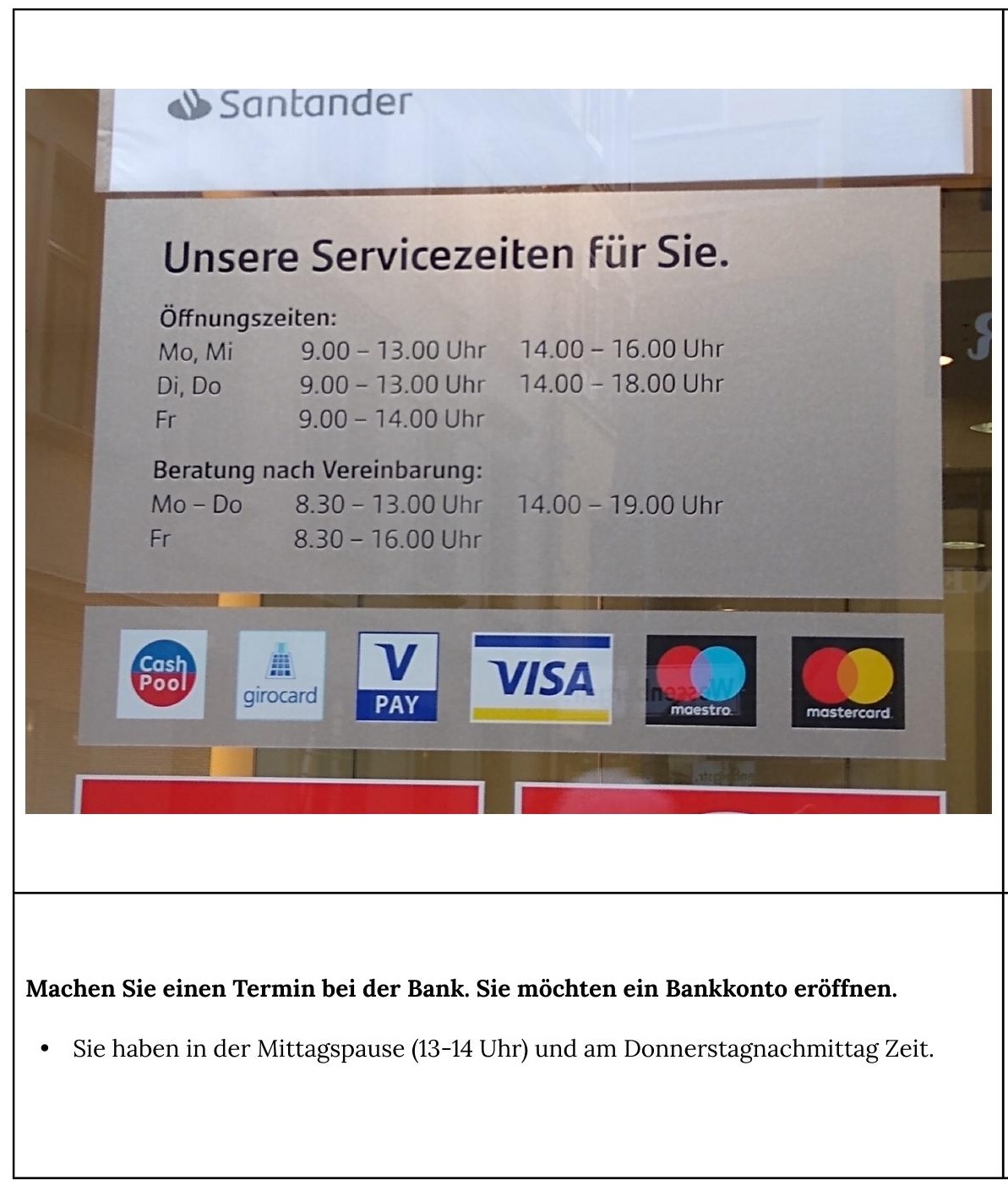




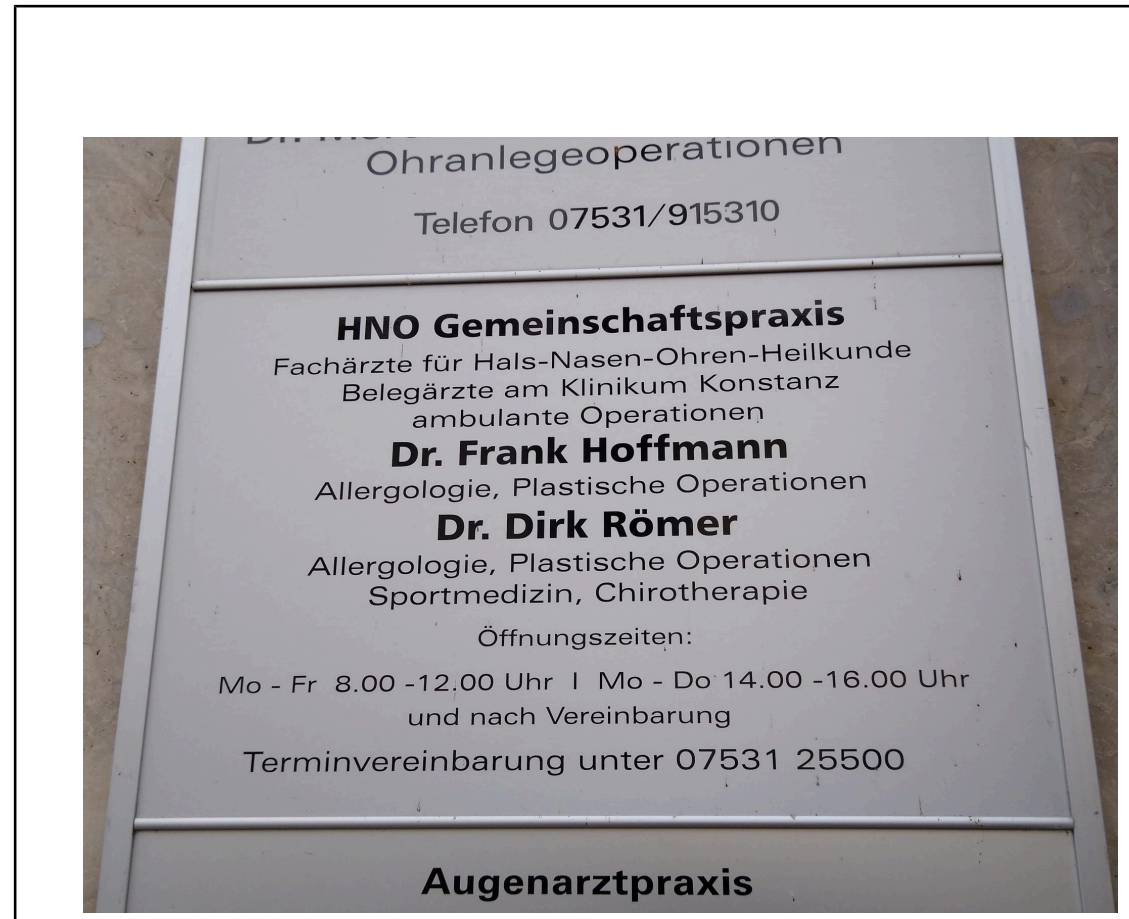

Machen Sie einen Termin beim HNO (Hals-Nasen-Ohren) Arzt. Sie haben Ohrenschmerzen.

- Es ist dringend. Sie können jederzeit kommen.

Professor Herrmanns Sprechstunde. Lesen Sie den Text. Lara schreibt eine E-Mail an Frau Prof. Herrmann, weil sie einen Termin möchte. 
Von: lara5@deutschuni.de

Di., 12. Nov

15:48

An: e.herrmann@deutschuni.de

Betreff: Fragen zur Hausarbeit

Sehr geehrte Frau Prof. Herrmann,

ich möchte gern einen Termin, weil ich ein paar Fragen zu meiner Hausarbeit habe.

Mit freundlichen Grüßen

Lara

Von: e.herrmann@deutschuni.de Fr., 13. Nov 9:05

An: lara5@deutschuni.de

Betreff: Fragen zur Hausarbeit

Guten Tag Lara,

ich habe am Dienstag und Donnerstag von 12-14 Uhr Sprechstunde.

Mit herzlichen Grüßen

Prof. Herrmann

Von: lara5@deutschuni.de

Fr., 13. Nov

10:27

An: e.herrmann@deutschuni.de

Betreff: Fragen zur Hausarbeit

Hallo Frau Prof. Herrmann,

ich kann leider am Dienstag nicht in Ihre Sprechstunde kommen, weil ich einen anderen Kurs habe. Und am Donnerstag muss ich nachmittags arbeiten. Können Sie mir bitte einen anderen Termin geben?

Vielen Dank

Lara 
Von: e.herrmann@deutschuni.de

Fr., 13. Nov 11:15

An: lara5@deutschuni.de

Betreff: Fragen zur Hausarbeit

Kein Problem, Lara! Ich habe am

Donnerstagvormittag ein bisschen

Zeit. Können Sie um 10 Uhr hier sein?

Prof. Herrmann

Von: lara5@deutschuni.de

Fr., 13. Nov

11:53

An: e.herrmann@deutschuni.de

Betreff: Fragen zur Hausarbeit

Ja, das passt sehr gut. Vielen Dank, Frau Prof. Herrmann, ich werde pünktlich sein.

Mit besten Grüßen

Lara

Von: e.herrmann@deutschuni.de

Fr., 13. Nov 14:08

An: lara5@deutschuni.de

Betreff: Fragen zur Hausarbeit

Gern geschehen. Bis Donnerstag, Lara.

Viele Grüße

Prof. Herrmann

- Welche Strukturen oder Wörter machen diese E-Mails höflich? 


\section{Media Attributions}

- group (C) IO-Images is licensed under a Public Domain license

- partner (C) IO-Images is licensed under a Public Domain license

- Bank (C) ckost is licensed under a CC BY-NC-SA (Attribution NonCommercial ShareAlike) license

- Tierarzt (C) ckost is licensed under a CC BY-NC-SA (Attribution NonCommercial ShareAlike) license

- HNO-Arzt (C) ckost is licensed under a CC BY-NC-SA (Attribution NonCommercial ShareAlike) license

- Volkshochschule (C) ckost is licensed under a CC BY-NC-SA (Attribution NonCommercial ShareAlike) license

- book (C) IO-Images is licensed under a Public Domain license 


\section{Einheit 4.10 (online)}

\section{E-Mail Etikette}

As you discovered in the email exchange in 4.9, there are certain structures and phrases that make an email more polite and are appropriate for a specific setting. Although emailing is not a formal way of writing, it is a good idea to use the proper way of addressing someone and finishing an email, especially if you ask that person for a favour or if you are in a more formal relationship with that person (for example, student-professor).

Here are some common greetings and farewells for formal and informal settings:

\begin{tabular}{|c|c|}
\hline $\begin{array}{l}\text { formal (with professors, } \\
\text { supervisors, official } \\
\text { inquiries) }\end{array}$ & $\begin{array}{l}\text { informal (with friends, family, } \\
\text { other students) }\end{array}$ \\
\hline $\begin{array}{l}\text { Start the email: } \\
\text { - } \quad \text { Sehr geehrter } \\
\text { Herr... (last name), } \\
\text { Sehr geehrte } \\
\text { Frau... (last name), }\end{array}$ & $\begin{array}{l}\text { Start the email: } \\
\text { - } \quad \text { Lieber (male name),/ } \\
\text { Liebe (female name), } \\
\text { Hallo..., }\end{array}$ \\
\hline $\begin{array}{l}\text { Finish the email: } \\
\text { - } \quad \text { Mit freundlichen } \\
\text { - Grüßen } \\
\text { Mit herzlichen } \\
\text { Grüßen } \\
\text { - } \quad \text { Mit besten Grüßen } \\
\text { - Ihr (male name)/ } \\
\text { Ihre (female name) }\end{array}$ & 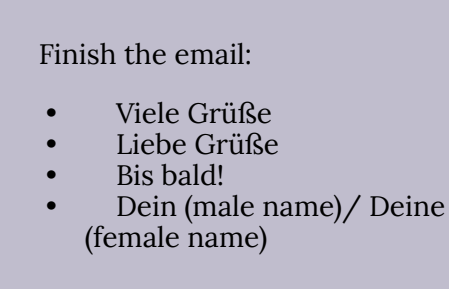 \\
\hline
\end{tabular}




\section{*ACHTUNG*}

In German, you put a comma after the salutation and then you begin your email or letter with a lower case.

There is no comma after the concluding expression.

\section{Wortschatz in Quizlet:}

Sonstige Wörter und Ausdrücke

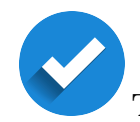

There is no quiz for 4.10 .

\section{邫}

\section{Task 4: Die E-Mail-Verabredung}

Together with a partner, you will write emails back and forth (at least 4 from each person) to find a time/day to do a common activity. In your conversation, you will encounter and navigate potential obstacles (e.g., not having time, different plans etc.). Make sure you use the "Redemittel" you learned in this unit.

When you have completed your email conversation, please forward the email thread to your instructor.

This task will be assessed according to the Rubric for Task 4 .

Extra Practice (optional):

Video Serie - Nicos Weg 
Click on the link and watch the video. Then click on "start" under the video and do the exercises.

\section{Media Attributions}

- $\underline{\text { link }}$ (C) IO-Images is licensed under a Public Domain license

- check mark (C janjf93 adapted by Solomon Hajramezan is licensed under a Public Domain license

- keyboard (C) IO-Images is licensed under a Public Domain license 


\section{Wortschatz}

Quizlet:

Wortschatz Einheit 4 (alle Kategorien)

Frühstück

Tagesablauf

Körper

Gesundheit und Krankheit

Pläne und Termine machen

Redemittel: sich verabreden

Redemittel: um einen Termin bitten

Modalverben

Sonstige Wörter und Ausdrücke

(⿶)

Wortschatz 4

Media Attributions

- $\underline{\text { link }}$ C IO-Images is licensed under a Public Domain license

- pdf (C) IO-Images is licensed under a Public Domain license 


\section{Zum Spaß!}

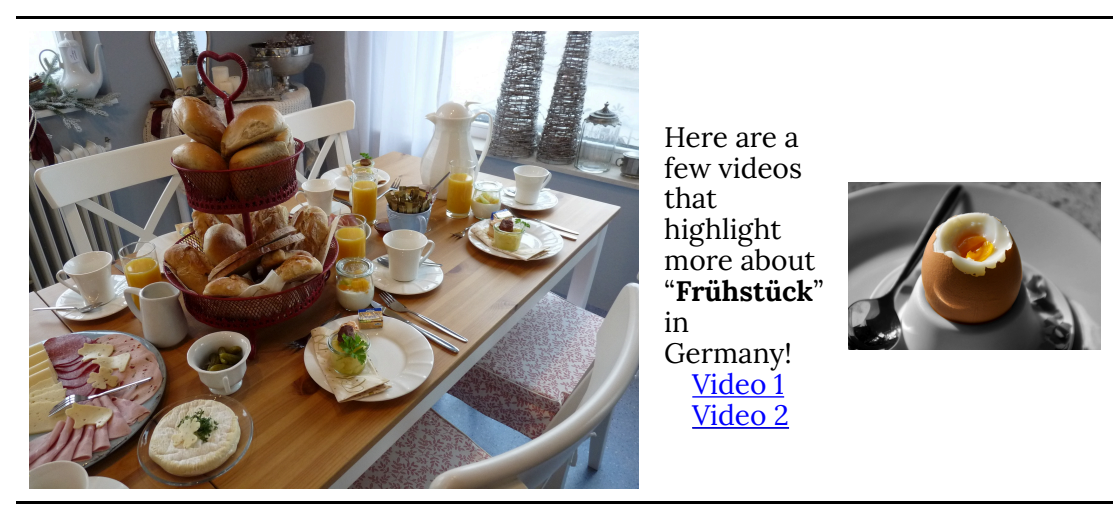




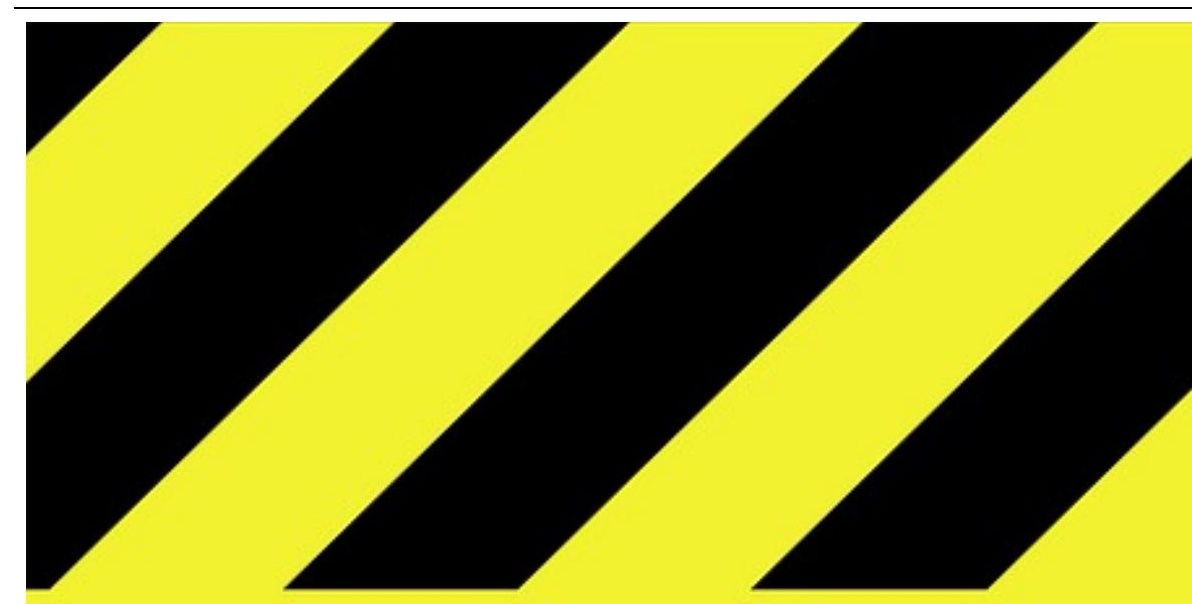

300 | Zum Spaß!

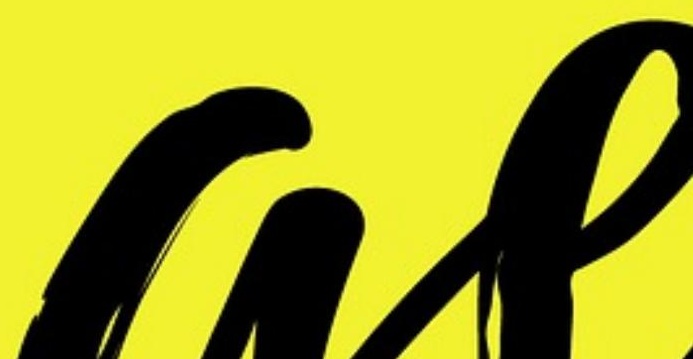




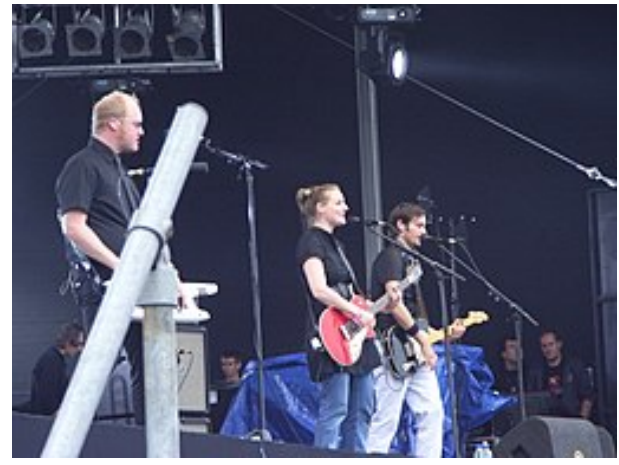

Check out the song "Müssen nur wollen" by the German band Wir sind Helden. Their music falls into the pop, pop rock, and alternative rock genre, and their songs are characterized by social commentary and criticism.

Watch to the video here.

Here are the lyrics if you want to read along.

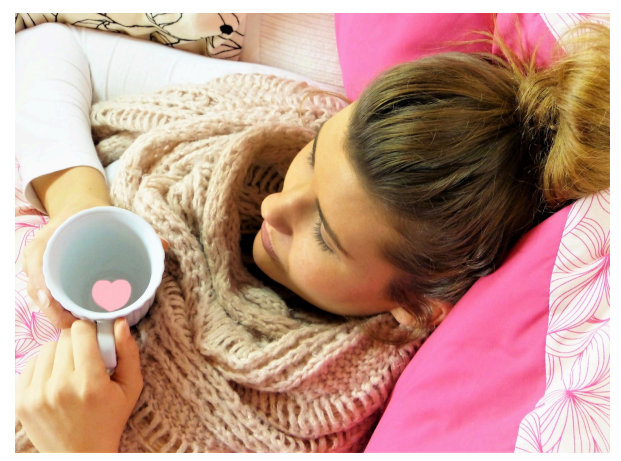

10 fun facts about health care in Germany! Watch thisvideo if you are interested to learn more.

Have you ever heard some say "Gesundheit" when you sneeze? Watch this video to learn about "Gesundheit" and other interjections you hear every day.

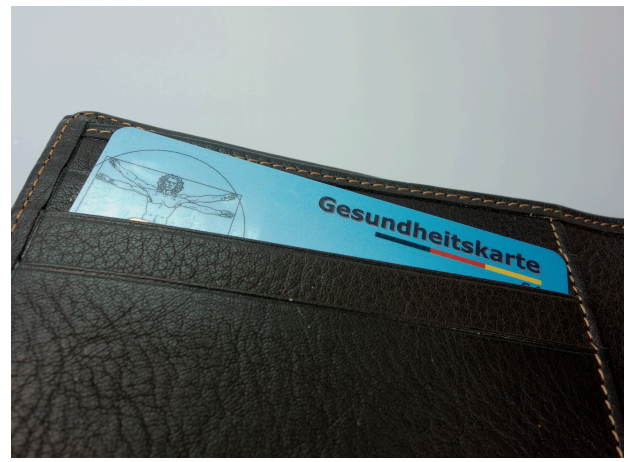

TheGoethe Institute is a terrific organization that teaches German all around the world. Here is an episode from a video series called "Erste Wege in Deutschland". In this episode Nevin isn't feeling well and goes to the "Arzt". Feel free to watch other episodes as well. There are activities to go along with the videos. 
Extra Practice (optional):

Frühstück Wortschatz: Can you find all the items on the "Frühstückstisch"?

An interactive H5P element has been excluded from this version of the text. You can view it online here:

https://openeducationalberta.ca/willkommendeutsch/?p=2856\#h5p-112

More extra Practice (optional): These activities are from the website Schubert-Verlag.

Tagesablauf I

Tagesablauf II

müssen

Imperativ

Beim Arzt

Modalverben

\section{Media Attributions}

- coziness-2100628_1920 C MitCharme is licensed under a Public Domain license

- breakfast-egg-2209048_1920 C Karl Allen Lugmayer is licensed under a Public Domain license

- closed-4952670 1920 C Gerd Altmann is licensed under a Public Domain license

- 256px-Wir_Sind_Helden (C) Danny Lechanteur is licensed under a CC BY-SA (Attribution ShareAlike) license

- young-woman (C) silviarita is licensed under a Public Domain 
license

- sick-card (C) Michael Schwarzenberger is licensed under a Public Domain license 
304 | Zum Spaß! 


\section{EINHEIT 5: HERZLICHEN GLÜCKWUNSCH ZUM GEBURTSTAG!}

At the end of Einheit 5, you will be able to...

- talk about things that happened in the past

- $\quad$ identify and discuss cultural phenomena surrounding the celebration of birthdays in Germany

- find out about someone's interests, likes and dislikes to select an appropriate present for them

You will also have learned about the following structures:

- $\quad$ perfect tense

- adverbs of time

- $\quad$ simple past tense of "haben" and "sein"

- ordinal numbers

- the dative case

- "wem"?

- adjective endings in dative

- personal pronouns in dative 
306 | Einheit 5: Herzlichen Glückwunsch zum Geburtstag! 


\section{Einheit 5.1}

\section{oog \\ Herzlichen Glückwunsch zum Geburtstag!}

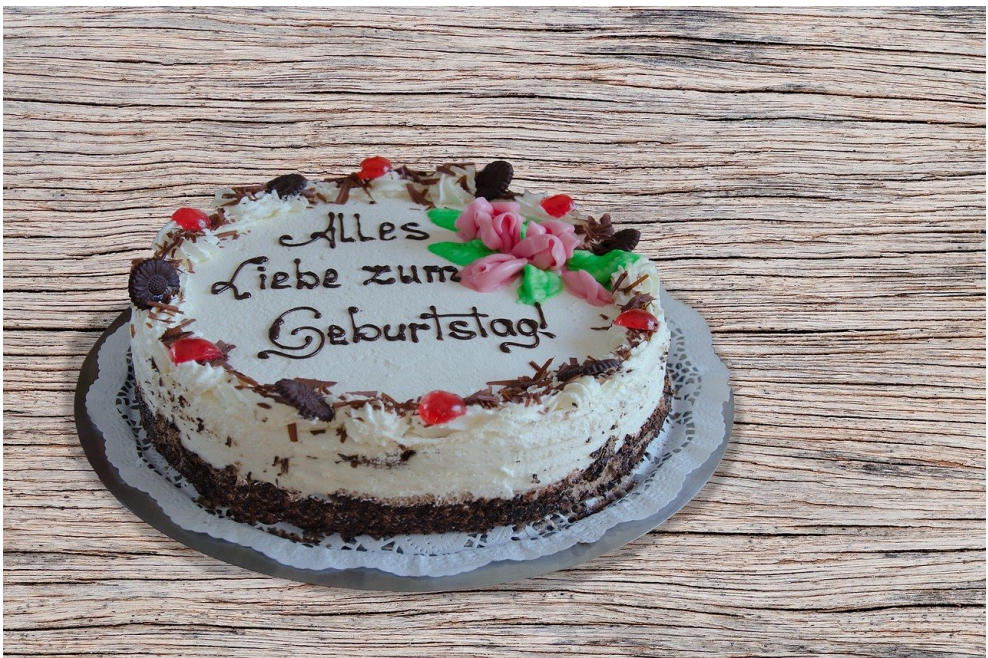

Geburtstage, Geburtstage! Luca erzählt von seinem Wochenende. Lesen Sie den Text und beantworten Sie die Fragen.

Ich hatte ein ziemlich volles Wochenende. Am Freitag hatte meine Oma Geburtstag. Meine ganze Familie ist zu ihr gefahren. Mein Bruder Nico hat einen Schokoladenkuchen für Oma gebacken, echt lecker! Wir haben zusammen Kaffee getrunken und Kuchen gegessen. Abends sind wir dann zu "Bella Italia" gefahren, das ist ein italienisches Restaurant, wo meine Oma gern isst. 


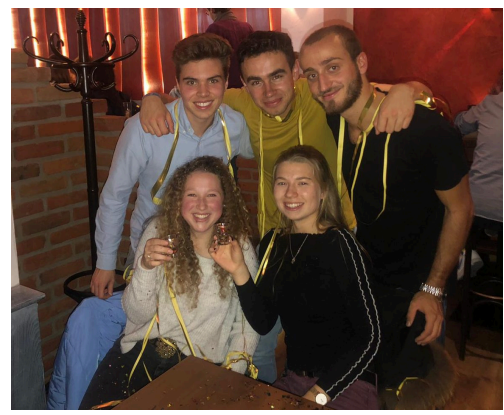

Maren ausgegangen. Wir sind $\mathrm{zu}$ einem neuen Club in Mainz gefahren. Unsere Freundin Ina hatte am Sonntag Geburtstag und wir haben in den Geburtstag reingefeiert. Wir haben ein paar Cocktails getrunken und haben viel getanzt. Die Musik war total super! Wir sind erst um 3 Uhr nachts nach Hause gekommen.

Am Sonntagmorgen um 11 Uhr bin ich zu Sebi gefahren. Wir haben zusammen gebruncht. Sebi hat Rühreier mit Speck gekocht, das kann er total gut, und ich habe frische Brötchen, Nutella, Wurst und Käse mitgebracht. Wir haben 2 Stunden lang gegessen! Am Nachmittag haben wir ein bisschen Tennis gespielt und am Abend sind wir ins Kino gegangen.

1. Warum hat Luca am Freitag seine Oma besucht?

2. Was haben sie zusammen gemacht?

3. Was hat Luca am Samstag gemacht? Unterscheiden Sie zwischen Aktivitäten, die Spaß machen, und Aktivitäten, die Arbeit sind.

4. Was haben Luca und Sebi am Sonntag gemacht?

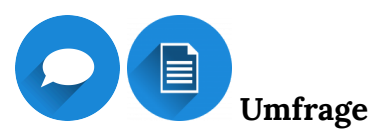

1. Bist du letzte Woche in ein Restaurant gegangen? 
2. Hast du schon mal italienisch gegessen?

3. Bist du am Freitagabend ausgegangen?

4. Hast du am Wochenende viel für die Uni gelernt?

5. Hast du gestern Kaffee getrunken?

6. Bist du letzten Monat mit dem Bus gefahren?

7. Hast du letzte Woche einen Kuchen gebacken?

8. Bist du am Sonntag früh aufgestanden?

\section{Was ist neu hier?}

An interactive H5P element has been excluded from this version of the text. You can view it online here:

https://openeducationalberta.ca/willkommendeutsch/?p=46\#h5p-210

\section{Media Attributions}

- group (C IO-Images is licensed under a Public Domain license 
- cake (C) 584652 is licensed under a Public Domain license

- book (C) IO-Images is licensed under a Public Domain license

- Party feiern 1 C ckost is licensed under a All Rights Reserved license

- speech bubble (C) IO-Images is licensed under a Public Domain license

- document (C) IO-Images is licensed under a Public Domain license

- question-mark (C) IO-Images is licensed under a Public Domain license 
Einheit 5.2 (online)

\section{Marens Wochenende}

Neue Wörter:

der Schwimmwettkampf - swimming competition

der Muskelkater - sore muscles

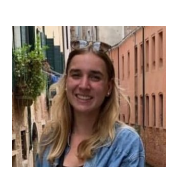

圈

An interactive H5P element has been excluded from this version of the text. You can view it online here:

https://openeducationalberta.ca/ willkommen-deutsch/?p=158\#h5p-131

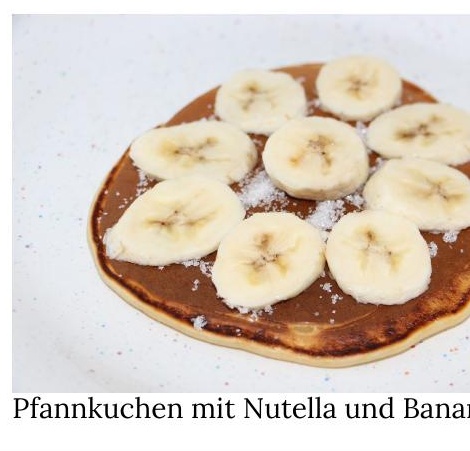

Übung 1: Leseverständnis. Beantworten Sie die Fragen.

An interactive H5P element has been excluded from this version of the text. You can view it online here:

https://openeducationalberta.ca/willkommendeutsch/?p=158\#h5p-132

\section{Grammatik}




\section{Perfect Tense (1)}

Please work through the following presentation to learn about the perfect tense.

Perfect Tense 1

\section{Übung 2: Inas Geburtstag}

An interactive H5P element has been excluded from this version of the text. You can view it online here:

https://openeducationalberta.ca/willkommendeutsch/?p=158\#h5p-140

Übung 3: Was hat Familie Klein gestern gemacht? Review your conjugation of "haben" and sein" here.

An interactive H5P element has been excluded from this version of the text. You can view it online here: 
https://openeducationalberta.ca/willkommen-

deutsch/?p=158\#h5p-233

\section{Grammatik}

Adverbs of time

Adverbs of time tell us when, how long or how often something happens. You already encountered a number of these adverbs of time, for example:

- regarding a point in time or a period of time: heute, morgen, gestern, später, zuerst, dann, danach, etc.

- $\quad$ regarding frequency: immer, meistens, oft, manchmal, selten, nie; montags (jeden Montag), vormittags (jeden Vormittag), etc.

The use of these adverbs of time structures a text chronologically and might make it easier to follow. It also adds cohesiveness to a text and allows you to use a different word order.

\section{Wortschatz in Quizlet:}

Zeitangaben 
Was wissen Sie jetzt? Klicken Sie hier für Quiz 5.2.

\section{Media Attributions}

- book (C) IO-Images is licensed under a Public Domain license

- Maren (C) ckost is licensed under a All Rights Reserved license

- pancake-640871_1920 C Tabeajaichhalt is licensed under a Public Domain license

- star (C) IO-Images is licensed under a Public Domain license

- link (C) IO-Images is licensed under a Public Domain license

- check mark (C janjf93 adapted by Solomon Hajramezan is licensed under a Public Domain license 
Einheit 5.3

909

Was haben Sie an einem langweiligen oder tollen Wochenende gemacht?

Wie war das Wochenende: langweilig oder toll? 
Thomas: Ich hatte ein total langweiliges Wochenende! Ich bin am Freitagabend zu Hause habe meine Freunde nicht getroffen. Das war echt doof! Am Sonntag habe ich zuerst meir

1. Was hat Thomas am Freitagabend gemacht?

2. Was war an seinem Fahrrad kaputt?

3. Was hat Thomas am Sonntag gemacht?

4. Was möchte Thomas nächstes Wochenende machen? 


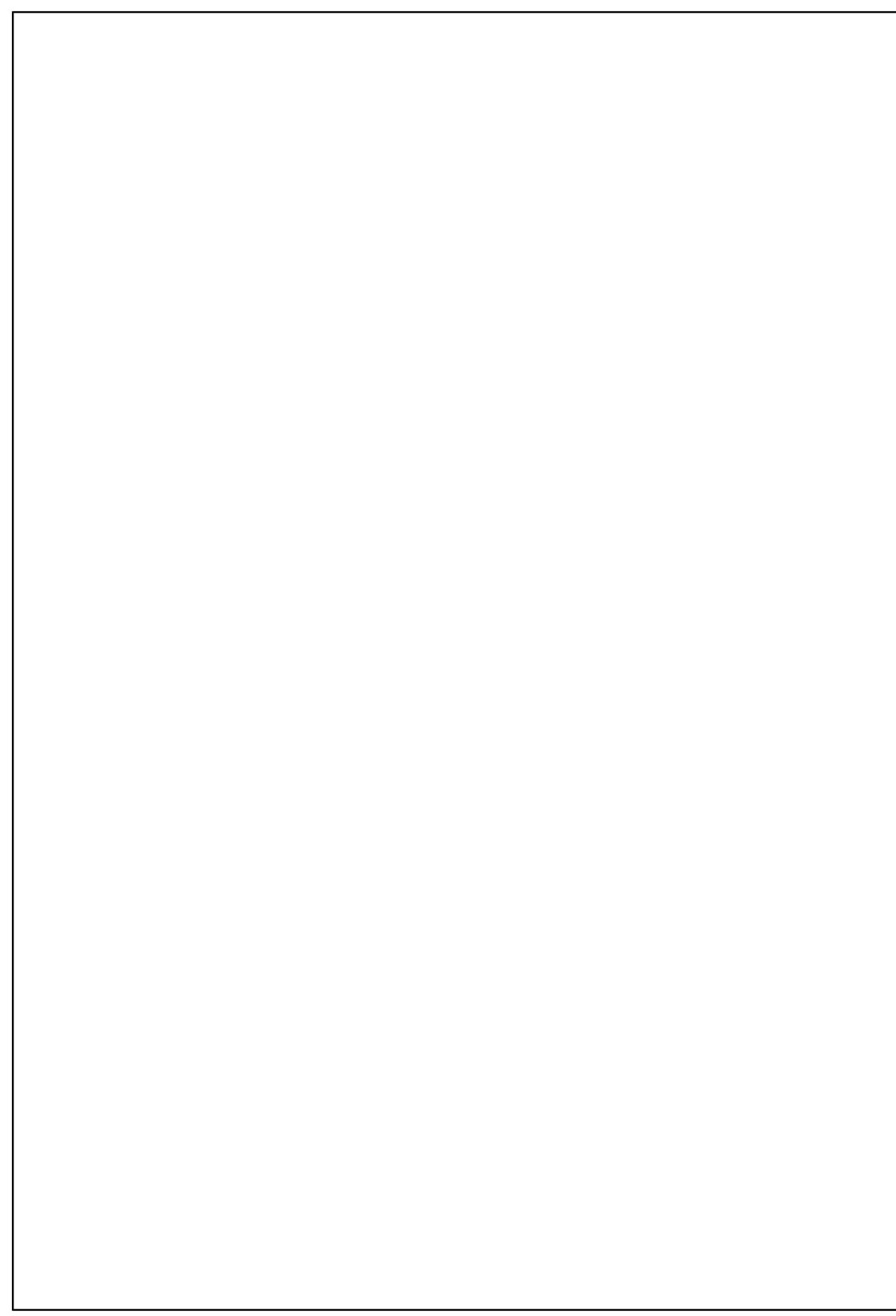

5.3 | 317 


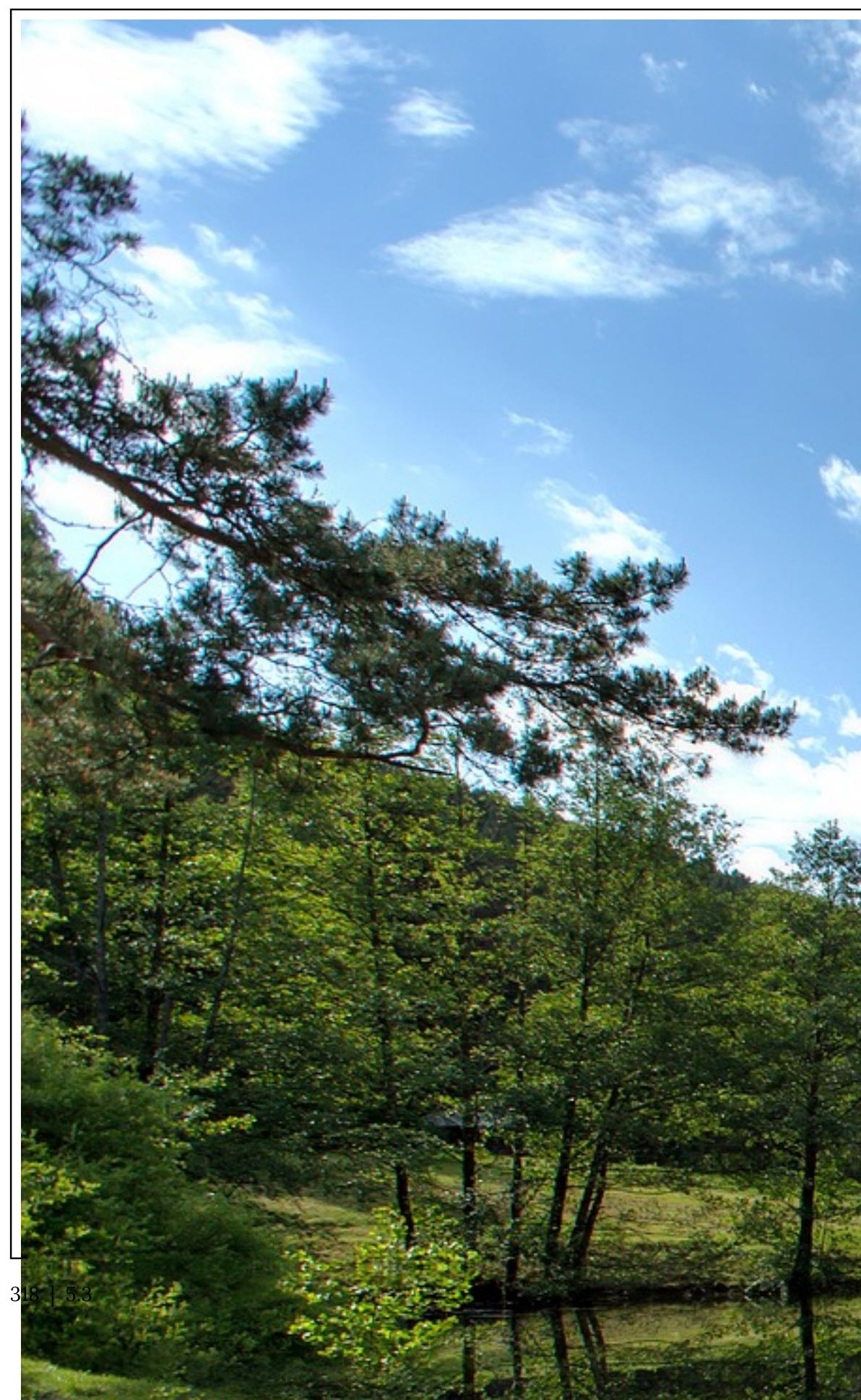




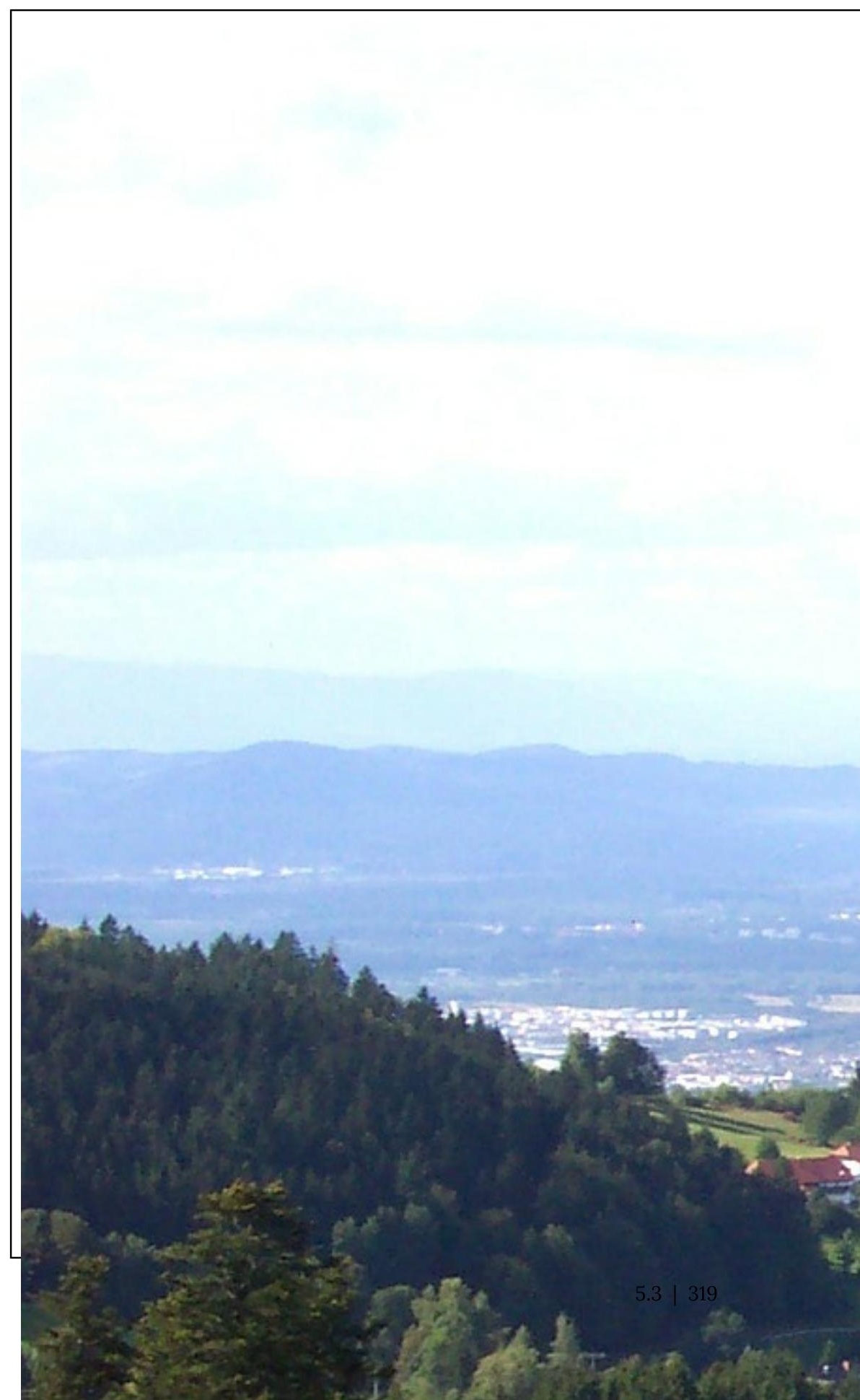


$\Omega$

Wann hast du das letzte Mal ...? Arbeiten Sie mit einer Partnerin oder mit einem Partner. Fragen und antworten Sie wie im Beispiel.

vor _- Jahren / letztes Jahr / vor 2 Monaten / vor 2 Wochen

letzte Woche / vorgestern / gestern / heute / noch nie

Beispiel:

S1: Wann hast du das letzte Mal deine Eltern besucht?

S2: Ich habe vor 2 Monaten meine Eltern besucht.

1. Wann hast du das letzte Mal deine Eltern besucht?

2. Wann bist du das letzte Mal in den Bergen gewandert?

3. Wann hast du das letzte Mal einen Film gesehen?

4. Wann bist du das letzte Mal spät ins Bett gegangen?

5. Wann bist du das letzte Mal den ganzen Abend zu Hause geblieben?

6. Wann hast du das letzte Mal deine Wohnung geputzt?

\section{Interview: Was hast du letzten Sonntag gemacht?}

1. Hast du am Sonntag lang geschlafen? Wie lang?

2. Hast du mit jemandem gefrühstückt?

3. Hast du Sport gemacht? Welchen Sport?

4. Hast du für die Uni gelernt? Für welche Kurse hast du gelernt?

5. Hast du ein Buch gelesen? Welches?

6. Bist du in ein Restaurant gegangen?

7. Bist du früh ins Bett gegangen? Wann? 


\section{Media Attributions}

- group (C) IO-Images is licensed under a Public Domain license

- book (C) IO-Images is licensed under a Public Domain license

- bike-502542_1920 (C) MeHe is licensed under a Public Domain license

- broom-1837434_1920 C Julio César Velásquez Mejía is licensed under a Public Domain license

- nature-3967142_1920 (C) tiago cardoso is licensed under a Public Domain license

- germany-77505 1920 C David Mark is licensed under a Public Domain license

- partner (C) IO-Images is licensed under a Public Domain license 
Einheit 5.4 (online)

Der erste Schultag

In Einheit 2.4, you learned about the German school system. Do you remember what children receive on the first day of school?

For German children, the first day of (elementary) school is a big event! As there is no pre-school in Germany, starting grade 1 in elementary school is a clear break from the playful kindergarten or daycare that most kids attend before. It signifies the start of their 9-13 years of education that follow and as such, it is celebrated in style.

The most important item that children receive on their first day of school is the "Schultüte" or school cone, made out of paper and filled with sweets, toys, small gifts, and school supplies. In some regions of Germany, the "Schultüte" is therefore also sometimes called a "Zuckertüte". "Schultüten" are meant to "sweeten" the children's entry into the more serious world of school and education.

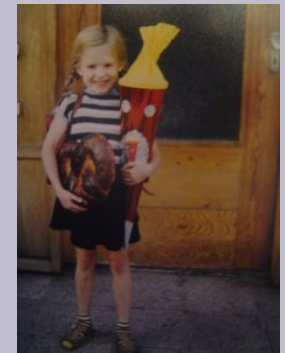

Claudias erster Schultag!

The tradition of the "Schultüte" goes back to the late 19th century, but it is still very much alive today. Children receive their "Schultüten" from their godparents or parents and take them to school on the first day. After school is over, they unpack their "Schultüten" at home and enjoy their presents. The first day of school is sometimes also celebrated by having cake in the afternoon with relatives and neighbors. 
Übung 1: Majas erster Schultag! Choose the correct auxiliary verb.
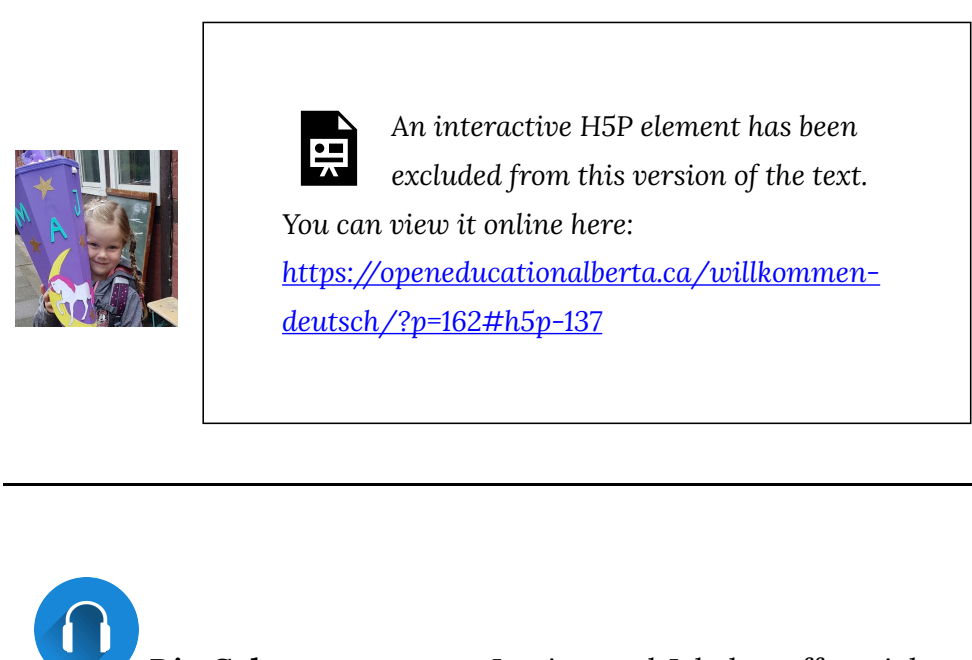

Die Geburtstagsparty. Jessica und Jakob treffen sich auf dem Marktplatz. Hören Sie zu und beantworten Sie die Fragen.

D

One or more interactive elements has been excluded from this version of the text. You can view them online here: https://openeducationalberta.ca/willkommendeutsch/?p=162\#audio-162-1 


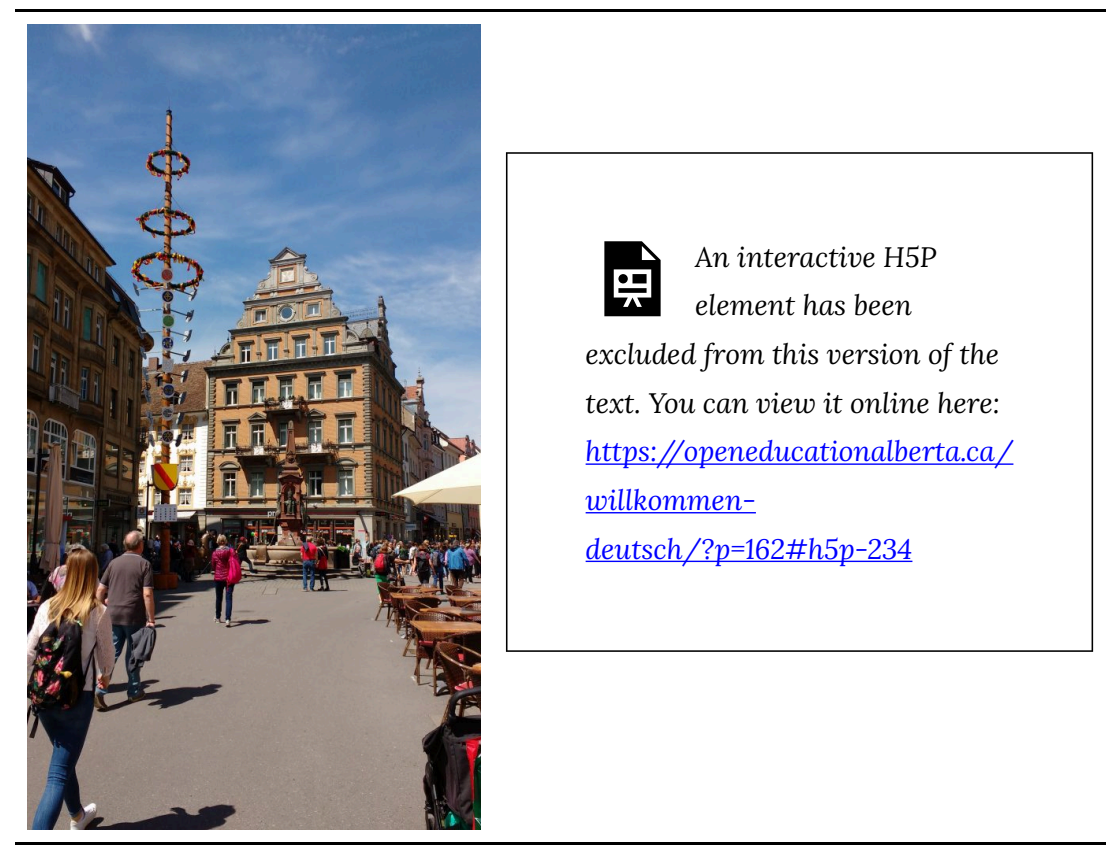

\section{Grammatik}

Simple Past Tense: "haben" and "sein"

Usually, when talking about events that happened in the past, we use the perfect tense. However, the verbs haben and sein are more commonly used in the simple past tense instead of the perfect tense.

You have seen examples of the simple past tense in 
Thomas' and Mario and Silvia's description of their weekends:

Thomas hatte ein total langweiliges Wochenende!

Sein Fahrrad hatte einen platten Reifen.

Silvia und ihre Freunde waren nach dem Frisbeespiel ein bisschen müde.

Das Essen im afghanischen Restaurant war sehr gut.

\begin{tabular}{|c|c|c|c|}
\hline sein & & haben & \\
\hline$i c h$ war & I was & ich hatte & I had \\
\hline$d u$ warst & you were & du hattest & you had \\
\hline $\begin{array}{l}\text { er/sie/es } \\
\text { war }\end{array}$ & $\begin{array}{l}\text { he/she/it } \\
\text { was }\end{array}$ & $\begin{array}{l}\text { er/sie/es } \\
\text { hatte }\end{array}$ & $\begin{array}{l}\text { he/she/it } \\
\text { had }\end{array}$ \\
\hline wir waren & we were & $\begin{array}{c}\text { wir } \\
\text { hatten }\end{array}$ & we had \\
\hline ihr wart & $\begin{array}{l}\text { you (plural) } \\
\text { were }\end{array}$ & ihr hattet & $\begin{array}{l}\text { you (plural) } \\
\text { had }\end{array}$ \\
\hline $\begin{array}{l}\text { sie/Sie } \\
\text { waren }\end{array}$ & $\begin{array}{c}\text { they/you } \\
\text { (formal) were }\end{array}$ & $\begin{array}{l}\text { sie/Sie } \\
\text { hatten }\end{array}$ & $\begin{array}{r}\text { they/you } \\
\text { (formal) had }\end{array}$ \\
\hline
\end{tabular}

\section{Übung 2: Anna war krank.}

An interactive H5P element has been excluded from this version of the text. You can view it online here: 
https://openeducationalberta.ca/willkommen-

deutsch/?p=162\#h5p-135

\section{Grammatik}

Perfect Tense (2)

Please work through the following presentation to learn more about the perfect tense.

Perfect Tense 2

*Achtung* Here is a list of common irregular verbs.

Übung 3: Ein schrecklicher Tag für Herrn Romano 


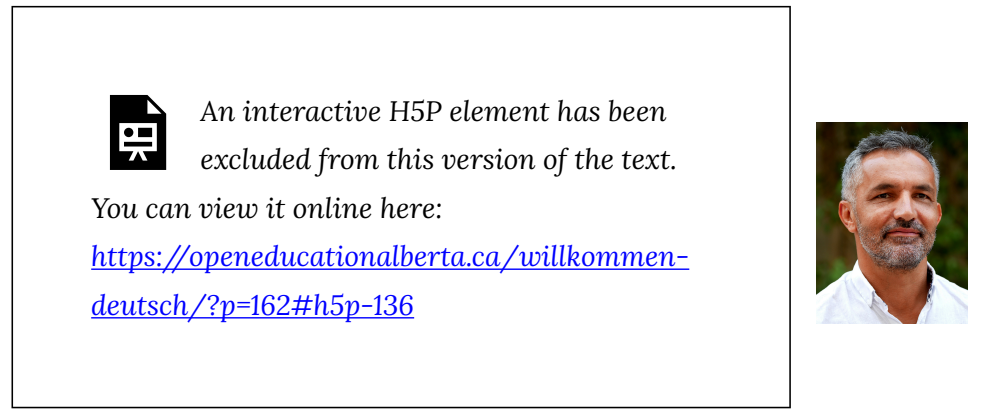

8

Wortschatz in Quizlet:

Sonstige Wörter und Ausdrücke

Sonstige Verben

Idiomatische Redewendungen

Was wissen Sie jetzt? Klicken Sie hier für Quiz 5.4.

Media Attributions

- star (C) IO-Images is licensed under a Public Domain license

- Maja (C) ckost is licensed under a All Rights Reserved license

- headphones (C) IO-Images is licensed under a Public Domain license

- Marktplatz (C) ckost is licensed under a CC BY-NC-SA (Attribution NonCommercial ShareAlike) license 
- link (C) IO-Images is licensed under a Public Domain license

- check mark (C) janjf93 adapted by Solomon Hajramezan is licensed under a Public Domain license 


\section{Einheit 5.5}

200

\section{Das Perfekt "Quiz"}

lernen / trinken / aufstehen / gehen / bezahlen

studieren / bleiben / spielen / singen / essen

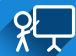

\section{Geschenke}

An interactive H5P element has been excluded from this version of the text. You can view it online here:

https://openeducationalberta.ca/willkommendeutsch/?p=164\#h5p-138

\section{8}

Und was schenken Sie? Viele Personen in Ihrer Familie und in Ihrem Freundeskreis haben bald Geburtstag. Sie möchten ihnen Geschenke kaufen. Stellen Sie Fragen und geben Sie Antworten wie im Beispiel.

\section{Beispiel:}

S1: Was schenkst du deiner Mutter?

S2: Ich schenke meiner Mutter einen Blumenstrauß. Was schenkst du deiner Mutter?

S1: Ich schenke meiner Mutter ein Buch. 


\begin{tabular}{|c|c|}
\hline Personen: & Geschenke: \\
\hline $\begin{array}{l}\text { - deiner Mutter } \\
\text { - deinem Vater } \\
\text { - deinem Bruder / deiner Schwester } \\
\text { - deiner Großmutter / deinem } \\
\text { Großvater } \\
\text { - deiner besten Freundin / deinem } \\
\text { besten Freund } \\
\text { - deinem Mitbewohner / deiner } \\
\text { Mitbewohnerin } \\
\text {... }\end{array}$ & $\begin{array}{l}\text { - der Gutschein } \\
\text { - das Buch } \\
\text { - der Blumenstrauß } \\
\text { - die Konzertkarte } \\
\text { - der Teddybär } \\
\text { - Geld } \\
\text {... }\end{array}$ \\
\hline
\end{tabular}

$\Omega$

Geschenke. Arbeiten Sie in einer Gruppe von 3 Studentinnen oder Studenten. Jede Person interviewt zwei andere Personen. Finden Sie heraus, welche Interessen die anderen Personen haben, was sie gern in ihrer Freizeit machen, was sie mögen oder nicht mögen. Entscheiden Sie dann, welche Geschenke Sie für diese zwei Personen kaufen können.

\section{Media Attributions}

- group (C) IO-Images is licensed under a Public Domain license

- presentation icon (C) quinntheislander adapted by Solomon Hajramezan is licensed under a Public Domain license

- partner (C) IO-Images is licensed under a Public Domain license 
Einheit 5.6 (online)
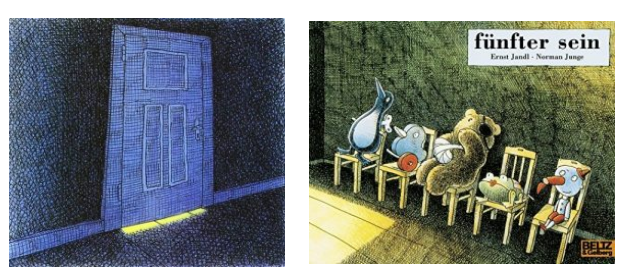

\section{fünfter sein}

(Gedicht von Ernst Jandl, Illustrationen von

Norman Junge)

Wenn Sie das Gedicht lesen wollen, klicken Sie hier.

Hier ist auch ein Video.
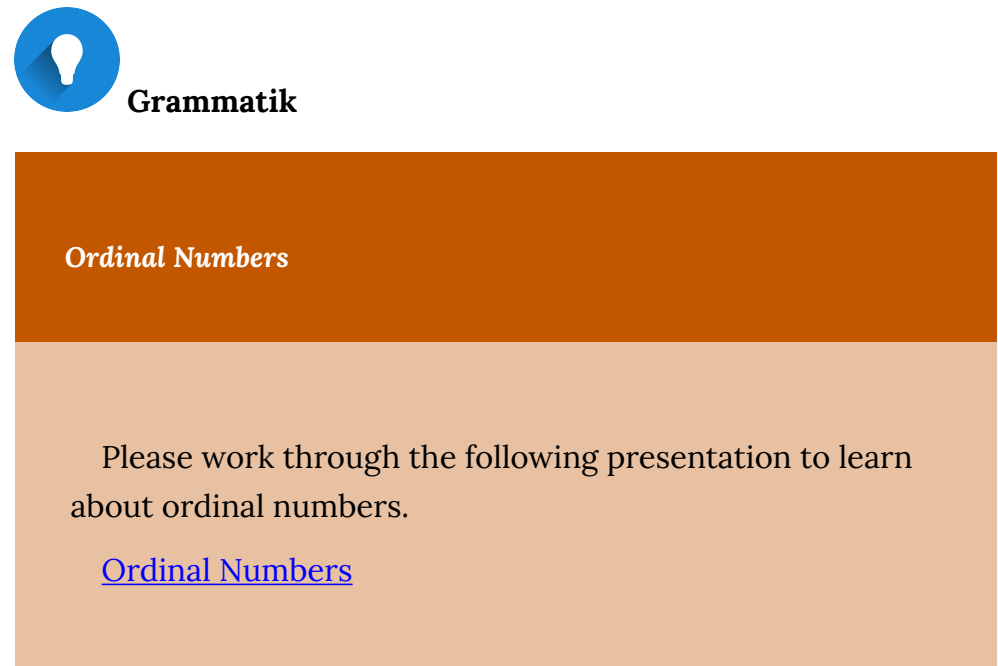

\section{Übung 1: Wichtige Daten}


An interactive $\mathrm{H} 5 \mathrm{P}$ element has been excluded from this version of the text. You can view it online here:

https://openeducationalberta.ca/willkommendeutsch/?p=166\#h5p-141

\section{Wortschatz in Quizlet:}

Geburtstage feiern und Geschenke

Ordinalzahlen 1-10

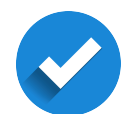

Was wissen Sie jetzt? Klicken Sie hier für Quiz 5.6.

\section{豐禺}

\section{Task 5: Eine E-Mail von Luca}

Imagine that you met Luca last year while on exchange in Germany. You have been writing emails back and forth a few times since you first met. Write a reply to Luca's email. Respond to all the questions he asks and ask him some questions as well. Write at least 120 words. 
Hallo ...,

wie geht es dir? Mir geht es gut, aber wir müssen am Ende des Semesters viele Prüfungen schreiben, du auch? Das ist ein bisschen stressig. Aber am Wochenende haben wir eine Pause gemacht: Sebi hatte Geburtstag und wir haben eine große Überraschungsparty für ihn organisiert. Am Samstag sind Maren und ich nach Aachen gefahren. Dort haben wir ein paar Freunde von Sebi getroffen und im Wohnheim den Partykeller geschmückt. Wir haben Bier und viele Snacks gekauft. Dann ist Sebi in den Partykeller gekommen und wir haben alle "Happy Birthday" gerufen. Er hat sich sehr gefreut! Natürlich haben wir ihm auch Geschenke gegeben. Maren hat ihm ein neues Buch von seinem Lieblingsautor geschenkt und ich habe Sebi eine Flasche richtig guten Whiskey gekauft. Sebis andere Freunde haben ihm zusammen einen neuen Tennisschläger geschenkt. Amelie und Michael, zwei andere Studierende im Wohnheim, haben einen Kuchen für Sebi gebacken. Von seinen Eltern hat Sebi einen Gutschein für eine Reise nach Amsterdam bekommen. Dann haben wir den ganzen Abend gefeiert und endlich mal nicht an unsere Prüfungen gedacht!

Was hast du an deinem letzten Geburtstag gemacht? Hast du gefeiert? Wie war das? Hast du viele Geschenke bekommen? Bitte schreib mir bald wieder.

Viele Grüße

Luca

This task will be assessed according to the Rubric for Task 5 .

\section{Media Attributions}

- fünfter sein 2 C Ernst Jandl/Norman Junge is licensed under a All Rights Reserved license

- fünfter sein (C) Ernst Jandl/Norman Junge is licensed under a All Rights Reserved license

- star (C) IO-Images is licensed under a Public Domain license

- link (C) IO-Images is licensed under a Public Domain license

- check mark (C) janjf93 adapted by Solomon Hajramezan is licensed under a Public Domain license

- keyboard (C) IO-Images is licensed under a Public Domain license 


\section{Einheit 5.7}

200

Wann haben Sie Geburtstag? Welche Geschenke kennen

Sie?

\section{ก}

Omas Geburtstag. Lucas Oma erzählt von ihrer Geburtstagsfeier. Hören Sie zu und beantworten Sie die Fragen.

One or more interactive elements has been excluded from this version of the text. You can view them online here: $\mathrm{https://openeducationalberta.ca/willkommen-}$ deutsch/?p=168\#audio-168-1

1. Wann hatte Oma Geburtstag?

2. Was haben sie am Nachmittag gemacht?

3. Was für Geschenke hat Oma bekommen?

4. Was hat die Familie am Abend gemacht?

5. Warum freut Luigi sich?

\section{Was ist neu hier?}

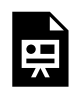
An interactive $\mathrm{H} 5 \mathrm{P}$ element has been excluded from this version of the text. You can view it online here:

https://openeducationalberta.ca/willkommendeutsch/?p=168\#h5p-189 
Wer - wem -was? Arbeiten Sie mit einer Partnerin oder mit einem Partner und schreiben Sie so viele Sätze wie möglich in 2 Minuten. Benutzen Sie possessive determiners "ihr" und "sein".

\begin{tabular}{|c|c|c|c|}
\hline $\begin{array}{l}\text { Wer? } \\
\text { (Nominativ) }\end{array}$ & & Wem? (Dativ) & Was? (Akkusativ) \\
\hline Stefan & $\begin{array}{l}\text { gibt } \\
\text { schenkt } \\
\text { bringt } \\
\text { kauft }\end{array}$ & $\begin{array}{l}\text { ihr.../sein... } \\
\qquad \begin{array}{l}\text { die Freundin } \\
\text { der Chef } \\
\text { die Kollegin } \\
\text { der Bruder } \\
\text { die Eltern } \\
\text { die Freunde } \\
\text { der Nachbar } \\
\text {... }\end{array}\end{array}$ & $\begin{array}{l}\text { der } \\
\text { Geburtstagskuchen } \\
\quad \text { das Buch } \\
\text { die Ohrringe } \\
\text { die Konzertkarte } \\
\text { der Gutschein } \\
\text { das Videospiel } \\
\text { Geld } \\
\text { der Kaffee } \\
\text {... }\end{array}$ \\
\hline
\end{tabular}

\section{Media Attributions}

- group (C) IO-Images is licensed under a Public Domain license

- headphones (C) IO-Images is licensed under a Public Domain license

- question-mark (C) IO-Images is licensed under a Public Domain license

- partner (C) IO-Images is licensed under a Public Domain license 


\section{Einheit 5.8 (online)}

\section{Übung 1: Was ist das?}

An interactive H5P element has been excluded from this version of the text. You can view it online here:

https://openeducationalberta.ca/willkommendeutsch/?p=170\#h5p-142

Geburtstage in Deutschland

Most people in Germany consider their birthday an important day. No matter the age of the person celebrating a birthday, there is always a birthday cake with candles on top. Blowing out the candles means good luck for the coming year.

Children usually invite their friends and relatives for their birthday. Everybody brings a present, but it doesn't have to be big or expensive. The kids spend the afternoon playing games. Sometimes they also go together to the swimming pool or the skating rink.

For teenagers, the 16th and the 18th birthday are especially important birthdays. With 16 , they are allowed to 
get a driver's license for a moped and they are allowed to drink beer. With 18, they are considered full adults; now they are allowed to vote. Young adults often celebrate their birthday with a larger party on a Saturday, either at home, at a club or bar, or at a rented hall. It is also customary to start celebrating the evening before so that at midnight, when the actual birthday starts, everybody can toast to the person having the birthday. This is called "reinfeiern" (to celebrate "into" the birthday).

Adults celebrate their birthdays at home with friends or go out to a restaurant. It's about having a good meal in good company, sometimes there is dancing involved. At the workplace it is customary for the person having the birthday to either treat their friends (to a drink) or to bring something to eat (cake, etc.) for everybody. Adults often celebrate their "round" birthdays $(30,40,50, \ldots)$ in a more elaborate way.

Older people usually celebrate their birthdays earlier in the day, by inviting friends and family for lunch at a restaurant or for coffee and cake in the afternoon.

In Germany, people never wish someone a "happy birthday" before the actual day of the birthday. It is considered bad luck and Germans are quite serious about this. On the actual day of the birthday, people say "Herzlichen Glückwunsch zum Geburtstag!" or "Happy Birthday!". They often also sing the "Happy Birthday" song (either in English or in German: "Zum Geburtstag viel Glück") or a different German birthday song called "Viel Glück und viel Segen". 


\section{Grammatik}

Cases: The Dative

Please work through the following presentation to learn about the dative case.

Cases: The Dative

Übung 2: Wer? Wem? Was?

An interactive H5P element has been excluded from this version of the text. You can view it online here:

https://openeducationalberta.ca/willkommendeutsch/?p=170\#h5p-143

Geburtstage in Deutschland. Watch the following video from Deutsche Welle. Then answer the following questions.

An interactive H5P element has been excluded from this version of the text. You can view it online here: 
https://openeducationalberta.ca/willkommen-

deutsch/?p=170\#h5p-101

Was wissen Sie jetzt? Klicken Sie hier für Quiz 5.8.

Media Attributions

- star (C) IO-Images is licensed under a Public Domain license

- check mark (C) janjf93 adapted by Solomon Hajramezan is licensed under a Public Domain license 


\section{Einheit 5.9}

200

Was wissen Sie über Weihnachten?

eng

Was passt zusammen?
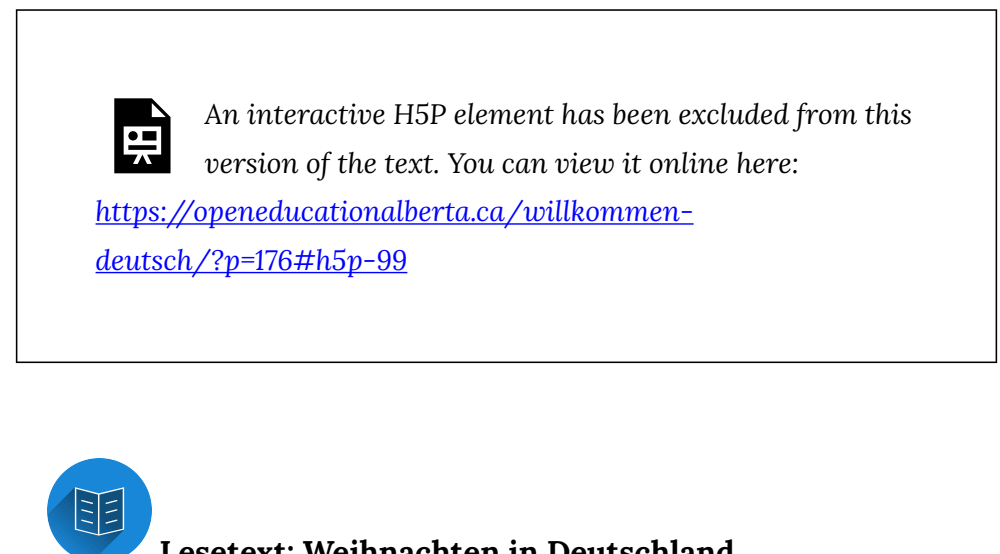

Lesetext: Weihnachten in Deutschland

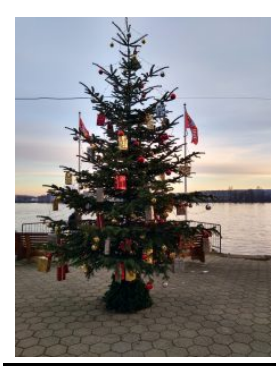

Weihnachten ist ein internationales Fest, man feiert es auf der ganzen Welt. Aber natürlich hat jedes Land seine eigenen Traditionen und Weihnachtsbräuche.

$\rightarrow$ Machen Sie 5 Gruppen in der Klasse. Jede Gruppe liest nur einen Teil des Textes. Der ganze Text ist hier.

\section{0}

Was haben Sie gelernt? Präsentieren Sie die Information von Ihrem Text.

\section{0}

Weihnachten "Quiz" 
An interactive H5P element has been excluded from this version of the text. You can view it online here:

https://openeducationalberta.ca/willkommen-

deutsch/?p=176\#h5p-100

\section{Media Attributions}

- group (C) IO-Images is licensed under a Public Domain license

- book (C) IO-Images is licensed under a Public Domain license

- Weihnachtsbaum am Rhein (C) ckost is licensed under a Public Domain license 


\section{Einheit 5.10 (online) \\ Grammatik}

Please work through the following presentation to learn about the personal pronouns and reflexive pronouns in the dative case.

$\underline{\text { Personal Pronouns and Reflexive Pronouns in the Dative }}$

Übung 1. Click the correct dative personal pronoun to replace the bolded noun in the first sentence.

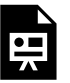

An interactive H5P element has been excluded from this version of the text. You can view it online here:

https://openeducationalberta.ca/willkommendeutsch/?p=174\#h5p-144

\section{Übung 2}


An interactive $\mathrm{H} 5 \mathrm{P}$ element has been excluded from this version of the text. You can view it online here:

https://openeducationalberta.ca/willkommen-

deutsch/?p=174\#h5p-145

\section{Grammatik}

Adjective Endings in Dative

As you already know, adjectives take an ending when they come directly before the noun they describe. The adjective endings vary depending on the gender, number, and case of the noun which they describe.

Adjective endings in the dative case are a bit simpler than the ones you learned before? In the dative case, if the adjective is preceded by a der-word (e.g., definite article), all adjectives (regardless of the gender of the noun) add -en. As you learned in Einheit 5.8, the masculine form of the definite article changes from der to dem, the feminine definite article changes to der, the neuter article changes to dem, and the plural article changes to den. 


\begin{tabular}{|l|l|l|l|}
\hline & masculine & feminine & neute \\
\hline nominative & der rote Rock & die weiße Bluse & das b \\
\hline accusative & den roten Rock & die weiße Bluse & das b \\
\hline dative & dem roten Rock & der weißen Bluse & dem \\
\hline
\end{tabular}

In the dative case, if the adjective is preceded by an ein-word (e.g., indefinite article, "kein", or any possessive adjective mein, dein, sein/ihr/sein, unser, euer, ihr/Ihr), the same rules as with $\mathbf{d e r}$-words apply: the adjective ending is -en.

\begin{tabular}{|l|l|l|c|}
\hline & masculine & feminine & neute \\
\hline nominative & ein roter Rock & eine weiße Bluse & ein bl \\
\hline accusative & einen roten Rock & eine weiße Bluse & ein bl \\
\hline dative & einem roten Rock & einer weißen Bluse & einen \\
\hline
\end{tabular}

*ACHTUNG* All nouns (except for some proper names) add $-n$ in the dative plural, unless their plural ends in $-\mathrm{s}$, for example:

die Freunde (Nom. pl.) $\rightarrow$ den Freunden (Dat. pl.)

die Bücher (Nom. pl.) $\rightarrow$ den Büchern (Dat. pl.) 
die Hobbys (Nom. pl.) $\rightarrow$ den Hobbys (Dat. pl.)

Übung 3: Das Geburtstagsgeschenk.

An interactive H5P element has been excluded from this version of the text. You can view it online here:

https://openeducationalberta.ca/willkommendeutsch/?p=174\#h5p-231

Q

Wortschatz in Quizlet:

Weihnachten

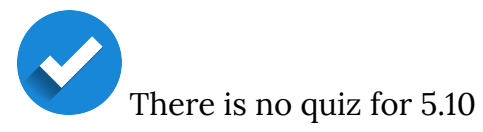

Extra Practice (optional):

\section{Video Serie - Nicos Weg}

Click on the link and watch the video. Then click on "start" under the video and do the exercises. 


\section{Media Attributions}

- star (C) IO-Images is licensed under a Public Domain license

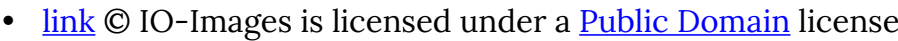

- check mark (C) janjf93 adapted by Solomon Hajramezan is licensed under a Public Domain license 


\title{
Wortschatz
}

\author{
Q Quizlet: \\ Wortschatz Einheit 5 (alle Kategorien) \\ Zeitangaben \\ Geburtstage feiern und Geschenke \\ Ordinalzahlen 1-10 \\ Weihnachten \\ $\underline{\text { Sonstige Wörter und Ausdrücke }}$ \\ Sonstige Verben \\ Idiomatische Redewendungen \\ $\underline{\text { Wortschatz } 5}$
}

Media Attributions

- link (C) IO-Images is licensed under a Public Domain license

- pdf (C) IO-Images is licensed under a Public Domain license 


\section{Zum Spaß!}

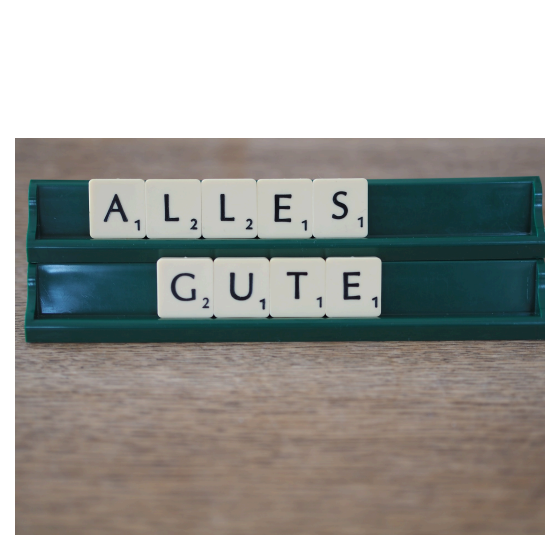

This chapter we

learned about

celebrating birthdays

in Germany! Here is a

video that reviews

some of the things we

learned as well as

introduces a few new

ways to encourage or

congratulate someone.

Interested to learn

when we say "Toi, toi,

toi!"? Watch this video! 


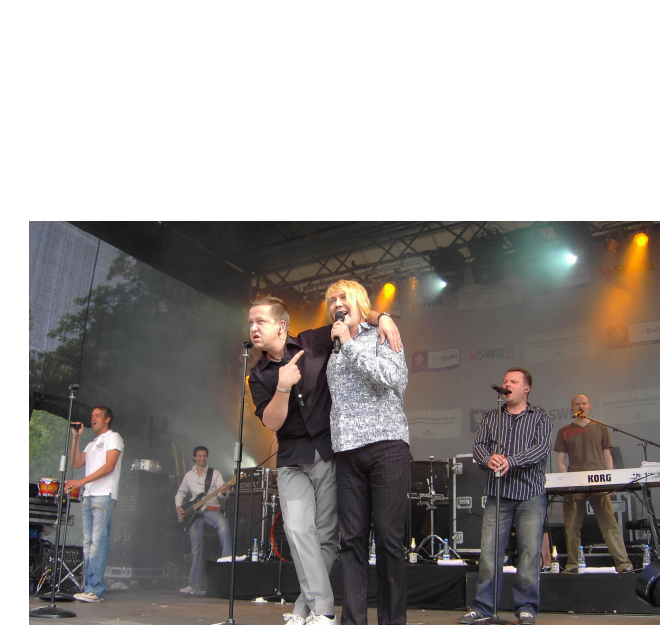

Check out the song "Was soll ich ihr schenken" by the

German band Die Prinzen. The band is made up of former members of the Thomanerchor (the choir of the Thomaskirche in Leipzig). Their songs are often sung a cappella. The lyrics of their songs are often humorous, tongue-in-cheek critiques of German government or society. Watch the video here. What does he eventually gift his girlfriend? Here are the lyrics if you want to read along or even sing along! 
350 | Zum Spaß! 


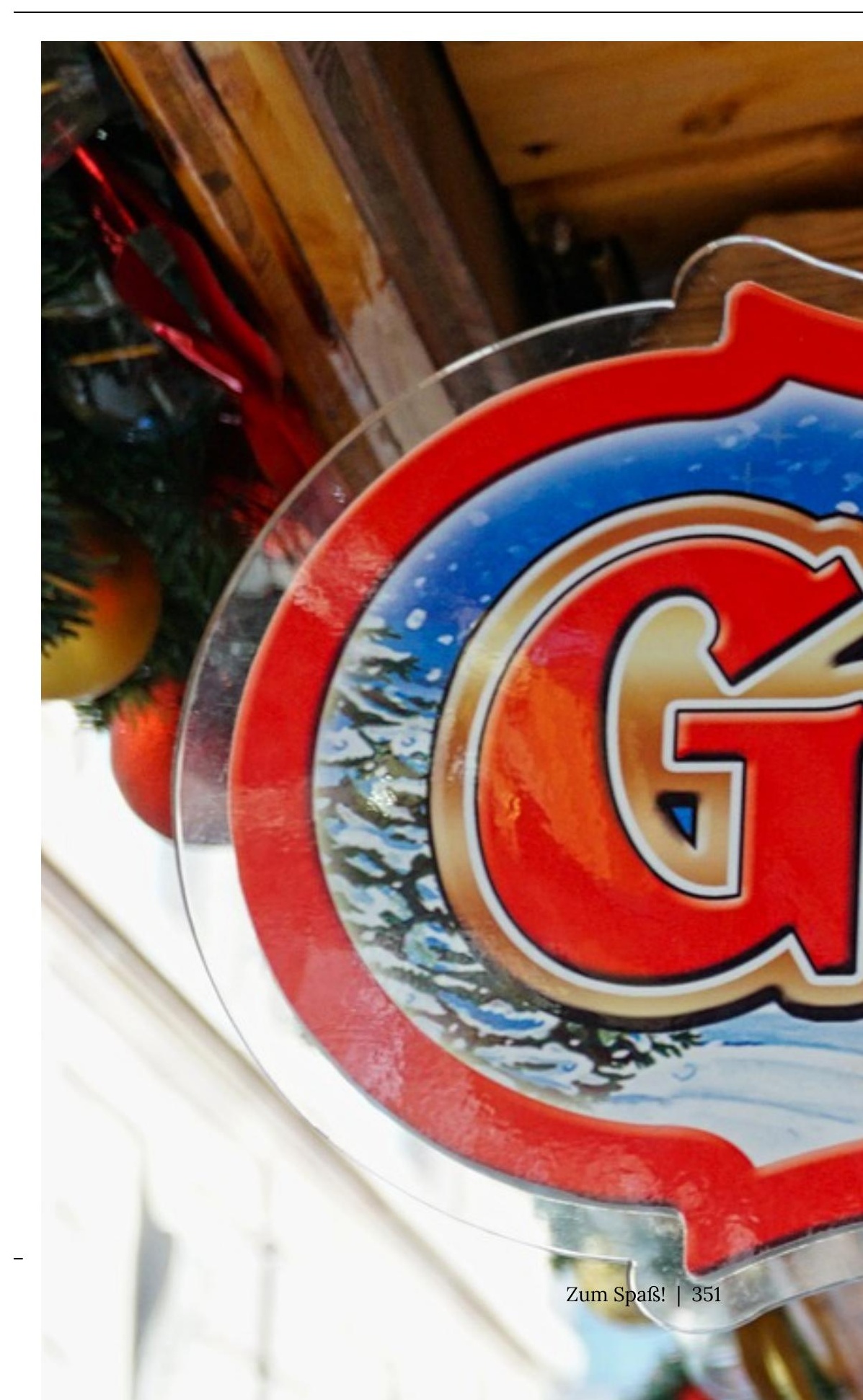



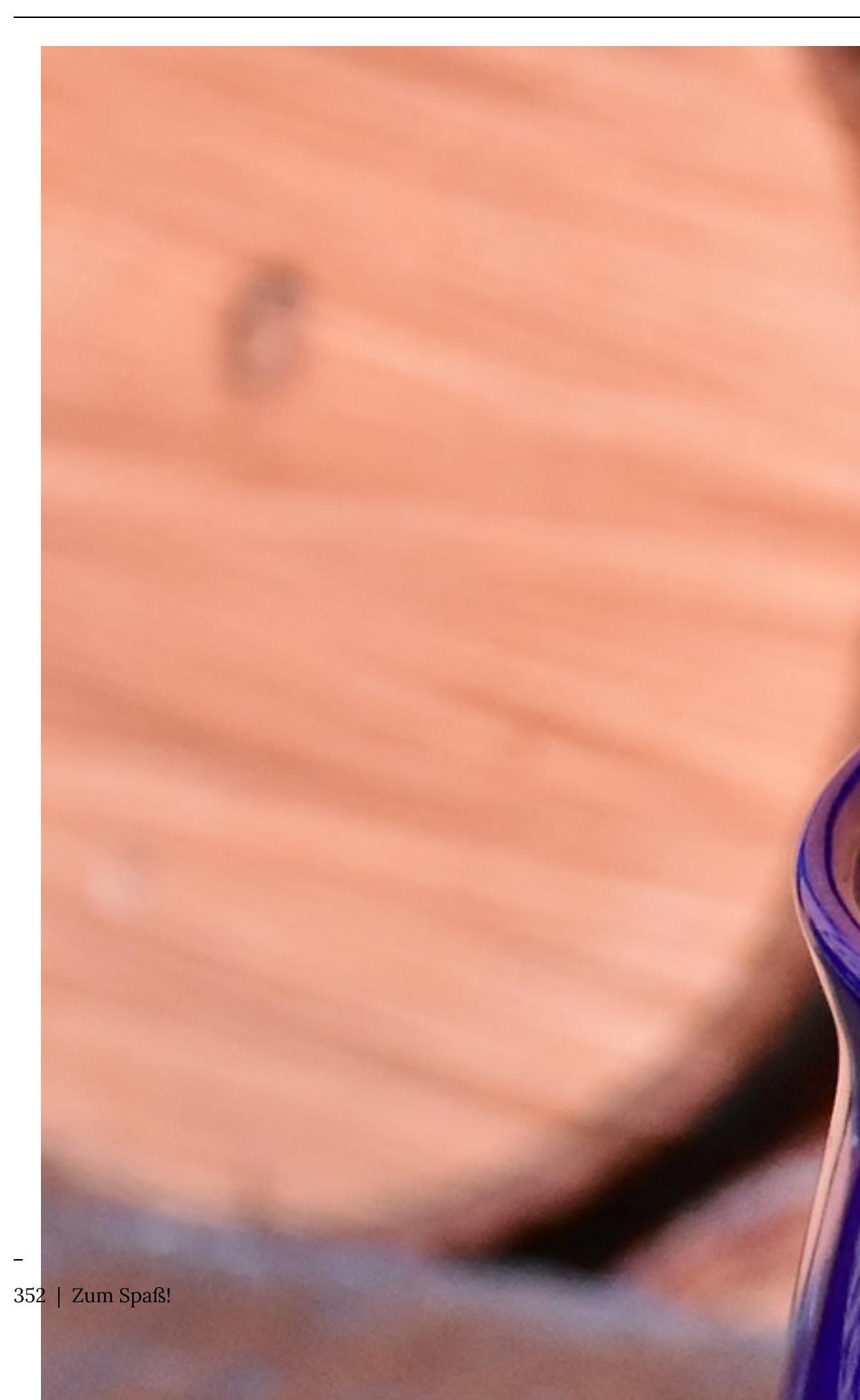
Extra Practice (optional): These activities are from the website Schubert-Verlag.

\section{Perfekt I}

Perfekt II

Perfekt III

Perfekt IV

Präsens oder Perfekt

Ordinalzahlen

Präteritum: haben und sein

Was schenken Sie wem zu Weihnachten?

$\underline{\text { Dativ }}$

Personalpronomen im Akkusativ und Dativ

Personalpronomen im Dativ

\section{Media Attributions}

- all-good (C) Ratfink1973 is licensed under a Public Domain license

- Prinzen2 (C) The weaver is licensed under a CC BY-SA (Attribution ShareAlike) license

- christmas-market (C) Albrecht Fietz is licensed under a Public Domain license

- mulled-claret-4647804 1920 @ Anrita1705 is licensed under a Public Domain license

- mulled-claret-1075689_1920 (C) RitaE is licensed under a Public Domain license 
354 | Zum Spaß! 


\section{EINHEIT 6: AUF EINER REISE}

At the end of Einheit 6, you will be able to...

- describe and compare different means of transportation

- describe landscapes and common geographical features

- discuss and compare various travel experiences

- $\quad$ talk about a famous German poem (Die Loreley, by H. Heine) in its cultural and historical context

- identify and describe some features of UNESCO world heritage sites, in particular the Oberes Mittelrheintal (Upper Middle Rhine Valley)

- $\quad$ plan a trip

- use a German search engine to find the best means of transportation

- research and book accommodations

- read German train schedules and buy a ticket for a train

You will also have learned about the following structures:

- $\quad$ comparative and superlative

- accusative prepositions 
356 | Einheit 6: Auf einer Reise 


\section{Einheit 6.1}

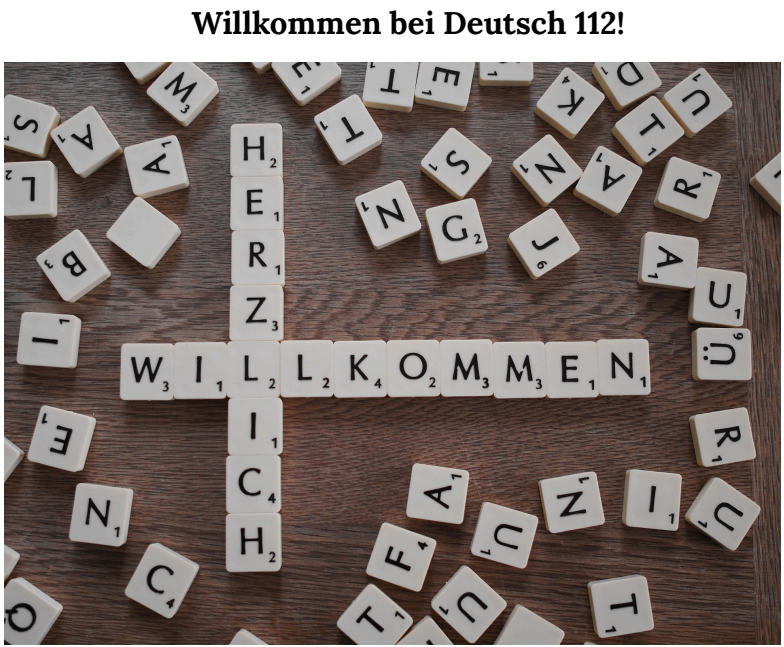

\section{0}

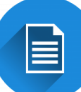

Menschen-Bingo zum Kennenlernen. Stellen Sie

anderen Studierenden die Fragen und versuchen Sie, eine BingoReihe zu bekommen. Das Menschen-Bingo ist im $\underline{\text { Student Handout }}$ PDF.

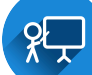

Informationen über Deutsch 112

\section{Media Attributions}

- saying-2736075_1920 C Ratfink1973 is licensed under a Public Domain license

- group (C IO-Images is licensed under a Public Domain license 
- document (C) IO-Images is licensed under a Public Domain license

- presentation icon (C) quinntheislander adapted by Solomon Hajramezan is licensed under a Public Domain license 


\section{Einheit 6.2 (online)}

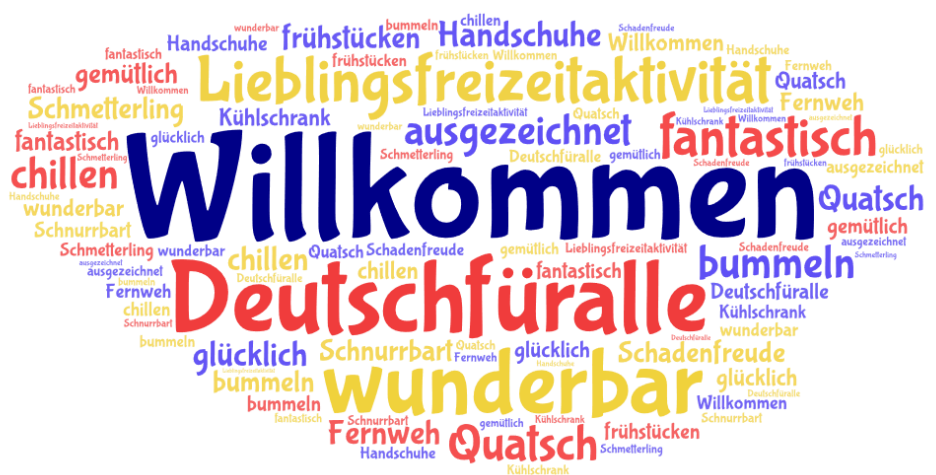

Lesen Sie den Syllabus auf eClass.

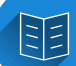

Was wissen Sie schon? Lesen Sie das PDF durch, bevor Sie die Wiederholung machen.

*ACHTUNG* For fill in the blank activities that correct automatically in this e-textbook, you can correct an incorrect answer right away by continuing to type in the "red" box.

Einheit 1 - 5 Wiederholung 
An interactive H5P element has been excluded from this version of the text. You can view it online here:

https://openeducationalberta.ca/willkommen-

deutsch/?p=192\#h5p-197

$x$

Auf einer Reise. Hören und lesen Sie die neuen Vokabeln.

佥

An interactive H5P element has been excluded from this version of the text. You can view it online here:

https://openeducationalberta.ca/willkommen-

deutsch/?p=192\#h5p-217

Übung 1: Wortschatz Wiederholung. Ergänzen Sie die fehlenden Wörter. Hier sind Sonderzeichen zum Kopieren und Einfügen: ä ö ü ̊s

An interactive H5P element has been excluded from this version of the text. You can view it online here: 
https://openeducationalberta.ca/willkommen-

deutsch/?p=192\#h5p-311

Wortschatz in Quizlet:

Auf einer Reise

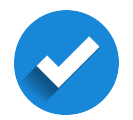

Was wissen Sie jetzt? Das Quiz ist in der nächsten Unterrichtsstunde.

\section{Media Attributions}

- book (C) IO-Images is licensed under a Public Domain license

- star (C) IO-Images is licensed under a Public Domain license

- presentation icon (C) quinntheislander adapted by Solomon Hajramezan is licensed under a Public Domain license

- link (C) IO-Images is licensed under a Public Domain license

- check mark (C janjf93 adapted by Solomon Hajramezan is licensed under a Public Domain license 


\section{Einheit 6.3}

909

Welche Gegenstände sehen Sie auf dem Foto? / Was nehmen Sie auf eine Reise mit?

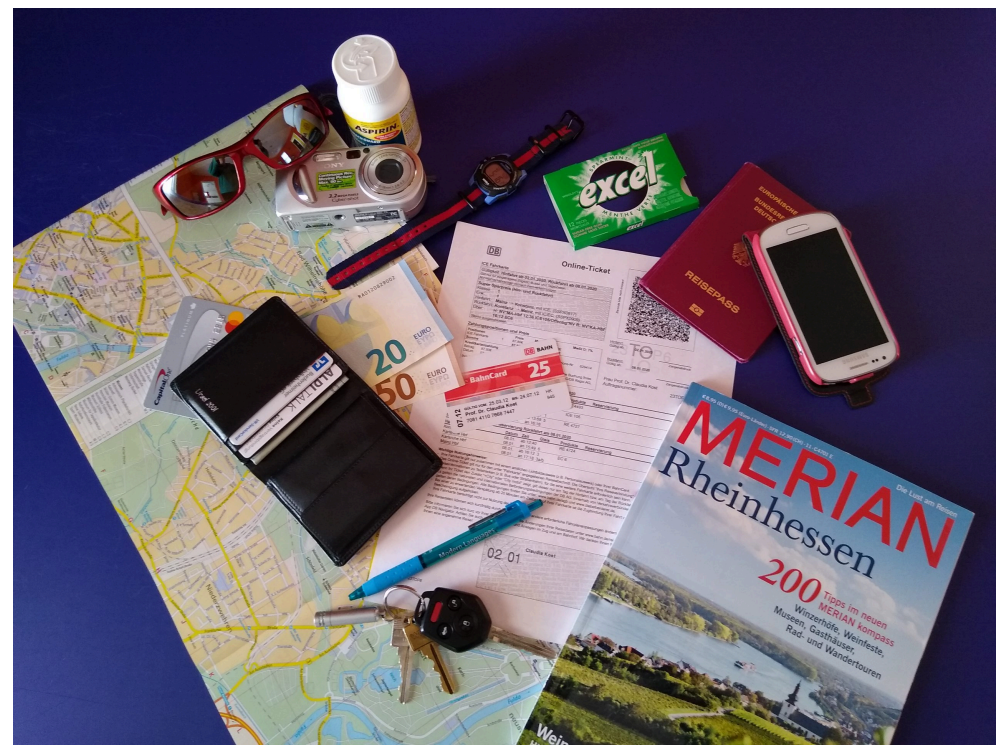

\section{$\varepsilon$}

Was nehmen Sie immer / manchmal / selten / nie mit?

Arbeiten Sie mit einer Partnerin oder mit einem Partner und stellen Sie sich gegenseitig Fragen.

der Reisepass / die Fahrkarte / das Aspirin / der Koffer / die Armbanduhr / das Geld

die Kamera / die Sonnenbrille / die Kreditkarte / der Stadtplan / der Kaugummi / das Ladegerät

der Autoschlüssel / die BahnCard / der Reiseführer / das

Portemonnaie /das Handy

Beispiel: 
S1: Was nimmst du immer auf eine Reise mit?

S2: Ich nehme immer meinen Reisepass mit. Und du?

Katelyns Reise-Blog. Lesen Sie den Text. Katelyn ist eine Austauschstudentin aus Edmonton. Sie hat im Sommer einen Deutschkurs an der Kanadischen Sommerschule in Kassel gemacht. Danach ist sie in Deutschland herumgereist. In ihrem Reise-Blog schreibt sie über einen Ausflug nach Mainz. 


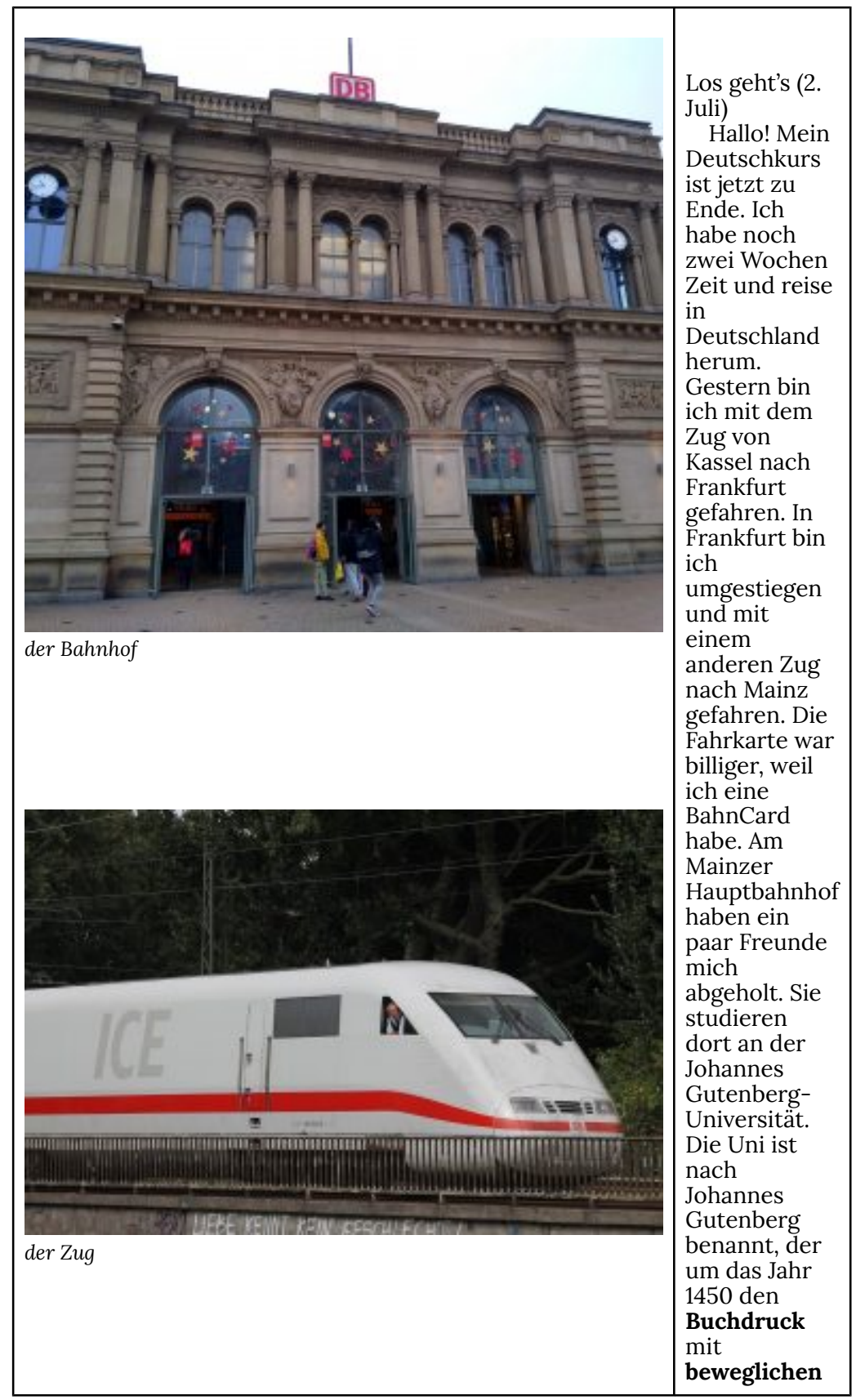




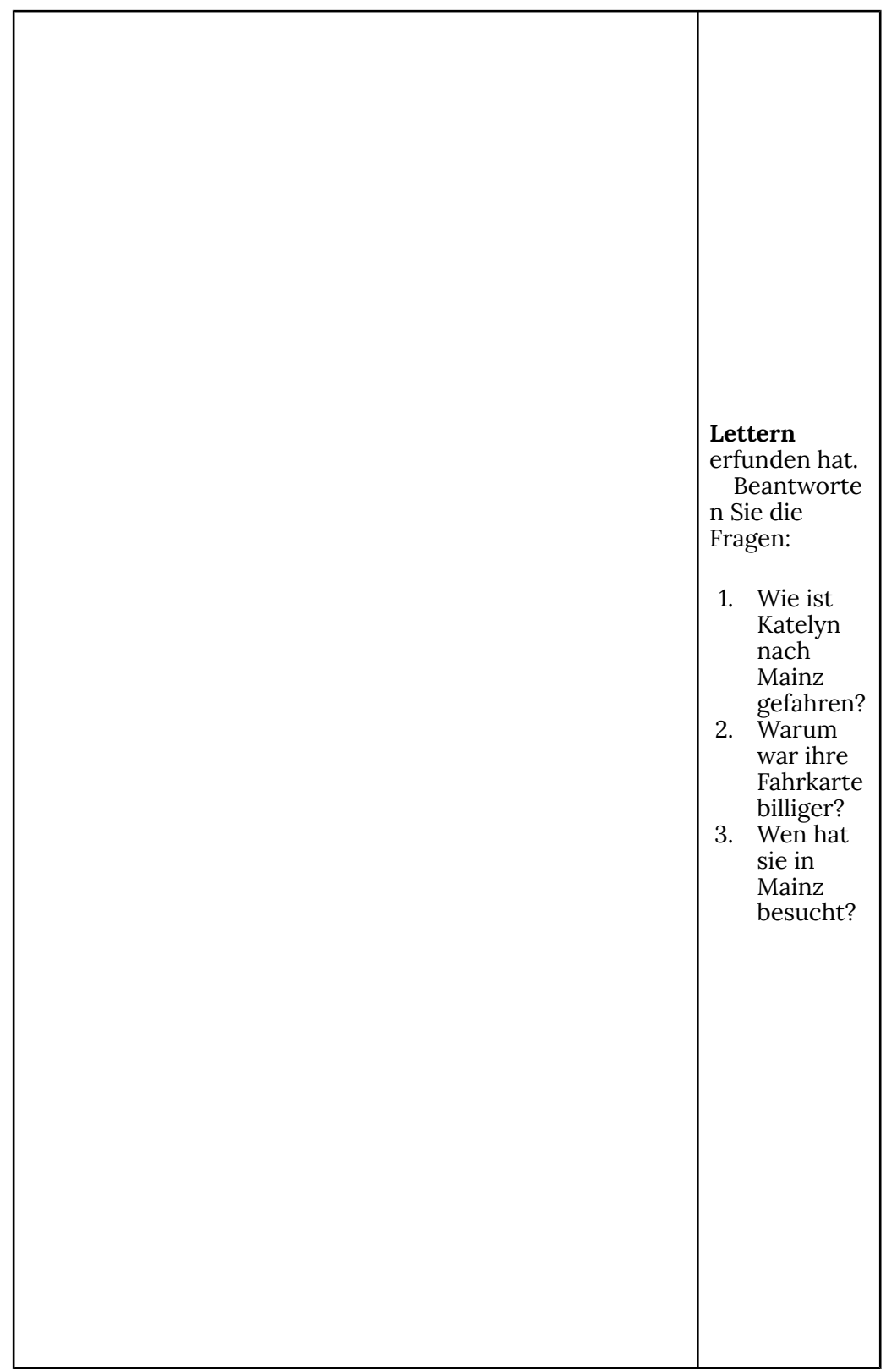




\section{Media Attributions}

- group (C) IO-Images is licensed under a Public Domain license

- Gegenstände für eine Reise (C) ckost is licensed under a CC BYNC-SA (Attribution NonCommercial ShareAlike) license

- partner (C) IO-Images is licensed under a Public Domain license

- book (C) IO-Images is licensed under a Public Domain license

- Mainz-Hauptbahnhof (C) ckost is licensed under a CC BY-NC-

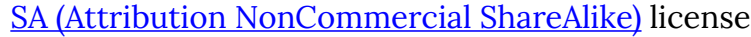

- transport-system-3255939_1280 C JürgenB is licensed under a Public Domain license 


\section{Einheit 6.4 (online)}

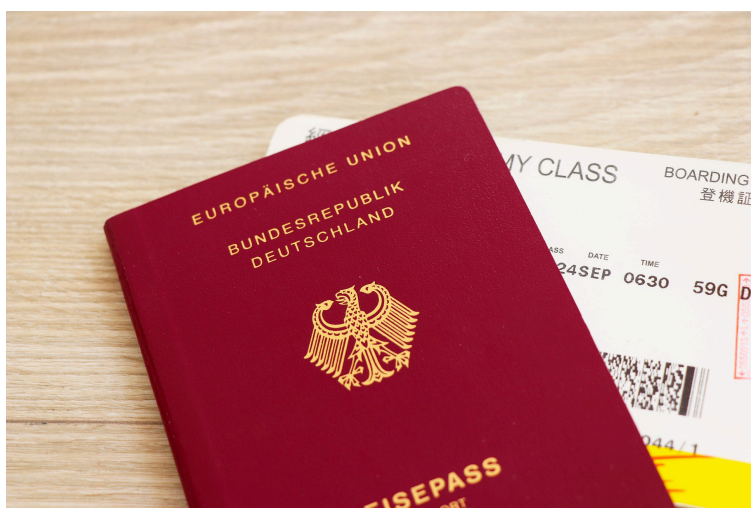

\section{Übung 1: Was ist das?}

An interactive H5P element has been excluded from this version of the text. You can view it online here:

https://openeducationalberta.ca/willkommen-

deutsch/?p=196\#h5p-149 


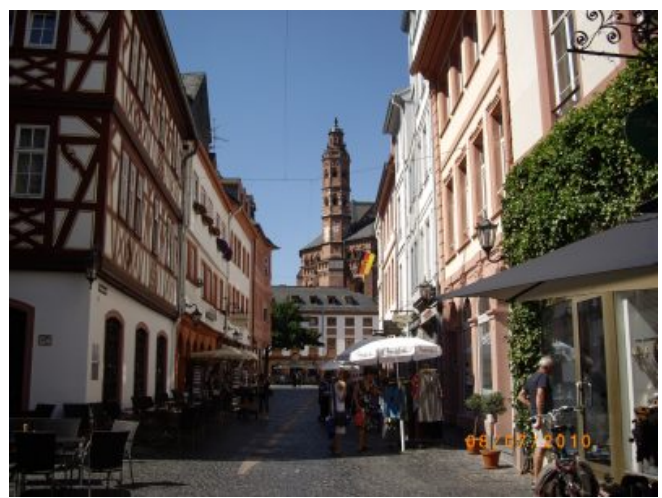

die Altstadt mit einer Fußgängerzone

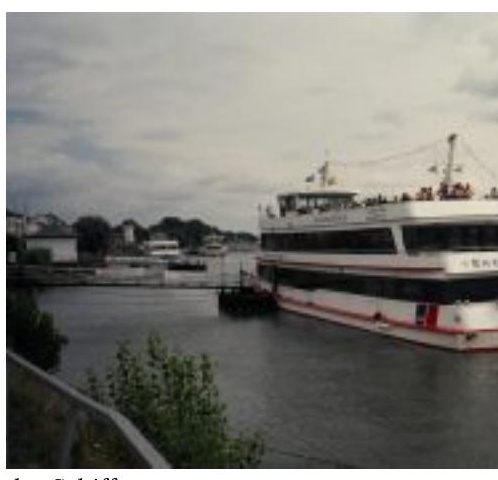

das Schiff

Katelyns Reise-Blog. Lesen Sie den Text und beantworten Sie die Fragen.

Heute haben meine Freunde mir die Stadt gezeigt. Mainz ist sehr alt, etwa 2000 Jahre alt! Das ist viel älter als unsere Städte in Kanada. In Mainz findet man immer wieder alte römische Ruinen. Aber heute ist Mainz sehr modern, man kann gut einkaufen, es gibt sehr nette Restaurants und nachts kann man viele Clubs besuchen und tanzen. Der Dom in Mainz ist über 1000 Jahre alt. Es gibt auch eine sehr schöne Altstadt mit einer Fußgängerzone. Nächste Woche fahre ich mit einem Schiff den Rhein (Fluss) hinunter und besuche die Loreley! Ich freue mich schon sehr!

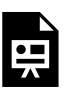

An interactive H5P element has been excluded from this version of the text. You can view it online here:

https://openeducationalberta.ca/willkommendeutsch/?p=196\#h5p-312 


\section{Tatsachen über Deutschland}

An interactive H5P element has been excluded from this

믐 version of the text. You can view it online here:

https://openeducationalberta.ca/willkommen-

deutsch/?p=196\#h5p-150

\section{Grammatik}

Comparative and Superlative

In the presentation about Germany you saw many comparative and superlative forms used. Please work through the following presentation to learn about comparative and superlative.

Comparative and Superlative

\section{Übung 2}


An interactive $\mathrm{H} 5 \mathrm{P}$ element has been excluded from this version of the text. You can view it online here:

https://openeducationalberta.ca/willkommendeutsch/?p=196\#h5p-151

Wortschatz in Quizlet:

Auf einer Reise

Was wissen Sie jetzt? Klicken Sie hier für Quiz 6.4.

\section{Media Attributions}

- passport-4521086 1920 C Edeltravel_is licensed under a Public Domain license

- star (C) IO-Images is licensed under a Public Domain license

- Dom_from_Kirschengarten_(C) ekeidar is licensed under a $\underline{\mathrm{CC}}$ BY-SA (Attribution ShareAlike) license

- Rheinstar (C) csawatzky is licensed under a CC BY-NC-SA (Attribution NonCommercial ShareAlike) license

- book (C) IO-Images is licensed under a Public Domain license

- presentation icon (C) quinntheislander adapted by Solomon Hajramezan is licensed under a Public Domain license

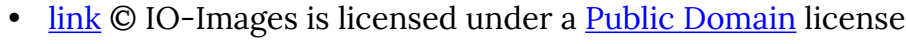

- check mark (C) janjf93 adapted by Solomon Hajramezan is licensed under a Public Domain license 


\section{Einheit 6.5}

200

Welche Transportmittel kennen Sie?

$x$

\section{Transportmittel \& Öffentliche Verkehrsmittel}

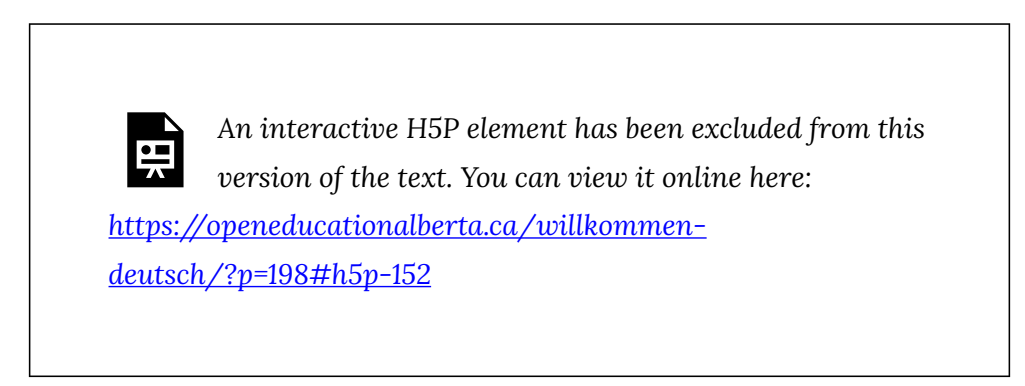

200

Transportmittel: Vergleiche. Richtig oder falsch?

1. _-_-_-_- Das Flugzeug ist schneller als das Fahrrad.

2. _-_-_-_- Der Bus ist länger als der Zug.

3. _-_-_-_- Das Fahrrad ist langsamer als das Motorrad.

4. _-_-_-_- Das schnellste Transportmittel ist die Straßenbahn.

5. _-_-_-_- Der Lastwagen ist größer als das Auto.

6. -_-_-_-_ Mit dem Taxi fahren ist besser als mit dem Bus fahren.

7. _-_-_-_-_ Das kleinste Transportmittel ist das Flugzeug.

8. _-_-_-_- Fahrradfahren ist am gesündesten und am umweltfreundlichsten.

9. _-_-_-_- Die U-Bahn ist so lang wie das Motorrad.

10. _-_-_-_- Das Fahrrad ist am teuersten. 
Von Tür zu Tür: Verkehrsmittelvergleich. Sehen Sie sich die zwei folgenden Tabellen an, die der Verkehrsclub Deutschland erstellt hat. Arbeiten Sie mit einer Partnerin oder mit einem Partner. Vergleichen Sie die Verkehrsmittel und schreiben Sie Sätze mit Komparativ und Superlativ. Benutzen Sie die Wörter in der Box.

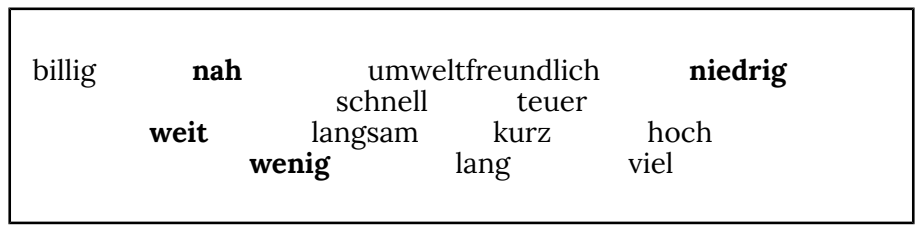

\section{Verkehrsmittelvergleich Kurzstrecke}

Beispiele:

Mit dem Fahrrad fahren ist billiger als mit dem Bus fahren.

Zu Fuß zur Humboldt-Universität gehen dauert am längsten.

\begin{tabular}{|l|l|l|l|l|}
\hline $\begin{array}{l}\text { Strecke } \\
\text { innerstädtisch } \\
\text { Berlin: Schlesisches } \\
\begin{array}{l}\text { Tor- } \\
\text { Humboldt-Universität }\end{array}\end{array}$ & Fahrrad & Bus \& Zug & Auto & zu Fuß \\
\hline Entfernung & $4,0 \mathrm{~km}$ & $5,9 \mathrm{~km}$ & $6,5 \mathrm{~km}$ & $4,0 \mathrm{~km}$ \\
\hline Kosten & 0,36 Euro & 2,10 Euro & 3,64 Euro & 0,00 Euro \\
\hline Zeit & $14 \mathrm{~min}$ & $26 \mathrm{~min}$ & $23 \mathrm{~min}$ & $49 \mathrm{~min}$ \\
\hline $\mathbf{C O}_{2}$-Ausstoß & $0,00 \mathrm{~kg}$ & $0,42 \mathrm{~kg}$ & $1,12 \mathrm{~kg}$ & $0,00 \mathrm{~kg}$ \\
\hline
\end{tabular}

\section{Verkehrsmittelvergleich Langstrecke}

Beispiele:

Mit dem Auto fahren ist weiter als mit dem Zug fahren.

Der $\mathrm{CO}_{2}$-Ausstoß von einem Reisebus ist niedriger als der $\mathrm{CO}_{2}$-Ausstoß von einem Flugzeug. 


\begin{tabular}{|l|l|l|l|l|}
\hline $\begin{array}{l}\text { Langstrecke } \\
\text { Berlin-Frankfurt }\end{array}$ & Zug & Auto & Flugzeug & Reisebus \\
\hline Entfernung & $510 \mathrm{~km}$ & $543 \mathrm{~km}$ & $433 \mathrm{~km}$ & $543 \mathrm{~km}$ \\
\hline Kosten & ab 29 Euro & 305 Euro & ab 33 Euro & 33 Euro \\
\hline Zeit & $4: 19 \mathrm{~h}$ & $5: 04 \mathrm{~h}$ & $5: 10 \mathrm{~h}$ & $9: 50 \mathrm{~h}$ \\
\hline $\mathbf{C O}_{2}$-Ausstoß & $26,0 \mathrm{~kg}$ & $94,2 \mathrm{~kg}$ & $81,2 \mathrm{~kg}$ & $19,2 \mathrm{~kg}$ \\
\hline
\end{tabular}

Media Attributions

- group (C) IO-Images is licensed under a Public Domain license

- presentation icon (C) quinntheislander adapted by Solomon Hajramezan is licensed under a Public Domain license

- partner (C) IO-Images is licensed under a Public Domain license 


\section{Einheit 6.6 (online)}

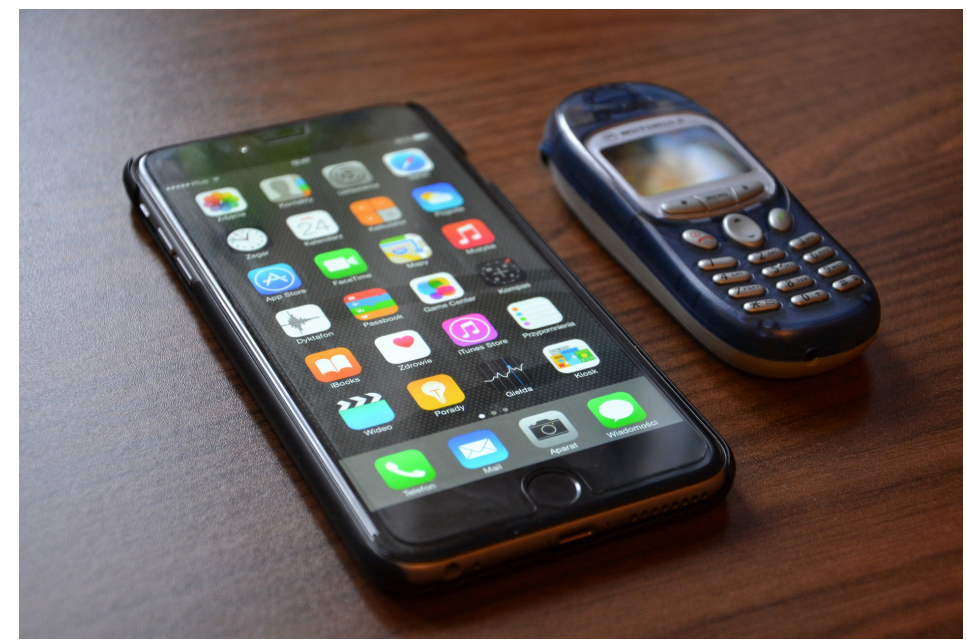

Das

Smartp ist gröls als das Handy.

\section{Übung 1: Transportmittel Wortschatz}

An interactive H5P element has been excluded from this
version of the text. You can view it online here:
deutsch/?p=200\#h5p-154

\section{i}

Vergessen Sie nicht! 
The preposition " $m i t$ " is always followed by the dative case! Need to review the dative case? Here is the presentation from Einheit 5.8.

Ich fahre jeden Tag mit dem Bus zur Uni. Ich bin noch nie mit einer U-Bahn gefahren. Sebi fährt mit seinem Auto nach Mainz.

\section{Übung 2: Komparativ \& Superlativ}

固

An interactive H5P element has been excluded from this version of the text. You can view it online here:

https://openeducationalberta.ca/willkommendeutsch/?p=200\#h5p-156

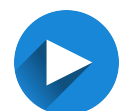

UNESCO-Welterbe. The UNESCO selects areas or landmarks that are culturally, historically, scientifically or otherwise significant and declares them world heritage sites. These sites are protected by international treaties. There are 46 World Heritage Sites in Germany (43 cultural and 3 natural).

Today, you will learn something about the "Oberes Mittelrheintal" (Upper Middle Rhine Valley). 


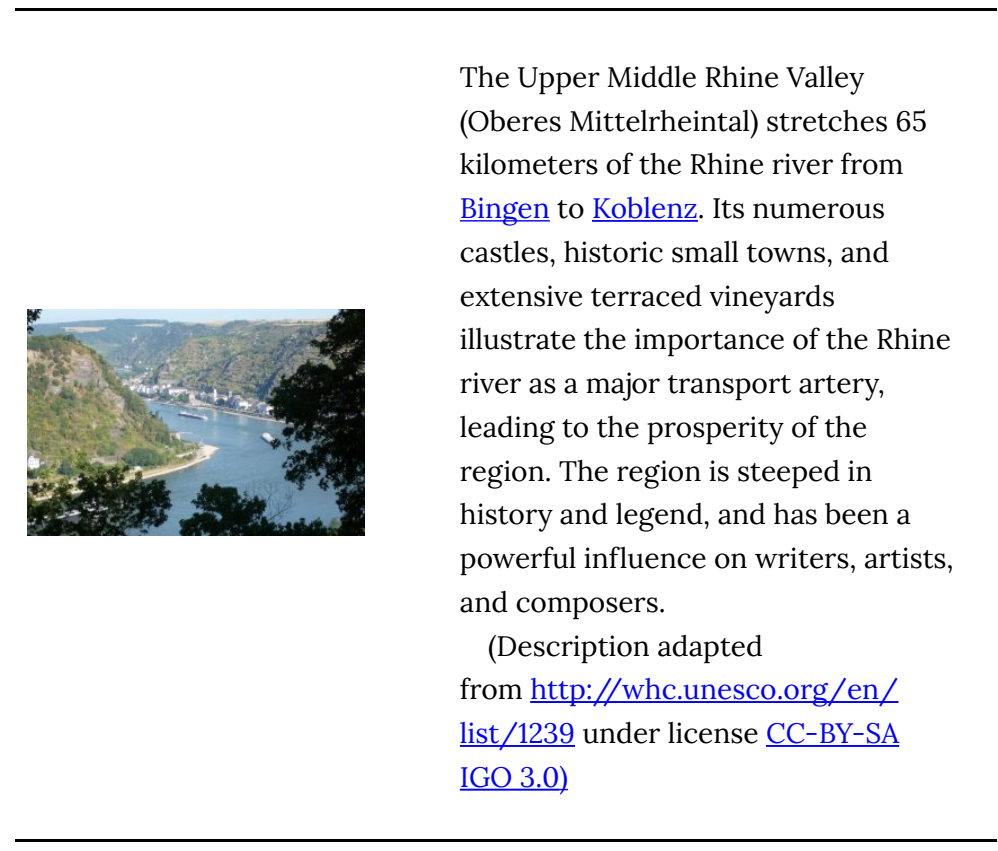

Wo liegt das Obere Mittelrheintal auf der Landkarte? Welterbe in Deutschland

Sehen Sie die zwei Videos an und machen Sie Übung 3.

Welterbe Oberes Mittelrheintal (1 Minute; Deutsch)

Upper Middle Rhine Valley (Deutsche Welle) (5:22 minutes; English)

\section{Übung 3: Oberes Mittelrheintal Fragen}

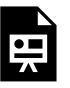

An interactive H5P element has been excluded from this version of the text. You can view it online here:

https://openeducationalberta.ca/willkommendeutsch/?p=200\#h5p-162 
Wer/Was/Wo ist die Loreley? Recherchieren Sie im Internet. Finden Sie 3 Dinge über die Loreley heraus (für die nächste Deutschstunde).

S

Wortschatz in Quizlet:

Transport

Transportmittel (plurals)

Adjektive

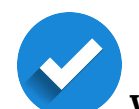

Was wissen Sie jetzt? Klicken Sie hier für Quiz 6.6.

\section{Media Attributions}

- phone-610148_1920 C kropekk_pl is licensed under a Public Domain license

- star (C) IO-Images is licensed under a Public Domain license

- information (C) IO-Images is licensed under a Public Domain license

- magnifying-glass (C) IO-Images is licensed under a Public Domain license

- $\underline{\text { link }(C) ~ I O-I m a g e s ~ i s ~ l i c e n s e d ~ u n d e r ~ a ~ P u b l i c ~ D o m a i n ~ l i c e n s e ~}$

- check mark (C janjf93 adapted by Solomon Hajramezan is licensed under a Public Domain license 


\section{Einheit 6.7}

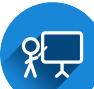

\section{Geografie}

\section{0}

Was haben Sie schon gelernt?

An interactive H5P element has been excluded from this version of the text. You can view it online here:

https://openeducationalberta.ca/willkommen-

deutsch/?p=6211\#h5p-153
- An interactive H5P element has been excluded from this version of the text. You can view it online here:

https://openeducationalberta.ca/willkommen-

deutsch/?p=6211\#h5p-212

\section{0}

Wer? Wie? Wo? Was? Beschreiben Sie die Bilder. 


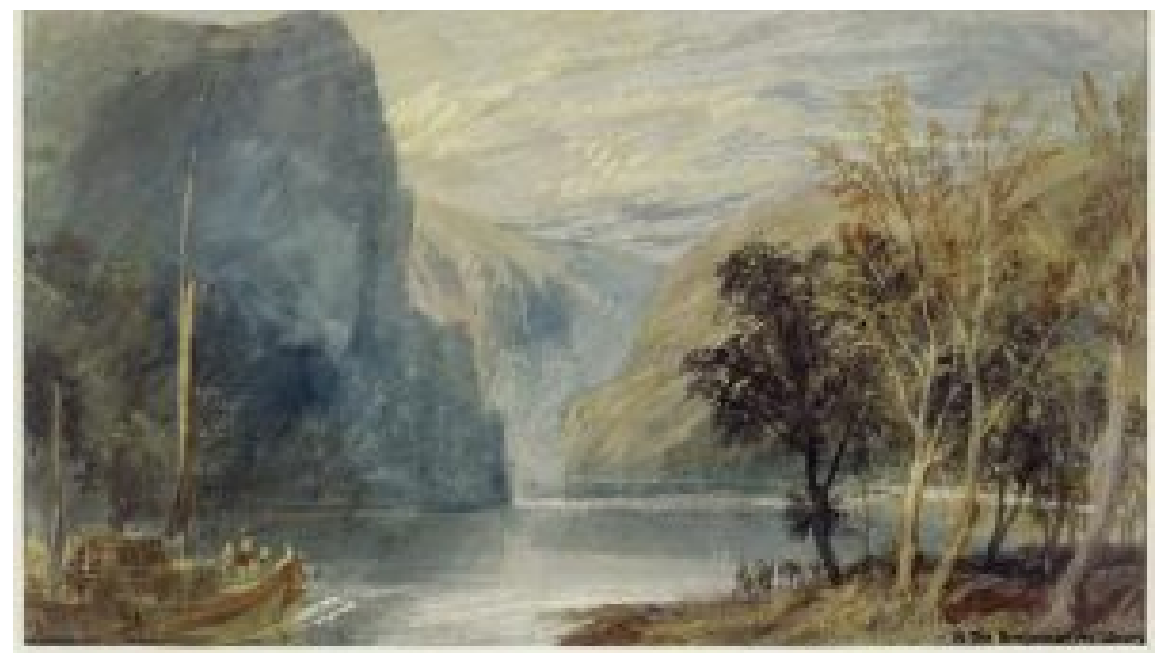

William Turner "The Lorelei Rock" (1817)

900

Was wissen Sie über die Loreley?

gog

Was passiert hier? 


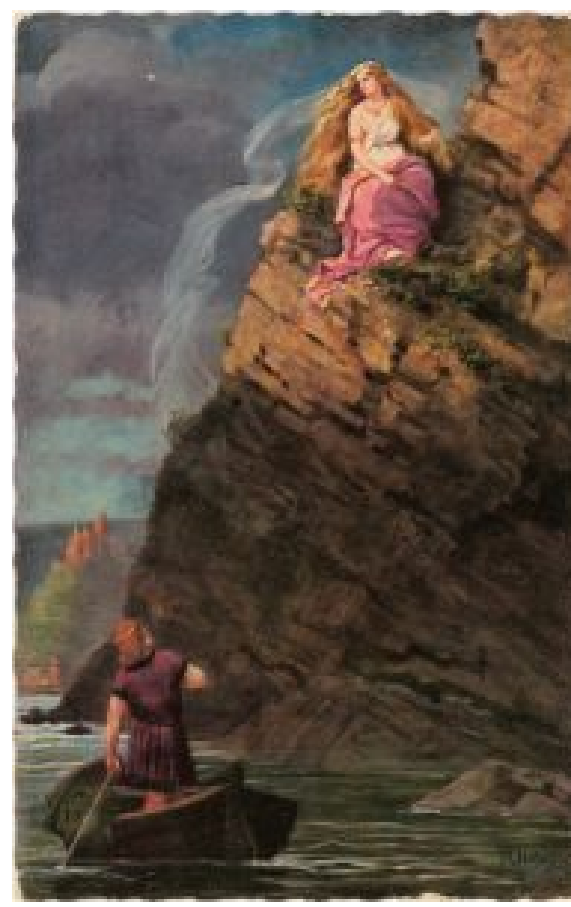

Wo sitzt Loreley?

Was macht der Mann im Boot?

Was passiert mit ihm?

Wie ist die Stimmung?

H. Hoffmann (1965)

Media Attributions

- presentation icon (C) quinntheislander adapted by Solomon Hajramezan is licensed under a Public Domain license

- group (C) IO-Images is licensed under a Public Domain license

- William Turner Loreley Rock (C) The Bridgeman Art Library

- Theodore Kaufman Lorelei (C) Theodore Kaufmann is licensed under a Public Domain license

- Loreley_Hoffmann (C) Goethe Zeitportal 


\section{Einheit 6.8 (online)}

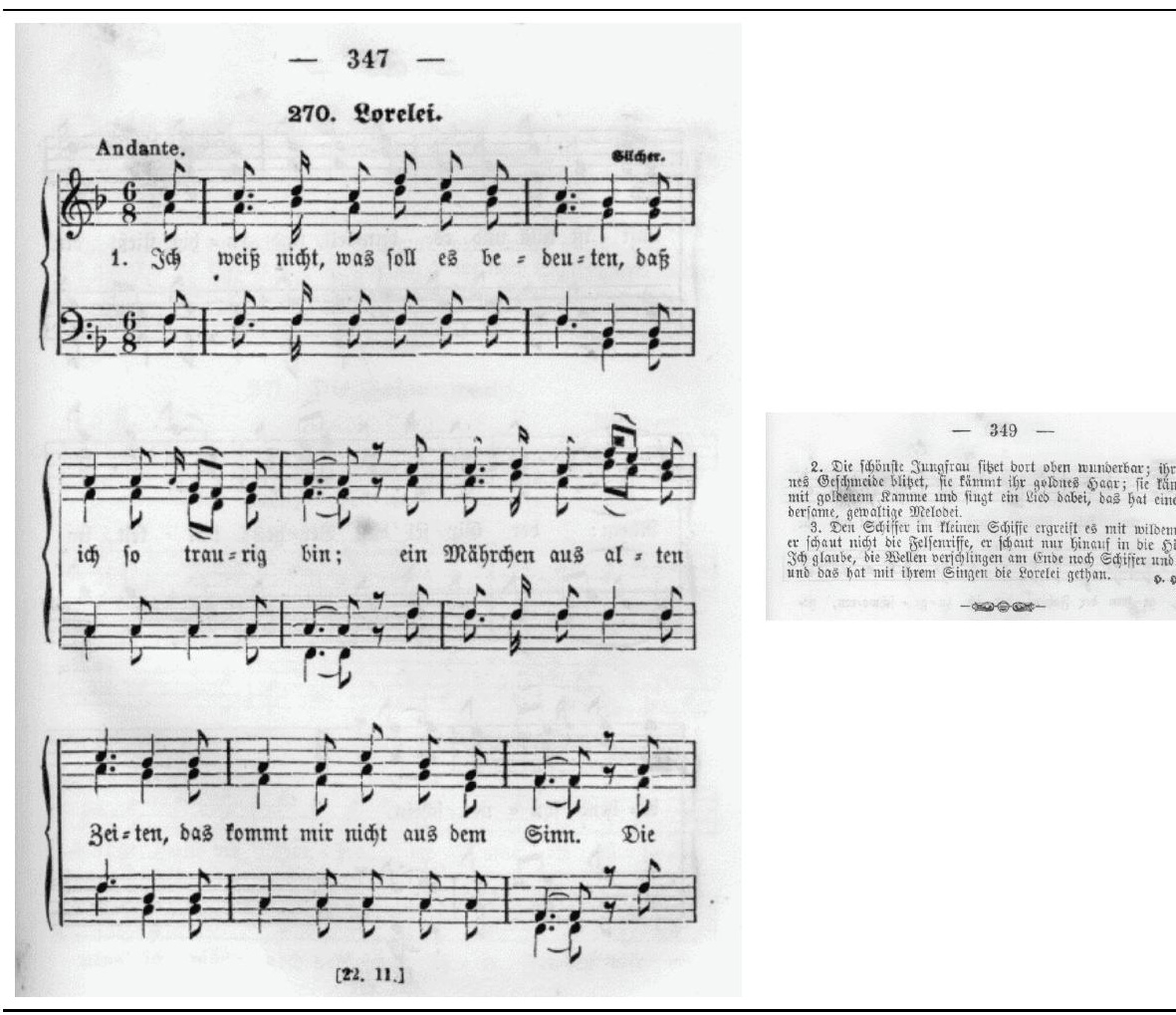

Übung 1: Geografie Wortschatz

An interactive H5P element has been excluded from this version of the text. You can view it online here:

https://openeducationalberta.ca/willkommen-

deutsch $/ ? p=6213 \# h 5 p-155$ 
Die Loreley. Lesen Sie das Gedicht "Die Loreley" (1824) von Heinrich Heine (1797-1856).

Ich weiß nicht, was soll es bedeuten,

dass ich so traurig bin;

ein Märchen aus alten Zeiten, das kommt mir nicht aus dem

Sinn.

Die Luft ist kühl und es dunkelt, und ruhig fließt der Rhein; der Gipfel des Berges funkelt im Abendsonnenschein.

Die schönste Jungfrau sitzet dort oben wunderbar; ihr goldnes Geschmeide blitzet, sie kämmt ihr goldenes Haar.
Sie kämmt es mit goldenem

Kamme

und singt ein Lied dabei; das hat eine wundersame, gewaltige Melodei.

Den Schiffer im kleinen Schiffe ergreift es mit wildem Weh; er schaut nicht die Felsenriffe, er schaut nur hinauf in die Höh.

Ich glaube, die Wellen verschlingen am Ende Schiffer und Kahn; und das hat mit ihrem Singen die Lore-Ley getan.

\section{ก}

Die Loreley. Hören Sie die Loreley als Gedicht und als Lied. (Text: Heinrich Heine, 1824; Melodie: Friedrich Silcher, 1837)

Loreley, das Gedicht wird vorgelesen

Lorelei, gesungen von Richard Tauber (1939)

Loreley, gesungen von den Fischer-Chören

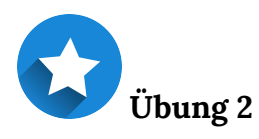

固

An interactive H5P element has been excluded from this version of the text. You can view it online here: 
https://openeducationalberta.ca/willkommen-

deutsch $/ ? p=6213 \# h 5 p-213$

Wortschatz in Quizlet:

Geografie

Was wissen Sie jetzt? Klicken Sie hier für Quiz 6.8.

\section{Media Attributions}

- Lorelei1 @ Friedrich Silcher and Heinrich Heine is licensed under a Public Domain license

- Lorelei3 (C) Friedrich Silcher and Heinrich Heine is licensed under a Public Domain license

- star (C) IO-Images is licensed under a Public Domain license

- book (C) IO-Images is licensed under a Public Domain license

- headphones (C) IO-Images is licensed under a Public Domain license

- link (C) IO-Images is licensed under a Public Domain license

- check mark (C janjf93 adapted by Solomon Hajramezan is licensed under a Public Domain license 


\section{Einheit 6.9}

ก

Die Loreley. Hören Sie die Loreley als Lied. (Text: Heinrich Heine, 1824; Melodie: Friedrich Silcher, 1837)

Loreley, gesungen vom Vokalensemble Rhein-Lahn

Die Loreley. Lesen Sie das Gedicht "Die Loreley" (1824) von Heinrich Heine (1797-1856).

Ich weiß nicht, was soll es bedeuten, dass ich so traurig bin; ein Märchen aus alten Zeiten, das kommt mir nicht aus dem Sinn.

Die Luft ist kühl und es dunkelt, und ruhig fließt der Rhein; der Gipfel des Berges funkelt im Abendsonnenschein.

Die schönste Jungfrau sitzet dort oben wunderbar; ihr goldnes Geschmeide blitzet, sie kämmt ihr goldenes Haar.
Sie kämmt es mit goldenem Kamme und singt ein Lied dabei; das hat eine wundersame, gewaltige Melodei.

Den Schiffer im kleinen Schiffe ergreift es mit wildem Weh; er schaut nicht die Felsenriffe, er schaut nur hinauf in die Höh.

Ich glaube, die Wellen verschlingen am Ende Schiffer und Kahn; und das hat mit ihrem Singen die Lore-Ley getan.

\section{$\varepsilon$}

Fragen zum Gedicht. Arbeiten Sie mit einer Partnerin oder mit einem Partner und beantworten Sie die folgenden Fragen.

1. Wann findet die Geschichte statt? Zu welcher Tageszeit?

2. Beschreiben Sie die Natur.

3. Was macht Loreley?

4. Was macht der Schiffer? Wie fühlt er sich?

5. Wie endet die Geschichte?

6. Kennen Sie ähnliche Geschichten? 
200

Wer ist in Europa schon mit dem Zug gefahren?

안?

Mit dem Zug fahren

An interactive H5P element has been excluded from this version of the text. You can view it online here:

https://openeducationalberta.ca/willkommen-

deutsch/?p=202\#h5p-159

Media Attributions

- headphones (C) IO-Images is licensed under a Public Domain license

- book (C) IO-Images is licensed under a Public Domain license

- partner (C) IO-Images is licensed under a Public Domain license

- group (C) IO-Images is licensed under a Public Domain license

- presentation icon (C) quinntheislander adapted by Solomon Hajramezan is licensed under a Public Domain license 


\section{Einheit 6.10 (online)}
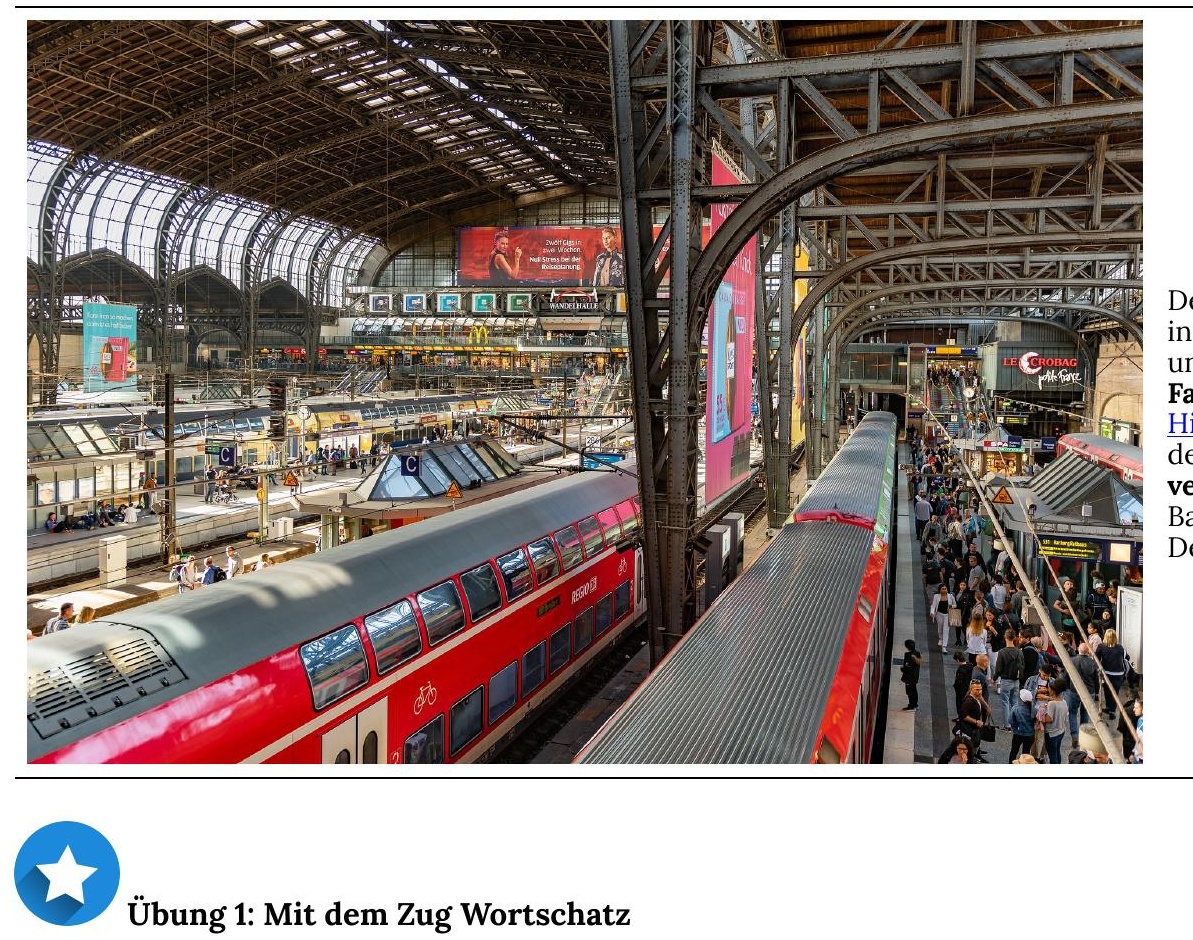

An interactive H5P element has been excluded from this
version of the text. You can view it online here:
https://openeducationalberta.ca/willkommen-
deutsch/?p=204\#h5p-214

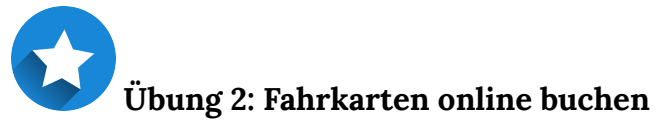


An interactive H5P element has been excluded from this version of the text. You can view it online here:

https://openeducationalberta.ca/willkommendeutsch/?p=204\#h5p-264

Katelyns Reise-Blog. Lesen Sie den Text. Katelyn ist eine Austauschstudentin aus Edmonton. Sie hat im Sommer einen Deutschkurs an der Kanadischen Sommerschule in Kassel gemacht. Danach ist sie in Deutschland herumgereist. In ihrem Reise-Blog schreibt sie über einen Ausflug zur Loreley. 


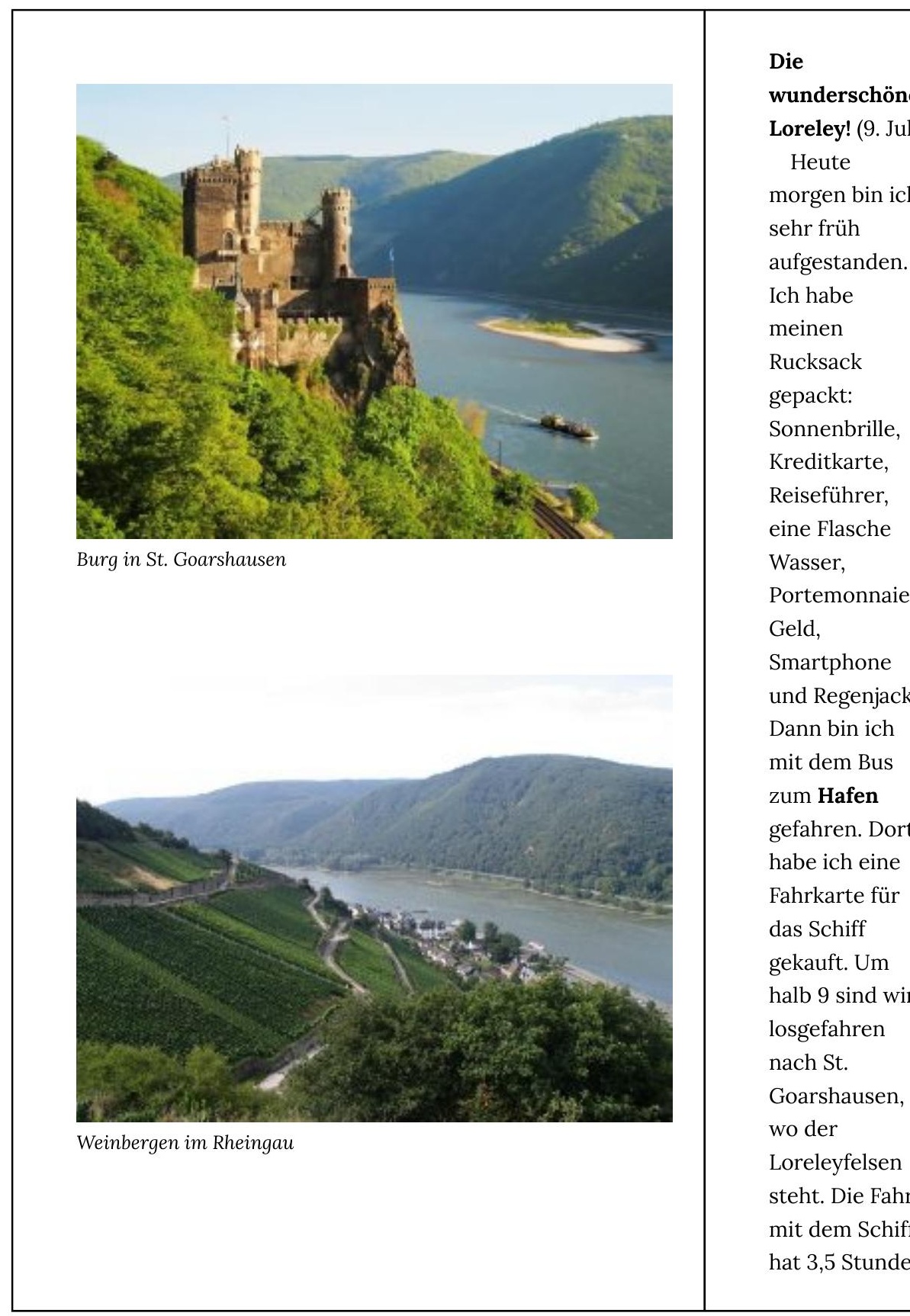


gedauert; das war länger, als ich gedacht hatte. Wir sinc zuerst an

Wiesbaden vorbeigefahre das ist die Hauptstadt vo Hessen. Dann haben wir auf der rechten Rheinseite der Rheingau mit ganz vielen Weinbergen gesehen, eine sehr gute Weinregion! Zwischen der Stadt Bingen und St.

Goarshausen haben wir viel Burgen und Ruinen auf des Hügeln am Uf gesehen, es w: unglaublich! 


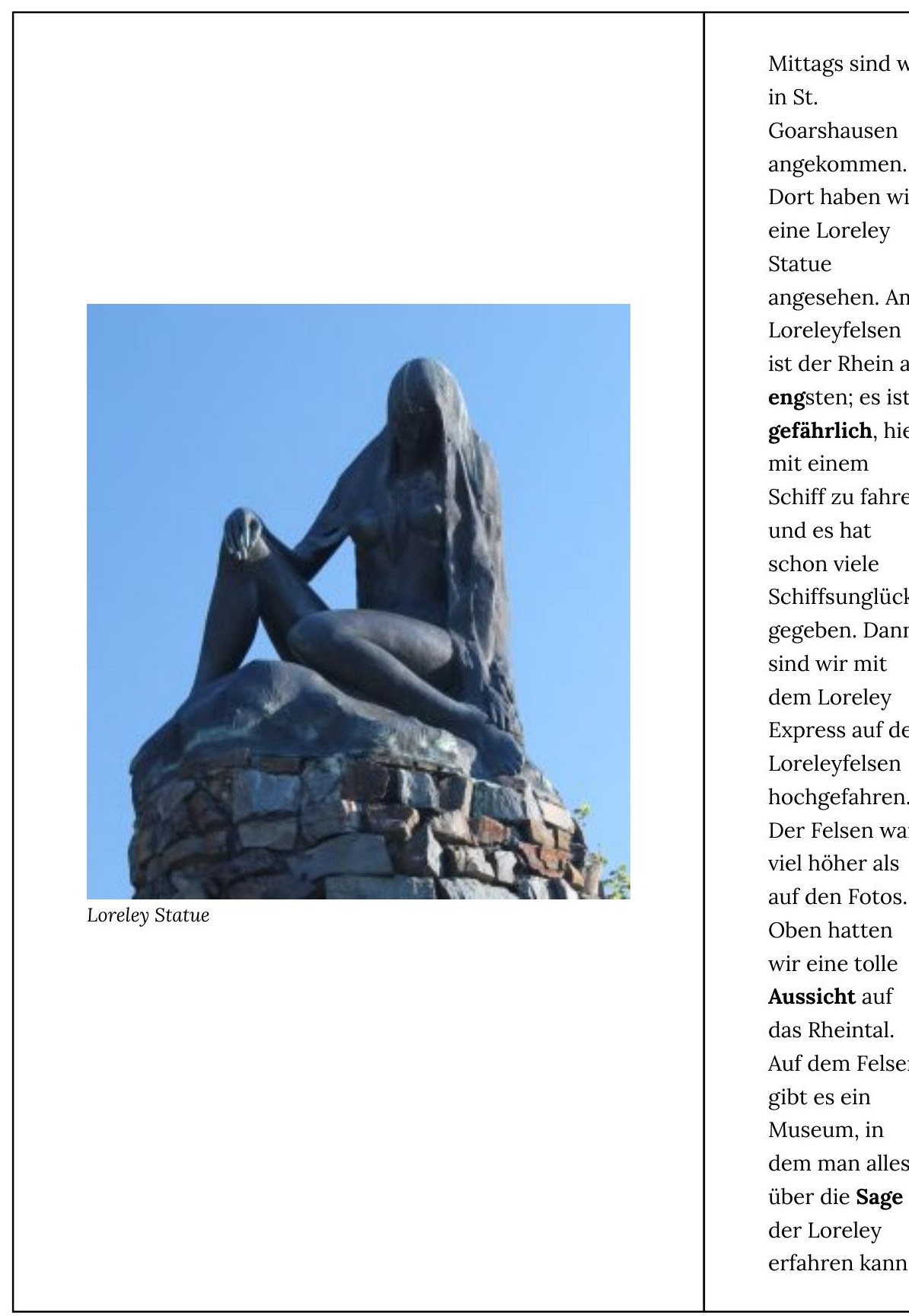




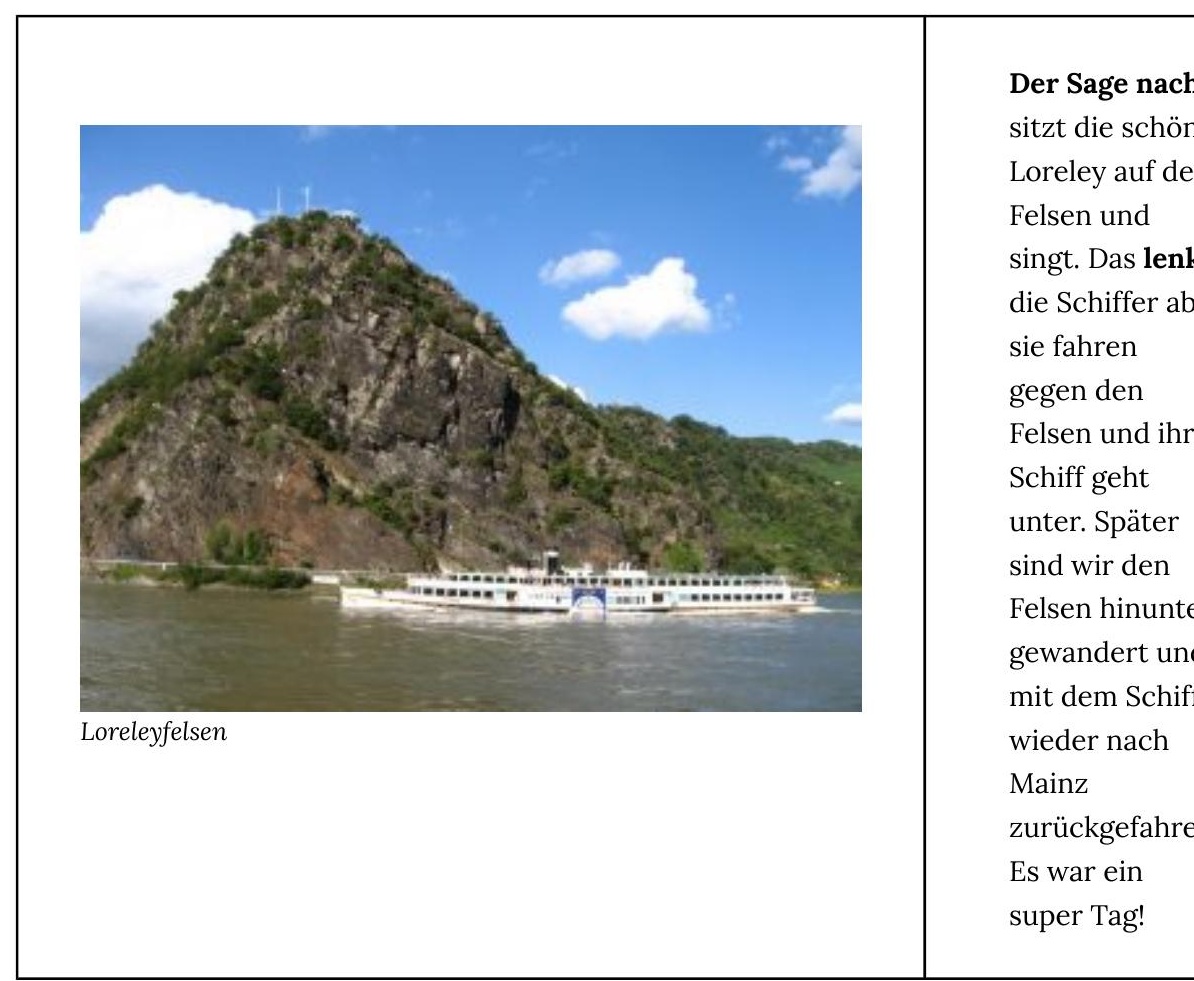

Übung 3: Fragen zu Katelyns Reise-Blog

An interactive H5P element has been excluded from this version of the text. You can view it online here:

https://openeducationalberta.ca/willkommendeutsch/?p=204\#h5p-215

Nicos Weg Videoserie. Sehen Sie sich das Video über 
Bahnreisen an und machen Sie Übungen 1 - 7. Sie können alle Übungen machen, aber Sie müssen nicht.

8

Wortschatz in Quizlet:

Mit dem Zug fahren

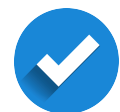

Was wissen Sie jetzt? Das Quiz ist in der nächsten Unterrichtsstunde.

\section{Media Attributions}

- railway-station-4170704_1920 (C) Kookay is licensed under a Public Domain license

- star (C) IO-Images is licensed under a Public Domain license

- book (C) IO-Images is licensed under a Public Domain license

- $\underline{\text { Rheinstein }(C) \text { Manfred Heyde is licensed under a CC BY-SA }}$ (Attribution ShareAlike) license

- Assmannshausen_Hoellenberg (C) Luidger is licensed under a CC BY-SA (Attribution ShareAlike) license

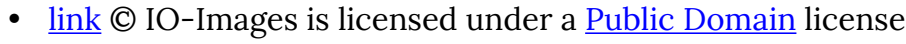

- check mark (C) janjf93 adapted by Solomon Hajramezan is licensed under a Public Domain license 


\section{Einheit 6.11}

2

Eine Reise planen. Schauen Sie sich die Fahrkarte für eine Zugfahrt von Mainz nach Konstanz an. Beantworten Sie die Fragen mit einer Partnerin oder mit einem Partner.

Was kostet die Fahrkarte?

- Hinfahrt:

Wann fährt der Zug in Mainz ab?

Wann kommt der Zug in Konstanz an?

Wie oft muss man umsteigen?

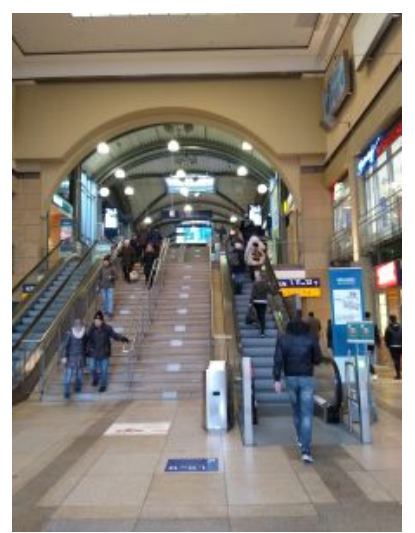

- Rückfahrt:

In welcher Stadt muss man umsteigen?

Wie lange ist der Aufenthalt?

Auf welchem Gleis kommt der Zug in Mainz an?

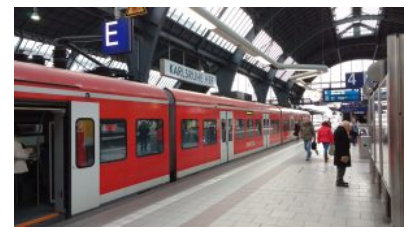

\section{(n) 自}

Dialog am Fahrkartenschalter. Hören Sie den Dialog. Was ist richtig oder falsch? 


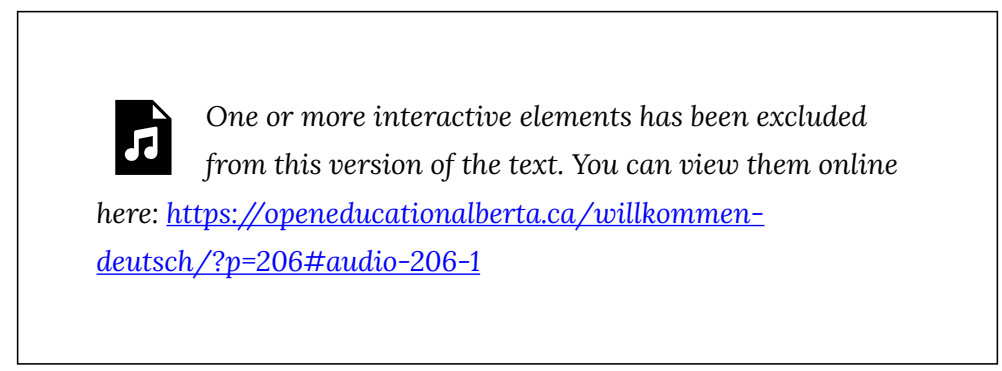

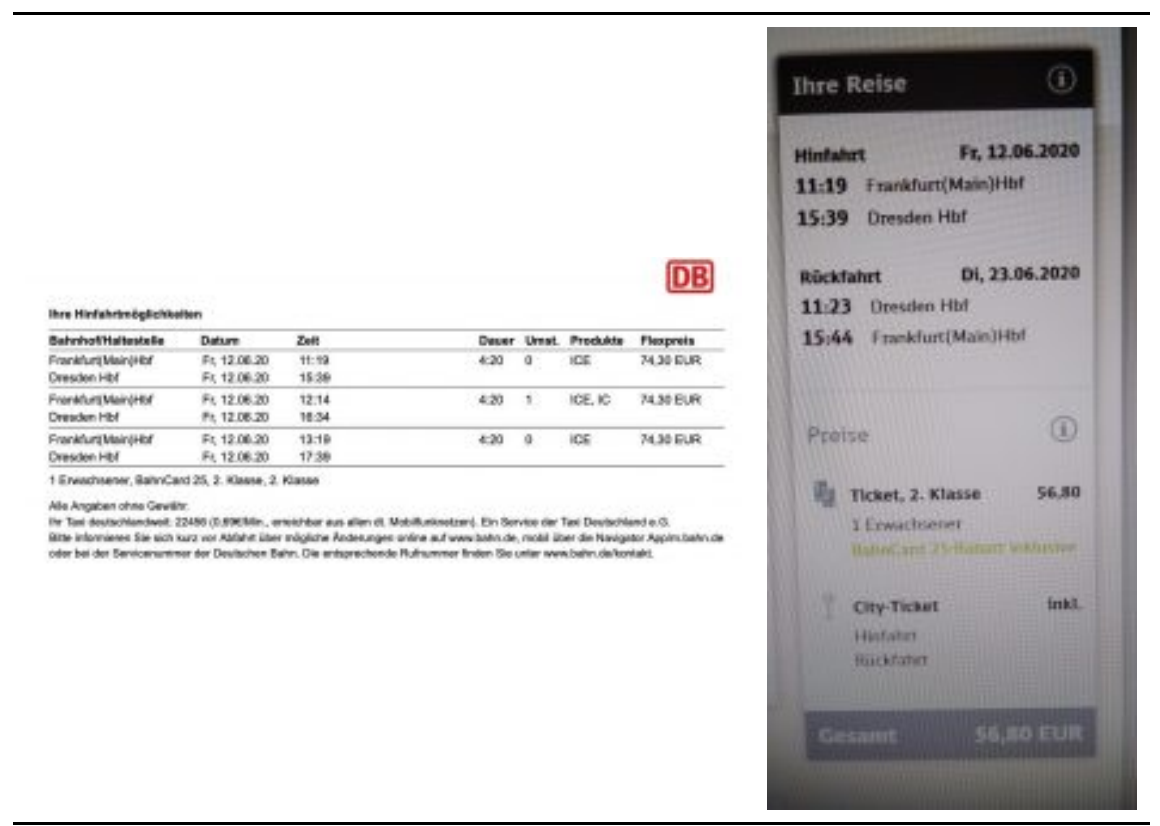

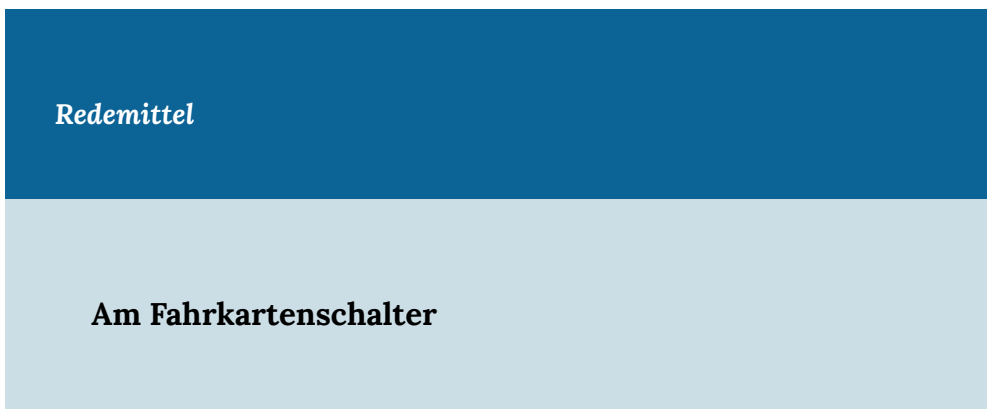


die/der Angestellte:

- Hin und zurück oder einfach?

- $\quad$ Sie kommen um ... in ... an.

- $\quad$ Abfahrt in ... ist um ... Uhr.

- Haben Sie eine BahnCard?

- Zahlen Sie bar oder mit Kreditkarte?

- $\quad$ Soll ich einen Sitzplatz reservieren?

- $\quad$ Soll ich die Verbindung ausdrucken?

- $\quad$ Gute Reise! die Kundin/der Kunde:

- Ich hätte gern eine Fahrkarte nach...

- Hinfahrt am...

- $\quad$ Rückfahrt am...

- Wann fährt der Zug $a b$ ?

- Wann kommt der Zug in ... an?

- $\quad$ Muss ich umsteigen?

- Von welchem Gleis fährt der Zug ab?

- Was kostet die Fahrkarte?

\section{Media Attributions}

- partner (C) IO-Images is licensed under a Public Domain license

- Mainz Hauptbahnhof Eingangshalle (C) ckost is licensed under a Public Domain license

- Karlsruhe Hbf 1 C ckost is licensed under a Public Domain license

- headphones (C) IO-Images is licensed under a Public Domain license

- document (C) IO-Images is licensed under a Public Domain license

- Frankfurt - Dresden is licensed under a Public Domain license 


\section{Einheit 6.12 (online)}
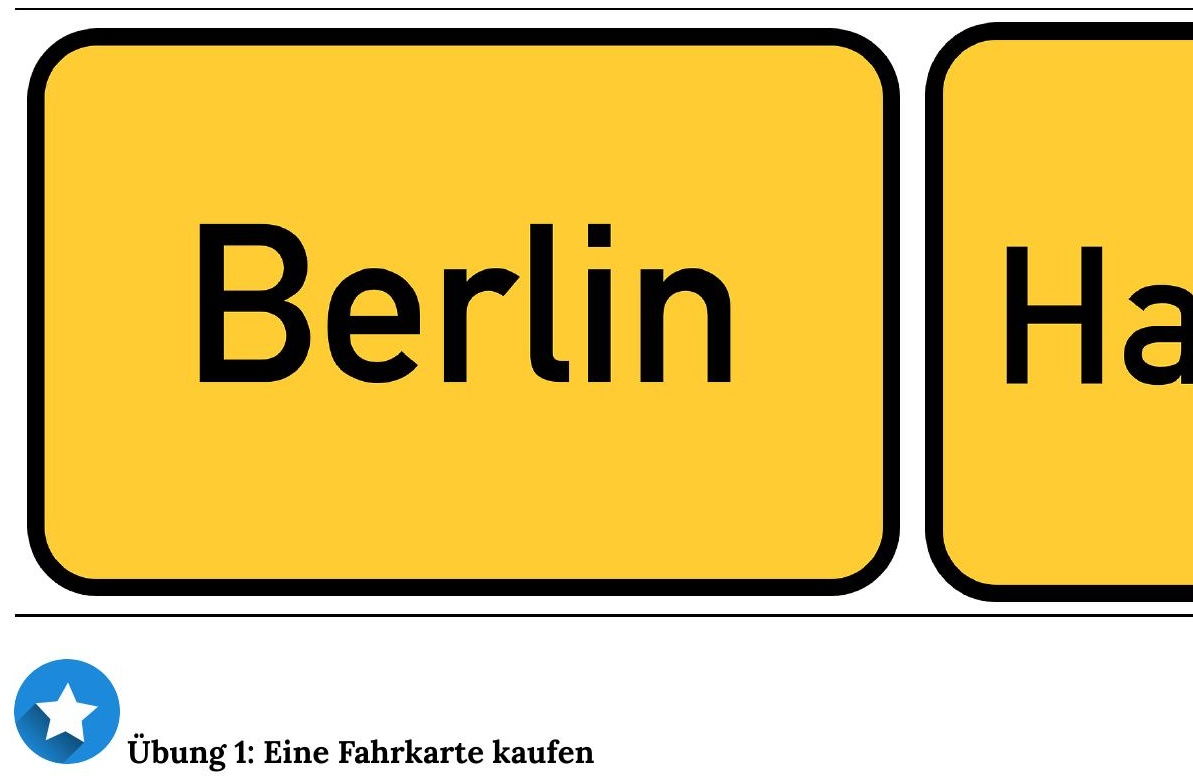

An interactive H5P element has been excluded from this
version of the text. You can view it online here:
$\underline{\text { https://openeducationalberta.ca/willkommen- }}$
$\underline{\text { deutsch/?p=208\#h5p-161 }}$

\section{Grammatik}


We have seen many prepositions throughout the etextbook and over the next few units we will learn more about them. In German, prepositions are always followed by a certain case. For example, in Einheit 5.8 you learned that mit, $z u$, bei, etc. are always followed by the dative case. Today we are focusing on the prepositions followed by the accusative case.

- durch (through) - Das Auto fährt durch den Tunnel.

- $\quad$ für (for) - Ich habe eine Fahrkarte für das Schiff gekauft.

- gegen (against) - Die Schiffer fahren gegen den Felsen.

- ohne (without) - Ich reise nie ohne meinen Reisepass.

- $\quad$ um (around) - Um die Ecke ist ein schönes Café.

If you remember the acronym FUDOG (für, um, durch, ohne, gegen) you will always remember the accusative prepositions!!

Or, if you're musically inclined ? you can sing the prepositions along with the "Happy Birthday" song (in the order from above: durch, für, gegen, ohne, um)!

*ACHTUNG* The prepositions gegen and um can also refer to time. The meaning of the prepositions then changes.

- $\quad$ gegen (around) - Kann ich gegen 14 Uhr fahren?

- um (at) - Ja, Sie können um 14:07 Uhr abfahren. 


\section{Übung 2}

An interactive H5P element has been excluded from this version of the text. You can view it online here:

https://openeducationalberta.ca/willkommen-

deutsch/?p=208\#h5p-318

Planen Sie eine Reise. Wählen Sie zwei Städte in Deutschland aus: Sie möchten von der einen Stadt in die andere Stadt fahren. Gehen Sie zur Fernbus Suchmaschine (www.busliniensuche.de) und suchen Sie die Verbindung, die am besten für Sie ist. Es gibt auf dieser Webseite Angebote für Fernbusse, Züge und Mitfahrgelegenheiten mit dem Auto.

Notieren Sie: Abfahrtszeiten, Preis, Transportmittel, etc. und schreiben Sie, warum Sie diese Verbindung gewählt haben. Sie brauchen diese Informationen für das Quiz.

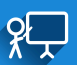

Im Hotel Wortschatz. Arbeiten Sie die Präsentation durch und lernen Sie die neuen Vokabeln.

An interactive H5P element has been excluded from this version of the text. You can view it online here: 
https://openeducationalberta.ca/willkommen-

deutsch/?p=208\#h5p-160

\section{Wortschatz in Quizlet:}

Redemittel: Am Fahrkartenschalter

Im Hotel

Sonstige Wörter und Ausdrücke

Was wissen Sie jetzt? Klicken Sie hier für Quiz 6.12.

\section{Media Attributions}

- berlin-790677 1280 (C) Taken is licensed under a Public Domain license

- hamburg-794170_1280 (C) Taken is licensed under a Public Domain license

- star (C) IO-Images is licensed under a Public Domain license

- magnifying-glass (C) IO-Images is licensed under a Public Domain license

- presentation icon (C) quinntheislander adapted by Solomon Hajramezan is licensed under a Public Domain license

- link (C) IO-Images is licensed under a Public Domain license

- check mark (C janjf93 adapted by Solomon Hajramezan is licensed under a Public Domain license 


\section{Einheit 6.13}

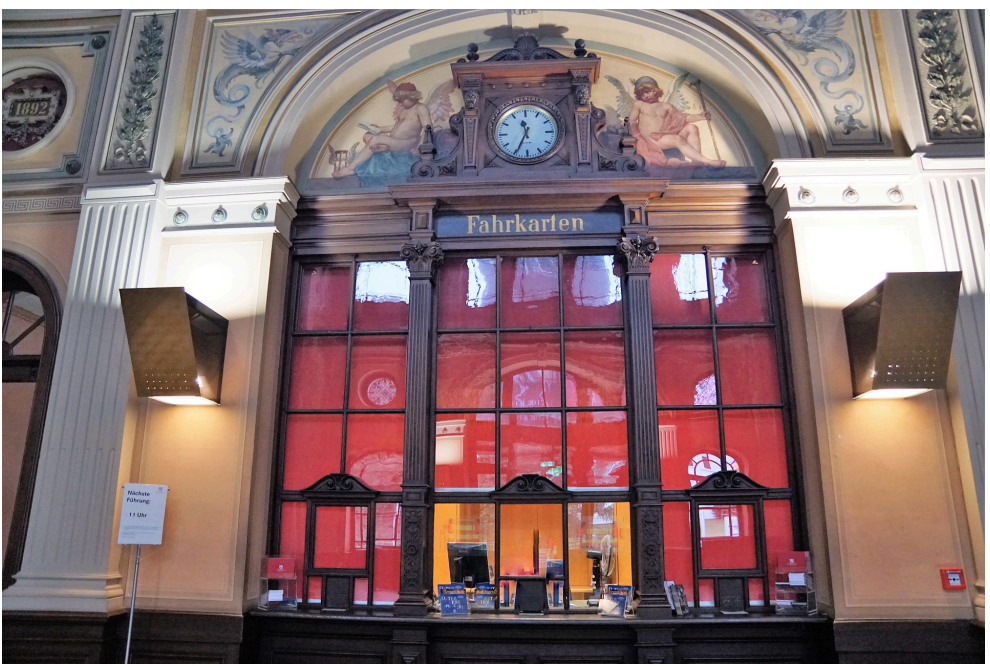

$\Omega$

Rollenspiel: Am Fahrkartenschalter. Arbeiten Sie mit einer Partnerin oder mit einem Partner. Eine Person möchte eine Fahrkarte von Frankfurt nach Weimar kaufen, die andere Person ist die/der Angestellte bei der Deutschen Bahn. Machen Sie einen Dialog und benutzen Sie die Redemittel aus Einheit 6.11. Hier sind die Informationen.

Redemittel (aus Einheit 6.11)

Am Fahrkartenschalter 
die/der Angestellte:

- $\quad$ Hin und zurück oder einfach?

- $\quad$ Sie kommen um ... in ... an.

- $\quad$ Abfahrt in ... ist um ... Uhr.

- Haben Sie eine BahnCard?

- Zahlen Sie bar oder mit Kreditkarte?

- $\quad$ Soll ich einen Sitzplatz reservieren?

- $\quad$ Soll ich die Verbindung ausdrucken?

- $\quad$ Gute Reise! die Kundin/der Kunde:

- Ich hätte gern eine Fahrkarte nach...

- Hinfahrt am...

- $\quad$ Rückfahrt am...

- Wann fährt der Zug $a b$ ?

- Wann kommt der Zug in ... an?

- $\quad$ Muss ich umsteigen?

- Von welchem Gleis fährt der Zug ab?

- Was kostet die Fahrkarte?

Was haben Sie schon gelernt?

固

An interactive $\mathrm{H} 5 \mathrm{P}$ element has been excluded from this version of the text. You can view it online here:

https://openeducationalberta.ca/willkommendeutsch/?p=3029\#h5p-218 


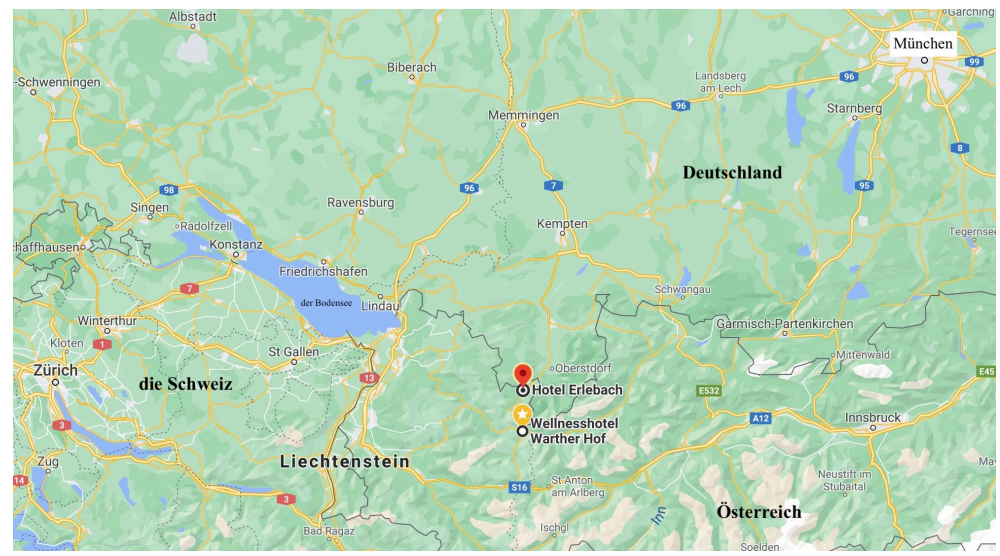

Wellness Hotels in Österreich. Lesen Sie die Texte in Kleingruppen. Diskutieren Sie dann: Welches Hotel möchten Sie buchen? Warum? Nennen Sie drei Gründe. 


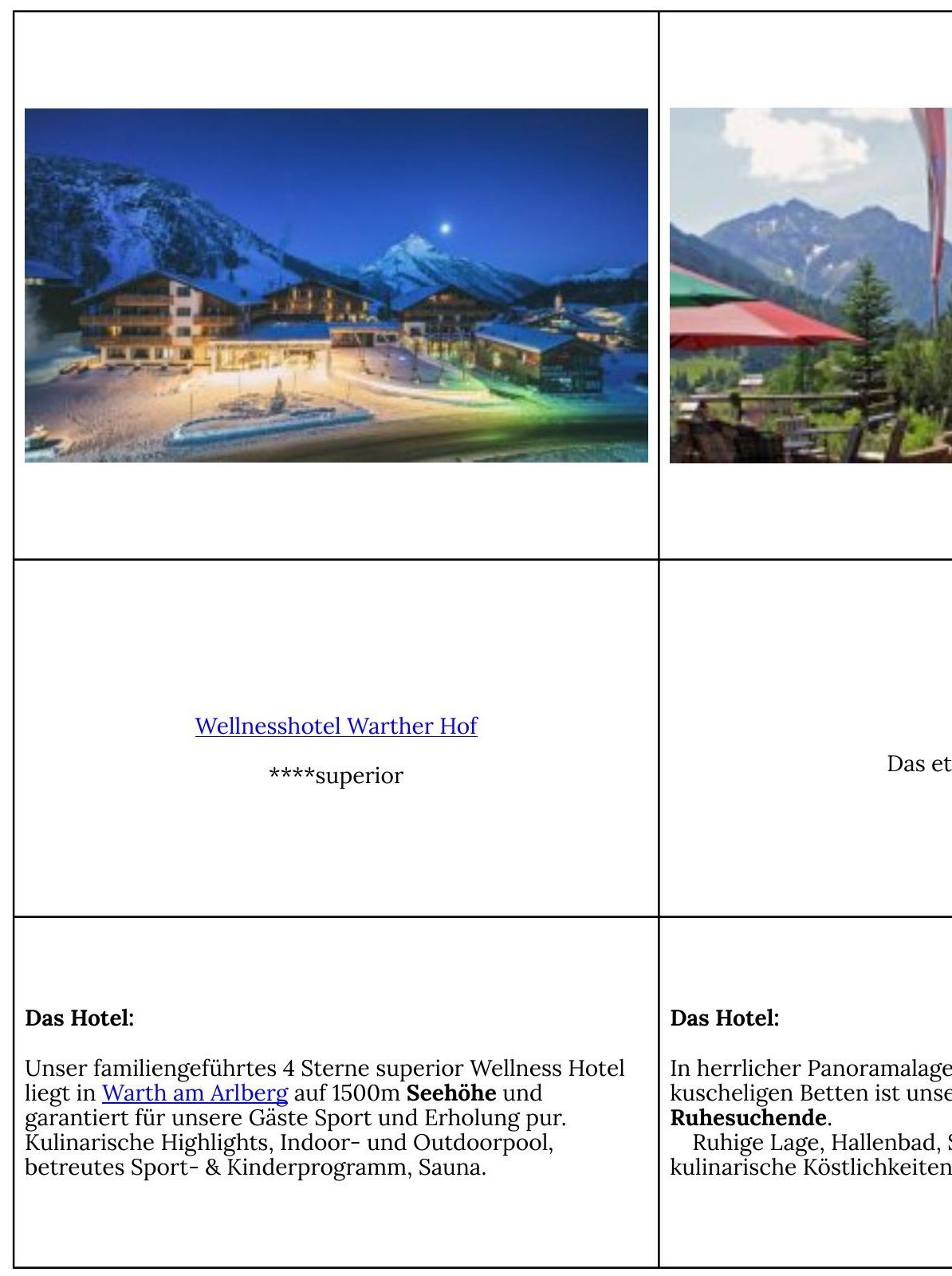




\section{Die Zimmer:}

In unseren 72 modern ausgestatteten Zimmern und Suiten haben Sie einen beeindruckenden Ausblick auf die schönsten Berge in der Umgebung. Alle Zimmer haben Telefon, Kabel TV, Safe, Dusche, WC, Haarföhn, WLAN.
Die Zimmer:

Von allen unseren 40 Zimm Blick auf die Berge des Klei Kosmetikspiegel, WLAN, Fe

\section{Wellnesshotel Serviceleistungen:}

Kinderclub, Fitnessraum, Sportprogramm mit Wassergymnastik, Nordic Walking und Yoga, Reiten, Golf, Skifahren, Langlauf, Massage, Musik und Tanz an der Hotelbar

Wellnesshotel Serviceleist

Wandern, Nordic Walking, Skifahren, Langlauf, Dampf

\section{Media Attributions}

- partner (C) IO-Images is licensed under a Public Domain license

- group (C) IO-Images is licensed under a Public Domain license

- Österreich (C) csawatzky is licensed under a Public Domain license

- book (C) IO-Images is licensed under a Public Domain license

- hotel-erlebach_gr is licensed under a CC BY-SA (Attribution ShareAlike) license 


\section{Einheit 6.14 (online)}

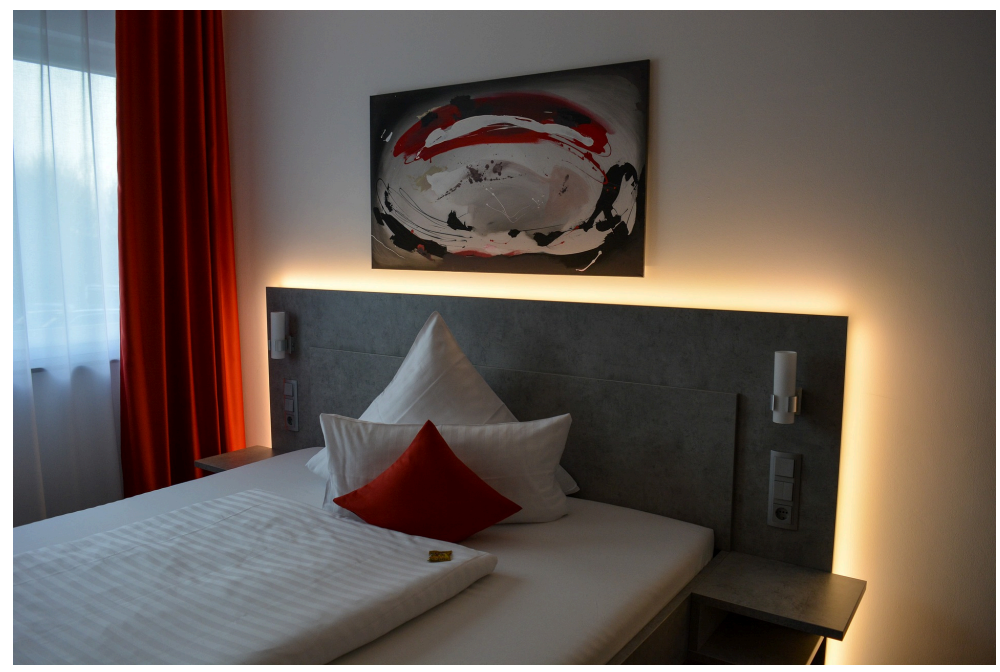

\section{Übung 1}

An interactive H5P element has been excluded from this

믓 version of the text. You can view it online here:

https://openeducationalberta.ca/willkommen-

deutsch/?p=3031\#h5p-216

Nicos Weg Videoserie. Sehen Sie sich das Video "Im Hotel" an und machen Sie Übungen 1 - 4. Sie können alle Übungen machen, aber Sie müssen nicht. 
Was wissen Sie jetzt? Klicken Sie hier für Quiz 6.14.

\section{卌}

\section{Task 6: Urlaub im Wellness Hotel}

You have been working in München and finally have a few days off. You want to spend a weekend in a wellness hotel in Austria. Use the description of the two wellness hotels in Einheit 6.13, the guiding questions and the information in the table below. Work together with a partner: discuss your options and come to some decisions.

- In welches Wellness Hotel möchten Sie fahren? Warum?

- Fahren Sie mit dem Zug, mit dem Bus oder mit dem Auto? Diskutieren Sie die Vorteile und Nachteile von jedem Verkehrsmittel.

\begin{tabular}{|l|l|l|l|}
\hline & Zug & Reisebus & Auto \\
\hline Preis & $\begin{array}{l}\text { 29 Euro + 4,50 } \\
\text { Euro }\end{array}$ & 33 Euro + 6,50 Euro & $\begin{array}{l}\text { 90 Euro } \\
\text { (inklusive } \\
\text { Benzin, usw.) }\end{array}$ \\
\hline Zeit & $\begin{array}{l}5 \text { Stunden } 15 \\
\text { Minuten }\end{array}$ & $\begin{array}{l}\text { 6 Stunden 37 } \\
\text { Minuten }\end{array}$ & $\begin{array}{l}\text { 4 Stunden 20 } \\
\text { Minuten }\end{array}$ \\
\hline Entfernung & $408 \mathrm{~km}$ & $456 \mathrm{~km}$ & $430 \mathrm{~km}$ \\
\hline $\begin{array}{l}\mathbf{C O}_{2} \\
\text { Ausstoß }\end{array}$ & $24,0 \mathrm{~kg}$ & $18,7 \mathrm{~kg}$ & $89,2 \mathrm{~kg}$ \\
\hline Sonstiges & $\begin{array}{l}\text { 1x umsteigen mit } \\
\text { dem Zug; 10 } \\
\text { Minuten Busfahrt } \\
\text { vom Bahnhof zum } \\
\text { Hotel }\end{array}$ & $\begin{array}{l}30 \text { Minuten } \\
\text { Busfahrt vom } \\
\text { Reisebus-Bahnhof } \\
\text { zum Hotel }\end{array}$ & $\begin{array}{l}\text { direkt, keine } \\
\text { extra Busfahrt, } \\
\text { Preis ist nicht } \\
\text { pro Person }\end{array}$ \\
\hline
\end{tabular}

Use the "Redemittel", vocabulary and structures that you have learned in this unit. Be creative and add more information for your 
reasons than what is in the chart. Record your conversation (ca. 3 minutes) as an audio or video.

This task will be assessed according to the Rubric for Task 6 .

Extra Practice (optional):

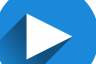

Video Serie - Easy German (Im Hotel). Sehen Sie das Video an.

\section{Media Attributions}

- bedroom-3185433_1920 (C) tomasines is licensed under a Public Domain license

- star (C) IO-Images is licensed under a Public Domain license

- play (C) IO-Images is licensed under a Public Domain license

- check mark (C) janjf93 adapted by Solomon Hajramezan is licensed under a Public Domain license

- keyboard (C) IO-Images is licensed under a Public Domain license 


\section{Wortschatz}

Quizlet:

Wortschatz Einheit 6 (alle Kategorien)

Auf einer Reise (6.2)

Auf einer Reise

Transport

Transportmittel (plurals)

Geografie

Mit dem Zug fahren

Redemittel: Am Fahrkartenschalter

Im Hotel

Adjektive

$\underline{\text { Sonstige Wörter und Ausdrücke }}$

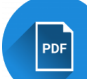

Wortschatz 6

Media Attributions

- $\underline{\text { link }}$ (C) IO-Images is licensed under a Public Domain license

- pdf (C IO-Images is licensed under a Public Domain license 


\section{Zum Spaß!}

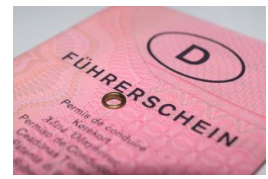

Das Auto! This was maybe one word you knew before you even started learning German, but what do you know about the "Autobahn" and driving in Germany? Here is a video all about cars and more.

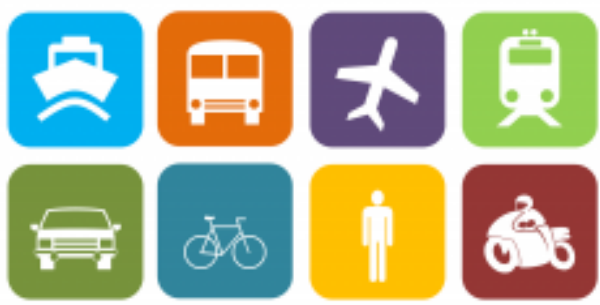

This chapter we learned about "Transportmittel". Are you curious about the favourite modes of transportation from people in Berlin? Watch this video.

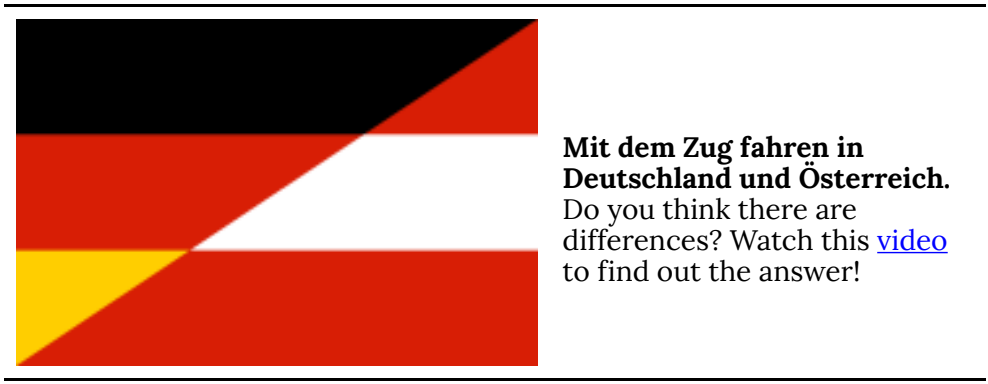




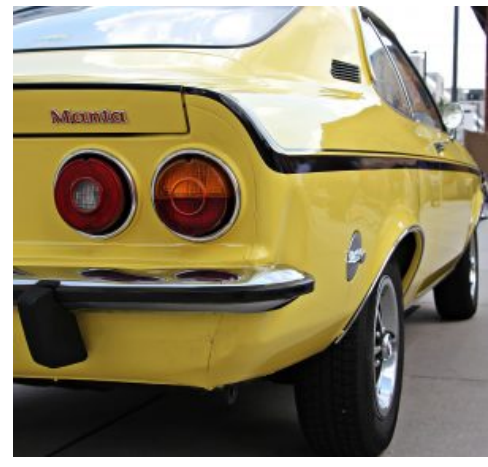

Check out the song "Mein

Fahrrad" by the German band Die

Prinzen. The band is made up of former members of the Thomanerchor (the choir of the Thomaskirche in Leipzig).

Their songs are often sung a cappella. The lyrics of their songs are often humorous, tongue-incheek critiques of German government or society. Watch the video here. Here are the lyrics if you want to read along or even sing along!

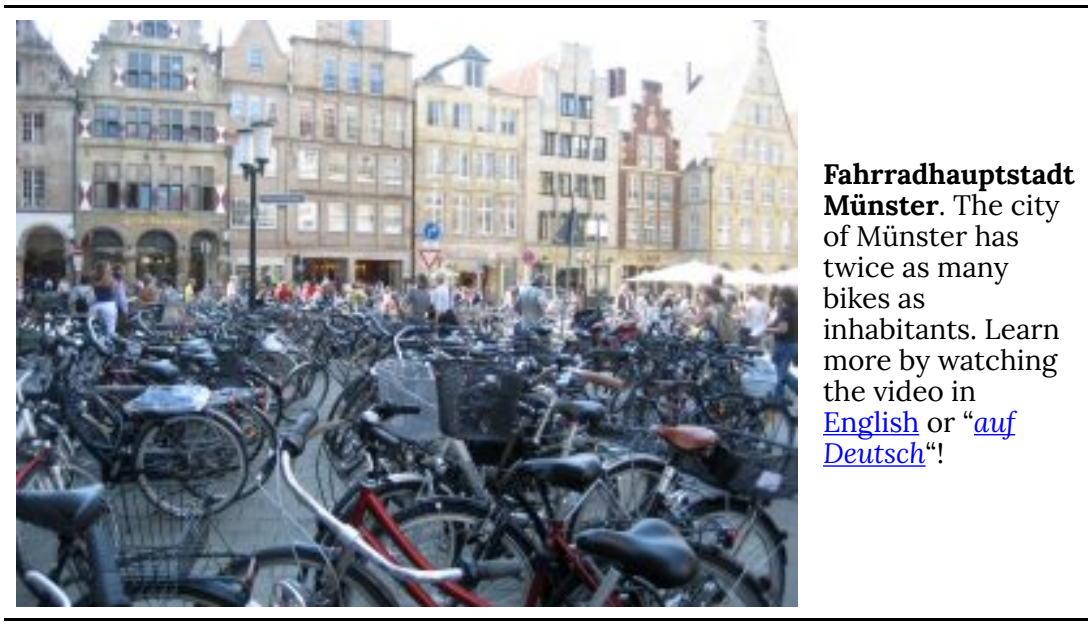


In Einheit 4

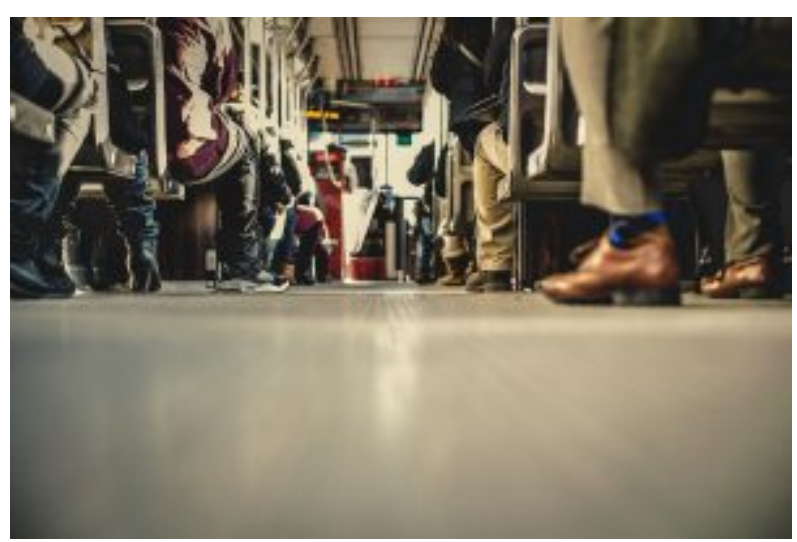

we were

introduced to

Nevin from a

video series

called "Erste

Wege in

Deutschland"

from the

Goethe

Institute. In

this

episode, Nevin

takes the bus

alone in

Germany for

the first time.

There are

activities to

go along with

the videos.

Extra Practice (optional): These activities are from the website

Schubert-Verlag.

Was nehmen Sie in den Urlaub mit?

Transportmittel I

Transportmittel II

Transportmittel (Hören)

Komparativ

Komparativ \& Superlativ

Urlaubspläne (Hören)

Reisen

Sascha macht Urlaub (Hören)

Eine Karte aus München (Perfekt)

Eine Postkarte aus dem Urlaub

An der Hotelrezeption (Hören) 


\section{Media Attributions}

- drivers-license-2534805_1920 @ Steffen L. is licensed under a Public Domain license

- transportation-3685043_1920 (C) Tumisu is licensed under a Public Domain license

- 200px-Flag_of_Germany_and_Austria.svg (C) Richie is licensed under a Public Domain license

- manta-1580282_1920 C S. Hermann \& F. Richter is licensed under a Public Domain license

- Münster (C) csawatzky is licensed under a CC BY-NC-SA (Attribution NonCommercial ShareAlike) license

- bus (C) Free-Photos is licensed under a Public Domain license 


\section{EINHEIT 7: EINE STADT KENNENLERNEN}

Learning Outcomes

At the end of Einheit 7, you will be able to...

- $\quad$ identify and describe some sights in the German city of Kassel

- $\quad$ ask for and give directions

- $\quad$ identify and describe some features of UNESCO world heritage sites, in particular the Bergpark Wilhelmshöhe in Kassel

- $\quad$ plan a trip to a city

- research sights and places to stay

- plan activities

- discuss some aspects of the life and work of the Brüder Grimm

- talk about an intensive summer language course (offered through the Canadian Summer School in Germany=CSSG) and the experiences of former participants

You will also have learned about the following structures:

- $\quad$ prepositions for giving directions

- $\quad$ perfect tense (review) 
- $\quad$ simple past tense of "haben" and "sein" (review)

- English "to": German "nach" vs. "in" 


\section{Einheit 7.1}

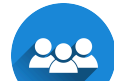

\section{Welche Städte kennen Sie in Deutschland?}

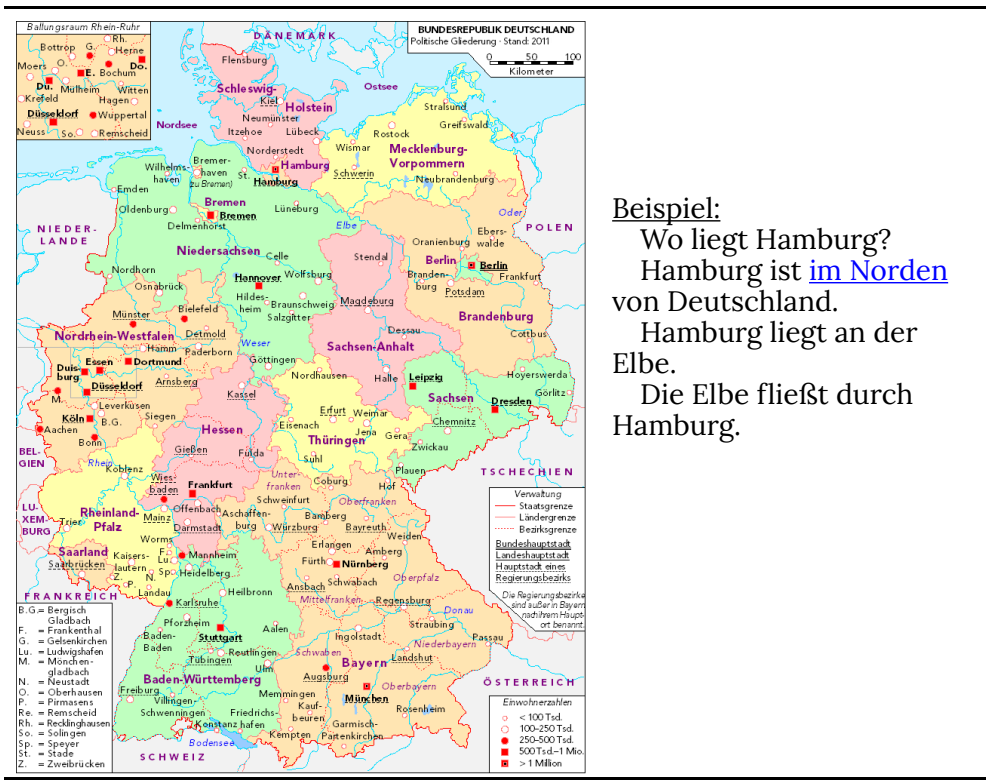

\section{0}

Wo liegt Kassel? Welterbe in Deutschland

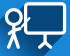

\section{Sehenswürdigkeiten}

An interactive H5P element has been excluded from this version of the text. You can view it online here: 
https://openeducationalberta.ca/willkommen-

deutsch/?p=210\#h5p-163

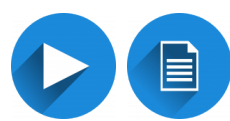

Kassel: Welterbe-Stadt und Kunstmekka. Sehen

Sie das Video über Kassel an und notieren Sie, über welche Sehenswürdigkeiten gesprochen wird.

$\square$ der Bergpark Wilhelmshöhe
$\square$ das Schloss Sanssouci
$\square$ das Brüder Grimm-Museum
$\square$ die Fußgängerzone
$\square$ das Goethe- und Schiller-Denkmal
$\square$ die Orangerie

$\square$ das Deutsche

Nationaltheater

$\square$ die Herkules-Statue

$\square$ die Karlsaue

$\square$ das Bauhausmuseum

$\square$ das Staatstheater

$\square$ die Wasserspiele

\section{Media Attributions}

- group (C) IO-Images is licensed under a Public Domain license

- Deutschland_politisch_bunt (C) Korny78 is licensed under a $\underline{\mathrm{CC}}$ BY-SA (Attribution ShareAlike) license

- presentation icon (C) quinntheislander adapted by Solomon Hajramezan is licensed under a Public Domain license

- document (C) IO-Images is licensed under a Public Domain license 


\section{Einheit 7.2 (online)}

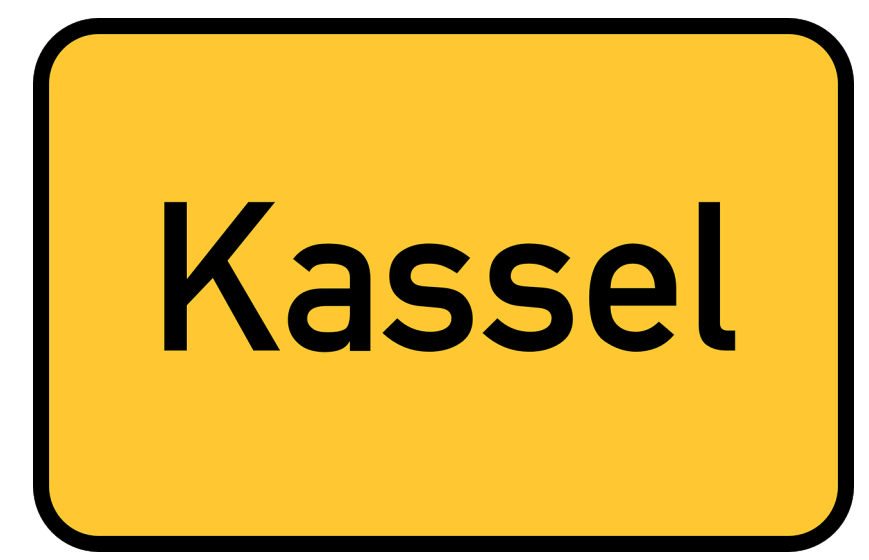

\section{Übung 1: Eine Exkursion in Kassel}
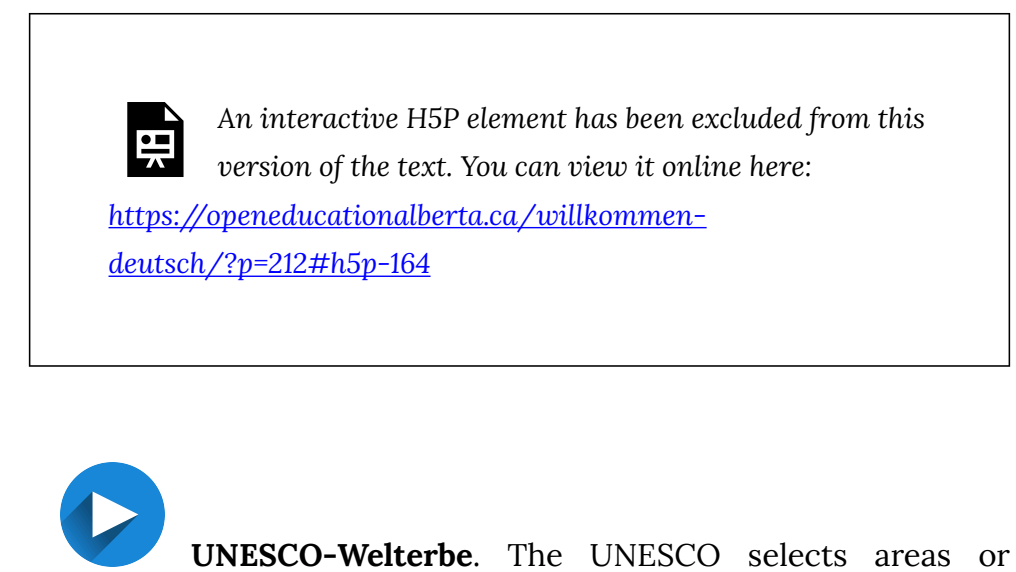

UNESCO-Welterbe. The UNESCO selects areas or landmarks that are culturally, historically, scientifically or otherwise significant and declares them world heritage sites. These sites are protected by international treaties. There are 46 World Heritage Sites in Germany (43 cultural and 3 natural). 
Today, you will learn something about the "Bergpark Wilhelmshöhe".

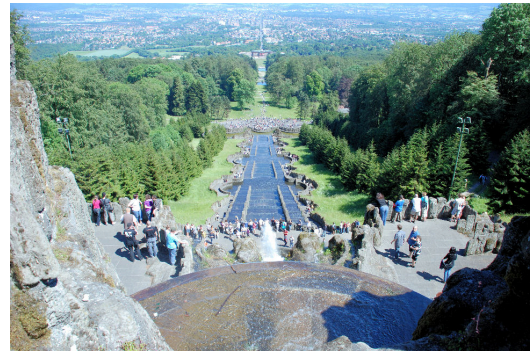

Bergpark Wilhelmshöhe - Wasserspiele

Wo liegt der Bergpark Wilhelmshöhe auf der Landkarte? Welterbe in Deutschland 
Sehen Sie die zwei Videos an und machen Sie Übung 2.

Kassel - Weltkulturerbe Bergpark Wilhelmshöhe (Deutsche Welle) (3:32 Minuten; Deutsch)

Wasserspiele / Wasserkünste im UNESCO Welterbe Bergpark Wilhelmshöhe in Kassel (Kassel Touristinformation) (2:53 Minuten)
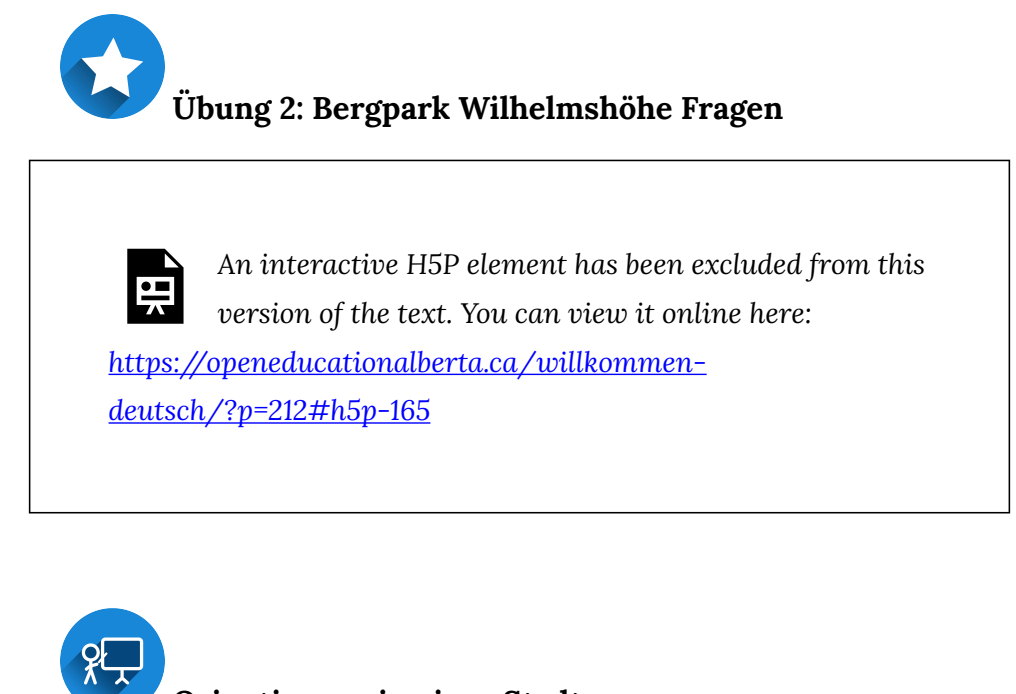

Orientierung in einer Stadt
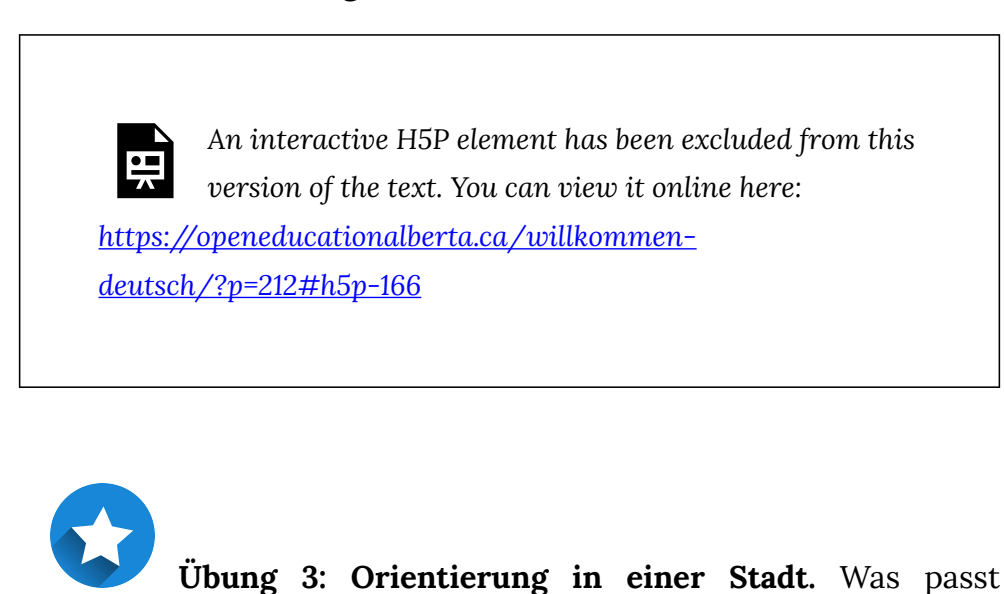

Übung 3: Orientierung in einer Stadt. Was passt zusammen? 
An interactive $\mathrm{H} 5 \mathrm{P}$ element has been excluded from this version of the text. You can view it online here:

https://openeducationalberta.ca/willkommen-

deutsch/?p=212\#h5p-167

Was wissen Sie jetzt? Klicken Sie hier für Quiz 7.2.

\section{Media Attributions}

- kassel-1099176_1280 (C) Taken is licensed under a Public Domain license

- star (C) IO-Images is licensed under a Public Domain license

- Wasserspiele_Kassel-Wilhelmshöhe_2011_von_oben-1 (C) Matthias Froherz is licensed under a CC BY-SA (Attribution ShareAlike) license

- presentation icon (C) quinntheislander adapted by Solomon Hajramezan is licensed under a Public Domain license

- check mark (C janjf93 adapted by Solomon Hajramezan is licensed under a Public Domain license 


\section{Einheit 7.3}

200

Was haben Sie schon gelernt?

An interactive H5P element has been excluded from this

근 version of the text. You can view it online here:

https://openeducationalberta.ca/willkommen-

deutsch/?p=214\#h5p-221

안

Sehenswürdigkeiten in Kassel. Hier lernen Sie noch mehr Sehenswürdigkeiten in Kassel kennen.

200

Orientierung in einer Stadt. Was passt zusammen? 


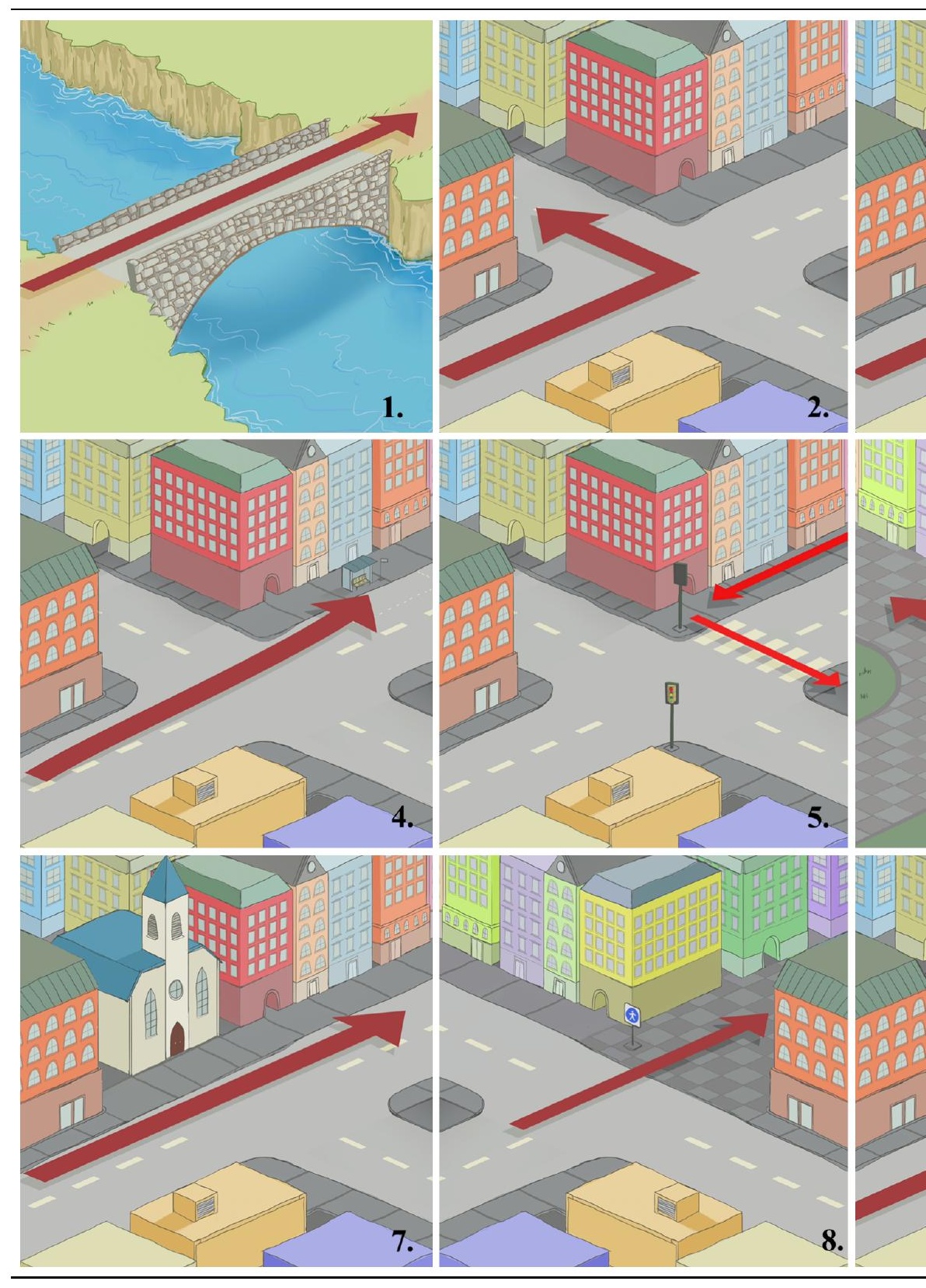


Entschuldigung, wo ist ...? Herr Ebert möchte vom Hauptbahnhof zum Schloss. Hören Sie die zwei Dialoge. Welche Wegbeschreibung ist auf dem Stadtplan eingezeichnet?

\section{Dialog 1:}

One or more interactive elements has been excluded $\boldsymbol{J}$ from this version of the text. You can view them online here: https://openeducationalberta.ca/willkommendeutsch/?p=214\#audio-214-1

\section{Dialog 2:}

a) One or more interactive elements has been excluded from this version of the text. You can view them online here: https://openeducationalberta.ca/willkommendeutsch/?p=214\#audio-214-2 


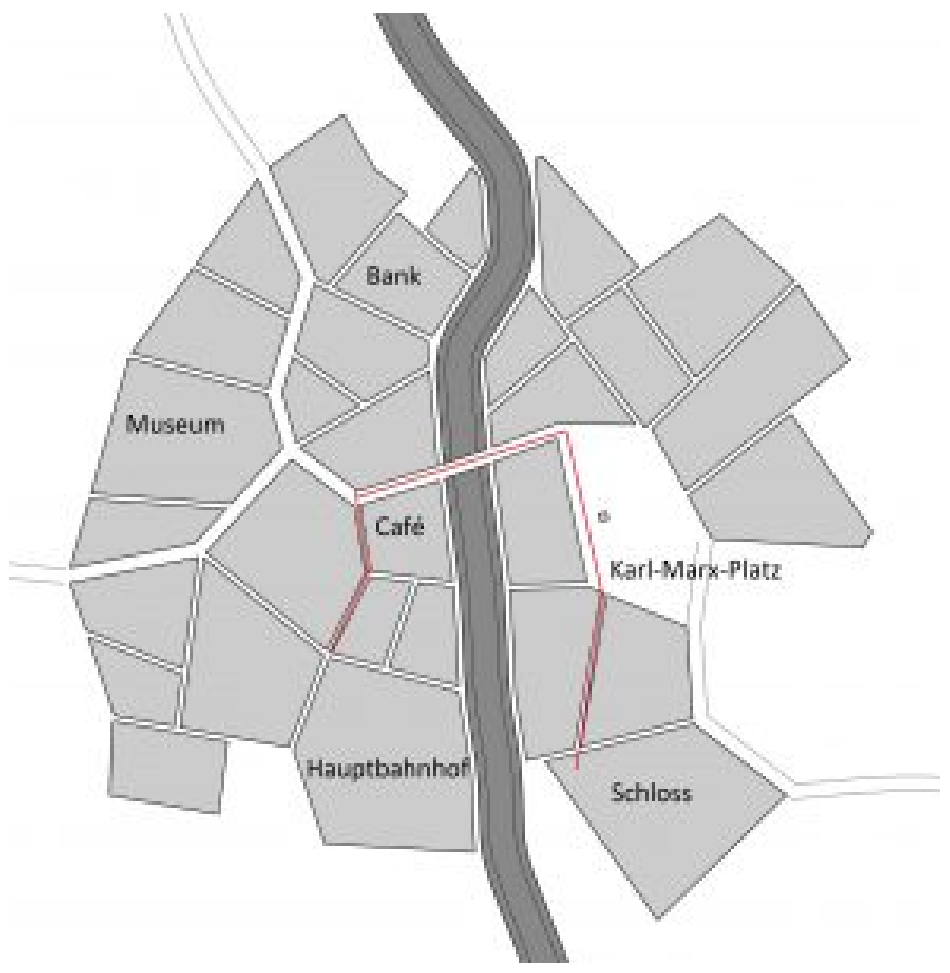

Entschuldigung, wo ist ...? Lesen Sie jetzt die Dialoge mit einer Partnerin oder mit einem Partner.

Media Attributions

- group (C) IO-Images is licensed under a Public Domain license

- presentation icon (c) quinntheislander adapted by Solomon Hajramezan is licensed under a Public Domain license

- Orientierung in einer Stadt (C) Solomon Hajramezan adapted by 
csawatzky is licensed under a All Rights Reserved license

- headphones (C) IO-Images is licensed under a Public Domain license

- Stadtplan Wegbeschreibung 1 (c) ckost is licensed under a Public Domain license

- book (C) IO-Images is licensed under a Public Domain license

- partner (C) IO-Images is licensed under a Public Domain license 


\section{Einheit 7.4 (online)}

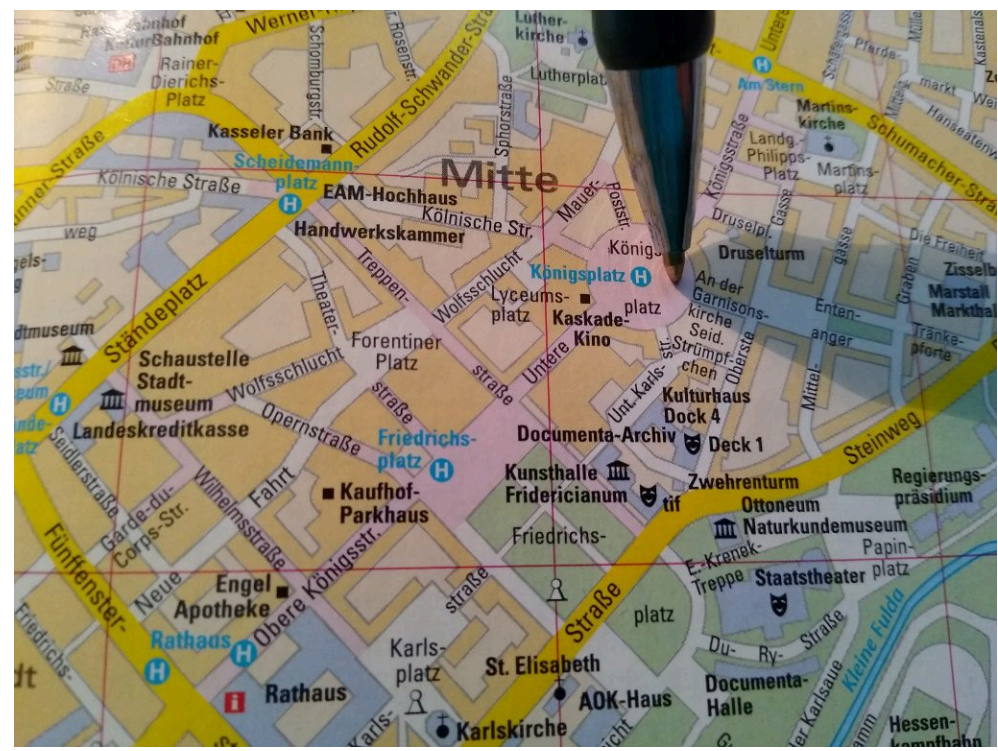

\section{Übung 1: Orientierung in der Stadt}

An interactive H5P element has been excluded from this version of the text. You can view it online here:

https://openeducationalberta.ca/willkommen-

deutsch/?p=216\#h5p-219

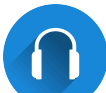

Wegbeschreibung. Hören Sie die Dialoge und finden Sie den Weg auf dem Stadtplan. Sie sind auf dem Rainer-Dierichs-Platz 
vor dem Hauptbahnhof in Kassel. (official buildings are coloured in red; streets are in yellow or white; the pedestrian zone is white and grey striped; bus lines are indicated by a red dashed line on the street with bus numbers written on the dashed line; street car lines are indicated by a blue line)

\section{Dialog 1:}

1 One or more interactive elements has been excluded from this version of the text. You can view them online here: https://openeducationalberta.ca/willkommendeutsch/?p=216\#audio-216-1

\section{Dialog 2:}

One or more interactive elements has been excluded
from this version of the text. You can view them online here: https://openeducationalberta.ca/willkommendeutsch/?p=216\#audio-216-2 

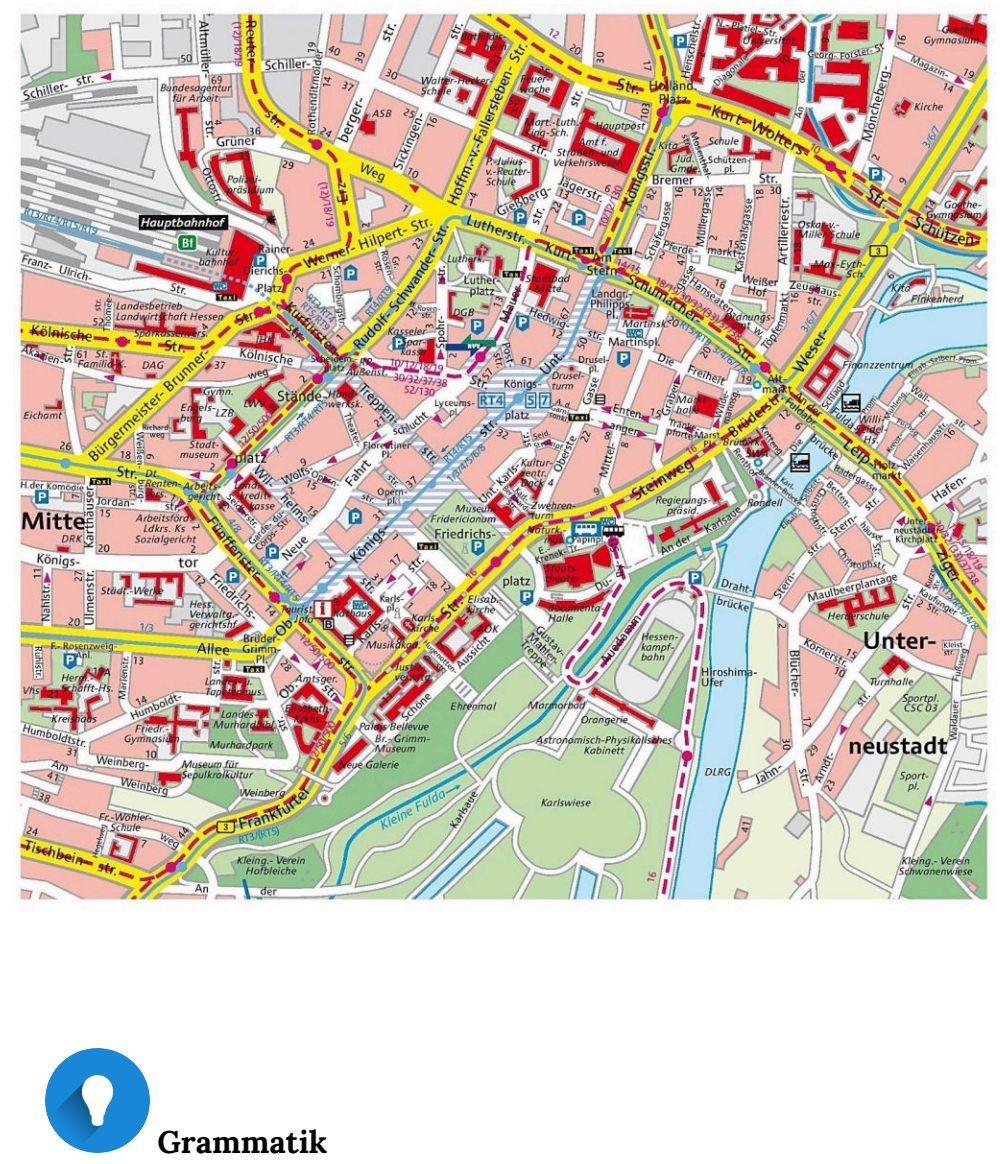

Prepositions for giving directions

When we use prepositions in German to give directions or describe where people are going, some prepositions take the accusative case and others take the dative case. This 
means that the articles are changed to their accusative or dative forms.

Wohin gehen die Touristen?

- in, durch, über, entlang + Accusative

\begin{tabular}{|c|c|c|c|c|}
\hline & in & durch & über & entlang \\
\hline$e^{d}$ & $\begin{array}{l}\quad \text { in den } \\
\text { Zoo } \\
\text { in den } \\
\text { Club }\end{array}$ & $\begin{array}{l}\text { durch den } \\
\text { Park }\end{array}$ & $\begin{array}{l}\quad \text { über den } \\
\text { Marktplatz } \\
\text { über den } \\
\text { Zebrastreifen }\end{array}$ & $\begin{array}{l}\text { den } \\
\text { Fluss } \\
\text { entlang }\end{array}$ \\
\hline$i e^{d}$ & $\begin{array}{l}\quad \text { in die } \\
\text { Galerie } \\
\text { in die } \\
\text { Kneipe }\end{array}$ & $\begin{array}{l}\quad \text { durch die } \\
\text { Stadt } \\
\text { durch die } \\
\text { Fußgängerzone }\end{array}$ & $\begin{array}{l}\quad \text { über die } \\
\text { Brücke } \\
\text { über die } \\
\text { Straße }\end{array}$ & $\begin{array}{c}\text { die } \\
\text { Straße } \\
\text { entlang }\end{array}$ \\
\hline${ }_{\text {as }}^{d}$ & \begin{tabular}{l}
\multicolumn{1}{c}{ ins } \\
Museum \\
ins \\
Theater
\end{tabular} & $\begin{array}{l}\text { durch das } \\
\text { Stadttor }\end{array}$ & $\begin{array}{l}\text { über das } \\
\text { Gelände }\end{array}$ & \\
\hline
\end{tabular}

Die Touristen laufen den Fluss entlang. (The tourists walk along the river.)

Die Touristen gehen ins Museum. (The tourists are going to the museum.)

- $\quad z u$, an...vorbei, bis zu... + Dative 


\begin{tabular}{|c|c|c|c|}
\hline $\mathbf{d}$ & $\boldsymbol{z u}$ & \multicolumn{1}{|c|}{... vorbei } & bis ... zu \\
\hline $\begin{array}{c}\text { zum Bahnhof } \\
\text { zum Zoo }\end{array}$ & $\begin{array}{l}\text { am Bahnhof } \\
\text { vorbei } \\
\text { am Zoo vorbei }\end{array}$ & $\begin{array}{c}\text { bis zum } \\
\text { Bahnhof } \\
\text { bis zum Zoo }\end{array}$ \\
\hline $\mathbf{i e}$ & $\begin{array}{l}\text { zur } \\
\text { Touristeninformation } \\
\text { zur Universität }\end{array}$ & $\begin{array}{l}\text { an der Kirche } \\
\text { vorbei } \\
\text { an der Ampel } \\
\text { vorbei }\end{array}$ & $\begin{array}{l}\text { bis zur } \\
\text { Kreuzung } \\
\text { bis zur Brücke }\end{array}$ \\
\hline $\mathbf{d}$ & $\begin{array}{c}\text { zum Museum } \\
\text { zum Stadion }\end{array}$ & $\begin{array}{c}\text { am Museum } \\
\text { vorbei }\end{array}$ & $\begin{array}{c}\text { bis zum } \\
\text { Museum }\end{array}$ \\
\hline
\end{tabular}

Die Touristen gehen an der Kirche vorbei. (The tourists are walking past the church.)

Die Touristen gehen zum Bahnhof. (The tourists are going to the train station.)

*ACHTUNG* Here are common contractions (preposition and article squeezed together):

$$
\begin{aligned}
& \text { ins }=\text { in das } \\
& \text { zum }=\text { zu dem } \\
& \text { zur }=\text { zu der } \\
& \text { am = an dem }
\end{aligned}
$$

Übung 2: Wegbeschreibung. Hören Sie die zwei Dialoge und machen Sie die Übungen.

\section{Dialog 1:}

I. One or more interactive elements has been excluded 
from this version of the text. You can view them online here: $\underline{\text { htps://openeducationalberta.ca/willkommen- }}$ deutsch/?p=216\#audio-216-3 An interactive H5P element has been excluded from this
version of the text. You can view it online here:

https://openeducationalberta.ca/willkommendeutsch/?p=216\#h5p-269

\section{Dialog 2:}

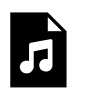

One or more interactive elements has been excluded from this version of the text. You can view them online here: $\underline{\text { https://openeducationalberta.ca/willkommen- }}$ deutsch/?p=216\#audio-216-4

固 An interactive H5P element has been excluded from this version of the text. You can view it online here:

https://openeducationalberta.ca/willkommendeutsch $/ ? p=216 \# h 5 p-270$ 


\section{Übung 3: Katelyns Eltern besuchen Kassel}

An interactive H5P element has been excluded from this version of the text. You can view it online here:

https://openeducationalberta.ca/willkommen-

deutsch/?p=216\#h5p-168

Q

Wortschatz in Quizlet:

In der Stadt

In der Stadt (plurals)

Orientierung in einer Stadt/Wegbeschreibung

Was wissen Sie jetzt? Das Quiz ist in der nächsten Unterrichtsstunde.

Extra Practice (optional):

\section{Video Serie - Nicos Weg}

Sehen Sie das Video über Wegbeschreibungen an und machen Sie alle Übungen. 


\section{Media Attributions}

- Kassel-Stadtplan (C) ckost is licensed under a Public Domain license

- star (C) IO-Images is licensed under a Public Domain license

- headphones (C) IO-Images is licensed under a Public Domain license

- Stadtplan-Kassel (C) Orange Smile is licensed under a Public Domain license

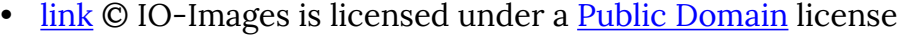

- check mark (C) janjf93 adapted by Solomon Hajramezan is licensed under a Public Domain license 


\section{Einheit 7.5}

\section{0}

\section{Wohin gehen die Touristen?}

An interactive H5P element has been excluded from this version of the text. You can view it online here:

https://openeducationalberta.ca/willkommen-

deutsch/?p=218\#h5p-171

\section{Redemittel}

\section{Nach dem Weg fragen:}

- $\quad$ Entschuldigung, wo ist...?

- Entschuldigung, wie komme ich zum/zur...?

- $\quad$ Entschuldigung, ich möchte zum/zur...

- $\quad$ Entschuldigung, wir suchen ...

\section{Den Weg beschreiben:}

- Zuerst gehen Sie geradeaus/ bis zur Kreuzung/ bis zur Ampel/ die Straße entlang.

- Dann biegen Sie rechts/links ab.

- Danach gehen Sie die erste/ zweite/ ... Straße rechts/ links.

- Gehen Sie über den Platz/ über die Brücke. 
- Gehen Sie am Schloss/ am Bahnhof/am Museum vorbei.

- Dann sehen Sie den/das/die ...

Sich bedanken und antworten:

- Vielen Dank!/ Danke schön! / Danke!

- Bitte!/ Bitte schön!/ Gern geschehen!

\section{(1) 숭}

Entschuldigung, ich suche ...? Hören Sie den Dialog und ergänzen Sie die fehlenden Wörter.

百

One or more interactive elements has been excluded

from this version of the text. You can view them online

here: https://openeducationalberta.ca/willkommen-

deutsch/?p=218\#audio-218-1

8

In Kassel: Wie komme ich zum...? Arbeiten Sie mit einer Partnerin oder mit einem Partner. Eine Person ist am Hauptbahnhof und fragt nach dem Weg zum Brüder-Grimm-Museum, die andere Person beschreibt den Weg. 


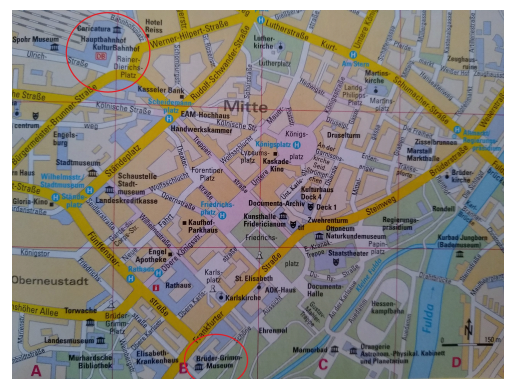

\section{Media Attributions}

- group (C IO-Images is licensed under a Public Domain license

- headphones (C) IO-Images is licensed under a Public Domain license

- document (C) IO-Images is licensed under a Public Domain license

- partner (C) IO-Images is licensed under a Public Domain license

- 7.5 Stadtplan Kassel is licensed under a Public Domain license 


\section{Einheit 7.6 (online)}

CSSG. Die Kanadische Sommerschule in Kassel (Canadian Summer School in Germany=CSSG) gibt es seit über 40 Jahren. Jeden Sommer fahren Studierende aus ganz Kanada nach Kassel, um dort 6 Wochen lang einen Deutsch-Intensivkurs zu machen. Sehen Sie die Videos an und beantworten Sie die Fragen.

One or more interactive elements has been excluded
from this version of the text. You can view them online here: https://openeducationalberta.ca/willkommendeutsch/?p=220\#oembed-1

An interactive H5P element has been excluded from this version of the text. You can view it online here:

https://openeducationalberta.ca/willkommendeutsch/?p=220\#h5p-170

圈 One or more interactive elements has been excluded from this version of the text. You can view them online here: https://openeducationalberta.ca/willkommendeutsch/?p=220\#oembed-2 
An interactive $\mathrm{H} 5 \mathrm{P}$ element has been excluded from this version of the text. You can view it online here:

https://openeducationalberta.ca/willkommen-

deutsch/?p=220\#h5p-194

\section{Q}

CSSG. Für mehr Informationen zur CSSG, klicken Sie hier.

Recherchieren Sie im Internet! Finden Sie eine Unterkunft in Kassel, die Sie mögen. Notieren Sie den Namen, den Typ, den Preis, usw. Finden Sie auch 3 Sehenswürdigkeiten, die Sie in Kassel sehen möchten. Notieren Sie Eintrittszeiten, Preise, usw. Bringen Sie die Informationen mit zur nächsten Deutschstunde.

Q

Wortschatz in Quizlet:

Redemittel: Wegbeschreibung

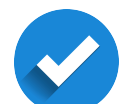

Was wissen Sie jetzt? Klicken Sie hier für Quiz 7.6.

\section{Media Attributions}

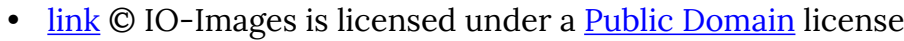

- magnifying-glass (C) IO-Images is licensed under a Public Domain license

- check mark @ janjf93 adapted by Solomon Hajramezan is 
licensed under a Public Domain license 


\section{Einheit 7.7}

200

Sommersprachkurs mit der CSSG. Was haben die Studierenden in den Videos darüber gesagt?

Sherwin: Vom Deutschlerner zum Deutschlehrer! Sehen Sie das Video an und beantworten Sie die Fragen.

On One or more interactive elements has been excluded from this version of the text. You can view them online here: https://openeducationalberta.ca/willkommendeutsch/?p=228\#oembed-1

An interactive H5P element has been excluded from this

version of the text. You can view it online here:

https://openeducationalberta.ca/willkommen-

deutsch/?p=228\#h5p-196

道

Sherwins Erlebnisse bei der CSSG. Lesen Sie über Sherwins Erlebnisse.

An interactive H5P element has been excluded from this 
version of the text. You can view it online here:

https://openeducationalberta.ca/willkommen-

deutsch $/ ? p=228 \#$ h5p-236

\section{0}

Eine Reise nach Kassel. Arbeiten Sie in einer kleinen Gruppe (2-3 Studierende) und planen Sie eine Reise nach Kassel.

- Was wollen Sie dort sehen oder machen? Schreiben Sie 3 Dinge auf und geben Sie einen Grund.

- Wo wollen Sie übernachten?

Benutzen Sie die Informationen, die Sie in 7.6 gesammelt haben, und machen Sie einen Reiseplan für 3 Tage. Präsentieren Sie dann Ihren Plan.

\section{Media Attributions}

- group (C) IO-Images is licensed under a Public Domain license

- book (C) IO-Images is licensed under a Public Domain license 


\section{Einheit 7.8 (online)}

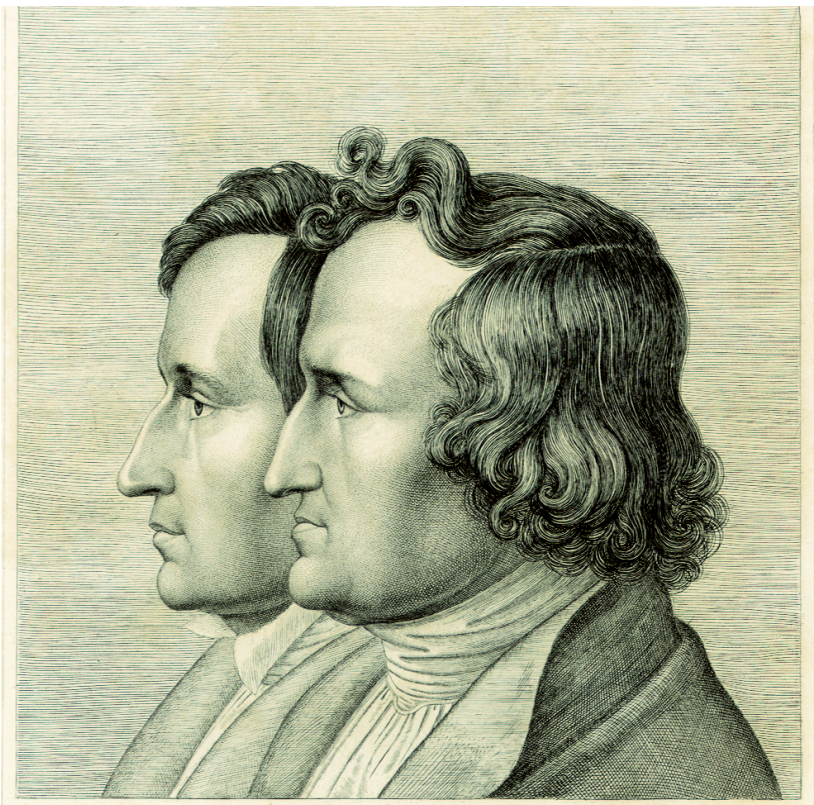

Wer sind die Brüder Grimm? Recherchieren Sie im Internet. Finden Sie 3 Dinge über die Brüder Grimm heraus (für die nächste Deutschstunde).

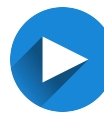

Marburg und Kassel - Spuren der Brüder Grimm. Sehen Sie das $\underline{\text { Video }}$ an und machen Sie Notizen.

An interactive H5P element has been excluded from this 
$\Delta$ version of the text. You can view it online here:

https://openeducationalberta.ca/willkommen-

deutsch/?p=222\#h5p-220
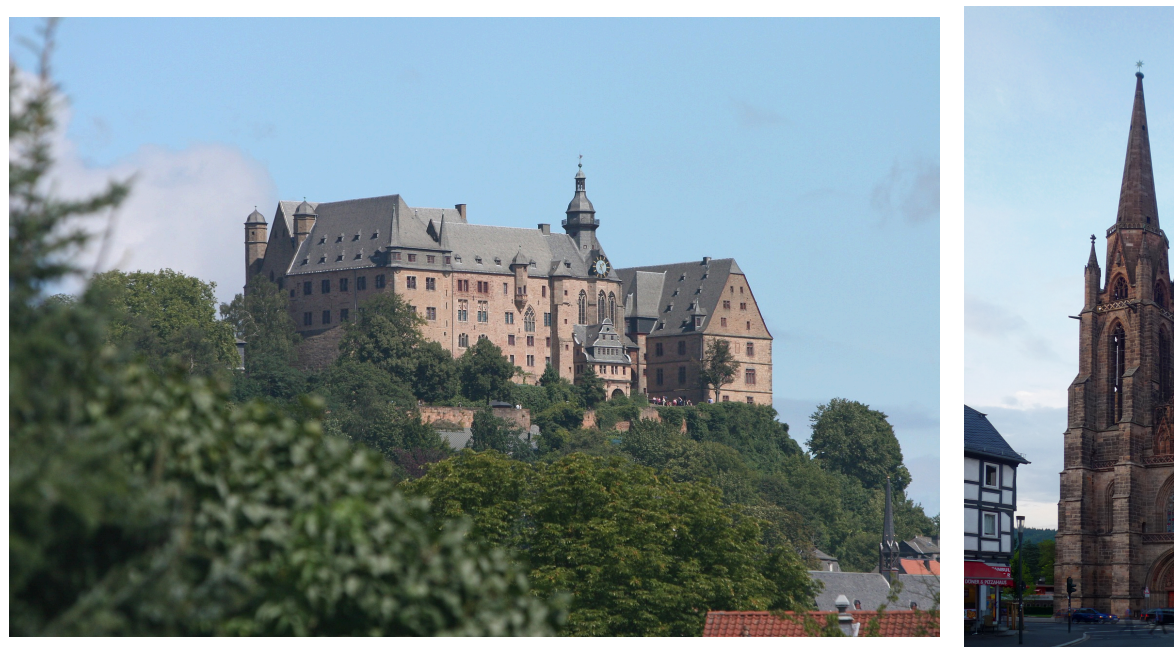

das Landgrafenschloss

die Elis

Übung 1: Eine Reise nach Marburg. Klicken Sie hier und Sie können das Perfekt und Präteritum wiederholen.

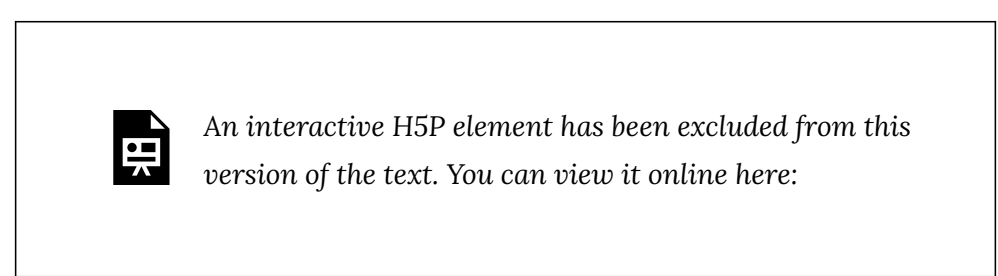


https://openeducationalberta.ca/willkommen-

deutsch/?p=222\#h5p-158

\section{Grammatik}

You may have noticed that each time you're going to use to word "when" you often pause and are unsure which word to choose. It is a tricky concept in German. Here are the three different ways and an explanation of when to use which word.

In Einheit 2.6 you learned the question word "wann". As we learned, we use "wann" when asking direct or indirect questions about a specific time or day.

Wann hast du Deutsch?

Weißt du, wann dein Zug ankommt?

In Einheit 4.8 you learned about the subordinating conjunction "wenn". Use "wenn" in these circumstances:

- repeated event in the past, present or future (whenever)

- Ich lese gern, wenn ich Freizeit habe. 
- Wenn Tante Emma uns besucht, bringt sie immer einen Kuchen mit.

- conditional (if/when)

- Wenn du mal nach Köln kommst, $\quad$ musst du mich besuchen!

Finally, the third way to say "when" is with "als". "Als" is also a subordinating conjunction. Use "als" in these circumstances:

- $\quad$ single event (point in time) in the past or present

- Als ich ins Klassenzimmer gekommen bin, war meine Professorin schon da.

- $\quad$ time period in the past

- Meine Eltern sind nach Luzern gezogen, als ich sechs war.

- $\quad$ Als ich ein Kind war, habe ich immer gelesen.

\section{Übung 2}

므 An interactive H5P element has been excluded from this version of the text. You can view it online here:

https://openeducationalberta.ca/willkommendeutsch/?p=222\#h5p-106 


\section{Vergessen Sie nicht!}

In Einheit 5.8 you first learned about prepositions that require the dative case. We have continued to see and use them throughout the last few units. Remember this means that any articles or pronouns used after the preposition are changed to their dative forms. Please notice that sometime it can also just be the preposition + a noun (and there is nothing in the "dative").

aus (out of/from): Ich hole den Reisepass aus meiner Tasche. / Ich komme aus den USA. außer (except for): Außer dir habe ich keinen Freund. bei (at/at the house of): Er arbeitet bei Mercedes. / Du kannst bei mir übernachten. mit (with/by): Ich wohne mit meinen Eltern. / Fährst du gern mit dem Bus?

nach (after/to): Nach der Schule spielt sie Tennis. / Wir fliegen nach Spanien.

seit (since/for): Seit September lerne ich Deutsch. / Ich studiere seit einem Jahr.

von (from/of): Ich komme von der Uni. / Der Bruder von meiner Mutter ist mein Onkel.

$\boldsymbol{z u}$ (to): Ich gehe zum Arzt. / Meine Schwester läuft zu unserer Oma. 
Was wissen Sie jetzt? Das Quiz ist in der nächsten Unterrichtsstunde.

\section{Media Attributions}

- Brüder Grimm Doppelporträt 1843 C Ludwig Emil Grimm is licensed under a Public Domain license

- magnifying-glass (C) IO-Images is licensed under a Public Domain license

- marburger-castle-83638_1920 C Philip von Geyr is licensed under a Public Domain license

- Marburg_Elisabethkirche_087-89_vhzd (C) Pedelecs is licensed under a CC BY-SA (Attribution ShareAlike) license

- star (C) IO-Images is licensed under a Public Domain license

- information (C) IO-Images is licensed under a Public Domain license

- check mark (C) janjf93 adapted by Solomon Hajramezan is licensed under a Public Domain license 


\section{Einheit 7.9}

200

\section{Was ist neu?}

An interactive H5P element has been excluded from this version of the text. You can view it online here:

https://openeducationalberta.ca/willkommen-

deutsch/?p=6318\#h5p-317

\section{0}

Was haben Sie schon gelernt?

An interactive H5P element has been excluded from this version of the text. You can view it online here:

https://openeducationalberta.ca/willkommendeutsch/?p=6318\#h5p-316

Die Brüder Grimm. Lesen und besprechen Sie den Text über die Brüder Grimm. Beantworten Sie dann die Fragen. 
.1. An interactive H5P element has been excluded from this version of the text. You can view it online here:

https://openeducationalberta.ca/willkommen-

deutsch/?p=6318\#h5p-169

\section{Die Wohlfahrtsmarke (charity stamp)}


Wohlfahrtsmark

en are a special

type of

commemorative

or special issue

stamp used to

raise money for

charitable

organizations by

adding a surtax to

the regular

postage. They

have been

published

biannually in

Germany since

1949. In the 1960s,

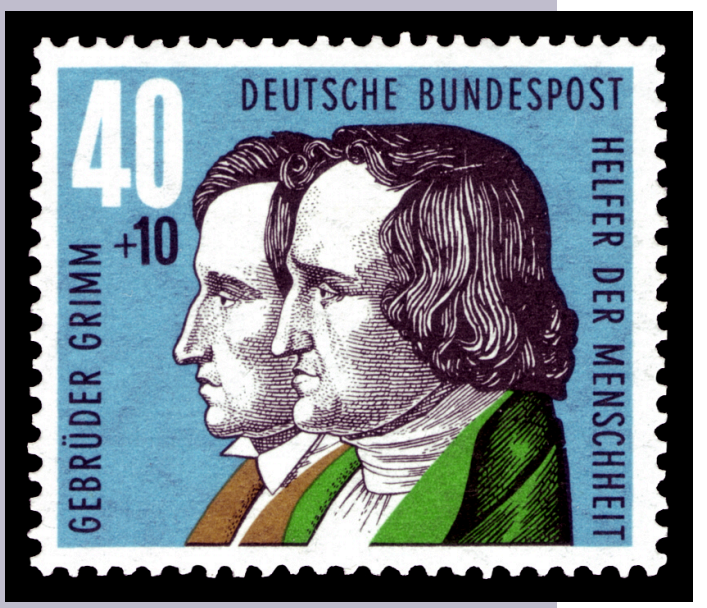

several series

featured fairy tale

motifs from the

Brothers Grimm.

\section{0}

Welche Märchen kennen Sie? Was passt zusammen?

The Frog King / The Wolf and the Seven Young Kids / Sleeping Beauty / Cinderella / Hansel and Gretel / Mother Holle / Little Red Riding Hood / Snow White / The Star Money 


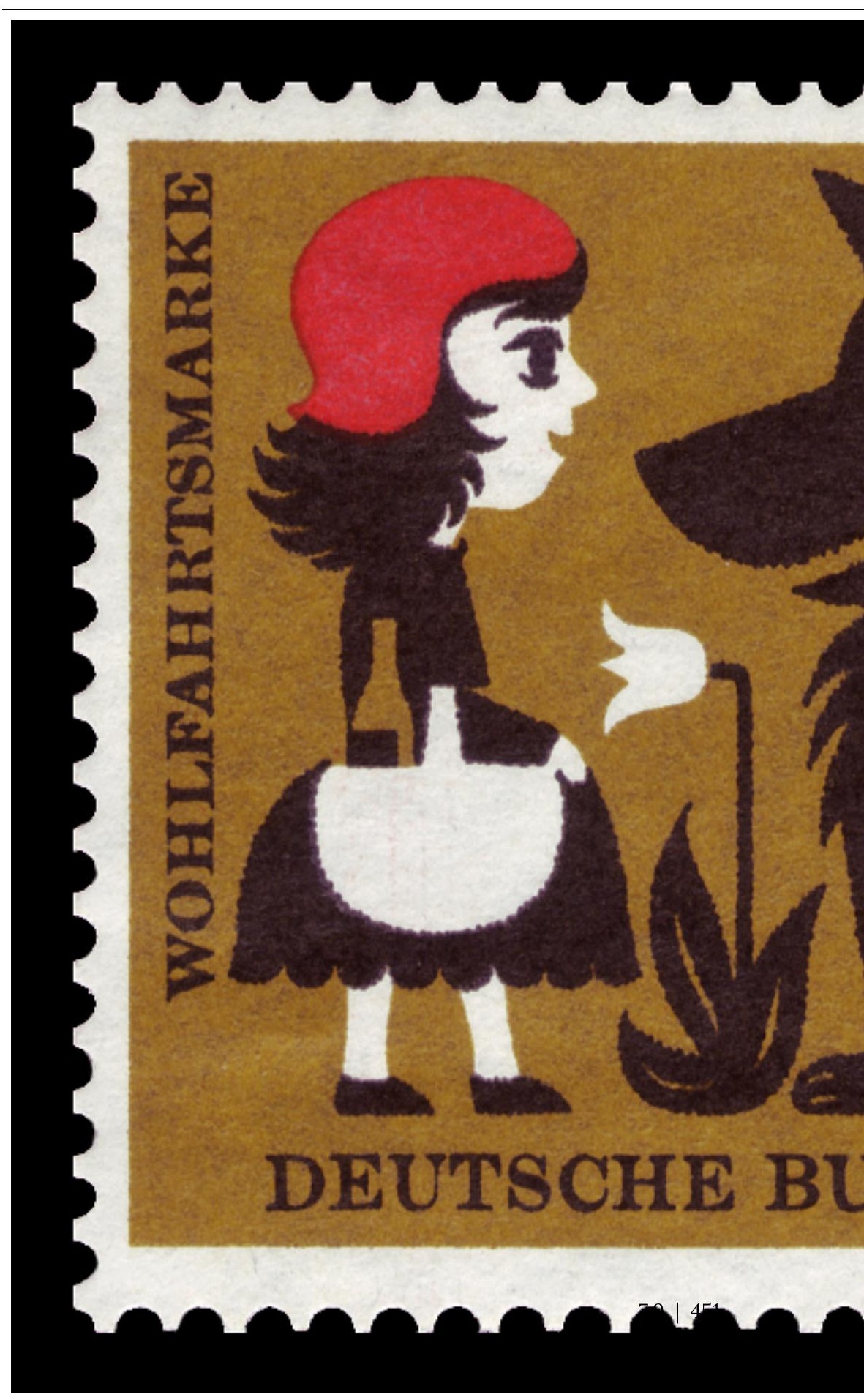




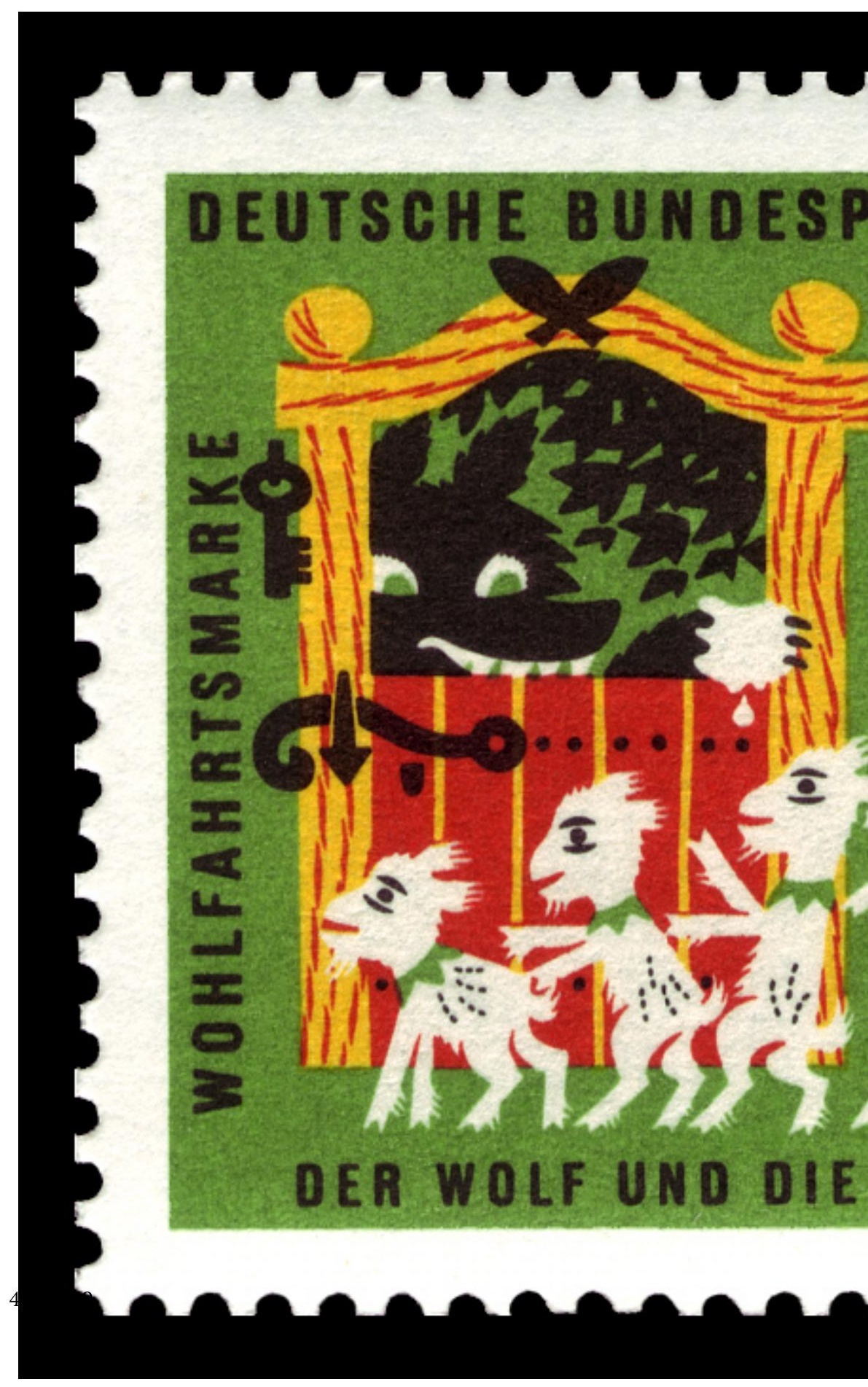




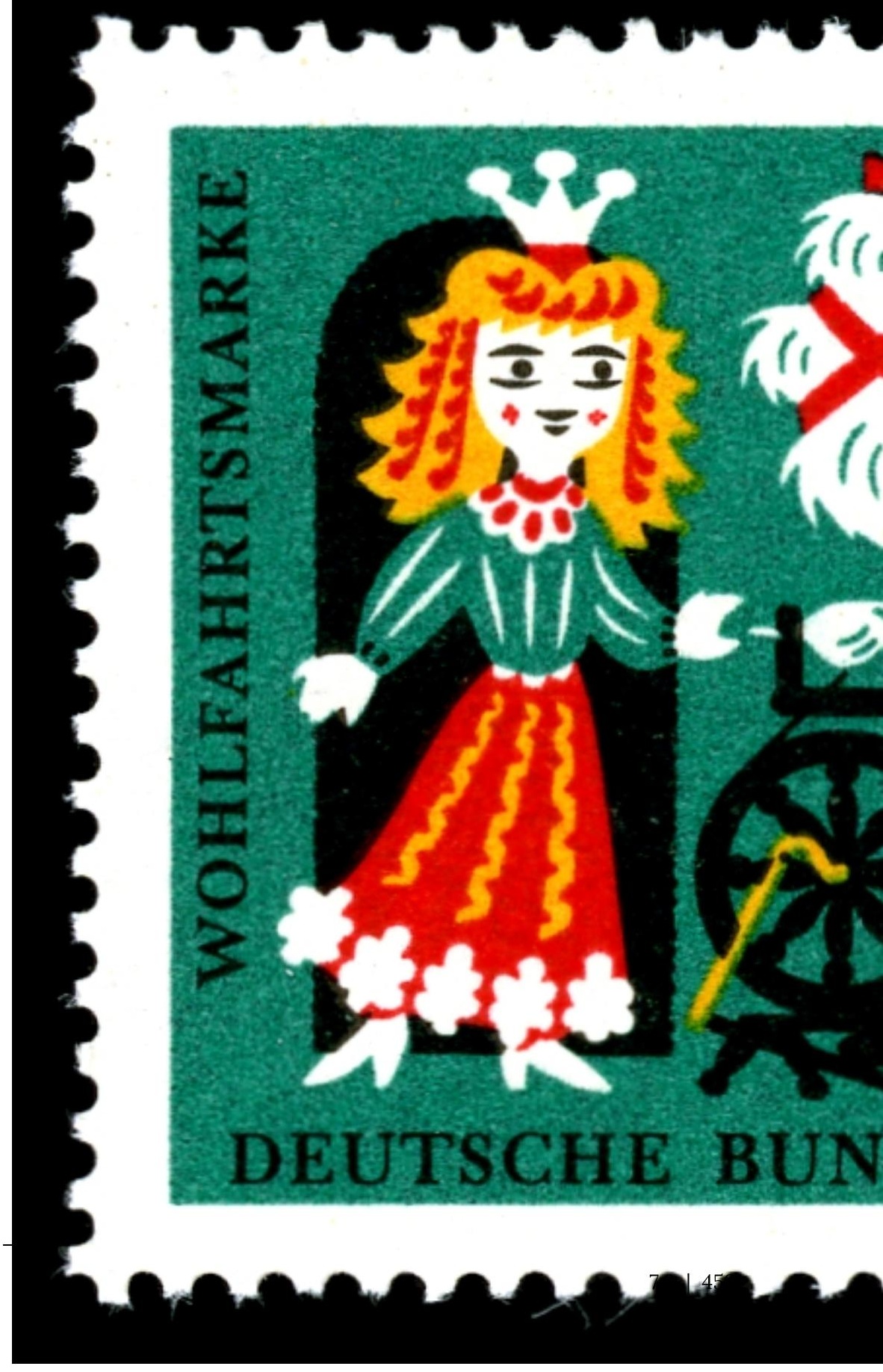




\section{Media Attributions}

- group (C) IO-Images is licensed under a Public Domain license

- book (C) IO-Images is licensed under a Public Domain license

- DBP_1959_325_Wohlfahrt_Sterntaler (C) NobbiP is licensed under a Public Domain license

- DBP_1960_340_Wohlfahrt_Rotkäppchen (C) NobbiP is licensed under a Public Domain license

- DBP_1961_369_Wohlfahrt_Hänsel_und_Gretel @ NobbiP is licensed under a Public Domain license

- DBP_1962_387_Wohlfahrt_Schneewittchen (C) NobbiP is licensed under a Public Domain license

- DBP_1963_409_Wohlfahrt_Wolf_und_Geisslein (C) NobbiP is licensed under a Public Domain license

- DBP_1965_487_Wohlfahrt_Aschenputtel C NobbiP is licensed under a Public Domain license

- DBP_1966_524_Froschkönig (C) McZack is licensed under a Public Domain license

- Stamps_of_Germany_(BRD)_Wohlfahrtsmarke_Dornröschen _1964_15_Pf is licensed under a Public Domain license

- DBP 1967539 Frau Holle C McZack is licensed under a Public Domain license

- DBP_1959_324_Wohlfahrt_Sterntaler (C) NobbiP is licensed under a Public Domain license 


\section{Einheit 7.10 (online)}

\section{Grammatik}

\section{English "to": German "nach" vs. "in"}

Nach is used if you are going to a city or a country.

Ich fahre mit dem Zug nach Berlin.

Im Sommer fliege ich nach Deutschland.

Nach is also used when you say you are going home: Ich gehe nach Hause. (idiom)

In is used instead of nach to express that you are going to a country if the name of the country has an article (z.B. der Libanon, die Schweiz, die USA). The article is in the accusative case.

Nächstes Jahr fahre ich in den Libanon.

Am Wochenende fahre ich in die Schweiz zum Ski fahren.

Morgen fliegen wir in die USA.

Here is a good list of countries with articles.

Wortschatz in Quizlet:

Brüder Grimm

Sonstige Wörter und Ausdrücke 
Was wissen Sie jetzt? Klicken Sie hier für Quiz 7.10.

业

Task 7: Planen Sie eine Reise!

Choose a city in Germany (not Kassel (-)), Switzerland, or Austria that you would like to visit and plan a 3-day trip. For each day include information about the activities you plan to do/sights you plan to see. This information may be in bullet points and should include more than the cost of the ticket or hours of operation. Write about other interesting facts from your research. There should also be information about where you will stay (lodging) and how you will get there (transportation).

Then add a brief written narrative (at least 100 words) describing the reasons why you want to visit the city, the sights and the activities you have chosen, etc.

Please include images to make your presentation visually appealing. Make sure you cite your sources (for images) and write your own text. Do not copy from any websites that you use.

This task will be assessed according to the Rubric for Task 7.

\section{Media Attributions}

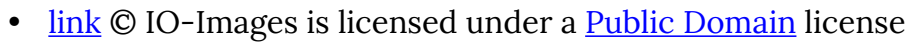

- check mark (C) janjf93 adapted by Solomon Hajramezan is licensed under a Public Domain license

- keyboard (C) IO-Images is licensed under a Public Domain license 


\title{
Wortschatz
}

\author{
Quizlet:
}

Wortschatz Einheit 7 (alle Kategorien)

In der Stadt

$\underline{\text { In der Stadt (plurals) }}$

Orientierung in einer Stadt/Wegbeschreibung

Redemittel: Wegbeschreibung

Brüder Grimm

Sonstige Wörter und Ausdrücke

Wortschatz 7

Media Attributions

- $\underline{\text { link }(C) ~ I O-I m a g e s ~ i s ~ l i c e n s e d ~ u n d e r ~ a ~ P u b l i c ~ D o m a i n ~ l i c e n s e ~}$

- pdf (C IO-Images is licensed under a Public Domain license 


\section{Zum Spaß!}
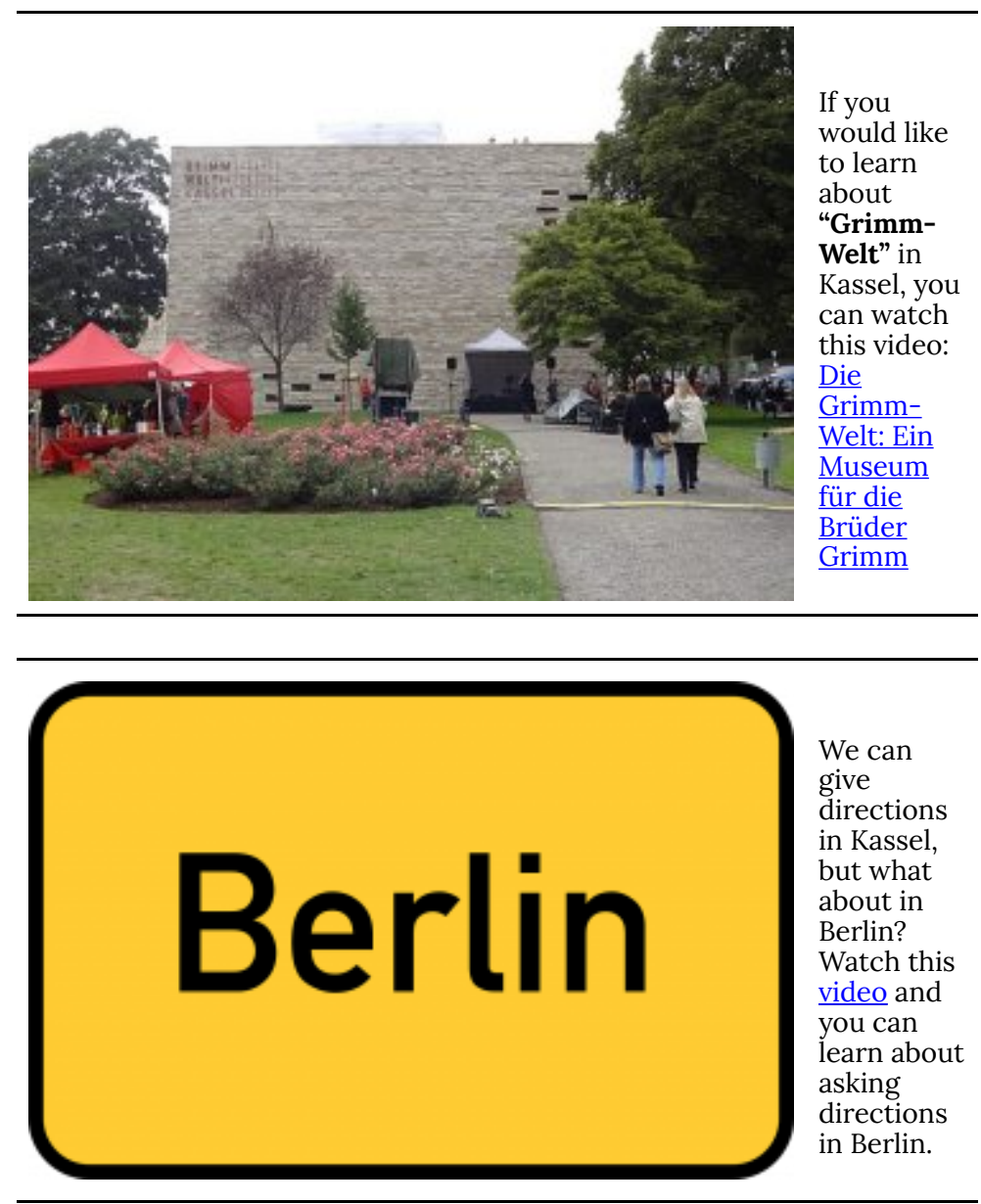


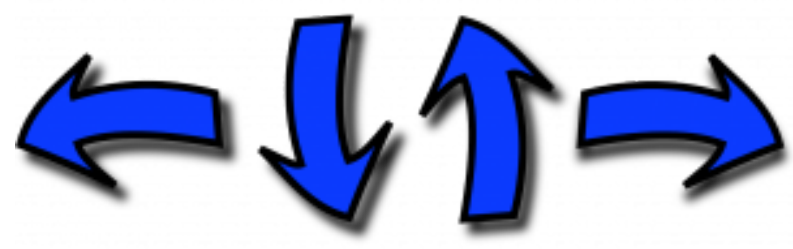

In this chapter we learned about

"Wegbeschreibung".

Here is a video that

gives you a few

more tips and tricks

for asking

directions in

German.

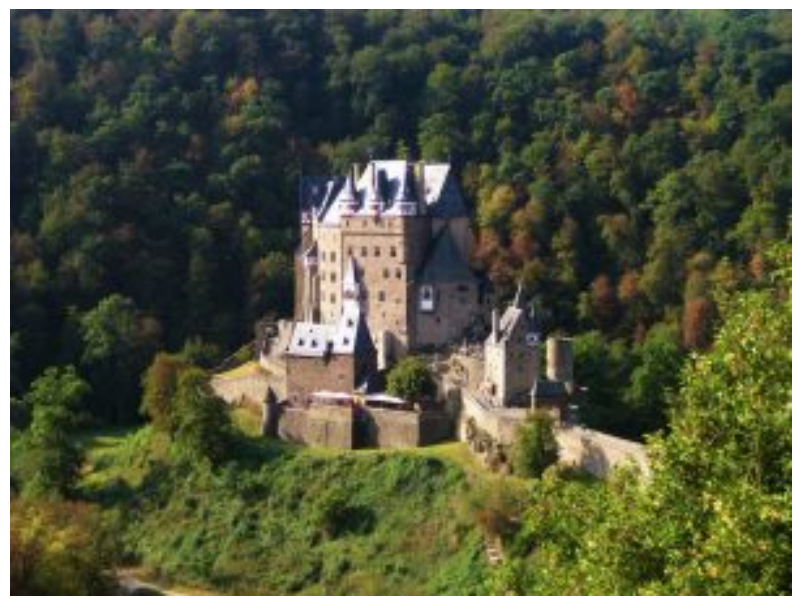

How many

castles are

there in

Germany?

This

chapter we

learned

more about

Löwenburg,

however in

this video

you can

learn about

a few

others. 


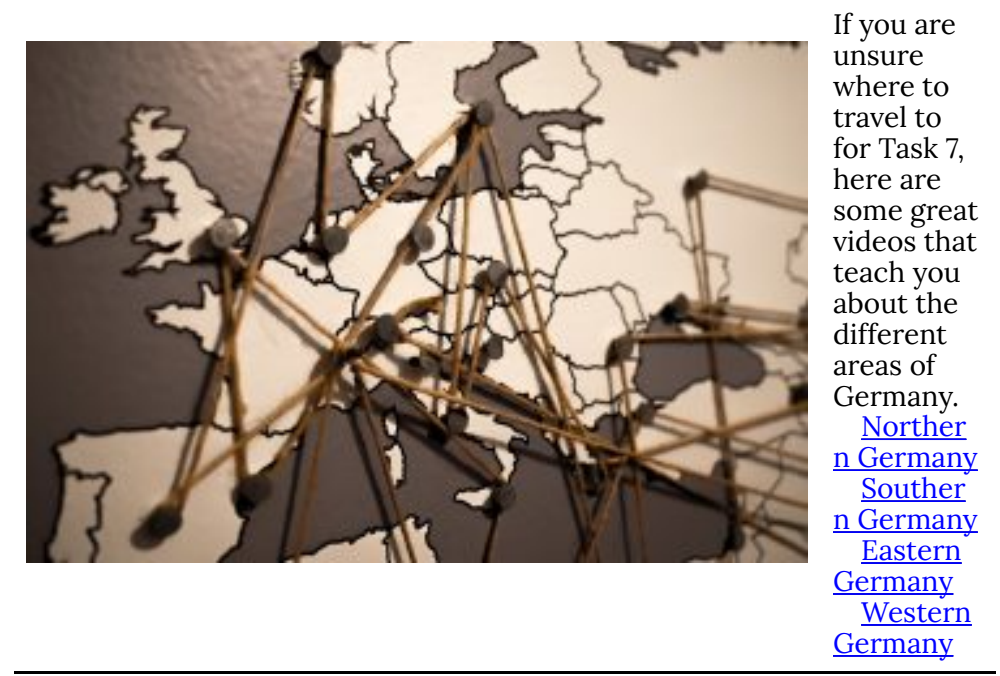

Extra Practice (optional): These activities are from the websites Schubert-Verlag and Lingua.

In der Stadt

Nach dem Weg fragen

Wegbeschreibung (Lesen)

Media Attributions

- berlin-790677_1280 C Taken is licensed under a Public Domain license

- arrow-35169_1280 @ Clker-Free-Vector-Images is licensed under a Public Domain license

- burg-1778421_1920 @ Christian1801 is licensed under a Public Domain license

- europe-g87d8b6be7 1920 (C) TheAndrasBarta is licensed under a Public Domain license 


\section{EINHEIT 8: MEIN ZUHAUSE}

\section{Learning Outcomes}

At the end of Einheit 8, you will be able to...

- compare different types of typical housing in Canada and Germany

- identify the rooms in a house or apartment

- describe the furniture in a room

- talk about the location or placing of objects in a room using the appropriate prepositions

- $\quad$ understand abbreviations and cultural intricacies in apartment ads

- $\quad$ make an appointment to view an apartment, ask further questions, and obtain details

- identify and describe some features of UNESCO world heritage sites, in particular the Siedlungen der Berliner Moderne (Berlin Modernism Housing Estates)

You will also have learned about the following structures:

- compound nouns

- two-way prepositions 
462 | Einheit 8: Mein Zuhause 


\section{Einheit 8.1}

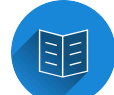

Wer wohnt wo? Lesen Sie die Texte und ordnen Sie die

Fotos zu.

Neue Wörter:

das Dorf - village

auf dem Land - in the country

gemütlich - cozy

stören - to disturb

genießen - to enjoy

gemeinsam - together, jointly

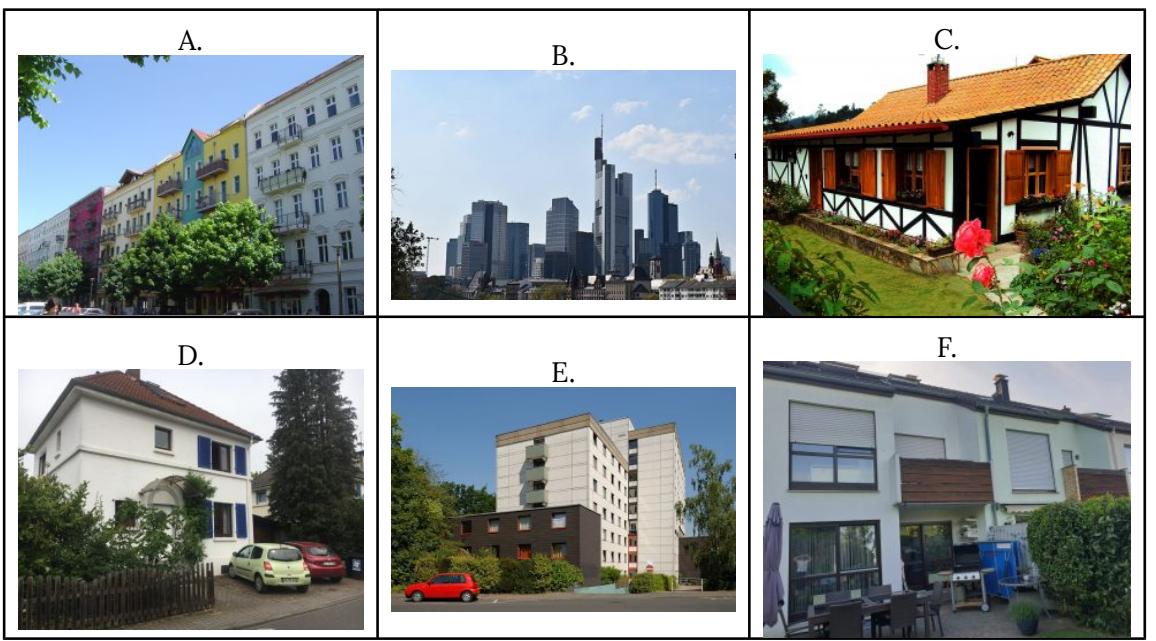

So wohne ich. Marita und Luca beschreiben ihre Wohnsituation. Hören Sie zu: Wer sagt was?

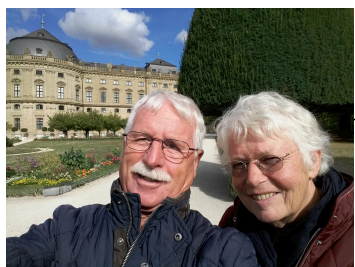

Marita:

A One or more interactive 
$\Delta$ elements has been excluded from this version of the text. You can view them online here:

https://openeducationalberta.ca/willkommen-

deutsch/?p=230\#audio-230-1

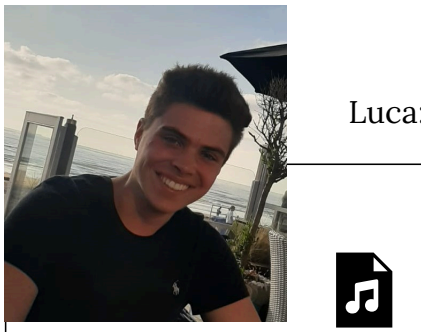

One or more interactive elements has

been excluded from this version of the

text. You can view them online here:

https://openeducationalberta.ca/willkommen-

deutsch/?p=230\#audio-230-2

\begin{tabular}{|c|c|}
\hline $\begin{array}{l}\text {... wohnt in einem } \\
\text { Mehrfamilienhaus. }\end{array}$ & $\begin{array}{l}\text {... hat einen Balkon mit schöner } \\
\text { Aussicht. }\end{array}$ \\
\hline ... hat ein eigenes Zimmer. & $\begin{array}{l}\text {... teilt Küche und Bad mit seinem } \\
\text { Mitbewohner. }\end{array}$ \\
\hline ... wohnt im Zentrum von Mainz. & $\begin{array}{l}\text {... hat eine gemütliche } \\
\text { 3-Zimmer-Wohnung. }\end{array}$ \\
\hline ... findet die Nachbarn sehr nett. & ... wohnt in einer WG. \\
\hline ... hat viele Fenster. & ... wohnt am Stadtrand. \\
\hline
\end{tabular}

\section{8}

Wie heißen die Zimmer in einem Haus? Sehen Sie den Grundriss des Einfamilienhauses der Firma bau-welt.de an und bilden Sie Wörter. 


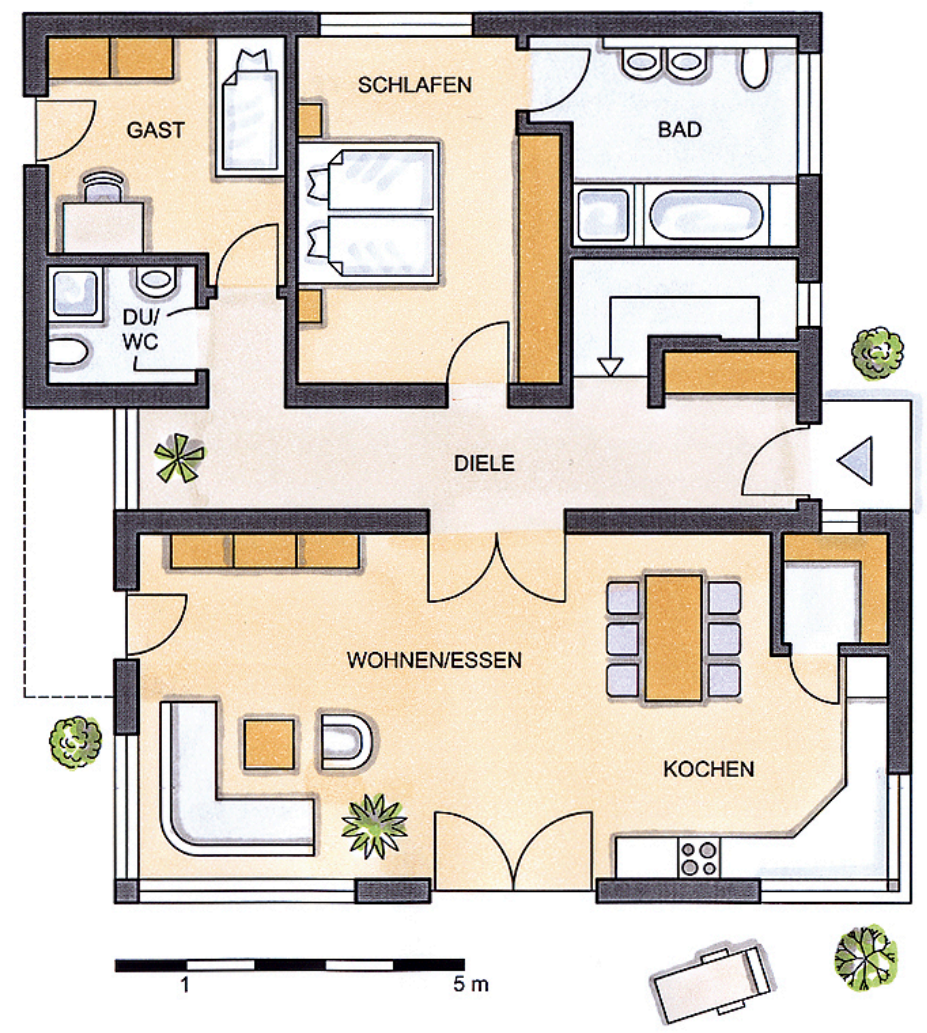

arbeiten: das Arbeitszimmer kochen:

essen:

schlafen: der Gast:

das Kind:

wohnen:

baden: 


\section{Media Attributions}

- book (C) IO-Images is licensed under a Public Domain license

- Berlin Prenzlauer Berg (C) ckost is licensed under a Public Domain license

- Frankfurt_Hochhäuser (C) Dung1802 is licensed under a CC BYSA (Attribution ShareAlike) license

- Einfamilienhaus (C) ckost is licensed under a Public Domain license

- Studentenwohnheim (C) Jochen Teufel is licensed under a $\underline{C C}$ BY-SA (Attribution ShareAlike) license

- headphones (C) IO-Images is licensed under a Public Domain license

- partner (C) IO-Images is licensed under a Public Domain license

- Praktik_Chalet_2_2_EG 


\section{Einheit 8.2 (online)}

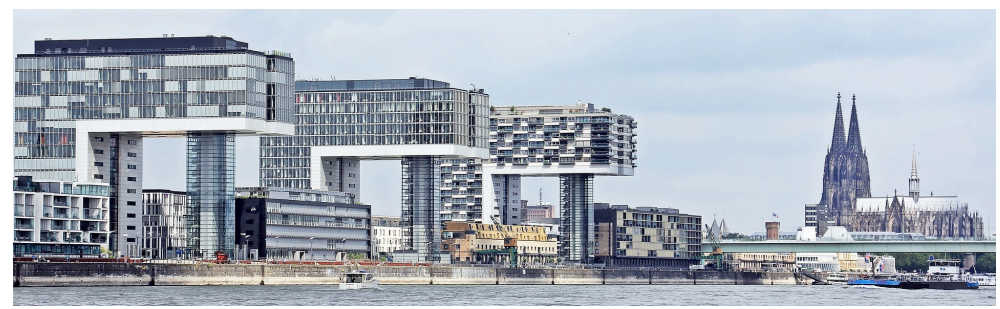

Kranhäuser in Köln

\section{Übung 1: Wohnmöglichkeiten}

An interactive H5P element has been excluded from this version of the text. You can view it online here:

https://openeducationalberta.ca/willkommendeutsch/?p=232\#h5p-235

Übung 2: Was für ein Wohnhaus ist das?

\footnotetext{
An interactive H5P element has been excluded from this version of the text. You can view it online here:
}

https://openeducationalberta.ca/willkommendeutsch/?p=232\#h5p-172 


\section{Zimmer in einem Haus / in einer Wohnung.}

An interactive H5P element has been excluded from this version of the text. You can view it online here:

https://openeducationalberta.ca/willkommen-

deutsch/?p=232\#h5p-313

\section{Grammatik}

Compound Nouns - Komposita

In German, we can easily combine two or more words to form a new word. You can combine different types of words:

- $\quad$ two or more nouns (der Stadtplan, das Fußballspiel)

- $\quad$ an adjective and a noun (der Kühlschrank, das Hochhaus)

- a verb and a noun (der Schreibtisch)

- a preposition and a noun (der Nachtisch)

The last word in a combination is the base word and determines the gender of the compound noun. The 
preceeding words provide more information about the base word.

- $\quad$ die Stadt + der Plan = der Stadtplan

- $\quad$ der Kaffee + die Tasse = die Kaffeetasse

- der Wein + das Glas = das Weinglas

- $\quad$ die Nacht + der Tisch + die Lampe $=$ die Nachttischlampe

- $\quad$ der Fuß + der Ball + das Spiel = das Fußballspiel

- $\quad$ der Schreibtisch + der Stuhl = der Schreibtischstuhl

In fact, Germans love to make really long words ? Here are some of the most well known ones:

- Donaudampfschiffahrtsgesellschaftskapitän (meaning: Danube steamship company captain) with 42 letters

- Rindfleischetikettierungsüberwachungsaufgabenüber tragungsgesetz (meaning: law for the delegation of monitoring beef labelling) with 63 letters!

- Kraftfahrzeug-Haftpflichtversicherung (motor vehicle liability insurance) with 36 letters

- Rechtsschutzversicherungsgesellschaften (insurance companies providing legal protection) with 39 letters

Sometimes people like to play around and make words even longer, for example:

der Donaudampfschiffahrtsgesellschaftskapitän + die Witwe $=$

die Donaudampfschiffahrtsgesellschaftskapitänswitwe (the widow of the Danube steamship company captain)

What is the longest German word?

$\underline{8 \text { of our favorite ridiculously long German words }}$ 
Wohnen in Kanada und in Deutschland. Lesen Sie und beantworten Sie die Fragen.

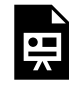

An interactive H5P element has been excluded from this version of the text. You can view it online here:

https://openeducationalberta.ca/willkommendeutsch/?p=232\#h5p-174

\section{Wortschatz in Quizlet:}

Wohnmöglichkeiten

Zimmer in einem Haus/in einer Wohnung

Wohnen in Kanada und Deutschland

Was wissen Sie jetzt? Klicken Sie hier für Quiz 8.2.

\section{Media Attributions}

- star (C) IO-Images is licensed under a Public Domain license

- presentation icon (C) quinntheislander adapted by Solomon Hajramezan is licensed under a Public Domain license

- $\underline{\text { link }}$ (C) IO-Images is licensed under a Public Domain license 
- check mark (C) janjf93 adapted by Solomon Hajramezan is licensed under a Public Domain license 


\section{Einheit 8.3}

2

Wo wohnst du? Machen Sie ein Interview mit Ihrer Partnerin oder mit Ihrem Partner.

1. Wo wohnst du? (in einer Wohnung, in einem Studentenwohnheim, in einem Einfamilienhaus, mit deiner Familie, mit einem Mitbewohner zusammen, ...)

2. Wo liegt deine Wohnung / dein Haus?

3. Was kostet dein Zimmer pro Monat?

4. Wie lange brauchst du zur Uni? (10 Minuten zu Fuß, 5 Minuten mit dem Fahrrad, eine halbe Stunde mit dem Auto/Bus, ...)

5. Hast du schon mal im Ausland gewohnt?

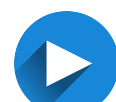

\section{Lucas Wohnung:das Badezimmer}

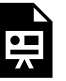

One or more interactive elements has been excluded

from this version of the text. You can view them online

here: https://openeducationalberta.ca/willkommen-

deutsch/?p=234\#oembed-1

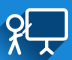

Das Badezimmer 


\section{Lucas Wohnung: die Küche}

One or more interactive elements has been excluded from this version of the text. You can view them online here: https://openeducationalberta.ca/willkommendeutsch/?p=234\#oembed-2

암ํㄹ

Die Küche

An interactive H5P element has been excluded from this
version of the text. You can view it online here:
https://openeducationalberta.ca/willkommen-
deutsch/?p=234\#h5p-223

\section{Lucas Wohnung: das Schlafzimmer}

- One or more interactive elements has been excluded from this version of the text. You can view them online 
here: https://openeducationalberta.ca/willkommen-

deutsch/?p=234\#oembed-3

Q00

Was hat Luca in seinem Schlafzimmer?

Media Attributions

- partner (C) IO-Images is licensed under a Public Domain license

- presentation icon (C) quinntheislander adapted by Solomon Hajramezan is licensed under a Public Domain license

- group (C) IO-Images is licensed under a Public Domain license 
Einheit 8.4 (online)

암ํำ

Das Schlafzimmer. Lernen Sie die neuen Vokabeln.

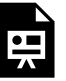

An interactive H5P element has been excluded from this version of the text. You can view it online here:

https://openeducationalberta.ca/willkommen-

deutsch/?p=6411\#h5p-314

Übung 1 \& 2: Was ist das? Achtung: Nicht alle Wörter werden verwendet.

An interactive H5P element has been excluded from this

믓 version of the text. You can view it online here:

https://openeducationalberta.ca/willkommen-

deutsch/?p=6411\#h5p-224

An interactive H5P element has been excluded from this version of the text. You can view it online here:

https://openeducationalberta.ca/willkommen-

deutsch/?p=6411\#h5p-225 
Das Wohnzimmer. Arbeiten Sie die Präsentation durch und lernen Sie die neuen Vokabeln.

An interactive H5P element has been excluded from this version of the text. You can view it online here:

https://openeducationalberta.ca/willkommendeutsch/?p=6411\#h5p-175

\section{Übung 3: Was ist das?}

\footnotetext{
An interactive H5P element has been excluded from this 믓 version of the text. You can view it online here:

https://openeducationalberta.ca/willkommendeutsch/?p=6411\#h5p-226
}

\section{Wortschatz in Quizlet:}

Möbel und andere Dinge im Haus Möbel und andere Dinge im Haus (plurals)

Was wissen Sie jetzt? Das Quiz ist in der nächsten Unterrichtsstunde. 
Extra Practice (optional):

\section{Video Serie - Nicos Weg}

Sehen Sie die Videos an und machen Sie die Übungen.

Video 1: $\underline{\text { So wohne ich }}$

Video 2: Meine Wohnung

Video 3: $\underline{\text { Sofa, Sessel und Tisch }}$

Video 4: $\underline{\text { Unser Haus }}$

\section{Media Attributions}

- presentation icon (C) quinntheislander adapted by Solomon Hajramezan is licensed under a Public Domain license

- star (C) IO-Images is licensed under a Public Domain license

- link (C) IO-Images is licensed under a Public Domain license

- check mark (C janjf93 adapted by Solomon Hajramezan is licensed under a Public Domain license 


\section{Einheit 8.5}

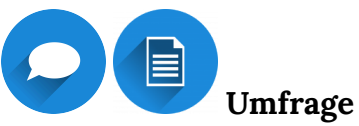

1. Wohnst du in einem Studentenwohnheim?

2. Hast du ein großes Schlafzimmer?

3. Wohnst du allein?

4. Hast du einen Balkon mit schöner Aussicht?

5. Ist deine Küche klein?

6. Hast du eine Garage?

\section{8}

Wo ist das? Stellen Sie Fragen und antworten Sie. Arbeiten Sie mit einer Partnerin oder mit einem Partner.

Beispiel:

S1: Wo ist die Badewanne?

S2: Sie ist im Badezimmer.

im Badezimmer / in der Küche / im Schlafzimmer / im

Wohnzimmer / im Arbeitszimmer

der Kühlschrank
der Kleiderschrank
das Bücherregal
der Spiegel
das Bett
der Herd

das Sofa
der Schreibtisch
die Kaffeemaschine
der Teppich
die Toilette
der Fernseher


Wo sind diese Dinge? Sehen Sie das Foto an und lesen Sie die Sätze.

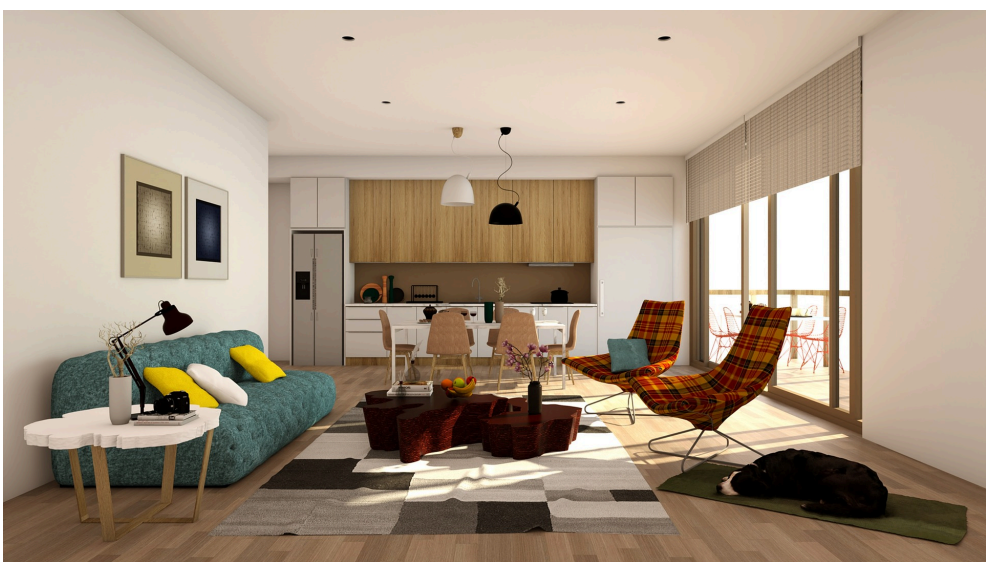

- Die schwarze Lampe steht auf dem Tisch.

- Die Bilder hängen an der Wand.

- Das weiße Kissen liegt zwischen den zwei gelben Kissen.

- Der Esstisch ist hinter dem Sofatisch.

- Der Hund liegt neben dem Sessel.

- Die weiße Lampe hängt über dem Esstisch.

- Die Blumen stehen in der Vase.

- Der Balkon ist vor dem Fenster.

- Der Teppich liegt unter dem Sofatisch.

Was ist neu hier? 
An interactive $\mathrm{H} 5 \mathrm{P}$ element has been excluded from this version of the text. You can view it online here:

https://openeducationalberta.ca/willkommen-

deutsch/?p=6416\#h5p-271

\section{Media Attributions}

- speech bubble (C) IO-Images is licensed under a Public Domain license

- $\underline{\text { document }}$ (C) IO-Images is licensed under a Public Domain license

- partner (C) IO-Images is licensed under a Public Domain license

- presentation icon (C) quinntheislander adapted by Solomon Hajramezan is licensed under a Public Domain license

- living-room-4193214 1920 C BUMIPUTRA is licensed under a Public Domain license

- question-mark (C) IO-Images is licensed under a Public Domain license 


\section{Einheit 8.6 (online)}

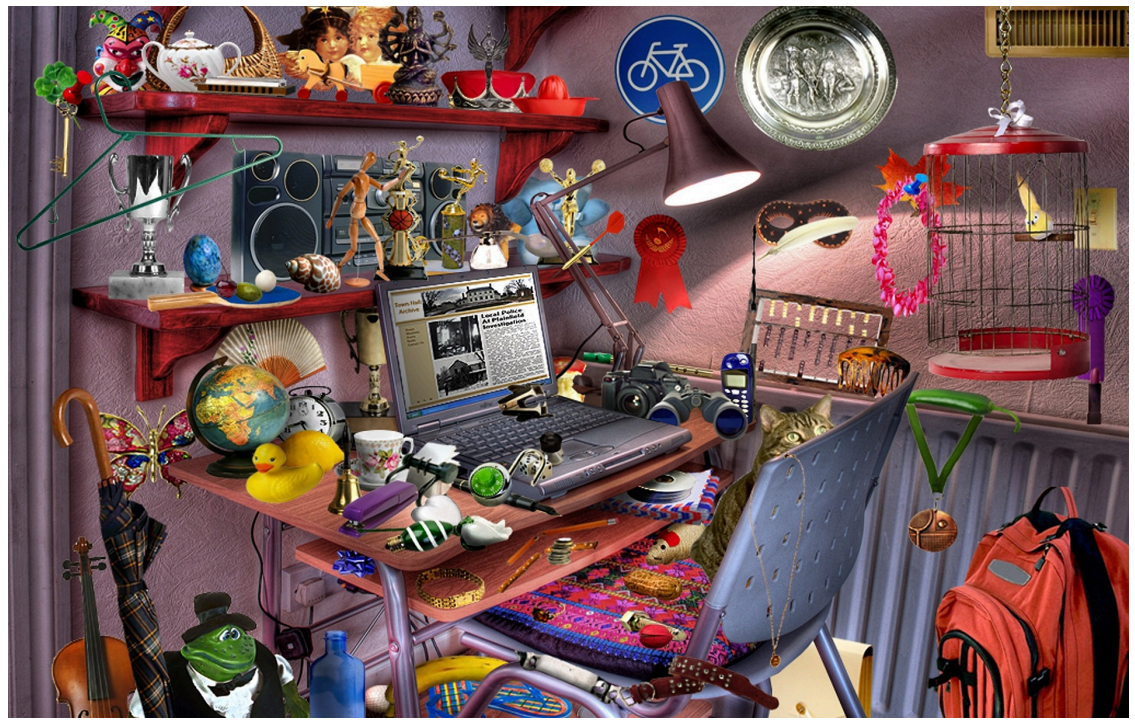

Übung 1: Was kann man zu Hause haben?

An interactive H5P element has been excluded from this version of the text. You can view it online here:

https://openeducationalberta.ca/willkommendeutsch/?p=236\#h5p-176

\section{Grammatik}


Please work through the following presentation to learn about two-way prepositions.

Two-Way Prepositions I (dative)

\section{Übung 2: Wo sind diese Dinge?}
An interactive H5P element has been excluded from this version of the text. You can view it online here:

https://openeducationalberta.ca/willkommendeutsch/?p=236\#h5p-227

Übung 3: Wo ist das? Sehen Sie das Foto an und machen Sie die Übung. 


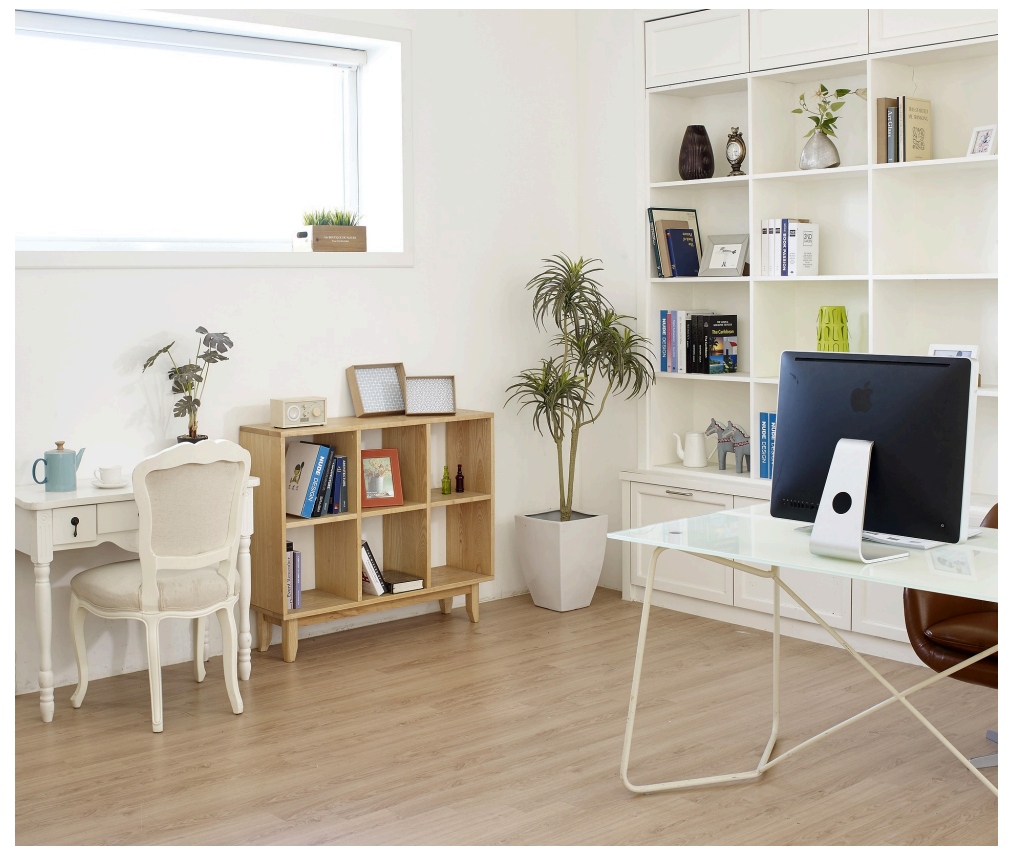

An interactive H5P element has been excluded from this version of the text. You can view it online here:

https://openeducationalberta.ca/willkommendeutsch/?p=236\#h5p-177

Übung 4: Wo ist was? 
An interactive $\mathrm{H} 5 \mathrm{P}$ element has been excluded from this version of the text. You can view it online here:

https://openeducationalberta.ca/willkommendeutsch $/ ? p=236 \#$ h5p-178

i

Vergessen Sie nicht!

All nouns (except for some proper names) add $\mathbf{- n}$ in the dative plural, unless their plural ends in $-\mathrm{s}$, for example:

die Freunde (Nom. pl.) $\rightarrow$ mit meinen Freunden (Dat. pl.)

die Kinder (Nom. pl.) $\rightarrow$ mit den Kindern (Dat. pl.)

die Bücher (Nom. pl.) $\rightarrow$ zwischen den Büchern (Dat. pl.)

die Sessel (Nom. pl.) $\rightarrow$ unter den Sesseln (Dat. pl.)

Was wissen Sie jetzt? Klicken Sie hier für Quiz 8.6.

\section{Media Attributions}

- computer-627220_1920 C levelord is licensed under a Public Domain license

- star (C) IO-Images is licensed under a Public Domain license 
- the-sanctum-sanctorum-1872194_1920 (C) manbob86 is licensed under a Public Domain license

- information (C) IO-Images is licensed under a Public Domain license

- check mark (C) janjf93 adapted by Solomon Hajramezan is licensed under a Public Domain license 


\section{Einheit 8.7}

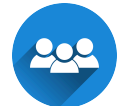

Andy und Christians Wohnzimmer. Was haben sie in ihrem Wohnzimmer?
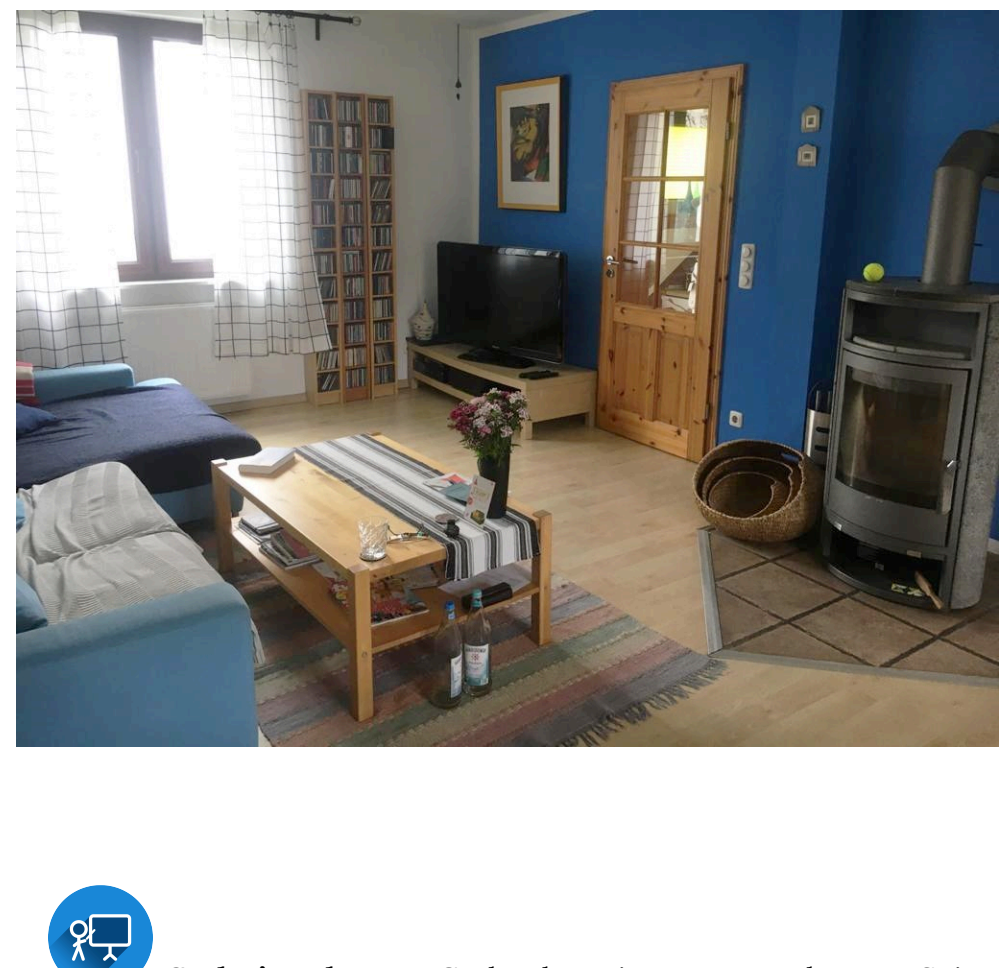

Carlos' Wohnung. Carlos hat eine neue Wohnung. Seine Freunde helfen ihm beim Umzug. 


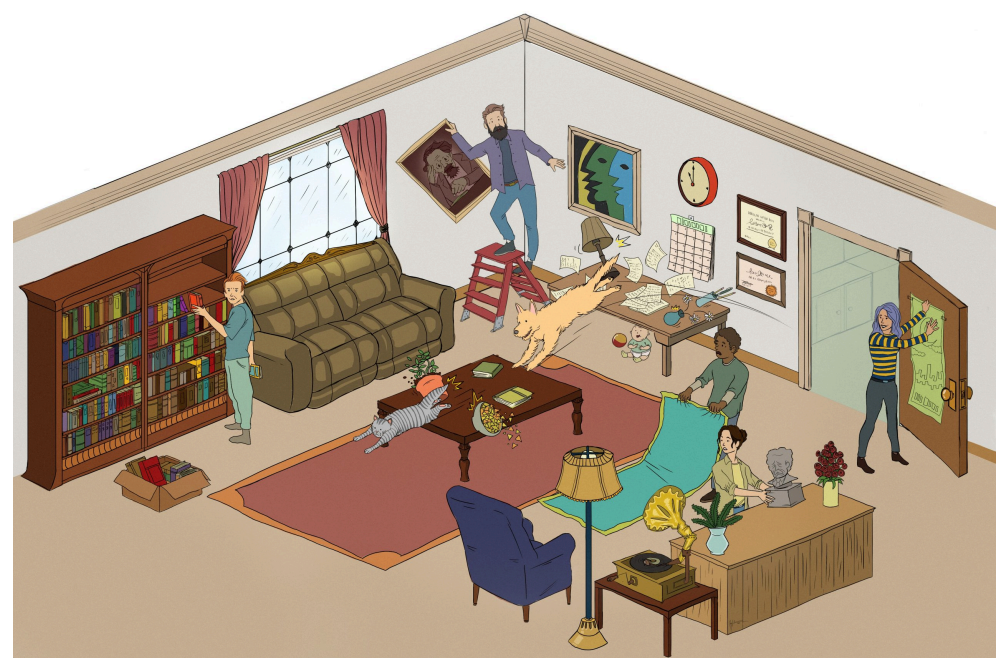

- Die Bücher stehen im Regal.

- Jakob stellt die Bücher ins Regal.

- Das Bild hängt an der Wand.

- Solomon hängt das Bild an die Wand.

- Der rote Teppich liegt auf dem Boden.

- Carlos legt den blauen Teppich auf den Boden.

\section{Was ist neu hier?}

An interactive H5P element has been excluded from this version of the text. You can view it online here: 
https://openeducationalberta.ca/willkommen-

deutsch $/ ? p=238 \# h 5 p-228$

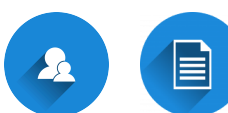

Wo? Wohin? Schreiben Sie die fehlende Präposition und den definiten Artikel im Akkusativ und Dativ. Benutzen Sie das Bild von Carlos' Wohnung.

\section{Media Attributions}

- group (C) IO-Images is licensed under a Public Domain license

- presentation icon (C) quinntheislander adapted by Solomon Hajramezan is licensed under a Public Domain license

- question-mark (C) IO-Images is licensed under a Public Domain license

- partner (C) IO-Images is licensed under a Public Domain license

- document (C) IO-Images is licensed under a Public Domain license 
Einheit 8.8 (online)

\section{Grammatik}

Two-Way Prepositions II

Please work through the following presentation to learn about two-way prepositions.

Two-Way Prepositions II (accusative)

*ACHTUNG* If you need a review of articles + case and/ or contractions. Check out this helpful review document.

\section{Übung 1: Wo? Wohin?}

Beispiel:

Wohin stellt Lin die Statue? (die Kommode) Lin stellt die Statue auf die Kommode.

Wo liegt das Buch? (der Sofatisch) Das Buch liegt auf dem Sofatisch.

An interactive H5P element has been excluded from this version of the text. You can view it online here:

https://openeducationalberta.ca/willkommendeutsch $/ ? p=240 \#$ h5p-179 
Übung 2: Die neue Küche. Mario und Silvia haben ihre Küche neu eingerichtet. Was haben sie gemacht? 


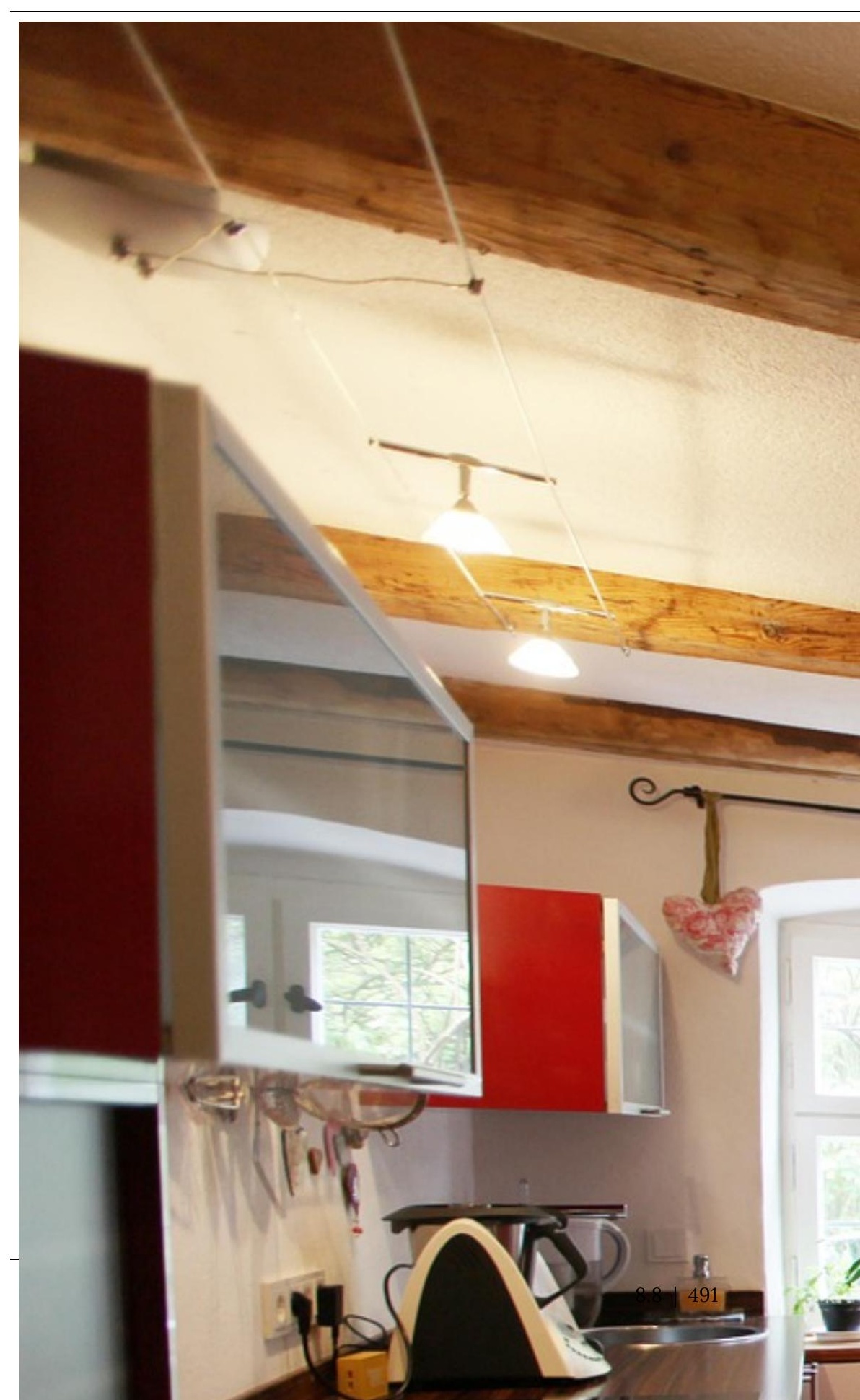


An interactive H5P element has been excluded from this version of the text. You can view it online here:

https://openeducationalberta.ca/willkommendeutsch/?p=240\#h5p-229

Wohnungsanzeigen verstehen. Arbeiten Sie die Präsentation durch und lernen Sie die neuen Vokabeln.

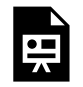
An interactive H5P element has been excluded from this version of the text. You can view it online here:

https://openeducationalberta.ca/willkommendeutsch/?p=240\#h5p-182

Q

\section{Wortschatz in Quizlet:}

Eine Wohnung/ein Zimmer mieten

Wechselpräpositionen und Verben

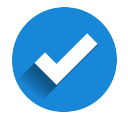

Was wissen Sie jetzt? Das Quiz ist in der nächsten Unterrichtsstunde. 
Extra Practice (optional):

\section{Video Serie - Nicos Weg}

Sehen Sie die Videos an und machen Sie alle Übungen.

Video 1: Auf Wohnungssuche

Video 2: Der Umzug

\section{Media Attributions}

- star (C) IO-Images is licensed under a Public Domain license

- stohrerhof-4970237_1920 @ bene1907 is licensed under a Public Domain license

- stohrerhof-4970238_1920 C bene1907 is licensed under a Public Domain license

- presentation icon (C) quinntheislander adapted by Solomon Hajramezan is licensed under a Public Domain license

- link (C IO-Images is licensed under a Public Domain license

- check mark (C) janjf93 adapted by Solomon Hajramezan is licensed under a Public Domain license 


\section{Einheit 8.9}

eog

Wohnungsanzeige Wortschatz "Quiz"

An interactive H5P element has been excluded from this version of the text. You can view it online here:

https://openeducationalberta.ca/willkommen-

deutsch/?p=242\#h5p-183

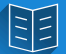

Auf Wohnungssuche. Sehen Sie die Wohnungsanzeigen an und lesen Sie die Texte über die Menschen, die Wohnungen suchen. Was passt zusammen?

Neue Wörter:

allein - alone

draußen - outside

eigen

- own

verdienen - to earn

vorbereiten - to prepare 


\begin{tabular}{|c|c|}
\hline $\begin{array}{l}\text { Anzeige A: } \\
\text { Zur Zwischenmiete!! Zentrale } \\
\text { möblierte 1-Zimmer-Wohnung } \\
\text { mit Einbauküche in Prenzlauer } \\
\text { Berg } \\
1 \text { Zimmer, } 34 \mathrm{~m}^{2} \text { Fläche, } \\
\text { Einbauküche, keine Haustiere, } 1 \\
\text { Monatsmiete Kaution. Kaltmiete } \\
500 €+150 € \text { NK, Gesamtmiete } \\
650 € . \text { Tel. } 0175-4355678\end{array}$ & $\begin{array}{l}\text { Anzeige B: } \\
\text { Schöne 2-ZKB Wohnung mit } \\
\text { Balkon in Prenzlauer Berg ab } \\
\text { sofort verfügbar! } \\
2 \text { Zimmer, } 48 \text { m² Fläche, Balkon, }^{2} \text {, Monatsmiete Kaution. Kaltmiete } \\
389,69 €+140 € \text { NK, Gesamtmiete } \\
529,69 € . \text { Tel. } 0173-8989670\end{array}$ \\
\hline $\begin{array}{l}\text { Anzeige C: } \\
2 \text { Zimmer + Wohnküche im } \\
\text { Erdgeschoss in Prenzlauer Berg } \\
2 \text { Zimmer, } 49,24 \mathrm{~m}^{2} \text { Fläche, } \\
\text { Keller, Einbauküche, Haustiere } \\
\text { nach Vereinbarung, Stellplatz, } 2 \\
\text { Monatsmieten Kaution. Kaltmiete } \\
492,40 €+187 € \text { NK, Gesamtmiete } \\
614,40 € . \text { Tel. } 0179-1213749\end{array}$ & $\begin{array}{l}\text { Anzeige D: } \\
\text { Wunderschöne 4-Zimmer- } \\
\text { Wohnung mit Altbau Charme in } \\
\text { Kreuzberg } \\
\quad 4 \text { Zimmer, } 94 \mathrm{~m}^{2} \text { Fläche, } \\
\text { Haustiere nach Vereinbarung, } 1 \\
\text { Monatsmiete Kaution. Kaltmiete } \\
841,44 €+200 € \text { NK, Gesamtmiete } \\
1041,44 € \text {. Tel. } 030-47361190\end{array}$ \\
\hline $\begin{array}{l}\text { Anzeige E: } \\
\text { Gepflegte 3-Raum-Wohnung mit } \\
\text { Balkon und Einbauküche in } \\
\text { Berlin-Pankow } \\
\quad 3 \text { Zimmer, } 77,35 \mathrm{~m}^{2} \text { Fläche, } \\
\text { Balkon, Keller, Aufzug, } \\
\text { Einbauküche, keine Haustiere, } \\
\text { Garage, } 1 \text { Monatsmiete Kaution. } \\
\text { Kaltmiete } 750 €+200 € \text { NK, } \\
\text { Gesamtmiete } 950 € \text { Tel. } \\
030-7782525\end{array}$ & $\begin{array}{l}\text { Anzeige F: } \\
\text { Helle familienfreundliche } \\
\text { 4-Zimmer-Wohnung in } \\
\text { Weißensee } \\
\quad 4 \text { Zimmer, } 116 \mathrm{~m}^{2} \text { Fläche, Garten, } \\
\text { Terrasse, Keller, Haustiere nach } \\
\text { Vereinbarung, 1 Monatsmiete } \\
\text { Kaution. Kaltmiete } 1489 €+348 € \\
\text { NK, Gesamtmiete } 1837 € . \text { Tel. } \\
\text { 030-46193748 }\end{array}$ \\
\hline
\end{tabular}

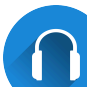

Einen Termin für eine Wohnungsbesichtigung machen. Hören Sie das Telefongespräch.

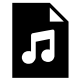

One or more interactive elements has been excluded

from this version of the text. You can view them online

here: https://openeducationalberta.ca/willkommendeutsch/?p=242\#audio-242-1 
1. Zu welcher Anzeige passt das Telefongespräch?

2. Warum kann Familie Möller die Wohnung nur am Nachmittag oder am Abend besichtigen?

3. Wann besichtigen sie die Wohnung?

\section{Media Attributions}

- group (C) IO-Images is licensed under a Public Domain license

- book (C) IO-Images is licensed under a Public Domain license

- headphones (C IO-Images is licensed under a Public Domain license 


\section{Einheit 8.10 (online)}

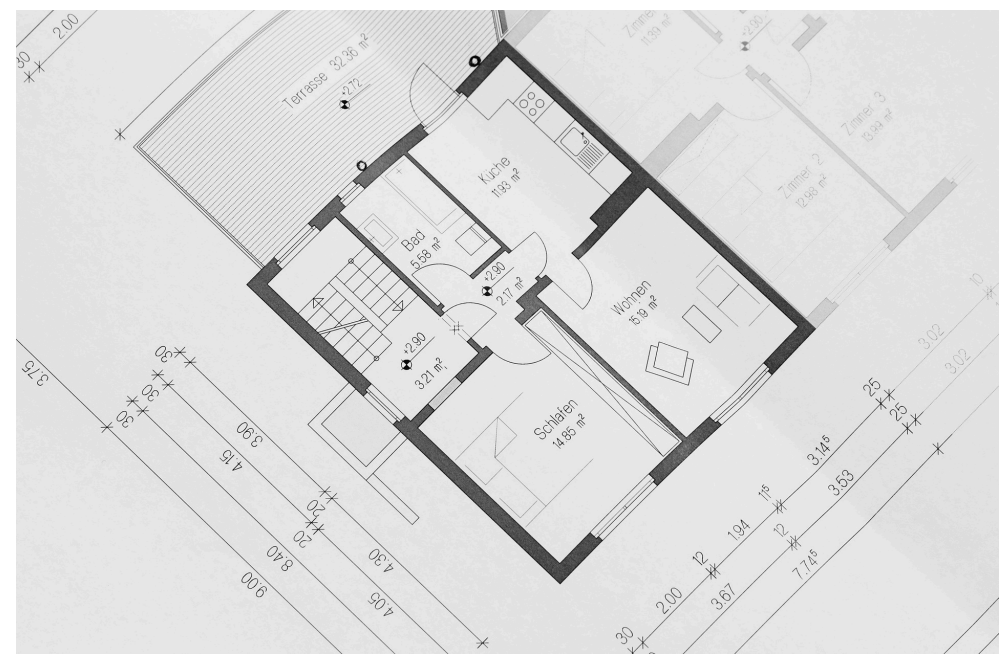

Erste Wege in Deutschland. Nevin wohnt jetzt seit zwei Monaten in Deutschland. Sie und ihr Mann suchen eine neue Wohnung. Sehen Sie den Film und machen Sie danach die Übungen zum Film.

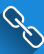

Abkürzungen in Wohnungsanzeigen. Wir haben manche Abkürzungen gelernt, aber wenn Sie noch mehr lernen wollen, gibt es hier eine Liste.

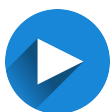

UNESCO-Welterbe. The UNESCO selects areas or landmarks that are culturally, historically, scientifically or otherwise significant and declares them world heritage sites. These sites are 
protected by international treaties. There are 46 World Heritage Sites in Germany (43 cultural and 3 natural).

Today, you will learn something about the "Siedlungen der Berliner Moderne" (Berlin Modernism Housing Estates).

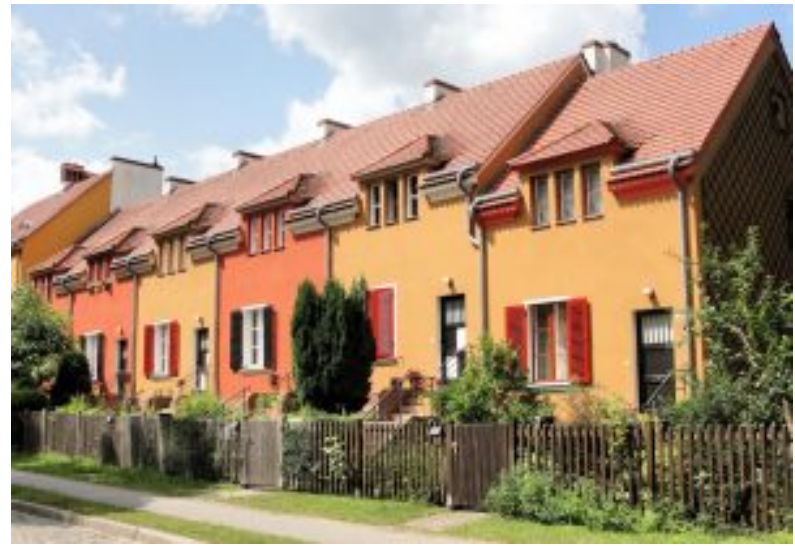

The Berlin Modernism

Housing Estates

consists of six housing estates that testify to innovative housing policies from 1910 to 1933, especially during the Weimar Republic, when the city of Berlir was particularly progressive socially, politically and culturally. The proper is an outstanding example of the buildin reform movement tha contributed to improving housing an living conditions for people with low incomes through nove approaches to town planning, architecture and garden design. (Description adapted from

http://whc.unesco.or en/list/1239 under license $\mathrm{CC}$-BY-SA IGO 3.0) 
Wo sind die Siedlungen der Berliner Moderne auf der Landkarte? Welterbe in Deutschland

Sehen Sie die zwei Videos an und machen Sie Übung 1.

Welterbe: Siedlungen der Berliner Moderne (Deutsche Welle) (1:05 Minuten; Deutsch)

Berlin Modernism Housing Estates (UNESCO/NHK) (2:33 minutes; English)

\section{Übung 1: Siedlungen der Berliner Moderne Fragen} An interactive H5P element has been excluded from this
version of the text. You can view it online here:

https://openeducationalberta.ca/willkommendeutsch/?p=244\#h5p-185

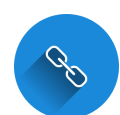

\section{Wortschatz in Quizlet:}

Sonstige Wörter und Ausdrücke

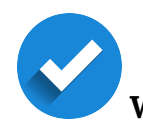

Was wissen Sie jetzt? Klicken Sie hier für Quiz 8.10.

\section{Media Attributions}

- building-plan-354233_1920 (C) cocoparisienne is licensed under a Public Domain license

- link (C) IO-Images is licensed under a Public Domain license

- star (C) IO-Images is licensed under a Public Domain license 
- check mark (C) janjf93 adapted by Solomon Hajramezan is licensed under a Public Domain license 


\section{Einheit 8.11}

200

\section{Was haben Sie schon gelernt?}

An interactive H5P element has been excluded from this version of the text. You can view it online here:

https://openeducationalberta.ca/willkommen-

deutsch/?p=246\#h5p-230

\section{(n) 自}

Auf Zimmersuche. Ina studiert nächstes Semester in Berlin. Jetzt sucht sie ein Zimmer. Hören Sie das Telefongespräch und ergänzen Sie die fehlenden Informationen.

Neue Wörter:

der Stadtteil - area of the city etwas abstellen - to park something

vorbeikommen - to come by klingeln - to ring

I One or more interactive elements has been excluded from this version of the text. You can view them online here: https://openeducationalberta.ca/willkommendeutsch/?p=246\#audio-246-1 


\section{Auf Wohnungssuche}

Ich habe Ihre Anzeige gelesen und ich interessiere mich für die Wohnung.

Ist die Wohnung noch frei? - ab sofort $\mathrm{zu}$ vermieten, ab 1.4. frei, ...

Wie groß ist die Wohnung? Wie viele Quadratmeter Wohnfläche hat die Wohnung?

Wie viele Zimmer hat die Wohnung?

In welchem Stock liegt die Wohnung? - im Erdgeschoss, im 1. Stock, ...

Liegt die Wohnung zentral? Wie weit ist es zum Bahnhof/ zum Zentrum?

Ist es ein Altbau?

Wie hoch ist die Kaltmiete? Wie hoch sind die Nebenkosten?

Muss ich Kaution bezahlen?

\section{Sind Haustiere erlaubt?}

Gibt es einen Keller/ eine Garage/ eine Terrasse/ einen Aufzug/ eine Einbauküche/ einen Balkon/ einen Garten?

Wann kann ich die Wohnung besichtigen/ansehen?

Was ist die genaue Adresse? 
Nach Informationen über eine Wohnung fragen. Arbeiten Sie mit einer Partnerin oder mit einem Partner. Eine Person fragt nach Informationen über Wohnung A (und hat Informationen über Wohnung B). Die andere Person fragt nach Informationen über Wohnung $B$ (und hat Informationen über Wohnung A). Benutzen Sie die Redemittel aus der Box.

\section{Media Attributions}

- group (C) IO-Images is licensed under a Public Domain license

- headphones (C) IO-Images is licensed under a Public Domain license

- document (C) IO-Images is licensed under a Public Domain license

- partner (C) IO-Images is licensed under a Public Domain license 


\section{Einheit 8.12 (online)}

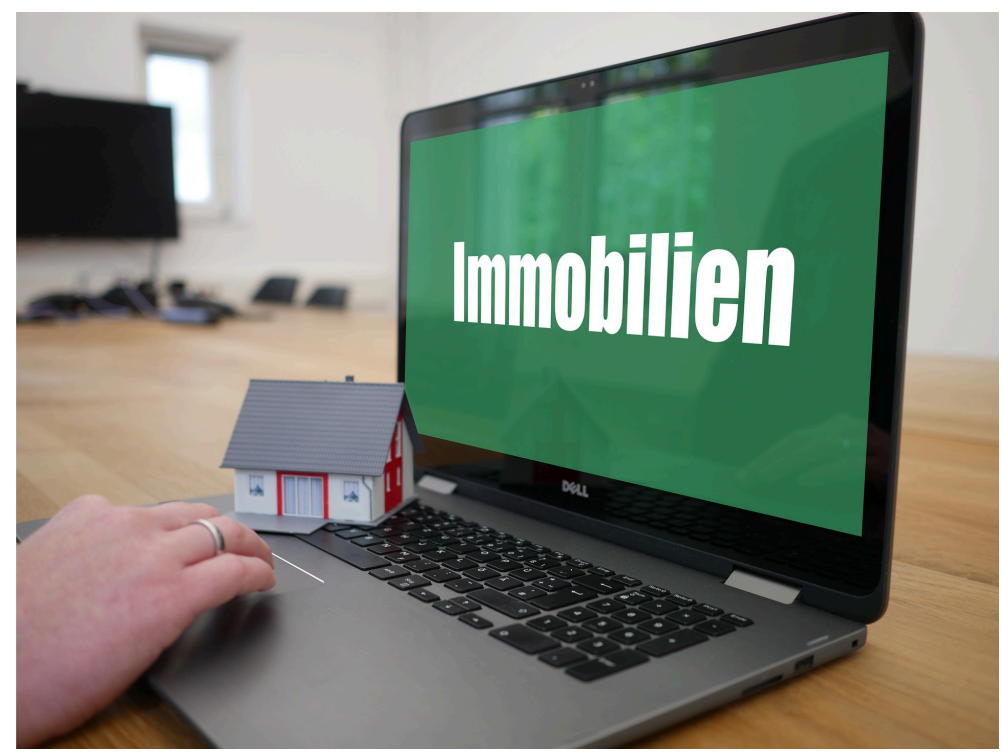

\section{Übung 1}

An interactive H5P element has been excluded from this

믓 version of the text. You can view it online here:

https://openeducationalberta.ca/willkommen-

deutsch/?p=248\#h5p-238

Übung 2. Jan Kopp möchte umziehen. Er hat diese 
Anzeige gelesen. Er möchte einen Termin für eine Wohnungsbesichtigung machen.
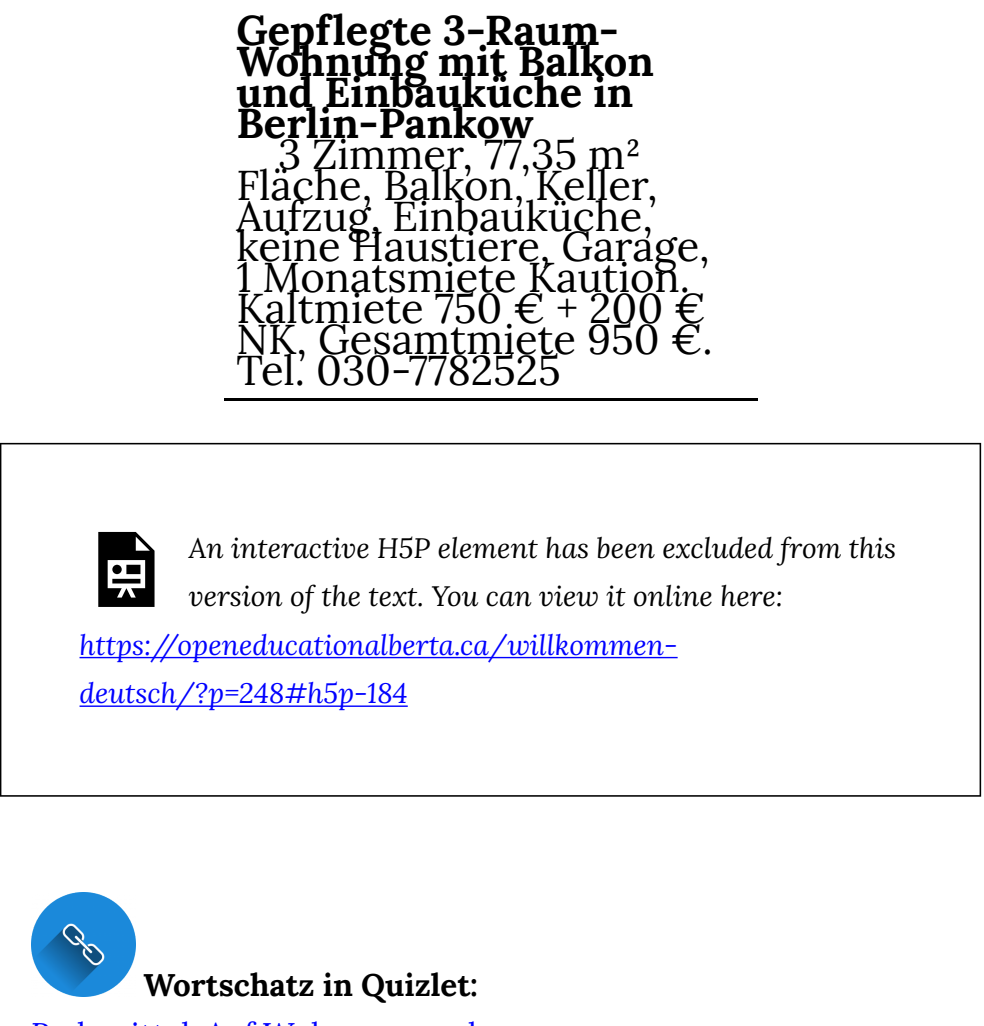

Redemittel: Auf Wohnungssuche

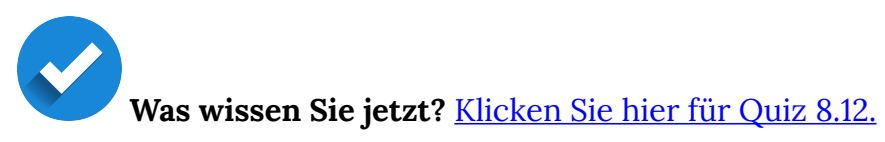

Media Attributions

- real-estate-4503734 1920 @ Jens Neumann is licensed under a 
Public Domain license

- star (C) IO-Images is licensed under a Public Domain license

- link (C) IO-Images is licensed under a Public Domain license

- check mark (C) janjf93 adapted by Solomon Hajramezan is licensed under a Public Domain license 


\section{Einheit 8.13}

200

\section{Wohnungsanzeige Wiederholung}

An interactive H5P element has been excluded from this version of the text. You can view it online here:

https://openeducationalberta.ca/willkommendeutsch/?p=6878\#h5p-296

Was ist eine WG? Sehen Sie das Video an.

\section{0}

Wie fragt man nach Informationen über eine Wohnung?

\section{$\Omega$}

Rollenspiel: Ein Zimmer in der WG. Machen Sie mit einer Partnerin oder mit einem Partner ein Rollenspiel. Wählen Sie eine der fünf Anzeigen für eine WG. Lesen Sie die Anzeigen.

Person A sucht ein Zimmer. Welche Informationen brauchen Sie? Denken Sie an die folgenden Themen:

- Preis des Zimmers

- Größe des Zimmers

- Nebenkosten

- wie weit zur Uni/zum Zentrum

- Besuch von Freunden ok 
Person B vermietet das Zimmer. Was möchten Sie über Person A wissen? Denken Sie an die folgenden Themen:

- Studienfach von Person A

- raucht er/sie

- laute Musik

- Haustiere

- Möbel

- Job

Machen Sie dann das Rollenspiel.

\section{0}

Rollenspiel Präsentationen

Media Attributions

- group (C IO-Images is licensed under a Public Domain license

- partner (C) IO-Images is licensed under a Public Domain license 


\section{Einheit 8.14 (online)}

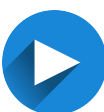

Auf Zimmersuche. Es kann kompliziert sein, ein Zimmer in Deutschland zu finden. Hier ist ein Video mit vielen Tipps! Sehen Sie das Video an, bevor Sie Task 8 machen.

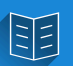

Eine Anzeige verstehen. Lesen Sie die Anzeige für eine WG in der Nähe von Münster und beantworten Sie die Fragen.

WG Zimmer in schöner 3er WG mit Garten

WG-Details: Die WG

- $10 \mathrm{~m}^{2}$ Zimmer in 3er WG

- Wohnungsgröße: $90 \mathrm{~m}^{2}$

- 3er WG (1 Frau / 1 Mann )

- Bewohneralter: 23 bis 25 Jahre

- Rauchen auf dem Balkon erlaubt

- Studenten-WG, keine Zweck-WG

- Sprache/n: Deutsch/Englisch

\section{Gesucht wird}

Kosten

Miete: $290 €$

Nebenkosten: $90 €$

Sonstige Kosten: $55 €$

Kaution: $580 €$

Verfügbarkeit

frei ab: 01.04.2023

Geschlecht egal zwischen 18 und 30 Jahren

\section{Zimmer:}

Die Wohnung liegt im Erdgeschoss. Das Zimmer ist ziemlich hell und (teil)möbliert. Das Zimmer ist nur ca. $10 \mathrm{~m}^{2}$ groß. Besonders schön ist der Schreibtisch direkt am Fenster. Es gibt auch einen kleinen Schrank und ein Bett im Zimmer. Im Haus gibt es außerdem eine Waschmaschine und einen Trockner. Als Ausgleich für das kleine Zimmer haben wir einen großen Wohn- und Essbereich und einen großen Garten, der nur unserer WG gehört.

\section{Lage:}

Da die Wohnung in Hiltrup liegt, sind wir natürlich etwas außerhalb des Zentrums. Dafür haben wir sehr viel Grün in der Umgebung. An Einkaufsmöglichkeiten gibt es Lidl, Aldi, Edeka, etc. 
Außerdem haben wir eine 24 Stunden Tankstelle um die Ecke (;) Mit dem Bus sind es ca. 25 Minuten bis zum Bahnhof in Münster.

\section{WG-Leben:}

Uns ist es wichtig, dass wir als WG gut miteinander klar kommen. Wir quatschen gern einfach mal in der Küche oder im Flur oder kochen zusammen an einem gemeinsamen WG-Abend. Natürlich haben Uni \& Arbeit Priorität und es ist keiner böse, wenn du im Zimmer bleibst :)

\section{Zu deinen Mitbewohnern:}

Joachim (23) studiert Biowissenschaften und macht in seiner Freizeit gerne Sport, vor allem Fitness. Er kocht gerne vegetarisch und ist super entspannt und lustig. Wenn er einkaufen geht, dann fragt er immer, ob er was mitbringen soll und manchmal bekommt man auch was von seinem leckeren gekochten Essen ab ?

Ich bin Magda (25) und studiere Geophysik im 4. Semester. Ich koche ebenfalls sehr gerne und arbeite bei der Post. Bei gutem Wetter/im Sommer bin ich außerdem meist an der frischen Luft zu finden.

Schreib einfach eine Nachricht und stell dich vor $\mathbb{*}$ ?

\section{Übung 1}
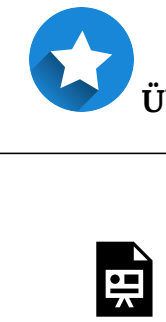

An interactive H5P element has been excluded from this version of the text. You can view it online here:

https://openeducationalberta.ca/willkommendeutsch/?p=6880\#h5p-239

Es gibt kein Quiz für 8.14. 


\section{卌}

Task 8: Das WG-Zimmer

Visit the website https://www.wg-gesucht.de. In the middle drop down menu click on "WG-Zimmer" and put in a city of your choice where it says "Stadt eingeben". Read through a couple of ads and pick one that you like. Write a fake email responding to the people who already live in the WG, introducing yourself, asking questions about them and the room/living arrangements. Remember you can review your email etiquette in Einheit 4.10.

Write at least 150 words. Include a screenshot of the ad you are responding to.

This task will be assessed according to the Rubric for Task 8 .

\section{Media Attributions}

- book (C) IO-Images is licensed under a Public Domain license

- star (C) IO-Images is licensed under a Public Domain license

- check mark (C) janjf93 adapted by Solomon Hajramezan is licensed under a Public Domain license

- keyboard (C) IO-Images is licensed under a Public Domain license 


\section{Wortschatz}

Quizlet:

Wortschatz Einheit 8 (alle Kategorien)

Wohnmöglichkeiten

Zimmer in einem Haus/in einer Wohnung

Wohnen in Kanada und Deutschland

Möbel und andere Dinge im Haus

Möbel und andere Dinge im Haus (plurals)

Eine Wohnung/ein Zimmer mieten

Redemittel: Auf Wohnungssuche

Wechselpräpositionen und Verben

Sonstige Wörter und Ausdrücke

Wortschatz 8

Media Attributions

- $\underline{\text { link }}$ C IO-Images is licensed under a Public Domain license

- pdf (C IO-Images is licensed under a Public Domain license 


\section{Zum Spaß!}

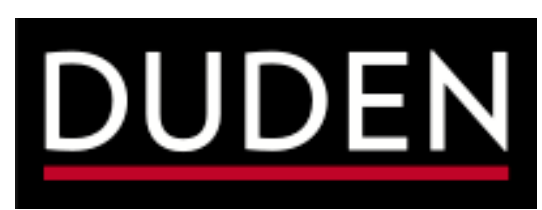

This chapter we learned about compound nouns! Here is a video that talks about other "funny" things about the German language. Interested to learn when one would say "Nöö!" or "Boah!"? Watch this video! 


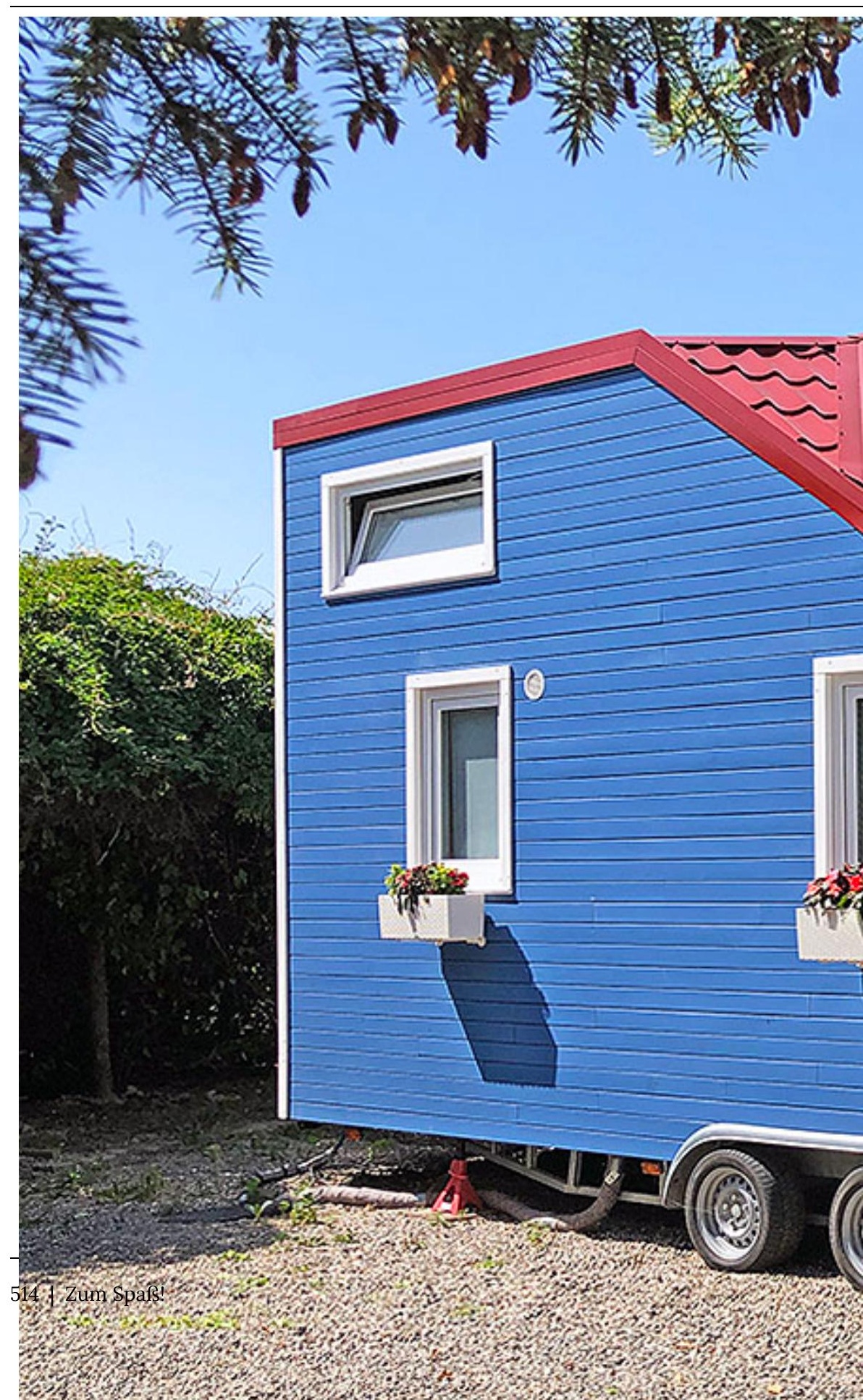



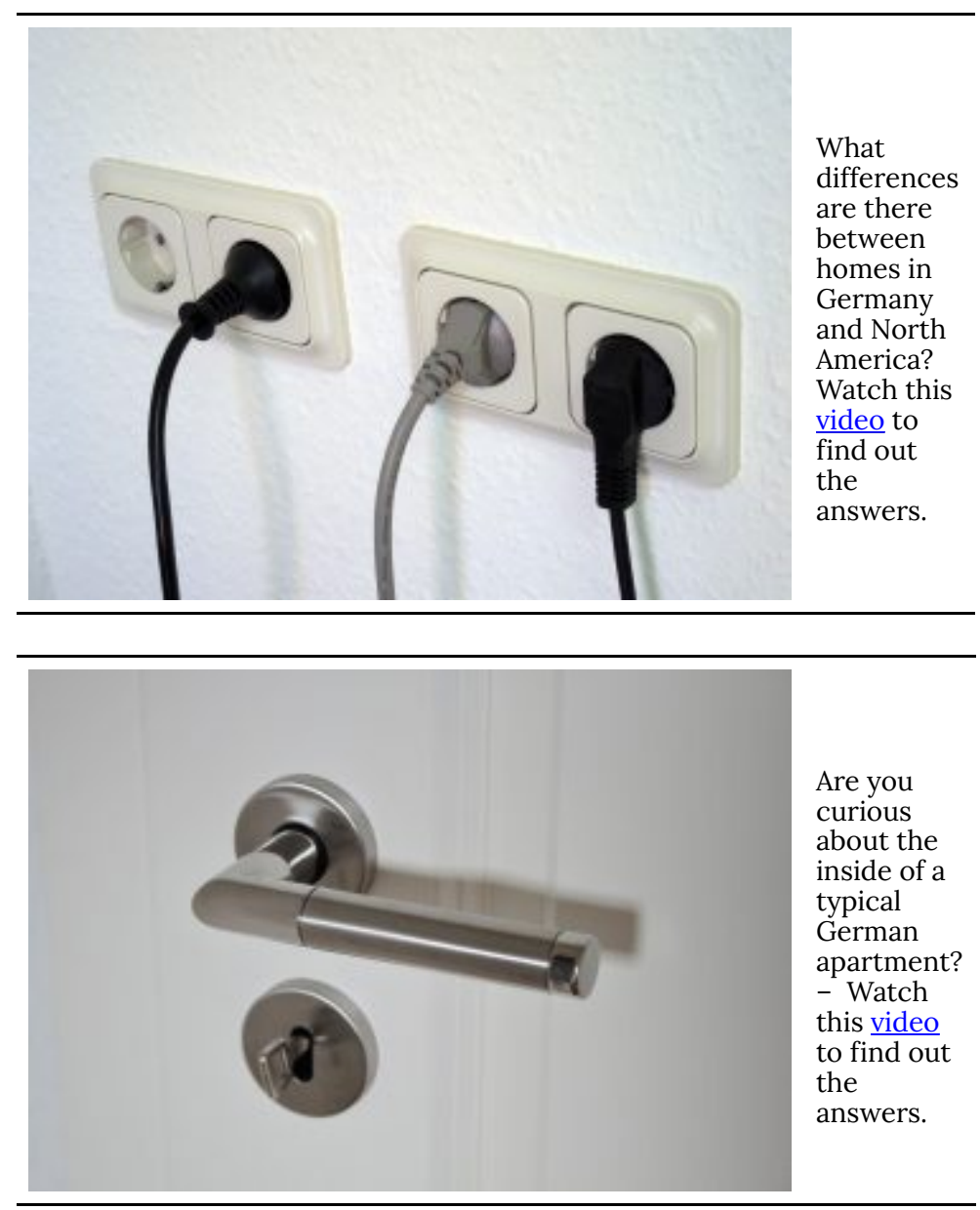

Extra Practice (optional): These activities are from the website Schubert-Verlag.

Wohnen in Deutschland

Meine neue Wohnung

In der Wohnung

Akkusativ oder Dativ

Die Wohnungseinrichtung

Wer wohnt wo?

Die neue Wohnung von Bettina 
Annas neue Wohngemeinschaft (Hören)

Media Attributions

- Duden Logo 2017.svg is licensed under a Public Domain license

- Rolling_Tiny_House_mit_Pelletofen_auf_PKW-Anhänger (C) Küste is licensed under a Public Domain license

- power-outlet-g51816d211_1920 (C) succo is licensed under a Public Domain license

- door-handle-gfb3363263_1920 (C) Anja is licensed under a Public Domain license 


\section{EINHEIT 9: GUTEN APPETIT!}

Learning Outcomes

At the end of Einheit 9, you will be able to...

- $\quad$ identify and describe grocery items

- go shopping in a supermarket/market

- describe the German recycling system and sort garbage accordingly

- $\quad$ name and describe some regional food specialties

- $\quad$ order food in a restaurant

- discuss cultural differences when going to a German restaurant (getting a table, placing your cutlery appropriately, tipping, etc.)

- $\quad$ identify and describe some features of UNESCO world heritage sites, in particular the Klassisches Weimar in Weimar

- discuss some aspects of the life and work of Johann Wolfgang von Goethe

- talk about a famous German drama (Faust, by Goethe) in its cultural and historical context

You will also have learned about the following structures:

- $\quad$ adjective endings (review)

- future tense 
- relative pronouns and relative clauses 


\section{Einheit 9.1}
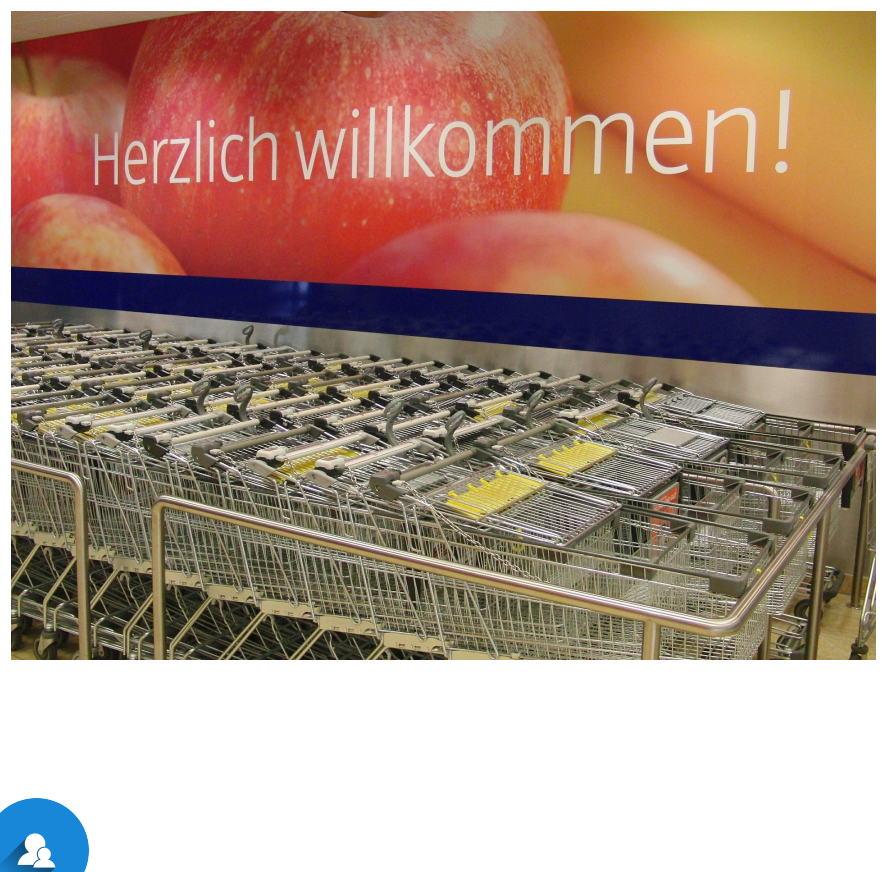

Wie oft...? Machen Sie ein Interview mit Ihrer Partnerin oder mit Ihrem Partner. Benutzen Sie die Beispiele in der Box in Ihrer Antwort.

$\begin{array}{ccccc}\text { einmal pro Tag } & \text { zweimal pro Woche } & \text { dreimal pro Monat } & \text { jeden } \\ \text { immer } & \text { manchmal } & \text { selten nie }\end{array}$

1. Wie oft kochst du selbst?

2. Wie oft frühstückst du?

3. Wie oft trinkst du Alkohol?

4. Wie oft lädst du Freunde zum Essen ein?

5. Wie oft isst du Süßigkeiten?

6. Wie oft gehst du ins Restaurant?

7. Wie oft bringst du leere Flaschen weg?

8. Wie oft kaufst du im Supermarkt ein? 
Beispiel:

S1: Wie oft kochst du selbst?

S2: Ich koche zweimal pro Woche selbst.

200

Welche Lebensmittel kennen Sie schon?

An interactive H5P element has been excluded from this version of the text. You can view it online here:

https://openeducationalberta.ca/willkommendeutsch/?p=731\#h5p-240

만

Lebensmittel

An interactive H5P element has been excluded from this version of the text. You can view it online here:

https://openeducationalberta.ca/willkommen-

deutsch/?p=731\#h5p-242

\section{Media Attributions}

- shopping-cart-452816_1920 C Sven Kleinschmidt is licensed under a Public Domain license

- partner (C) IO-Images is licensed under a Public Domain license

- group (C) IO-Images is licensed under a Public Domain license 
- presentation icon (C) quinntheislander adapted by Solomon Hajramezan is licensed under a Public Domain license 
Einheit 9.2 (online)
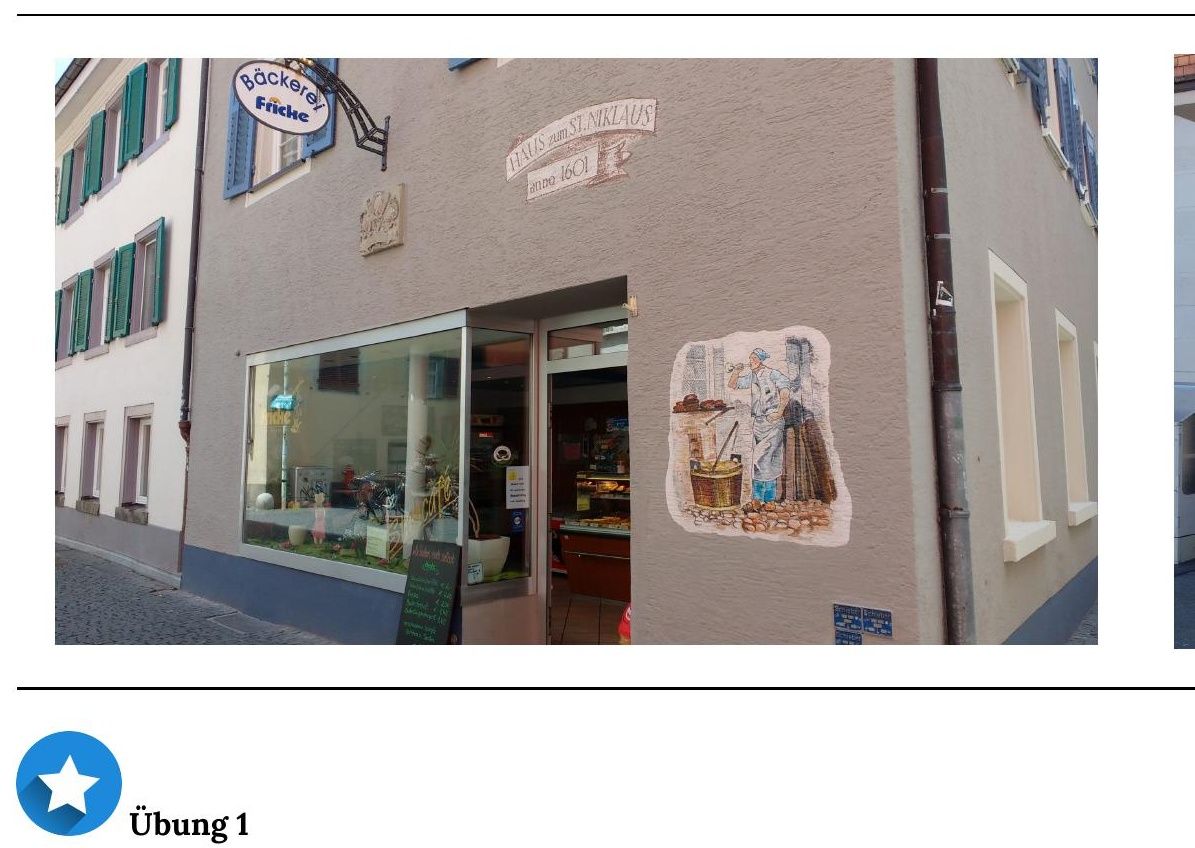

An interactive H5P element has been excluded from this
version of the text. You can view it online here:
https://openeducationalberta.ca/willkommen-
deutsch/?p=734\#h5p-243

Übung 2. Wo kaufen Sie diese Lebensmittel ein? 
An interactive H5P element has been excluded from this version of the text. You can view it online here:

https://openeducationalberta.ca/willkommen-

deutsch/?p=734\#h5p-244

Metzger vs. Fleischer

Different regions in the German-speaking countries often use a different word for certain professions, food items, etc.

As you can see in the image, Schlachter is used primarily in the north, Fleischer in the east, Metzger in the west and south, and Fleischhacker and Fleischhauer in Austria. 


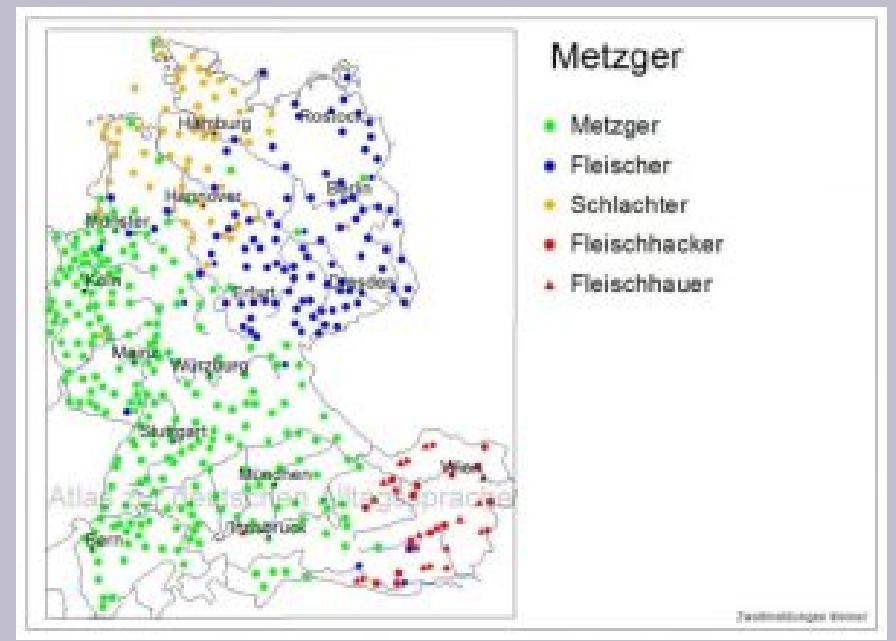

Quelle: Metzger bzw. Schlachter; Atlas zur deutschen Alltagssprache

What are these interesting meats? Do all Germans eat meat? Find out the answers in this video. 

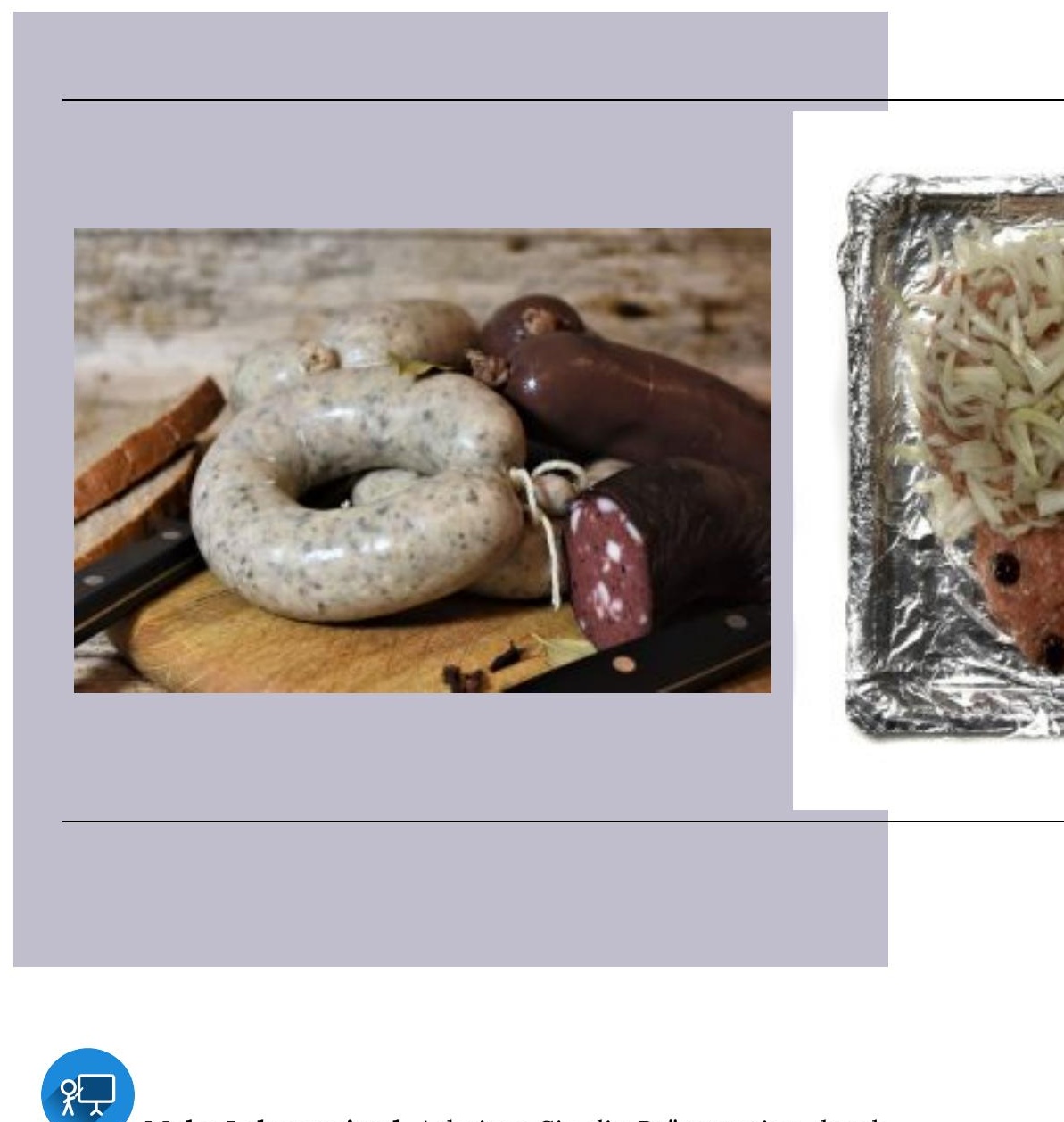

Mehr Lebensmittel. Arbeiten Sie die Präsentation durch und lernen Sie die neuen Vokabeln.

An interactive H5P element has been excluded from this version of the text. You can view it online here: 
https://openeducationalberta.ca/willkommen-

deutsch/?p=734\#h5p-241

Übung 3. Wenn man einkaufen geht, muss man oft Mengenangaben benutzen. Sie können die Ausdrücke mit dieser Übung lernen.

An interactive H5P element has been excluded from this version of the text. You can view it online here:

https://openeducationalberta.ca/willkommen-

deutsch/?p=734\#h5p-245

ก

Christian geht einkaufen. Hören Sie den Dialog und machen Sie Übung 4.

One or more interactive elements has been excluded

1 from this version of the text. You can view them online

here: https://openeducationalberta.ca/willkommen-

deutsch/?p=734\#audio-734-1 


\section{Übung 4}

An interactive H5P element has been excluded from this

뭇 version of the text. You can view it online here:

https://openeducationalberta.ca/willkommen-

deutsch/?p=734\#h5p-246

\section{Redemittel}

Beim Einkaufen 


\begin{tabular}{|c|c|}
\hline $\begin{array}{l}\text { die Verkäuferin/der } \\
\text { Verkäufer: }\end{array}$ & die Kundin/der Kunde: \\
\hline $\begin{array}{l}\text { fragen, was jemand möchte: } \\
\text { - } \quad \text { Was darf es sein? } \\
\text { - } \quad \text { Bitte schön?/ Sie } \\
\text { wünschen? } \\
\text { - Welchen Käse } \\
\text { möchten Sie? } \\
\text { - Welche Wurst ...?/ } \\
\text { - Welches Brot ...? } \\
\text { Darf es sonst noch } \\
\text { etwas sein? }\end{array}$ & $\begin{array}{l}\text { sagen, was man möchte: } \\
\text { - } \quad 2 \text { Kilo Zwiebeln/ } 300 \\
\text { - } \quad \text { Ich hätte gern .../ Ich } \\
\text { möchte ... } \\
\text { - } \quad \text { Ich nehme den Gouda. } \\
\text { - } \quad \text { Haben Sie ...? } \\
\text { - } \quad \text { Danke, das ist alles. }\end{array}$ \\
\hline $\begin{array}{l}\text { den Preis nennen: } \\
\text { - } \quad 300 \text { Gramm kosten } 3 \\
\text { Euro } 99 . \\
\text { Das macht } 25 \text { Euro } 45 \\
\text { zusammen. }\end{array}$ & $\begin{array}{l}\text { nach dem Preis fragen: } \\
\text { - Was kostet ...?/ Wie } \\
\text { viel kosten ...? } \\
\text { - Was macht das? }\end{array}$ \\
\hline
\end{tabular}

\section{Wortschatz in Quizlet:}

$\underline{\text { Obst }}$

Gemüse

Obst und Gemüse (plural)

Fleisch, Fisch und Geflügel

Einkaufsmöglichkeiten

Mengenangaben

$\underline{\text { Redemittel: Beim Einkaufen }}$

Was wissen Sie jetzt? Klicken Sie hier für Quiz 9.2. 


\section{Media Attributions}

- die Bäckerei (C) ckost is licensed under a CC BY-NC-SA (Attribution NonCommercial ShareAlike) license

- die Metzgerei (C) ckost is licensed under a CC BY-NC-SA (Attribution NonCommercial ShareAlike) license

- star (C) IO-Images is licensed under a Public Domain license

- Metzger vs Fleischer (C) Atlas zur deutschen Alltagssprache is licensed under a Public Domain license

- liver-sausage-g303b87890_1920 C RitaE is licensed under a Public Domain license

- Mettigel_1 (C) Boris Kumicak + Kai Namslau - Studio Kumicak + Namslau is licensed under a CC BY-SA (Attribution ShareAlike) license

- meatloaf-ge19189faf_1920 (C) RitaE is licensed under a Public Domain license

- presentation icon (C) quinntheislander adapted by Solomon Hajramezan is licensed under a Public Domain license

- headphones (C) IO-Images is licensed under a Public Domain license

- link (C) IO-Images is licensed under a Public Domain license

- check mark (C) janjf93 adapted by Solomon Hajramezan is licensed under a Public Domain license 


\section{Einheit 9.3}

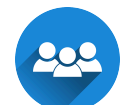

\section{Was haben Sie schon gelernt?}
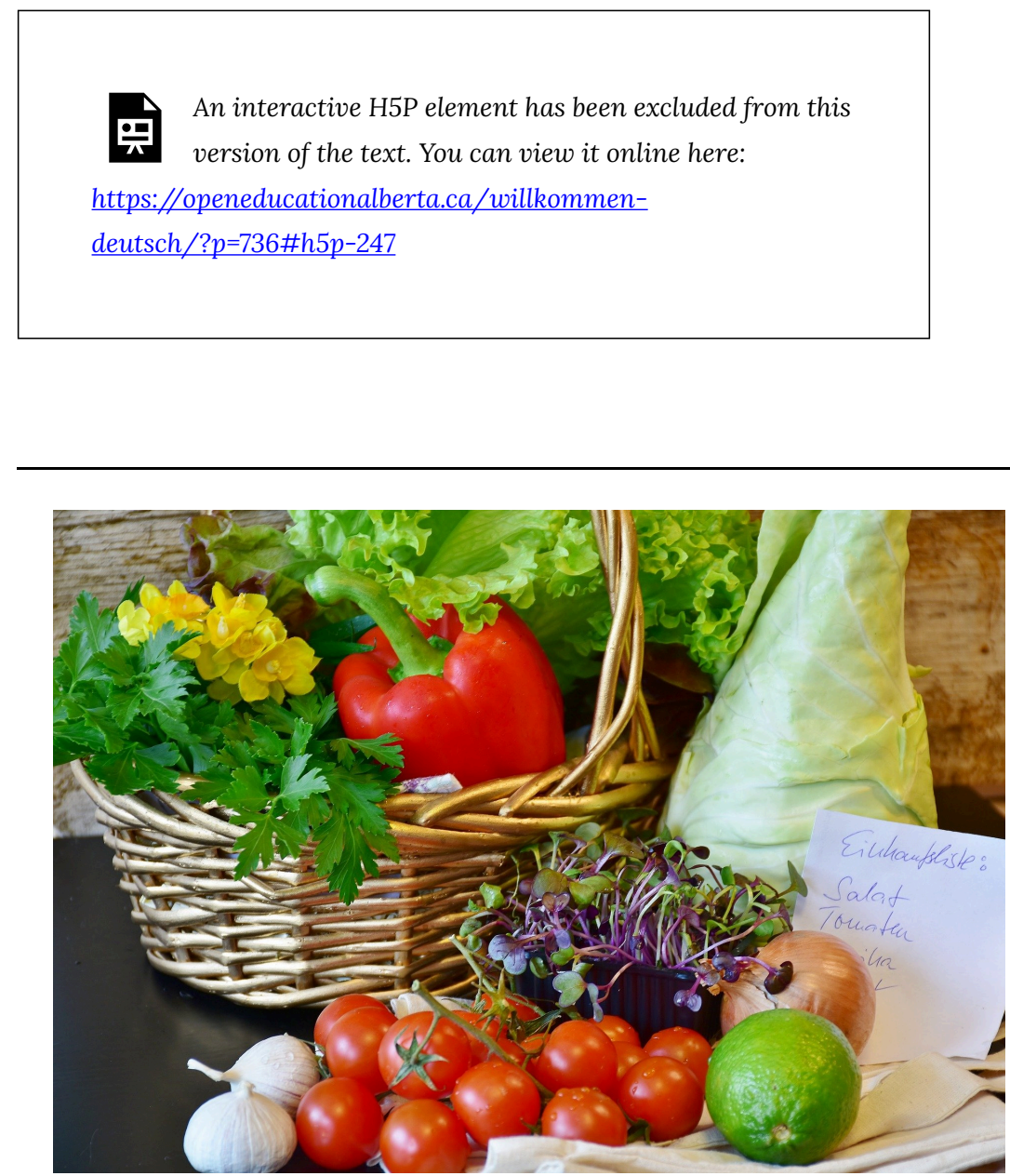
Auf dem Markt. Hören Sie den Dialog und ergänzen Sie die fehlenden Informationen.

One or more interactive elements has been excluded $\sqrt{ }$ from this version of the text. You can view them online here: https://openeducationalberta.ca/willkommendeutsch/?p=736\#audio-736-1

\section{eog}

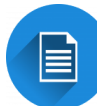

Einkaufen auf dem Markt. Machen Sie ein Rollenspiel: einige von Ihnen sind Verkäuferinnen oder Verkäufer bei einem Marktstand, die anderen bekommen einen Einkaufszettel und kaufen ein. Benutzen Sie die Redemittel von 9.2.

An interactive H5P element has been excluded from this
version of the text. You can view it online here:
https://openeducationalberta.ca/willkommen-
$\underline{\text { deutsch/?p=736\#h5p-259 }}$

\section{Media Attributions}

- group (C) IO-Images is licensed under a Public Domain license

- vegetables-2268682_1920 (1) (C) RitaE is licensed under a Public Domain license 
- der Markt 1 (C) ckost is licensed under a Public Domain license

- headphones (C) IO-Images is licensed under a Public Domain license

- document (C) IO-Images is licensed under a Public Domain license 
Einheit 9.4 (online)
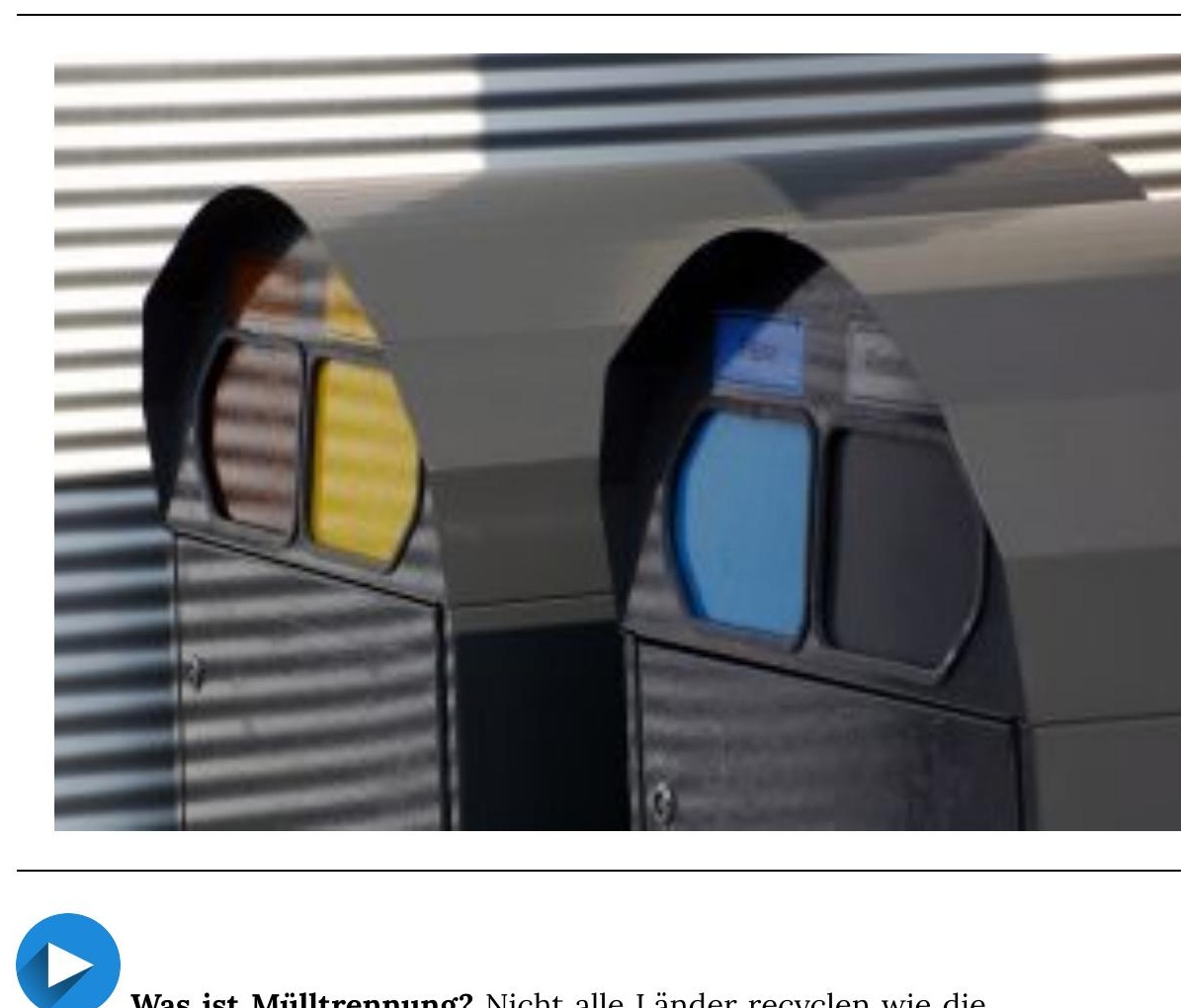

Was ist Mülltrennung? Nicht alle Länder recyclen wie die Deutschen. Duncan kommt aus Neuseeland und wohnt in einer WG in Deutschland. Er lernt sehr schnell, was "Mülltrennung" bedeutet. Sehen Sie das Video an, bevor Sie mehr über Mülltrennung lernen.

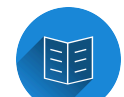

Mülltrennung in Deutschland. Lesen Sie den Text.

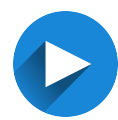

Wie trenne ich meinen Müll? Sehen Sie die zwei Videos über Mülltrennung an.

1. Wie trenne ich den Müll in Deutschland?

2. Mülltrennung in Deutschland 
Altglasein

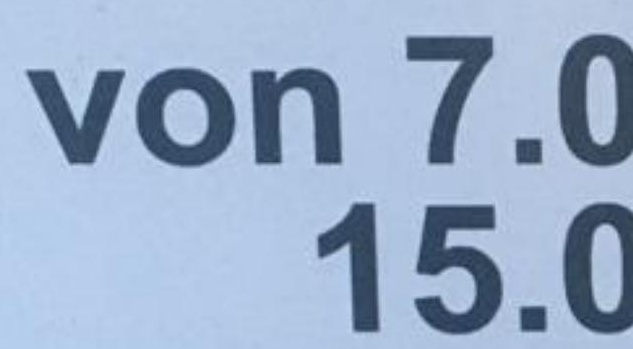

Sonn- u

Bitte nehmen Sie Vie 
Übung 1. Sortieren Sie den Müll in die richtige Tonne.
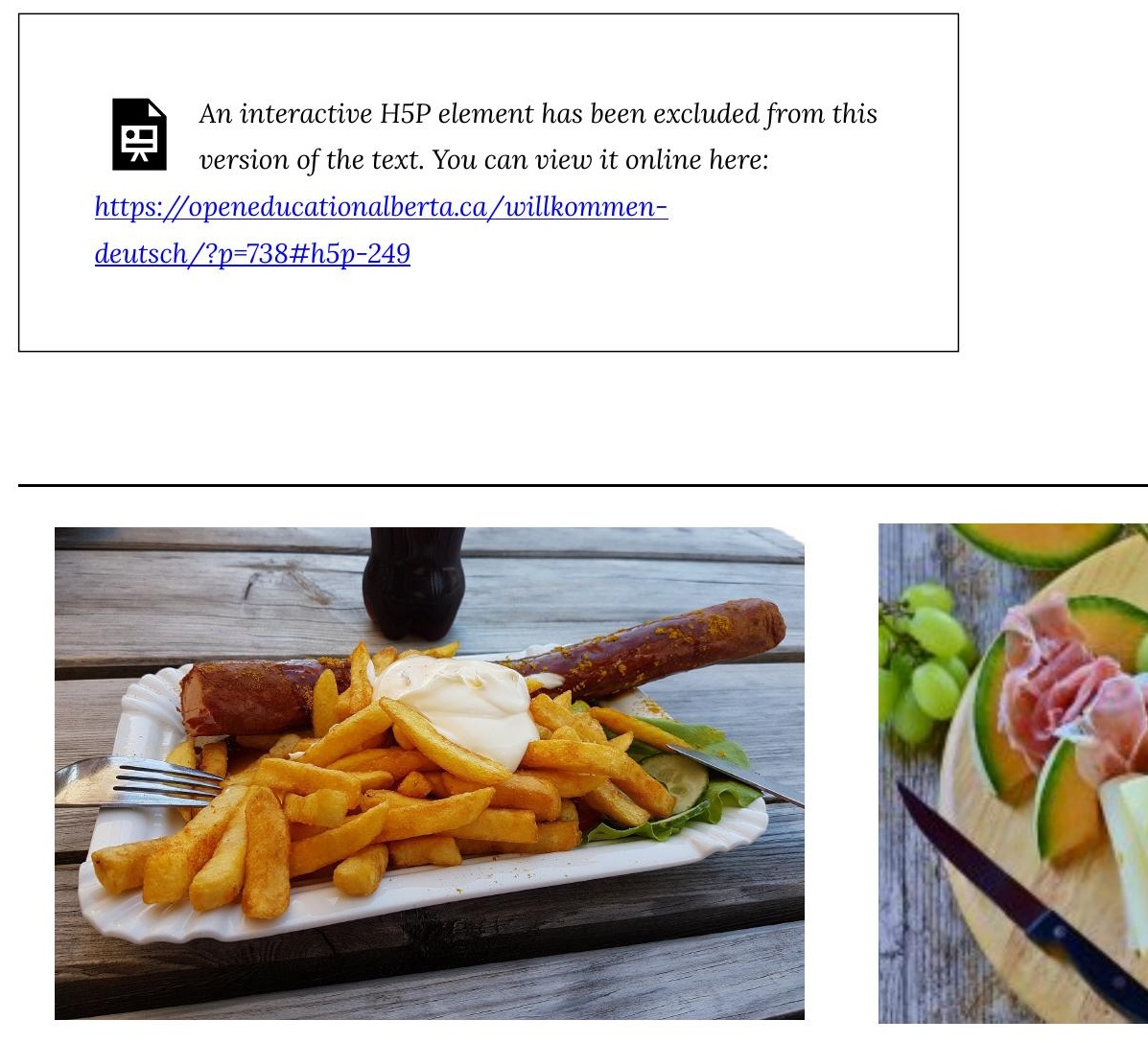

Mittagessen vs. Abendessen 


\section{In the}

German-

speaking

countries,

people usually

eat their hot

meal for lunch.

University

students often

eat in the Mensa, a canteen at the university,

where they can

select from a

variety of food

items, from

appetizers to

main courses to

deserts. The food is usually quite good and very affordable for the students. People working in businesses might go to a restaurant, get a quick snack (Imbiss) or bring their own lunch. Large companies often have their own canteen
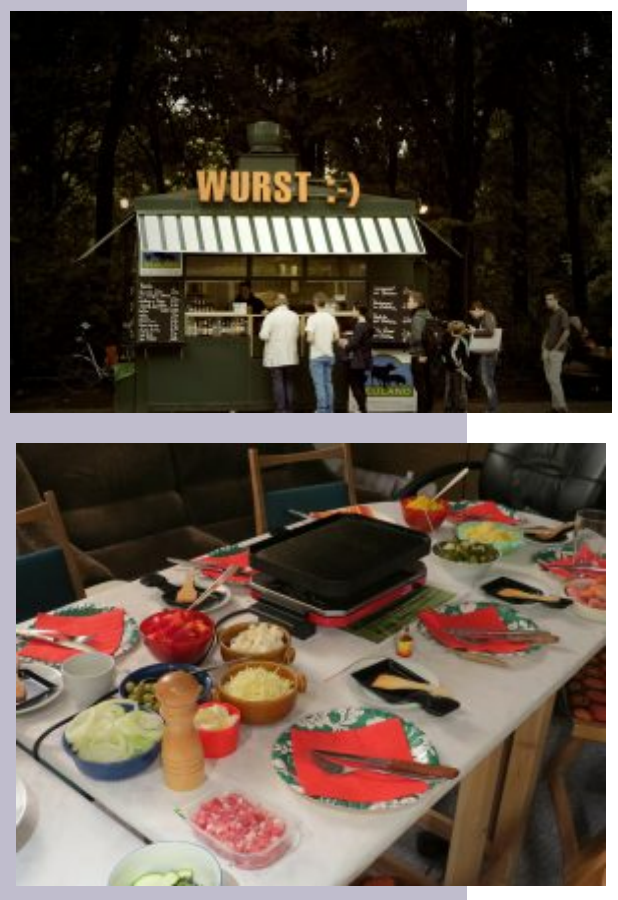
where

employees can

eat hot meals for

lunch.

Most of the

time,

the Abendessen is

a smaller meal, consisting of

bread, cold cuts,

cheese, or a

salad. On special

occasions and

celebrations,

some people

would have a hot

meal in the

evening, such as

when they make

fondue or

raclette.

This video gives you an overview of Mittagessen vs.

Abendessen as well as regional dishes and of course Kaffee und Kuchen.

Would you like to learn more about Abendessen or what is sometimes called Abendbrot? Watch these videos:

- Why Germans eat bread for dinner

- $\quad$ Abendbrot: Warum isst man in Deutschland abends kalt? 
Wortschatz in Quizlet:

Mülltrennung

Mahlzeiten

Was wissen Sie jetzt? Klicken Sie hier für Quiz 9.4.

Extra Practice (optional):

\section{Video Serie - Nicos Weg}

Sehen Sie das Video über Recycling und Mülltrennung an und machen Sie alle Übungen.

\section{Media Attributions}

- garbage-1506937_1920 @ Friedrich Frühling is licensed under a Public Domain license

- book (C) IO-Images is licensed under a Public Domain license

- IMG-20201230-WA0004 C ckost is licensed under a Public Domain license

- IMG-20201230-WA0005 @ ckost is licensed under a Public Domain license

- star (C) IO-Images is licensed under a Public Domain license

- eat-4346396_1920 (1) (C) Jens Thramann is licensed under a Public Domain license

- bread-3571266_1920 (C) RitaE is licensed under a Public Domain license

- snack-bar-413742_1920 C Picography is licensed under a Public Domain license 
- raclette-81401_1920 (C) Hans Braxmeier is licensed under a Public Domain license

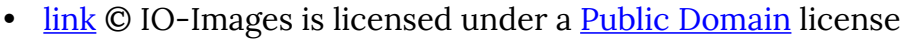

- check mark ( janjf93 adapted by Solomon Hajramezan is licensed under a Public Domain license 


\section{Einheit 9.5}

\section{0}

Müll sortieren: Was kommt in welche Tonne?

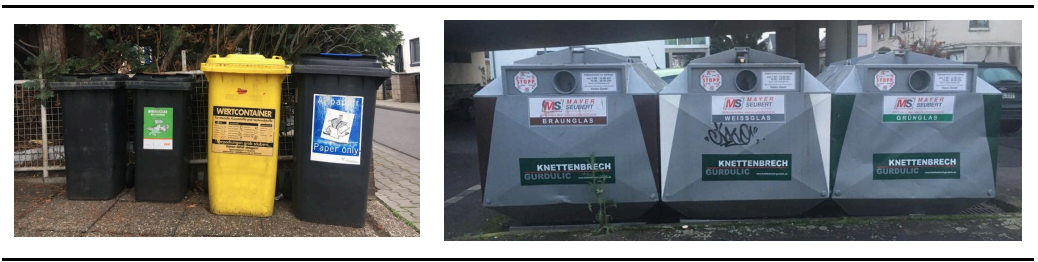

\section{0}

Wo essen Sie normalerweise zu Mittag?

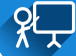

Das Mittagessen

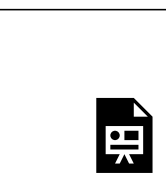

An interactive H5P element has been excluded from this version of the text. You can view it online here:

https://openeducationalberta.ca/willkommendeutsch/?p=740\#h5p-248

Wo geht ihr gern essen? Lesen Sie die Texte in einer Kleingruppe.

Neue Wörter:

die Auswahl - choice

unglaublich - incredible

$540 \mid 9.5$ 


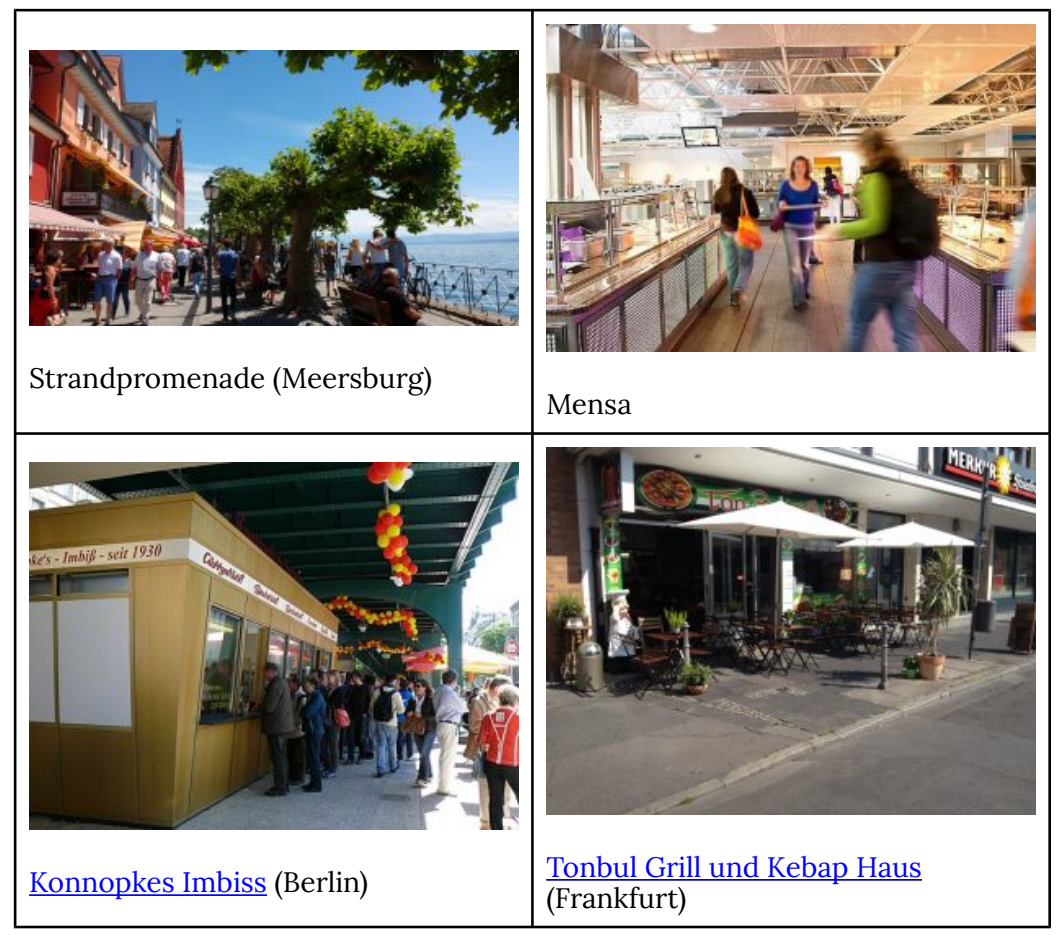

Media Attributions

- group (C) IO-Images is licensed under a Public Domain license

- Mülltonnen (C) ckost is licensed under a Public Domain license

- Altglascontainer (C) ckost is licensed under a Public Domain license

- presentation icon (C) quinntheislander adapted by Solomon Hajramezan is licensed under a Public Domain license

- book (C) IO-Images is licensed under a Public Domain license

- Meersburg Promenade (C) ckost is licensed under a Public Domain license 
- HHU_Mensa (C) Heinrich-Heine-Universität Düsseldorf is licensed under a CC BY-SA (Attribution ShareAlike) license

- Konnopkes Imbiss (C) Fridolin freudenfett (peter Kuley) is licensed under a CC BY-SA (Attribution ShareAlike) license

- Tonbul Grill und Kebap Haus is licensed under a CC BY-SA (Attribution ShareAlike) license 


\section{Einheit 9.6 (online)}

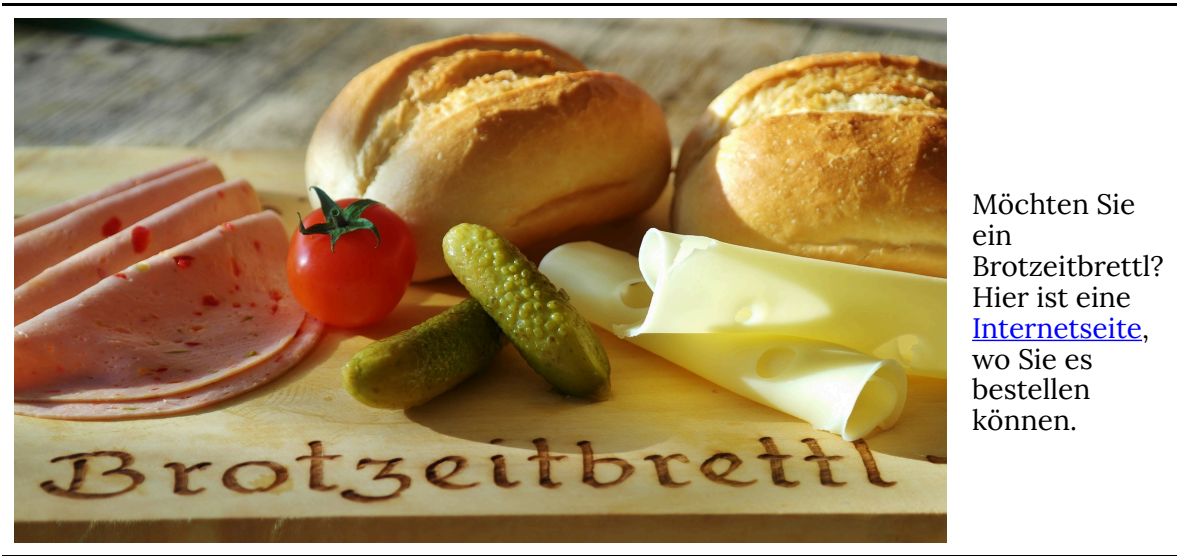

Übung 1

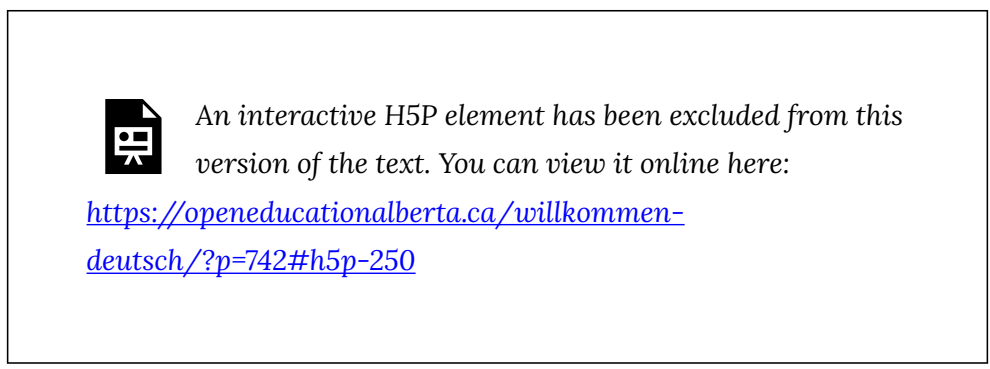

\section{Grammatik}

Adjective Endings 
In Einheit 3, you already learned the adjective endings for the der-words and the ein-words in the nominative case (Einheit 3.6) and in the accusative case (Einheit 3.10), and in Einheit 5, you learned the adjective endings in the dative case (Einheit 5.10). Here are some tables for review:

\section{der-words}

\begin{tabular}{|c|c|c|c|c|}
\hline & $\begin{array}{c}\text { masculi } \\
\text { ne }\end{array}$ & feminine & $\begin{array}{c}\text { neute } \\
\mathrm{r}\end{array}$ & plural \\
\hline $\begin{array}{c}\text { nominat } \\
\text { ive }\end{array}$ & $\begin{array}{c}\text { der } \\
\text { starke } \\
\text { Kaffee }\end{array}$ & $\begin{array}{l}\text { die } \\
\text { italienische } \\
\text { Salami }\end{array}$ & $\begin{array}{l}\text { das } \\
\text { kalte } \\
\text { Bier }\end{array}$ & $\begin{array}{l}\text { die } \\
\text { frischen } \\
\text { Brötchen }\end{array}$ \\
\hline \multirow{2}{*}{ accusati } & $\begin{array}{c}\text { den } \\
\text { starken } \\
\text { Kaffee }\end{array}$ & $\begin{array}{l}\text { die } \\
\text { italienische } \\
\text { Salami }\end{array}$ & $\begin{array}{l}\text { das } \\
\text { kalte } \\
\text { Bier }\end{array}$ & $\begin{array}{l}\text { die } \\
\text { frischen } \\
\text { Brötchen }\end{array}$ \\
\hline dative & $\begin{array}{c}\text { dem } \\
\text { starken } \\
\text { Kaffee }\end{array}$ & $\begin{array}{l}\text { der } \\
\text { italienischen } \\
\text { Salami }\end{array}$ & $\begin{array}{l}\text { dem } \\
\text { kalten } \\
\text { Bier }\end{array}$ & $\begin{array}{l}\text { den } \\
\text { frischen } \\
\text { Brötchen }\end{array}$ \\
\hline
\end{tabular}

Beispiele:

Nominative: Das kalte Bier schmeckt gut!

Accuative: Hast du diesen starken Kaffee gemacht?

Dative: Mit der italienischen Salami schmeckt das Brot besonders gut!

\section{ein-words}




\begin{tabular}{|c|l|l|l|l|}
\hline & $\begin{array}{c}\text { masculi } \\
\text { ne }\end{array}$ & feminine & $\begin{array}{c}\text { neute } \\
\mathrm{r}\end{array}$ & plural \\
\hline $\begin{array}{c}\text { nominat } \\
\text { ive }\end{array}$ & $\begin{array}{l}\text { ein } \\
\text { Starker } \\
\text { Kaffee }\end{array}$ & $\begin{array}{l}\text { eine } \\
\text { italienische } \\
\text { Salami }\end{array}$ & $\begin{array}{l}\text { ein } \\
\text { kaltes } \\
\text { Bier }\end{array}$ & $\begin{array}{c}\text { keine } \\
\text { frischen } \\
\text { Brötchen }\end{array}$ \\
\hline \multirow{2}{*}{ accusati } & $\begin{array}{l}\text { einen } \\
\text { starken } \\
\text { Kaffee }\end{array}$ & $\begin{array}{l}\text { eine } \\
\text { italienische } \\
\text { Salami }\end{array}$ & $\begin{array}{l}\text { ein } \\
\text { kaltes } \\
\text { Bier }\end{array}$ & $\begin{array}{l}\text { keine } \\
\text { frischen } \\
\text { Brötchen }\end{array}$ \\
\hline \multirow{2}{*}{ dative } & $\begin{array}{l}\text { einem } \\
\text { starken } \\
\text { Kaffee }\end{array}$ & $\begin{array}{l}\text { einer } \\
\text { italienischen } \\
\text { Salami }\end{array}$ & $\begin{array}{l}\text { eine } \\
\text { kalten } \\
\text { Bier }\end{array}$ & $\begin{array}{l}\text { keinen } \\
\text { frischen } \\
\text { Brötchen }\end{array}$ \\
\hline
\end{tabular}

Beispiele:

Nominative: Ein starker Kaffee ist wichtig am Morgen.

Accusative: Magst du keine frischen Brötchen?

Dative: Mit einem kalten Bier kann man gut relaxen.

There are also circumstances when there is no article in front of the adjective. We call these "unpreceded" and the adjective takes the ending of the der-words.

unpreceded (=no article in front of the adjective) 


\begin{tabular}{|c|c|c|c|c|}
\hline $\begin{array}{c}\text { masculi } \\
\text { ne } \\
\text { ive }\end{array}$ & feminine & $\begin{array}{c}\text { neut } \\
\text { er }\end{array}$ & plural \\
\hline accusati & $\begin{array}{c}\text { starker } \\
\text { Kaffee }\end{array}$ & $\begin{array}{c}\text { italienisc } \\
\text { he Salami } \\
\text { Kaffee }\end{array}$ & $\begin{array}{c}\text { kalte } \\
\text { s Bier }\end{array}$ & $\begin{array}{c}\text { frische Brötch } \\
\text { en }\end{array}$ \\
\hline he Salami & $\begin{array}{c}\text { kalte } \\
\text { s Bier }\end{array}$ & $\begin{array}{c}\text { frische Brötch } \\
\text { en }\end{array}$ \\
\hline dative & $\begin{array}{c}\text { starke } \\
\text { m Kaffee }\end{array}$ & $\begin{array}{c}\text { italienisc } \\
\text { her Salami }\end{array}$ & $\begin{array}{c}\text { kalte } \\
\text { m Bier }\end{array}$ & $\begin{array}{c}\text { Brischen } \\
\text { Brötchen }\end{array}$ \\
\hline
\end{tabular}

Beispiele:

Nominative: Italienische Salami ist am besten!

Accusative: Ich trinke gern starken Kaffee!

Dative: Von kaltem Bier bekomme ich Bauchschmerzen?

*ACHTUNG* Remember, many prepositions take a specific case in German. Here is a list of the most common prepositions and their case.

Übung 2: Trattoria Da Fausto.

An interactive H5P element has been excluded from this version of the text. You can view it online here:

https://openeducationalberta.ca/willkommendeutsch/?p=742\#h5p-252 


\section{Am Esstisch}

An interactive H5P element has been excluded from this

version of the text. You can view it online here:

https://openeducationalberta.ca/willkommen-

deutsch/?p=742\#h5p-251

Wie lege ich mein Besteck richtig hin?

Using your cutlery appropriately can send clear messages. 


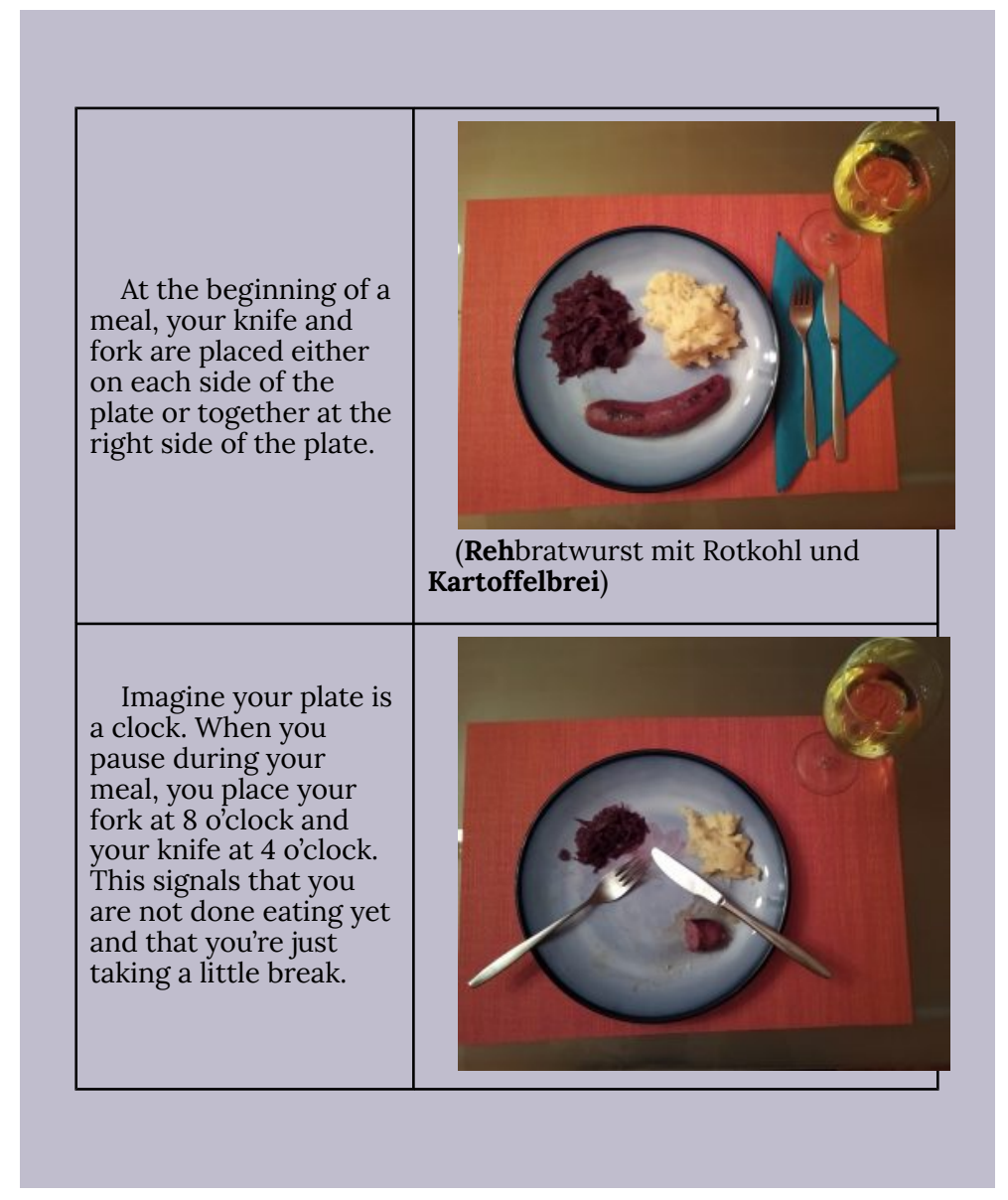




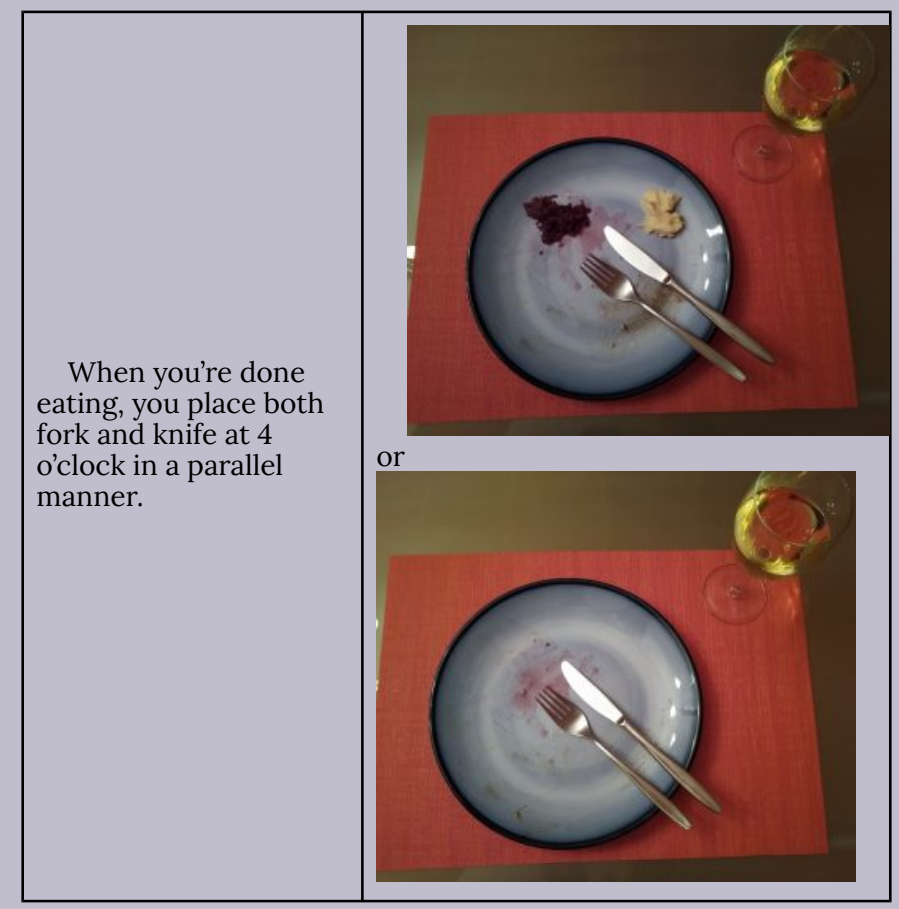

Here are a few more tips on good table etiquette. Only watch the video to $1: 48$.

Wortschatz in Quizlet:

Gerichte

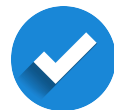

Was wissen Sie jetzt? Das Quiz ist in der nächsten Unterrichtsstunde. 


\section{卌}

\section{Task 9: Das Geburtstagsessen planen}

Imagine that you are living in Germany, Austria or Switzerland and you and a friend are planning a birthday dinner for one of your other friends. Make sure to discuss multiple options and disagree on certain aspects of the planning, buying, etc.

- Welches Menü planen Sie? Warum?

- Was kochen Sie als Vorspeise, Hauptgericht oder Nachtisch? Was trinken Sie?

- Welche Lebensmittel brauchen Sie? Wer kauft was? Wohin gehen Sie um diese Lebensmittel zu kaufen?

- Laden Sie auch andere Freunde ein? Kaufen Sie auch Geschenke?

Use the vocabulary and structures that you learned in this unit. Be creative and make your conversation as natural as possible. Record your conversation (ca. 4 minutes) as an audio or video and submit it on eClass. You can plan out what you will talk about, but do not read from a script; do it in one take and do not "edit" your audio/video.

This task will be assessed according to the Rubric for Task 9.

\section{Media Attributions}

- snack-1415680_1920 C RitaE is licensed under a Public Domain license

- star (C) IO-Images is licensed under a Public Domain license

- presentation icon (C) quinntheislander adapted by Solomon Hajramezan is licensed under a Public Domain license

- Rehbratwurst mit Rotkohl und Kartoffelbrei @ ckost is licensed under a Public Domain license

- Pause beim Essen (C) ckost is licensed under a Public Domain license 
- fertig mit dem Essen 1 ( ) ckost is licensed under a Public Domain license

- fertig mit dem Essen 2 (c) ckost is licensed under a Public Domain license

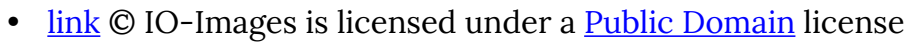

- check mark (C) janjf93 adapted by Solomon Hajramezan is licensed under a Public Domain license

- keyboard (C) IO-Images is licensed under a Public Domain license 


\section{Einheit 9.7}

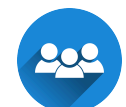

\section{Was ist Ihre Lieblingsmahlzeit?}
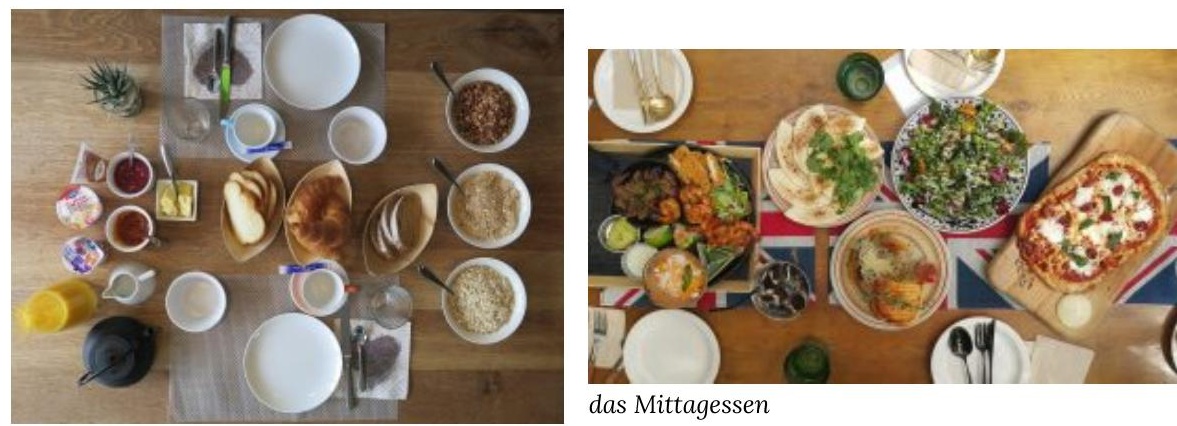

das Mittagessen

das Frühstück

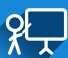

Im Restaurant: Kleiner Kiepenkerl.

An interactive H5P element has been excluded from this version of the text. You can view it online here:

https://openeducationalberta.ca/willkommendeutsch/?p=744\#h5p-261

\section{0}

Im Restaurant. Nicole, Mehmed und Mia gehen 
$\mathrm{zu}$ ihrem Lieblingsrestaurant in Stuttgart. Ergänzen Sie die Adjektivendungen.

\section{$\varepsilon$}

Wo isst du gern? Machen Sie ein Interview mit Ihrer Partnerin oder mit ihrem Partner.

1. Isst du lieber zu Hause oder im Restaurant?

2. Gibt es in dieser Stadt ein deutsches Restaurant? Warst du schon einmal dort essen?

3. Gibt es ein Restaurant, in dem du oft isst? Was isst du da am liebsten?

\section{Media Attributions}

- group (C) IO-Images is licensed under a Public Domain license

- breakfast-2591033_1920 C Ludwig Willimann is licensed under a Public Domain license

- food-1351287_1920 @ Lisy is licensed under a Public Domain license

- table-1589012_1920 (C) Karrie Zhu is licensed under a Public Domain license

- dinner-3425334_1920 @ tomwieden is licensed under a Public Domain license

- presentation icon (C) quinntheislander adapted by Solomon Hajramezan is licensed under a Public Domain license

- document (C) IO-Images is licensed under a Public Domain license

- partner (C) IO-Images is licensed under a Public Domain license 
Einheit 9.8 (online)

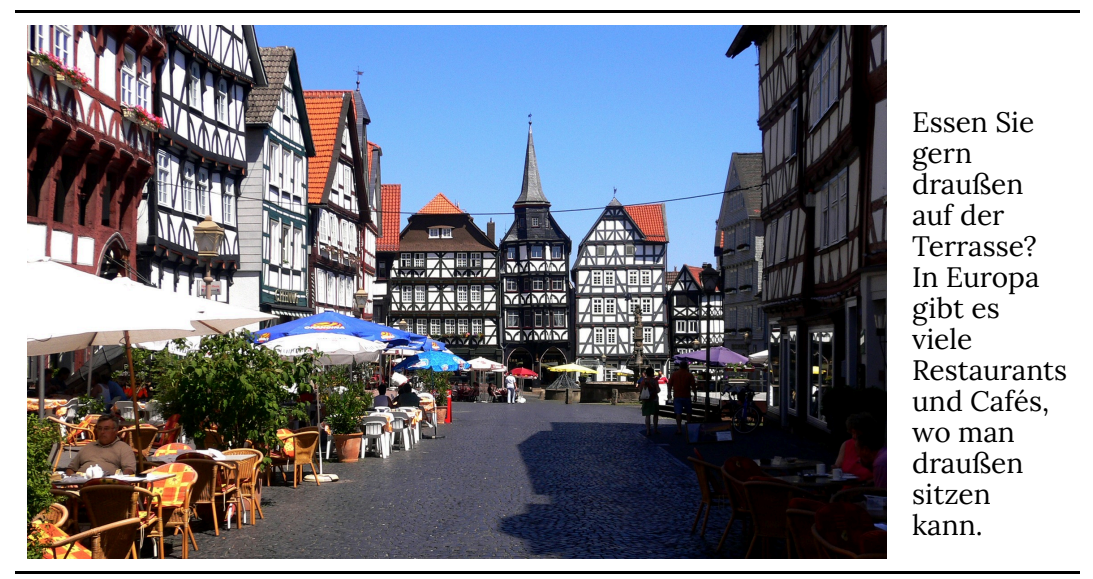

Im Restaurant

When you go to a restaurant in Germany, there are a couple of things that might surprise you:

Usually, there is no hostess to show you to your seat. You just find our own table where you want to sit.

If there is no free table, it is quite customary to sit together with people you don't even know. You would go to their table and ask: "Entschuldigung, ist hier noch frei?" and usually they would offer you the free seats: "Ja, bitte schön" (unless they're expecting more of their friends to arrive).

The waitress or waiter will not come by your table frequently to ask you how your food is.

When you pay, you only give a small tip as the service 
charge is included in the bill in the German-speaking countries. Waitresses and waiters get higher hourly wages than in the North American context. Therefore, people usually tip less; you just round up to the nearest currency unit (9 Euro 20 -> you would give 10 Euro), or if the bill is larger, you round up and add a couple of Euros (37 Euro 40 $\rightarrow$ you would give 40 Euros).

\section{Übung 1}

An interactive H5P element has been excluded from this version of the text. You can view it online here:

https://openeducationalberta.ca/willkommendeutsch/?p=746\#h5p-254 


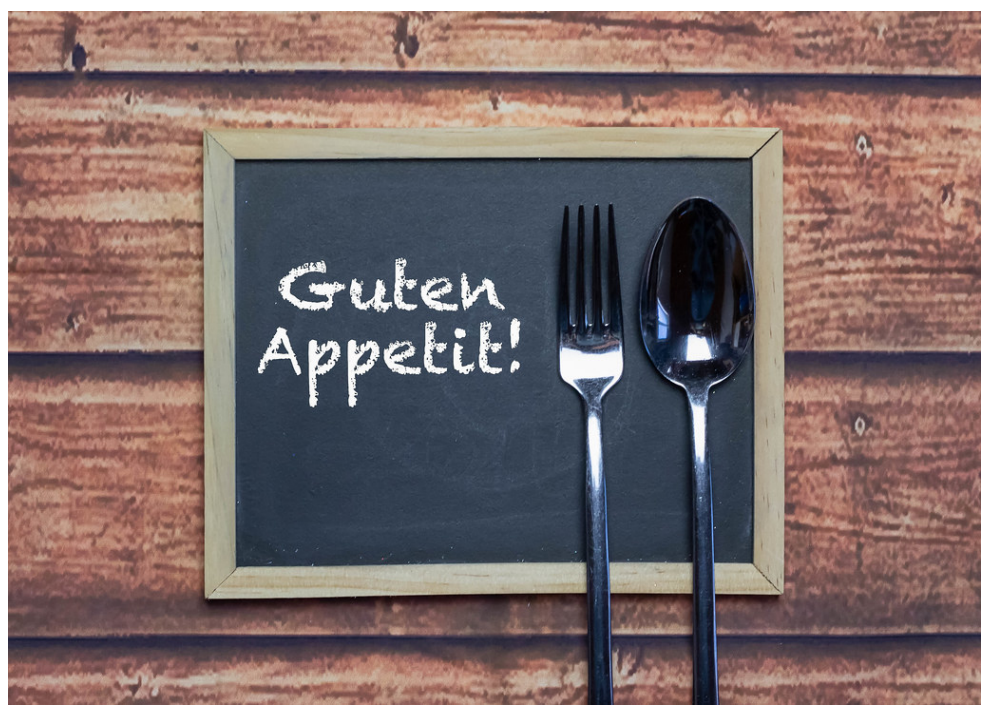

Redemittel

Im Restaurant 


\begin{tabular}{|c|c|}
\hline $\begin{array}{l}\text { die Bedienung (die } \\
\text { Kellnerin/der Kellner) }\end{array}$ & $\begin{array}{l}\text { der Gast (die Kundin/der } \\
\text { Kunde) }\end{array}$ \\
\hline $\begin{array}{l}\text { nach Wünschen fragen: } \\
\text { - Was kann ich Ihnen } \\
\text { bringen? } \\
\text { Haben Sie schon } \\
\text { gewählt? (after seeing } \\
\text { the "Speisekarte") }\end{array}$ & $\begin{array}{l}\text { etwas bestellen: } \\
\text { - Kann ich bitte die } \\
\text { Speisekarte haben? } \\
\text { Ich hätte gern.../ Wir } \\
\text { hätten gern... } \\
\text { Ich nehme.../ Ich } \\
\text { möchte... }\end{array}$ \\
\hline $\begin{array}{l}\text { sich entschuldigen: } \\
\text { - Das tut mir leid. Ich } \\
\text { bringe Ihnen eine } \\
\text { andere... } \\
\text { Ja, natürlich, ich } \\
\text { bringe Ihnen sofort eine } \\
\text { Gabel... }\end{array}$ & $\begin{array}{l}\text { sich über etwas } \\
\text { beschweren: } \\
\text { - Der/die/das ... ist } \\
\text { kalt/ist zu salzig. } \\
\text { Können Sie mir bitte } \\
\text { noch eine Gabel/ ein } \\
\text { Messer/ einen Löffel/ } \\
\text { Salz/ Pfeffer bringen? }\end{array}$ \\
\hline $\begin{array}{l}\text { sich über das Essen } \\
\text { erkundigen: } \\
\text { - Schmeckt es Ihnen?/ } \\
\text { Sind Sie zufrieden? }\end{array}$ & $\begin{array}{l}\text { das Essen kommentieren: } \\
\text { - Ja, danke, sehr gut./ } \\
\text { Es geht. }\end{array}$ \\
\hline $\begin{array}{l}\text { zahlen: } \\
\text { - Gern, das macht } 13 \\
\text { Euro } 40 . \\
\text { - Vielen Dank! }\end{array}$ & $\begin{array}{l}\text { zahlen: } \\
\text { - Wir würden gern } \\
\text { zahlen./ Zahlen, bitte. / } \\
\text { Die Rechnung, bitte. } \\
\text { (gives 15): Das stimmt } \\
\text { so! }\end{array}$ \\
\hline
\end{tabular}

\section{Übung 2}


An interactive $\mathrm{H} 5 \mathrm{P}$ element has been excluded from this version of the text. You can view it online here:

https://openeducationalberta.ca/willkommen-

deutsch/?p=746\#h5p-253

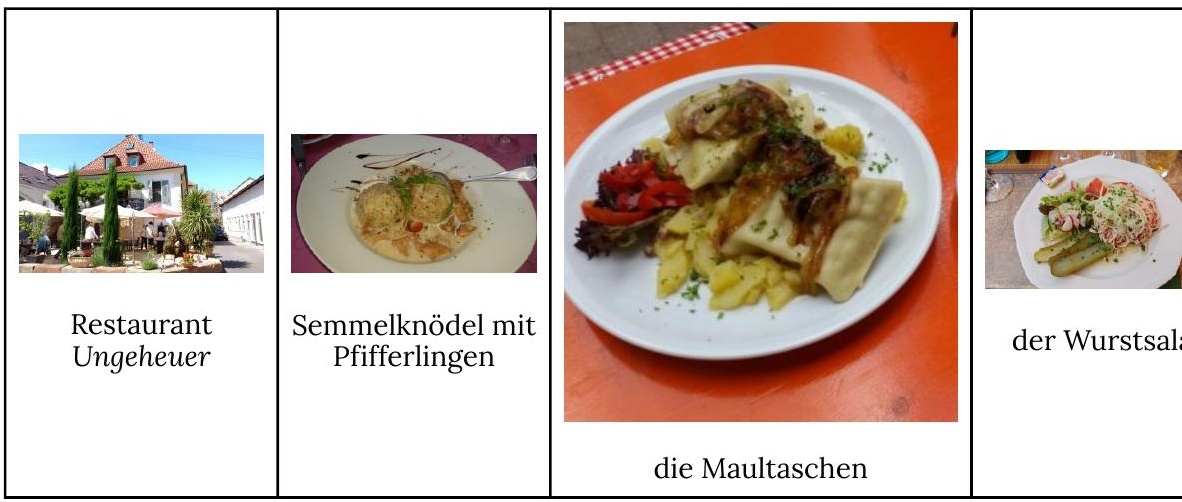

(

Im Restaurant Ungeheuer in Forst (Pfalz).

An interactive H5P element has been excluded from this

믓 version of the text. You can view it online here:

https://openeducationalberta.ca/willkommen-

deutsch/?p=746\#h5p-315 


\section{Grammatik}

We have already used the verb werden as equivalent to the English verb "to become":

Wenn ich groß bin, werde ich Pilotin. (When I'm grown up, I'll become a pilot.)

Werden + infinitive is used to talk about the future:

Wirst du heute Abend zu Hause essen? (Will you eat at home tonight?)

Nein, ich werde in mein Lieblingsrestaurant gehen. (No, I will go to my favourite restaurant.)

When there is an adverb of time in a sentence and it is clear that future actions or events are indicated, German speakers usually just use the present tense:

Nächstes Jahr fahre ich nach Spanien. (Next year, I'm going to Spain.)

Morgen besucht Thomas seine Eltern. (Tomorrow, Thomas is going to visit his parents.)

The verb werden has to be conjugated and placed in the 
appropriate position in the sentence, while the infinitive goes to the end of the sentence:

Ich werde am Sonntag ins Restaurant gehen.

Am Sonntag werde ich ins Restaurant gehen.

In a dependent clause, it goes to the end of the dependent clause:

Ich weiß nicht, wann ich wieder in ein Restaurant gehen werde.

\begin{tabular}{|l|l|}
\hline singular & plural \\
\hline ich werde & wir werden \\
\hline$d u$ wirst & ihr werdet \\
\hline er/sie/es wird & sie/Sie werden \\
\hline
\end{tabular}

Wortschatz in Quizlet:

Im Restaurant

Im Restaurant Redemittel

Was wissen Sie jetzt? Klicken Sie hier für Quiz 9.8.

Media Attributions

- summer-1277076_1920 (C) K. H. J. / MCI is licensed under a Public Domain license 
- star (C) IO-Images is licensed under a Public Domain license

- Guten Appetit (C) Marco Verch Professional is licensed under a CC BY (Attribution) license

- Forst Restaurant Ungeheuer (C) ckost is licensed under a Public Domain license

- Semmelknödel mit Pfifferlingen (C) ckost is licensed under a Public Domain license

- Maultaschen (C) ckost is licensed under a Public Domain license

- Wurstsalat (C) ckost is licensed under a Public Domain license

- headphones (C) IO-Images is licensed under a Public Domain license

- link (C IO-Images is licensed under a Public Domain license

- check mark (C) janjf93 adapted by Solomon Hajramezan is licensed under a Public Domain license 


\section{Einheit 9.9}

\section{0}

Bildgeschichte: Ein Abendessen mit Problemen. Gestern haben Houssem und Zara im Restaurant Arabella zu Abend gegessen. Was ist passiert? Arbeiten Sie in einer Kleingruppe und schreiben Sie eine Geschichte (1 Satz pro Bild).
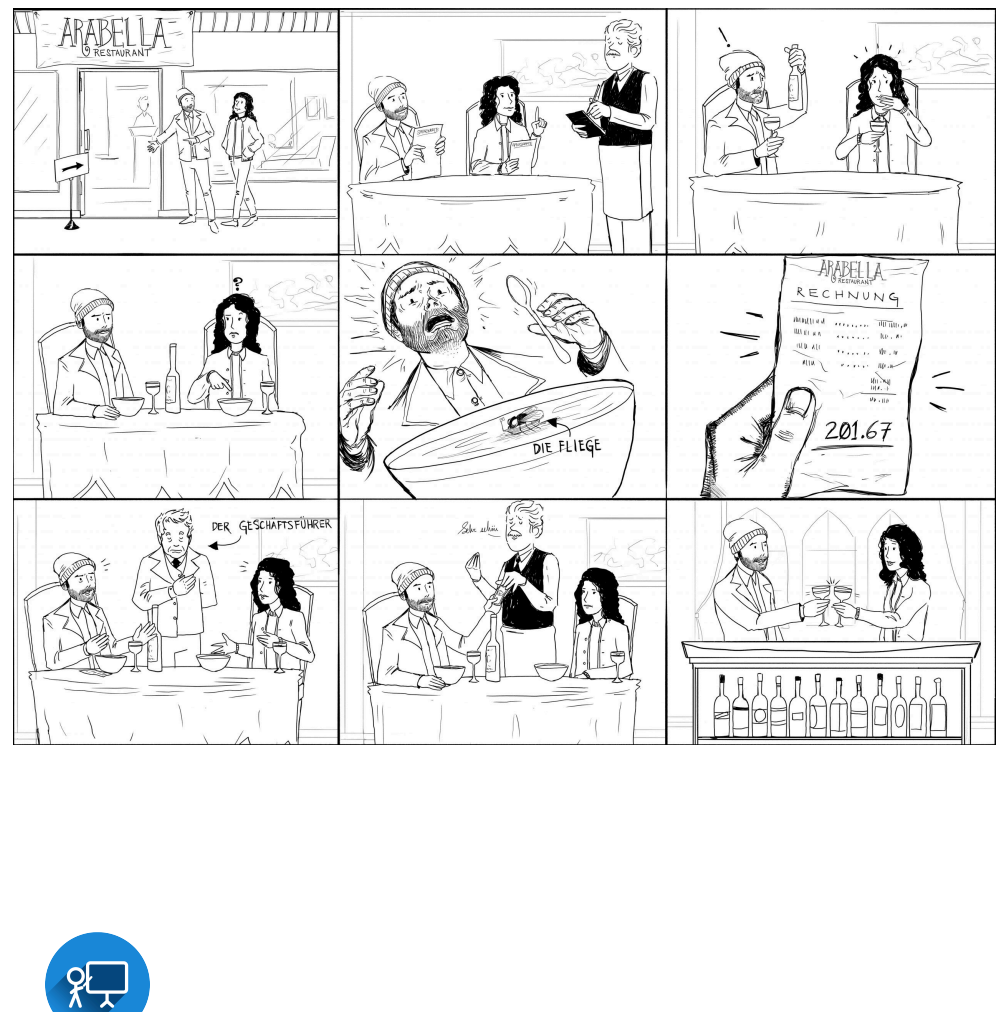

Relativsätze 
https://openeducationalberta.ca/willkommen-

deutsch/?p=748\#h5p-256

\section{Media Attributions}

- group (C) IO-Images is licensed under a Public Domain license

- Bildgeschichte (C) Solomon Hajramezan is licensed under a All Rights Reserved license

- presentation icon (c) quinntheislander adapted by Solomon Hajramezan is licensed under a Public Domain license 


\section{Einheit 9.10 (online)}

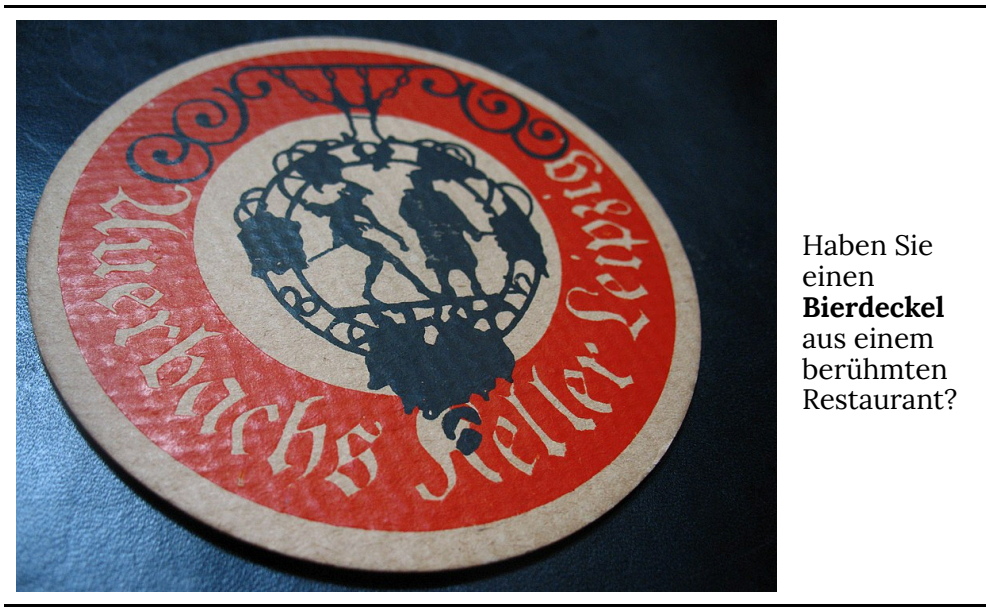

Relative Pronouns and Relative Clauses

Please work through the following presentation to learn about relative pronouns and relative clauses.

$\underline{\text { Relative Pronouns and Relative Clauses }}$

\section{Übung 1: Das Dunkelrestaurant.}


https://openeducationalberta.ca/willkommen-

deutsch $/ p=750 \#$ h5p-257

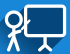

Ein berühmtes Restaurant in Leipzig und seine Geschichte. Lesen Sie und beantworten Sie die Fragen.

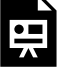

An interactive H5P element has been excluded from this version of the text. You can view it online here:

https://openeducationalberta.ca/willkommendeutsch/?p=750\#h5p-258

\section{Q}

Auerbachs Keller. Besuchen Sie Auerbachs Keller und sehen Sie sich die Speisekarte vom Restaurant "Großer Keller" an. Schreiben Sie auf, welche Vorspeise, welches Hauptgericht und welchen Nachtisch Sie gern essen möchten (schreiben Sie auch die Preise auf). Bringen Sie diese Informationen mit in die nächste Deutschstunde.

Wortschatz in Quizlet:

Auerbachs Keller 
Was wissen Sie jetzt? Klicken Sie hier für Quiz 9.10.

Extra Practice (optional):

Video Serie - Nicos Weg

Sehen Sie die Videos an und machen Sie alle Übungen.

Video 1: Essen gehen

Video 2: Die Karte bitte!

Video 3: Was darf es sein?

Media Attributions

- + Bierdeckel DDR - Auerbachs Keller Leipzig - Bild 001 C Lupus in Saxonia is licensed under a CC BY-SA (Attribution ShareAlike) license

- star (C) IO-Images is licensed under a Public Domain license

- presentation icon (C) quinntheislander adapted by Solomon Hajramezan is licensed under a Public Domain license

- magnifying-glass $($ C IO-Images is licensed under a Public Domain license

- $\underline{\text { link }(C) ~ I O-I m a g e s ~ i s ~ l i c e n s e d ~ u n d e r ~ a ~ P u b l i c ~ D o m a i n ~ l i c e n s e ~}$

- check mark (C) janjf93 adapted by Solomon Hajramezan is licensed under a Public Domain license 


\section{Einheit 9.11}

\section{0}

Redemittel: Im Restaurant. Was sagt man?

- nach Wünschen fragen

- etwas bestellen

- sich über etwas beschweren

- sich entschuldigen

- sich über das Essen erkundigen

- das Essen kommentieren

- zahlen

\section{8}

Rollenspiel: In Auerbachs Keller. Stellen Sie sich vor, dass Sie im Restaurant "Großer Keller" in Auerbachs Keller essen.

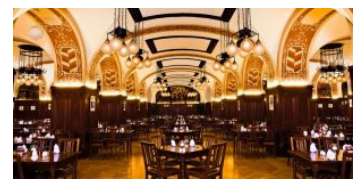

Restaurant "Großer Keller"
Machen Sie ein Rollenspiel mit Ihrer Partnerin oder Ihrem Partner.

- bestellen Sie das Essen (Vorspeise, Hauptgericht, Nachtisch, die Sie als Hausaufgabe notiert haben)

- beschweren Sie sich bei der Bedienung über etwas

- fragen Sie nach der Rechnung, bezahlen Sie und geben Sie ein Trinkgeld

Eine kurze Biografie: Goethe. Lesen Sie den Text und beantworten Sie die Fragen. 


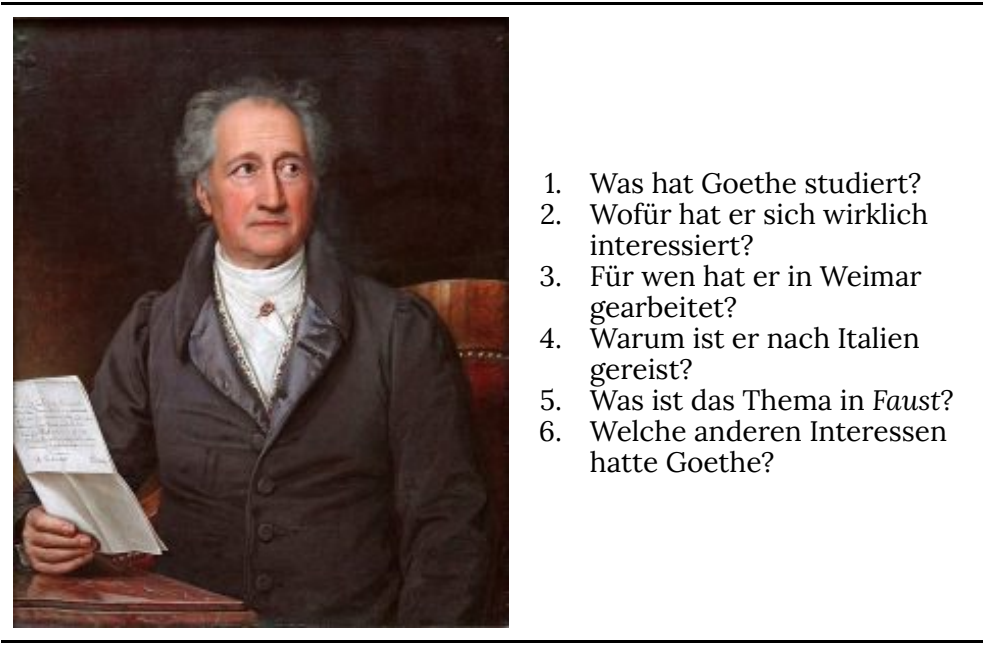

\section{Media Attributions}

- group (C) IO-Images is licensed under a Public Domain license

- partner (C) IO-Images is licensed under a Public Domain license

- cropped-Grosser Keller Gesamtansicht 5fd4a29646c93-e1a3 $\underline{5 f}$ C Auerbachs Keller is licensed under a All Rights Reserved license

- book (C) IO-Images is licensed under a Public Domain license

- 512px-Goethe_(Stieler_1828) (C) Joseph Karl Stieler is licensed under a Public Domain license 


\section{Einheit 9.12 (online)}

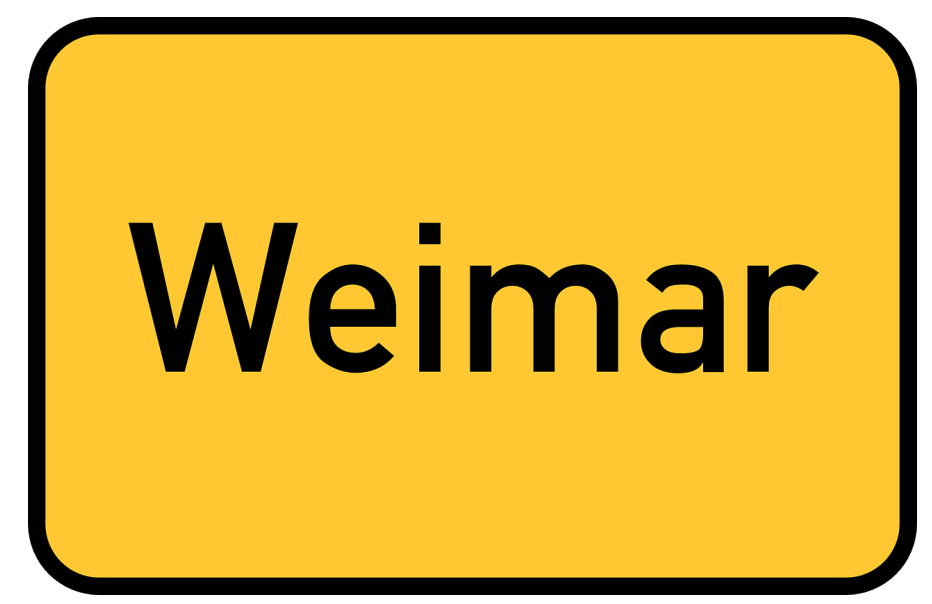

Weimar - From Goethe to Gropius. Sehen Sie das Video an und machen Sie Übung 1.

\section{Übung 1}
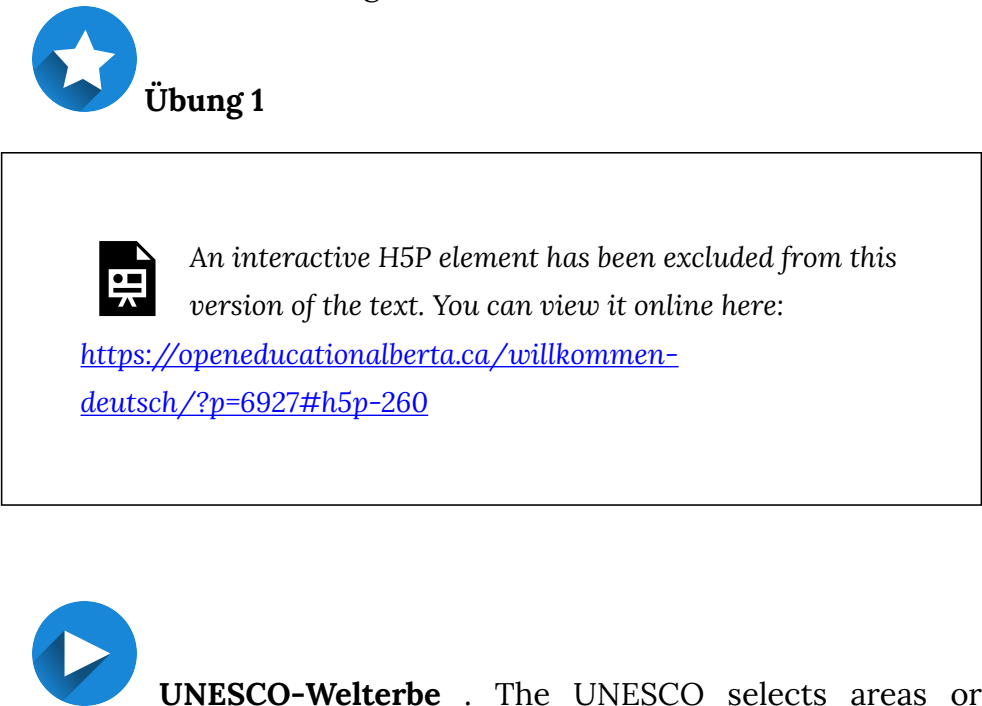

UNESCO-Welterbe . The UNESCO selects areas or landmarks that are culturally, historically, scientifically or otherwise 
significant and declares them world heritage sites. These sites are protected by international treaties. There are 46 World Heritage Sites in Germany (43 cultural and 3 natural).

Today, you will learn something about the "Klassisches Weimar".

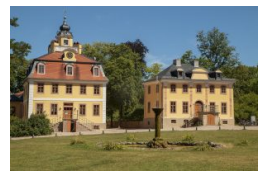

Sc

hlo

ss

$\mathrm{Bel}$

ve

de

re

un

$d$

Sc

hlo

ssp

ar

k

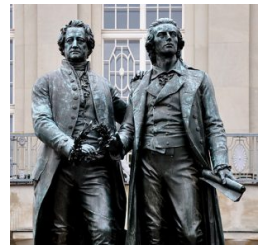

Go

eth

e-

un

$d$

$\mathrm{Sc}$

hill

er-

De

$n k$

ma

$l$
In the late 18th and early 19th century the small Thuringian town of Weimar witnessed a remarkable cultural flowering, led by the Duchess Anna Amalia and her son Duke Carl August. As patrons of art and literature, they invited many eminent writers and scholars to Weimar, notably Johann Wolfgang von Goethe, Christoph Martin Wieland, Johann Gottfried Herder and Friedrich Schiller.

The high point of the town's cultural influence resulted from the creative relationship between Goethe and Schiller that began in 1794 and was intensified when Schiller moved to Weimar in 1799. This period became known as Weimar's Classical period (Weimarer Klassik) or Classical Weimar (Klassisches Weimar). During this time, literary works of extraordinary importance were created, characterized by open-mindedness and humanistic aspirations. The high artistic quality of many buildings from this period and the parks in the surrounding area testify to the cultural flowering of Weimar's Classical period. (Description adapted from https://whc.unesco.org/en/list/846 under license $\underline{\text { CC-BY-SA IGO 3.0). }}$. 
Wo liegt das "Klassische Weimar" auf der Landkarte? Welterbe in Deutschland

Sehen Sie die zwei Videos an.

Welterbe Klassikerstadt Weimar (Deutsche Welle) (0:59 Minuten; Deutsch)

Weimar - von Goethe bis Gropius (Deutsche Welle) (5:50 Minuten; Deutsch)

\section{目目}

Weimar: von Goethe bis Gropius. Lesen Sie den Text und beantworten Sie die Fragen.

\section{Übung 2}
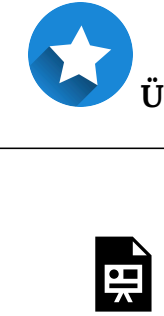

An interactive $\mathrm{H} 5 \mathrm{P}$ element has been excluded from this version of the text. You can view it online here:

https://openeducationalberta.ca/willkommendeutsch/?p=6927\#h5p-262

\section{Q}

Wer war Dr. Johann Faust? Was können Sie über Goethes

Drama Faust herausfinden? Recherchieren Sie im Internet. Finden Sie 3 Dinge über Dr. Faust und über Goethes Drama Faust heraus (für die nächste Deutschstunde).

\section{Wortschatz in Quizlet:}

Goethe Text

Weimar: von Goethe bis Gropius Text 
Was wissen Sie jetzt? Klicken Sie hier für Quiz 9.12.

\section{Media Attributions}

- weimar-856079_1280 (C) Taken is licensed under a Public Domain license

- star (C) IO-Images is licensed under a Public Domain license

- 2020-07-31_Schlosspark_Belvedere_by_OlafKosinsky_MG_2 $\underline{752}$ @ O Olaf Kosinsky is licensed under a CC BY-SA (Attribution ShareAlike) license

- Weimar_Goethe-Schiller-Denkmal_2012_02 C Andreas

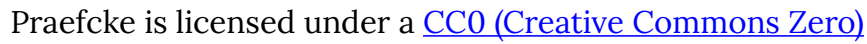
license

- book (C) IO-Images is licensed under a Public Domain license

- magnifying-glass (C) IO-Images is licensed under a Public Domain license

- $\underline{\text { link }}$ (C) IO-Images is licensed under a Public Domain license

- check mark (C janjf93 adapted by Solomon Hajramezan is licensed under a Public Domain license 


\section{Einheit 9.13}

\section{0}

\section{Was haben Sie schon gelernt?}

An interactive H5P element has been excluded from this

뭇 version of the text. You can view it online here:

https://openeducationalberta.ca/willkommen-

deutsch/?p=6933\#h5p-300

운만

Faust

An interactive H5P element has been excluded from this version of the text. You can view it online here:

https://openeducationalberta.ca/willkommendeutsch $/ ? p=6933 \#$ h5p-266

\section{目目}

Der Pakt. Lesen Sie das Exzerpt aus Goethes Faust, wo Faust und Mephistopheles einen Pakt schließen.

Faust 
An interactive H5P element has been excluded from this version of the text. You can view it online here:

https://openeducationalberta.ca/willkommen-

deutsch/?p=6933\#h5p-267

\section{Media Attributions}

- group (C) IO-Images is licensed under a Public Domain license

- presentation icon (C) quinntheislander adapted by Solomon Hajramezan is licensed under a Public Domain license

- book (C) IO-Images is licensed under a Public Domain license 


\section{Einheit 9.14 (online)}

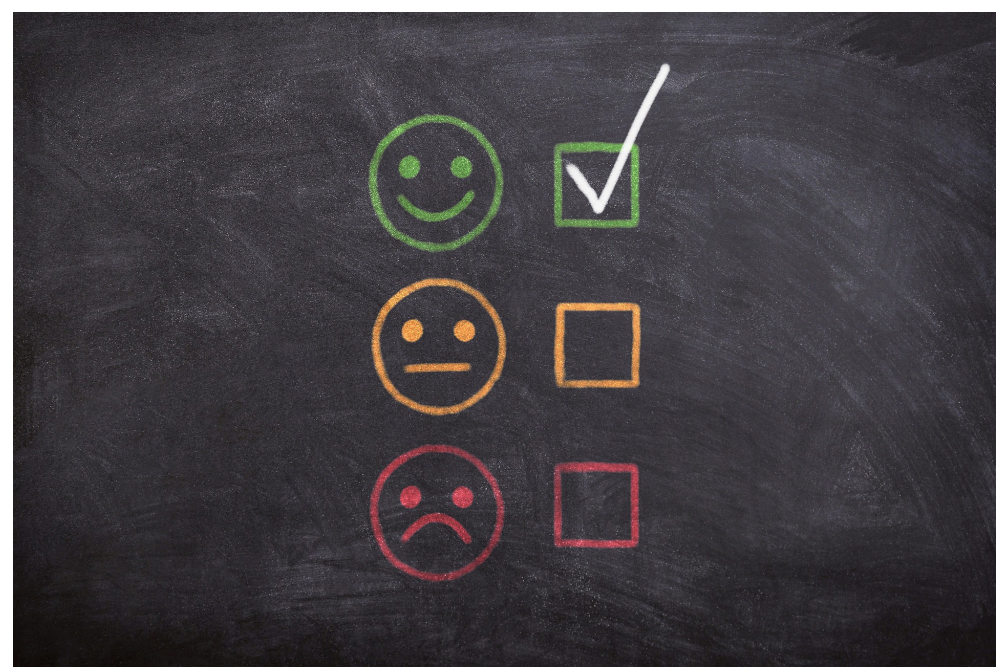

Übung 1: Zum weißen Schwan.

An interactive H5P element has been excluded from this

믐 version of the text. You can view it online here:

https://openeducationalberta.ca/willkommen-

deutsch/?p=6935\#h5p-265

\section{Wortschatz in Quizlet:}

$\underline{\text { Faust }}$ 
Es gibt kein Quiz für 9.14.

䰝

Oral Presentation: Regionale Spezialitäten

For your oral presentation, you will research a regional food or beverage from the German-speaking countries. You can work in pairs or by yourself.

Please sign up for a specific item on the list on eClass. In your presentation, describe the food/beverage, how it is made, what it consists of, in what region it is consumed, any historical background you may find about its origins, etc. You can also research an item that has different names in different regions and tell us about that.

Your presentation should be no longer than four slides: include some images and short text in bullet points and record your narration (at least 2 minutes per person). In your narration, please do not just read out your bullet points, but narrate in full sentences. Make sure you cite your sources (for images) and write your own narration. Do not copy text from any websites that you visit.

After you submit your presentation on eClass, you will read/listen to 3 presentations of your classmates (your choice). "Reply" to these three presentations in German and comment whether you would like to try the item or not and why.

This oral presentation will be assessed according to the Rubric for Oral Presentation.

\section{Media Attributions}

- board-3700116 1920 C athree23 is licensed under a Public Domain license 
- star (C) IO-Images is licensed under a Public Domain license

- link (C) IO-Images is licensed under a Public Domain license

- check mark (C) janjf93 adapted by Solomon Hajramezan is licensed under a Public Domain license

- keyboard (C) IO-Images is licensed under a Public Domain license 


\section{Wortschatz}

Quizlet:

Wortschatz Einheit 9 (alle Kategorien)

Obst

Gemüse

Obst und Gemüse (plural)

Fleisch, Fisch und Geflügel

Einkaufsmöglichkeiten

Mengenangaben

Redemittel: Beim Einkaufen

Mülltrennung

Mahlzeiten

Gerichte

Im Restaurant

Redemittel: Im Restaurant

Auerbachs Keller

Goethe Text

Weimar: von Goethe bis Gropius Text

Faust

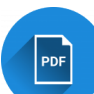

Wortschatz 9

Media Attributions

- $\underline{\text { link }}$ (C) IO-Images is licensed under a Public Domain license

- pdf (C) IO-Images is licensed under a Public Domain license 


\section{Zum Spaß!}
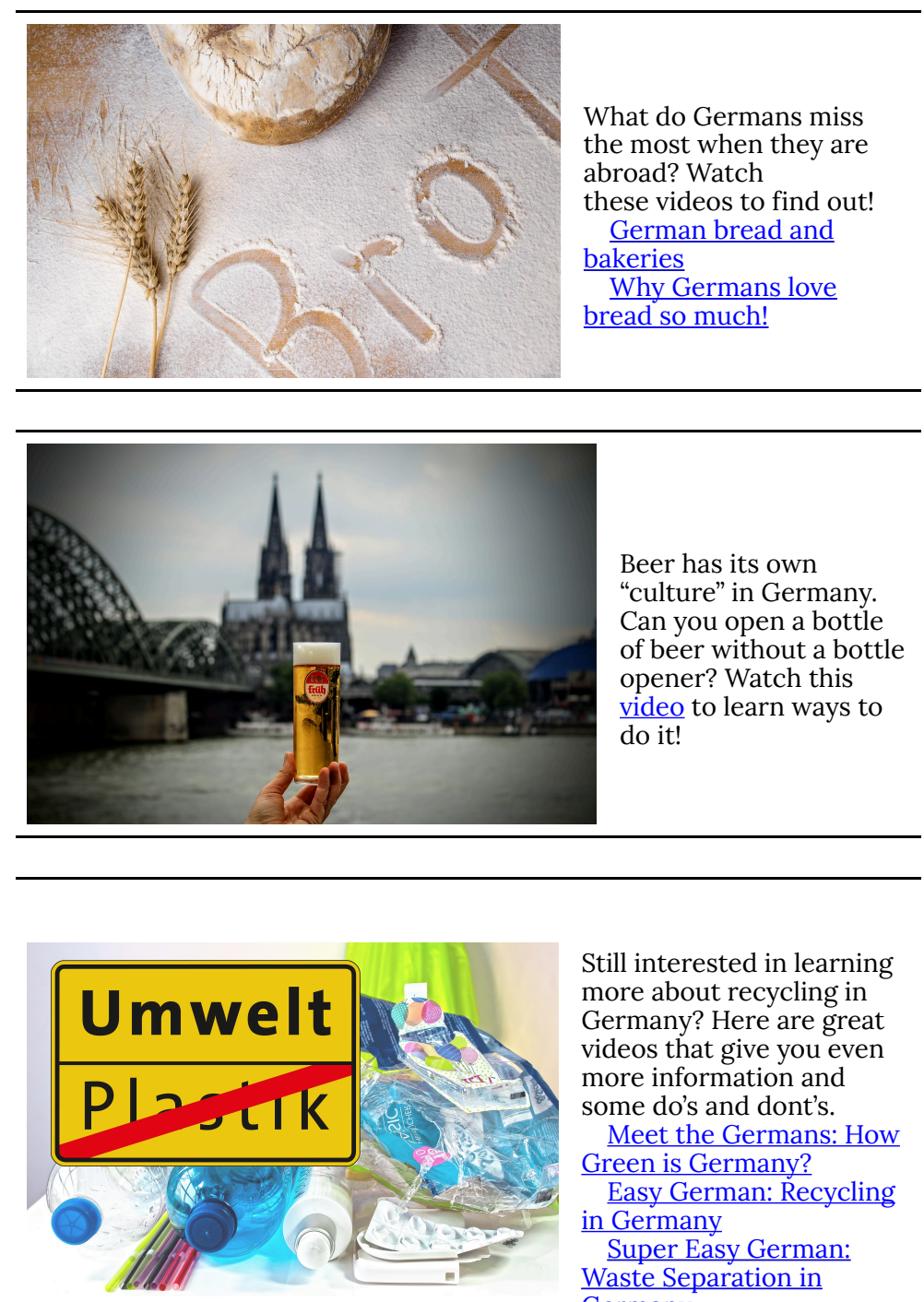

Still interested in learning more about recycling in Germany? Here are great videos that give you even more information and some do's and dont's. Meet the Germans: How Green is Germany? Easy German: Recycling in Germany

Super Easy German: Waste Separation in Germany 

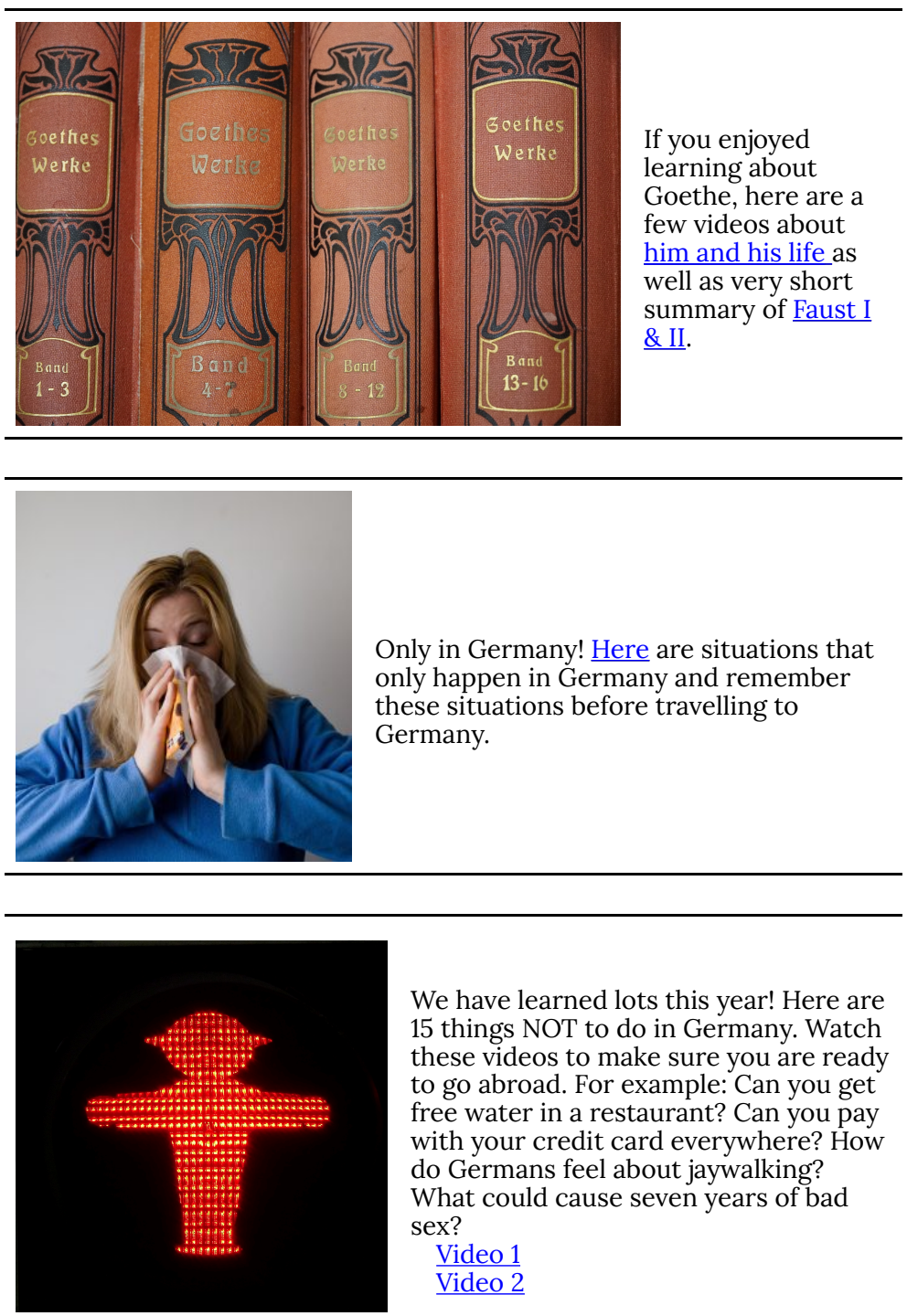

We have learned lots this year! Here are 15 things NOT to do in Germany. Watch these videos to make sure you are ready to go abroad. For example: Can you get free water in a restaurant? Can you pay with your credit card everywhere? How do Germans feel about jaywalking? What could cause seven years of bad sex?

$\underline{\text { Video } 1}$

Extra Practice (optional): These activities are from the websites Schubert-Verlag und Lingua.

Lebensmittel

Lebensmittel 
Im Café: Etwas bestellen

Im Restaurant (Lesen)

Restaurants in Deutschland (Hören)

Was essen die Menschen gern? (Hören)

Im Restaurant (Hören)

Essen und Trinken in Deutschland

Beim Gemüsehändler

Ich finde es gut, dass ...

\section{Media Attributions}

- bread-1001362_1280 (C) Hanjörg Scherzer is licensed under a Public Domain license

- cologne-4873905_1920 (c) Carola68 is licensed under a Public Domain license

- plastic-waste-3964464_1920 @ Stux is licensed under a Public Domain license

- Goethes Werke (C) jhenning is licensed under a Public Domain license

- woman-g9fabdd94c_1920 (C) mojpe is licensed under a Public Domain license

- traffic-light-traffic-light-figure-1349250_1920 (c) bernswaelz is licensed under a Public Domain license 
582 | Zum Spaß! 


\section{EINHEIT IO: NACHBAR NR.}

\section{5}

At the end of Einheit 10, you will be able to...

- $\quad$ read and understand a longer cohesive text in German

- use a variety of reading strategies to understand this text:

- by using visual clues to predict and understand the story

- by identifying and summarizing the main points

- $\quad$ by asking questions about the text

- by inferring meaning of unknown vocabulary from context

- by recognizing suffixes and other patterns of word formation to understand new words

You will also have learned about the following structures:

- $\quad$ kennen vs. wissen (to know)

- masculine n-nouns

You will also have reviewed the following structures:

- $\quad$ stem-vowel changing verbs 
- perfect tense

- $\quad$ comparative \& superlative

- conjunctions: denn \& weil

- "du" imperative

584 | Einheit 10: Nachbar Nr. 5 
Einheit 10.1

$10.1 \mid 585$ 


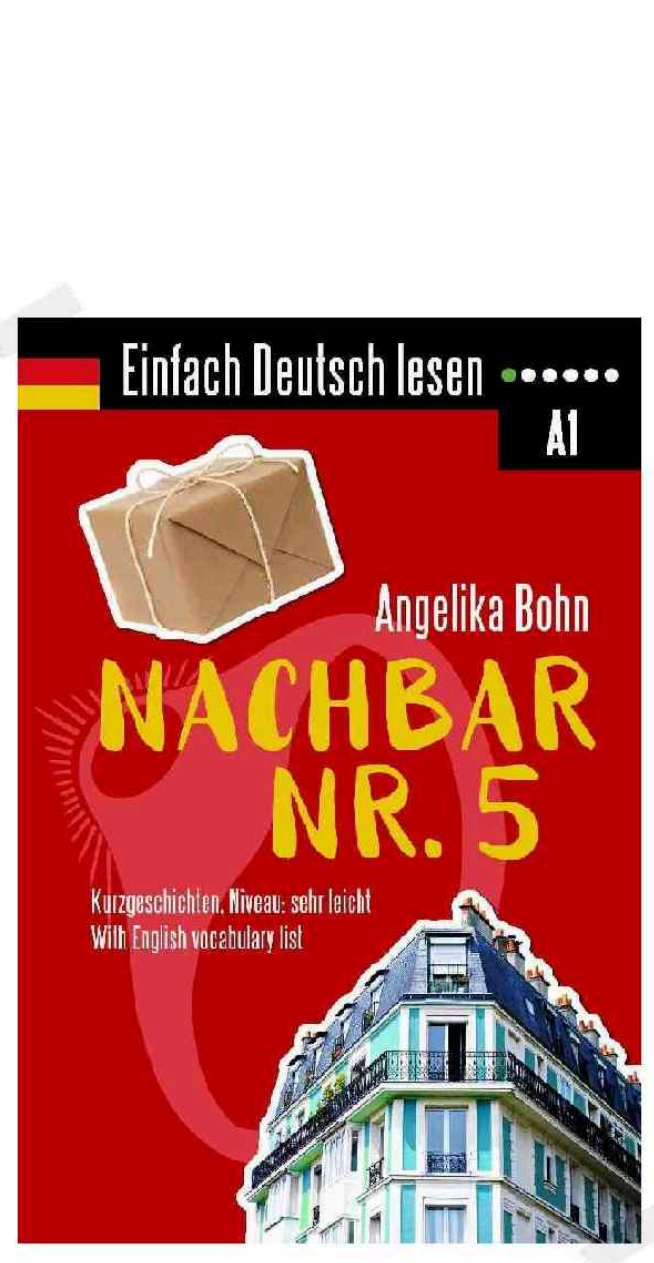

In this unit, we will be reading the short novel Nachbar Nr. 5 by Angelika Bohn. As a teacher of German as a foreign language, she writes books that are geared towards various levels of German language skills.

We are grateful for her permission to use and adapt some teaching materials from her website.

Based on what you have learned in 
the past

two

semesters

of German, we think

you will be

able to

understand

and enjoy

this story.

\section{目目}

\section{Was passiert in diesem Buch?}

Finn und Amelie sind heute ein Jahr zusammen. Finn hat seiner Freundin einen Ring im Internet gekauft und möchte ihn ihr heute beim Abendessen schenken. Aber er hat ein Problem: Die Post hat den Ring einem Nachbarn gegeben, dem Nachbarn Nr. 5. Aber wer ist das? Finn wohnt erst seit vier Wochen in dieser Straße und kennt die Leute im Haus nicht. Kann er den Ring bis 18 Uhr finden? Finn hat nur eine Chance: Er muss bei allen Nachbarn fragen. Aber die sind nicht ganz normal ...

\section{$x$}

\section{Die Stadt Köln}

An interactive H5P element has been excluded from this version of the text. You can view it online here:

https://openeducationalberta.ca/willkommendeutsch/?p=6852\#h5p-272 


\section{0}

Eine Einladung zum Abendessen. Was machen Sie, bevor Sie Ihre Freundin oder Ihren Freund zu sich nach Hause einladen? Wir machen ein Assoziogramm oder eine Mind-Map zusammen.

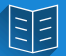

Nachbar Nr. 5. Wir lesen Seite 7-9.

\section{Media Attributions}

- Nachbar Nr 5 (c) Angelika Bohn is licensed under a All Rights Reserved license

- book (C IO-Images is licensed under a Public Domain license

- presentation icon (C) quinntheislander adapted by Solomon Hajramezan is licensed under a Public Domain license

- group ( IO-Images is licensed under a Public Domain license 
Einheit 10.2 (online)

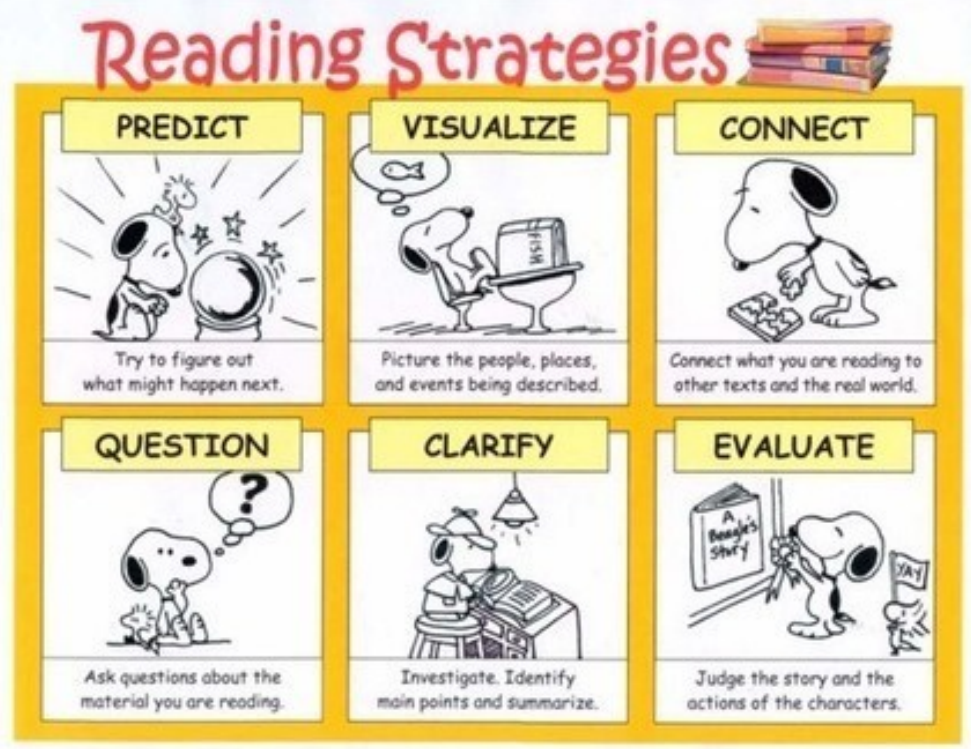

While we are reading Nachbar Nr. 5, we will also introduce you to some reading strategies to help you deal with a longer text. Sometimes you will read about a certain strategy at home and try it out by yourself, sometimes we will use a strategy together in class.

\section{Lesestrategien}


Activating background knowledge

Before you start reading a text, you can activate any knowledge you already have by looking at two different things:

- Text Type: what kind of text are you going to read? A magazine article, a story, an advertisement? All these types of texts have certain features or conventions of how they present their information. If you recognize the text type, you will be able to anticipate certain structures that might help you understand the text.

- Predicting Content: always look at images provided with a text and titles of chapters to predict or hypothesize what the chapter might be about. In class, we can use a semantic map (or an Assoziogramm) like we did in 10.1 to elicit any vocabulary that you might already know to get you prepared for reading the text.

\section{Was wissen Sie schon?}

므 An interactive H5P element has been excluded from this version of the text. You can view it online here:

https://openeducationalberta.ca/willkommendeutsch/?p=6854\#h5p-273

\section{Lesestrategien}




\section{How to read effectively in a foreign language}

Here are a few tips:

- read the chapter all the way through: it's ok if you don't understand everything, just try to understand the main ideas about the story

- do not stop to look up any words, just try to follow what's going on

- at the end of the chapter, take some notes on the characters, places, ideas, and events

- re-read the chapter: do you understand more details now? add them to your notes

- finally, look up a few words that you don't understand but that seem important (rule of thumb: if you encountered the word 5 times or more in the chapter and still don't know what it means, now it's time to look it up)

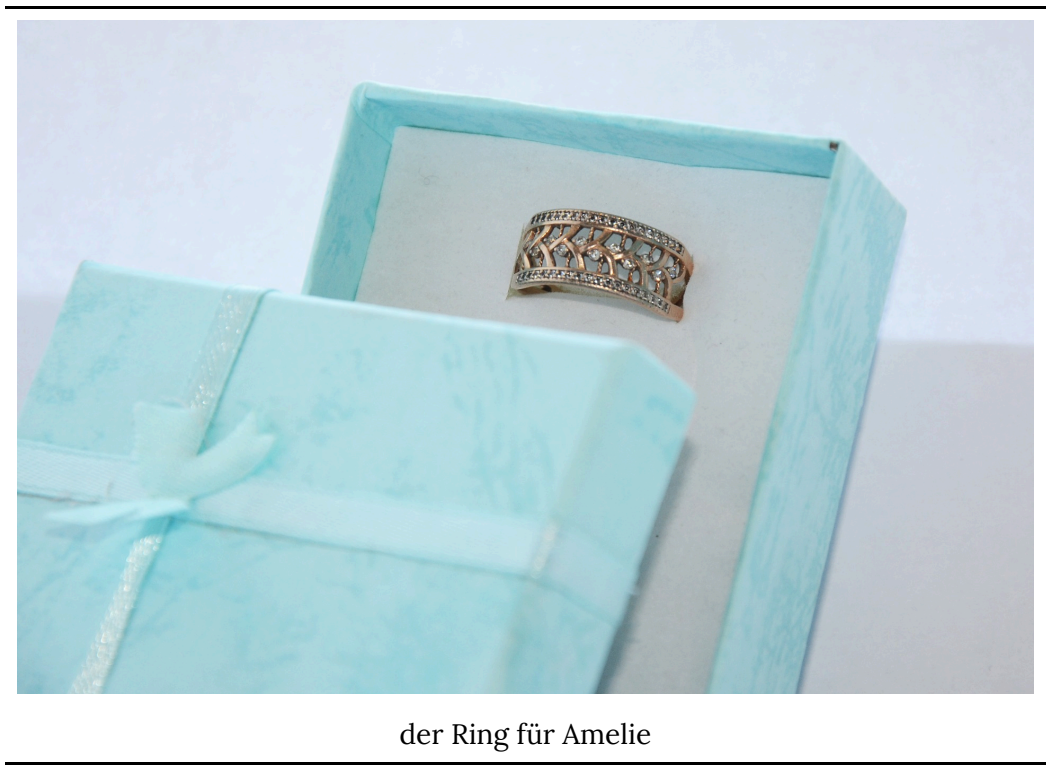

Nachbar Nr. 5. Lesen Sie den Rest von Kapitel 1 "Das Päckchen". 
Nach dem Lesen: Was haben Sie verstanden?

An interactive H5P element has been excluded from this version of the text. You can view it online here:

https://openeducationalberta.ca/willkommen-

deutsch/?p=6854\#h5p-274

\section{Grammatik}

"wissen" vs. "kennen" (English: to know)

In German, we use two different words to express the meaning of "to know".

"Kennen" is used to express familiarity with people and places. It always takes a direct object.

- Kennst du seine Schwester? - Ja, ich kenne sie sehr gut.

- $\quad$ Finn kennt Amelie seit ein paar Jahren.

"Wissen" is used to express a knowledge of facts. It may take a direct object.

- Weißt du, wo ich wohne? - Ja, aber ich weiß deine 
Telefonnummer nicht.

- $\quad$ Finn weiß, dass der Paketdienst immer zwischen 13 und 18 Uhr kommt.

Vor dem Lesen: neue Wörter lernen. Raten Sie, was diese neuen Wörter von Kapitel 2 bedeuten. An interactive H5P element has been excluded from this
version of the text. You can view it online here:

https://openeducationalberta.ca/willkommendeutsch/?p=6854\#h5p-275

\section{Wortschatz in Quizlet:}

Kapitel 1

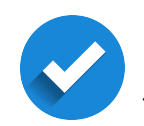

Was wissen Sie jetzt? Das Quiz ist in der nächsten Unterrichtsstunde. 


\section{Media Attributions}

- $\underline{\text { Reading Strategies is licensed under a All Rights Reserved }}$ license

- wrench (C) IO-Images is licensed under a Public Domain license

- 10.2 Activating background knowledge (C) ckost is licensed

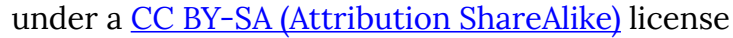

- star (C) IO-Images is licensed under a Public Domain license

- 10.2 how to read effectively (C) ckost is licensed under a CC BYSA (Attribution ShareAlike) license

- ring (C) Miroslavik is licensed under a Public Domain license

- book (C) IO-Images is licensed under a Public Domain license

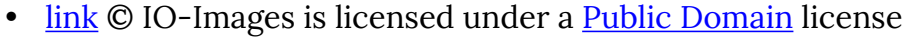

- check mark (C) janjf93 adapted by Solomon Hajramezan is licensed under a Public Domain license 


\section{Einheit 10.3}

\section{0}

Eine kurze Wiederholung: Kapitel 1 "Das Päckchen"

- Was wissen Sie über diese Personen: Finn, Oliver, Amelie, Oma

- Was möchte Finn heute Abend machen?

- Was ist das Problem?

Nachbar Nr. 5. Wir lesen Kapitel 2 "Adonis" mit verteilten Rollen.

\&

\section{Lesestrategien}

Identifying the main point:

Identifying the main points is a useful strategy that you can employ while you are reading a text.

- Try to summarizea specific section of the text with one short sentence or one keyword (you can do this in English or German). This sentence or keyword is supposed to capture the essence of that entire text section.

- If you are reading a longer text, you might want to use this strategy after each page; if you read a shorter text like an essay or an article, you might want to use this strategy after each paragraph.

- Having identified and summarized the main points of each section (and written them down, maybe in the margin or at the top or bottom of each page) will also come in handy when you want to review what you have read so far.

\section{Q00}

Lesestrategie anwenden. Arbeiten Sie in einer Kleingruppe und schreiben Sie einen Satz oder ein Wort pro Seite als Zusammenfassung. 


\section{Media Attributions}

- group (C) IO-Images is licensed under a Public Domain license

- book (C) IO-Images is licensed under a Public Domain license

- wrench (C) IO-Images is licensed under a Public Domain license

- 10.3 Identifying the main points (C) ckost is licensed under a $\underline{C C}$ BY-SA (Attribution ShareAlike) license 


\section{Einheit 10.4 (online)}

\section{Kapitel 2 "Adonis": Was wissen Sie schon?}

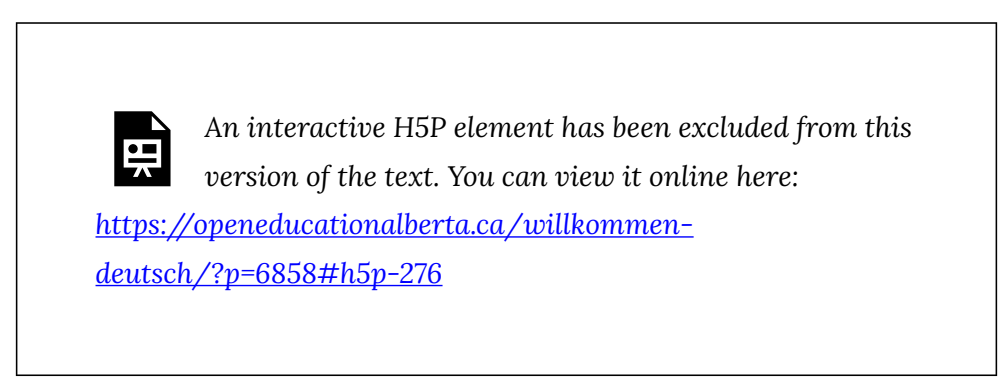

\section{Wortschatz Wiederholung}

An interactive H5P element has been excluded from this 믓 version of the text. You can view it online here:

https://openeducationalberta.ca/willkommendeutsch/?p=6858\#h5p-277

\section{Grammatik}


Please work through the following presentations to review the Stem-Vowel Changing Verbs.

\section{Übung 1}

An interactive H5P element has been excluded from this

圆 version of the text. You can view it online here:

https://openeducationalberta.ca/willkommen-

deutsch/?p=6858\#h5p-305

Vor dem Lesen: neue Wörter lernen. Bevor Sie Kapitel 3 beginnen, ergänzen Sie diese neuen Wörter. Sie können die Wörter in Kapitel 3 im Buch oder im Wortschatz PDF finden.

An interactive H5P element has been excluded from this version of the text. You can view it online here:

https://openeducationalberta.ca/willkommendeutsch $/ ? p=6858 \# h 5 p-278$ 


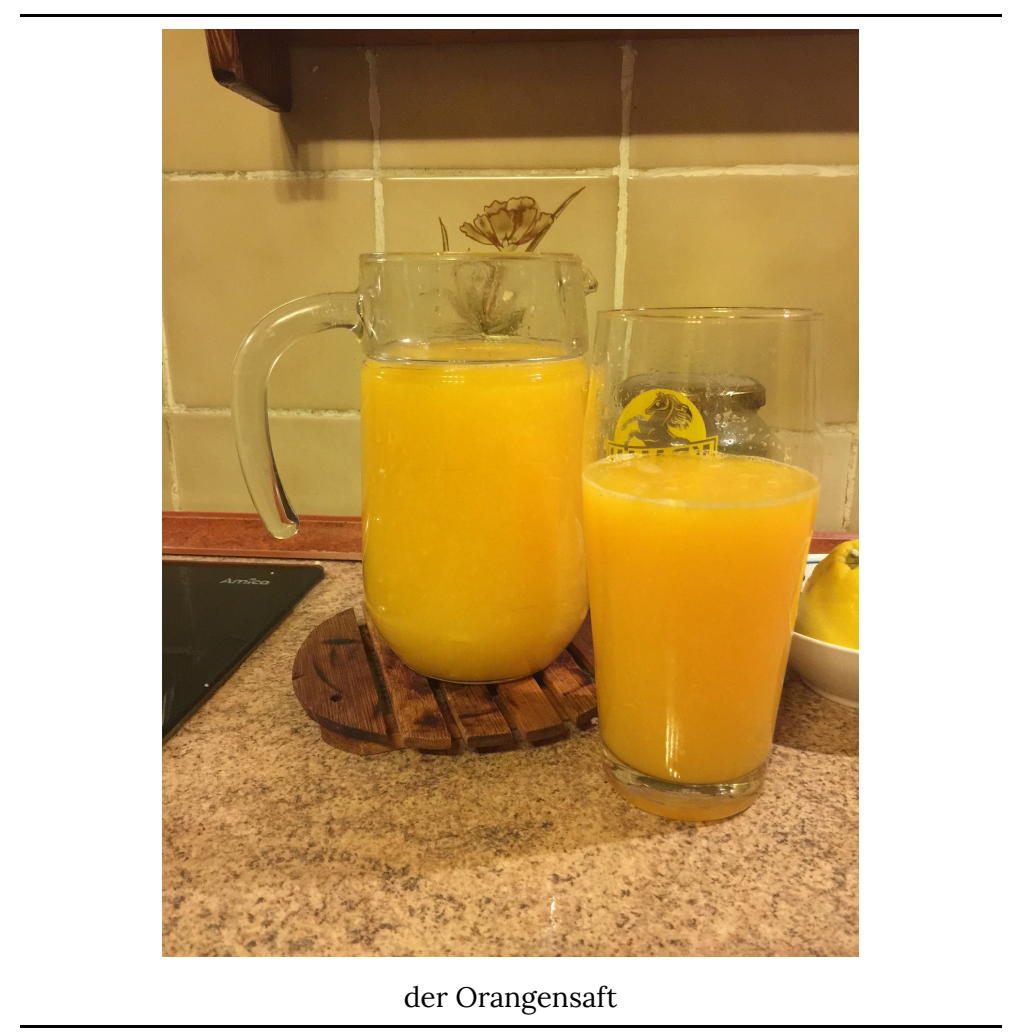

Nachbar Nr. 5. Lesen Sie Kapitel 3 "Die Autobiografie".
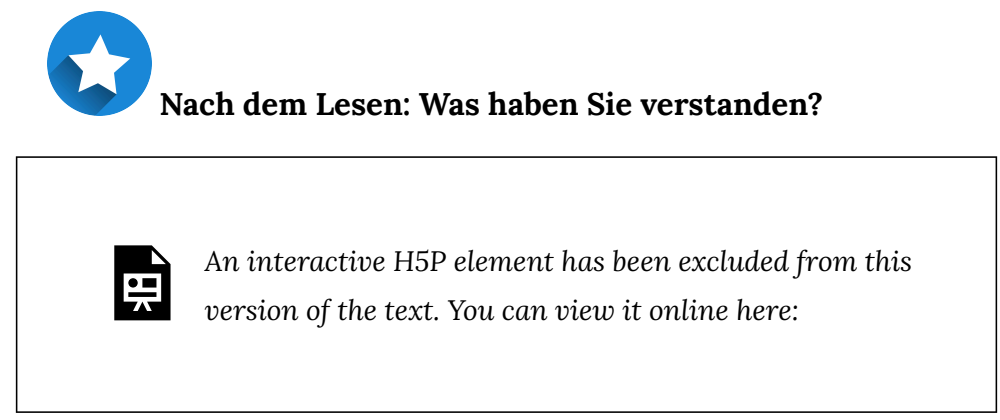
https://openeducationalberta.ca/willkommen-

deutsch/?p=6858\#h5p-279

\section{Wortschatz in Quizlet:}

\section{Kapitel 2}

Kapitel 3

Was wissen Sie jetzt? Das Quiz ist in der nächsten Unterrichtsstunde.

\section{Media Attributions}

- star (C) IO-Images is licensed under a Public Domain license

- juice (C) kropekk_pl is licensed under a Public Domain license

- book (C) IO-Images is licensed under a Public Domain license

- link (C) IO-Images is licensed under a Public Domain license

- check mark (C) janjf93 adapted by Solomon Hajramezan is licensed under a Public Domain license 


\section{Einheit 10.5}

eog

Eine kurze Wiederholung: Kapitel 3 "Die Autobiografie"

- Wie reagiert die alte Frau, als Finn in ihre Wohnung kommt?

- Für wen hält Mimi Friedmann Finn?

- Was wissen Sie über Mimi Friedmann?

- Was erfahren wir noch über Amelie?

- Was ist in der Vase?

- Warum hat Finn den Orangensaft nicht getrunken?

\begin{tabular}{|c|c|}
\hline 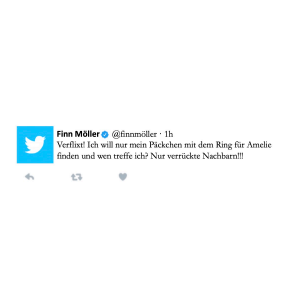 & $\begin{array}{l}\text { Finn ist ganz verzweifelt und } \\
\text { schickt auf Twitter eine } \\
\text { Nachricht an seine Freunde. } \\
\text { Eine Reporterin der Sülzer } \\
\text { Stadtnachrichten liest den } \\
\text { Tweet und findet die } \\
\text { Situation sehr interessant. Sie } \\
\text { möchte Finns Nachbarn } \\
\text { interviewen. }\end{array}$ \\
\hline
\end{tabular}

8

Die Reportage. Machen Sie ein Rollenspiel mit einer Partnerin oder einem Partner. Eine Person spielt die Reporterin (oder einen Reporter), die andere Person spielt eine Figur aus dem Buch. Was denken die Nachbarn über Finn? Make sure you stay in character!

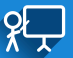

Vor dem Lesen: Kapitel 4 Wortschatz 
An interactive H5P element has been excluded from this version of the text. You can view it online here:

https://openeducationalberta.ca/willkommendeutsch $/ ? p=6862 \# h 5 p-280$

\section{Media Attributions}

- group (C) IO-Images is licensed under a Public Domain license

- Tweet (C) csawatzky is licensed under a Public Domain license

- partner (C) IO-Images is licensed under a Public Domain license

- presentation icon (C) quinntheislander adapted by Solomon Hajramezan is licensed under a Public Domain license 


\section{Lesestrategien}

Asking $W$-questions about a text

This is a strategy that you can use while you are reading a text. It will help you practice asking and answering questions about the text, thereby increasing your understanding of the text and helping you identify the main ideas or important details.

Following a basic journalism inquiry, use the $\mathrm{W}$-questions to create questions about a text. You can make a chart for visualization. Add your questions and also your answers to these questions. Your chart will also help you quickly review what happened in the text.

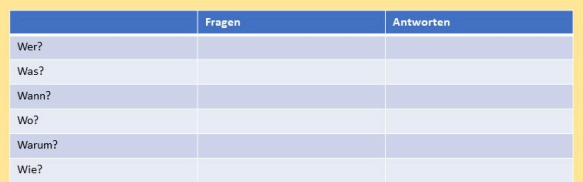

Nachbar Nr. 5. Lesen Sie Kapitel 4 "Scrabble".

Lesestrategie anwenden. Machen Sie eine Tabelle und schreiben Sie W-Fragen und Antworten über Kapitel 4. Bringen Sie die Fragen und Antworten mit zur nächsten Deutschstunde. (Make at least one question for each question word.) 
Nach dem Lesen: Was haben Sie verstanden?
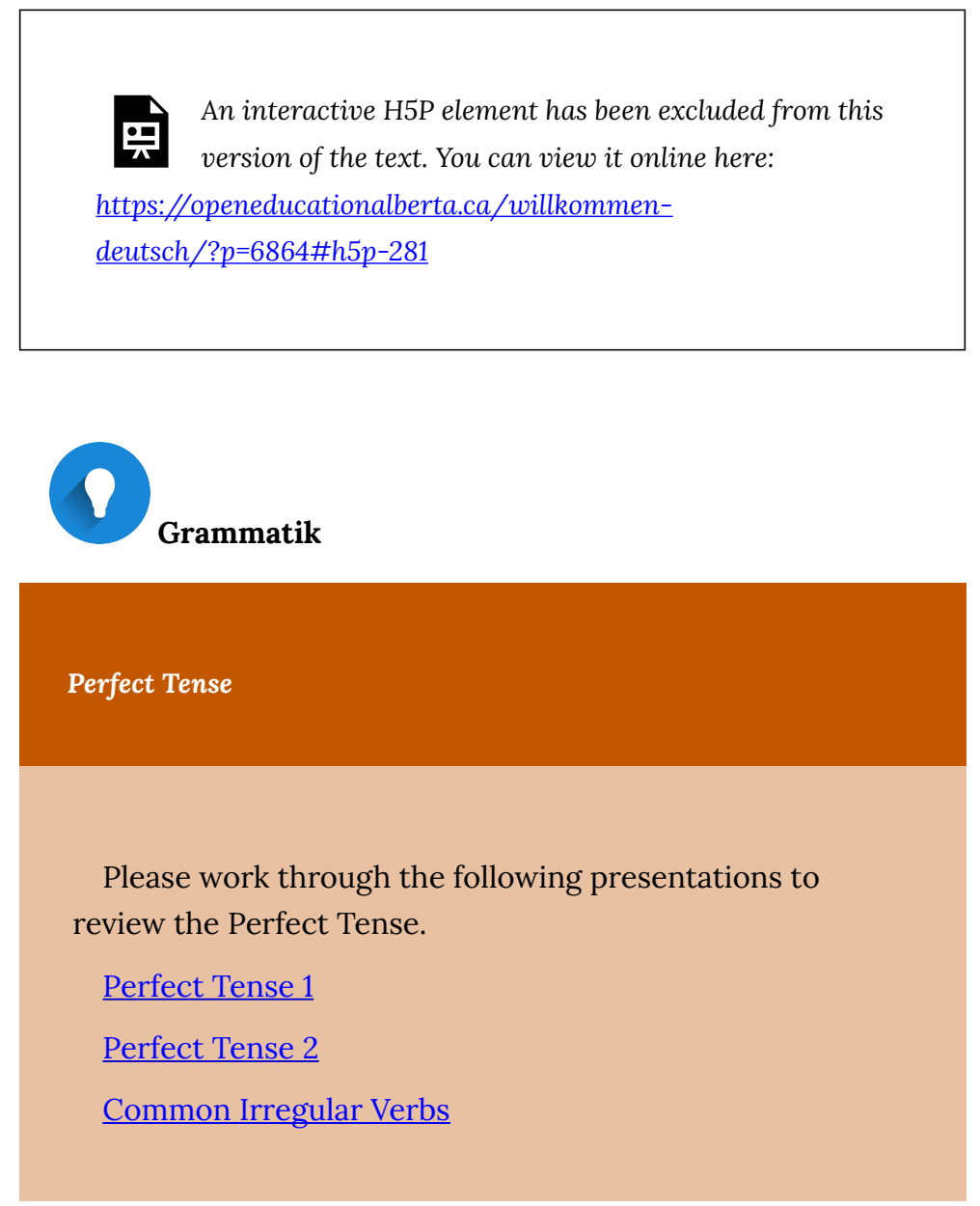

Am nächsten Tag erzählt Finn Amelie von Herrn Eberhardt. 
An interactive $\mathrm{H} 5 \mathrm{P}$ element has been excluded from this version of the text. You can view it online here:

https://openeducationalberta.ca/willkommen-

deutsch/?p=6864\#h5p-282

\section{Grammatik}

Finn kennt seine Nachbarn im Haus noch nicht.Finn gibt dem Studenten sein Buch.

You've seen those $\boldsymbol{- n}$ or $\boldsymbol{- e n}$ endings numerous times already in German texts. If you ever wondered why they are there, here is the answer: Those nouns belong to a group of masculine nouns that take the ending $\mathbf{- n}$ or $-\boldsymbol{e n}$ in all cases except the nominative singular (hence the name masculine n-nouns).

$\mathrm{N}$-nouns are a group of masculine nouns that take the ending $\mathbf{- n}$ or $-\mathbf{e n}$ in all cases except the nominative singular. Look at the word "der Student" as an example: 


\begin{tabular}{|l|l|l|}
\hline & Singular & Plural \\
\hline Nominative & der Student & die Student \\
\hline Accusative & den Studenten & die Student \\
\hline Dative & dem Studenten & den Studen \\
\hline Genitive & des Studenten & der Studen \\
\hline
\end{tabular}

Here are some other common n-nouns:

der Kunde, -n der Mensch, -en

der Herr, -n der Athlet, -en

der Name, $-\mathrm{n} \quad$ der Patient, -en

der Junge, $-\mathrm{n} \quad$ der Polizist, -en

der Kollege, -n der Präsident, -en

der Nachbar, $-\mathrm{n} \quad$ der Tourist, -en

der Hase, $-n \quad$ der Elefant, - -en

*ACHTUNG* Remember that in the dative plural, all nouns add $-n$ to the plural ending, unless the plural already ends in $-\mathrm{n}$ (and except for a few nouns whose plural ends in $-\mathrm{s})$. 


\begin{tabular}{|l|l|}
\hline Plural & Dative Plural \\
\hline die Männer & den Männern \\
\hline die Frauen & den Frauen \\
\hline die Kinder & den Kindern \\
\hline $\begin{array}{c}\text { but: die } \\
\text { Autos }\end{array}$ & den Autos \\
\hline die Handys & den Handys \\
\hline
\end{tabular}

\section{Wortschatz in Quizlet:}

\section{Kapitel 4}

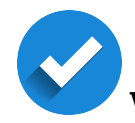

Was wissen Sie jetzt? Klicken Sie hier für Quiz 10.6.

\section{Media Attributions}

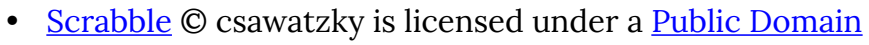
license

- wrench (C) IO-Images is licensed under a Public Domain license

- 10.6 Asking W-questions about a text (C) ckost is licensed under a CC BY-SA (Attribution ShareAlike) license

- book (C) IO-Images is licensed under a Public Domain license

- pen (C) IO-Images is licensed under a Public Domain license

- star (C) IO-Images is licensed under a Public Domain license 
- link (C) IO-Images is licensed under a Public Domain license

- check mark (C) janjf93 adapted by Solomon Hajramezan is licensed under a Public Domain license 


\section{Einheit 10.7}

Q00

Eine kurze Wiederholung: Kapitel 4 "Scrabble"

Arbeiten Sie in einer Kleingruppe. Stellen Sie Fragen (von Einheit 10.6) und beantworten Sie die Fragen.
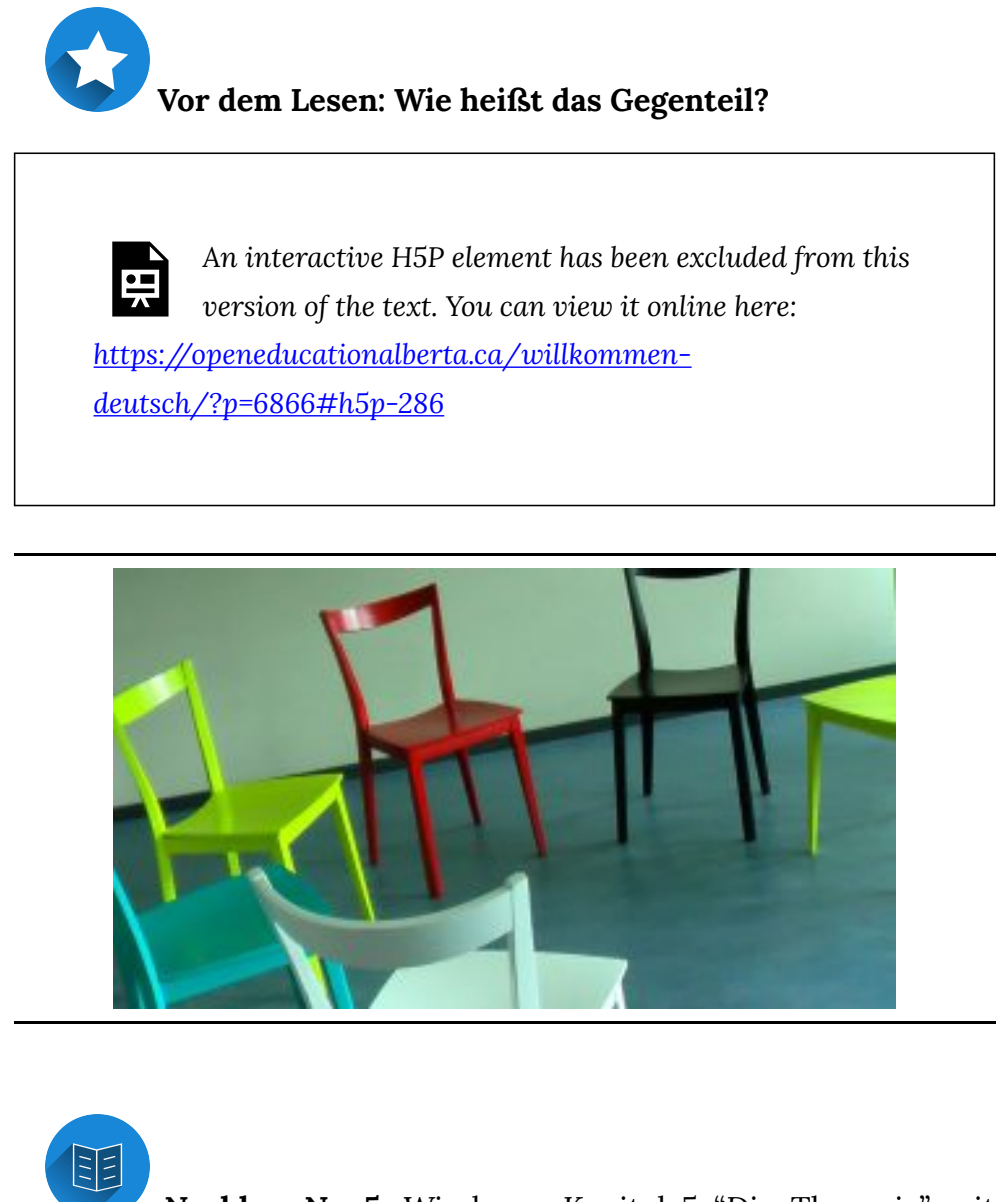

Nachbar Nr. 5. Wir lesen Kapitel 5 "Die Therapie" mit verteilten Rollen. 


\section{Media Attributions}

- group (C) IO-Images is licensed under a Public Domain license

- star (C) IO-Images is licensed under a Public Domain license

- chairs-g7576c3295_1280 C wollyvonwolleroy is licensed under a Public Domain license

- book (C) IO-Images is licensed under a Public Domain license 


\section{Einheit 10.8 (online)}

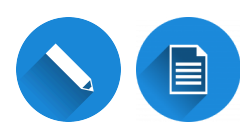

Nach dem Lesen: Was haben Sie verstanden?

Füllen Sie die Tabelle mit Informationen aus und bringen Sie die Antworten mit zur nächsten Deutschstunde.

\begin{tabular}{|l|l|l|l|l|}
\hline Personen & Beruf & $\begin{array}{c}\text { Aussehen/ } \\
\text { Eigenschaften }\end{array}$ & Kleidung & Problem \\
\hline Dr. Lange & & & & \\
\hline Olaf & & & & \\
\hline Jürgen & & & & \\
\hline Helene & & & & \\
\hline
\end{tabular}

Wiederholung: Was wissen wir über die Nachbarn von

\section{Kapitel 2-5?}

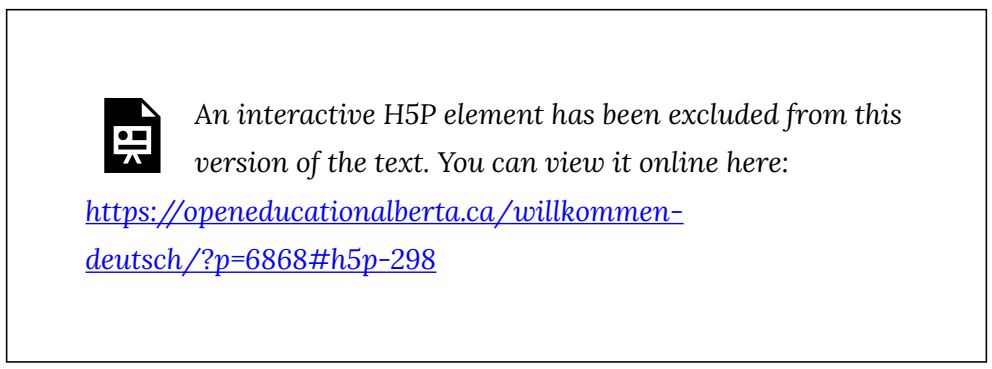

*ACHTUNG* 
Throughout the first few chapters of this book, we have seen interesting usages of the words: ja, aber, doch, denn, etc. These little words are called modal particles. These words add "flavour" or change the tone of a sentence, question, etc. Sometimes they can soften the harshness of a comment or even add a persuasive or suggestive element to a request.

Here are some examples from the book so far:

Mach doch eine kleine Pause.

Wer bist du denn?

Im Internet sehen Sie aber ein bisschen älter aus.

Wir haben ja vor einigen Tagen telefoniert.

\section{Grammatik}

Please work through the following presentations to review the Comparative \& Superlative.

\section{Übung 1}




\section{固}

An interactive H5P element has been excluded from this version of the text. You can view it online here:

https://openeducationalberta.ca/willkommen-

deutsch $/ ? p=6868 \#$ h5p-307

\&.

\section{Lesestrategien}

Recognizing a suffix to discover the meaning of unknown words

Recognizing the meaning of a suffix helps you understand new words and is also useful for word formation. The suffix - los means "without" in German. It can be added to a number of nouns to turn those into adjectives.

\section{Beispiele:}

Die Französischlehrerin Helene hat keine Söhne oder Töchter. Sie ist kinderlos.

Der Himmel ist heute sehr blau. Er ist wolkenlos.

Bei der Therapie weiß Finn nicht, was er sagen soll. Er ist sprachlos.

Finn kann sein Päckchen nicht finden. Er ist in einer hoffnungslosen Situation.

Übung 2. Ergänzen Sie die Wörter mit -los.

圈

An interactive H5P element has been excluded from this

version of the text. You can view it online here:

https://openeducationalberta.ca/willkommen-

deutsch/?p=6868\#h5p-284 
Vor dem Lesen: neue Wörter lernen. Raten Sie, was diese neuen Wörter von Kapitel 6 bedeuten.

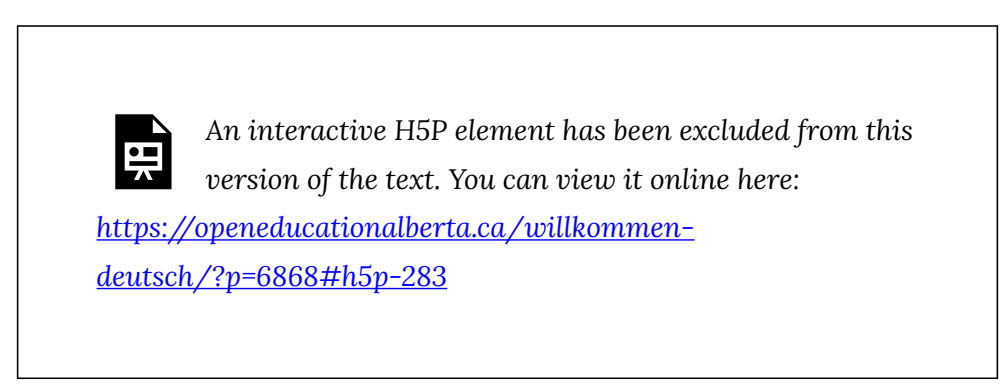

https://openeducationalberta.ca/willkommen-
deutsch/?p=6868\#h5p-283

\section{Q Wortschatz in Quizlet:}

Kapitel 5

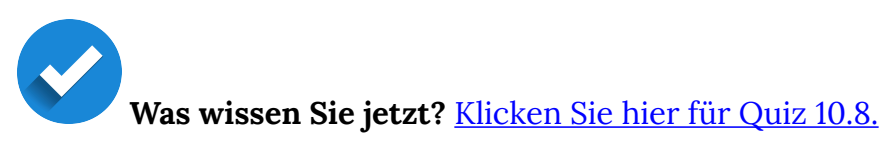

Media Attributions

- pen (C) IO-Images is licensed under a Public Domain license

- document (C) IO-Images is licensed under a Public Domain license

- star (C) IO-Images is licensed under a Public Domain license

- wrench (C) IO-Images is licensed under a Public Domain license

- 10.8 Recognizing a suffix (C) ckost is licensed under a CC BYNC-SA (Attribution NonCommercial ShareAlike) license

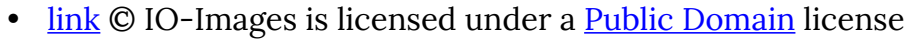

- check mark (C janjf93 adapted by Solomon Hajramezan is 
licensed under a Public Domain license 


\section{Einheit 10.9}

\section{eog}

Nach dem Lesen: Was haben Sie verstanden?

Diskutieren Sie die Tabelle von Einheit 10.8 (Hausaufgabe) in einer Kleingruppe.

\begin{tabular}{|l|l|l|l|l|}
\hline Personen & Beruf & $\begin{array}{c}\text { Aussehen/ } \\
\text { Eigenschaften }\end{array}$ & Kleidung & Problem \\
\hline Dr. Lange & & & & \\
\hline Olaf & & & & \\
\hline Jürgen & & & & \\
\hline Helene & & & & \\
\hline
\end{tabular}

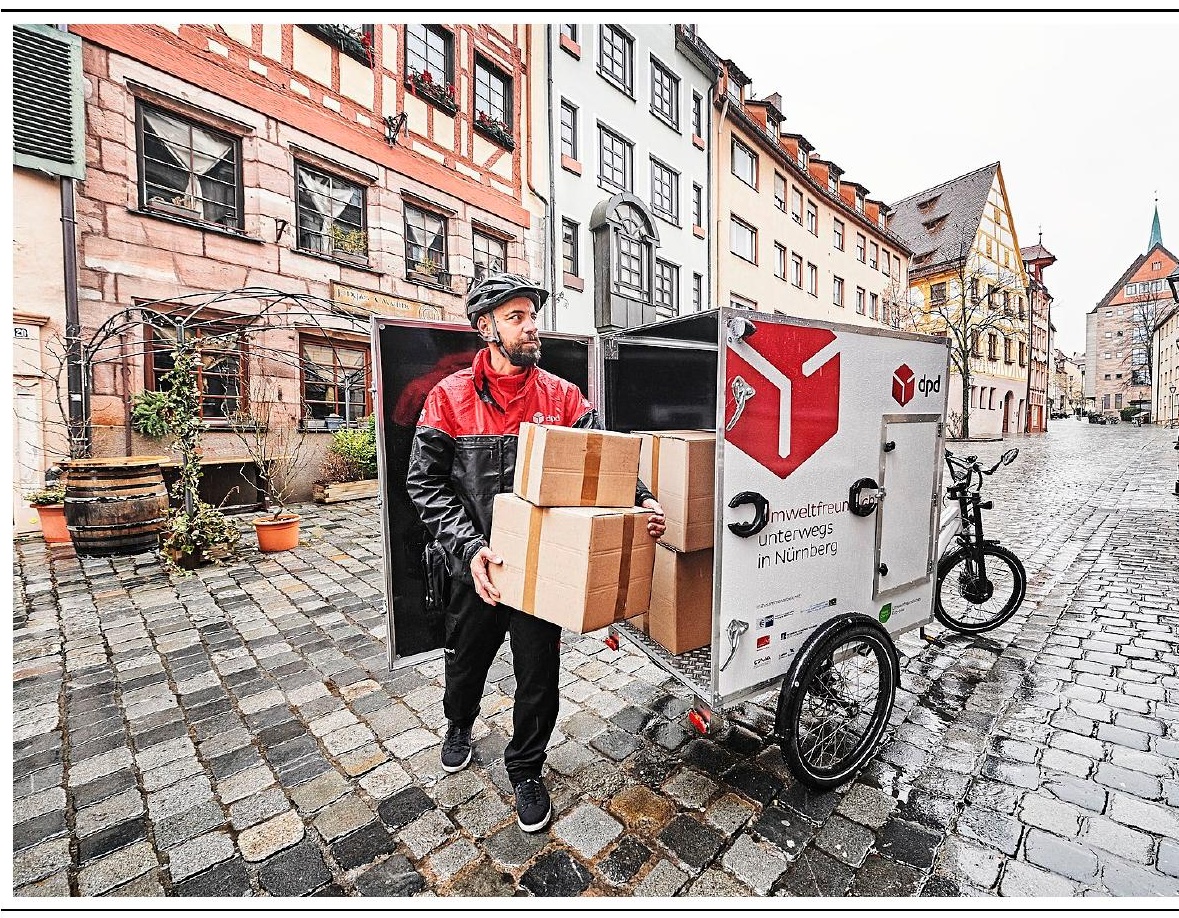


Nachbar Nr. 5. Wir lesen Kapitel 6 "Die Hotline" in kleinen Gruppen.

\section{0}

Nach dem Lesen: Verständnisfragen. Beantworten Sie die Fragen.

- Warum ruft Finn beim Paketdienst an?

- Was wissen wir über Frau Stauder?

- Worüber sprechen Finn und Emil?

\section{Media Attributions}

- group (C) IO-Images is licensed under a Public Domain license

- document (C) IO-Images is licensed under a Public Domain license

- DPD_Lastenrad (C) DPD de is licensed under a CC BY-NC-SA (Attribution NonCommercial ShareAlike) license

- book (C) IO-Images is licensed under a Public Domain license 


\section{Einheit 10.10 (online)}

\section{Kapitel 6 "Die Hotline": Was wissen Sie schon?}

An interactive H5P element has been excluded from this version of the text. You can view it online here:

https://openeducationalberta.ca/willkommen-

deutsch/?p=6872\#h5p-285

Vor dem Lesen: neue Wörter lernen. Bevor Sie Kapitel 7 beginnen, ergänzen Sie diese neuen Wörter. Sie können die Wörter in Kapitel 7 im Buch oder im Wortschatz PDF finden.

目

An interactive H5P element has been excluded from this version of the text. You can view it online here:

https://openeducationalberta.ca/willkommendeutsch/?p=6872\#h5p-287

Nachbar Nr. 5. Lesen Sie Kapitel 7 "Der Autor".

Nach dem Lesen: Was haben Sie verstanden? Hier gibt 
es eine erfundene und eine wahre Geschichte, wie Finn seine Freundin kennengelernt hat.

An interactive H5P element has been excluded from this
version of the text. You can view it online here:
https://openeducationalberta.ca/willkommen-
deutsch/?p=6872\#h5p-288
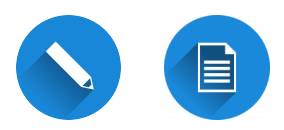

Nach dem Lesen: Verständnisfragen.

Beantworten Sie die Fragen. Schreiben Sie ganze Sätze. Bringen Sie die Antworten mit zur nächsten Deutschstunde.

1. Wie sieht Herr König aus und welche Kleidung trägt er?

2. Was liegt in Herrn Königs Wohnzimmer auf dem Boden?

3. Was ist Herr Königs Problem?

4. Warum muss Herr König ein Pseudonym benutzen?

5. Wie hat Herr König Inspiration für ein neues Manuskript gesucht?

6. Herr König öffnet den Schrank im Flur. Was passiert dann?

\section{Grammatik}

Conjunctions

Please work through the following presentations to review the conjunction "because": $\underline{\text { denn }}$ and weil 


\section{Übung 1}

An interactive H5P element has been excluded from this version of the text. You can view it online here:

https://openeducationalberta.ca/willkommen-

deutsch/?p=6872\#h5p-306

Q

Wortschatz in Quizlet:

Kapitel 6

Kapitel 7

Was wissen Sie jetzt? Klicken Sie hier für Quiz 10.10.

\section{Media Attributions}

- star (C) IO-Images is licensed under a Public Domain license

- book (C) IO-Images is licensed under a Public Domain license

- pen (C) IO-Images is licensed under a Public Domain license

- document (C) IO-Images is licensed under a Public Domain license

- link (C) IO-Images is licensed under a Public Domain license

- check mark (C) janjf93 adapted by Solomon Hajramezan is licensed under a Public Domain license 


\section{Einheit 10.11}

\section{0}

Eine kurze Wiederholung: Kapitel 7 "Der Autor".

Diskutieren Sie die Verständnisfragen von Einheit 10.10 (Hausaufgabe) in einer Kleingruppe.

1. Wie sieht Herr König aus und welche Kleidung trägt er?

2. Was liegt in Herrn Königs Wohnzimmer auf dem Boden?

3. Was ist Herr Königs Problem?

4. Warum muss Herr König ein Pseudonym benutzen?

5. Wie hat Herr König Inspiration für ein neues Manuskript gesucht?

6. Herr König öffnet den Schrank im Flur. Was passiert dann?

\section{안?}

Vor dem Lesen: Kapitel 8 Wortschatz

- An interactive H5P element has been excluded from this version of the text. You can view it online here:

https://openeducationalberta.ca/willkommendeutsch/?p=6874\#h5p-310

Nachbar Nr. 5. Wir lesen Kapitel 8 "Schmerzen" in kleinen Gruppen.

\section{Q00}

Nach dem Lesen: Was haben Sie verstanden? Arbeiten Sie in einer Kleingruppe und schreiben Sie eine kurze Zusammenfassung des Kapitels (5 Sätze). 


\section{Media Attributions}

- group (C) IO-Images is licensed under a Public Domain license

- document (C) IO-Images is licensed under a Public Domain license

- presentation icon (C) quinntheislander adapted by Solomon Hajramezan is licensed under a Public Domain license

- book (C) IO-Images is licensed under a Public Domain license 


\section{Einheit 10.12 (online)}

Wortschatz Wiederholung: Was haben Sie gelernt? Sie können die Wörter in Kapitel 8 im Buch oder im Wortschatz PDF finden.

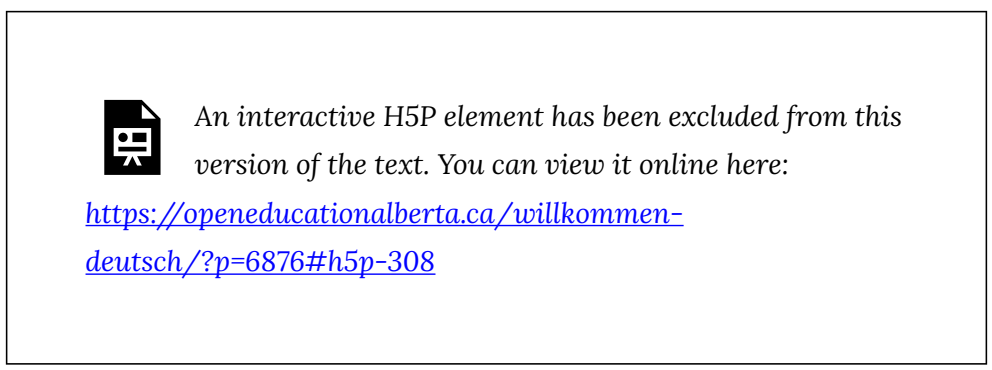

\section{Grammatik}

\section{"du"-imperative}

Please work through the following presentations to review the "du"-imperative.

\section{Übung 1}

An interactive H5P element has been excluded from this 
version of the text. You can view it online here:

https://openeducationalberta.ca/willkommen-

deutsch/?p=6876\#h5p-309

Vor dem Lesen: neue Wörter lernen. Welche Wörter haben eine ähnliche Bedeutung?

An interactive H5P element has been excluded from this

믐 version of the text. You can view it online here:

https://openeducationalberta.ca/willkommen-

deutsch/?p=6876\#h5p-289 


\section{Lesestrategien}

Recognizing patterns for word formation

In German, there are several ways to form new words. Recognizing these patterns helps you to understand unfamiliar words and enables you to use parts of a word to form a new word.

- Many adjectives can be turned into nouns in German by capitalizing the adjective and adding the ending -e, for example:

dick $\rightarrow$ der/die Dicke alt $\rightarrow$ der/die Alte klein $\rightarrow$ der/die Kleine

- Many verbs can be turned into nouns by capitalizing the verb stem and adding -er for the masculine or -erin for the feminine, for example with professions:

fahren $\rightarrow$ der Fahrer/die Fahrerin

lehren $\rightarrow$ der Lehrer/die Lehrerin

lernen $\rightarrow$ der Lerner/die Lernerin $\quad$ sprechen $\rightarrow$ der Sprecher/die Sprecherin

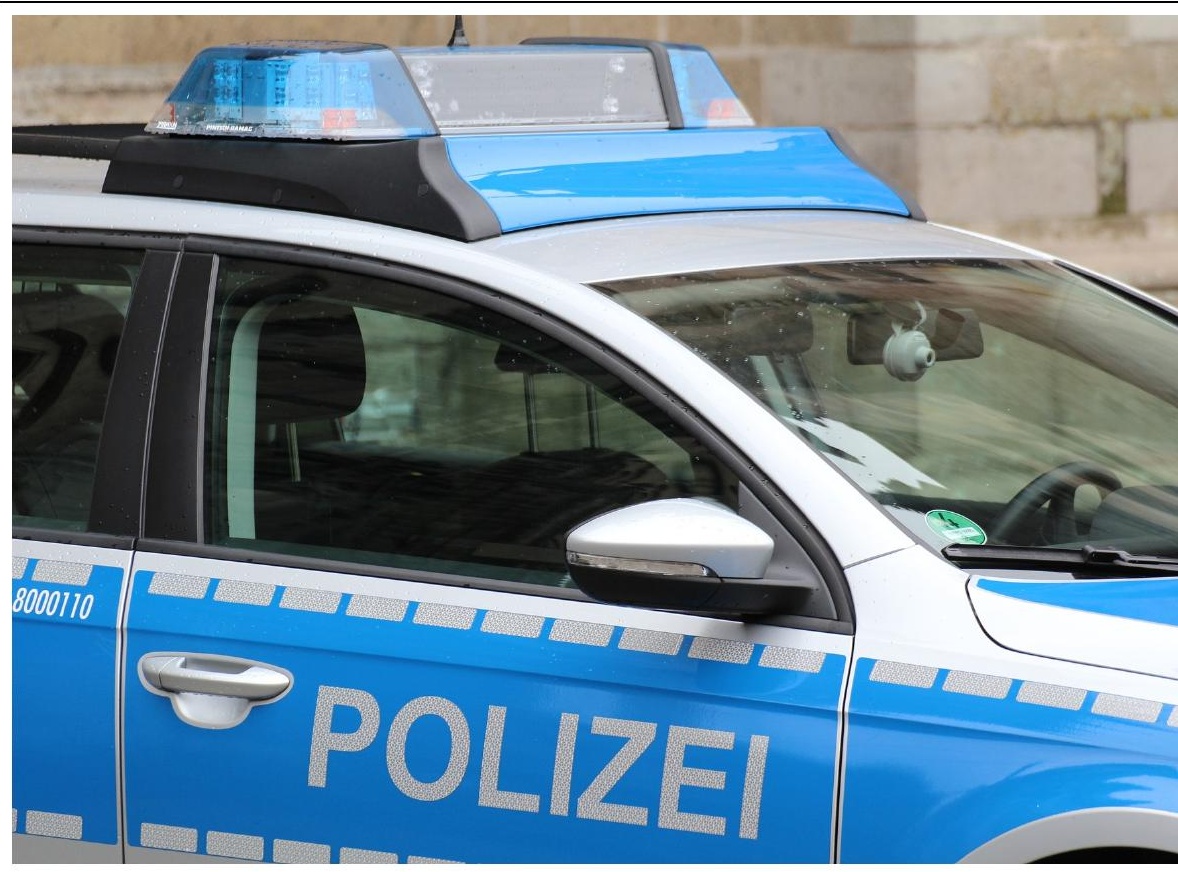

Wer sucht Finns Nachbar Thomas: die Polizei oder die Drogendealer? 
Nachbar Nr. 5. Lesen Sie Kapitel 9 "Schnee in der Wohnung".

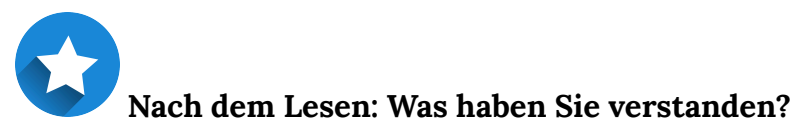

An interactive H5P element has been excluded from this version of the text. You can view it online here:

https://openeducationalberta.ca/willkommendeutsch/?p=6876\#h5p-295

Q

Wortschatz in Quizlet:

$\underline{\text { Kapitel } 8}$

Kapitel 9

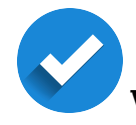

Was wissen Sie jetzt? Das Quiz ist in der nächsten Unterrichtsstunde.

\section{Media Attributions}

- star (C) IO-Images is licensed under a Public Domain license

- wrench (C) IO-Images is licensed under a Public Domain license

- 10.12 Recognizing patterns for word formation (C) ckost is licensed under a $\underline{\mathrm{CC} B Y-\mathrm{NC}-\mathrm{SA} \text { (Attribution NonCommercial }}$ 
ShareAlike) license

- police (C) Ingo Kramarek is licensed under a Public Domain license

- book (C) IO-Images is licensed under a Public Domain license

- link (C) IO-Images is licensed under a Public Domain license

- check mark (C) janjf93 adapted by Solomon Hajramezan is licensed under a Public Domain license 


\section{Einheit 10.13}

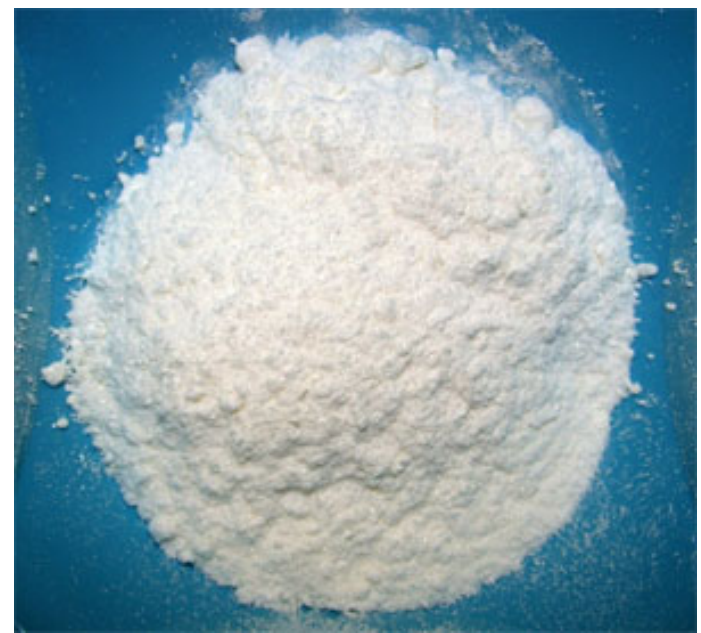

\section{0}

Eine kurze Wiederholung: Kapitel 9 "Schnee in der Wohnung"

- Warum springt Thomas Eichner vom Balkon?

- Warum sind zwei Männer in Lederjacken in Thomas' Wohnung?

- Welche Informationen haben die Polizistin und der Polizist am Ende des Kapitels?

Nachbar Nr. 5. Wir lesen Kapitel 10 "Amelie" mit verteilten Rollen.

Nach dem Lesen: Was haben Sie verstanden? 
- Was schenkt Amelie Finn?

- Wie findet Finn endlich sein Päckchen?

- Finn und Amelie möchten den Abend ungestört zusammen verbringen.

Aber das ist nicht leicht. Wer stört die beiden?

\section{Media Attributions}

- cocaina (C) Davidfernandocoronel is licensed under a CC BY-SA (Attribution ShareAlike) license

- group (C) IO-Images is licensed under a Public Domain license

- book (C) IO-Images is licensed under a Public Domain license 


\section{Einheit 10.14 (online)}
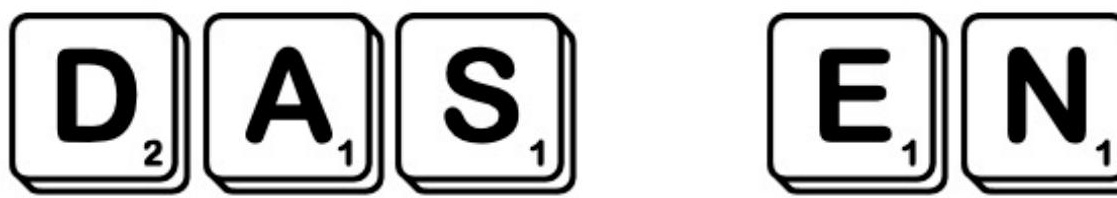

Wiederholung: Was ist nicht wahr? Sie haben viele "interessante" Leute im Buch kennengelernt. Lesen Sie die Sätze. Was ist eine Lüge?

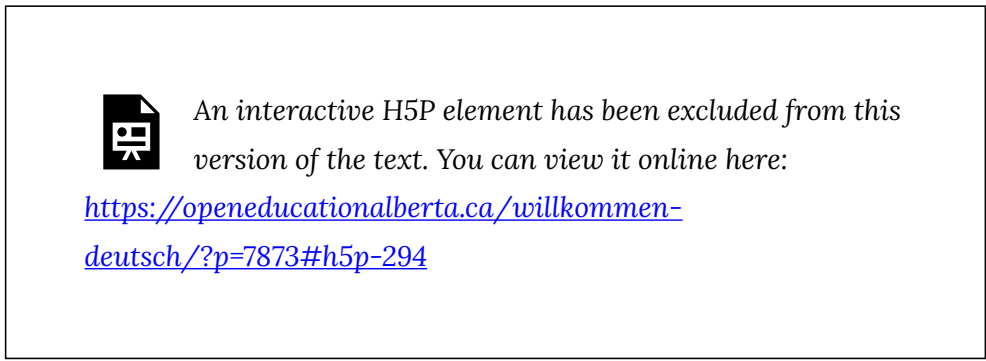

Wortschatz Wiederholung: Was haben Sie gelernt? 
https://openeducationalberta.ca/willkommen-

deutsch/?p=7873\#h5p-297

\section{Wortschatz in Quizlet:}

\section{Kapitel 10}

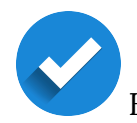

Es gibt kein Quiz für 10.14 .

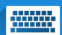

Composition: Nachbar Nr. 5

Now that we have finished reading this short novel, you get to write a creative composition. You have two options:

A. Wie geht die Geschichte weiter? Continue the story of Finn and Amelie. What happens after Amelie opens the package?...

B. Noch ein verrückter Nachbar! Imagine there is yet another neighbour living in this house. Describe the encounter between this neighbour and Finn searching for his package.

Write a composition of 175-250 words. Make sure you include dialogue as well as narrative.

This composition will be assessed according to the Rubric for Composition. 


\section{Media Attributions}

- Das Ende (C) csawatzky is licensed under a Public Domain license

- star (C) IO-Images is licensed under a Public Domain license

- link (C) IO-Images is licensed under a Public Domain license

- check mark (C) janjf93 adapted by Solomon Hajramezan is licensed under a Public Domain license

- keyboard (C) IO-Images is licensed under a Public Domain license 


\section{Wortschatz}

\section{Quizlet:}

\section{Wortschatz Einheit 10 (alle Kategorien)}

Kapitel 1

Kapitel 2

Kapitel 3

Kapitel 4

Kapitel 5

Kapitel 6

Kapitel 7

Kapitel 8

Kapitel 9

$\underline{\text { Kapitel } 10}$

Wortschatz 10

Media Attributions

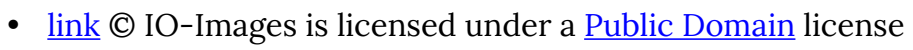

- pdf (C) IO-Images is licensed under a Public Domain license 


\section{Zum Spaß!}

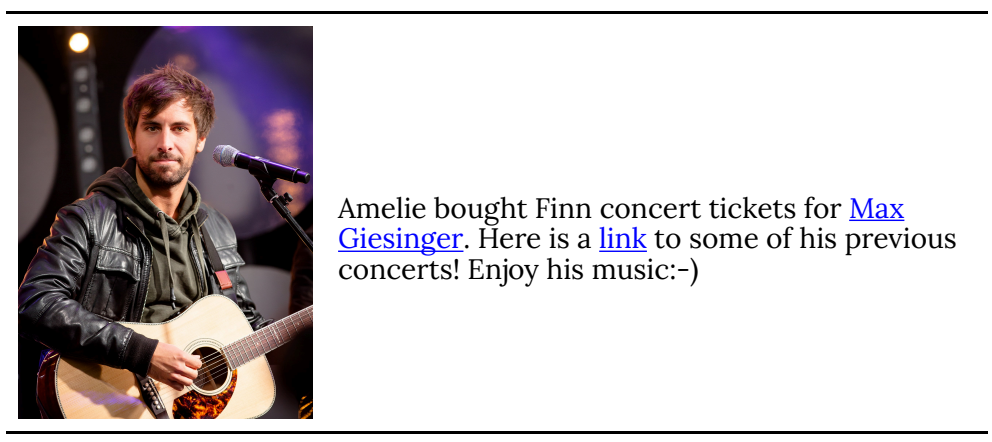




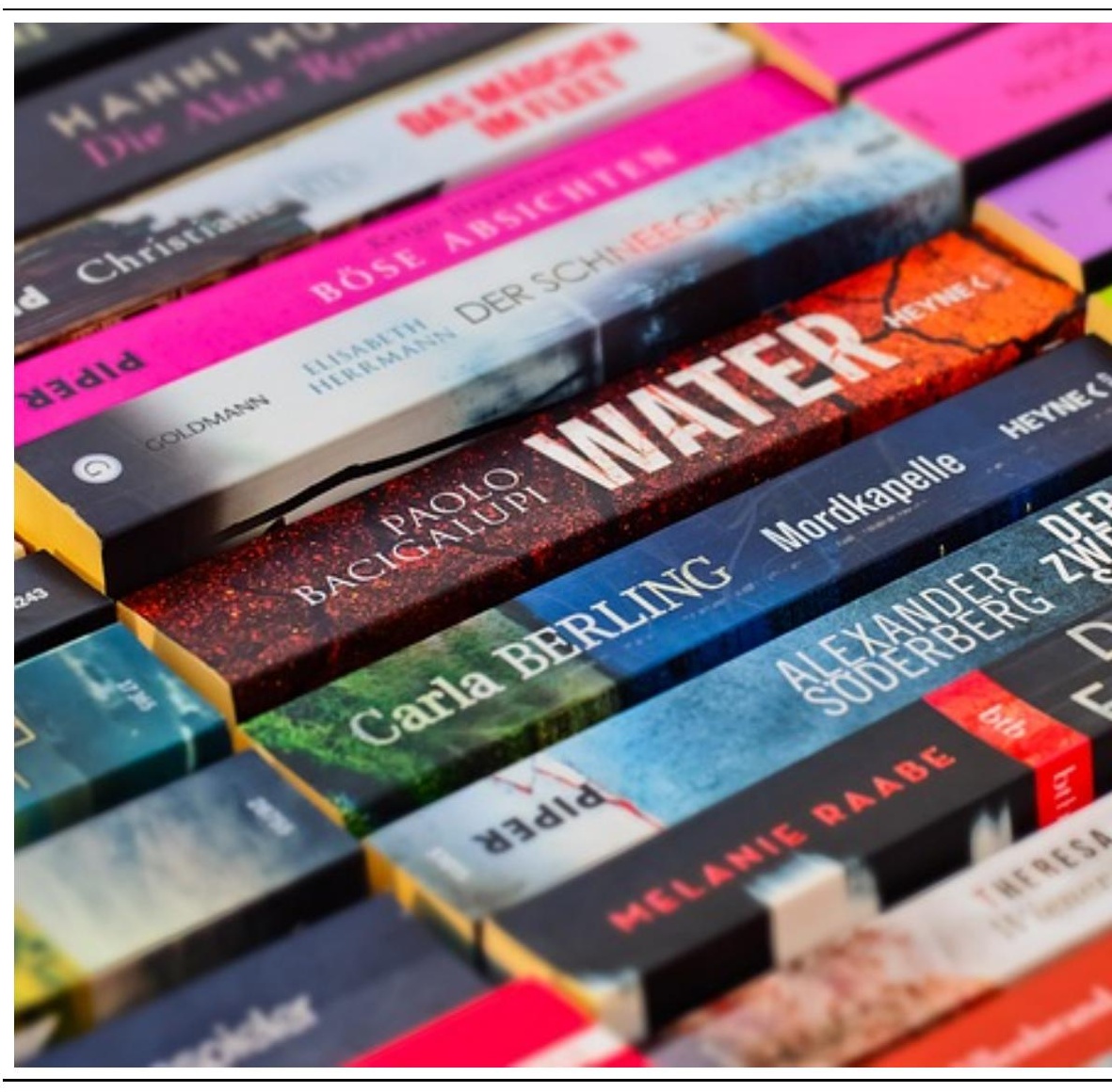




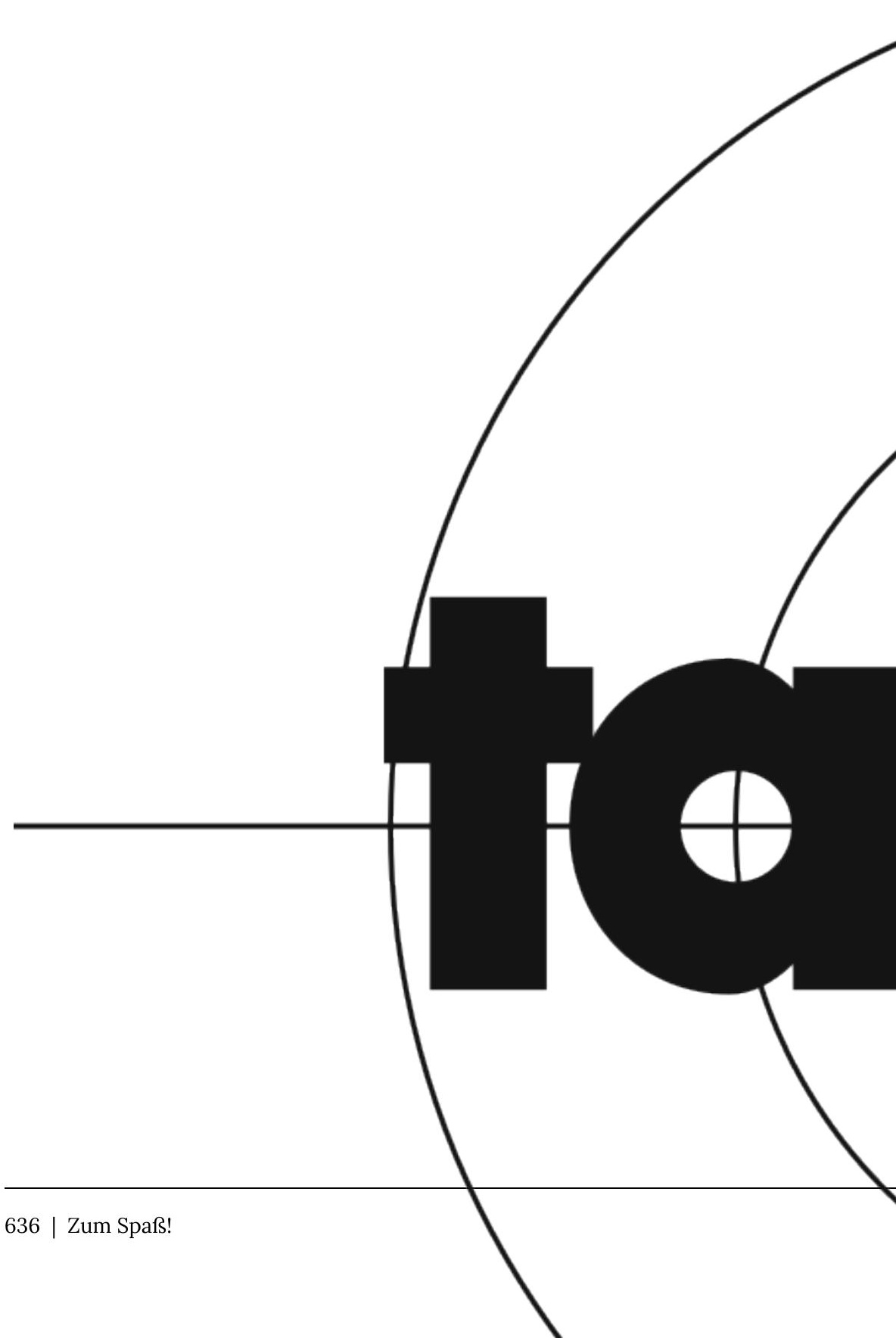




\section{Media Attributions}

- Max_Giesinger (C) Harald Krichel is licensed under a CC BY-SA (Attribution ShareAlike) license

- books (C) MichaelGaida is licensed under a Public Domain license

- Tatort_Logo_ARD is licensed under a Public Domain license 
638 | Zum Spaß! 
For quick reference, all grammar structures are listed here (linked back to the appropriate unit or directly to a PDF).

Nouns and Pronouns:

Personal pronouns 1.8

Grammatical Gender: Nouns and Pronouns 1.10

Negation with "kein" 2.2

Plural forms of nouns 2.2

Definite and indefinite articles 2.2

Possessive determiners: $2.4 \underline{3.2}$

Dieser/jeder/welcher 3.6

Personal pronouns in the accusative 3.16

Reflexive pronouns in the accusative 4.2

Personal pronouns and reflexive pronouns in the dative 5.10

Compound Nouns 8.2

Relative Clauses 9.10

Masculine n-nouns 10.6 
Verbs:

"Sie"-imperative 1.4

"Du"-imperative 4.4

Conjugation of "sein" and "haben" 1.8

Conjugation of verbs (1) 1.8

Conjugation of verbs (2) 2.8

Expressing likes and dislikes: "gern"/"nicht gern"/"auch gern" 2.8

Separable-prefix verbs 2.12

Stem-vowel changing verbs 2.12

möchten 3.14

Modal verbs: können, wollen, müssen 4.4

Modal verbs: dürfen, sollen, mögen 4.6

Perfect Tense 15.2

Perfect Tense 25.4

Simple past tense: "haben" and "sein" 5.4

Future tense 9.8

wissen vs. kennen 10.2

List of common irregular verbs

Cases:

Cases: The nominative 2.2

Cases: The accusative 3.8 
Cases: The dative 5.8

\section{Conjunctions:}

Coordinating conjunctions 2.4

Subordinating conjunction weil 3.4

Subordinating conjunctions weil, wenn, dass, ob 4.8

Als, wenn, wann 7.8

\section{Adjectives:}

Adjective endings in nominative 3.6

Adjective endings in accusative 3.10

Adjective endings in dative 5.10

Comparative and Superlative 6.4

Adjective ending review 9.6

$\underline{\text { Adjective ending chart PDF }}$

\section{Prepositions:}

Accusative prepositions 6.12

Prepositions for giving directions 7.4

Dative prepositions 7.8

English "to": German "nach" vs. "in" 7.10

Two-Way Prepositions I (dative) 8.6 
Two-Way Prepositions II (accusative) 8.8

List of prepositions (and corresponding cases)

\section{Other concepts:}

Word Order in Statements and Questions 2.6

Question words: wer, wen, wem 2.6/3.8/5.8

Adverbs of time 5.2

Ordinal Numbers 5.6

Word order review (Einheit 1-5) 6.2

Articles, Cases, Prepositions \& Contractions (review) 


\section{Vergessen Sie nicht!}

For quick reference, all the "Vergessen Sie nicht" sections are listed here in the order they appear.

2.12 Position of nicht

$\underline{3.10}$ Verbs heißen and sein

4.6 zu Hause vs. nach Hause

6.6 mit + dative case

7.8 Dative prepositions

8.6 Dative plural nouns

\section{Media Attributions}

- information (C) IO-Images is licensed under a Public Domain license 
For quick reference, here are all "*ACHTUNG*" sections again:

\section{2}

All activities in this e-textbook require ä, ö, ü, and $₫$ where necessary and you should learn how to spell words the way we present them. You also need to use ä, $\mathrm{o}, \mathrm{u}$, and $§$ when you write tasks and quizzes. If you do not know how to make an umlaut or Eszett (ß), please refer to this short article. Also please note that we try to always provide the special characters for you so that you can copy and paste them from the instructions. In the German-speaking countries, people usually only use the ae, oe, ue as mentioned in the video when they do a crossword puzzle. Otherwise, they use the umlaut.

\section{6}

You will often use colours as adjectives to describe things:

Der Frosch ist grün.

Der Apfel ist rot.

However, there may be times when you use a colour as a noun. Remember all nouns are always capitalized.

Was ist deine Lieblingsfarbe? Meine Lieblingsfarbe ist Blau. 


\section{1}

Das ist/Das sind ("this is/these are") have nothing to do with the article das.

\section{$\underline{2.8}$}

As you have seen in this presentation as well as earlier in this unit, German verbs are sometimes a combination of a noun + verb or verb + verb:

Fußball spielen - Luca spielt gern Fußball.

Musik hören - Karolina hört gern Musik.

Fotos machen - Houssem macht gern Fotos.

ins Konzert gehen - Houssem geht heute Abend ins

Konzert.

Sport machen - Sasha macht gern Sport.

essen gehen - Houssem geht mit Freunden essen.

Please note that you conjugate the verb in the second position and put the other verb or noun at the end of your sentence. It is the complement that gives you more information about the verb.

\section{$\underline{3.6}$}

In Einheit 3.5 you heard these sentences in the listening: Ja, ich suche eine neue Hose.

Diese Jeans kostet nur 39 Euro.

Please note that "die Hose", "die Jeans" and "die Brille" are 
singular. There are plural forms as well.Die Hosen sind teuer.

Die Jeans kosten mehr als die Jogginghosen.

\section{$\underline{3.12}$}

Throughout the e-textbook you will encounter this expression:

es gibt ... = "there is" and "there are"

Bei MediaMarkt gibt es einen sehr billigen

Computer. (singular)

Es gibt viele Personen in meiner Familie. (plural)

$\underline{10.8}$

Throughout the first few chapters of this book, we have seen interesting usages of the words: ja, aber, doch, denn, etc. These little words are called modal particles. These words add "flavour" or change the tone of a sentence, question, etc. Sometimes they can soften the harshness of a comment or even add a persuasive or suggestive element to a request.

Here are some examples from the book so far:

Mach doch eine kleine Pause.

Wer bist du denn? 
Im Internet sehen Sie aber ein bisschen älter aus.

Wir haben ja vor einigen Tagen telefoniert. 
앚만

Wortschatz Präsentationen

For quick reference, all vocabulary presentations are listed here in alphabetical order.

Alphabet 1.2

Aufforderungen 1.4

Begrüßen und Verabschieden 1.3

Beschreibungen und Eigenschaften 3.2

Einkaufsmöglichkeiten 9.1

Esstisch 9.6

Familie 3.1

Farben 1.6

Freizeitaktivitäten $\underline{2.7} / \underline{2.8} / \underline{2.11}$

Frühstück 4.1

Gegenstände im Seminarraum 2.1

Geografie 6.7

Geschenke 5.5

Himmelsrichtungen 1.7

Hotel 6.12

Kaufhaus $\underline{3.7}$ / $\underline{3.8}$

Kleidung 3.5

Körper 4.4

Länder 1.6

Lebensmittel $\underline{9.1} / \underline{9.2}$

Mengenangaben 9.2

Mittagessen 9.5

Möbel und andere Dinge im Haus $\underline{8.3}$ / 8.4

Monate und Jahreszeiten 1.7

Mülltrennung 9.4

Orientierung in einer Stadt 7.2

Reise 6.2

Restaurant 9.7

Sehenswürdigkeiten 7.1

Sprachen 1.6

Studienfächer 2.3

648 | Wortschatz Präsentationen 
Tagesablauf 4.1

Transportmittel \& Öffentliche Verkehrsmittel 6.5

Uhrzeit $\underline{2.5} / \underline{2.6}$

Was möchten Sie? 3.14

Weihnachten 5.9

Wegbeschreibung $\underline{7.3} / \underline{7.4}$

Wetter 1.7

Wochentage 2.5

Wohnmöglichkeiten $\underline{8.1}$ / $\underline{8.2}$

Wohnungsanzeigen 8.8

Zahlen $\underline{1.3} / \underline{1.4}$

Zimmer in einem Haus $\underline{8.1} / \underline{8.2}$

Zug fahren 6.9

\section{Media Attributions}

- presentation icon (C) quinntheislander adapted by Solomon Hajramezan is licensed under a Public Domain license 
For quick reference, all cultural topics are listed here in the order they appear.

Sie, du oder ihr? 1.2

Die deutschsprachigen Länder 1.8

Wissenschaft 2.4

Schule und Studium 2.4

Uhrzeit 2.6

Gender-inclusive and gender-neutral language in German 2.14

Das Frühstück 4.2

E-Mail Etikette 4.10

Der erste Schultag 5.4

Fünfter sein (Gedicht) 5.6

Geburtstage in Deutschland 5.8

Weihnachten 5.9

Tatsachen über Deutschland 6.4

UNESCO-Welterbe: Oberes Mittelrheintal 6.6

Die Loreley (Gedicht) 6.8

UNESCO-Welterbe: Bergpark Wilhelmshöhe 7.2

$\underline{\text { Kassel }} 7.3$

$\underline{\text { CSSG } 7.6}$

Brüder Grimm $\underline{7.8 ~ / ~} \underline{7.9}$ 
Wohnen in Kanada und Deutschland 8.2

UNESCO-Welterbe: Siedlungen der Berliner Moderne 8.10

Metzger vs Fleischer 9.2

Mülltrennung 9.4

Mittagessen vs Abendessen 9.4

Wie lege ich mein Besteck richtig hin? 9.6

Im Restaurant 9.8

Auerbachs Keller 9.10

Goethe 9.11

Weimar 9.12

UNESCO-Welterbe: Klassisches Weimar 9.12

Faust 9.13

Köln 10.1 
For quick reference, all "Redemittel" sections are listed here in the order they appear.

Sich vorstellen 1.1

Sich vorstellen 1.5

Verben 3.10

Komplimente machen/Kritik üben 3.15

Sich verabreden/einen Termin machen 4.8

Am Fahrkartenschalter 6.11

Nach dem Weg fragen/Den Weg beschreiben 7.5

Auf Zimmersuche 8.11

Beim Einkaufen 9.2

Im Restaurant 9.8 
This PDF contains audio scripts for the book.

\section{Media Attributions}

- pdf (C) IO-Images is licensed under a Public Domain license 


\section{Here are some helpful resources:}

\section{Dictionaries:}

http://www.dict.cc/

http://dict.leo.org/

https://www.wordreference.com/

https://www.linguee.com/

\section{Verb Conjugation:}

https://conjugator.reverso.net/conjugation-german.html

http://www.verbix.com/languages/german.shtml

\section{Pronunciation:}

https://forvo.com/languages/de/ (you can type in individual words and hear the pronunciation)

https://www.thoughtco.com/the-german-alphabet-1444644

(alphabet with pronunciation guide and examples)

http://www.joycep.myweb.port.ac.uk/pronounce/index.html (all letters and sounds)

https://blogs.ubc.ca/germanpronunciation/ (some knowledge of the IPA would be helpful)

German Consonants (some knowledge of the IPA would be helpful)

German Vowels (some knowledge of the IPA would be helpful)

The German Spelling System (some knowledge of the IPA would be helpful)

\section{Grammar Explanations:}

https://deutsch.lingolia.com/en/

http://www.deutschseite.de/

http://www.nthuleen.com/teach.html 